Karla Peitl Miller

\title{
ESTUDO DA FLUÊNCIA EM VIGAS DE CONCRETO REFORÇADO COM FIBRAS DE AÇO, COM APLICAÇÃO DE CONCEITOS DA MECÂNICA DA FRATURA
}

Dissertação apresentada à Escola de Engenharia de São Carlos da Universidade de São Paulo como parte dos requisitos para obtenção do Título de Mestre em Engenharia Civil (Engenharia de Estruturas).

Orientador: Prof. Titular João Bento de Hanai.

São Carlos 

Aos meus pais Mauro e Célia, meu irmão Wagner e a Alan. 



\section{AGRADECIMENTOS}

Inicialmente a Deus, pela vida.

Aos meus pais, Mauro e Célia, e ao meu irmão, Wagner, pelo apoio e compreensão da minha ausência durante minha dedicação à conclusão de mais esta etapa. Sem o amor da minha família, nada seria possível.

Ao meu namorado Alan, pela importância que tem na minha vida, pelo carinho e apoio de todas as horas, sempre companheiro. Além de meu namorado, meu melhor amigo.

Aos meus avós, Aparecida e Oscar, que sempre acompanham meus passos em São Carlos desde 2000, participando de cada conquista, fornecendo conforto nos momentos difíceis. Á minha avó Arlette pelo carinho e pela "torcida" para tudo desse certo. Ao meu avô Willibaldo (in memoriam), pois sei que está sempre olhando por mim. Aos meus tios queridos Oscar e Nívea, pelo apoio constante.

Ao meu orientador, professor João Bento de Hanai, pela oportunidade de desenvolver este trabalho, pelo incentivo, sempre transmitido de forma confiante, por sua amizade e também pelos valiosos ensinamentos e contribuições.

Ao professor Luiz Eduardo Teixeira Ferreira, pela co-orientação, pela amizade, por sua participação ativa em minha formação, mas principalmente devo agradecê-lo pela confiança em mim depositada.

A todos os professores do Departamento de Engenharia de Estruturas que contribuíram para minha formação, em especial aos Profs. Mounir Khalil El Debs e Toshiaki Takeya.

As meninas da sala cinco, Érika, Marcela, Fernanda e Camila, e à minha companheira de república Alice, pessoinha muito especial, minha irmã mais nova.

A todos os amigos que fiz, incluindo pessoas das turmas "setmestrado" 2005, 2006 e 2007, além do pessoal do doutorado. Em especial, gostaria de agradecer pelo apoio, contribuições, e pelos bons momentos compartilhados: Marlos, Gustavo, Manoel Denis, Vinícius, Jonatas, João César, Aquino, Rômulo, Charlton, Sudano, Eduardo, Sandra, Walter, Vladimir, Angelitta, Rodrigo Matta e Fernando Menezes.

Aos funcionários do Laboratório de Estruturas: Amaury, Fabiano, Mário, Mauri, Romeu, Valdir, cuja competência e disposição foram fundamentais para o sucesso do programa experimental. Ao $\mathrm{Eng}^{\circ}$ Dr. Luiz Vicente Vareda, por sua amizade e pelas inúmeras contribuições técnicas.

Ao Departarmento de Engenharia de Estruturas da EESC-USP pela oportunidade e pelas instalações.

Aos todos os funcionários do SET, sempre prestativos e eficientes.

À FAPESP, pela bolsa de mestrado e pelo apoio financeiro através do Projeto Temático "Nucleação e incremento da pesquisa, inovação e difusão em concreto pré-moldado e estruturas mistas para a Modernização da Construção Civil”. 



\section{RESUMO}

MILLER, K. P. Estudo da fluência em vigas de concreto reforçado com fibras de aço, com aplicação de conceitos da mecânica da fratura. 2008. Dissertação (Mestrado) - Escola de Engenharia de São Carlos, Universidade de São Paulo, São Carlos, 2008.

Embora sejam reconhecidas diversas vantagens na adição de fibras curtas de aço ao concreto (CRFA), em especial o ganho de tenacidade, pouco se sabe a respeito da fluência desses materiais compostos. Este trabalho teve como objetivo principal investigar o potencial e as dificuldades inerentes de um método de avaliação experimental da fluência pelo ensaio de vigas, como possível alternativa aos ensaios de compressão axial já consagrados. Ao mesmo tempo, considerando a nova tendência de exploração de compósitos híbridos - formados por fibras de diferentes características, de modo a obter respostas adequadas aos processos de micro e macrofissuração - tomou-se como objeto de estudo experimental um conjunto de modelos e corpos-de-prova de CRFA comum e de CRFA híbrido, este formado pela combinação de fibras de aço de diferentes comprimentos, umas mais longas e outras mais curtas. Para caracterização dos materiais, foram efetuados ensaios para determinação das principais propriedades mecânicas de interesse em distintas idades. As proporções da mistura adotada neste programa experimental foram baseadas em dados de estudos anteriores, que suscitaram investigações mais detalhadas. Entretanto, neste particular programa de ensaios, a adição das fibras, principalmente as mais curtas, acarretou maior teor de ar incorporado ao compósito, o que penalizou o seu desempenho em alguns aspectos. Os resultados desses ensaios demonstraram pouca influência das fibras sobre as propriedades de resistência à compressão, módulo de elasticidade e resistência à tração por compressão diametral. Quanto à fluência, o desempenho do CRFA e do compósito híbrido foi inferior ao da matriz. Por outro lado, notou-se maior restrição à retração do concreto com a adição de fibras. Na análise dos resultados experimentais, o estudo das flechas diferidas foi efetuado pelas correspondentes deformações, para interpretação do fenômeno por meio das curvas de fluência específica. $\mathrm{O}$ ajuste de resultados experimentais para curvas de fluência específica demonstrou que a fluência em vigas, apesar de apresentar - comparativamente aos modelos teóricos fundamentados em ensaios de compressão - maior taxa inicial, maiores coeficientes de fluência e estabilização aparentemente mais rápida, pode ser representada por modelos teóricos semelhantes aos usuais. As curvas de tendência determinadas para a matriz foram comparadas com aquelas derivadas de expressões dadas por normas técnicas (NBR 6118:2003 e ACI209:1982), assim como com as obtidas em simulações numéricas efetuadas como software DIANA ${ }^{\circledR}$. A fluência também foi avaliada experimentalmente em vigas entalhadas, submetidas apenas à ação do peso-próprio, sendo estes ensaios também simulados por meio de modelagem numérica e aplicação de conceitos da Mecânica da Fratura. Os resultados analisados permitem dizer que há possibilidade de avaliar a fluência pela metodologia estudada, o que oferece um método alternativo para avaliação experimental da fluência. Nesta pesquisa, avaliou-se também a alteração de rigidez das vigas ensaiadas em decorrência dos efeitos do tempo, por meio de ensaios dinâmicos de vibração livre, segundo a ASTM C 215:1991a.

Palavras-chave: fluência, concreto reforçado com fibras de aço, flexão, flechas diferidas, Mecânica da Fratura. 



\section{ABSTRACT}

MILLER, K. P. Creep analysis of steel fiber reinforced concrete based on beam tests and fracture mechanics concepts. 2008. MSc. Thesis - Escola de Engenharia de São Carlos, Universidade de São Paulo, São Carlos, 2008.

Despite of the well known advantages of steel fiber addition to concrete (SFRC), especially the toughness improvement, only a few number of studies has been developed about creep on these composites. The main purpose of this research is to investigate the feasibility and inherent difficulties related to a particular creep evaluation method. This method is based on beam test results and their analysis by Fracture Mechanics Theory. It is intended to become an alternative method instead of the usual creep analysis of axial compression test results. At the same time, looking at the development of hybrid composites - made of distinct kind of fibers to obtain the best responses for micro and macrocracking - an experimental program was performed. Specimens molded with plain concrete, ordinary SFRC and hybrid SFRC were tested in flexure, the last one made of an association of short and large steel fibers. Characterization tests were performed to obtain the main mechanical properties of these materials at several ages. The mixture proportions were based in previous studies, where good performance characteristics were observed in hybrid composites. Nevertheless, in this particular test series, the addition of shorter steel fibers resulted in high air contents, what probably caused the decrease of the composite's performance in some aspects. The test results displayed low influence of the fiber addition on mechanical properties such compression strength, modulus of elasticity and tensile strength. Creep performance showed to be worse in the SFRC and hybrid composites than in plain concrete matrix. However, the reinforcement with steel fibers improved the shrinkage restrain. The analysis of the long-term beam deflections was made by finding the corresponding strains in the sections. Afterwards, specific creep functions were obtained by regression methods. The experimental creep functions were compared to the existing ones in literature and design codes. Despite of some differences, such as higher initial creep rate, higher creep coefficients and faster stabilization, it may be concluded that these functions represented quite well the phenomenon. Also experimental functions for plain concrete showed good results when compared to creep prediction model given by design codes, such as the Brazilian NBR 6118:2003 and ACI 209:1982. Comparison with numerical modeling results also gave satisfactory results. Creep in flexure was also evaluated by means of notched beam tests, where the sustained load was performed only by the beam self-weight. The test results were analyzed by numerical modeling and application of Fracture Mechanic concepts. The overall results showed the feasibility of creep assessing by the beam test method, which can be, after further detailed test series, a good alternative method instead of axial compression tests. Also dynamic free vibration tests were performed, according to ASTM C - 215:1991 recommendations, to investigate the beam stiffness loss due to long term loading effects. These tests showed that modal analysis can be a helpful method in the tests, since it does not introduce damages in the test specimens.

Key-words: creep, steel fiber reinforced concrete, flexure, long-term deflection, Fracture Mechanics. 



\section{SUMÁRIO}

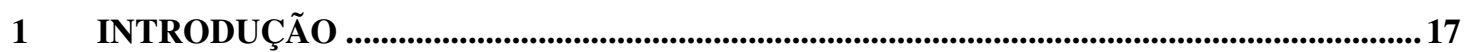

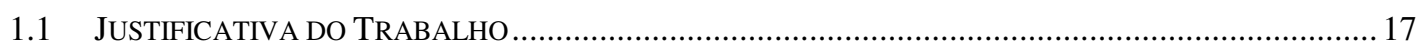

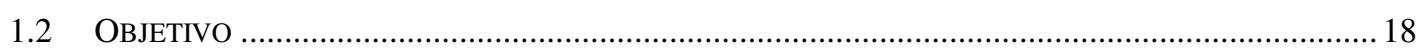

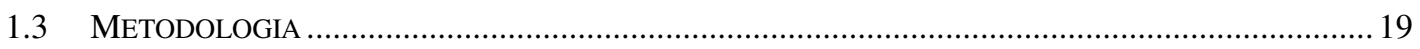

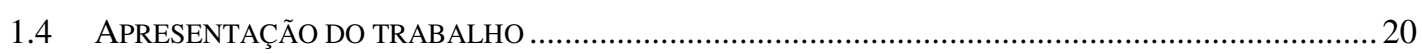

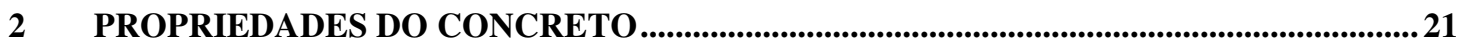

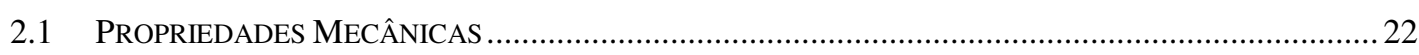

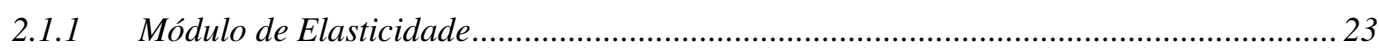

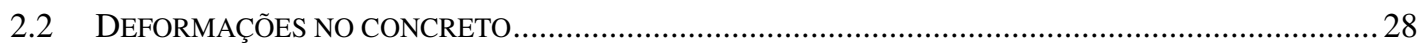

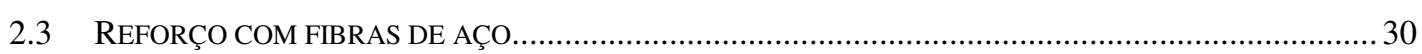

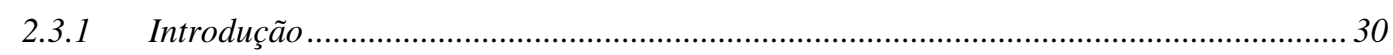

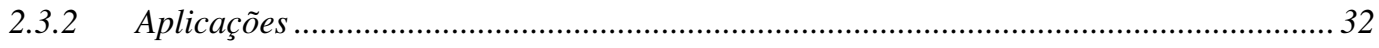

2.3.3 Mecanismos de Transferência de Tensões ....................................................................... 33

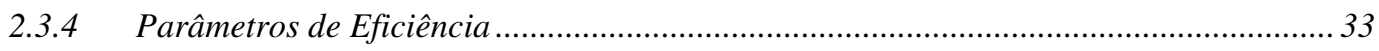

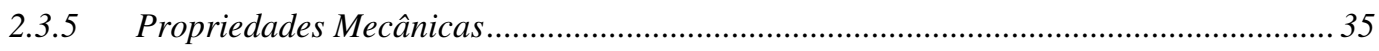

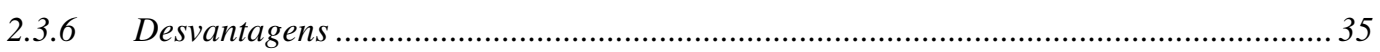

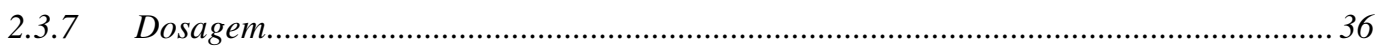

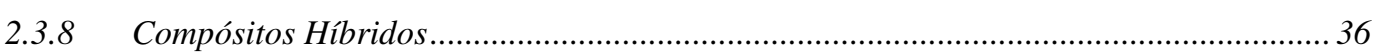

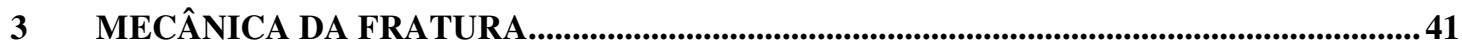

3.1 MeCÂNiCA Da Fratura Elástica LineaR: Conceitos Básicos ............................................ 43

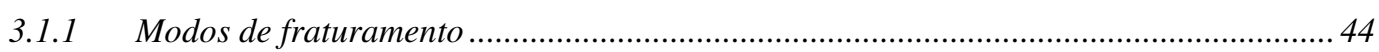

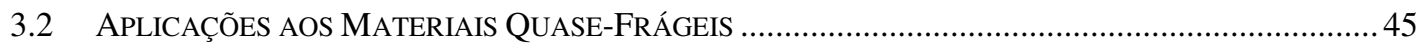

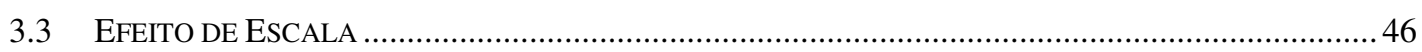

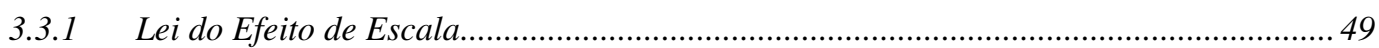

3.4 PRINCIPAIS MODELOS DE FRATURAMENTO DO CONCRETO …….................................................. 50

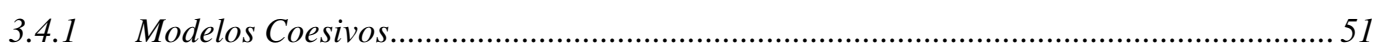

3.4.1.1 Modelo da Fissura Fictícia (Hillerborg et. al., 1976) ............................................................53

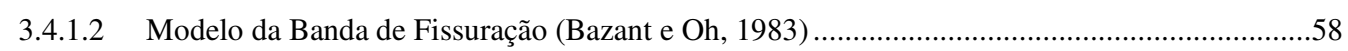

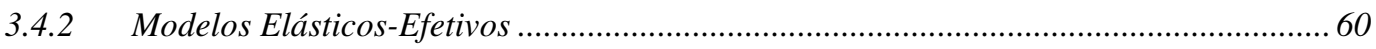

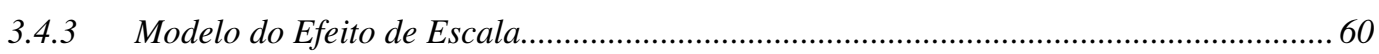

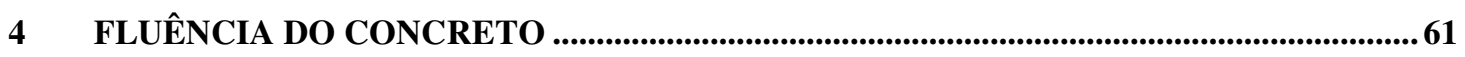

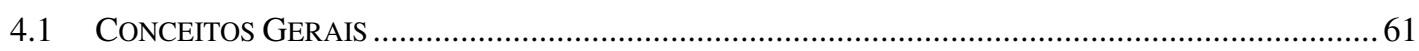

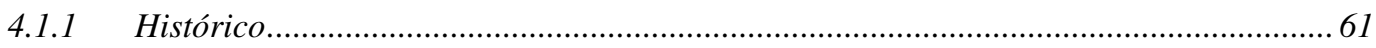

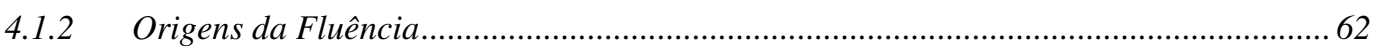

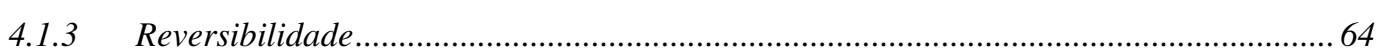




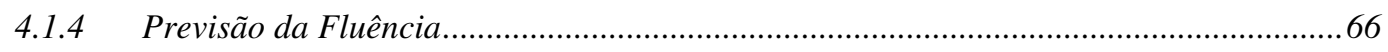

4.1.5 Expressões Matemáticas para a fluência .........................................................................69

4.1.6 Principais implicações do fenômeno ................................................................................72

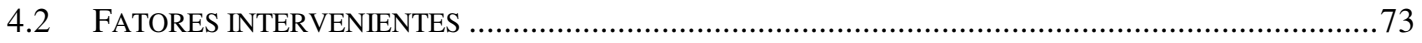

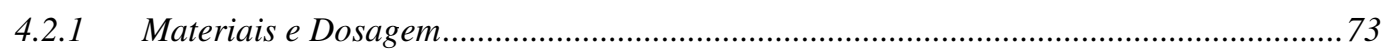

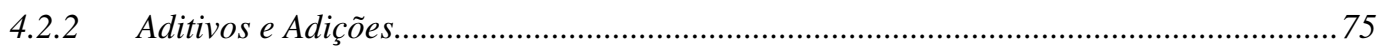

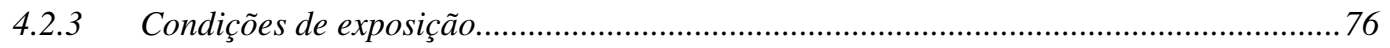

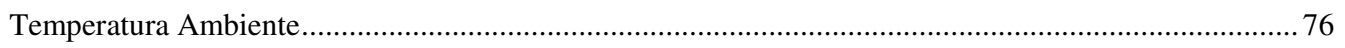

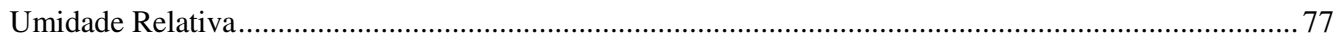

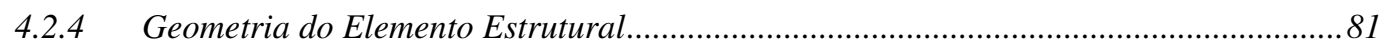

4.2.5 Intensidade do carregamento aplicado ..................................................................... 82

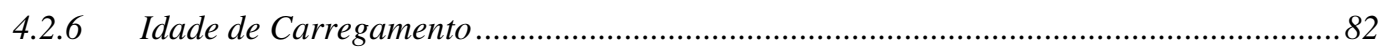

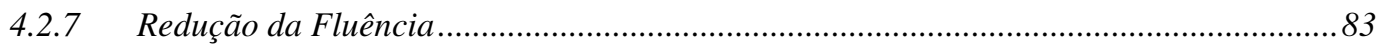

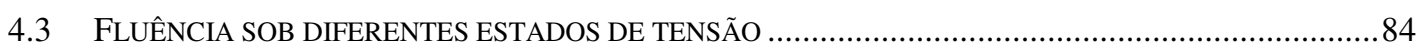

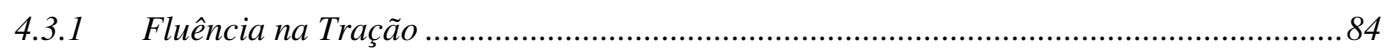

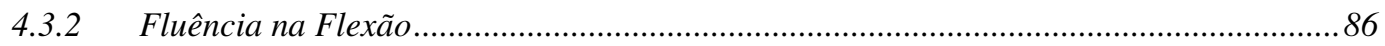

4.4 FLUÊNCIA DO CONCRETO REFORÇADO COM FIBRAS - GENERALIDADES ....................................8 88

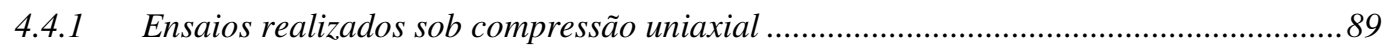

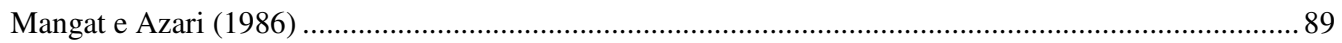

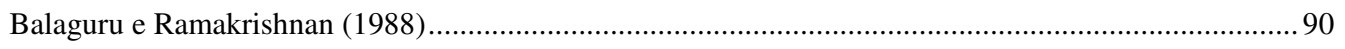

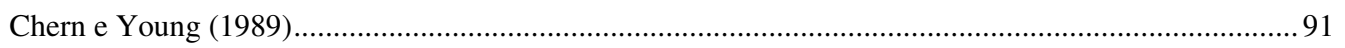

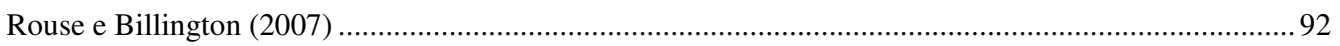

4.4.2 Ensaios realizados sob solicitação de flexão..................................................................92

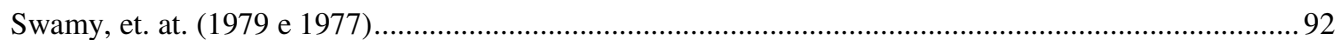

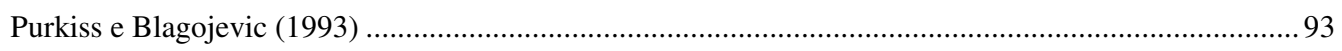

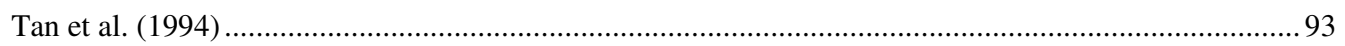

4.4.3 Ensaios realizados sob solicitação de tração ..............................................................94

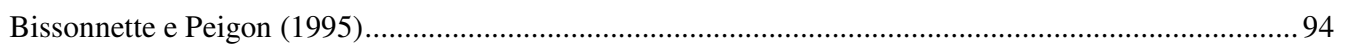

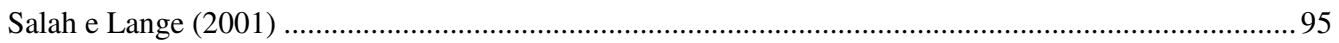

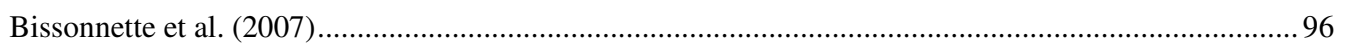

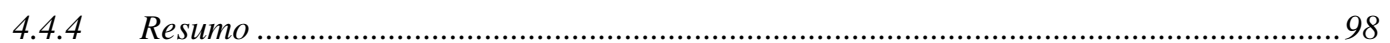

4.5 INTERAÇÃO ENTRE OS FENÔMENOS DE FLUÊNCIA E DE FRATURAMENTO.................................100

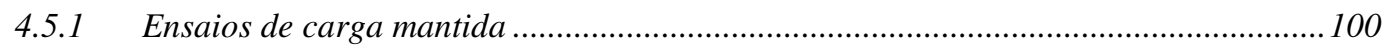

4.5.2 Efeito da taxa de carregamento.................................................................................... 101

4.5.3 Ensaios de Relaxação (Deformação mantida) ........................................................... 103

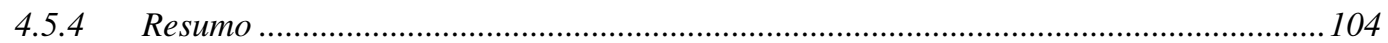

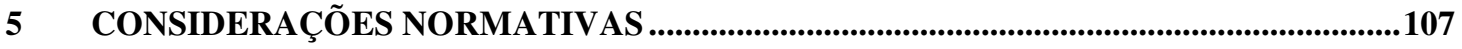

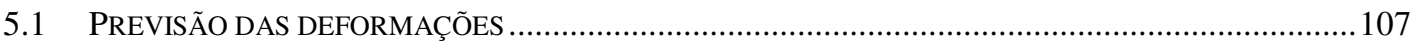

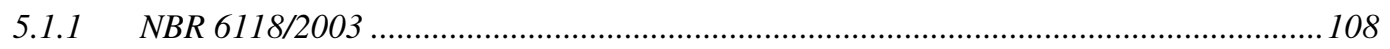

5.1.1.1 Forma Simplificada (item 8.2.11 da norma) .................................................................. 108 
5.1.1.2 Método preciso (Anexo A da norma NBR-6118) .................................................................109

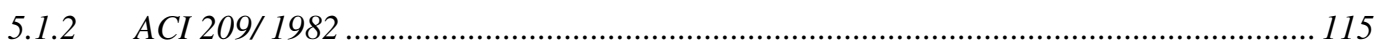

5.1.2.1 Previsão do coeficiente de fluência.............................................................................................116

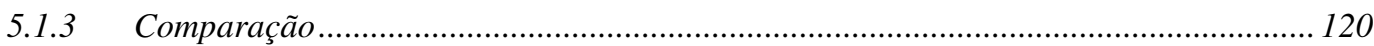

5.2 FLUÊNCIA EM TERMOS DE DESLOCAMENTOS ................................................................. 130

5.2.1 Cálculo da flecha diferida no tempo para vigas de concreto armado ......................... 132

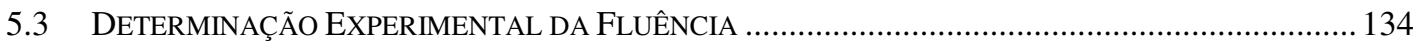

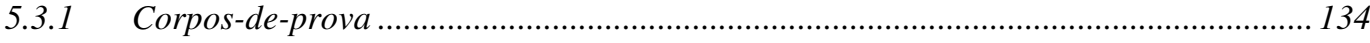

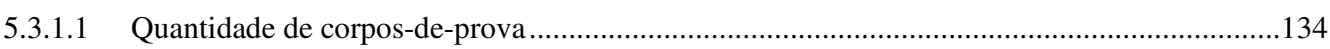

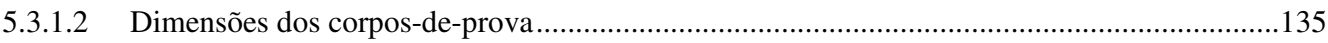

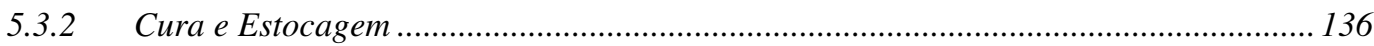

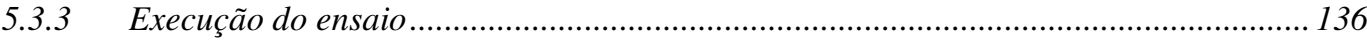

5.3.3.1 Idade de aplicação do carregamento ......................................................................................136

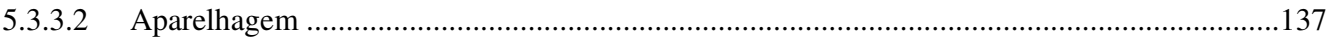

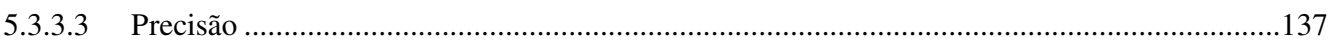

5.3.3.4 Condições de exposição durante o ensaio................................................................................138

5.3.3.5 Aplicação do Carregamento ...............................................................................................138

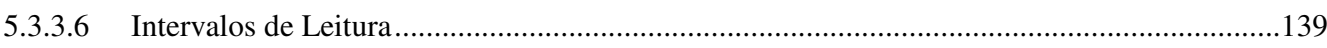

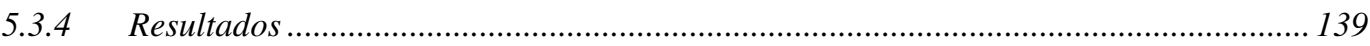

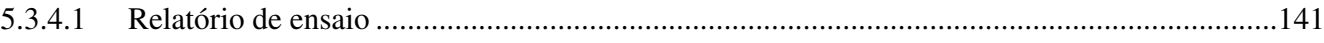

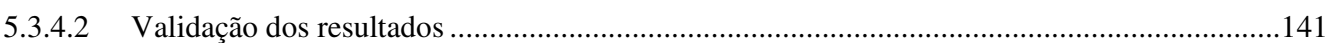

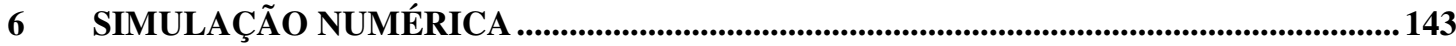

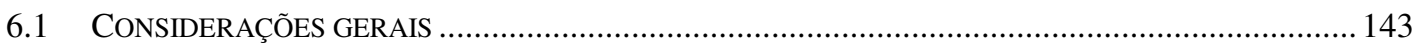

6.2 DESCRIÇÃO DA SIMULAÇÃO........................................................................................ 143

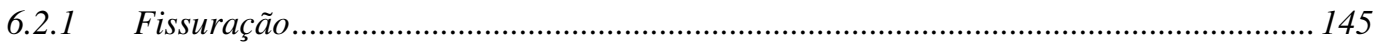

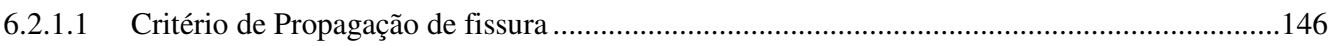

6.2.2 Amolecimento (esmagamento do concreto).............................................................. 147

6.2.3 Retenção ao Cisalhamento.......................................................................................... 148

6.2.4 Modelo de Fluência do concreto................................................................................. 149

6.2.4.1 Análise não linear -passos de tempo ......................................................................................150

6.2.4.2 Parâmetros utilizados para simulação da fluência ................................................................151

6.2.4.3 Equívocos encontrados no modelo de fluência do DIANA ${ }^{\circledR}$..................................................152

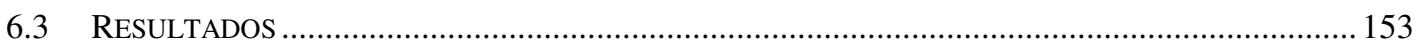

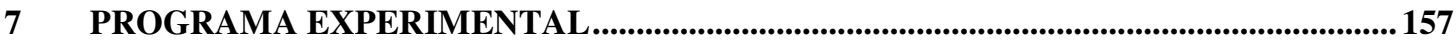

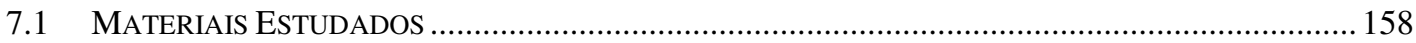

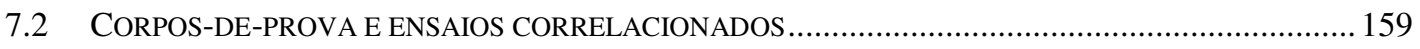

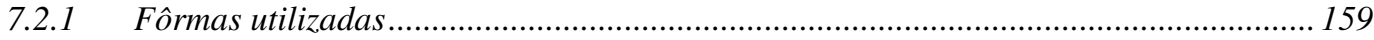

7.3 CONDIÇÕES DE ACLIMATAÇÃO DOS CORPOS-DE-PROVA …...................................................... 162

7.3.1 Dimensionamento da geometria do entalhe e do peso-morto .................................... 162

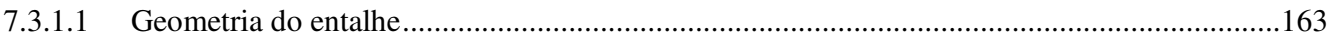


7.3.1.2 Determinação da carga concentrada (peso-morto) ............................................................... 164

7.4 CARACTERÍSTICAS DAS MISTURAS, MOLDAGEM E ARMAZENAMENTO.....................................165

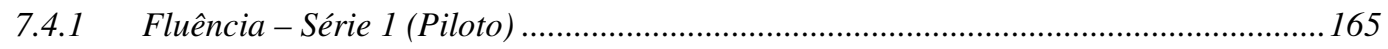

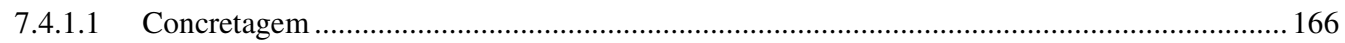

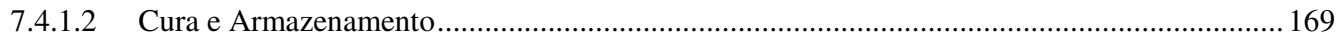

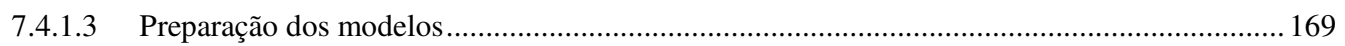

7.4.2 Fluência - Série 2 (Definitivo) ................................................................................. 170

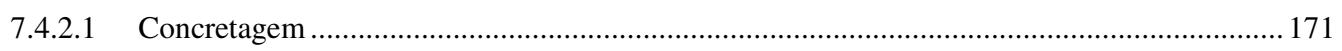

7.4.2.2 Cura e Armazenamento .................................................................................................. 172

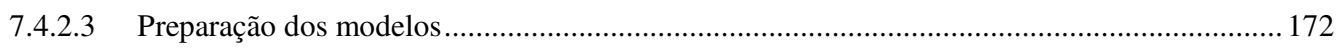

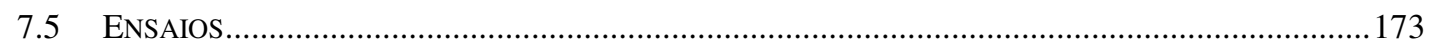

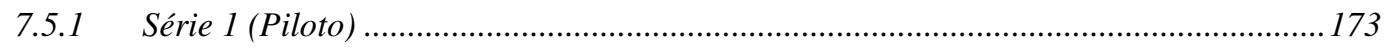

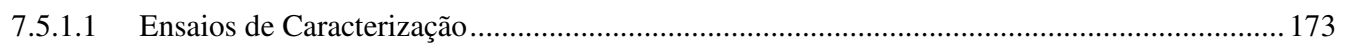

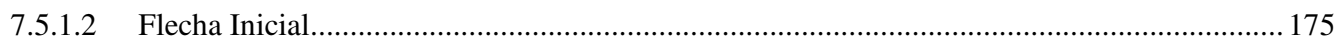

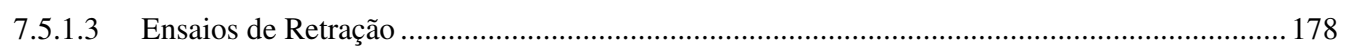

7.5.1.4 Ensaios de Fluência................................................................................................................. 179

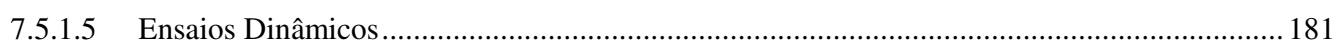

7.5.2 Série 2 (Definitivo) .................................................................................................. 184

7.5.2.1 Ensaios de Caracterização ................................................................................................. 184

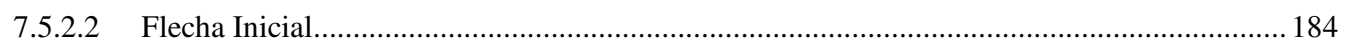

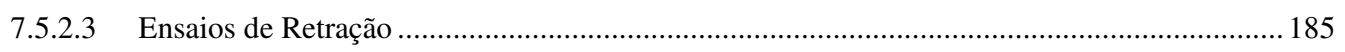

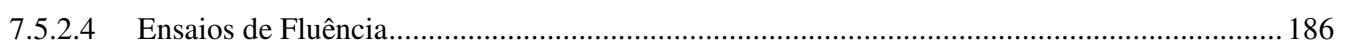

7.5.2.5 Ensaios Dinâmicos................................................................................................................. 187

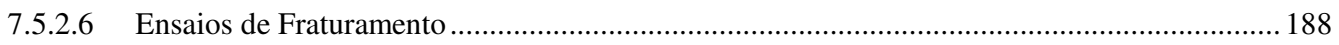

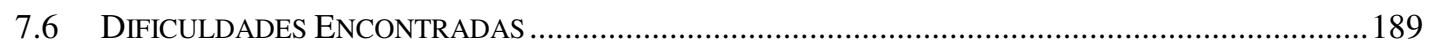

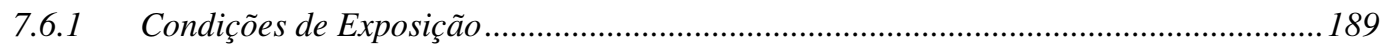

7.6.2 Preservação das características da matriz de concreto nos compósitos estudados...... 190

7.6.3 Viabilização dos Ensaios na Câmara Climatizada .................................................... 191

7.6.4 Definição da Instrumentação das Vigas................................................................... 193

7.6.5 Monitoramento da abertura do entalhe ...........................................................................200

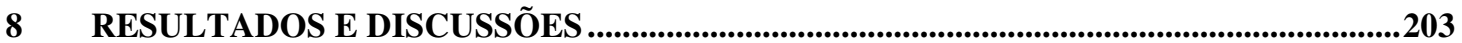

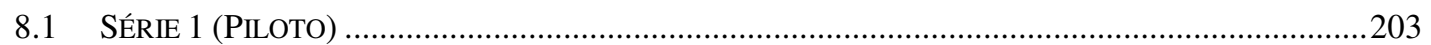

8.1.1 Ensaios de Caracterização …...................................................................................203

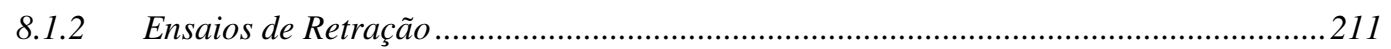

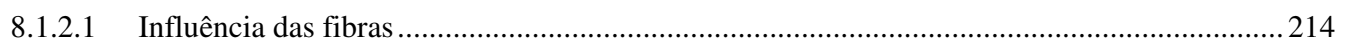

8.1.3 Ensaios de Fluência............................................................................................... 215

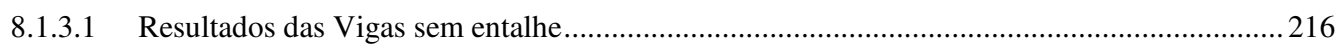

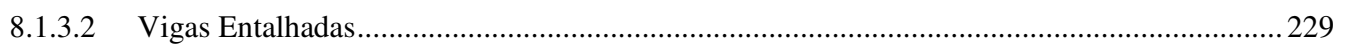

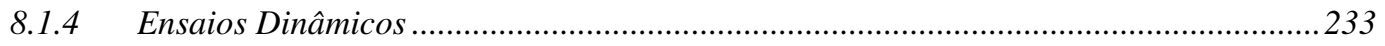

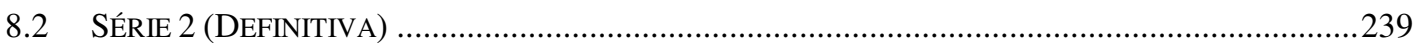

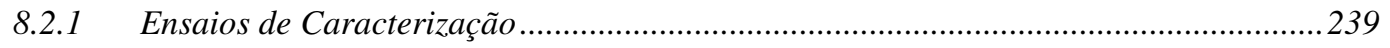




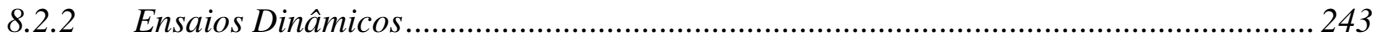

8.2.3 Temperatura e Umidade na Câmara.............................................................................. 245

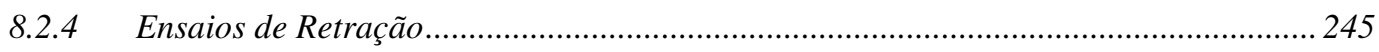

8.2.4.1 Influência da Umidade Relativa do Ambiente .......................................................................249

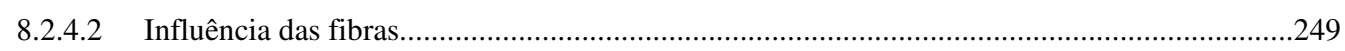

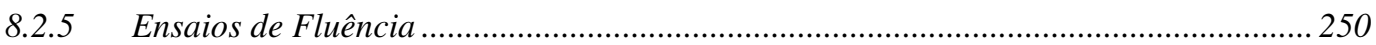

8.2.5.1 Resultados das Vigas Sem Entalhe (VSE) ........................................................................251

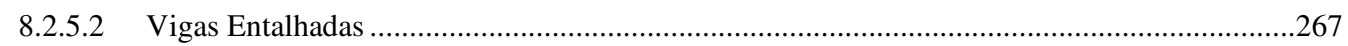

8.3 COMPARAÇÃO ENTRE AS SÉRIES - AVALIAÇÃO DA IDADE DO CARREGAMENTO.......................276

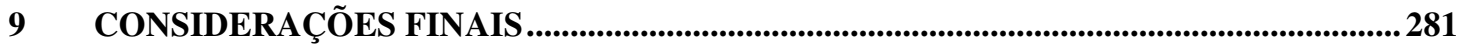

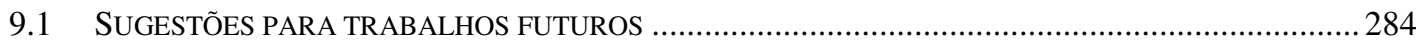

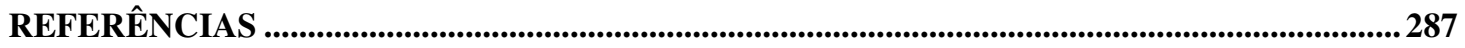

APÊNDICE A - ENSAIOS DE CARACTERIZAÇÃO ......................................................297

APÊNDICE B - MOMENTO DE FISSURAÇÃO/ FLECHA ELÁSTICA ......................................301

APÊNDICE C - LEITURAS CMOD ........................................................................................303 



\subsection{Justificativa do Trabalho}

De forma geral, existe uma grande carência na avaliação da fluência do concreto estrutural submetido a solicitações diferentes da compressão uniaxial. Isto ocorre principalmente devido a dificuldades experimentais - especialmente por conta dos baixos valores das deformações -, alto custo da instrumentação e falta de experiências anteriores. Entretanto, o conhecimento da fluência na tração e na flexão é de grande importância, tendo em vista as principais implicações deste fenômeno na prática estrutural, tais como o aumento dos deslocamentos - que pode comprometer as condições de serviço de edificações e obras de arte -, e a relaxação das tensões de tração induzidas por retração restringida, sendo este tópico de interesse em casos de reparo estrutural e estruturas massivas, que sofrem por retração diferencial, como as barragens.

Nos últimos anos, têm-se estudado intensamente novas tecnologias para obtenção de concretos de elevado desempenho. Entenda-se por desempenho não apenas o ganho de resistência, mas sim a melhoria de diversas propriedades como tenacidade, ductilidade, restrição à formação de fissuras e deformabilidade, estando esta última relacionada diretamente ao comportamento do concreto ao longo do tempo.

Neste sentido, diversos pesquisadores têm se dedicado ainda mais ao estudo do desempenho do concreto reforçado com fibras de aço (CRFA), cujas vantagens são reconhecidas no ganho de tenacidade na flexão, restrição à fissuração, ductilidade e capacidade última pós-pico de resistência. Contudo, o conhecimento do comportamento do CRFA submetido a tensões mantidas ainda carece de estudos, podendo-se observar inúmeras lacunas e contradições na literatura sobre o assunto, o que justifica parte dos objetivos deste trabalho.

Por outro lado, dentre as linhas de pesquisas promissoras para o avanço do 
conhecimento e previsão da fluência destaca-se a interação entre os fenômenos de fluência e fraturamento (Bazant, 1993). Desta forma, parece interessante e potencialmente esclarecedora a realização de ensaios de longa duração em vigas entalhadas, com o objetivo de analisar a evolução dos deslocamentos verticais, com controle da formação de fissuras pelo monitoramento dos deslocamentos de abertura da entrada do entalhe (CMOD).

Para tanto, considerou-se que, numa viga, a intensificação de tensões promovida por um entalhe seria suficiente para a aceleração do processo de fluência, dispensando a utilização de cargas mortas de grande magnitude. A constatação de viabilidade destes ensaios, estando as vigas apenas sob solicitação de seu peso-próprio, abriria novas possibilidades para o estudo da fluência à flexão.

\subsection{Objetivo}

O principal objetivo da pesquisa foi analisar o potencial e as dificuldades inerentes a um método de caracterização da fluência do concreto por meio de ensaios de flexão, com a aplicação de conceitos da Mecânica da Fratura em vigas entalhadas submetidas apenas à ação do peso próprio.

Ao mesmo tempo - ao eleger-se o concreto reforçado com fibras de aço (CRFA) como objeto de investigação no programa experimental -, objetivou-se também analisar a influência da adição das chamadas "microfibras" de aço ao CRFA convencional sobre o seu comportamento à fluência.

Como objetivos secundários - porém não menos importantes para a formação acadêmica da pesquisadora - estabeleceram-se sub-projetos de pesquisa, alguns à procura de resultados objetivos, outros com vistas ao aperfeiçoamento metodológico, que foram:

○ sistematizar a investigação experimental para caracterização do concreto reforçado com fibras de aço, determinando-se, em diferentes idades, suas propriedades mecânicas como resistência à compressão, resistência à tração e módulo de elasticidade;

- desenvolver métodos de obtenção de parâmetros experimentais de fluência, como fluência específica, coeficiente de fluência e função de fluência, para confrontação com resultados encontrados na literatura;

- estabelecer procedimentos para compararação de curvas de fluência obtidas 
experimentalmente com aquelas derivadas dos modelos numéricos efetuados no programa computacional DIANA ${ }^{\circledR}$ e também com o modelo de previsão da norma brasileira (NBR 6118:2003) e da norma americana (ACI 209:1982);

- avaliar métodos de quantificação do processo de danificação devido à fluência e retração, por meio de Análise Dinâmica Modal sobre resultados de ensaios dinâmicos de vibração livre;

○ contribuir, em geral, ao desenvolvimento de trabalhos que envolvam o efeito de ações de longa duração nas estruturas de concreto que venham a ser realizados no Laboratório de Estruturas (LE-EESC).

\subsection{Metodologia}

O primeiro passo para elaboração do trabalho foi realizar uma extensa revisão bibliográfica relativa aos aspectos envolvidos na pesquisa. Desta maneira, a partir de todo material colhido na literatura, foram compostos os capítulos iniciais da dissertação, os quais sintetizam a fundamentação teórica.

A partir dos objetivos estabelecidos e do embasamento teórico, iniciou-se pela simulação numérica dos ensaios de fluência a realizar, com o intuito de estimar a ordem de grandeza dos deslocamentos, a possibilidade de fissuração, etc. Logo, foram dimensionados os modelos e obtidas as curvas de deslocamento ao longo do tempo na forma que se desejava analisar.

O passo seguinte tratou da definição dos procedimentos de ensaio e dos parâmetros constantes ou variáveis para a realização do programa experimental. Dentre as decisões a serem tomadas, listam-se os materiais a serem utilizados, equipamentos e instrumentos, além da análise dos aspectos envolvidos na viabilização dos ensaios (tais como transporte dos modelos, posicionamento, armazenamento, etc.).

Cumprido o programa experimental, foram realizadas novas simulações numéricas, utilizando desta vez dados de entrada provenientes dos ensaios, de forma que os resultados experimentais pudessem ser comparados com aqueles fornecidos numericamente. Para análise dos resultados foram também obtidas curvas de fluência segundo expressões normativas. Finalizada a análise dos resultados, foram estabelecidas as conclusões do trabalho e outras considerações finais. 


\subsection{Apresentação do trabalho}

Apresentou-se no presente capítulo a motivação do tema escolhido, assim como a declaração dos objetivos da pesquisa e uma síntese da metodologia adotada para sua realização.

No Capítulo 2, é feita uma abordagem introdutória sobre os materiais constituintes e as principais propriedades do concreto simples e do concreto reforçado com fibras de aço (CRFA). Neste capítulo são definidas as propriedades mecânicas de interesse, sendo dada atenção especial àquela diretamente relacionada à deformabilidade do concreto, o módulo de elasticidade. Desta forma, comenta-se os principais fatores que interferem nesta propriedade, assim como sua determinação experimental e estimativa por expressões analíticas.

No Capítulo 3, são apresentados fundamentos da Mecânica da Fratura, iniciando pelos conceitos básicos da MFEL (Mecânica da Fratura Elástica Linear). Em seguida, são discutidas as particularidades do fraturamento de materiais de ruptura quase-frágil, como o concreto.

No Capítulo 4, são discutidos diversos aspectos sobre a fluência do concreto, tratando os conceitos básicos sobre o fenômeno, os fatores influentes, as expressões matemáticas de ajuste e previsão, a fluência em concretos reforçados com fibras e as pesquisas realizadas sobre a interação entre fluência e fraturamento.

No Capítulo 5, são descritos os procedimentos normativos para previsão e avaliação experimental da fluência. Considerando-se que nas simulações numéricas foi utilizado o modelo de fluência da norma americana ACI 209:1982, é feita a descrição deste modelo assim como a descrição das expressões da norma brasileira (NBR 6118:2003). Esta abordagem parece interessante, uma vez que parte da análise dos resultados foi realizada comparando-se as curvas experimentais e numéricas com aquelas derivadas dos modelos de previsão.

No Capítulo 6, são descritos os procedimentos que envolveram a simulação computacional no software DIANA ${ }^{\circledR}$. Foram modeladas vigas de mesma geometria, condições de apoio e carregamento que aquelas ensaiadas, sendo que, como dados de entrada dos modelos numéricos foram utilizados dados dos ensaios. As análises consideraram a não linearidade física do material, tendo em vista o objetivo de avaliar a fluência e a fissuração.

No Capítulo 7, descreve-se detalhadamente todo o programa experimental do trabalho. Os resultados do estudo experimental são apresentados e discutidos no Capítulo 8. Finalizando, no Capítulo 9, as conclusões e sugestões para trabalhos futuros são apresentadas. 
O concreto é, sem dúvida, o material mais utilizado na Construção Civil. O alto consumo deste material justifica-se basicamente por sua excelente resistência à água, pela possibilidade de moldar diferentes formas e tamanhos e principalmente pelo custo e acessibilidade dos materiais constituintes, facilmente encontrados em praticamente todas as regiões. Além disso, resíduos industriais podem ser reciclado no concreto, substituindo tanto o aglomerante como o agregado, o que torna seu emprego mais sustentável (METHA; MONTEIRO, 1994).

Conforme ilustrado na Fig. 2.1, nota-se a maior deformabilidade do concreto em comparação com a do agregado, quando considerado isoladamente. Isso decorre do fato de que em um material composto, as deformações dependem não apenas das propriedades de seus constituintes de forma isolada, mas também do modo no qual eles se combinam e interagem.

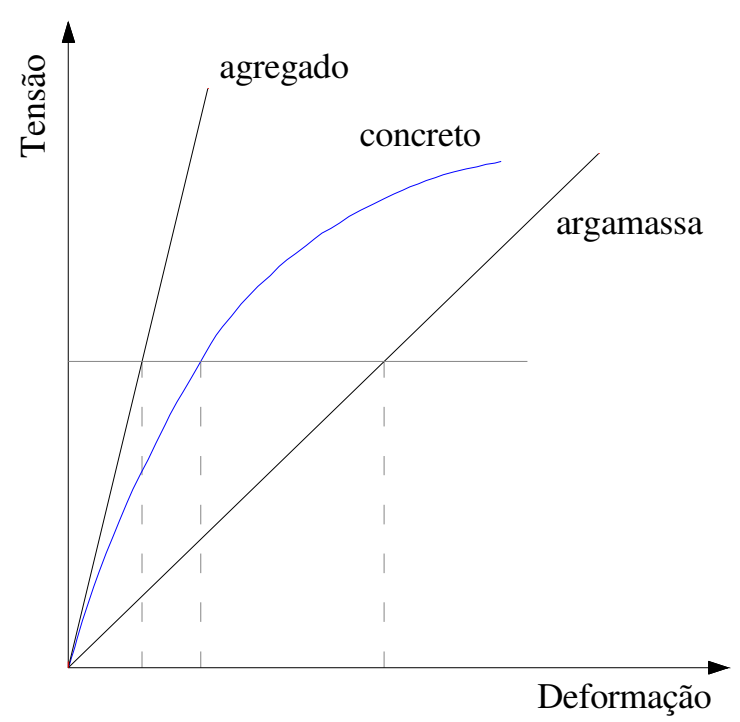

Fig. 2.1: Comportamento tensão-deformação da pasta de cimento, do agregado e do concreto. Adaptado de Metha e Monteiro, 1994.

Mesmo antes da aplicação de carga externa, o concreto apresenta microfissuras na zona de transição entre a argamassa e o agregado graúdo. O número e abertura destas fissuras 
dependem, entre outros fatores, das características de exudação, resistência da zona de transição e da história de cura do concreto. Sob condições normais de cura, devido às diferenças nos seus módulos de deformação, deformações diferenciais surgem entre a matriz e o agregado, causando fissuras na zona de transição.

Além disso, a resistência do material composto é inferior às resistências individuais de cada um de seus componentes. Essa contradição à Lei das Misturas decorre do importante papel da zona de transição entre o agregado e a matriz.

\subsection{Propriedades Mecânicas}

Em projeto, como se considera o concreto como material mais adequado para resistir a esforços de compressão, a resistência à compressão é geralmente especificada como parâmetro principal. As resistências à tração e à flexão são da ordem de 10 e 15\%, respectivamente, da resistência à compressão.

O módulo de elasticidade, ou módulo de Young, é definido como a relação entre a tensão e a deformação resiliente. No caso do concreto, podem-se ter deformações em regime elástico para tensões entre 30 e 50\% da carga de ruptura, dependendo da classe de resistência do concreto. $\mathrm{O}$ módulo de elasticidade à compressão do concreto varia de 14 a $40 \mathrm{GPa}$.

Ultrapassado o limite de elasticidade, a relação tensão-deformação torna-se não-linear, ocorrendo deformações permanentes. A quantidade de deformação permanente que pode ocorrer antes do rompimento é uma medida de ductilidade do material. Já a tenacidade é a propriedade mecânica apresentada pelo material de dissipar energia durante o processo de colapso.

Neste trabalho, sem dúvida, a propriedade mecânica do concreto de maior relevância é aquela relacionada à medida de deformabilidade do concreto estrutural, ou seja, o módulo de elasticidade. Seu valor influencia diretamente o cálculo das flechas em vigas, assim como é parâmetro fundamental dos modelos de fraturamento, além é claro de ser uma propriedade mensurável nos ensaios dinâmicos de vibração livre. A variação do módulo de elasticidade está também intimamente relacionada às deformações dependentes do tempo (fluência e retração).

Dada a relevância do módulo de elasticidade como parâmetro de análise nesta pesquisa, considerações mais detalhadas são feitas sobre sua determinação experimental 
através de ensaios estáticos, estimativa por expressões normativas a partir da resistência à compressão, e determinação do módulo de elasticidade dinâmico (estimativa teórica e determinação experimental).

\subsubsection{Módulo de Elasticidade}

O limite de elasticidade indica a deformação máxima permitida antes de o material adquirir deformação permanente e também é uma maneira de identificar o grau de restrição à deformação. Além disso, ultrapassado o limite de elasticidade ocorre diminuição na rigidez do elemento de concreto, em virtude da fissuração.

O módulo de elasticidade pode ser obtido a partir da curva tensão-deformação resultante de um ensaio estático de compressão axial, sendo neste caso, definido como módulo de elasticidade estático $\left(E_{c}\right)$. De acordo com a reta utilizada na sua determinação, $E_{c}$ pode ser tangente ou secante, conforme ilustra a Fig. 2.2. A inclinação da reta tangente ao diagrama em um ponto qualquer define o módulo tangente, aplicado a pequenas variações de carga em relação ao ponto considerado. O módulo tangente inicial é dado pela inclinação da reta tangente à curva na origem. Já o módulo secante, é a inclinação da reta secante ao diagrama definida da origem (ou a partir de um valor mínimo) ao ponto que equivale à tensão considerada.

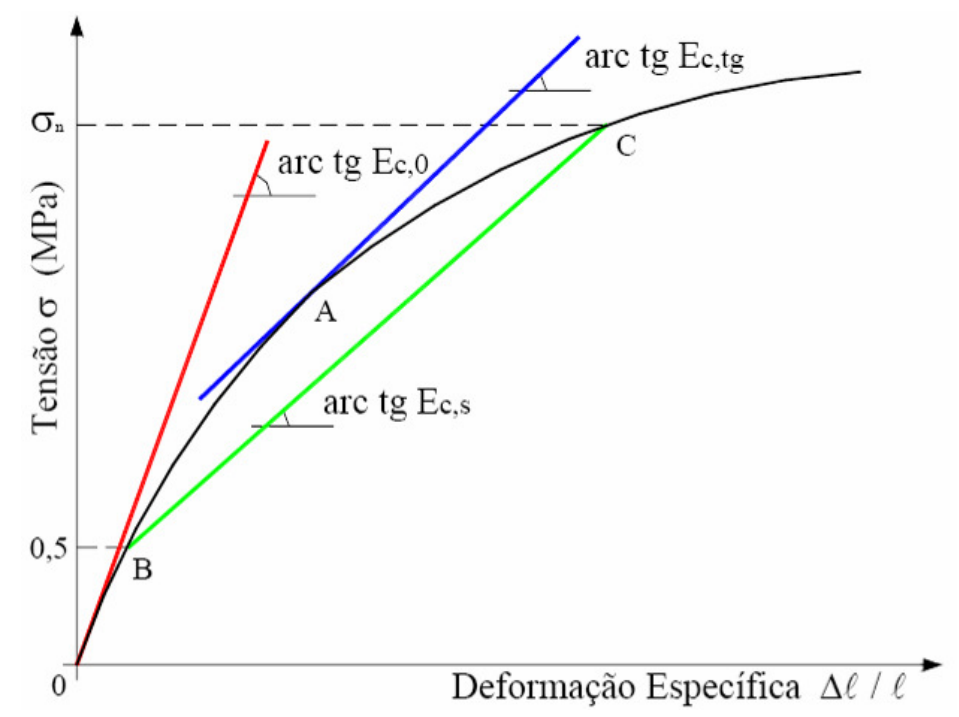

Fig. 2.2: Representação esquemática dos módulos de elasticidade: tangente $\left(\mathrm{E}_{\mathrm{c}, \mathrm{tg}}\right)$, tangente inicial $\left(\mathrm{E}_{\mathrm{c}, 0}\right)$, e secante $\left(\mathrm{E}_{\mathrm{c}, \mathrm{s}}\right)$. Fonte: Almeida, 2005.

No caso da obtenção experimental do módulo secante, é interessante indicar quais os níveis de tensão que delimitaram a reta utilizada na sua determinação. Tendo em vista o 
comportamento não-linear, decorrente do processo de microfissuração, conforme maior a tensão superior, menor o módulo.

Para concretos de diferentes resistências, o $E_{c, s}$ é tanto maior quanto maior a resistência do concreto, pois sob uma mesma tensão, as deformações em um concreto de maior resistência serão menores e, conseqüentemente, maior será a inclinação da reta.

De acordo com a norma brasileira NBR 6118:2003, o módulo tangente inicial deve ser utilizado para avaliação do comportamento global da estrutura e cálculo das perdas de protensão, ao passo que o módulo secante deve ser utilizado para análises estáticas (determinação de esforços solicitantes e verificação dos estados limites de serviço) e para avaliação do comportamento de um elemento estrutural ou seção transversal.

A NBR 6118:2003 indica também que o valor do módulo secante $\left(E_{c, s}\right)$ tem valor igual a $85 \%$ do módulo tangente inicial $\left(E_{c, 0}\right)$, sendo que essa redução tem como finalidade considerar as deformações plásticas iniciais. O módulo secante é o recomendado a ser utilizado nas análises elásticas de projeto.

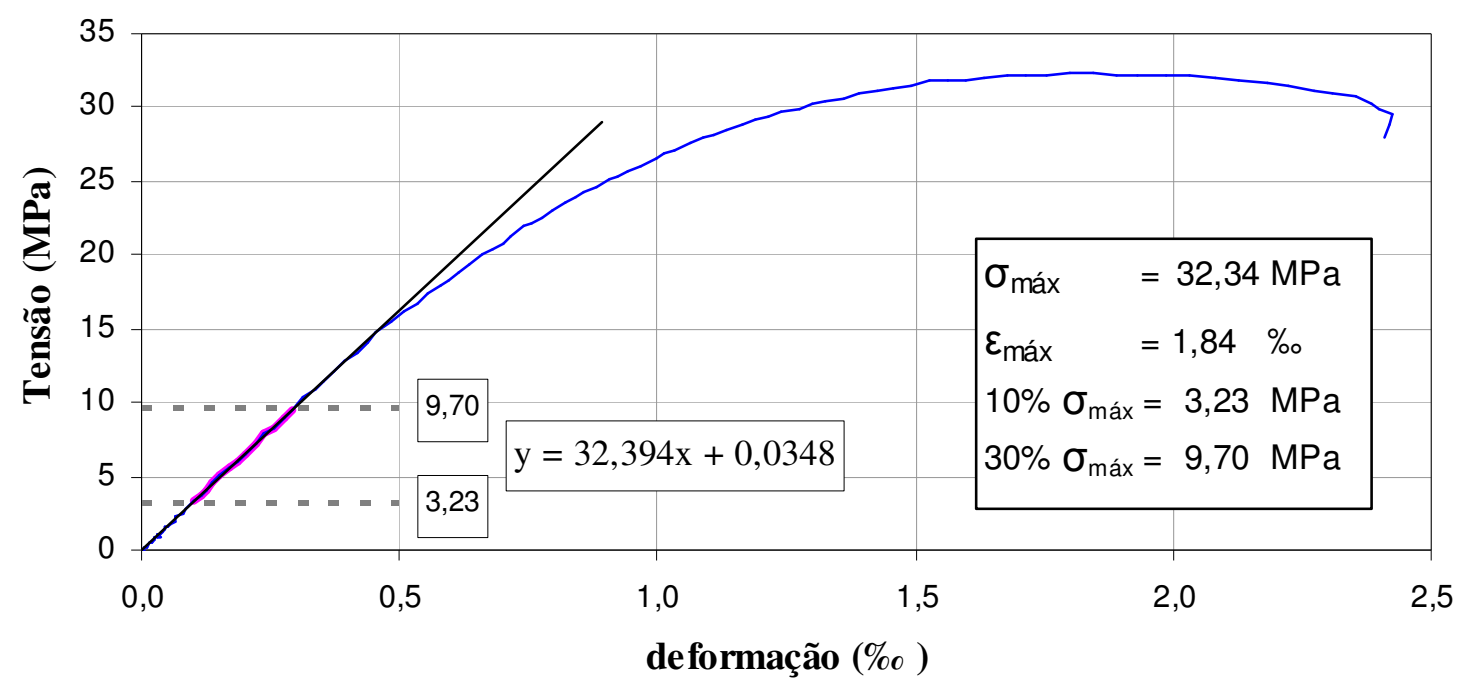

Fig. 2.3: Determinação experimental do módulo de elasticidade.

A norma brasileira NBR 8522:2003 estabelece os limites de 0,5 MPa e 30\% da carga máxima, para ensaio padronizado de compressão axial. Já de acordo com a norma americana ACI 318:1992, sua determinação experimental consiste na linha reta que une a tensão nula à tensão de $0,45 f_{c}^{\prime}$.

Neste trabalho a determinação do módulo de elasticidade, a partir de ensaios estáticos de compressão axial, foi realizada considerando como trecho elástico o intervalo da curva tensão-deformação limitado entre $10 \%$ e $30 \%$ da tensão de ruptura. Para este intervalo é feita 
uma regressão linear, sendo que o coeficiente angular da reta define o módulo de elasticidade, conforme ilustra a Fig. 2.3.

O valor do módulo de elasticidade depende tanto de condições de ensaio como das características da mistura. A primeira categoria engloba as condições de exposição durante a armazenagem e o grau de saturação do corpo-de-prova, além da taxa de carregamento. Em corpos-de-prova expostos a condições de secagem podem surgir fissuras em decorrência da retração, o que acarreta em menor restrição à deformação. Já a velocidade de aplicação da carga afeta a magnitude das deformações, a taxa de fissuração e o grau de não-linearidade (formato do diagrama tensão-deformação). Quanto maior a taxa de carregamento, maior o valor do módulo e da resistência à compressão.

Com relação às características da mistura existem diversos fatores que direta ou indiretamente afetam o módulo de elasticidade, como: as propriedades dos materiais constituintes, (porosidade, dimensão máxima, forma, textura superficial, granulometria, composição mineralógica, módulo de elasticidade, etc.); a dosagem da mistura e a relação água/cimento; a porosidade da matriz, os espaços vazios e as microfissuras da zona de transição.

\section{- Expressões normativas para estimativa do módulo de elasticidade.}

Tabela 2.1: Expressões normativas para o módulo de elasticidade (módulo e resistência em MPa).

\begin{tabular}{|c|c|c|}
\hline $\begin{array}{l}\text { ACI } \\
\text { (massa específica entre } \\
1442 \text { e } 2483 \mathrm{~kg} / \mathrm{m}^{3} \text { e com } \\
\text { resistência até } 41 \mathrm{MPa} \text { ). }\end{array}$ & $E_{c}=0,043 \cdot \sqrt{w_{c}^{3} \cdot f_{c}}$ & $\begin{array}{l}w_{c}: \text { massa específica }\left(\mathrm{kg} / \mathrm{m}^{3}\right) \\
f_{c}: \text { resistência à compressão. }\end{array}$ \\
\hline $\begin{array}{c}\text { NBR } \\
\text { (concretos do Grupo I da } \\
\text { NBR 8953:1992, ou seja, } \\
\text { concretos C20, C25, C30, } \\
\text { C35, C40 e C50). }\end{array}$ & $E_{c i}=5600 \sqrt{f_{c k}}$ & $\begin{array}{l}f_{c k:} \text { resistência à compressão } \\
\text { característica ( } 28 \text { dias). }\end{array}$ \\
\hline $\begin{array}{l}\text { CEB } \\
\text { (concreto de peso normal } \\
\text { e resistência de até } 80 \\
\mathrm{MPa} \text { ). }\end{array}$ & $E_{c, 0}=\alpha \cdot\left(2,15 \times 10^{4}\right) \cdot\left(\frac{f_{c m}}{10}\right)^{1 / 3}$ & $\begin{array}{l}E_{c, 0}: \text { módulo de elasticidade } \\
\text { inicial, aos } 28 \text { dias. } \\
f_{c m}: \text { resistência média à } \\
\text { compressão aos } 28 \text { dias. } \\
\alpha: \text { fator de correção, função do } \\
\text { agregado graúdo (Tabela } 2.2 \text { ). }\end{array}$ \\
\hline
\end{tabular}


$\mathrm{Na}$ falta de dados experimentais, há à disposição inúmeras expressões normativas que relacionam o módulo de elasticidade com a resistência à compressão. Algumas delas o correlacionam com a raiz quadrada da resistência (ACI 318:2002 e NBR 6118:2003) e outras com a raiz cúbica (CEB 1990 e norma britânica CP 110:1972). A Tabela 2.1 traz as expressões mais utilizadas.

Tabela 2.2: Índice de correção do módulo de elasticidade em função da natureza do agregado, aplicável unicamente ao CEB 1990.

\begin{tabular}{c|c}
\hline Tipos de agregado & $\boldsymbol{\alpha}$ \\
\hline Basalto, diabásio e calcário sedimentar denso & 1,1 a 1,2 \\
\hline Granito e gnaisse & 1,0 \\
\hline Calcário metamórfico e metasedimento & 0,9 \\
\hline Arenito & 0,7 \\
\hline
\end{tabular}

\section{- Módulo de elasticidade dinâmico}

O módulo de elasticidade dinâmico $\left(E_{c, d}\right)$ pode fornece informações a respeito da deformabilidade do concreto, da rigidez de um elemento estrutural e da integridade da estrutura, inclusive daquelas que estão submetidas a ações estáticas usuais. A qualidade e a repetibilidade, apresentadas nos resultados dos ensaios experimentais dinâmicos, fazem com que o módulo dinâmico seja um parâmetro global, obtido de maneira integrada e com alto grau de confiabilidade. Por ser uma propriedade que pode ser obtida num mesmo corpo-deprova, ao longo de um determinado período, o módulo dinâmico pode ser empregado em ensaios que avaliam as alterações do concreto submetido a solicitações contínuas, tais como fluência e retração, além de possibilitar a quantificação de dano e deterioração (Almeida, S. F., 2005).

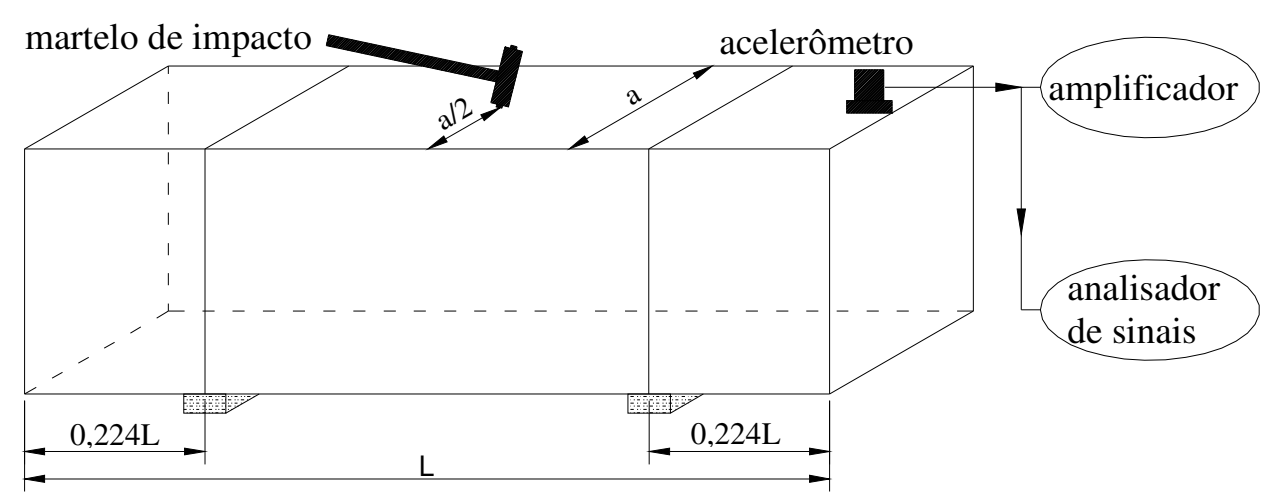

Fig. 2.4: Disposição esquemática dos equipamentos para ensaio da frequiência de ressonância. Método da Ressonância de Impacto - Vibração Transversal. 
Neste trabalho, a obtenção experimental do módulo de elasticidade dinâmico foi realizada por meio de ensaios de vibração livre, pelo método da freqüência de ressonância de impacto, observando as recomendações da norma ASTM C - 215:1991. Neste método, a amostra, normalmente uma barra de dimensões conhecidas, é apoiada pelos pontos nodais e excitada por um martelo de impacto. As vibrações mecânicas são captadas por um sensor (acelerômetro piezoelétrico) e convertidas em sinais de resposta. Essas respostas são amplificadas e enviadas a um aparelho ou a um sistema de aquisição que, após tratamento matemático adequado, geram funções de resposta de freqüência (FRF). A análise da FRF permite identificar as freqüências de ressonância correspondentes aos diversos modos de vibração. A Fig. 2.4 ilustra a disposição dos instrumentos e sua posição, para determinação da freqüência fundamental transversal de vibração no Modo I.

De acordo com a norma americana, os apoios devem possuir frequiência fundamental fora da faixa de freqüência do material estudado. As amostras podem ser cilíndricas ou prismáticas, desde que a relação entre o comprimento e a maior dimensão da seção transversal seja entre 3 e 5 (valor ideal), podendo ser diferente destes valores, porém maior do que 2. Para valores muito grandes ou muito pequenos torna-se difícil excitar a amostra na freqüência fundamental. Obtida a freqüência fundamental transversal a partir do ensaio, procede-se o cálculo do módulo de dinâmico, a partir a seguinte formulação (ASTM C - 215:1991):

$$
E_{c, d}=C_{m} \cdot m \cdot f^{2}
$$

Sendo:

- $\quad E_{c, d}$ é o módulo de elasticidade dinâmico $(\mathrm{Pa})$;

- $\quad m$ é a massa da amostra $(\mathrm{kg})$;

- $\quad f$ é a freqüência fundamental transversal, obtida do ensaio $(\mathrm{Hz})$;

- $\quad C_{m}=0.9464\left(\frac{L^{3} \cdot T}{b \cdot t^{3}}\right)$, para prismas ou $C_{m}=1.6067\left(\frac{L^{3} \cdot T}{b \cdot t^{3}}\right)$, para cilindros;

- $\quad L$ é o comprimento da amostra $(\mathrm{m})$;

- $\mathrm{d}$ é o diâmetro do cilindro (m);

- $\quad$ t, b são as dimensões da seção transversal do prisma, sendo t na direção da vibração (m);

- $\quad$ é um fator de correção que depende da relação entre o raio de giração (i) e o comprimento da amostra e do coeficiente de Poisson $(v)$;

- $\quad$ i é o raio de giração, dado por $i=d / 4$, para cilindros e $i=0,2887 t$, para prismas. 
Os valores do fator de correção T são tabelados relativos a um coeficiente de Poisson igual a 1/6. Para um coeficiente de Poisson diferente de 1/6, o fator de correção $\left(T^{\prime}\right)$ deve ser obtido com a seguinte expressão:

$$
T^{\prime}=T \cdot\left[\frac{1+\left(0,26 v+3,22 v^{2}\right) \cdot(i / l)}{1+0,1328 \cdot(i / l)}\right]
$$

O fator de correção é obtido por uma formulação que envolve o coeficiente de Poisson e leva em consideração os efeitos do cisalhamento e da inércia à rotação, que são normalmente desprezados quando a relação comprimento/largura é suficientemente grande (hipótese de Euler-Bernoulli).

De acordo com Almeida, S. F. (2005), o ponto central dos métodos de detecção de dano baseados em ensaios de vibração é que os parâmetros dinâmicos dependem das propriedades físicas da estrutura (propriedades elásticas, geometria e densidade do material) e, portanto, qualquer alteração em uma dessas propriedades provoca mudança nos parâmetros dinâmicos (freqüências naturais, fatores de amortecimento e modos de vibração).

Segundo Metha e Monteiro (1994), o módulo dinâmico é normalmente 20, 30, e 40\% maior do que o módulo estático para concretos de alta, média e baixa resistência, respectivamente.

\subsection{Deformações no concreto}

Quando exposto à secagem, um elemento de concreto mantido sob tensão constante apresentará, em um tempo $t$ (sendo $t>t_{0}$, e $t_{0}$ a data de aplicação do carregamento), uma deformação total, denominada $\varepsilon_{c t}\left(t, t_{0}\right)$. A deformação total é dada pela soma das deformações dependentes da tensão aplicada, que são a deformação elástica inicial $\varepsilon_{c i}\left(t_{0}\right)$ e deformação por fluência $\varepsilon_{c c}\left(t, t_{0}\right)$ com as deformações volumétricas independentes da tensão aplicada, como a retração $\varepsilon_{c s}\left(t_{0}, t\right)$ e a deformação devida à variação de temperatura $\mathcal{E}_{c T}(t, T)$, conforme se apresenta pela expressão:

$$
\mathcal{E}_{c t}\left(t, t_{0}\right)=\varepsilon_{c i}\left(t_{0}\right)+\varepsilon_{c c}\left(t, t_{0}\right)+\varepsilon_{c s}\left(t, t_{0}\right)+\varepsilon_{c T}(t, T)
$$

O primeiro subscrito refere-se à inicial do material "concreto". O segundo subscrito refere-se à origem da deformação: fluência (creep, em inglês), retração (shrinkage, em inglês) 
ou variação de temperatura.

- Deformações dependentes da tensão aplicada

A deformação elástica inicial é facilmente obtida conhecendo-se o módulo de elasticidade e a tensão aplicada. Outras considerações sobre a determinação e previsão do módulo de elasticidade são apresentadas no Capítulo 4.

Já a determinação das deformações por fluência pode ser feita diretamente por dados experimentais, pela extrapolação de ensaios de curta duração e expressões matemáticas de ajuste ou ainda por meio de modelos analíticos de fluência disponíveis na literatura. Considerações adicionais a esse respeito são apresentadas nos itens 4.1.4 e 4.1.5.

\section{- Retração}

A retração é um fenômeno independente do carregamento, que ocorre em virtude da perda de água adsorvida na micro-estrutura do concreto, especificamente na estrutura dos silicatos de cálcio hidratados (C-S-H), provocando diminuição de volume ao longo do tempo. Se o encurtamento de um elemento estrutural causado pela retração é restringido, forças axiais e/ou excêntricas se desenvolvem, podendo induzir o surgimento de fissuras, caso a resistência última do concreto à tração seja excedida.

Mesmos nas situações onde a retração ocorre livremente, existe a possibilidade de ocorrência de fissuração, pois a retração diferencial entre a superfície e o interior da massa de concreto causa um estado de tensões de compressão no interior que é equilibrado com as tensões de tração na superfície.

Em corpos-de-prova selados, em que a umidade varia entre 97 e 99\%, o concreto exibe uma pequena retração, chamada de retração autógena. Ela é decorrência de alterações volumétricas devido às reações de hidratação e é cerca de 20 vezes menor do que a retração por secagem.

- Deformações por variação da temperatura

No caso geral de distribuição de temperatura um elemento estrutural sofre alterações em suas dimensões. Se essas variações dimensionais são restringidas, desenvolvem-se tensões de restrição, que são superpostas às tensões de auto-equilíbrio causadas pela distribuição nãolinear da temperatura. As tensões resultantes, dependendo de suas magnitudes, poderão provocar fissuração do elemento estrutural, caso a resistência num dado ponto seja ultrapassada. 
A deformação do concreto provocada pela variação da temperatura ao longo do tempo é determinada pela expressão a seguir, onde $\alpha_{c T}$ é coeficiente de dilação térmica linear do concreto e $\Delta T(t)$ é a variação da temperatura ao longo do tempo. Esta expressão se aplica à maioria dos materiais da Engenharia que, para efeitos práticos, podem ser considerados isotrópicos.

$$
\varepsilon_{c T}(t, T)=\alpha_{c T} \cdot \Delta T(t)
$$

O coeficiente de dilatação térmica do concreto depende do tipo e do volume de agregado usado, bem como do grau de hidratação da pasta de cimento utilizada na confecção do traço do concreto. Este coeficiente geralmente varia entre 5,5x10-6 (1/ $\left.{ }^{\circ} \mathrm{C}\right)$ e $14 \times 10-6$ $\left(1 /{ }^{\circ} \mathrm{C}\right)$, sendo adotado pela norma NBR-6118:2003 um valor intermediário igual à 10x10-6 $\left(1 /{ }^{\circ} \mathrm{C}\right)$.

\subsection{Reforço com fibras de aço}

$\mathrm{Na}$ presente pesquisa foram avaliadas diversas propriedades mecânicas do concreto reforçado com fibras de aço (CRFA), o que justifica uma descrição, ainda que breve, sobre os principais aspectos relacionados à produção, características no estado fresco e desempenho no estado endurecido deste material. Desta forma, o texto foi elaborado buscando-se responder as seguintes perguntas:

- Quais as vantagens de se incorporar fibras de aço ao concreto, e em que situações esta tecnologia tem sido aplicada?

- Quais são os fatores que interferem no desempenho do CRFA?

- De que maneira o tipo de fibra e sua dosagem devem ser escolhidos para se atingir um determinado desempenho?

- Quais as propriedades mecânicas do CRFA?

- No que consiste a obtenção de um compósito híbrido, e quais as vantagens de sua utilização?

\subsubsection{Introdução}

O ACI 544.1R (2004) define o concreto com fibras de aço como um material feito de cimento hidráulico contendo agregados miúdos e graúdos e fibras discretas e descontínuas. O 
concreto reforçado com fibras de aço pode ser considerado um compósito, onde a matriz é o concreto de cimento Portland e o reforço é constituído pelas fibras de aço distribuídas aleatoriamente na matriz.

Segundo Figueiredo (2000), há no Brasil três tipos de fibras metálicas mais acessíveis no mercado. O primeiro deles consiste da fibra corrugada. Esta fibra é obtida a partir do fio chato que sobra da produção de lã de aço. Este fio é cortado em tiras de 25 a $50 \mathrm{~mm}$ e corrugado, o que aumenta a aderência entre a fibra e a matriz. O segundo tipo de fibra possui extremidade em gancho e seção retangular, produzida a partir de chapas de aço, cortadas na largura da fibra e, concomitantemente, conformadas para obter a ancoragem desejada.

Já o terceiro tipo também consiste em fibras com extremidade em gancho, porém de seção circular. Estas fibras são produzidas a partir de fios trefilados progressivamente até chegar ao diâmetro desejado, o que garante maior resistência mecânica (devido ao encruamento). Suas dimensões mais comuns são: diâmetro entre $0.5 \mathrm{~mm}$ e $1.0 \mathrm{~mm}$ e comprimento entre $25 \mathrm{~mm}$ e $60 \mathrm{~mm}$. Mais informações sobre diferentes formatos e características de fibras metálicas podem ser encontradas em Bentur e Mindess (1990) e no Manual Técnico da Maccaferri ${ }^{1}$.

O principal mecanismo de atuação das fibras trata de obstaculizar ou controlar a abertura de fissuras. Desta forma, dependendo de suas características, as fibras podem atuar tanto nas microfissuras, retardando o processo de coalescência, ou agir sobre as macrofissuras, no trecho pós-pico de resistência, conferindo um aumento significativo da energia associada à ruptura do material. No primeiro caso, pode-se ter aumento na resistência do compósito, e no segundo caso, incremento de ductilidade e tenacidade.

Segundo Ferreira (2007), essa melhoria de desempenho traduzida pelo aumento da sua tenacidade (quer flexional, quer ao fraturamento), é usualmente quantificada a partir da área sob a curva Carga x Deslocamento ou Carga x CMOD (Crack Mouth Opening Displacement), obtida em ensaios laboratoriais, como por exemplo, em ensaios de flexão de vigas ou placas. A ilustração do aumento dessas propriedades, em função do teor de fibras (em massa) incorporado à matriz de um concreto de alta resistência, é apresentada na Fig. 2.5.

\footnotetext{
${ }^{1}$ FIBRAS como elemento estrutural para reforço de concreto: Manual técnico (2008). Maccaferri. Disponível em: <http://www.maccaferri.com.br/downloadDe.php?idioma=0\&download=103>. Acesso em: $10 / 08$.
} 


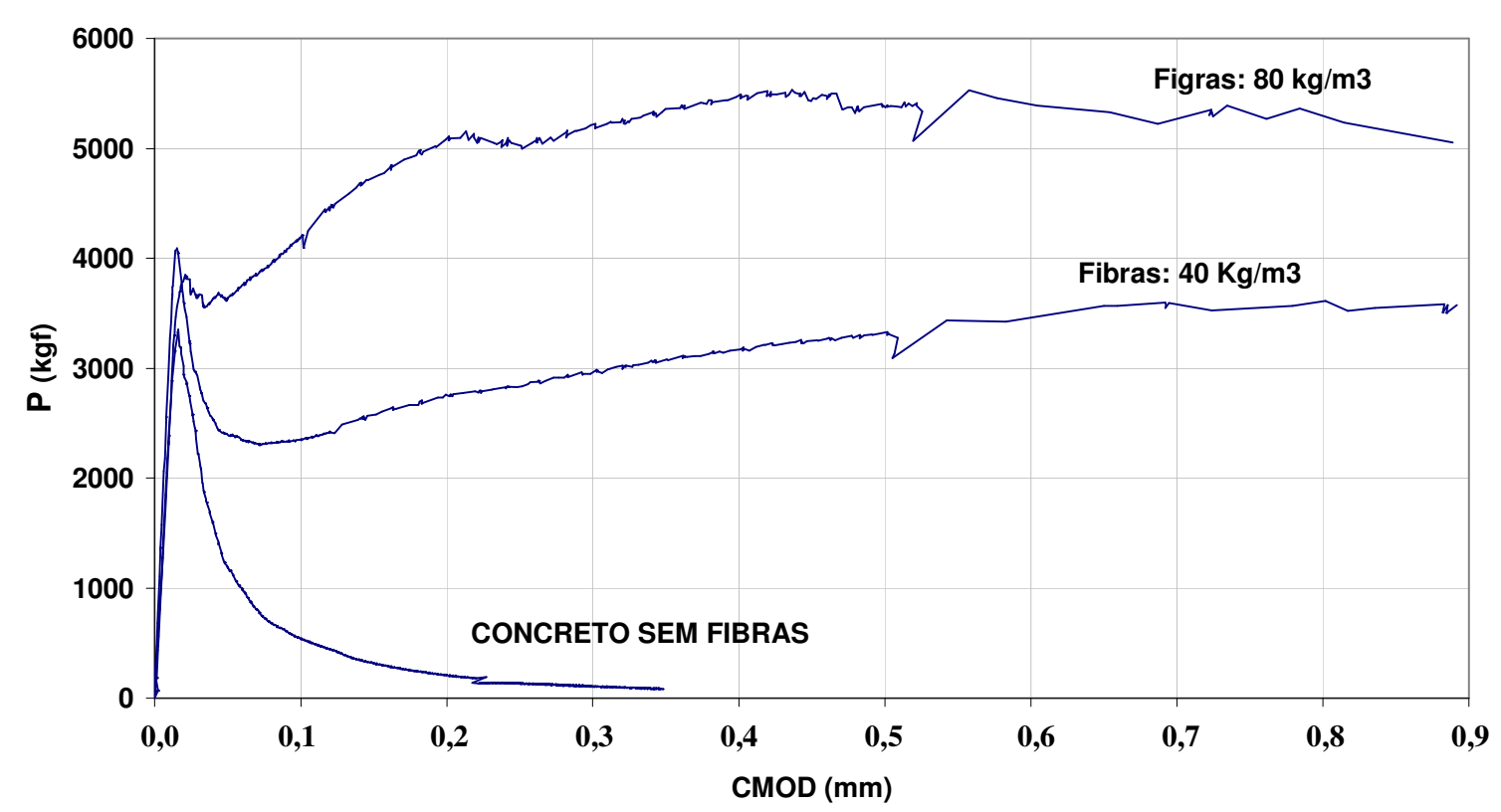

Fig. 2.5: Curvas $P-C M O D$ para concreto de alta resistência reforçado com diferentes teores de fibras metálicas. Fonte: Ferreira (2007).

Sendo assim, além da possibilidade de conferir maior resistência à tração, as principais vantagens decorrentes da incorporação da fibra de aço são reflexo da restrição à fissuração e ganho de tenacidade. Além da alteração no modo de ruptura do concreto, o qual se torna mais dúctil, diversas pesquisas apontam ao melhor desempenho do CRFA quanto a solicitações cíclicas e de impacto. Devido ao maior controle da fissuração o concreto fica mais protegido contra ataques de agentes agressivos, assim como é menor a probabilidade de corrosão das armaduras, o que confere maior durabilidade.

\subsubsection{Aplicações}

Segundo Bentur e Mindess (1990) a utilização recente das fibras como reforço para concreto ocorreu em duas frentes distintas: nas peças delgadas, visando à busca de compósitos substitutivos do cimento-amianto (com volumes acima de 5\% para melhorar a tenacidade, a durabilidade e a resistência da matriz de cimento), e em peças de concreto como armadura secundária (com volumes reduzidos de até $2 \%$ ) para melhorar a tenacidade, o controle da fissuração induzida e o desempenho sob forças dinâmicas.

As fibras de aço vêm sendo utilizadas em usos estruturais e não-estruturais, como por exemplo: estruturas hidráulicas (barragens, vertedouros e para resistir à cavitação), pavimentos de aeroportos e rodovias, pisos industriais, fundações de máquinas, concreto refratário, pisos de pontes, revestimentos de túneis e minas, revestimentos lançados para estabilização de taludes em rodovias e ferrovias, cascas finas, estruturas resistentes à 
explosão, reservatórios de líquidos e elementos pré-frabicados (ACI 544.3R, 1993). Informações mais detalhadas sobre aplicações do CRFA podem se encontradas nas seguintes publicações: ACI 506.1R-84, 1998; Manual Técnico da Maccaferri² ${ }^{2}$

\subsubsection{Mecanismos de Transferência de Tensões}

Nos materiais compósitos as tensões são resistidas em conjunto pela matriz e pelas fibras, sendo as forças transmitidas por aderência. Basicamente dois fatores regem a qualidade desta aderência: a ancoragem mecânica da fibra na matriz e a adesão físico-química entre os materiais. Tais fatores são influenciados pelas características das fibras (teor, módulo de elasticidade, resistência, orientação e geometria), pelas características da própria matriz (composição, condição de fissuração, propriedades físicas e mecânicas) e também pelas características da interface fibra-matriz.

Até que seja atingida a carga relativa à primeira fissura, a aderência de cisalhamento é elástica, ou seja, as deformações entre fibra e matriz são compatíveis e as tensões são proporcionais às deformações. Entretanto, com o aumento do carregamento pode-se atingir o valor limite da tensão de cisalhamento, denominado de resistência ao cisalhamento adesional. Após ser atingido este limite, passa a ocorrer deslocamentos relativos entre a matriz e a fibra, e a transferência de tensões entre os dois materiais passa a ser controlada por atrito. Já na pósfissuração, quando as fissuras são atravessadas pelas fibras, estas acabam atuando como pontes de transferência de esforços.

Desta forma, pode-se dizer que os fatores que influem na aderência entre as fibras e a matriz, conseqüentemente em partes, também definem a eficiência da utilização das fibras. Para avaliar a eficiência devido à adição de fibras, deve-se considerar três frentes de avaliação: as fibras, a matriz de concreto e a região de interface entre a fibra e a matriz (zona de transição).

\subsubsection{Parâmetros de Eficiência}

Para atuar com sucesso no mecanismo de ponte de transferência as fibras devem ter comprimento adequado e estar presente em volume adequado. Neste sentido, encontram-se na literatura dois parâmetros importantes: o volume crítico $\left(\mathrm{V}_{\mathrm{fc}}\right)$ e o comprimento crítico $\left(\mathrm{l}_{\mathrm{fc}}\right)$. $\mathrm{O}$

\footnotetext{
${ }^{2}$ FIBRAS como elemento estrutural para reforço de concreto: Manual técnico (2008). Maccaferri. Disponível em: <http://www.maccaferri.com.br/downloadDe.php?idioma=0\&download=103>. Acesso em: $10 / 08$.
} 
volume crítico é aquele que confere ao CRFA um comportamento o mais próximo possível do elástico-plástico perfeito. Figueiredo (2000) comenta que para a manutenção da capacidade portante do concreto com fibras de aço, uma boa estimativa $\mathrm{d}$ o volume crítico leva à um teor de fibras igual a $1 \%$.

Um comprimento adequado das fibras deve ser aquele que contemple a sua distribuição aleatória na matriz e esteja dimensionalmente compatível com a dimensão máxima do agregado. De acordo com Figueiredo (2000) esta compatibilidade possibilita a atuação da fibra como reforço do concreto e não como mero reforço da argamassa do concreto. Isto porque, em concretos de baixa e moderada resistência, a fratura se propaga preferencialmente na região de interface entre o agregado graúdo e a pasta. Desta forma, recomenda-se que o comprimento da fibra seja igual ou o dobro da dimensão máxima do agregado.

O formato da fibra também é importante, já que algumas geometrias proporcionam maior ou menor ancoragem mecânica. Para avaliar a geometria da fibra é comum a determinação do fator de forma, dado pela razão entre o comprimento da fibra e seu diâmetro. Uma explanação mais detalhada é feita por Bentur e Mindess (1990) e Figueiredo (2000).

A interface entre as fibras e a matriz, ou zona de transição, apresenta uma microestrutura bastante similar àquela observada em torno dos agregados. Esta região é caracterizada por uma alta porosidade e grandes depósitos de cálcio $(\mathrm{CH})$ em torno da fibra. Assim, um espaço preenchido por água se forma em torno da fibra e com o progresso da hidratação ele se torna apenas parcialmente preenchido pelos produtos da hidratação.

Para que a aderência fibra-matriz possa ser melhorada, existe grande interesse em se modificar a natureza da zona de transição. Cura adequada, densificação da matriz através de uma dosagem adequada, uso de aditivos minerais (como sílica ativa) e de materiais poliméricos são alternativas que estão sendo adotadas visando incrementar a qualidade da zona de transição e, conseqüentemente, o comportamento do material (LOPES, 2005).

A resistência da matriz também interfere na eficiência das fibras. $O$ concreto de alta resistência tende a ser mais frágil que o de resistência normal, e para que concretos de resistência elevada tenham sua ductilidade melhorada é preciso um volume de fibras mais elevado do que o usado nos concretos menos resistentes (OLIVEIRA, 2005). 


\subsubsection{Propriedades Mecânicas}

Para teores de fibras inferiores à $2 \%$, normalmente não se observa ganho na resistência à compressão, módulo de elasticidade e Poisson. Alguns trabalhos inclusive demonstram que pode haver diminuição da resistência por conta de acréscimo no teor de ar incorporado decorrente da adição das fibras. Os acréscimos da resistência à tração direta podem variar desde valores muito pequenos até $60 \%$, sendo valores intermediários mais prováveis.

Já a resistência à tração na flexão pode ser muito maior do que a obtida para a matriz. Esta propriedade é diretamente influenciada pelo volume de fibras e pela razão de aspecto, sendo que quanto maior a razão de aspecto, maior o acréscimo na resistência, o qual pode chegar a $100 \%$.

Mais informações sobre resultados experimentais de ensaios de caracterização do CRFA (resistência à compressão, resistência à tração, tenacidade, módulo de elasticidade, Poisson), assim como ensaios de outras naturezas (cisalhamento, torção, impacto, fadiga, corrosão, abrasão) são encontradas em referências bibliográficas como: Bentur e Mindess (1990); Manual Técnico da Maccaferri; Thomas e Ramaswamy (2007); Altun et. al. (2005); Gao et. al. (1997); Jo et. al. (2001). Quanto ao comportamento do CRFA ao longo do tempo, ou seja, com relação à fluência e à retração, uma descrição mais detalhada é feita no Capítulo 4 (página 88).

\subsubsection{Desvantagens}

Apesar das melhorias proporcionadas ao concreto no estado endurecido, a adição de fibras altera as condições de consistência no estado fresco e, portanto, interfere na trabalhabilidade. Isto porque em decorrência da adição de fibras aumenta-se a área superficial que demanda água de molhagem. Desta forma, quanto menor for o diâmetro da fibra, maior será a influência da mesma na perda de fluidez. Além de alterar o tipo de fibra utilizada, outra medida que fornece melhora na trabalhabilidade é o uso de plastificantes e superplastificantes.

Deve-se considerar também que adição de baixos teores de fibras altera as condições de trabalhabilidade sem necessariamente reduzir a compactação do material (CECCATO, NUNES E FIGUEIREDO $1997^{3}$ apud FIGUEIREDO 2000). Os métodos para se medir a

\footnotetext{
${ }^{3}$ CECCATO, M. R.; NUNES, L. N.; Figueiredo, A. D. (1997). Estudo de controle da trabalhabilidade do concreto reforçado com fibras de aço. In. IV Congresso Iberoamericano de Patologia das Construções e VI Congresso de Controle da Qualidade. Porto Alegre, Brasil. Vol II. ANAIS. P. 539-46.
} 
trabalhabilidade do CRFA estão descritos em ACI 544R.3 (1993).

Outro problema associado à adição das fibras consiste no embolamento destas, que causa a formação dos chamados ouriços. Os ouriços acarretam a redução do teor de fibra distribuída homogeneamente, além de constituir um ponto fraco, devido à alta porosidade. Para evitar seu aparecimento recomenda-se a mistura das fibras em taxas controladas. Como outra alternativa tem-se o emprego de fibras coladas em pentes.

As fibras de aço têm um papel muito importante na definição do custo do CRFA. Segundo Shah $^{4}$ (1991 apud FIGUEIREDO 2000) mesmo com consumos regulares, abaixo do volume crítico, que já apresentam grandes vantagens para a aplicação do material, o custo por metro cúbico do concreto pode dobrar. Desta forma a dosagem correta do teor de fibras tornase parâmetro para viabilidade econômica.

\subsubsection{Dosagem}

Normalmente, fixa-se o traço independentemente das características da matriz e também das fibras. Entretanto, para definir o teor de fibras, além de avaliar o volume crítico, deve-se considerar a relação entre a resistência da matriz e o ganho de tenacidade requerido. Mantendo-se a quantidade e as características das fibras adicionadas ao concreto, isto ocorre porque no caso da matriz mais resistente, as tensões que serão transferidas às fibras após a fissuração são altas (mais altas que no caso de uma matriz de menor resistência), e conseqüentemente, para um mesmo ganho de tenacidade deve-se adicionar uma quantidade maior de fibras.

Já a escolha da fibra está condicionada à aplicação do CRFA. Fibras mais longas e que possuem melhor ancoragem mecânica em geral promovem maior tenacidade. $\mathrm{O}$ comprimento da fibra, conforme já comentado também está relacionado à dimensão máxima do agregado. No caso de concreto projetado deve-se considerar que o comprimento da fibra seja metade do diâmetro interno do mangote.

\subsubsection{Compósitos Híbridos}

Por uma definição muito simples, a hibridização consiste em incorporar ao concreto diferentes tipos de fibras com o intuito de alcançar um determinado desempenho. As fibras

\footnotetext{
${ }^{4}$ SHAH, S. P. (1991). Do fibers improve the tensile strength of concrete? In: First Canadian UniversityIndustry Workshop on Fiber Reinforced Concrete. Quebec, 1991. Proceedings, p. 10-30.
} 
usadas como reforço podem ser efetivas para restringir a fissuração em dois níveis de observação, microscópico e macroscópico. No primeiro caso, as fibras inibem a iniciação e propagação das fissuras. Após a aplicação de certo valor da carga, ocorre o processo de coalescencia destas microfissuras, o que origina as macro-fissuras. Neste ponto, as fibras atuam como ponte de transferência de tensões, impedindo a propagação instável das macrofissuras. Como já discutido, os principais ganhos pela adição das fibras referem-se à resistência à tração (destacando sua determinação indireta na flexão), tenacidade e ductilidade.

Quando os compósitos híbridos são bem dosados, há uma interação positiva entre a atuação das diferentes fibras, de forma que os resultados do composto híbrido conduzem a uma performance superior à soma das performances de quanto se consideram estas fibras separadamente; fenômeno o qual é definido como sinergia. A seguir são descritas algumas combinações possíveis que podem proporcionar sinergia (BANTHIA; GUPTA, 2004).

a) Hibridização baseada na resposta constitutiva das fibras

Neste caso, um tipo de fibras é mais rígido e mais resistente, promovendo razoável resistência à primeira fissura e incremento a capacidade resistente do compósito, enquanto que o segundo tipo de fibras é relativamente flexível e conduz à melhoria na tenacidade e capacidade de deformação no trecho pós-pico de resistência.

b) Hibridização baseada nas dimensões das fibras

Esta hibridização consiste da utilização de fibras semelhantes, porém de "tamanhos" diferentes. Um tipo de fibras é menor sendo a responsável por atuar ao nível da formação e propagação das microfissuras, anterior à coalescencia das mesmas. Já o segundo tipo de fibras tem como função impedir a propagação das macrofissuras, o que conseqüentemente resulta em uma melhora substancial na tenacidade do compósito.

Ou seja, por esta combinação espera-se que as fibras curtas atuem no trecho prépico de resistência, adiando a coalescência das microfissuras, e as fibras longas atuem no trecho pós-pico retardando a ruptura do compósito por conta do efeito ponte, pelo arrancamento e ruptura das fibras (mecanismos já discutidos anteriormente).

Resultados ilustrando o desempenho de compósitos híbridos deste tipo são apresentados na Figura 2.6. 
c) Hibridização baseada na função da fibra

Neste caso, pretende-se que um tipo de fibra melhore as propriedades do concreto no estado fresco, tais como trabalhabilidade e restrição à retração plástica, ao passo que o outro tipo de fibra deve conduzir à melhora das propriedades mecânicas. Quanto a esta combinação, Banthia e Gupta (2004) comentam inclusive a existência no mercado de misturas de fibras já preparadas com uma dosagem menor de fibras de polipropileno $(<0,2 \%)$ e uma dosagem mais elevada de fibras metálicas $(\approx 0,5 \%)$.

Resultados de $\mathrm{Wu}$, Li e Wu (2002) demonstram que com a utilização de uma pequena quantidade de fibras (total de $0,5 \%$ em volume), através da combinação de macrofibras metálicas e microfibras de carbono, conduz a resultados excelentes em termos de tenacidade, resistência à compressão e resistência à tração. A Fig. 2.7 ilustra as curvas experimentais obtidas para os compostos híbridos comparativamente à matriz.

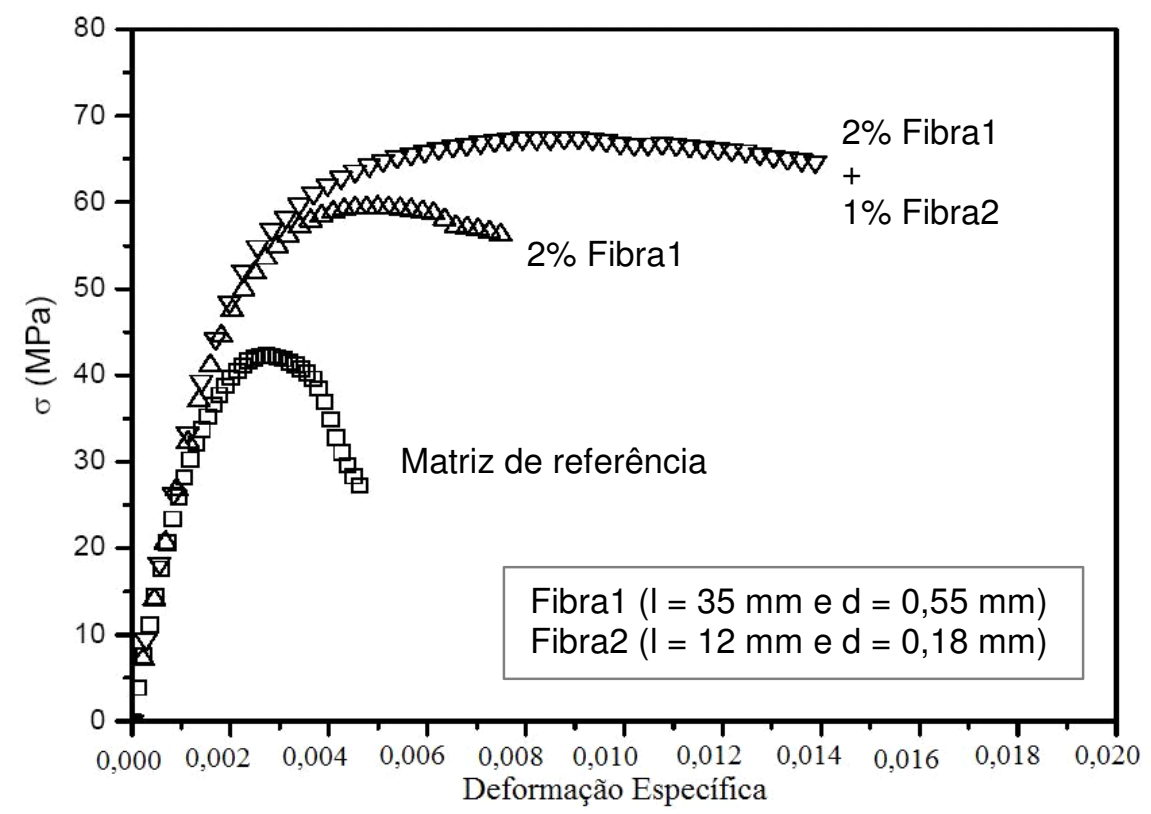

Fig. 2.6: Curvas Tensão-Defomação obtidas a partir de ensaio de compressão axial. Fonte: Lopes, 2005.

Com o objetivo de combater diferentes fenômenos associados à fissuração, pesquisadores propuseram em diferentes ocasiões, a adição de microfibras às fibras de aço convencionais, numa tentativa clara de modificar o material em sua microestrutura, tornandoo mais eficaz. Contudo, não há até o presente, critérios claros para a implantação dessa estratégia, especialmente que se justifiquem do ponto de vista mecânico, o que faz prevalecer certo empirismo em torno do assunto (FERREIRA, 2007). 


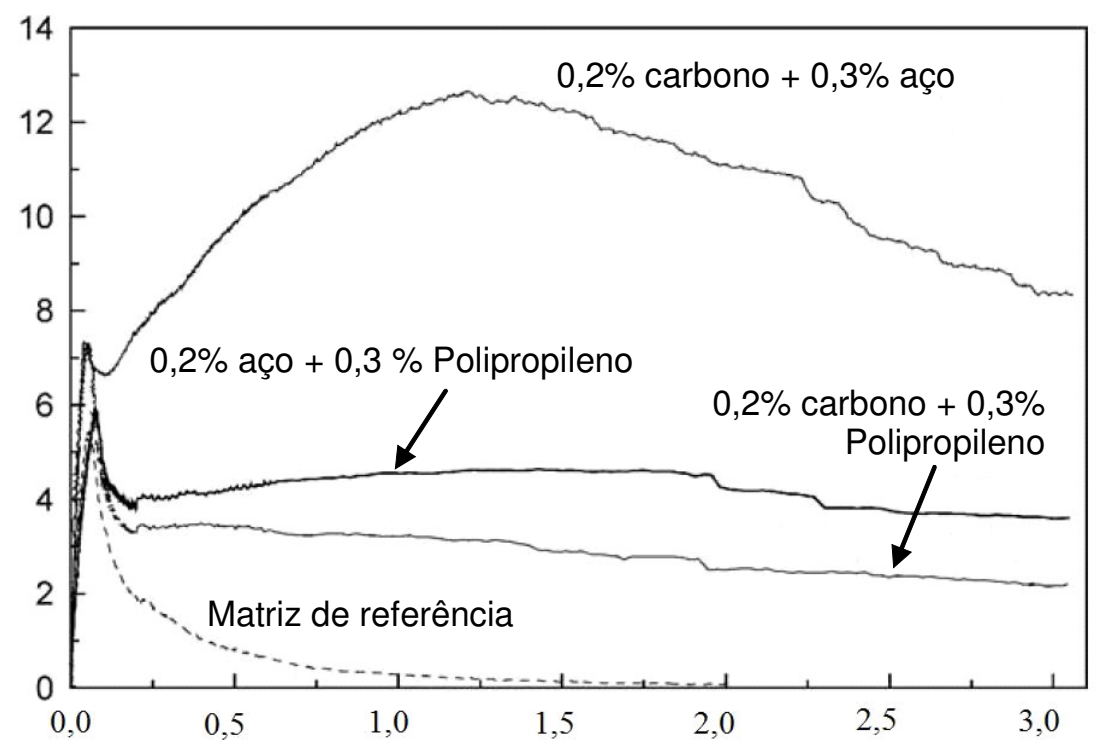

Fig. 2.7: Curvas $P-\delta$ obtidas a partir de ensaios de flexão. Fonte: Wu, Li e Wu (2002).

Sorelli, Meda e Plizzari (2005) avaliaram diferentes compósitos híbridos encontrando uma melhora significativa no desempenho tanto no trecho pré-pico de resistência quanto no trecho pós-pico por conta da combinação de fibras metálicas de diferentes dimensões (fibras longas associadas à fibras curtas). Segundo os autores isto é interessante pois melhora a performance do material tanto em termos de estado limite último (por acréscimo na resistência) quanto em termos de estado limite de serviço (pela restrição à fissuração).

Sun et. al. (2000) combinaram fibras de aço de tamanhos diferentes entre si assim como com fibras de PVA e de polipropileno. Além dos ensaios para caracterização mecânica dos materiais, os autores avaliaram alterações na porosidade dos compósitos concluindo que a combinação das fibras pode ocasionar uma diminuição da porosidade, sendo que com relação à distribuição em tamanho dos poros, diminui-se a quantidade de poros "nocivos" (diâmetro $\geq$ $50 \mathrm{~nm}$ ) o que é compensado pelo aumento de poros "inofensivos" (diâmetro $<50 \mathrm{~nm}$ ). Isto melhora a resistência à retração e torna o material mais impermeável.

A caracterização de compósitos híbridos elaborados à base de diferentes tipos e tamanhos de fibras pode também ser encontrada em Lawer, Zampini e Shah (2005); Chen e Liu (2004); Banthia e Gupta (2004).

Nesta pesquisa foram avaliadas as propriedades de um CRFA comum e de um composto híbrido, formado pela combinação de fibras de tamanhos diferentes. Para a definição dos tipos das fibras e sua dosagem contou-se com os resultados prévios de Ferreira, Hanai e Ferrari (2007); Ferrari, (2007) e Ferreira (2007). 


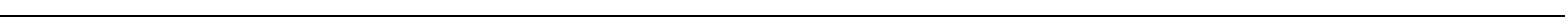




\section{MECÂNICA DA FRATURA}

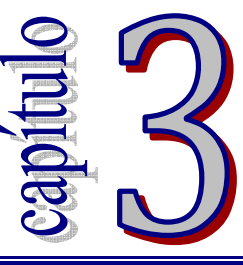

A Mecânica da Fratura é uma disciplina de Engenharia que quantifica as condições sob as quais um sólido, sob ação de um carregamento, pode ir ao colapso devido à propagação de uma fissura pré-existente. Para o correto entendimento do processo de fraturamento, são necessários conceitos ligados à descrição adequada do processo de deformação de sólidos, em conjunto com outros ligados aos mecanismos físicos locais. Entretanto, como diferentes materiais apresentam diferentes mecanismos físicos de deformação, existem diferentes modelos de fraturamento que devem ser aplicados de forma a descrever o fraturamento adequadamente (BITTENCOURT, 1999).

Antes do conhecimento dos princípios da Mecânica da Fratura, a elaboração de projetos de uma forma geral baseava-se estritamente nos critérios de resistência, sendo a adoção de altos fatores de segurança uma prática comum, que mascarava a ação de possíveis falhas ou mudanças da geometria sobre a resistência das estruturas.

Entretanto, no início do século XX, a prática de utilizar altos fatores de segurança deixou de ser bem sucedida para evitar o colapso estrutural, particularmente em áreas de sistemas amplos e complexos, tais como a indústria naval. A partir de 1901, o colapso repentino do navio "Cobra" em duas partes (considerado, até então, o mais rápido do mundo) deu início a uma sucessão de acidentes similares, sem que fossem encontradas falhas de projeto que justificassem tais acidentes. Isso tornou claro que os conceitos clássicos de tensão e deformação desenvolvidos por Hooke, Young, Cauchy e outros, não eram mais suficientes para prever o colapso estrutural (BLAKE, 1996).

Ainda no século XV, Leonardo da Vinci verificou, por análises experimentais utilizando cabos de aço, que as dimensões do corpo e possíveis falhas (pequenas fissuras) no material afetavam sua resistência. Nestes ensaios da Vinci obteve uma relação inversa entre resistência e comprimento dos cabos, para diâmetros constantes. A percepção do fator de concentração de tensão decorreu dos trabalhos de Inglis, por volta de 1913. Essa foi a 
primeira evidencia que defeitos localizados poderiam causar uma elevação local no campo de tensões.

Entretanto, o estudo científico formal da Mecânica da Fratura teve como marco inicial a pesquisa de Griffith no início na década de 20. Seus ensaios experimentais com fibra de vidro determinaram as primeiras relações quantitativas entre tamanho da fissura e resistência. Para explicar a dependência da resistência com a escala, Griffith propôs um critério energético, no qual foi introduzido o conceito de energia de superfície ao balanço de energia, como sendo a energia associada à criação de uma nova superfície durante o processo de fratura (BROEK, 1986; BARSON, 1977).

Aplicando esse conceito ao resultado obtido por Inglis para uma placa uniformemente tracionada com fissura elíptica, Griffith obteve uma expressão para tensão que é inversamente proporcional à extensão da fissura (METHA; MONTEIRO, 1994):

$$
\sigma=\sqrt{\frac{2 E \gamma}{\pi a}}(\text { para estado plano de tensão) }
$$

Baseado nos princípios da energia, Griffith foi o primeiro a desenvolver uma teoria racional da Mecânica da Fratura, que relaciona as condições específicas sobre as quais a propagação da fissura se torna estável. Griffith assumiu que a propagação da fissura nos matérias de ruptura frágil ocorre quando a energia fornecida na ponta da fissura é igual ou maior do que a energia necessária para criar novas faces da fissura.

Nas décadas de 30 e 40, foram desenvolvidas soluções matemáticas para meios elásticos, por meio de métodos utilizando variáveis complexas, para os campos de tensão e deformação em regiões próximas à ponta da fissura. Nesse sentido destacam-se os trabalhos de Willians e Westergard (ANDERSON, 1991).

Irwin, no final da década de 40, foi o responsável por tornar a Mecânica da Fratura uma ferramenta adicional de avaliação da integridade estrutural, dando a ela um "status" similar ao da Resistência dos Materiais nas aplicações de Engenharia. O seu trabalho, ligado fortemente à indústria de construção naval, marca o início da Mecânica da Fratura do ponto de vista de utilização. Segundo Anderson (1991), o entendimento da forma de ruptura dos materiais e a habilidade de evitar tais colapsos aumentaram consideravelmente após a Segunda Guerra Mundial. 


\subsection{Mecânica da Fratura Elástica Linear: Conceitos Básicos}

Segundo Barson (1977), o princípio fundamental da Mecânica da Fratura é que o campo de tensões à frente da ponta da fissura em um elemento estrutural pode ser caracterizado em termo do fator de intensidade de tensão $(K)$, sendo denominada de região de domínio de $K$. O fator $\mathrm{K}$, que é função do carregamento externo, das dimensões do corpo fissurado, da extensão da fissura e da vinculação.

Internamente à região de domínio de $\mathrm{K}$, encontra-se a zona de processos inelásticos (ZPI), região definida por um anel, imediatamente à frente da ponta da fissura (ver Fig. 3.1). A extensão da ZPI comparativamente às dimensões significativas do sólido fissurado assim como à extensão da própria fissura define o tipo de modelagem ao fraturamento que pode ser aplicada.

Segundo Broek (1986), a Teoria da Elasticidade é usada para calcular o campo de tensões existente na região à frente da ponta da fissura e o material é considerado como elástico, homogêneo, e isotrópico, seguindo a lei de Hooke. A Mecânica da Fratura Elástica Linear (MFEL) pode ser utilizada quando a área plastificada em frente à ponta da fissura (zona de processos inelásticos) é muito pequena, quando comparada com as outras dimensões do sólido, podendo dessa maneira ser desprezada.
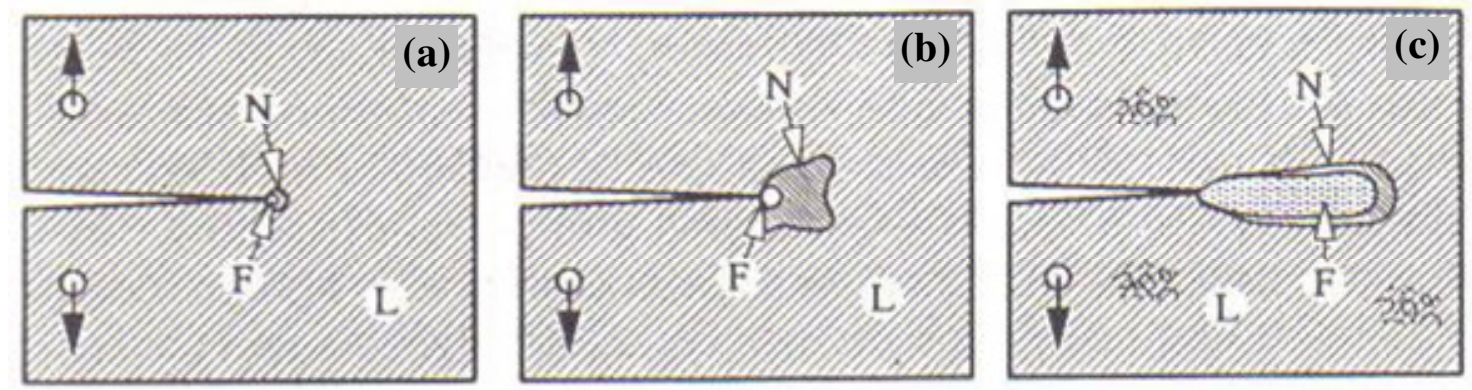

Fig. 3.1: Área de danificação à frente da ponta da fissura em materiais distintos.

(a) material elástico linear, (b) material plástico não-linear, (c) material quase-frágil não-linear. $L$ se refere à região elástica linear, $N$ região microfissurada e $F$ à zona de fraturamento ou zona de processos inelásticos. (Fonte: KARIHALOO, 1995).

No concreto observa-se uma zona de processos inelásticos de grandes dimensões à frente da fissura, o que torna essa área representativa no cálculo das tensões. Dessa maneira, para poder aplicar a MFEL ao concreto é necessário que a zona de processos inelásticos à frente da fissura seja desprezível quando comparada com as outras dimensões do elemento estrutural, o que requer que o elemento estrutural tenha grandes dimensões, como por exemplo, as barragens. 


\subsubsection{Modos de fraturamento}

As fissuras podem se propagar em um sólido de três maneiras diferentes, dependendo do tipo de solicitação a qual está sendo submetido. Essas maneiras distintas de propagação são chamadas "Modos de Fraturamento" e são apresentadas na Fig. 3.2.

Quando a fissura se propaga de tal maneira que os esforços promovem a abertura da fissura, tem-se o Modo I ("opening mode" ou "modo de abertura"), ou seja, a fissura se propaga no plano que a contêm, sem qualquer variação angular, por abertura normal à face da fissura.

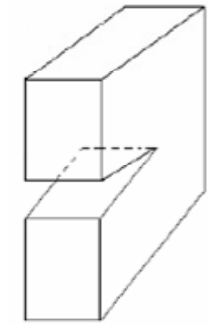

Modo I

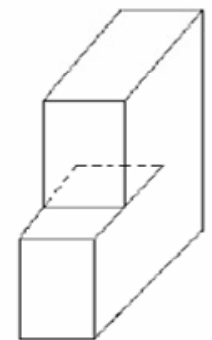

Modo II

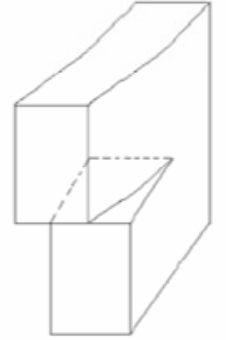

Modo III

Fig. 3.2: Modos de Fraturamento.

O Modo II ("shear mode" ou "modo cisalhante") é caracterizado por uma propagação no plano, provocada pelo escorregamento entre as faces na direção do comprimento da fissura. A fissura pode se propagar no espaço por cisalhamento anti-plano na direção normal ao comprimento da fissura. Neste caso tem-se o Modo III ("tearing mode" ou "modo de rasgamento").

Normalmente os Modos II e III ocorrem em combinação com o Modo I. O modo II é um modo desviador, isto é, em uma análise plana ele é responsável pelas mudanças na trajetória da fissura. Com as sucessivas mudanças de direção ao longo da propagação, o cisalhamento é minimizado e o modo I passa a prevalecer. Quanto ao modo III, ele só faz sentido na análise tridimensional do processo de fraturamento. Assim como o Modo II, esse modo é desviador, por excelência, provocando o giro da linha de frente da fissura. (FERREIRA $^{5}$, 2006).

Segundo Broek (1986), quando ocorrer a presença simultânea dos três modos de fraturamento, as fissuras rapidamente irão "escolher" a direção de propagação do Modo I.

\footnotetext{
${ }^{5}$ FERREIRA, L. E. T. (2006). Departamento de Engenharia de Estruturas, EESC/USP. Comunicações privadas.
} 
Por isso a maioria dos casos combinados é reduzida naturalmente ao primeiro modo de fraturamento e, dessa maneira, existem poucos casos que não possam ser tratados puramente como Modo I.

\subsection{Aplicações aos Materiais Quase-Frágeis}

A aplicação dos conceitos da Mecânica da Fratura a materiais quase-frágeis como o concreto é relativamente nova, tendo início com os estudos de Kaplan na década de 60. Os resultados destes estudos, entretanto, não tiveram êxito, uma vez que os conceitos da MFEL não poderiam ser diretamente aplicados a materiais cuja ruptura não ocorre de forma elástica e linear. Estudos mais criteriosos começaram a ser realizados no fim dos anos 70 e durante a década de 80.

De acordo com Metha e Monteiro (1994), e Bazant e Planas (1997) a primeira aplicação da Mecânica da Fratura para o concreto deu-se em 1961, quando Kaplan realizou a primeira pesquisa experimental e determinou o valor crítico da taxa de energia liberada para amostras de diferentes tamanhos. Pesquisadores subseqüentes estudaram os fatores intervenientes na determinação de parâmetros como o $\mathrm{K}_{\mathrm{IC}}$ (Tenacidade a Fratura) e $\mathrm{G}_{\mathrm{f}}$ (energia de fratura) e várias conclusões de grande utilidade por meio de estudos experimentais puderam ser tiradas:

> A tenacidade à fratura cresce com o aumento do volume de agregado, com sua dimensão máxima característica e com sua textura áspera;

> A tenacidade diminui com o aumento da relação água/cimento e com o aumento do teor de ar no concreto;

As contribuições citadas anteriormente foram importantes para a adaptação de conceitos da Mecânica da Fratura Elastoplástica (não-linear) objetivando o estudo do fraturamento de materiais quase-frágeis, tais como o concreto, as argamassas, certas rochas e diversas cerâmicas. Um passo importante na análise do fraturamento de estruturas de concreto se deu com o desenvolvimento dos modelos coesivos.

Pode-se dizer que o amadurecimento da Mecânica da Fratura aplicada a materiais de ruptura quase-frágil, ocorrido após a década de 80, teve como base o melhor entendimento do processo de fraturamento, no que diz respeito à quantificação e formato da zona de processos inelásticos. 


\subsection{Efeito de Escala}

Nas estruturas de concreto e outros materiais de ruptura quase-frágil a região à frente da fissura é danificada por uma zona de microfissuração, ao passo que em metais dúcteis a zona de processos inelásticos é caracterizada pela plastificação. Como, nesse caso, a zona de processos inelásticos apresenta extensões consideráveis, o efeito de escala passa a acentuar-se, influenciando a correta avaliação de parâmetros de tenacidade obtidos com os conceitos da Mecânica da Fratura Elástica Linear (BAZANT, 1984).

Segundo Shah, Swartz e Ouyang (1995), o tamanho da zona de processos inelásticos no concreto é consideravelmente maior do que a zona plástica observada nos metais e devido a este fato é necessária uma viga de grandes dimensões para se obter parâmetros válidos de Mecânica da Fratura utilizando a MFEL.

As razões das distorções nos resultados de tenacidade e energia de fraturamento, também decorrem da heterogeneidade do concreto, que ocasiona o comportamento não linear dentro de uma zona relativamente grande adjacente a frente da fissura, enquanto que para a aplicação da Mecânica da Fratura Linear esta zona deveria ser pequena comparativamente com outras dimensões (extensão da fissura e ligamento).

Diversos autores têm pesquisado a influência do caráter heterogêneo do concreto nos parâmetros de fraturamento. Neste sentido os resultados de Nallathambi, Karihaloo e Heaton (1985) mostram que a energia de fraturamento aumenta proporcionalmente com o aumento do diâmetro máximo do agregado. Gettu e Salvídar (1998), em uma avaliação da Lei do Efeito de Escala (BAZANT, 1984), verificaram que a formulação forneceu valores praticamente exatos nos casos em que o comprimento inicial da fratura (entalhe) não era pequeno comparado com o diâmetro máximo do agregado. Para entalhes pequenos, o modelo subestimava a carga de ruptura.

Desta forma uma formulação que explique o efeito de escala do concreto para correção dos resultados de ensaios laboratoriais é de grande interesse. A resistência do concreto é inversamente proporcional à escala estrutural (BAZANT, 1984). Sendo assim, a resistência considerada no projeto de estruturas de grande porte, como barragens, por exemplo, pode ser inferior à resistência real da estrutura, permitindo a ocorrência de fissuração subcrítica muito antes do esperado, o que diminui o fator de segurança considerado e afeta a durabilidade da estrutura. 
Até poucos anos atrás se acreditava que o efeito de escala poderia ser explicado pela teoria estatística para distribuição da resistência atribuída a Weibul, e que o uso de coeficientes de segurança seria suficientes. Contudo, isto pode ser válido apenas para materiais com comportamento puramente frágil (BAZANT; PLANAS, 1997).

Embora o efeito de escala devido à liberação de energia seja dominante na maioria das estruturas, a natureza estatística da resistência do material não pode ser totalmente desprezada. Contudo, a teoria existente, baseada em Weibul (1939), é teoricamente inadequada visto que ela ignora a redistribuição de tensão devido ao crescimento da fissura que ocorre durante a formação da zona de processos inelásticos (interface coesiva) na fase sub-crítica, isto é, anterior à carga máxima, o que conduz à uma situação determinística.

De acordo com o critério de resistência, o qual é usualmente utilizado nas normas e códigos de projeto, uma estrutura atinge a ruptura quando, por tração, a tensão no nominal $\sigma_{N}$ se iguala à resistência à tração do material $f_{t}$. Sabe-se que a tensão nominal é obtida pela expressão:

$$
\sigma_{N}=c_{N} P / b d
$$

Sendo que o coeficiente $c_{N}$ se refere ao formato da estrutura e ao tipo de solicitação a qual esta está submetida, $d$ é o valor da dimensão característica (no caso de uma viga, sua altura), e $b$ o valor da espessura.

Introduzindo o parâmetro adimensional, $\lambda$, dado pela relação da dimensão característica e o diâmetro máximo do agregado $\left(\lambda=d / d_{a}\right)$, podem-se representar convenientemente os valores de $\lambda$ e $\sigma_{N}$ em um gráfico bi-logarítmico. Desta maneira, o formato da função de $\sigma_{N}$ será, independente do critério de resistência adotado, representado por uma reta paralela ao eixo das abscissas (reta horizontal).

Já com relação à teoria da Mecânica da Fratura Elástica Linear, a representação de $\sigma_{N}$ e $\lambda$ pelo mesmo gráfico bi-logaritmico fornece uma reta com inclinação de $-1 / 2$, indicando uma diminuição da tensão nominal com o aumento da escala (ver Fig. 3.3).

Da MFEL, sabe-se que a condição para que haja propagação da fissura é que o fator de intensidade de tensão $K_{I}$ atinja o valor crítico dado por $K_{I C}$, indicando que a tensão nominal $\sigma_{N}$ alcançou um valor limite $\sigma_{N i}$ (o índice i se refere ao início da propagação da fissura), de forma que: 


$$
\sigma_{N i}=\frac{K_{I C}}{\sqrt{D} k\left(\alpha_{0}\right)}
$$

Onde $D$ é a dimensão característica, $k(\alpha)$ uma função adimensional e $\alpha_{0} \quad \alpha_{0}$ o comprimento relativo inicial da fissura $\left(\alpha_{0}=a_{0} / D\right)$. Após este ponto, a fissura irá propagar e a tensão nominal irá variar de forma a manter a igualdade $K_{I}=K_{I C}$.

$$
\sigma_{N}=\frac{K_{I C}}{\sqrt{D} k(\alpha)}, \text { para } \alpha>\alpha_{0}
$$

Observando a expressão anterior, fica evidente que após atingir a carga máxima, se a função adimensional crescer em função de $\alpha$, o valor da tensão nominal irá decair. Estruturas com este tipo de comportamento, de acordo com Planas e Elices (1989a) apud Bazant e Planas (1997), são classificadas de geometria positiva. Neste caso, tem-se:

$$
\sigma_{N_{U}}=\sigma_{N i}=\frac{K_{I C}}{\sqrt{D} k(\alpha)}, \text { para } k^{\prime}\left(\alpha_{0}\right)>0
$$

Por outro lado, se $k(\alpha)$ decrescer em função e $\alpha$, o valor da tensão nominal irá crescer. Estas estruturas, ditas de geometria negativa, a carga máxima ocorre quando o comprimento da fissura alcança o valor de $\alpha_{M}$, para o qual corresponde um valor mínimo de $k(\alpha)$, e então:

$$
\sigma_{N_{U}}=\frac{K_{I C}}{\sqrt{D} k\left(\alpha_{M}\right)} \text {, para } k^{\prime}\left(\alpha_{0}\right)>0 \text { e } k\left(\alpha_{M}\right)=\text { valor mínimo }
$$

Analisando as expressões apresentadas, válidas para similaridade em duas dimensões, percebe-se que para estruturas geometricamente similares, os valores de $\alpha_{M}$ e $\alpha_{0}$ são constantes, o que implica concluir que a resistência nominal será sempre inversamente proporcional à raiz quadrada da dimensão característica. Considerando-se duas estruturas entalhadas similares, identificadas por 1 e 2 , com $D_{2}=\lambda D_{1}\left(D_{2}>D_{1}\right)$, suas resistências nominais são relacionadas da seguinte forma:

$$
\sigma_{N_{U}}=\sigma_{N_{U i}} \sqrt{\frac{D_{2}}{D_{1}}}=\lambda^{-1 / 2} \sigma_{N_{U i}} \propto D^{-1 / 2}
$$

De modo que se explica o formato da representação do efeito de escala da MFEL 
encontrado no gráfico bi-logaritmico (Fig. 3.3).

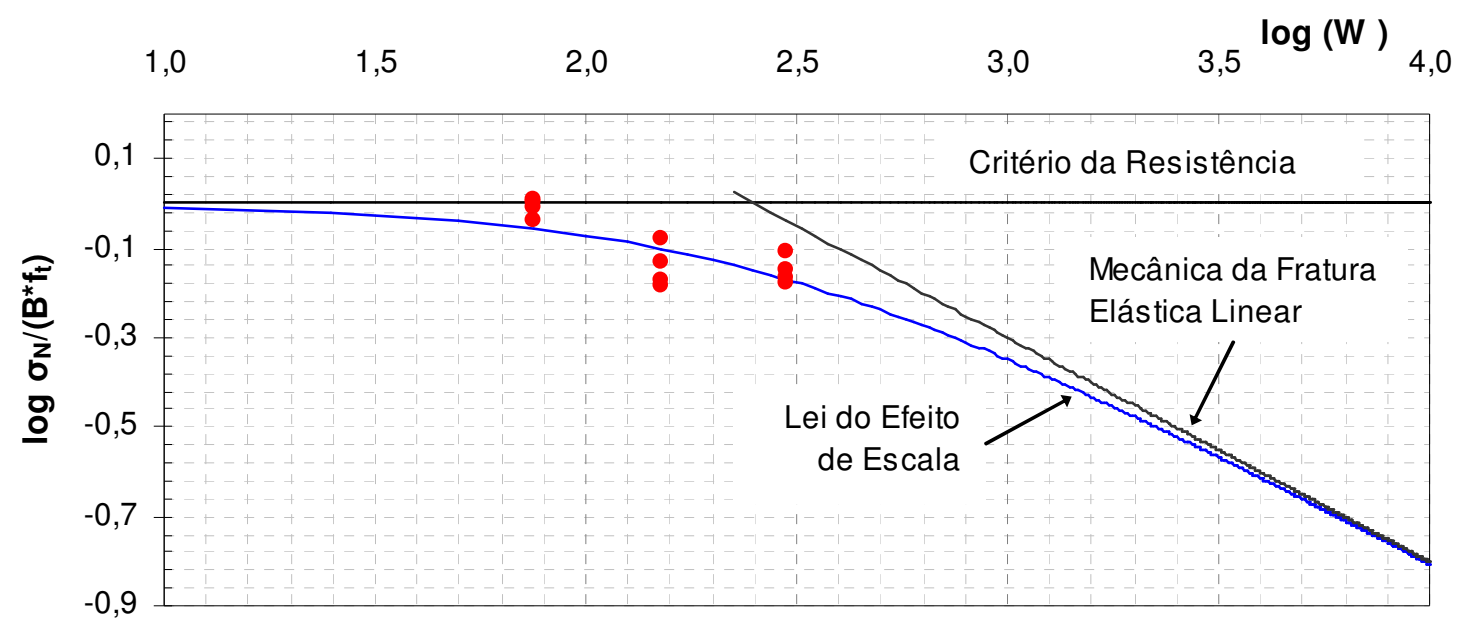

Fig. 3.3: Curva do efeito de escala. Fonte: o autor.

De acordo com os resultados obtidos por Walsh em 1979, com exceção de estruturas muito grandes, as quais se enquadram na Mecânica da Fratura Elástica Linear, a reta que descreve graficamente o efeito de escala para esta teoria parece muito íngreme para representar adequadamente os dados encontrados para estruturas com dimensões intermediárias. Desta forma, para estruturas de concreto, a melhor representação do efeito de escala é obtida pela transição gradual entre as retas do critério de resistência e da MFEL.

\subsubsection{Lei do Efeito de Escala}

A Lei do Efeito de escala está fundamentada na hipótese de que a energia potencial total $W$ liberada devido ao crescimento da fissura é função tanto da extensão $a$ da fissura, como da área da zona micro-fissurada. A largura da banda de fissuração, considerada constante, é proporcional ao diâmetro máximo do agregado $\left(w_{c}=n \cdot d_{a} \cdot a\right)$, como mostra a Fig. 3.4. a seguir:

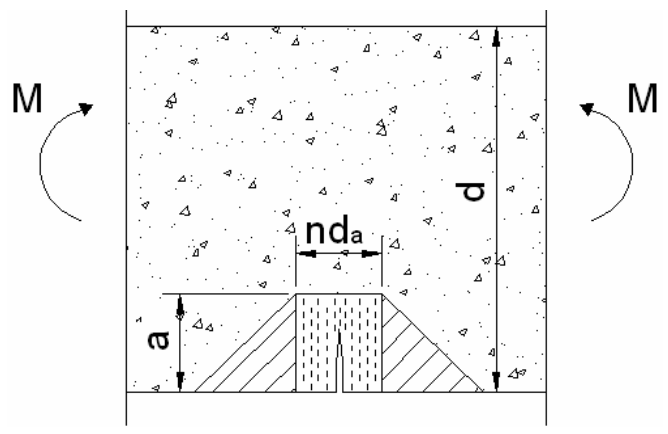

Fig. 3.4: Representação da banda de propagação da fissura. 
A expressão geral que fornece o valor de $W$ segundo esta teoria é:

$$
W=\frac{1}{2 E_{c}}\left(\frac{P}{b d}\right)^{2} b d^{2} f\left(\alpha_{1}, \alpha_{2}, \xi_{1}\right)
$$

Sendo $P$ a carga aplicada, $E_{c}$ o módulo de Young, $b$ espessura, $d$ a altura e $f\left(\alpha_{1}, \alpha_{2}, \xi_{i}\right)$ uma função de parâmetros adimensionais.

Sabendo-se que uma condição necessária para propagação da fissura é estabelecida pela igualdade $\partial W / \partial a=G_{f} b$. Diferenciando a expressão de $W$, substituindo a expressão da energia de fraturamento encontrada pelo modelo da banda de fissuração (BAZANT; OH, 1983) e reescrevendo a carga como o produto da tensão $\sigma_{N}$ pela área $b d$, tem-se:

$$
\sigma_{N}=B f_{t}\left(1+\frac{d}{\lambda_{0} d_{a}}\right)^{-1 / 2}
$$

Sendo $B$ e $\lambda_{0}$ são constantes empíricas.

Ao analisar a expressão da tensão nominal, percebe-se que para estruturas de grandes dimensões, $d \gg \lambda_{0} d_{a}$, o que conduz a $\sigma_{N} \propto d^{-1 / 2}$, que é a forma do efeito de escala da Mecânica da Fratura Elástica Linear. Se $d<<\lambda_{0} d_{a}$, tem-se que $\sigma_{N}=B f_{t}$, que conduz ao valor para a tensão nominal, de acordo com o critério de resistência. Para valores intermediários de $d$, a lei do efeito de escala prevê a transição gradual entre esses dois limites, através da curva apresentada na Fig. 3.3.

\subsection{Principais modelos de fraturamento do concreto}

Os principais modelos de fraturamento para o concreto foram desenvolvidos ao longo da década de 80 e situam-se em duas categorias distintas, a saber: modelos coesivos e modelos elásticos equivalentes. Quando a modelagem da fissura é feita utilizando os princípios de dissipação de energia de Griffith-Irwin, a fissura é quase-frágil é denominada fissura efetiva, e o modelo Elástico-Efetivo. Entretanto, se a fissura quase-frágil for modelada segundo os mecanismos de Dugdale/Baremblach, esta recebe o nome de fissura fictícia, e o modelo é denominado Coesivo.

Existe ainda o modelo do efeito de escala proposto por Bazant. A formulação para o 
efeito de escala desenvolvida pelo autor permite que, a partir dos resultados de ensaios laboratoriais, sejam determinados, por uma lei de extrapolação, os parâmetros de fraturamento para estruturas de grandes dimensões. Considera-se que em estruturas de dimensões finitas a zona de processos inelásticos atinja toda sua plenitude, e seja pequena, comparativamente às demais dimensões significativas da estrutura. Sendo assim, para estas estruturas, as teorias da MFEL são aplicáveis.

\subsubsection{Modelos Coesivos}

As formulações matemáticas capazes de representar o fraturamento coesivo, que é o caso do concreto, só começaram a ser desenvolvidas a partir do modelo proposto por Dugdale em 1960. No entanto, o grande desenvolvimento dessa área só se deu com o surgimento do Modelo da Fissura Fictícia ("Fictious Crack Model") proposto por Hillerborg, Mordeer e Petersson. (1976).

Nas décadas de 80 e 90 houve pesquisas intensas e a Mecânica da Fratura pôde ser utilizada com mais freqüência nos projetos de vigas, ancoradouros e grandes barragens. Atualmente é muito estudada a aplicação da Mecânica da Fratura para concretos reforçados com fibras e concretos de elevada resistência. Também se tem dado muita atenção à caracterização de novos modelos constitutivos capazes de simular computacionalmente o comportamento de estruturas de concreto submetidas a processos de fraturamento.

Dentre os modelos denominados coesivos destacam-se, para análise do fraturamento de materiais cimentícios, o Modelo Fictício desenvolvido por Hillerborg, Mordeer e Petersson (1976) e o Modelo da Banda da Fissuração, proposto por Bazant (1984). A importância desses modelos justifica-se na maior facilidade de implementação computacional que proporciona em programas baseados no método dos elementos finitos ou no método dos elementos de contorno.

Nos materiais de comportamento quase-frágil, para que haja propagação da fissura, além da energia necessária à formação de novas faces da fissura, é necessária a supressão da pressão de fechamento, $\sigma(w)$, que ocorre na interface coesiva, cuja extensão é denominada $l_{P}$. Admite-se que a distribuição dessa pressão ocorra segundo uma função monotonicamente decrescente da abertura de fissura $w$, de forma que: quando $w=0, \sigma(w)=f_{t}$; e quando $w=w_{C}, \sigma(w)=0$ (ver Fig. 3.5). 


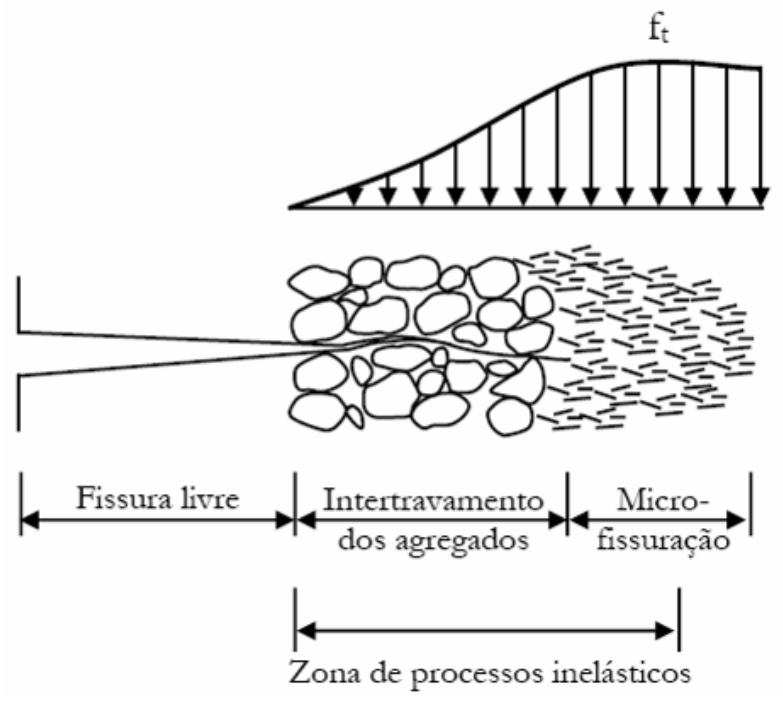

Fig. 3.5: Zona de Processos Inelásticos em estruturas de concreto.

A pressão de fechamento tem origem em diversos mecanismos, como intertravamento dos grãos, desvio da direção de propagação, fricção interfacial, arrancamento dos grãos entre as faces da fissura, bifurcação de caminho, dentre outros (ver Fig. 3.6). A pressão de fechamento representa a principal característica da interface coesiva: capacidade de transmissão das tensões entre as faces da fissura.
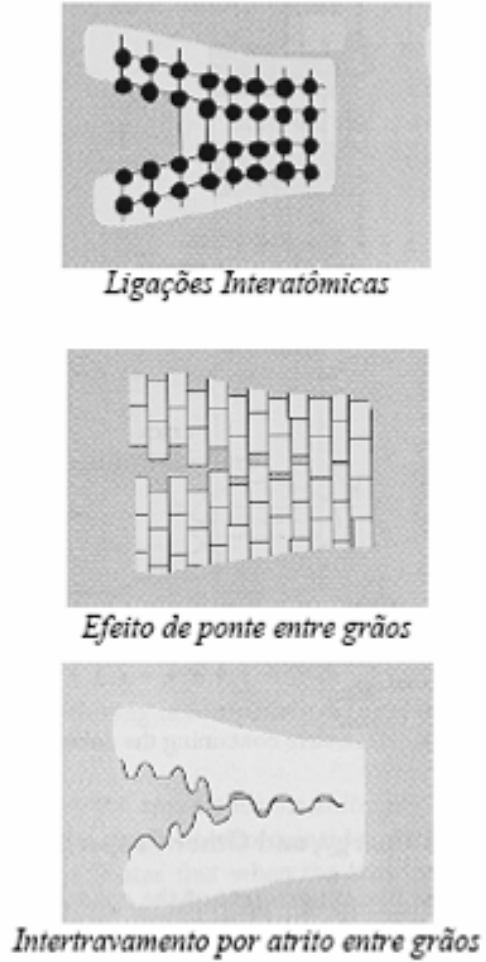
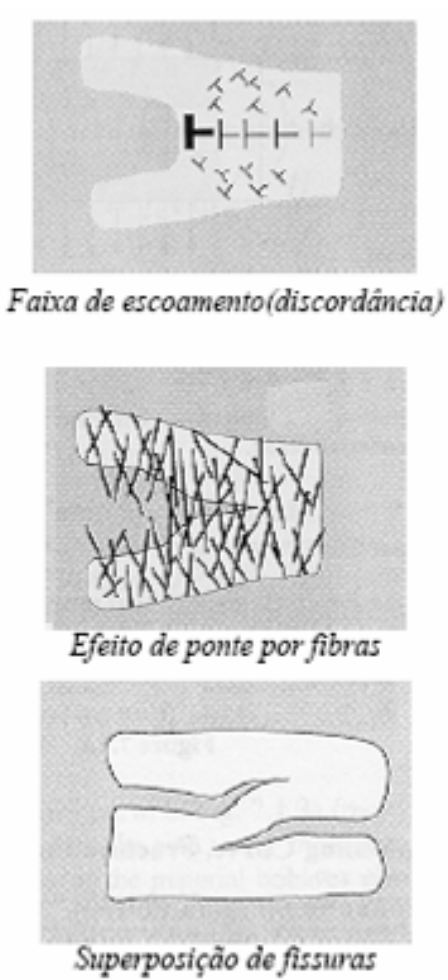

Fig. 3.6: Modelos Físicos de Fissuras Coesivas. 


\subsubsection{Modelo da Fissura Fictícia (Hillerborg et. al., 1976)}

O modelo da fissura coesiva é influenciado pela dissipação volumétrica do material, pela condição de início da fissura (diferentemente de outros modelos, não há a necessidade de uma fissura pré-existente para iniciar o processo de fraturamento), e pela função de evolução da fissura (função de amolecimento). Usualmente admitem-se hipóteses simplificadoras com relação a esses aspectos, com a finalidade de facilitar a implementação computacional, assim como explorar os métodos já bem estabelecidos da Mecânica da Fratura Elástica Linear (GUINEA, 1995).

Desta forma, são adotadas as seguintes hipóteses:

- Relação tensão-deformação do material isotrópica, elástica-linear;

- A propagação da fissura tem início quando a tensão principal $\sigma_{1}$ atinge o valor de da resistência à tração do material $f_{t}$;

- O processo de propagação de fissura ocorre enquanto houver transferência da pressão coesiva entre as faces da fissura. Considera-se que a pressão coesiva é função do histórico do deslocamento de abertura da fissura $w$.

- Para o fraturamento no modo I (modo de abertura) a transferência da tensão coesiva $\sigma$ é normal às faces da fissura, dependendo unicamente da abertura de fissura $w$, ou seja: $\sigma=f(w)$.

A função $f(w)$ denominada função de amolecimento define o trecho descendente da curva tensão versus abertura da fissura $w(\sigma \times w)$, após carga máxima. Essa curva, que pode ser determinada experimentalmente, promove a análise de importantes características do material, como a ductilidade e a energia de fratura.

De acordo com Hillerborg (1985), entende-se por energia de fratura a energia por unidade de área da superfície fraturada (projeção da área em um plano perpendicular à direção da tensão).

Observando a Fig. 3.7, tem-se que para abertura de fissura nula $(w=0)$, a tensão $\sigma(w)$ é igual à resistência à tração do material $f_{t}$, e quando $w$ atinge o valor crítico de $w_{C}$, que caracteriza a distância máxima entre as faces da fissura, a partir da qual não há transmissão de esforços, a tensão $\sigma$ cai à zero. A energia de fratura $G_{f}$ é determinada pela área sob a curva de amolecimento. 


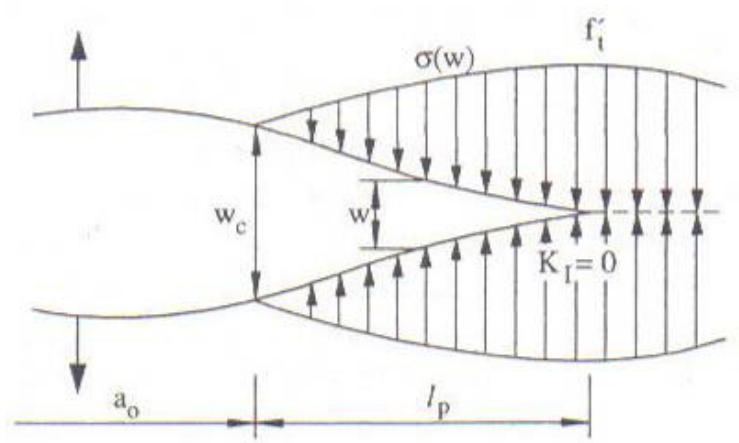

Fig. 3.7: Modelagem da fissura coesiva (Fonte: Karihaloo, 1995).

Como exposto, o modelo depende fortemente da curva de amolecimento. Sua determinação experimental por meio de ensaios de tração direta é bastante difícil de realizar em concreto, devido à tendência do material ao modo de fratura assimétrico. Desta forma, são utilizados métodos indiretos, em que a forma da curva de amolecimento é pré-estabelecida, em função de parâmetros obtidos nos ensaios. As relações $\sigma-w$ mais simples são as lineares e bi-linear, entretanto encontram-se na literatura diversas funções para a tensão de amolecimento (SHAH; SWARTZ; OUYANG, 1995).

Outro parâmetro de interesse fornecido pelo Modelo da Fissura Fictícia é o comprimento característico $l_{c h}$, determinado pela expressão a seguir:

$$
l_{c h}=\frac{E G_{f}}{f_{t}}
$$

O comprimento característico tem dimensão de comprimento e é proporcional à zona de processos inelásticos. Seu valor indica o índice de fragilidade do material, sendo assim, quanto menor o valor de $l_{c h}$, menor é a extensão da zona de processos inelásticos, e, portanto, mais frágil o material.

Levando em consideração de que os valores de $l_{c h}$ para o concreto variam entre 15 e $40 \mathrm{~cm}$, o intervalo para um amplo desenvolvimento da zona de processos inelásticos encontrase entre 30 e $220 \mathrm{~cm}$. Isto explica porque não é possível utilizar a formulação da Mecânica da Fratura Elástica Linear para os corpos-de-prova de escala laboratorial (BAZANT; PLANAS, 1997).

\subsection{Determinação Experimental: RILEM - Comitê Técnico n50, 1990}

Trata-se de um ensaio de flexão em três pontos, em vigas entalhadas, submetidas a carregamento quase-estático. Devem-se aquisitar os valores da carga aplicada (P) e do 
deslocamento vertical da linha de carga $(\delta)$. Preferencialmente o ensaio deve ser concluído quando a carga for descarregada até zero. Desta forma evita-se a realização do prolongamento da curva $\mathrm{P}-\delta$. Entretanto, se não for possível obter a curva completa de amolecimento, esse prolongamento é efetuado utilizando a relação momento curvatura (ELICES; GUINEA; PLANAS, 1992).

A confecção do entalhe central visa, além de simular uma fissura pré-existente, proporcionar um plano preferencial de fraturamento, de forma que a dissipação energética seja, o tanto quanto possível, planar. Visando obter um ensaio quase-estático, aconselha-se que a carga máxima seja atingida após 1 min. do início do ensaio. Devem ser ensaiados no mínimo 4 corpos-de-prova.

\section{Características Geométricas:}

A fim de evitar o quanto possível dissipações volumétricas de energia, recomenda-se utilizar a relação entre a extensão inicial da fissura $a_{0}$ e a altura da viga $\mathrm{W}$ igual a 0,5.
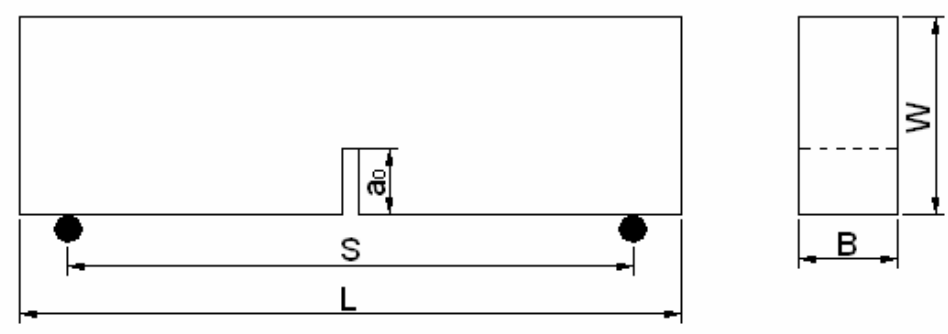

Fig. 3.8: Viga ensaiada em flexão à três pontos: nomenclatura da geometria.

No caso do concreto, as dimensões do corpo-de-prova são determinadas em função da dimensão máxima característica do agregado graúdo, $d_{a}$, com alturas $W$ variando entre 100 e $400 \mathrm{~mm}$, bases $B$ compreendidas entre 100 e $200 \mathrm{~mm}$ e vão - livres $S$, variando entre 800 e $1600 \mathrm{~mm}$ (ver geometria da viga na Fig. 3.8).

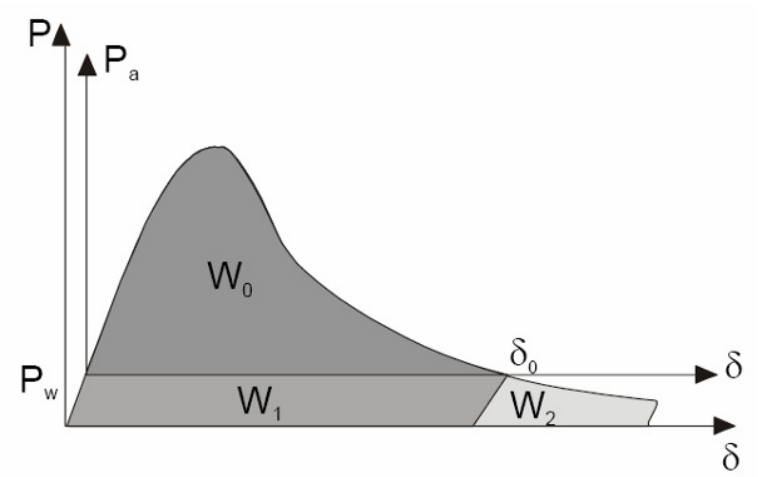

Fig. 3.9: Parcelas de trabalho associadas ao Modelo da Fissura Fictícia. 
A determinação de $G_{f}$ a partir do ensaio realizado é através da seguinte formulação:

$$
G_{f}=\frac{W_{0}+W_{1}+W_{2}}{A l}=\frac{W_{0}+2 W_{1}}{A l}
$$

Sendo:

$W_{0}=$ trabalho realizado pela força externa;

$W_{1}=$ trabalho realizado pela força fictícia $F_{1}$, representativa do peso próprio do corpode-prova mais os acessórios;

$W_{2}=$ trabalho complementar realizado pela força fictícia $F_{1}$. Considera-se que $W_{2}=W_{1}$;

$A_{L}=$ área do ligamento.

O valor de $W_{0}$ é obtido calculando-se área sob a curva corrigida dos dados experimentais. Entende-se por curva "corrigida" a curva encontrada depois de realizada extrapolação dos dados até o ponto em que a força se anule. A maneira padronizada de efetuar tal extrapolação é feita utilizando a relação momento curvatura. A área sob a curva pode ser determinada numericamente (regra do trapézio).

Cálculo de $W_{1}$ e $A_{L}$ :

$$
\begin{array}{r}
W_{1}=\left(\frac{w p}{2}+w a\right) \cdot \delta_{f} \\
A_{L}=B \cdot\left(W-a_{0}\right)
\end{array}
$$

Sendo $w p$ o peso próprio da viga, wa o peso dos acessórios e $\delta_{f}$ o deslocamento máximo obtido (correspondente à carga nula)

Já o módulo de elasticidade é determinado pela formula:

$$
E=\left(\frac{S}{W}\right)^{3} \cdot \frac{A^{*} \cdot v\left(\alpha_{0}\right)}{4 B}
$$

Sendo:

$A^{*}=$ coeficiente angular da reta que descreve o trecho elástico linear do gráfico.

$v\left(\alpha_{0}\right)=$ valor da função adimensional de dependência geométrica e de condições de 
contorno para o deslocamento vertical da linha de carga calculada para $\alpha_{0}$, sendo $\alpha_{0}=W / a_{0}$. No trabalho de Ferreira, Hanai e Bittencourt (2008) encontram-se os coeficientes das funções polinomiais $v(\alpha)$ para diversas relações $\mathrm{S} / \mathrm{W}$.

Como o método não depende do controle de deslocamentos de abertura da fissura (CMOD), é considerado um método de ensaio simples. Tendo em vista a formulação necessária para obter a energia de fraturamento, pode-se dizer que as operações envolvidas em sua determinação são fáceis, uma vez que não é necessário efetuar nenhum processo iterativo.

Apesar da simplicidade do procedimento de cálculo, como depende apenas de considerações energéticas, o método apresenta forte influência de qualquer perda de energia relacionada com as medidas de deslocamento. Sendo assim, o valor obtido para $G_{f}$ não pode ser considerado como um parâmetro do material, uma vez que apresenta dependência da escala estrutural.

De acordo com Shah, Swartz e Ouyang, (1995) um aumento em 2 ou 3 vezes a altura do corpo-de-prova, corresponde a valores cerca de 20 e $30 \%$ superiores de energia de fratura. Esta dependência da escala estrutural é atribuída à absorção de energia fora da zona de fratura. Esta absorção indesejada é dependente de escala.

Planas, Guinea, e Elices estudaram a influência dos procedimentos experimentais, dissipação de energia volumétrica e interrupção prematura da cura $P-\delta$. Eles concluíram que ao efetuar corretamente a extrapolação da curva e ao levar em consideração as perdas de energia espúria: por histerese do equipamento de ensaio, atrito nos apoios e deformação volumétrica, a dependência de $G_{f}$ com a escala estrutural diminui, porém não desaparece por completo (ELICES et. al., 1992; GUINEA et. al., 1992; PLANAS et. al., 1992).

Concentrados em outra linha de raciocínio, Hu e Wittmann em diversos trabalhos, discutem o efeito do contorno do corpo-de-prova na extensão da zona de processo de fratura. A extensão do ligamento inicial $\left(W-a_{0}\right)$ exerce forte influência no confinamento da zona de processos. Na situação em que essa dimensão seja suficientemente grande para o total desenvolvimento da zona de processos, não ocorrerá mais variação da energia de fratura local, e esta passa a representar a energia de fratura $G_{f}$. 


\subsubsection{Modelo da Banda de Fissuração (Bazant e Oh, 1983)}

A modelagem da fratura como uma linha discreta equivalente, discutida anteriormente, não é a única aproximação possível. No presente modelo, o fraturamento do concreto é modelado como a propagação de uma banda de fissuração de largura $w_{c}$, constituída de fissuras distribuídas de forma contínua e uniforme à frente da ponta da fissura.

Esta formulação ganhou popularidade por tornar mais satisfatórios os resultados de problemas de fratura modelados pelo método dos elementos finitos. Como já foi discutido, o critério de resistência não revela a influência da escala estrutural na variação dos parâmetros de fraturamento.

Para considerar a formação de uma fissura em um corpo não fissurado e sem a presença de concentradores de tensão, o conceito de resistência é aceitável. Mas, quando o corpo apresenta uma fissura pré-existente, haverá uma concentração de tensão à ponta da fissura que, de acordo com a análise elástica, tende a um valor infinito. Desta forma, concluise erroneamente que haverá propagação da fissura mesmo que o carregamento aplicado seja muito pequeno.

Este raciocínio equivocado, quando aplicado em aproximações numéricas via elementos finitos, conduz a uma situação incoerente. Quando a malha de elementos finitos é refinada, a carga necessária para se alcançar o limite de resistência depende fortemente da escolha da dimensão do elemento finito e incorretamente converge para zero (BAZANT E $\mathrm{OH}, 1983)$.

Rashid em 1968 idealizou uma distribuição contínua de infinitas microfissuras paralelas, de abertura infinitamente pequena, sobre o elemento finito. Desta forma, a região da curva carga versus deslocamento caracterizada pelo amolecimento das deformações pôde ser convenientemente modelada reduzindo a rigidez e a resistência na direção normal às fissuras, depois de atingida a carga máxima (BAZANT; PLANAS, 1997).

A teoria da banda de fissuração restringe-se à análise do fraturamento no Modo I, ou seja, situações em que não haja tensões de cisalhamento à frente da ponta da fissura. Entretanto sua aplicação aos problemas de fratura não fica prejudicada visto que a maioria dos problemas de fratura de concreto no Modo-Misto (Modos I e II) acaba sendo governada pelo Modo-I, como já exposto anteriormente.

Neste modelo, o processo de fraturamento é idealizado pela existência de uma banda 
de fissuração de largura constante $w_{c}$, constituída por microfissuras distribuídas de forma uniforme e contínua, a frente da ponta da fissura (Fig. 3.4).

$\mathrm{O}$ valor de $w_{c}$ é proporcional ao máximo diâmetro do agregado $\left(w_{c}=n \cdot d_{a}\right)$, e de acordo com os resultados de diversos ensaios realizados por Bazant e Oh (1983), o valor ótimo de $w_{c}$ para o concreto é cerca de 3 vezes o diâmetro máximo do agregado.

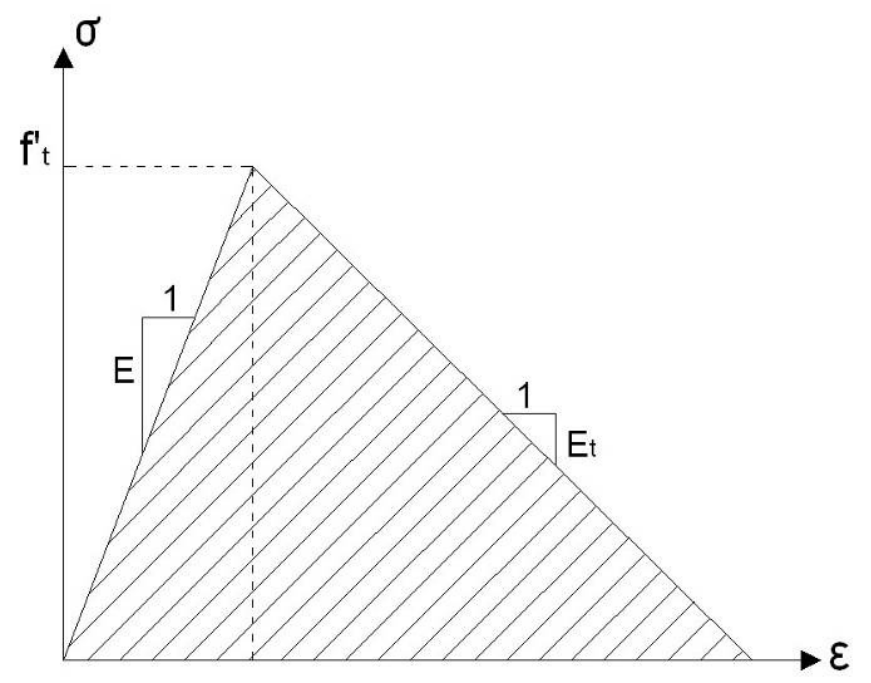

Fig. 3.10: Idealização do diagrama Tensão-Deformação para a zona de processo de fratura.

A microfissuração progressiva na zona de processo inelásticos é descrita por um estado multiaxial de tensões, exibindo amolecimento das deformações com uma redução gradual das tensões a zero. A formulação uniaxial desta relação tensão-deformação é então idealizada em um diagrama bi-linear, conforme ilustra a Fig. 3.10.

A região anterior à tensão de ruptura $f_{t}^{\prime}$ é caracterizada pelo módulo de elasticidade $E_{c}$ do concreto. Já a região da curva pós-pico é caracterizada pelo módulo de amolecimento (strain-softening modulus) $E_{t}$, cujo valor é negativo.

Desta forma a energia consumida por "unidade de formação da banda de fissuração", denominada energia de fratura, pode ser equacionada como o produto da área sob a curva tensão-deformação pela largura $w_{c}$ da banda de fissuração, e, portanto:

$$
G_{f}=w_{c}\left(1-\frac{E_{c}}{E_{t}}\right) \frac{f_{t}^{\prime 2}}{2 E_{c}}
$$

A análise dos resultados de ensaios realizados por diversos pesquisadores (Naus, Walsh, Mindess, Kaplan, Shah, dentre outros), conduziu, aplicando os conceitos deste 
modelo, à obtenção das seguintes expressões a seguir, sendo o valor de $f_{t}^{\prime}$ dado em psi (BAZANT; OH, 1983):

$$
\begin{array}{r}
G_{f} \cong\left(2.72+0.0214 f_{t}^{\prime}\right) f_{t}^{\prime 2} \frac{d_{a}}{E} \\
E_{t} \cong \frac{-69.9 E}{56.7+f_{t}^{\prime}}
\end{array}
$$

\subsubsection{Modelos Elásticos-Efetivos}

Nos modelos elásticos efetivos, a modelagem da zona de processo de fratura é feita considerando o mecanismo simples de dissipação de energia de Griffith-Irwin, assumindo $\sigma(w)=0$; ou seja, o modelo admite uma fissura elástica equivalente sujeita à tração livre. A fissura equivalente é governada pelo critério da MFEL, e a equivalência entre ela e a fissura real será descrita para cada modelo. Dentre os modelos elásticos-efetivos tem-se o Modelo dos Dois Parâmetros, proposto por Jenq e Shah em 1990; e o Modelo da Fissura Efetiva, proposto por Karihaloo e Nallathambi em 1989.

\subsubsection{Modelo do Efeito de Escala}

O Modelo do Efeito de Escala se baseia na formulação desenvolvida por Bazant (BAZANT, 1984; BAZANT; PFEFFEIR, 1987). O método de efeito de escala proposto permite a determinação da energia de fratura $G_{C}$ para vigas entalhadas geometricamente similares. A energia de fratura obtida se refere à energia de fratura específica (energia por unidade de área plana) requerida para o crescimento da fissura em um corpo de prova infinitamente grande. Também podem ser obtidos pelo modelo: a tenacidade ao fraturamento $K_{I C}^{b}$, o comprimento da zona de processos de fratura $c_{f}$, e o deslocamento crítico de abertura da fissura $\delta_{C}$.

Como o modelo depende apenas das cargas máximas atingidas, a realização do ensaio é rápida e não depende de equipamentos sofisticados. A análise dos resultados também é simples, uma vez que depende apenas da aplicação direta dos dados de uma regressão linear (coeficientes angular e linear) nas expressões. $\mathrm{O}$ modelo fornece ainda parâmetros estatísticos para avaliar se os dados proporcionaram uma análise satisfatória do efeito de escala para o conjunto de vigas ensaiado. A Fig. 3.3 traz a curva resultante da aplicação experimental do modelo. 


\subsection{Conceitos Gerais}

\subsubsection{Histórico}

A primeira publicação sobre o comportamento do concreto sob carga mantida é atribuída a Hatt, 1907. Em seu trabalho, foram ensaiadas, à idade de 60 dias, vigas de concreto armado, submetidas à flexão em três pontos durante 45 dias, mantidas ao ar livre. Os resultados indicaram que após o período de observação a flecha medida foi praticamente o dobro da flecha inicial. Desta forma, Hatt comenta a observação de uma espécie de plasticidade no comportamento do concreto quando submetido a uma carga constante. Entretanto, em sua avaliação não se considera a retração do concreto, que certamente ocorreu (haja vista a manutenção das vigas ao ar-livre) e contribuiu para o aumento considerável das flechas medidas.

White, em publicação da ASTM de 1911, comenta a respeito do desenvolvimento de tensões devidas à retração. Contudo, apenas em 1915 com o trabalho de McMillan, faz-se referência às deformações transientes do concreto dependentes do carregamento (fluência) e não-dependentes do carregamento (NEVILLE, 1970).

Um artigo publicado por Smith em 1917 merece atenção especial por mostrar que a retirada do carregamento promove tanto a recuperação da deformação elástica quanto uma parcela da deformação por fluência. Desta forma, a reversibilidade da fluência havia sido estabelecida.

Até a década de 70 do século passado inúmeros trabalhos envolvendo a avaliação experimental da fluência e retração foram realizados, tratando de vários aspectos da fluência: fluência como uma propriedade do material, as implicações deste fenômeno no comportamento estruturas de concreto e hipóteses sobre os mecanismos envolvidos. 
Entretanto, de acordo com Neville (1970), para um real entendimento da natureza da fluência, o conhecimento empírico deve ser associado com o conhecimento da microestrutura da pasta hidratada de cimento.

Bazant, Z. P. (1993) comenta que a partir da década de 1970, as teorias da fluência e da retração do concreto sofreram um desenvolvimento expressivo. O principal impulso para este progresso foi inicialmente fornecido pelas necessidades da indústria de energia nuclear, o que impulsionou uma grande injeção de capital para pesquisa. Essa fonte de capital diminuiu drasticamente e em muitos países quase desapareceu em 1985. Entretanto, a motivação para a continuação dos progressos tem, apesar disso, fornecida o desafio de manter e reconstruir a infraestrutura de pontes e rodovias, o que até a década de 90 foi a força motriz para novos desenvolvimentos.

Começando com os estudos pioneiros de Glanville, Dischinger, Arutyunyan, Maslov, McHenry e outros antes e depois da segunda guerra mundial, a análise visco-elástica com envelhecimento linear das estruturas de concreto tem sido estudada sistematicamente.

\subsubsection{Origens da Fluência}

Define-se como fluência, o aumento da deformação sob condições de tensão constante, fenômeno que pode ocorrer ou não, sob a influência do teor de umidade.

A fluência ocorre na pasta de cimento e está relacionada com os movimentos internos da água adsorvida ou intercristalina, isto é, a percolação interna. Experiência de Glucklich e Ishai $^{6}$ (1962 apud NEVILLE 1983) mostraram que, num concreto em que foi removida toda água evaporável, não se observa, praticamente, nenhuma fluência. Desta forma, o fenômeno está fortemente vinculado às condições de exposição antes e durante o carregamento.

De uma forma geral, a deformação do concreto ao longo do tempo, sob condições de tensão constante, pode ser entendida como a composição de duas parcelas (MEHTA; MONTEIRO, 1994). A primeira delas, denominada fluência básica, ocorre mesmo que não se verifique a evaporação ou perda de umidade no concreto, ocorrendo, inclusive, em condições de umidade relativa da ordem de $100 \%$. A segunda parcela, por outro lado, decorre da secagem do elemento estrutural, e está fortemente associada a mecanismos de retração, o que torna o estudo da fluência uma tarefa bastante complexa, dado que o desacoplamento do

\footnotetext{
${ }^{6}$ GLUCKLICH, J.; ISHAI, O. (1962). Creep mechanisms in cement mortar. ACI Journal. Vol. 59, p. $923-48$.
} 
fenômeno de retração da resposta global de deformação seria necessário.

A descrição matemática dessa composição de parcelas foi sugerida por L'Hermite (L'HERMITE 1960 apud BAZANT 1988), por meio da expressão que segue:

$$
\varepsilon_{c}=\varepsilon_{c}^{o}\left(1+Q_{o} \varepsilon_{s h}\right)
$$

Na expressão anterior, $\varepsilon_{c}^{o}$ e $Q_{o}$ são constantes empíricas relacionadas à fluência básica e o produto $\varepsilon_{s h} \varepsilon_{c}^{o} Q_{o}$, associado às deformações decorrentes da retração, representa a fluência por secagem.

Segundo Neville (1970), a fluência pode ser considerada como uma deformação que se soma à deformação elástica, no instante da sua determinação, isto porque a deformação elástica diminui gradativamente, dado que o módulo Young do concreto aumenta com a idade.

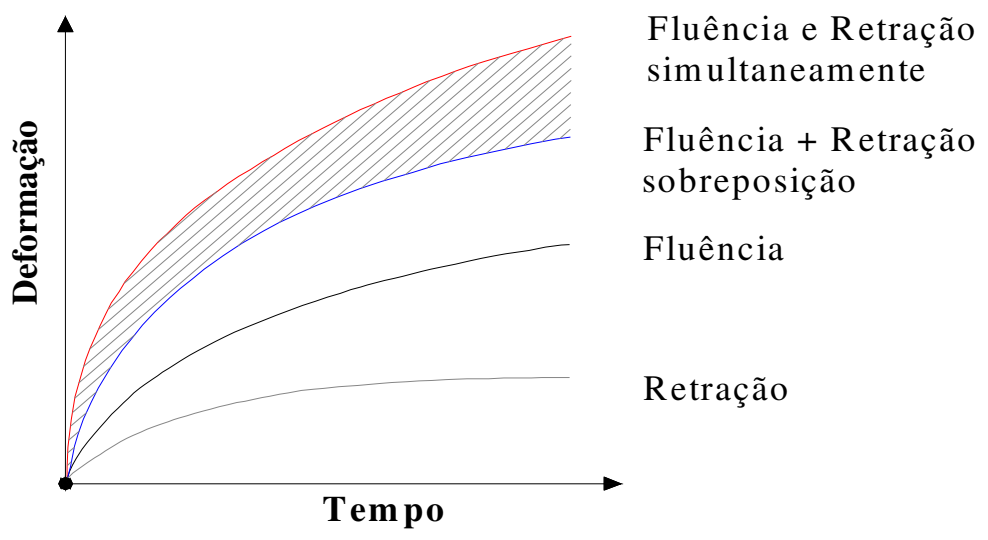

Fig. 4.1: Efeito da secagem simultânea à fluência do concreto.

Apesar da conveniência em desacoplar as deformações por fluência básica e fluência por secagem, é evidente que a deformação total resultante não depende de forma distinta do estado de tensões interno e da força externa, mas sim da atuação conjunta destas tensões. (BAZANT, 1988). Isto pode ser observado esquematicamente através da Fig. 4.1.

Além da subdivisão em parcelas que se referem à umidade relativa, pode-se também subdividir as deformações decorrentes da fluência em função do tempo, ou seja: a parcela de fluência rápida, que pode ser explicada pela redistribuição de água na microestrutura, e a parcela de longa duração, causada por deslocamento das partículas do gel.

Uma possível explicação para o aumento da fluência sob condições de secagem baseia-se no fato de que, devido ao desequilíbrio hídrico com o meio, a água se movimenta na 
microestrutura, facilitando a migração de partículas sólidas. Outra causa macroscópica, e talvez a mais significativa, são as tensões e microfissuras produzidas pela secagem no corpode-prova como um todo (BAZANT, 1988).

Uma vez que pode ocorrer a fluência em concreto-massa, conclui-se que a percolação da água capilar, para fora do concreto, não é essencial à evolução da fluência básica, embora esse processo possa ocorrer na fluência por secagem. No entanto, é possível a percolação interna da água das camadas adsorvida para vazios tais como os capilares. A relação entre a fluência e a resistência da pasta hidratada evidencia indiretamente o papel desses vazios. Entende-se que a fluência é uma função da "quantidade relativa de espaços não preenchidos" e pode-se especular que são vazios do gel que determinam tanto a resistência como a fluência; neste caso, os vazios podem ser relacionados com a percolação.

O volume de vazios é naturalmente, uma função da relação água/cimento e depende do grau de hidratação. Logo, é provável que a componente lenta da fluência, a longo prazo, decorra de outras causas além da percolação (ainda que a deformação só possa ocorrer com a presença de água evaporável). Isto sugere escoamento ou deslizamento viscoso entre as partículas de gel. Esse mecanismo é compatível com a influência da temperatura sobre a fluência e pode, também, explicar o caráter nitidamente irreversível da fluência em longo prazo (NEVILLE, 1983).

\subsubsection{Reversibilidade}

A respeito do comportamento do concreto à fluência, deve-se observar a ocorrência da recuperação da fluência. Ao se descarregar uma amostra de concreto, a recuperação instantânea das deformações elásticas é seguida por uma redução gradual da deformação global, chamada recuperação da fluência. Essa recuperação não é total, o que, por conseqüência sugere a existência de uma parcela de fluência perfeitamente reversível e outra, irreversível (Fig. 4.2).

Porém, pesquisadores como Dutron $^{7}$ (1957 pud NEVILLE, 1983) consideram a recuperação como uma simples manifestação de uma ligeira expansão da pastonda de cimento, aliviada da carga à medida que o concreto volta gradualmente ao estado de equilíbrio higrométrico.

\footnotetext{
${ }^{7}$ DUTRON, R. (1957). Creep in concretes. RILEM Buletin, Paris, No. 34, pp. 11-33.
} 
Por outro lado, McHenry ${ }^{8}$ (1943 apud NEVILLE 1983) explica tal recuperação como decorrente de uma superposição de efeitos. Segundo Neville, a superposição de deformações implica em tratar a fluência como fenômeno elástico com retardamento, sendo a recuperação total impedida pela hidratação progressiva do cimento. O princípio de superposição leva à erros toleráveis quando aplicado apenas na "parcela" de fluência básica.

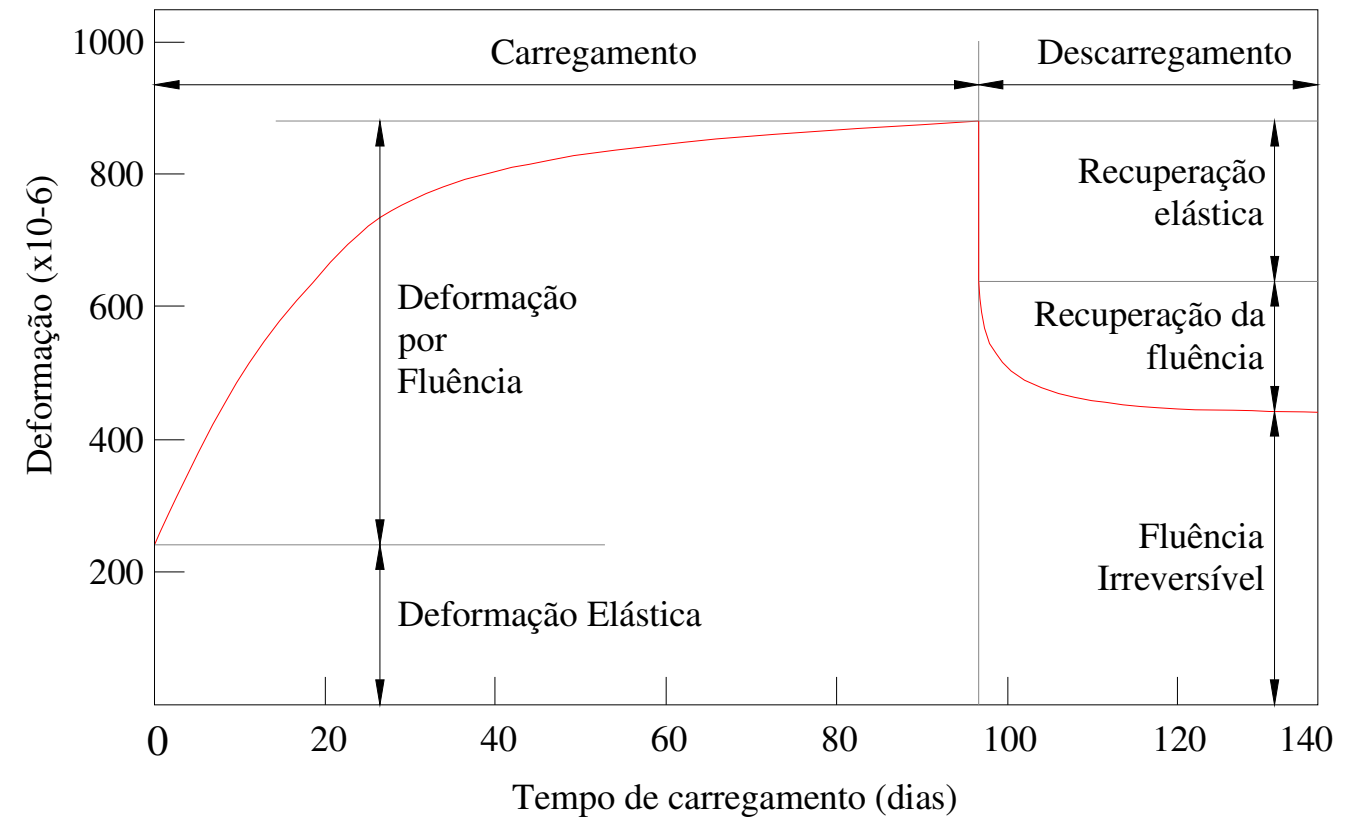

Fig. 4.2: Reversibilidade da Fluência. Adaptado de Metha e Monteiro (1994)

O princípio da superposição, equivalente à hipótese de linearidade, determina que a resposta para a soma de dois históricos de tensão seja equivalente à soma das respostas destes históricos considerados separadamente. Este princípio estabelece que as deformações produzidas no concreto a qualquer tempo t por um incremento de tensão aplicado em um momento qualquer $t_{0}$, são independentes dos efeitos de qualquer tensão aplicada antes ou depois de $t_{0}$. Segue então que, se a tensão é removida à idade $t_{1}$, a recuperação resultante da fluência será igual à fluência de um elemento semelhante submetido a uma tensão igual de compressão à idade $t_{1}$.

O princípio da superposição se aplica de forma precisa, nos casos em que os dados obedeçam às seguintes premissas:

- As tensões são inferiores a $40 \%$ da resistência (por conta da consideração de linearidade);

\footnotetext{
${ }^{8}$ McHENRY, D. (1943). A new aspecto $\mathrm{f}$ creep in concrete and its application to design, Proc. ASTM, 43, pp. 1069-84.
} 
- As deformações não decrescem em magnitude (não haja recuperação de fluência devido à retirada do carregamento);

- Os modelos (corpos-de-prova) não são submetidos à secagem severa durante o ensaio de fluência (sob esta condição de exposição, intensifica-se a não-linearidade das tensões, seja por microfissuração ou comportamento não linear do concreto na tração);

- Não há grandes acréscimos na tensão aplicada após o primeiro carregamento (requer análise não-linear).

De acordo com Neville (1983), a partir de dados da literatura é possível observar certa tendência quanto à aplicação do princípio da superposição: as deformações resultantes são subestimadas para um decréscimo da carga, e sobreestimadas para um acréscimo da carga.

A partir de dados experimentais observa-se a ocorrência da reversibilidade das deformações devido ao aumento da umidade relativa. Este comportamento foi observado por Altoubat e Lange (2001) e Christiansen K. (1988) na avaliação de flechas diferidas, estando os corpos-de-prova expostos à umidade variável. A recuperação de flechas diferidas e deformações por retração também foi verificada nesta pesquisa, principalmente no caso das vigas carregadas apenas com o peso-próprio. Detalhes sobre o comportamento das vigas avaliadas são abordados em Resultados e Discussões (Capítulo 8).

\subsubsection{Previsão da Fluência}

Desconsiderando as deformações decorrentes de retração ou variação da temperatura, as deformações de um elemento de concreto sujeito a um carregamento constante em um tempo qualquer $t$, posterior à aplicação da carga no tempo $t_{0}$, podem ser previstas conhecendo-se a função de fluência $J\left(t, t_{0}\right)$. Esta função relaciona a parcela elástica das deformações, representada pelo termo $1 / E_{c}\left(t_{0}\right)$, e a parcela viscosa, representada por outra função, $C\left(t, t_{0}\right)$, definida como fluência específica:

$$
J\left(t, t_{0}\right)=\frac{1}{E_{c}\left(t_{0}\right)}+C\left(t, t_{0}\right)
$$

A fluência específica, por sua vez, deriva da relação entre a deformação por fluência em um tempo $t$ e a tensão aplicada no tempo $t_{0}$ (ver equação 4.2). Essa função é bastante útil, e na maioria das publicações de estudos experimentais, os resultados são apresentados em 
termos da fluência específica. Na realidade, é como se os resultados fossem normalizados em termos da tensão aplicada, o que facilita análises comparativas no caso da aplicação de diferentes níveis de tensão.

$$
C\left(t, t_{0}\right)=\frac{\varepsilon_{c c}\left(t, t_{0}\right)}{\sigma_{c i}}
$$

Há também outro parâmetro importante da avaliação da fluência, definido como coeficiente de fluência $\phi\left(t, t_{0}\right)$. Conforme a equação 4.3 , o coeficiente de fluência representa em um tempo $t$, a relação entre a deformação por fluência, $\varepsilon_{c c}\left(t, t_{0}\right)$, e a deformação elástica imediata, $\varepsilon_{c i}\left(t_{0}\right)$; ou seja, seu valor reflete de certa forma a amplificação da deformação elástica, sendo normalmente encontrados valores entre 2,5 e 3 após 3 anos (para solicitação de compressão). Na determinação do coeficiente de fluência pode ser utilizado o módulo de elasticidade na ocasião do carregamento (modelos do ACI 209:1982 e de Bazant e Panula, 1978) ou então o módulo obtido aos 28 dias (modelos do CEB 1990 e da NBR 6118:2003).

$$
\begin{array}{r}
\phi\left(t, t_{0}\right)=\frac{\varepsilon_{c c}\left(t, t_{0}\right)}{\varepsilon_{c i}\left(t_{0}\right)} \\
\phi\left(t, t_{0}\right)=C\left(t, t_{0}\right) \cdot E_{c}\left(t_{0}\right)
\end{array}
$$

É possível correlacionar o coeficiente de fluência e a fluência específica de acordo com a equação 4.4. Desta forma pode-se escrever a função de fluência $J\left(t, t_{0}\right)$ também em termos do coeficiente de fluência, conforme a equação 4.5, apesar de a notação que utiliza a fluência específica ser mais comum.

$$
J\left(t, t_{0}\right)=\frac{1}{E_{c}\left(t_{0}\right)}+\frac{\phi\left(t, t_{0}\right)}{E_{c}\left(t_{0}\right)}
$$

Nota-se que todos os parâmetros relacionados ao comportamento viscoelástico do material são apresentados como função da idade do carregamento $t_{0}$ e da idade $t$, posterior à $t_{0}$, na qual se deseja avaliar as deformações. Não se pode simplesmente considerar o tempo referente ao intervalo entre $t$ e $t_{0}$, em virtude do envelhecimento não-linear do concreto decorrente do processo contínuo das reações de hidratação.

Nesse sentido, costuma-se desmembrar a fluência específica em outras duas funções, 
uma que considere a duração do carregamento, $f\left(t-t_{0}\right)$; e outra que leve em conta as características do material no instante de aplicação da carga, ou seja, as mudanças do concreto com a idade, conhecido como efeito de envelhecimento, $F\left(t_{0}\right)$.

Na literatura, encontram-se modelos somatórios de fluência, como por exemplo, o modelo da NBR 6118:2003, em que a função específica é definida pela soma das funções $f\left(t-t_{0}\right)$ e $F\left(t_{0}\right)$, e também modelos produtórios, quando a função de fluência é resultado da multiplicação destas duas funções. O emprego de modelos produtórios é mais difundido, sendo adotado em diversos códigos de norma (ACI 209:1982, CEB-FIB, Bazant e Panula 1979), já que sua apresentação e tratamento são mais simples que dos modelos somatórios.

Existem diversas publicações em que modelos analíticos de previsão da fluência são comparados entre si, assim como com resultados de ensaios experimentais. De suas conclusões é possível distinguir certas tendências de comportamento, entretanto, não há como apontar o melhor modelo de previsão, já que se observam grandes variações dos resultados ao efetuar alterações nos dados de entrada, considerando situações distintas. Como exemplo, pode-se citar os trabalhos de Goel, Kumar e Paul (2007) e Fanourakis e Ballim (2006).

Ao aplicar modelos matemáticos consagrados da literatura dados experimentais do banco de dados da RILEM e de um estudo de caso, Goel, Kumar e Paul (2007) observaram que os códigos de normas do CEB90 e do ACI subestimaram a fluência específica, ao passo que o modelo recomendado pela RILEM (Modelo B3) superestimou os resultados. Os autores concluem que em geral, nenhum dos modelos fornece resultados precisos de fluência considerando diferentes durações de carregamento e para diferentes classes de resistência de concreto. Contudo apontam que, de uma forma geral, o modelo GL2000 (atribuído à Gardner e Lockman) foi o mais adequado, além de requerer dados de entrada mais simples.

Certamente um dos modelos mais complexos é o Modelo BP (atribuído à Bazant e Panula de 1978). Bazant, Z. P. (1988) comenta que este modelo se aplica em amplos intervalos de tempo e considera numerosos fatores negligenciados por outros, tais como: carregamento cíclico, temperatura, secagem anterior ao carregamento, dilatação em condições de saturação na água e retração autógena do material selado. Entretanto, as curvas obtidas por sua formulação nem sempre são as de melhor ajuste aos dados experimentais.

Fanourakis e Ballim (2006) também compararam curvas de fluência específica fornecida por modelos de previsão com curvas experimentais obtidas em ensaios de Fanourakis, nos quais foram avaliados 3 diferentes agregados e 2 relações água/cimento. 
Pôde-se observar que em dois extremos o modelo do ACI209 subestima os resultados e o modelo do CEB78 superestima os resultados. Os autores comentam que modelos mais complexos não implicam em previsões mais precisas e concluem que, para as condições da África do Sul o modelo mais recomendado é o proposto na norma inglesa (BS 8110:1985).

Hisdolf e Muller sugerem que um coeficiente de fluência último $\left(\phi_{\infty}\right)$ entre 2 e 4 é típico para $80 \%$ dos casos de aplicação do concreto estrutural e para todas as condições de exposição (NEVILLE, 1983).

Tendo em vista a grande dispersão encontrada entre os coeficientes de erro dos modelos analíticos quando confrontados com diferentes situações experimentais, Neville (1983) assume uma posição prática, porém um tanto radical e conservadora, ao afirmar que nenhum modelo necessariamente fornece estimativa mais confiável do que a simples aproximação de utilizar $\phi_{\infty}$ igual a 3 .

Nesta pesquisa, foram utilizados para comparação com os dados experimentais os modelos de previsão da norma brasileira NBR 6118:2003 e da norma americana ACI 209:1982, sendo este modelo também utilizado na consideração da fluência nas simulações computacionais realizadas no DIANA ${ }^{\circledR}$. Desta forma, maiores informações sobre esses dois códigos assim como comparações entre eles, são apresentadas no Capítulo seguinte.

\subsubsection{Expressões Matemáticas para a fluência}

Existem na literatura diversas expressões matemáticas para o ajuste de dados experimentais de fluência, de forma que os resultados de ensaios de curta duração possam ser extrapolados para períodos maiores, assim como possa ser realizada análises paramétricas de acordo com o modelo matemático representativo do fenômeno.

Estas expressões descrevem o comportamento da fluência no tempo, sendo que demais fatores intervenientes são considerados em constantes obtidas empiricamente. Dentre as expressões matemáticas mais usuais tem-se: as expressões do tipo exponencial e a hiperbólica, as quais fornecem um valor limite de fluência; e expressões de potência e logarítmicas, que consideram a evolução contínua do fenômeno. A esse respeito nota-se divergência entre códigos correntes: O ACI-209 fornece um valor de fluência final finito enquanto que o CEB-78 não. A questão para a maioria dos casos práticos não é importante, uma vez que, por exemplo, de acordo com o CEB-78, a diferença entre os valores de fluência básica a 50 e 100 anos é apenas 8\%, aproximadamente (METHA; MONTEIRO, 1994). 
Independente do modelo ou expressão matemática utilizada, a função de fluência específica $C\left(t, t_{0}\right)$ deve atender as seguintes postulações (METHA; MONTEIRO, 1994):

a) Para uma dada idade de carregamento $t_{0}$, a função de fluência é monotônica crescente do tempo;

b) O incremento da taxa de fluência é sempre negativo:

c) A alteração da estrutura do concreto com o tempo causa um decréscimo na fluência, quando a idade de carregamento $t_{0}$ aumenta. Para um dado período de duração de carga $\left(t-t_{0}\right)$, devido ao envelhecimento do concreto.

$$
\frac{\partial C\left(t, t_{0}\right)}{\partial t} \geq 0 \quad \frac{\partial^{2} C\left(t, t_{0}\right)}{\partial t^{2}} \leq 0 \quad\left[\frac{\partial C\left(t, t_{0}\right)}{\partial t}\right]_{\left(t-t_{0}\right)} \leq 0
$$

$\mathrm{Na}$ literatura a faixa de tempo de avaliação experimental da fluência se estende desde ensaios de curtíssima duração (7 dias) até ensaios extremamente prolongados, dos quais decorrem observações de até 30 anos. Para propósitos práticos, em estruturas usuais considera-se cessado o processo de fluência após 4 ou 5 anos, o que não é válido para estruturas massivas.

Dados da literatura permitem concluir que a fluência é um processo contínuo de deformação, porém, maiores deformações ocorrem nos menores espaços de tempo, isto é, nos períodos iniciais do carregamento (até 1 ano). De acordo com os resultados de pesquisas de 20 anos de fluência Troxell, Raphael e Davis ${ }^{9}$ (1958 apud NEVILLE 1983) obtiveram os seguintes percentuais da deformação total no tempo sob carga: 18\% a 35\% (média 26\%) após 2 semanas; $40 \%$ a 70\% (média 55\%) após 3 meses; 64\% a 83\% (média 76\%) após 1 ano.

A seguir são apresentadas as expressões de ajuste mais comuns para a função de fluência específica $C\left(t, t_{0}\right)$ :

- Expressão logarítmica: $\quad C\left(t, t_{0}\right)=F\left(t_{0}\right) \cdot\left(t-t_{0}+1\right)$

Essa expressão foi proposta pelo "U.S. Bureau of Reclamation" para projetos envolvendo concreto-massa, e é válida quando a relação tensão-limite de resistência não

\footnotetext{
${ }^{9}$ TROXELL, G. E.; RAPHAEL, J. M.; DAVIS, R. E. (1958). Long-time creep and shrinkage tests of plain and reinforced concrete. Proc. ASTM. 58, pp. 1101-20.
} 
ultrapassa $35 \%$. O termo $F\left(t_{0}\right)$ é uma função da idade do carregamento, sendo que para sua obtenção devem-se conhecer os resultados para quatro diferentes idades de carregamento.

A equação foi originalmente desenvolvida para modelar fluência básica de grandes barragens e a duração do carregamento é medida em dias. A expressão usualmente superestima a fluência em idades avançadas e prevê uma fluência última infinita.

\section{- Expressão de potência: $\quad C\left(t, t_{0}\right)=a \cdot\left(t-t_{0}\right)^{m}$}

As constantes $a$ e $m$ são obtidas em um gráfico log-log, onde a equação acima resulta em uma reta. A expressão é capaz de prever bem a fluência nas primeiras idades, mas a superestima ao considerar idades avançadas. Também prevê uma fluência última infinita (METHA; MONTEIRO, 1994). Em Neville (1970), podem-se encontrar variações desta equação propostas por diversos pesquisadores. Já na publicação de 1983, Neville comenta a boa concordância desta expressão para fluência básica do concreto.

$$
\text { - Expressão hiperbólica: } \quad C\left(t, t_{0}\right)=\frac{\left(t-t_{0}\right)}{a+b\left(t-t_{0}\right)}
$$

Esta expressão foi inicialmente proposta por Ross e ao contrário da expressão de potência, usualmente subestima a fluência a curtas idades, mas fornece uma boa previsão para a fluência em idades avançadas. As constantes $a$ e $b$ determinadas diretamente dos resultados experimentais. Um gráfico de $\left(t-t_{0}\right) / C\left(t, t_{0}\right)$ versus $\left(t-t_{0}\right)$ fornece uma reta cujos coeficientes linear e angular são os valores de $a$ e $b$, respectivamente. Uma variação da expressão hiperbólica é utilizada na formulação do ACI 209:1982 para previsão da fluência.

$$
\text { - Expressão exponencial: } \quad C\left(t, t_{0}\right)=a\left(1-e^{-b\left(t-t_{0}\right)}\right)
$$

Os valores de a e b são constantes empíricas. Sua utilização para ajuste de dados experimentais pode não conduzir à bons resultados. Para análise numérica, são usualmente incorporados mais termos (METHA; MONTEIRO, 1994). Neville (1983) comenta que ajustes melhores são obtidos ao adicionar outra função exponencial. Variações desta expressão são encontradas em Neville (1970). A determinação das constantes $a$ e $b$ pode ser realizada por regressão ou ainda plotando em um gráfico a taxa de fluência versus a fluência. 


\subsubsection{Principais implicações do fenômeno}

Do conhecimento prático sabe-se que as estruturas podem estar sujeitas a grandes deformações, assim como grandes tensões devido à retração e fluência do concreto. As conseqüências são flechas excessivas, amplificação de fissuras nas áreas tracionadas do concreto e redistribuição de tensões em estruturas estaticamente indeterminadas. Entretanto, tais observações têm sido efetuadas em estruturas antigas de concreto. Logo, no caso de novas estruturas, onde a resistência do concreto e a taxa de armadura são exploradas de forma mais eficiente, levando à projeção de elementos mais delgados, a fluência e retração devem ser consideradas com cuidado e atenção especiais (SMERDA; KRISTEK, 1988).

Normalmente, erros na previsão da fluência não ocasionam o colapso estrutural, entretanto o aumento de flechas e deformações decorrentes destes erros, além dos limites aceitáveis para uso em serviço, pode levar à interdição da estrutura.

No caso de estruturas aporticadas muito altas, a redistribuição de esforços internos devida a deformações diferenciais entre os pilares internos e externos provocadas por fluência e retração é significativa. Destas deformações podem surgir fissuras na alvenaria e no revestimento, assim como intensificação de excentricidade nos pilares, sendo esta uma consequiência mais preocupante do ponto de vista estrutural.

Em estruturas estaticamente indeterminadas, a fluência pode aliviar as concentrações de tensões, induzidas por retração, variações de temperatura e recalque dos apoios. Tal alívio ocasiona redução da fissuração, sendo muito bem vindo nos casos de retração restringida e também no desenvolvimento de materiais de reforço. $O$ alívio de tensões também é de extrema importância no caso de estruturas de concreto-massa, sujeitas a tensões térmicas oriundas do resfriamento do concreto.

Além de erros de projeto, falhas durante a obra podem contribuir de forma significativa no comportamento da estrutura relacionado à fluência. A esse respeito, deve-se considerar a verificação da resistência e do módulo de elasticidade para o plano de escora e re-escora, cuidados com o concreto nas primeiras idades, previsão das cargas construtivas (que muitas vezes podem se igualar às cargas de serviço). De acordo com Kuperman (2007), tais cargas agindo em concretos jovens podem causar maiores deformações e, embora estes carregamentos possam perdurar apenas por curto intervalo de tempo, podem causar efeitos adversos nas deformações, devido ao fato da fluência não ser totalmente reversível.

No caso da execução de edificações com concreto moldado em loco, os elementos 
estruturais moldados em fases construtivas diferentes apresentarão comportamentos distintos quanto à fluência e retração. Isto ocorre por conta da variabilidade nas condições de exposição ambientais e também das diferenças nas propriedades dos materiais e das características do carregamento (incrementos de carga em diferentes idades, no caso de pilares).

Ainda que variações volumétricas ocorram livremente antes da montagem em obra, as estruturas pré-moldadas também estão sujeitas às deformações por retração e fluência. Nestes casos a redistribuição de tensões decorrente da fluência pode originar fissuras nas regiões das vigas sob os consolos de apoio, assim como fissuras devido a tensões de cisalhamento ocasionadas por retração.

Quando painéis de lajes pré-moldados de idades distintas são montados lado a lado, pode ocorrer uma diferença entre as flechas diferidas dos painéis. Conseqüentemente, fissuras induzidas por tensões de cisalhamento desenvolvem-se na junção dos painéis, levando-os à trabalhar isoladamente.

Os efeitos da fluência podem, portanto, ser nocivos, especialmente em se tratando de estruturas de concreto protendidas, onde as perdas de carregamento decorrem, em grande parte, desse fenômeno; mas no final, a fluência (o que não sucede com a retração) é benéfica quando resulta em alívio de concentrações de tensões, e tem contribuído, de forma considerável, para o sucesso do concreto como material estrutural.

\subsection{Fatores intervenientes}

Diversos autores (L'HERMITE; MAMILLAN 1968 apud BAZANT 1988; MEHTA; MONTEIRO 1994), apontam a perda de água adsorvida como a principal causa da fluência. As demais causas que contribuem para este fenômeno são bastante complexas, sendo determinadas por vários processos físicos químicos (BAZANT, 1988).

Segundo o autor, diversos fatores podem influenciar as respostas de fluência do concreto, dentre outros são citados a natureza dos materiais utilizados, a composição da mistura, o envelhecimento do concreto, as condições de umidade ao longo do tempo, além da geometria do elemento estrutural, fatores que passam a ser discutidos em seus principais aspectos.

\subsubsection{Materiais e Dosagem}

Segundo Neville (1983), a fluência é um fenômeno que se origina na pasta endurecida 
de cimento, ocorrendo não linearmente em função do teor volumétrico de pasta de cimento na matriz. Desta forma, com relação à dosagem, o efeito, sobre a fluência do concreto, do consumo de cimento e de água, não é direto, dado que um aumento (em volume) de pasta de cimento significa um decréscimo na fração de agregado e, conseqüentemente, um acréscimo correspondente nas deformações do concreto (dependente da umidade).

De acordo com Neville (1970), o tipo de cimento é o principal fator interveniente, já que é o cimento o material que determina a hidratação da matriz. Cimentos de alta resistência inicial apresentam menor fluência específica. Cimentos pozolânicos conferem maior fluência, provavelmente devido à resistência da matriz nas primeiras idades ser reduzida. A Fig. 4.3 ilustra a influência do tipo de cimento.

O tipo de cimento altera a fluência na medida em que influencia a resistência do concreto no momento de aplicação da carga. Por isso, qualquer comparação de fluência de concretos preparados com cimentos diferentes deve levar em conta os efeitos do tipo de cimento sobre a resistência às primeiras idades de concreto.

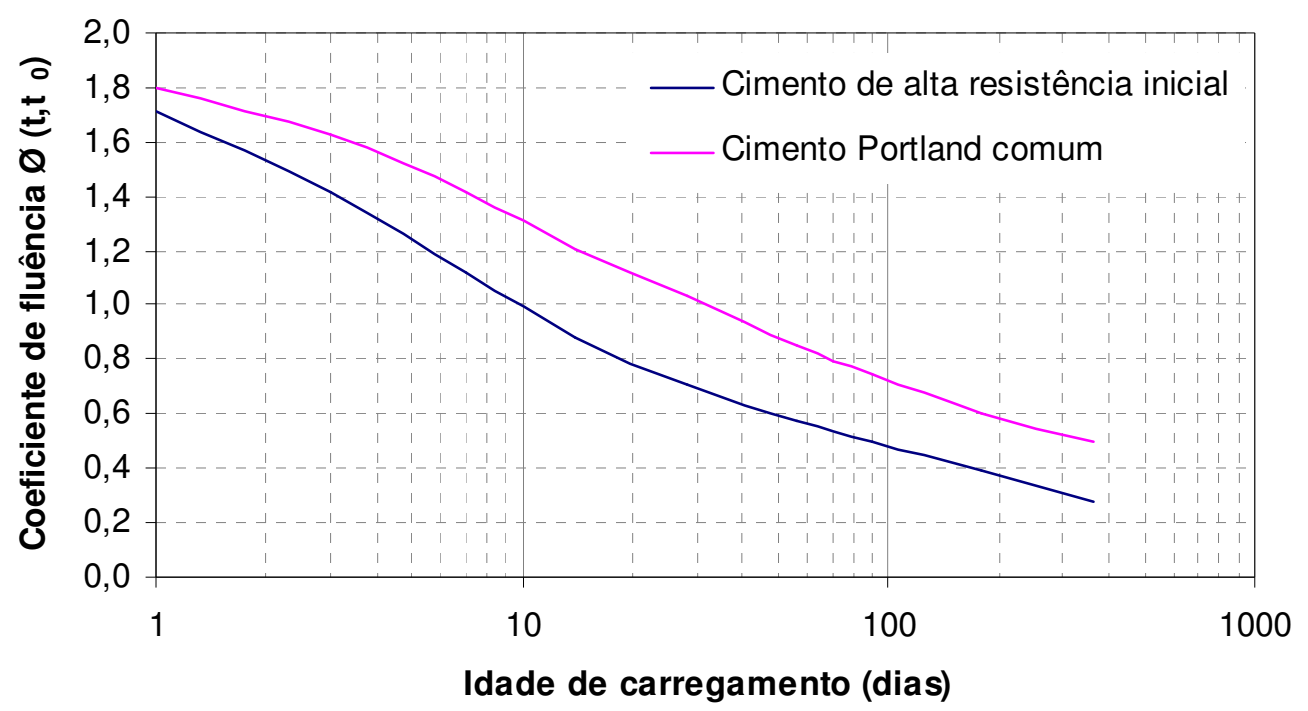

Fig. 4.3: Efeito do tipo de cimento sobre a fluência de concretos. Adaptado de Metha e Monteiro 1994.

Para um dado consumo de cimento, sabe-se que um aumento na relação água-cimento implica em um aumento na fluência. Isso provavelmente pode ser explicado devido ao decréscimo da resistência e do módulo de deformação e um acréscimo na permeabilidade. De acordo com os resultados de Fanourakis e Ballim (2006), um aumento na relação água cimento de 0,4 para 0,56 causa aproximadamente um aumento de $60 \%$ na fluência específica medida. 
Com relação aos agregados, a quantidade utilizada e seu módulo de elasticidade interferem diretamente na deformabilidade do concreto assim como na restrição às deformações por fluência. Desta forma, além de suas propriedades físicas, características relacionadas direta ou indiretamente ao teor de agregado, tais como granulometria, tamanho máximo e formato, alteram a fluência do concreto (NEVILLE, 1983).

A importância do módulo do agregado no controle das deformações é confirmada por estudos que mostram que, tanto a fluência como a retração por secagem aumentam 2,5 vezes quando um agregado de alto módulo de elasticidade é substituído por outro de baixo módulo (METHA; MONTEIRO, 1994). A Fig. 4.4 ilustra as curvas de fluência obtidas para concretos preparados com diferentes tipos de agregados. Mais resultados a esse respeito podem ser encontrados no trabalho de Alexandre, M. G. (1996).

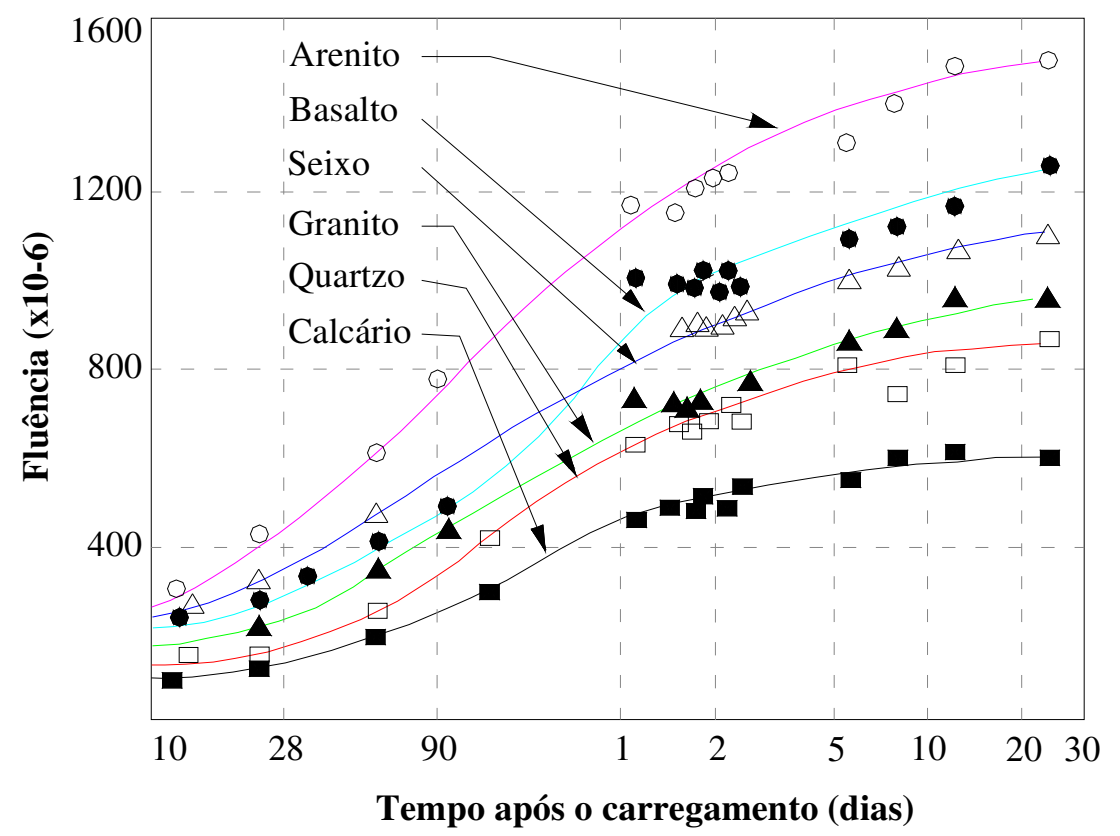

Fig. 4.4: Fluência de concretos com traços iguais, preparados com diversos agregados, carregados à idade de 28 dias, e conservados ao ar a $21^{\circ} \mathrm{C}$ e umidade de $50 \%$. Adaptado de Neville.

\subsubsection{Aditivos e Adições}

O efeito de aditivos químicos, como o superplastificante, e de adições, como escória de alto forno e materiais pozolânicos é controverso, havendo resultados de ensaios mostrando que a fluência pode ser menor, igual ou maior que a dos respectivos concretos de referência. De maneira geral há escassez de informações sobre o efeito dos diversos tipos de aditivos, principalmente os mais modernos, pois os dados disponíveis representam uma enorme gama de diferentes ensaios, realizados sob diferentes condições, não permitindo uma generalização 
(KUPERMAN, 2007).

Brooks J. J. (1989) comenta que se deve ter cuidado ao avaliar a influência de aditivos e adições. Quando a utilização desses componentes é efetuada simultaneamente com alterações no traço original, a comparação entre as duas misturas é incorreta. Desta forma, uma avaliação mais confiável decorre da utilização de aditivos apenas para melhorar a trabalhabilidade da mistura.

Como a principal propriedade mecânica relacionada com a fluência é o módulo de elasticidade, se o uso destes componentes na mistura resultar em um concreto com módulo maior, o concreto obtido será menos deformável, o que indica menor fluência.

Os resultados de Cabrera, Brooks e Berenjian (1993) mostram que, concretos com superplastificantes dos tipos Copolímero e MLS (modified lignosulfonate) apresentaram acréscimos de fluência de 16 e 19\%, enquanto que concretos com superplastificantes dos tipos SNFC (sulphonated naphthalene formaldehyde condensate) e SMFC (sulphonated melanine formaldehyde condensate) apresentaram reduções nas deformações por fluência de $1 \%$. Brooks (1989) também encontrou resultados bastante discrepantes para diferentes tipos de superplastificantes, obtendo acréscimos na fluência variando entre 3\% e 132\%.

$\mathrm{Na}$ realidade, a diferença entre o efeito provocado por um ou outro superplastificante sobre a fluência está relacionada às alterações na porosidade da matriz (quantidade e distribuição em tamanhos dos poros) e também a diferenças no grau de hidratação, em decorrência da ação do aditivo na microestrutura do concreto. Neste sentido, os resultados de Cabrera, Brooks e Berenjian (1993) demonstram que o uso de superplastificantes dos tipos Copolímeros e MLS, os quais reduzem sensivelmente o grau de hidratação, produzem pastas de cimento com alta porosidade e estrutura porosa mais grosseira. Além disso, estes aditivos promovem uma redução da tensão superficial da água em torno de $20 \%$, o que facilita a saída da água adsorvida.

\subsubsection{Condições de exposição}

\section{Temperatura Ambiente}

$\mathrm{O}$ efeito térmico que primordialmente influencia o comportamento à fluência do concreto é o que decorre do processo de hidratação do cimento (NEVILLE, 1970). Entretanto, a temperatura do ambiente, durante o carregamento da peça, pode influenciar substancialmente os valores das deformações decorrentes da fluência, podendo contribuir 
tanto para o aumento como para a diminuição das deformações, dependendo do momento em que o concreto for submetido a temperaturas mais elevadas.

Se isso ocorrer antes do carregamento, o efeito ocorrerá no sentido de diminuir as deformações por fluência. Por outro lado, se a peça já carregada for submetida a temperaturas mais elevadas, o efeito oposto será verificado (MEHTA; MONTEIRO, 1994).

\section{Umidade Relativa}

Segundo Neville (1970), maiores deformações por fluência ocorrem em peças de concreto expostas a teores menores de umidade relativa. Tal fato pode estar associado à hipótese de Pickett: uma vez que a baixa umidade relativa ocasiona retração, a fluência pode ser uma conseqüência da retração. Contudo, ainda hoje não há consenso entre os pesquisadores sobre a ordem exata em os fenômenos acontecem, uma vez que o limite entre um e outro é muito tênue.

Torna-se, então, bastante interessante quantificar a influência da umidade relativa na fluência. A Fig. 4.5 ilustra a influência a umidade relativa de exposição sobre as deformações por fluência. Para concretos em ambientes com umidade relativa de $50 \%$ a fluência pode ser de duas a três vezes maior do que para concretos a $100 \%$ de umidade relativa. Dentre as pesquisas desenvolvidas na área, tem-se aquelas elaboradas por Drögsler, de la Peña e Neville (NEVILLE, 1970).

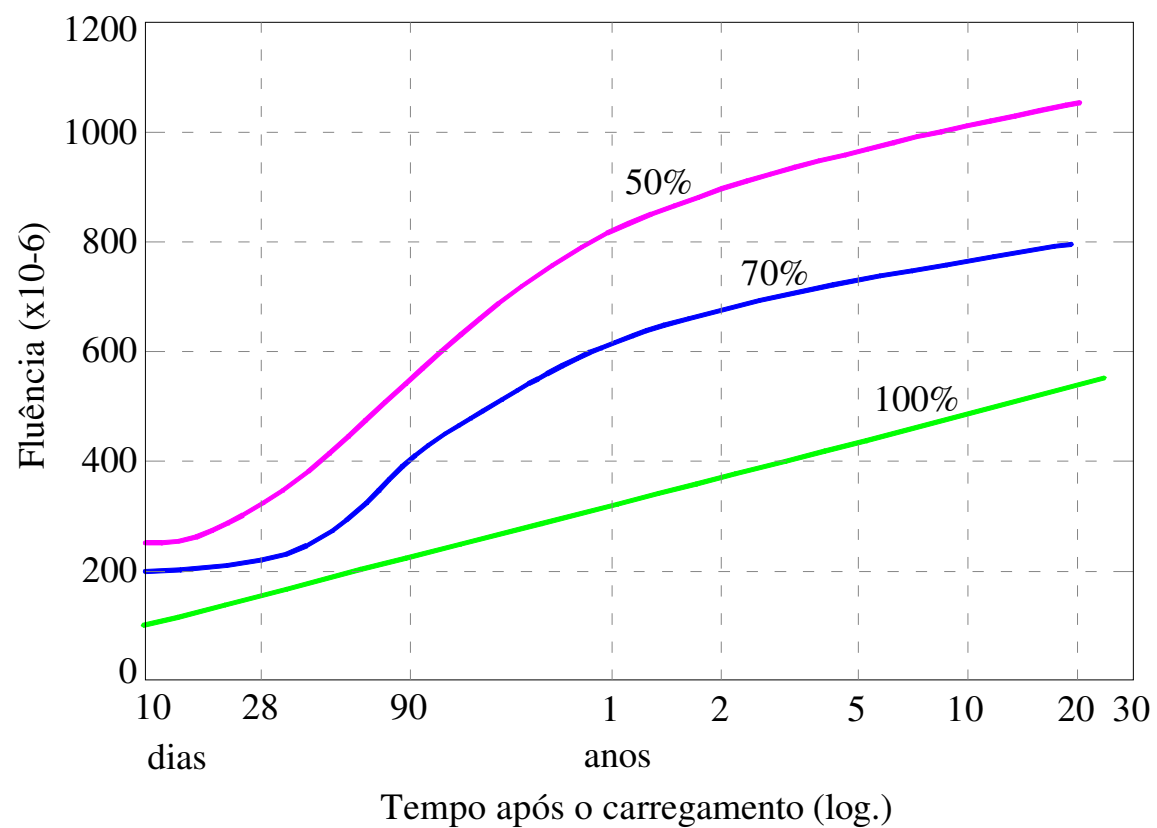

Fig. 4.5: Efeito da umidade relativa na fluência de concretos. Adaptado de Neville, 1981. 
No caso de elementos que já tenham atingido o equilíbrio higroscópico com o meio, antes da aplicação da carga, a influência da umidade relativa é bem menor. Desta forma podese afirmar que na verdade, não é a umidade relativa que tem efeito sobre a fluência, mas sim o processo de secagem, isto é, a ocorrência da fluência por secagem. Não se deve esquecer que um concreto curado, carregado e exposto a uma umidade relativa constante apresenta deformação por fluência, e esta não resulta em perda significativa de água do concreto para o meio, nem ocorre qualquer aumento de massa durante a recuperação dessa deformação (NEVILLE, 1983).

Relacionado ainda à umidade tem-se as condições de cura. O concreto submetido a situações repetidas e alternadas de secagem e molhagem terá na prática, respostas diferentes daquele tratado em laboratório, em relação ao comportamento estudado.

\section{Pré-secagem}

A fluência não depende apenas da perda de água que ocorre durante o processo de fluência, mas também da quantidade de água no momento da aplicação do carregamento. Segundo Neville (1983), experiências de Glucklich mostraram que num concreto em que foi removida toda água evaporável não se observa, praticamente, nenhuma fluência.

A magnitude absoluta da fluência de concreto exposto à condição de secagem anteriormente ao carregamento é muitas vezes menor do que considerando concreto selado. Observa-se também que a taxa de fluência deste concreto se estabiliza após poucas semanas de ensaio (NEVILLE, 1983). A influência da pré-secagem está ilustrada na Fig. 4.6.

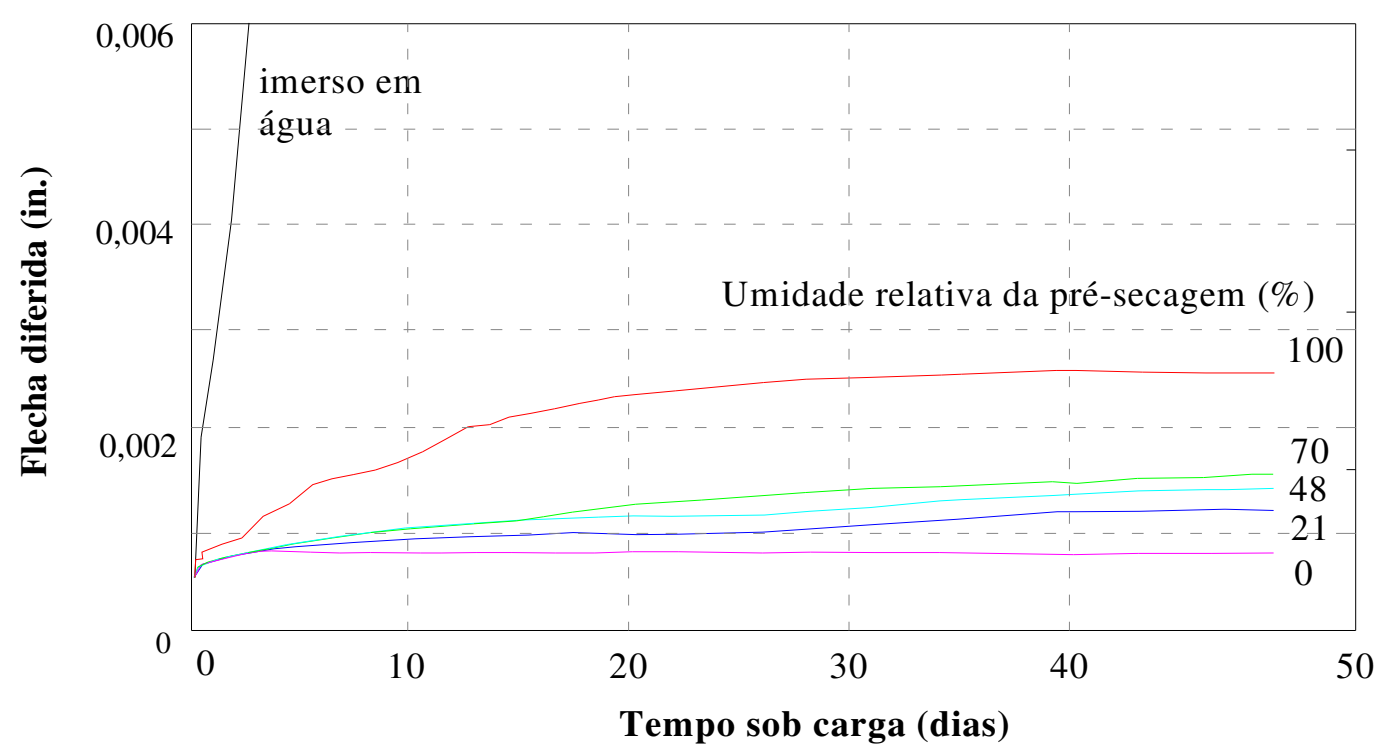

Fig. 4.6: Efeito da pré-secagem na fluência de concretos. Adaptado de Neville, 1982. 


\section{$>$ Variação da Umidade Relativa (umidade alternada)}

É comum que os ensaios em laboratório sejam realizados considerando um teor de umidade relativa constante. Desta forma, tem-se um problema ao aplicar os dados obtidos experimentalmente às estruturas reais, haja vista que estas ficam sujeitas à condições de exposição de umidade relativa variável entre dois limites. Dada a dificuldade nesta pesquisa em manter a umidade relativa aproximadamente em um valor constante (ou seja, dentro de uma faixa de variação estreita), julgou-se conveniente apresentar alguns resultados encontrados na literatura para ensaios realizados nestas condições.

Hansen observou em 1958 que a umidade relativa do ambiente alternada entre dois limites resulta em deformações por fluência maiores do que aquelas obtidas ao manter a umidade relativa do ambiente em um valor constante dentro do referido intervalo. Entretanto, este comportamento também depende das condições de armazenamento das peças antes de realizar os ensaios.

Este fenômeno já havia sido notado por Pickett em 1942, mas como não havia explicação disponível, ele foi simplesmente esquecido. Sendo estes resultados confiáveis, pode-se inferir que a previsão da fluência a partir de ensaios à umidade relativa constante pode subestimar as deformações por fluência que ocorre nas estruturas reais.

A Fig. 4.7 ilustra resultados de Hansen T. C. ${ }^{10}$ (1960 apud NEVILLE 1970). Comparando as curvas em verde e em azul, nota-se que a influência da variação cíclica da umidade relativa é mais pronunciada no caso em que não houve pré-secagem. A curva em azul, referente às peças que foram submetidas à secagem anterior ao carregamento, aproximase daquela obtida para umidade mantida no limite superior de $70 \%$ (curva em preto).

Comparando as curvas em verde e em vermelho, tem-se que para ciclos maiores de secagem e umidificação (ou seja, a variação de umidade ocorre lentamente), a curva de fluência praticamente coincide com aquela obtida mantendo a umidade no limite inferior de $50 \%$. Ao diminuir o ciclo, o comportamento se aproxima daquele obtido para umidade relativa constante média do intervalo de variação.

Neville (1970) também comenta o estudo de Bernhardt (1969), que avaliou experimentalmente a fluência de corpos-de-prova de concreto submetidos, sob carga, a ciclos de saturação em água e secagem (umidade relativa de $35 \%$ a $55 \%$ ).

\footnotetext{
${ }^{10}$ HANSEN, T. C. (1960). Creep and stress relaxation of concrete. Proc. No. 31. Swedish Cement and Concrete Research Institute: Stokolm. 112 p.
} 
O autor observou que quanto maior o tempo de secagem, para um mesmo período sob saturação, maior o coeficiente de fluência. Já considerando um ciclo de 7 dias, quanto maior o tempo sob saturação (e, portanto, menor o tempo sob secagem) maior o coeficiente de fluência.

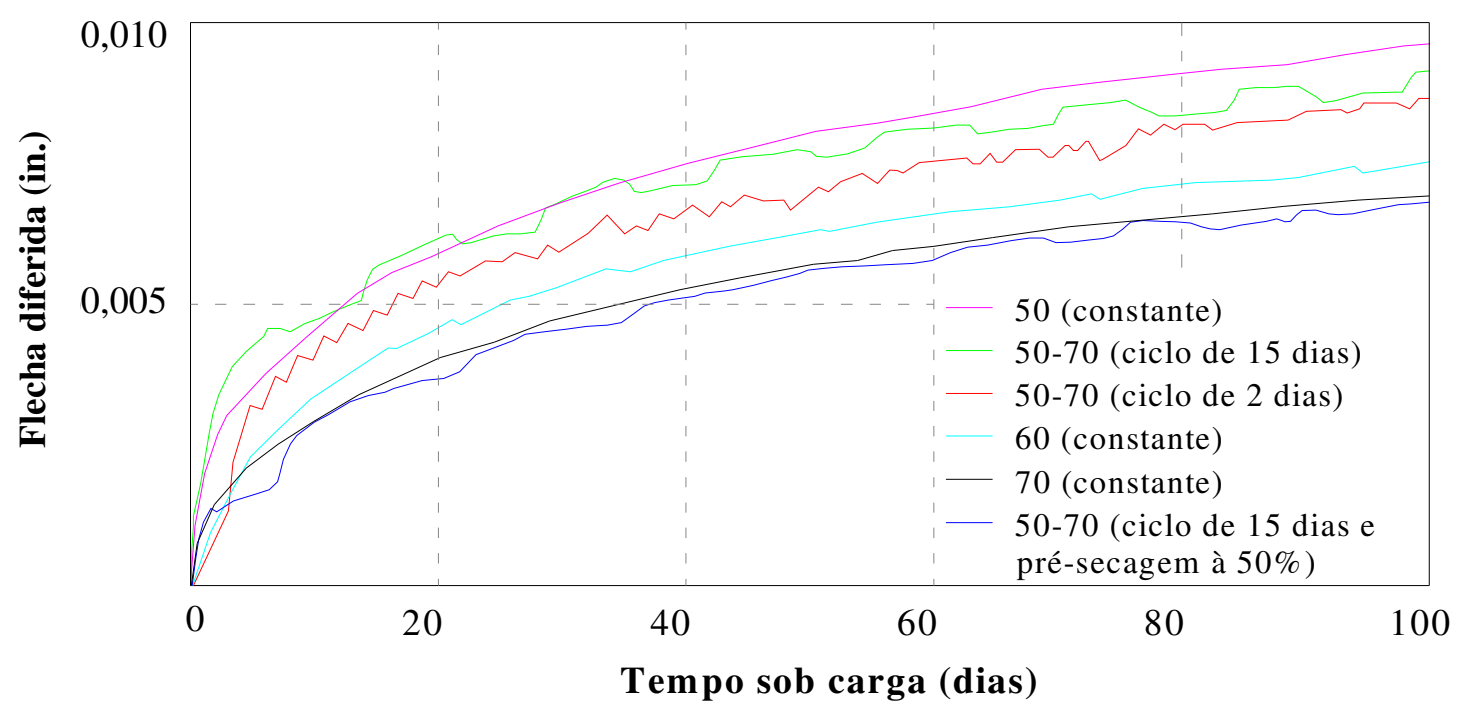

Fig. 4.7: Flecha por fluência de vigas de argamassa armazenadas em umidade relativa alternada. Adaptado de Neville, 1970.

L’Hermite e Malliman $^{11}$ (1968 apud NEVILLE 1970) estudaram o comportamento do concreto exposto à variações da umidade relativa ao ar-livre mas protegido de chuva. Os resultados são mostrados na Fig. 4.8, e parece não haver uma diferença substancial na fluência ou na deformação total entre a exposição em loco, onde a umidade relativa variou entre 60 e 90\%, a armazenada em laboratório à uma umidade relativa de $50 \%$.

Isto sugere que a umidade relativa alternada aumenta a fluência um tanto além do que o limite inferior de umidade, de modo que muito cuidado deve ser tomado ao aplicar os resultados de ensaios submetidos a umidade constante à condição real de exposição: um pequeno acréscimo de fluência correspondente à umidade relativa um tanto menor do que o verdadeiro limite inferior de exposição parece desejável.

De acordo com os resultados de Müller e Pristl (1993) avaliaram comparativamente a fluência sob variação cíclica de umidade em corpos-de-prova cilíndricos de diferentes tamanhos, submetidos a diferentes níveis de tensão.

${ }^{11}$ L'HERMiTE, R. G.; MAMILLAN, M. (1968). Further results of shrinkage and creep tests. Proc. Int. Conf. on the Structure od Concrete. Ceement and Concrete Association: London. pp. 423-33. 
Os resultados indicam um comportamento semelhante ao relatado por Hansen: a fluência dos corpos-de-prova expostos à umidade variável foi cerca de $20 \%$ maior do que a fluência daqueles mantidos em umidade relativa constante, sendo essa diferença proporcional ao tempo de ensaio.

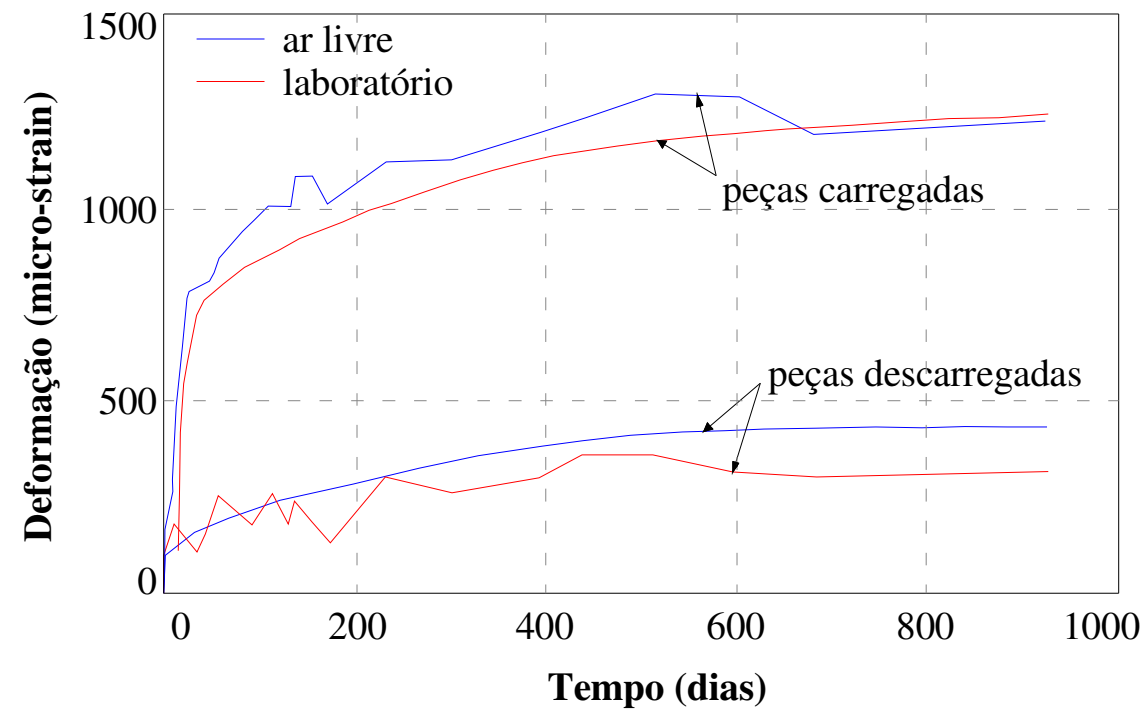

Fig. 4.8: Fluência em concreto exposto ao ar livre e em laboratório à umidade relativa de 50\%. (prismas 20x20x60 cm sob tensão de $12 \mathrm{MPa}$ ). Adaptado de Neville, 1970.

\subsubsection{Geometria do Elemento Estrutural}

Sabe-se que o principal fator que contribui no fenômeno da fluência é a evaporação de água do concreto. Sendo assim, a dificuldade de evaporação na peça de concreto acaba determinando o fenômeno. A geometria da peça real influencia relativamente ao caminho que a água terá que fazer para ser expelida (NEVILLE, 1983; METHA; MONTEIRO, 1994).

Constatou-se que a fluência diminui com o aumento das dimensões da peça. Isto pode ser devido aos efeitos da retração e ao fato de que a fluência ocorre na superfície em condições de secagem, e é, portanto, maior do que no interior da peça onde as condições se aproximam das mesmas de cura de um concreto-massa. Mesmo que com o tempo a secagem atinja o interior, esta parte já deverá estar extensivamente hidratada e terá atingido uma resistência mais elevada, o que resulta em fluência menor. Em concreto-massa não se nota efeito das dimensões (NEVILLE, 1983).

De acordo com Bazant, Z. P. (1993), uma das linhas de pesquisas promissoras para o correto entendimento e previsão da fluência e da retração consiste justamente em considerar o gradiente térmico e de umidade que existe no interior de um elemento de concreto, através da Teoria da Difusão. 


\subsubsection{Intensidade do carregamento aplicado}

Dados experimentais encontrados na literatura permitem afirmar que há uma proporcionalidade válida entre a intensidade da tensão aplicada, estando as tensões na faixa linear da relação tensão-deformação, e o fenômeno da fluência. Quanto mais elevados forem os níveis das tensões aplicadas, maiores serão as deformações decorrentes do processo de fluência (MEHTA; MONTEIRO, 1994). Entretanto, o limite de proporcionalidade entre tensão aplicada e fluência varia em função do tipo de solicitação à que o concreto está submetido, sendo normalmente admitida tal proporcionalidade até $50 \%$ da tensão resistente para compressão e valores superiores na tração.

Ainda a respeito da dependência, entre a fluência e a relação tensão/resistência, pode se notar que, para um determinado concreto, existe uma correlação entre a resistência e o módulo de deformação e entre a fluência e o módulo de deformação.

Acima do limite de proporcionalidade, a fluência evolui a uma razão crescente com o aumento de tensão e acima de um valor determinado da relação entre a tensão e a resistência, a fluência, com o tempo, produz ruptura. Esta relação, tensão-resistência, se situa entre 0.8 e 0.9 da resistência estática instantânea. A fluência resulta em um aumento da deformação total até que seja atingido um valor limite que corresponde à deformação limite do concreto considerado. Esta proposição implica no conceito de ruptura a uma deformação limite, pelo menos na pasta de cimento.

\subsubsection{Idade de Carregamento}

A relação inversamente proporcional entre a fluência e a idade de carregamento é conseqüência direta das reações de hidratação. Devido ao envelhecimento do concreto, tem-se um aumento na resistência ao longo do tempo, o que reflete em uma diminuição do módulo de elasticidade, mesmo que a evolução dessas propriedades ocorra em velocidades diferentes.

Sabe-se que fluência é um fenômeno relacionado à maior ou menor deformabilidade do concreto, estando intimamente ligado ao módulo de elasticidade no momento de aplicação da carga. Entretanto, com a idade, ocorrem também modificações na microestrutura do material que conduzem à diminuição do conteúdo de água evaporável (já que esta é consumida nas reações de hidratação), e também da porosidade, o que torna a matriz mais compacta.

Todos esses fatores contribuem para que a fluência diminua com a idade do 
carregamento, desde que seja mantida a relação tensão-resistência. Esse comportamento pode ser observado na Fig. 4.9, decorrente de ensaios realizados por Reis, 2003.

Em geral, após aproximadamente um mês a fluência torna-se independente da idade de carregamento. A partir de resultados de ensaios de Furnas, comprovou-se que a partir dos 28 dias de idade de carregamento os valores de fluência não são significativamente alterados quando comparados aos concretos carregados com 90, 180 ou 365 dias.

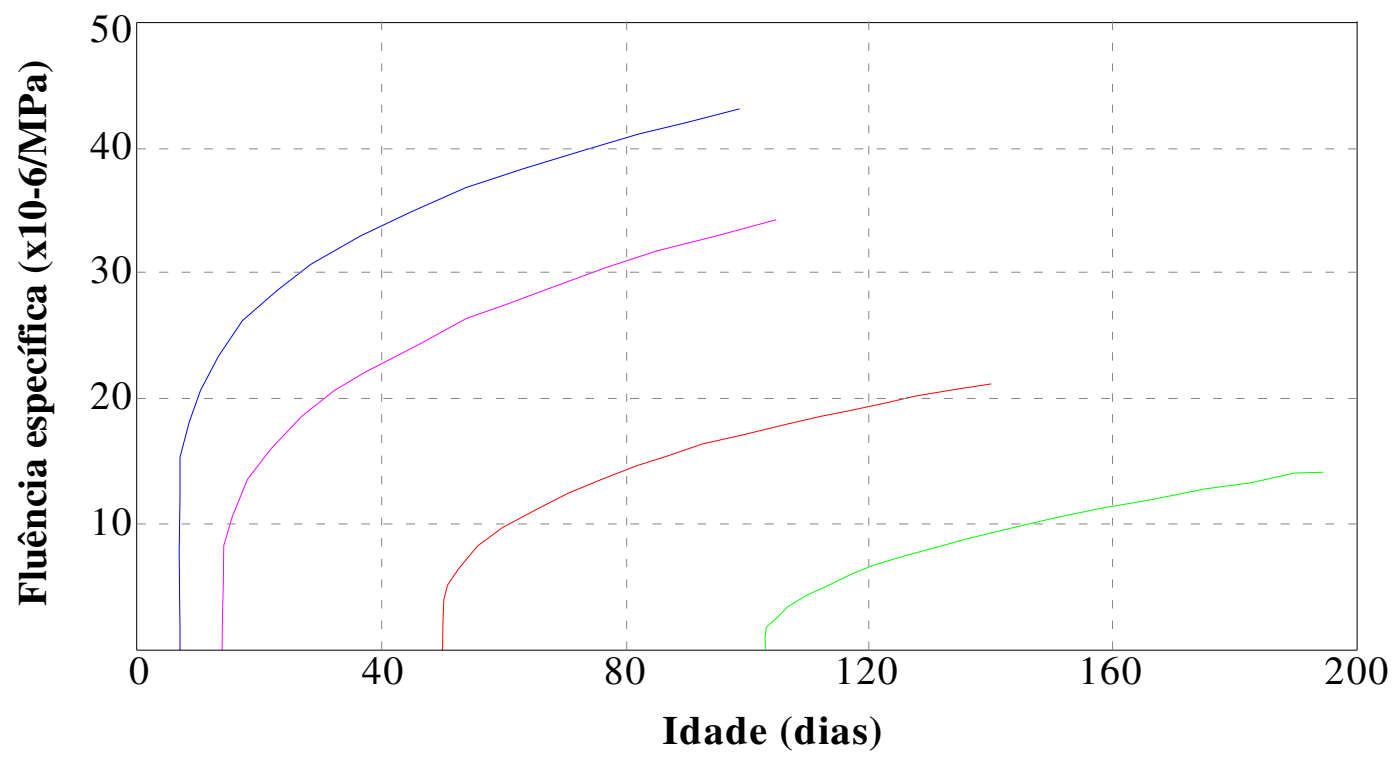

Fig. 4.9: Efeito da idade do carregamento na fluência à compressão de concretos. Adaptação dos resultados de Reis, 2003.

\subsubsection{Redução da Fluência}

Com relação aos materiais e dosagens, pode-se reduzir a fluência através de combinações que propiciem maior resistência, e conseqüente maior módulo de deformação, menor porosidade e quantidade de água intracristalina na matriz cimentícia. Como a fluência ocorre na matriz a diminuição do consumo de cimento pode minorar as deformações lentas.

Após moldado, a cura e manutenção do concreto em ambientes com elevada umidade relativa proporciona redução da fluência, ganhos de resistência e do módulo de elasticidade (relacionados às reações de hidratação) e redução da retração.

A redução dos efeitos danosos da fluência também é obtida adiando o carregamento prematuro das estruturas de concreto (relacionados às operações de escoramento e reescoramento e aplicação de cargas construtivas), haja vista a influência da idade de carregamento sobre o fenômeno. A solicitação da estrutura à níveis de tensão menores 
também contribuem para menores deformações desta natureza, sendo que para relação tensãoresistência de até $40 \%$ a redução da fluência é proporcional àquela imposta para a tensão.

\subsection{Fluência sob diferentes estados de tensão}

Até agora se discutiu o caso de compressão uniaxial, mas a fluência ocorre em outras condições de carregamento, e as informações sobre o comportamento nessas condições, são particularmente úteis para o conhecimento da sua natureza e para certos problemas de projeto.

Sabe-se que a fluência pode ter um efeito benéfico em elementos tracionados, por conta da redistribuição de tensões que ocasiona; ao passo que em elementos fletidos, a ampliação dos deslocamentos verticais ocasionada pelo fenômeno não é bem vinda, de modo que a previsão incorreta no dimensionamento pode afetar a durabilidade da estrutura devido a restrições de serviço. Nesse sentido, o estudo experimental da fluência na tração e na flexão pode inclusive ser útil para avaliar a adequação dos Modelos de Fluência disponíveis em códigos de projeto (baseados em resultados experimentais de ensaios de compressão).

Infelizmente, se dispõe de poucos resultados experimentais e, em muitos casos, não é possível a avaliação quantitativa e a comparação com o comportamento sob compressão. Por essa razão, só se pode fazer algumas afirmativas genéricas a respeito. Foram encontradas algumas referências sobre avaliação da fluência à tração; entretanto, quase não há publicações do estudo de fluência á flexão.

\subsubsection{Fluência na Tração}

A fluência à tração é de interesse para avaliar a possibilidade de fissuração devido à retração, no cálculo de tensões de tração de vigas protendidas ou mesmo no projeto de estruturas de contenção de água (novamente relacionado à fissuração). O comportamento na tração é também relevante na avaliação de várias hipóteses do mecanismo da fluência (NEVILLE, 1970).

Avaliar experimentalmente a fluência à tração é complicado: como a tensão aplicada deve ser baixa (haja vista que a resistência à tração do concreto é cerca de $10 \%$ da resistência à compressão), as deformações resultantes são muito pequenas, o que compromete a precisão das medições com os equipamentos disponíveis em laboratório. Além disso, se o concreto está submetido à secagem durante os ensaios, as deformações por retração podem mascarar os resultados, já que sua ordem de grandeza pode ser superior as deformações por fluência. Por 
estas razões, deve-se a carência de trabalhos sobre fluência à tração no concreto.

A fluência do concreto-massa, sob tração uniaxial, é 20 a $30 \%$ maior do que sob tensão de compressão de igual valor absoluto. A diferença depende da idade no carregamento e pode chegar a 100\%, para conservação a 50\% de umidade relativa, se o concreto for carregado às primeiras idades. A forma das curvas de fluência específica versus tempo na tração é semelhante àquela na compressão, mas o decréscimo de velocidade de fluência é menos pronunciado na primeira porque é menor o aumento da resistência com o tempo. A secagem acentua a fluência tanto na tração como na compressão (NEVILLE, 1983).

Resultados encontrados na literatura por Mamillan, Davis e Illston indicam ocorrer uma maior taxa de fluência inicial à tração, assim como uma estabilização mais rápida destas deformações, o que pode ser observado na Fig. 4.10 (NEVILLE, 1970).

Assim como na compressão, parece haver proporcionalidade entre a fluência à tração e a tensão aplicada. Entretanto, na tração o limite de proporcionalidade é um pouco maior: 50\% da resistência à tração ou mais.

A forma como a idade de carga afeta a taxa de fluência à tração também parece ser equivalente à encontrada na compressão. Dados da literatura também demonstram que condições de secagem intensificam as deformações. (BISSONNETTE et al., 2007; BISSONNETTE e PIGEON, 1995; NEVILLE, 1983; ALTOUBAT e LANGE 2001).

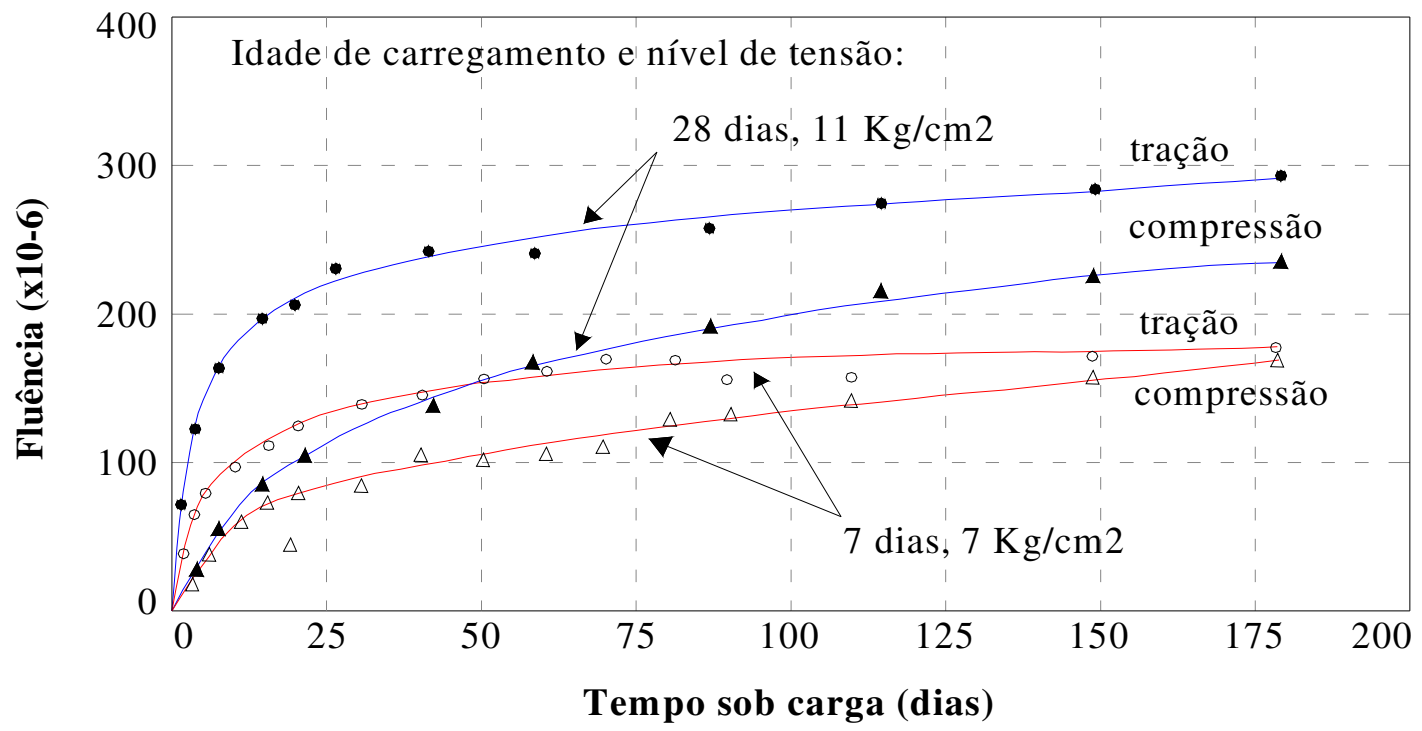

Fig. 4.10: Fluência a tração e a compressão. Concreto submetido a cura úmida, ensaiado à temperatura de $21^{\circ} \mathrm{C}$ e umidade relativa de $50 \%$. Adaptado de Neville (1970). 
Resultados da $U$. S. Army Engineer's mostraram que a fluência na tração direta é menor do que a encontrada para a fibra mais tracionada de elementos fletidos, mesmo considerando, proporcionalmente à tensão de ruptura, uma tensão solicitante menor na flexão. Entretanto, Neville (1970) comenta que são resultados difíceis de serem analisados, e para avaliação da fluência na tração ainda é preferível realizar ensaios de tração uniforme.

A fluência na tração é particularmente útil quando se tem elementos de concreto submetidos à retração restringida. Nestes casos, a restrição das deformações por retração causa tensões de tração que podem originar fissuração. Contudo, em virtude do comportamento viscoelástico do concreto, estas tensões são aliviadas pela re-distribuição de tensões causada pela fluência. Dados de publicações recentes confirmam a importância de se conhecer a capacidade de deformação por fluência à tração do concreto, com valores de fluência específica na tração variando entre 25 e $100 \times 10^{-6} \mathrm{MPa}^{-1}$, dependendo das composições do concreto e condições de troca de umidade.

\subsubsection{Fluência na Flexão}

O comportamento da fluência do concreto na flexão é ilustrado na Fig. 4.11, obtida a partir dos dados de Le Camus, B. ${ }^{12}$ (1947 apud NEVILLE 1970). Inicialmente verifica-se certa equivalência entre as deformações das fibras tracionadas e comprimidas (já corrigidas das deformações por retração). Entretanto, após aproximadamente um mês de ensaio a taxa de fluência na fibra tracionada cai praticamente à zero.

Neville (1970) comenta que uma possível causa deste comportamento está na correção das deformações por retração: a retração nas fibras tracionadas foi mais acentuada do que nas fibras comprimidas, de forma que ao subtrair da deformação total as deformações por retração, nas fibras tracionadas a fluência foi menor. Contudo, o porquê desta diferença nas deformações por retração não foi explicado. Pode-se imaginar que isto esteja relacionado à microfissuração induzida por tensões tração devido à retração.

Ao ensaiar vigas de concreto não armado, Davis et al ${ }^{13}$ (1937 apud NEVILLE 1970) também encontrou deformações por fluência maiores nas fibras tracionadas. Já a umidade relativa afetou de forma quantitativamente diferente as faces superior e inferior das vigas: o

\footnotetext{
12 LE CAMUS, B. (1947). Recherches experimentales sur la deformation du betone $\mathrm{t}$ du beton arme, Part II: Deformation lentes, Institut Technique du Batiment et des Travaux Publics, Paris, pp. 1-19.

${ }^{13}$ DAVIS, R. E., DAVIS, H. E.; BROWN, E. H. (1937). Plastic flow and volume changesof concrete. Proc. ASTM, 37, Part 2, pp. 317-30.
} 
acréscimo da fluência devido à secagem nas fibras comprimidas foi cerca de 3 vezes o observado nas fibras tracionadas.

De certa forma, pode-se inferir que estes resultados contrariam os resultados de Le Camus, levando a conclusão de que não há como estabelecer uma relação clara entre a umidade relativa do ambiente e a fluência à tração.

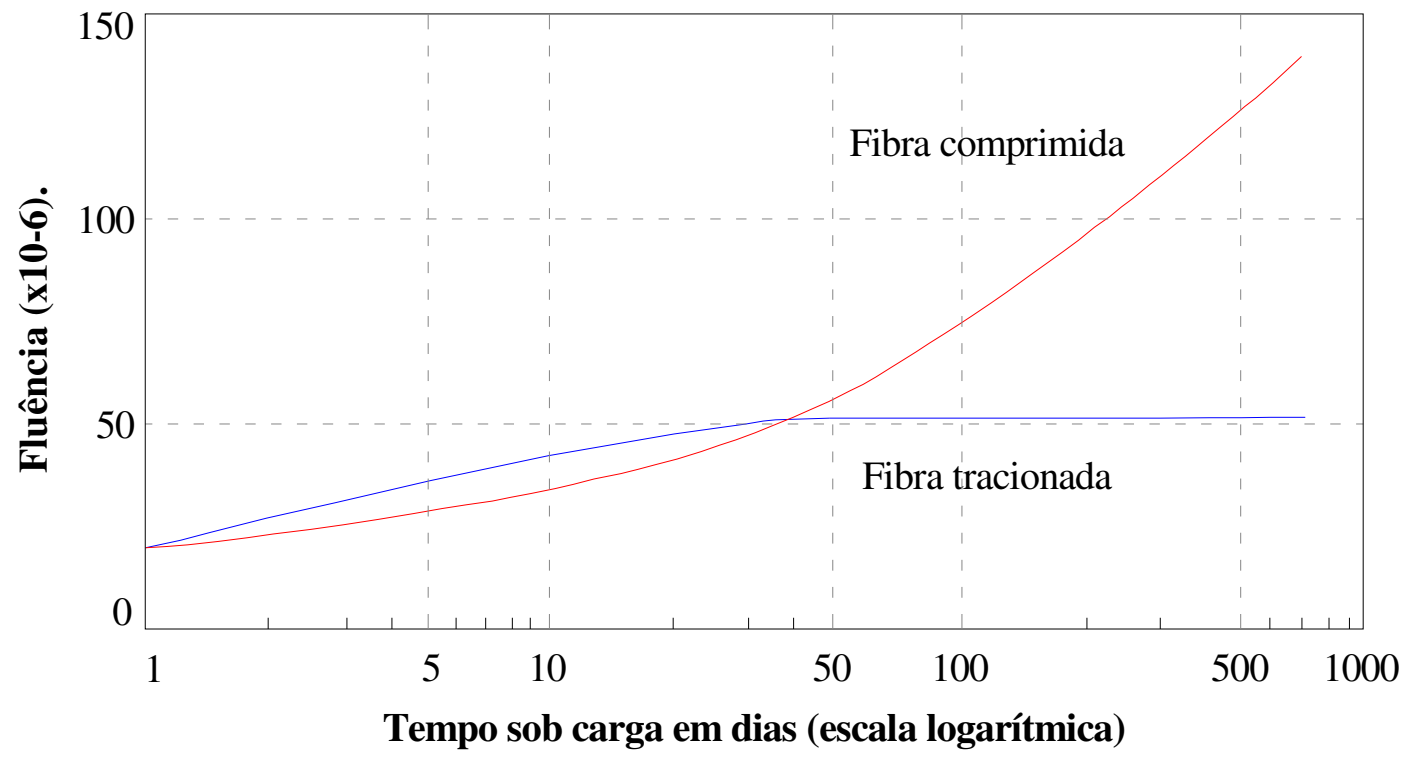

Fig. 4.11: Fluência na flexão. Adaptado de Neville (1970).

De acordo com os resultados de Oberti $^{14}$ (1946 apud NEVILLE 1970), a idade de carregamento afeta a fluência na flexão qualitativamente de forma similar que na compressão ou na tração. Ao aumentar a idade de carregamento, observou-se a diminuição dos coeficientes de fluência obtidos para 4 anos de ensaio: 5.6 para 7 dias, 4.7 para 28 dias e 4 para 4 meses.

Sobre a reversibilidade da fluência na flexão, Neville (1970) comenta não haver dados suficientes disponíveis para estabelecer qualquer comparação confiável com o que ocorre na compressão uniforme. Contudo, dados experimentais de Bäckström ${ }^{15}$ (1956 apud NEVILLE 1970) demonstram que a recuperação medida é inferior à esperada pelo princípio da superposição. De acordo com dados da literatura, esse comportamento é equivalente ao que ocorre na compressão.

${ }^{14}$ OBERTI, G. (1946). Deformazioni anelastiche del calcestruzo della Diga Oziglietta. Giornale del Genio Civile. Vol 83, No. 5, pp. 1-16.

${ }^{15}$ BÄCKSTRÖM, S. (1956). Creep and creep recovery of cement mortar. Preliminary Report of the Fifth Congress of the International Association for Bridge on Structural Engineering. Lisbon, pp. $77-$ 83. 
Ensaios específicos sobre a influência da distribuição de tensões na fluência foram realizados por Zia e Stevenson ${ }^{16}$ (1964 apud NEVILLE 1970). Estes pesquisadores encontraram um coeficiente empírico $R_{T}$ que relaciona a fluência que ocorre em um elemento solicitado à uma distribuição de tensões não-uniforme com aquela que ocorre sob tensão uniforme, sendo que $R_{T}$ dependente do gradiente de distribuição de tensões e do formato da seção transversal do elemento fletido. Por exemplo, os valores de $R_{T}$ para uma distribuição de tensões trapezoidal de 1,4 a 8,4 MPa foram: 1,27 para seção T, 1,44 para seção triangular, e 1,2 para seção quadrada. Zia e Stevenson utilizaram estes dados para modificar o cálculo das flechas diferidas de vigas de concreto protendido de diferentes seções transversais.

Grande parte dos estudos experimentais sobre o comportamento ao longo do tempo de peças fletidas de concreto refere-se à avaliação das flechas diferidas em vigas de concreto armado. Desta forma, de posse das curvas experimentais $\delta\left(t, t_{0}\right)$-tempo, podem-se realizar comparações com as curvas obtidas de expressões normativas ou então propor novas expressões para a previsão de flechas diferidas.

Neste sentido, tem-se, por exemplo, os trabalhos de Solanki e Sabnis (1987) e Bakoss et. al. (1982). O primeiro propôs um novo método para previsão das flechas diferidas, sendo validado por concordância com diversos resultados experimentais da literatura; a os últimos realizaram ensaios experimentais, comparando os resultados àqueles previstos pela norma americana e pela norma inglesa.

Maiores informações sobre a previsão das flechas diferidas em vigas de concreto armado serão realizadas no próximo capítulo, onde serão apresentadas as expressões normativas da norma brasileira e da norma americana.

\subsection{Fluência do concreto reforçado com fibras - generalidades}

O conhecimento do comportamento ao longo do tempo de materiais compósitos é interessante uma vez que o reforço com fibras promove maior acomodação devido à movimentos causados por influências externas e o controle da tendência à fissuração (NEVILLE, 1983). Existem à disposição fibras de diversos materiais, como: vidro, aço,

\footnotetext{
${ }^{16}$ ZIA, P.; STEVENSON, J. F. (1964). Creep of Concrete under Non-Uniform Stress Distribution and its Effect on Camber of Prestressed Concrete Beams. University of North Carolina at Raleigh, June 1964, $111 \mathrm{pp}$.
} 
asbesto e polímeros (polipropileno), além de fibras naturais (fibras de coco e sisal, por exemplo).

A inclusão de fibras no concreto tem pouca influência no módulo de elasticidade, retração por secagem e na fluência à compressão. A fluência à tração é reduzida levemente, mas a fluência de flexão pode ser substancialmente diminuída, quando são usadas fibras de carbono muito rígidas. Entretanto, na maioria dos estudos, por causa do pequeno volume, as fibras agem simplesmente como inclusões rígidas na matriz, sem produzirem muito efeito na estabilidade dimensional do compósito (METHA; MONTEIRO, 1994).

Neville (1983) comenta que as fibras podem ser entendidas como uma parcela adicional de agregado de formato especial que permitem ganho de rigidez e melhoram a ligação entre a pasta de cimento e os agregados finos. Dessa forma, as fibras podem contribuir para aumentar a restrição às movimentações da matriz, melhorando o desempenho com relação à fluência.

Na revisão da bibliografia sobre a influência de fibras metálicas sobre a deformação lenta, foram encontradas publicações de estudos experimentais envolvendo diferentes tipos de fibras metálicas, utilizadas em elementos de concreto submetidos a esforços de tração, flexão e compressão.

Os resultados destes estudos experimentais fornecem conclusões contraditórias a respeito do comportamento do concreto reforçado com fibras, de forma que não é possível prever a ação de uma determinada fibra no concreto. Isto ocorre, uma vez que o comportamento final é reflexo da ação conjunta de inúmeros fatores tais como: dosagem e materiais utilizados na matriz, formato, dimensões da fibra utilizada, teor de fibra utilizado e tipo de solicitação.

\subsubsection{Ensaios realizados sob compressão uniaxial}

\section{Mangat e Azari (1986)}

Mangat e Azari (1986) observaram experimentalmente a fluência e retração do concreto reforçado com dois tipos de fibras metálicas: fibras provenientes de metal fundido (diversas dimensões) e fibras com ganchos nas extremidades (comprimento igual a 28,2 mm e diâmetro de $0,42 \mathrm{~mm})$. O teor de fibra utilizado variou entre $0 \%$ e $3 \%$. 
Foram utilizados corpos-de-prova prismáticos $(10 \times 10 \times 50 \mathrm{~cm})$, carregados com diferentes níveis de tensão (relações tensão-resistência entre 0,3 e 0,55), armazenados em sua maioria em condições climáticas controladas. As principais conclusões foram:

- As fibras conduziram a menores deformações por fluência para todas as matrizes cimentíceas avaliadas, sendo que, conforme maior o consumo de fibras, melhor o desempenho do material. Esse comportamento foi observado para todas as relações tensão-resistência utilizadas, sendo que a restrição foi maior para menores níveis de tensão.

- As restrições provocadas pelas fibras de aço tornam-se mais evidentes após certo período de ensaio. Segundo os autores, este fato reflete a ação das fibras apenas na parcela irreversível da fluência, a qual é dominante apenas para maiores idades.

- Os materiais compósitos apresentaram recuperação das deformações elásticas e da parcela reversível das deformações por fluência de forma equivalente, o que segundo os autores reforça a hipótese da interferência das fibras apenas na parcela irreversível das deformações lentas;

- O comportamento da fluência dos materiais compósitos ao longo do tempo pode ser satisfatoriamente representado por expressões matemáticas do tipo logarítmicas e hiperbólicas.

\section{Balaguru e Ramakrishnan (1988)}

Balaguru e Ramakrishnan (1988) realizaram ensaios para avaliação da fluência e retração seguindo as recomendações da norma americana ACI 209:1882. Os ensaios tiveram duração média de um ano e meio, sendo que, finalizadas as observações de fluência os corpos-de-prova foram descarregados por 12 dias e depois rompidos. Foram avaliados 4 materiais, provenientes de dois traços distintos e da adição de fibras metálicas com tipo com gancho nas extremidades, de comprimento nominal igual a $50 \mathrm{~mm}$ e diâmetro de $0,5 \mathrm{~mm}(\mathrm{~L} / \mathrm{D}$ =100). Os corpos-de-prova foram mantidos em câmara climatizada à temperatura de $23^{\circ} \mathrm{C} \mathrm{e}$ $50 \%$ de umidade relativa. Foram obtidos os seguintes resultados:

- As deformações por retração geralmente foram menores para o concreto reforçado, sendo que as diferenças tornam-se mais significativas após 150 dias. Contudo, a magnitude dessas diferenças não foi substancial. A estabilização da taxa das deformações nos materiais compósitos ocorreu após um período de ensaio menor 
do que para as matrizes de referência;

- As deformações por fluência foram consideravelmente maiores para os concretos reforçados, sendo que a discrepância entre o concreto sem fibras e com fibras foi mais proeminente para a matriz com maior consumo de cimento e proporcionalidade entre o nível de tensão aplicada e as deformações lentas;

- Com relação à recuperação das deformações por fluência, o comportamento do concreto reforçado com fibras é equivalente ao comportamento do concreto simples, considerando tanto a parcela reversível como irreversível da fluência;

\section{Chern e Young (1989)}

Chern e Young (1989) avaliaram o comportamento do concreto reforçado com fibras metálicas de extremidades achatadas, de comprimento $19 \mathrm{~mm}$ e diâmetro de $0,43 \mathrm{~mm}$, sendo utilizados 3 teores de fibras $(0 \%, 1 \%$ e $2 \%)$. Foram mensuradas as deformações de fluência básica, fluência por secagem e retração (neste caso não foram subdivididas as parcelas de retração autógena, dilatação e retração por secagem). Para tanto os corpos-de-prova foram mantidos em 3 ambientes diferentes, com controle de umidade e temperatura. Os ensaios foram realizados em corpos-de-prova cilíndricos, sendo também avaliada a influência da data de carregamento (7 e 28 dias após a moldagem). As principais conclusões foram:

- A taxa de fluência sob condições de exposição a altas temperaturas $\left(35^{\circ} \mathrm{C}\right)$ é inferior no concreto reforçado com altos teores de fibra (2\%);

- O comportamento da fluência e retração dos materiais compósitos é equivalente ao da matriz (mesmo formato das curvas deformação-tempo);

- As fibras promoveram menor retração, fluência básica e fluência por secagem, sendo que quanto maior o volume de fibras, maiores às restrições a esses fenômenos;

- A idade de carregamento tem influência significativa sobre as deformações de retração e fluência (conforme mais velho o concreto, menores as deformações). A restrição à retração passa a ser mais significativa após certo tempo (no caso, por volta de uma semana). 


\section{Rouse e Billington (2007)}

Rouse e Billington (2007) estudaram a influência de micro-fibras poliméricas (diâmetro entre 8 e $28 \mu \mathrm{m}$ ) sobre a fluência e retração, utilizando para tanto corpos-de-prova cilíndricos $(75 \times 650 \mathrm{~mm})$ submetidos à compressão axial (no caso da retração corpos-de-prova descarregados). Foi observado que para os materiais compósitos a fluência foi consistentemente maior do que a observada nos corpos-de-prova sem fibras, assim como a recuperação elástica após o descarregamento; ao passo que as fibras conduziram a aberturas de fissuras por retração em torno de 2,5 vezes inferior do que a matriz.

\subsubsection{Ensaios realizados sob solicitação de flexão}

Swamy, et. at. (1979 e 1977)

Dentre os primeiros trabalhos encontrados sobre a avaliação do concreto reforçado com fibras têm-se aqueles desenvolvidos por Swamy, et. al. ${ }^{17}$ (1977 apud NEVILLE 1983) e Swamy, et. al. ${ }^{18}$ (1979 apud NEVILLE 1983). Foram executados ensaios de flexão em corpos-de-prova prismáticos $(10 \times 50 \times 2,5 \mathrm{~mm})$ de concreto reforçadas com três tipos de fibras: fibra de aço ondulada de $50 \mathrm{~mm}$ de comprimento e $0,5 \mathrm{~mm}$ de diâmetro, fibras de vidro de 25 $\mathrm{mm}$ de comprimento e fibras de polipropileno de $50 \mathrm{~mm}$ de comprimento.

Comparado com a matriz, o compósito mostrou uma redução na retração livre entre 20 e $35 \%$ quando exposto à condição ambiental de $23 \mathrm{C}$ e $56 \%$ de umidade relativa por oitenta dias. Já os ensaios de retração restringida indicaram que as fibras permitiram maior capacidade à formação da primeira fissura assim como da espessura das fissuras.

$\mathrm{Na}$ avaliação da fluência à flexão foram medidas as deformações nas fibras tracionadas e nas fibras comprimidas. A adição das fibras metálicas proporcionou o melhor desempenho, seguido das fibras de vidro e do material compósito formado pela adição de fibras de vidro e de polipropileno. Os resultados indicaram também uma restrição da fluência nas fibras comprimidas significativamente maior do que nas fibras tracionadas, sendo esse comportamento observado para todos os casos.

\footnotetext{
${ }^{17}$ SWAMY, R. N.; THEODORAKOPOULOS, D. D.; STAVRIDES, H. (1977). Shrinkage and creep characteristics of glassfiber reinforced cement composites. Proc. Int. Congress on Glassfiber Reinforced Cement. Brighton, 12-14, October, p. 75-96.

18 SWAMY, R. N.; THEODORAKOPOULOS, D. D. (1979). Flexural creep behaviour of fiber reinforced cment composites. Int. Journal of Cement Composites. Vol. 1, No. 1, May 1979, p. 37-47.
} 
Provavelmente, a microfissuração na zona tracionada pode conduzir à relação tensãoresistência maior do que na zona comprimida, distorcendo os resultados.

\section{Purkiss e Blagojević (1993)}

Purkiss e Blagojevic (1993) ensaiaram por 28 dias 15 vigas de concreto armado, utilizando teor de 1,5\% de fibras do tipo "Melt Extract" de aço inoxidável de $35 \mathrm{~mm}$ de comprimento e diâmetro de 0,64 $\mathrm{mm}$. Os resultados mostraram que a adição das fibras ao concreto armado convencional aumenta a resistência na flexão e também diminui a flecha inicial e a quantidade de fissuração. Em longo prazo a introdução das fibras reduz a fluência, sem, entretanto ser perceptível alteração na taxa de fluência, o que está em desacordo com os resultados de outros pesquisadores relatados anteriormente.

\section{Tan, Paramasivam e Tan (1994)}

Tan, Paramasivam e Tan (1994) avaliaram experimentalmente o comportamento de vigas $(100 \times 125 \times 2000 \mathrm{~mm})$ de concreto armado reforçadas com diferentes teores (variando entre $0 \%$ a $2 \%$ ) de fibras de aço com ganchos na extremidade, de $30 \mathrm{~mm}$ de comprimento e 0,5 mm de diâmetro. Foram moldados também corpos-de-prova prismáticos $(100 \times 120 \times 400$ $\mathrm{mm})$ para avaliação da retração e cilíndricos $(150 \times 300 \mathrm{~mm})$ para caracterização dos materiais e de fluência. Diversos níveis de tensão foram impostos às vigas, variando entre 0,35 e 0,8 . As principais conclusões do estudo de Tan, Paramasivam e Tan (1994) foram:

- Tanto o coeficiente de fluência como as deformações por retração foram significativamente inferiores para os concretos reforçados com fibras de aço comparativamente aos corpos-de-prova moldados com a matriz;

- As fibras também proporcionaram menores flechas imediatas, sendo que estas foram satisfatoriamente previstas pelos modelos analíticos desenvolvidos;

- As vigas de materiais compósitos apresentaram menores deformações por fluência, promovendo reduções de até $20 \%$ para teores de $2 \%$ de fibras. As fibras foram mais eficientes no controle das flechas diferidas para maiores níveis de tensão do que aqueles estipulados para serviço;

- Os efeitos da idade de carregamento e da recuperação da fluência no comportamento das vigas reforçadas foram equivalentes àqueles encontrados para as vigas de controle (matriz). Estas semelhanças foram observadas 
independentemente do nível da tensão solicitante.

Os resultados dos ensaios de fluência na compressão foram utilizados na calibração de dois modelos analíticos para previsão de flechas diferidas em vigas de materiais compósitos, baseadas no método do módulo efetivo (EMM) e no método do Módulo Efetivo com Idade Ajustada. A função de fluência específica utilizada foi do tipo hiperbólica. Os dois modelos analíticos propostos forneceram previsões das flechas diferentes bastante precisas.

\subsubsection{Ensaios realizados sob solicitação de tração}

\section{Bissonnette e Pigeon (1995)}

Bissonnette e Pigeon (1995) estudaram a influência das fibras sobre a fluência na tração uniaxial. Para tanto, foram avaliados comparativamente o comportamento de três materiais: a matriz de referência, a matriz com adição de macrofibras metálicas (16 mm de comprimento), do tipo trançada com extremidade cortada; e a matriz com adição de microfibras metálicas (3 $\mathrm{mm}$ de comprimento e $25 \mu \mathrm{m}$ de diâmetro). $\mathrm{O}$ traço utilizado $(1: 2,65: 1,77: 0,55)$ fornece um consumo de cimento de $383 \mathrm{~kg} / \mathrm{m}^{3}$, sendo que apenas para adição das fibras foi utilizado $0,2 \%$ de superplastificante, para melhorar a trabalhabilidade. Os ensaios foram realizados em câmara climatizada, com condição ambiental de $23 \pm 2{ }^{\circ} \mathrm{C}$ e $50 \pm 5 \%$ de umidade relativa, durante 45 dias. Foram utilizados corpos-de-prova prismáticos (50x50x70 mm) para os ensaios de fluência básica e fluência por secagem, e corpos-de-prova prismáticos (50x50x400 mm) nos ensaios de retração por secagem.

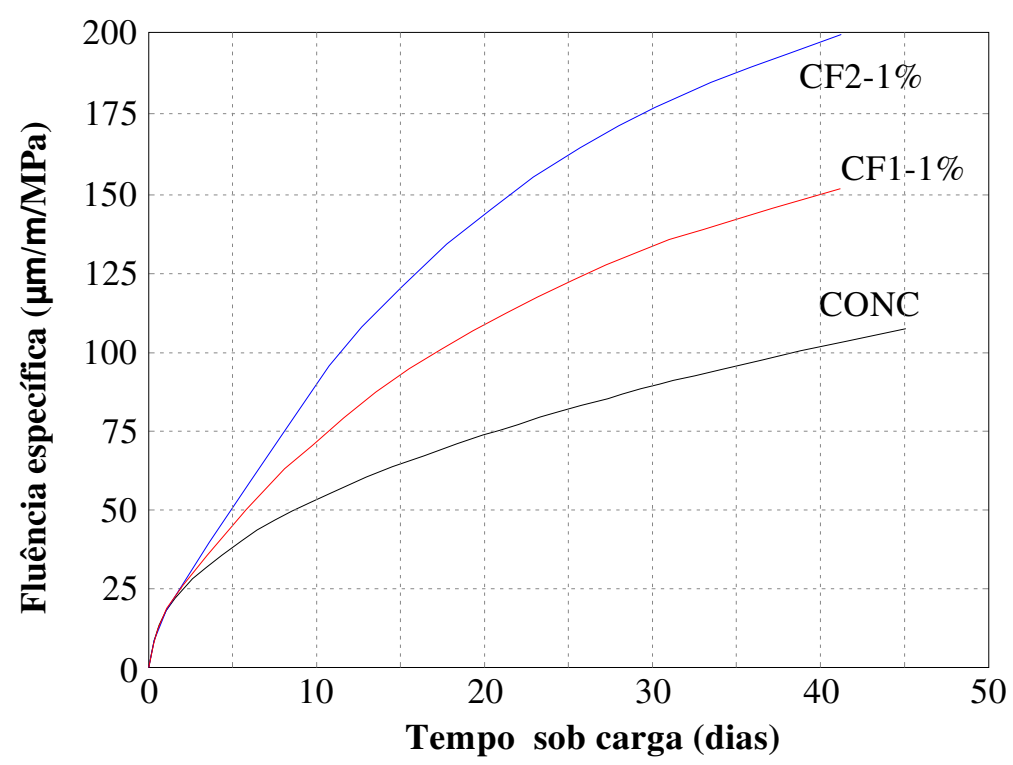

Fig. 4.12: Resultados da fluência na tração. Adaptado de Bissonnette e Pigeon (1995). 
Neste estudo, observou-se que a adição das fibras proporcionou um aumento considerável das deformações por fluência, sendo que o concreto reforçado com a macrofibra apresentou, após 45 dias, fluência 42\% superior à deformação correspondente da matriz, e para o concreto reforçado com microfibras, este aumento foi de 100\% (ver Fig. 4.12).

Os autores comentam que para o concreto reforçado com microfibra, parte deste aumento deve-se ao maior índice de vazios da mistura, que ocasionou menor resistência. Mas para as macrofibras, cuja mistura conteve $3 \%$ de ar aprisionado apenas, além de propriedades mecânicas muito similares àquelas da mistura de referência, este aumento deve estar relacionado com a influência das fibras na microestrutura da pasta (interface entre a pasta e a fibra). Com relação à retração, notou-se que fibras não tiveram interferência significativa sobre as deformações de retração.

\section{Altoubat e Lange (2001)}

Altoubat e Lange (2001) avaliaram a influência das fibras sobre o comportamento do concreto nas primeiras idades. Foram realizados ensaios de tração uniaxial de fluência de curta duração ( 7 dias) em peças de concreto reforçado com teor de $0,5 \%$ de fibras metálicas, de extremidades achatadas de $30 \mathrm{~mm}$ de comprimento e $0,4 \mathrm{~mm}$ de diâmetro; sendo que os ensaios tiveram início às 14 horas. Os corpos-de-prova utilizados têm formato do tipo "DogBonne". O traço utilizado para mistura forneceu um consumo de cimento de $533 \mathrm{~kg} / \mathrm{m}^{3}$ e consumo de água de 0,4, sendo utilizado ainda $0,2 \%$ de aditivo redutor de água. Foram moldados também corpos-de-prova para ensaios de retração livre, retração restringida e determinação da resistência à tração direta e módulo de elasticidade. Os corpos-de-prova foram mantidos em câmara climatizada. As principais conclusões desta pesquisa foram:

- Em comparação com a matriz de referência, o reforço com fibras proporcionou aumento das deformações por fluência;

- Os corpos-de-prova moldados com material compósito apresentaram restrição substancial quanto ao aparecimento da primeira fissura. Este comportamento aparentemente inconsistente com o mau desempenho à fluência está influenciado por outros fatores provavelmente relacionados com os mecanismos de fluência por secagem associados com a microfissuração. 


\section{Bissonnette, Pigeon e Vaysburd (2007)}

Bissonnette, em parceria com Pigeon e Vaysburg, avaliou experimentalmente a interferência de dois tipos de fibras metálicas sobre a fluência na tração uniaxial. Para a mistura da matriz de referência foi utilizado consumo de cimento de $450 \mathrm{~kg} / \mathrm{m}^{3}$ e relação água-cimento de 0,4. Foram adicionadas fibras de formato ondulado (comprimento de $30 \mathrm{~mm}$ , diâmetro de $0,5 \mathrm{~mm}$, e razão de aspecto $\mathrm{L} / \mathrm{D}=60$ ), com teores de $0,5 \%$ e $1 \%$ em volume; e fibras com ganchos na extremidade (comprimento de $30 \mathrm{~mm}$, diâmetro de $0,25 \mathrm{~mm}$, razão de aspecto $\mathrm{L} / \mathrm{D}=120)$, com teor de $0,5 \%$ em volume, originando desta forma 3 materiais compósitos originados da mesma matriz. Também foram determinadas as propriedades mecânicas de interesse (resistência à compressão, resistência à tração direta, resistência à tração por compressão diametral, e módulo de elasticidade) aos 7 e 28 dias, além, é claro da avaliação conjunta das deformações por retração.

As deformações por retração foram levemente restringidas pelas fibras, entretanto comportamentos bastante interessantes foram observados nas deformações da fluência. $\mathrm{O}$ compósito resultante da adição de $40 \mathrm{~kg} / \mathrm{m} 3$ de fibras ganchos na extremidade apresentou aumento nas deformações por fluência entre $30 \%$ e $35 \%$, enquanto que a mesma dosagem das fibras onduladas conduziu a uma redução na fluência da mesma ordem. Além disso, o aumento no teor das fibras onduladas, de 0,55 para $1 \%$ ocasionou uma piora no comportamento do material compósito, ainda que a curva resultante seja inferior àquela obtida para a matriz (ver Fig. 4.13).

Considerando que tanto os materiais compósitos quanto a matriz de concreto possuem quantidades similares de ar aprisionado e também propriedades mecânicas semelhantes, e que as fibras normalmente reduzem as deformações por tração, os resultados da Fig. 4.13 sugerem que uma importante parcela das deformações por fluência esteja ocorrendo na interface entre a matriz e as fibras (região de maior porosidade).

Desta forma há fundamentalmente dois fatores que definem se as fibras proporcionarão melhora no desempenho à fluência. Por um lado, tem-se o formato da fibra, que determina sua maior ou menor capacidade de ancoragem mecânica. Por outro lado devese considerar o aumento na porosidade do compósito em decorrência da interface entre a fibra e a matriz.

Se a porosidade da região de interface por preponderante no desempenho da fibra, em detrimento de sua ancoragem mecânica, quanto maior a superfície específica, maiores as 
deformações por fluência (ou seja, quanto maior o teor de fibras, pior o desempenho do compósito quanto à fluência).

Entretanto, ao comparar o desempenho de duas fibras, como é o caso do trabalho de Bissonnette et. al. (2007), o que conta na realidade é um balanço entre esses dois fatores. A Fig. 4.13 ilustra os resultados, sendo utilizadas as seguintes siglas: CONC, para o concreto sem fibras; CF1-40, para o concreto com $40 \mathrm{~kg} / \mathrm{m}^{3}$ da fibra com gancho na extremidade; $\mathrm{CF} 2-$ 40 e CF2-80, para os compósitos formados por incorporação de 40 e $80 \mathrm{~kg} / \mathrm{m}^{3}$ de fibra ondulada.

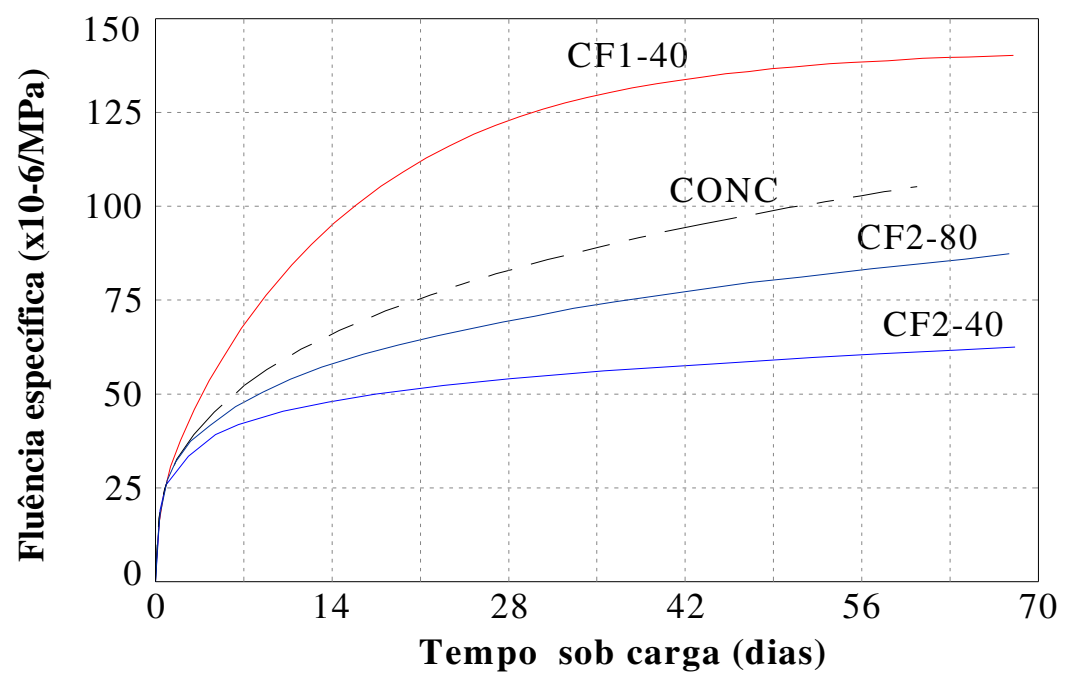

Fig. 4.13: Resultados da fluência na tração. Adaptado de Bissonnette B. et al. (2007).

Na utilização das fibras com gancho (as quais têm uma parte central reta e longa), a um teor de $1 \%$, a porosidade na região de interface é preponderante à habilidade das fibras de restringir deformações (posto que seu formato não favorece boa ancoragem mecânica, relativamente a fibras onduladas).

Já para o CRFA decorrente da adição de $1 \%$ das fibras onduladas, foi preponderante a boa ancoragem mecânica destas fibras, o que refletiu em menores deformações com relação à matriz. Contudo, ao aumentar o teor de fibra ondulada, ocorre uma piora no desempenho do compósito, o qual passa a apresentar maiores deformações por fluência.

$\mathrm{O}$ aumento na fluência com a dosagem das fibras para misturas reforçadas com as fibras onduladas é consistente com a hipótese do papel desempenhado pela zona de transição entre as fibras e a matriz.

A fluência do compósito com 1\% destas fibras (curva CF2-80), contudo, é ainda menor do que aquela apresentada pelo concreto de referência. Provavelmente isto significa 
que o efeito de restrição das fibras onduladas é ainda mais importante do que a influência das áreas de interface, considerando a adição de teores de até $1 \%$ destas fibras.

Se tivessem sido ensaiados corpos-de-prova da mesma matriz reforçada com teores maiores de fibras onduladas, certamente haveria um teor que corresponderia a uma inversão no comportamento, a partir do qual a boa ancoragem mecânica deste tipo de fibra passaria a ter uma importância inferior à porosidade da interface fibra-matriz no desempenho do compósito quanto à fluência. Ou seja, se a quantidade de fibras onduladas fosse aumentada, haveria um limite, a partir do qual o CRFA passaria a apresentar um desempenho quanto à fluência pior do que a matriz.

\subsubsection{Resumo}

A princípio imagina-se que a adição de fibras possa diminuir a fluência por conta de sua capacidade de transmitir tensões, contudo alguns autores sugerem que as fibras possam criar caminhos dentro da matriz que facilitam o escoamento de água (ROUSE; BILLINGTON, 2007). Nesse sentido a interface entre as fibras e a matriz torna-se equivalente à zona de transição entre o agregado e a matriz. Neste caso, portanto, a adição das fibras acaba por aumentar a quantidade de regiões enfraquecidas no concreto, promovendo maior fluência.

Curiosamente, observa-se uma diferença no desempenho dos materiais compósitos submetidos a diferentes solicitações. Mangat e Azari (1986), Balaguru e Ramakrishnan (1988), Rouse e Billington (2007) e Chern e Young (1989) realizaram ensaios à compressão axial e obtiveram melhor desempenho dos materiais compósitos tanto para fluência como para retração. Entretanto, estudos feitos à tração revelam acréscimo nas deformações por fluência e uma melhoria não muito significativa nas deformações por retração, conforme resultados de Bissonnette e Pigeon (1995) Altoubat e Lange (2001) e Bissonnette, Pigeon e Vaysburg (2007). A Tabela 4.1 resume os dados das publicações envolvendo reforço com fibras metálicas e fluência.

Com relação à fluência na flexão, a pesquisadora teve acesso a apenas um trabalho que trata de prismas de concreto não armado reforçado com fibras de aço, que foi um dos trabalhos pioneiros relacionando fluência e fibras, atribuído a Swamy, et. al. (1979 e 1977). Seus resultados indicaram menores flechas diferidas decorrentes da incorporação das fibras metálicas. Foi observada também uma restrição da fluência nas fibras comprimidas significativamente maior do que nas fibras tracionadas. Provavelmente, a microfissuração na 
zona tracionada pode conduzir à relação tensão-resistência maior do que na zona comprimida, distorcendo os resultados.

Purkiss e Blagojević (1993) e Tan et al. (1994) realizaram ensaios de flexão em vigas de concreto reforçado com fibras obtendo para esses materiais melhor comportamento com relação à fluência. Entretanto, como se tratava de vigas de concreto armado entende-se que o principal papel das fibras neste caso foi transmitir tensões e restringir deformações.

Tabela 4.1: Resumo da utilização de fibras metálicas na avaliação da fluência, de acordo com dados experimentais encontrados na literatura.

\begin{tabular}{|c|c|c|c|c|c|}
\hline Ensaio $^{1}$ & Referência & $\begin{array}{c}\text { Formato da fibra } \\
\text { metálica }\end{array}$ & Dimensões & teor $(\%)$ & fluência \\
\hline \multirow{2}{*}{$\mathrm{C}$} & \multirow{2}{*}{$\begin{array}{l}\text { Mangat e Azari } \\
\text { (1986) }\end{array}$} & "melt extract" & variável & entre 0 e 3 & हो \\
\hline & & $\begin{array}{l}\text { extremidade em } \\
\text { gancho. }\end{array}$ & $\begin{array}{l}l_{f}=28.2 \mathrm{~mm} \\
d_{f}=0.42 \mathrm{~mm}\end{array}$ & entre 0 e 3 & हो \\
\hline $\mathrm{C}$ & $\begin{array}{c}\text { Balaguru e } \\
\text { Ramakrishnan } \\
(1988)\end{array}$ & $\begin{array}{l}\text { extremidade em } \\
\text { gancho. }\end{array}$ & $\begin{array}{l}l_{f}=50 \mathrm{~mm} \\
d_{f}=0.5 \mathrm{~mm}\end{array}$ & 0.5 & 得 \\
\hline $\mathrm{C}$ & $\begin{array}{c}\text { Chern e Young } \\
(1989)\end{array}$ & $\begin{array}{l}\text { extremidade } \\
\text { achatada. }\end{array}$ & $\begin{array}{l}l_{f}=19 \mathrm{~mm} \\
d_{f}=0.43 \mathrm{~mm}\end{array}$ & 0,1 e 2 & हो \\
\hline $\mathrm{F}$ & $\begin{array}{l}\text { Swamy et. al. } \\
\text { (1977 e 1979) }\end{array}$ & ondulada & $\begin{array}{l}l_{f}=50 \mathrm{~mm} \\
d_{f}=0.50 \mathrm{~mm}\end{array}$ & ------- & हो \\
\hline $\mathrm{F}^{2}$ & $\begin{array}{c}\text { Purkiss e } \\
\text { Blagojević (1993) }\end{array}$ & "melt extract" & $\begin{array}{l}l_{f}=35 \mathrm{~mm} \\
d_{f}=0.64 \mathrm{~mm}\end{array}$ & 1.5 & $\Leftrightarrow$ \\
\hline $\mathrm{F} 2$ & $\begin{array}{l}\text { Tan, Paramasivam } \\
\text { e Tan (1994) }\end{array}$ & $\begin{array}{l}\text { extremidade em } \\
\text { gancho. }\end{array}$ & $\begin{array}{l}l_{f}=50 \mathrm{~mm} \\
d_{f}=0.50 \mathrm{~mm}\end{array}$ & entre 0 e 2 & हो \\
\hline \multirow{2}{*}{$\mathrm{T}$} & \multirow{2}{*}{$\begin{array}{l}\text { Bissonnette e } \\
\text { Pigeon (1995) }\end{array}$} & $\begin{array}{c}\text { trançada com } \\
\text { extremidade reta. }\end{array}$ & $l_{f}=13 \mathrm{~mm}$ & 1 & 得 \\
\hline & & microfibra & $\begin{array}{l}l_{f}=3 \mathrm{~mm} \\
d_{f}=25 \mu \mathrm{m}\end{array}$ & 1 & 行 \\
\hline $\mathrm{T}$ & $\begin{array}{c}\text { Altoubat e Lange } \\
\qquad(2001)\end{array}$ & $\begin{array}{l}\text { extremidade } \\
\text { achatada. }\end{array}$ & $\begin{array}{l}l_{f}=30 \mathrm{~mm} \\
d_{f}=0.40 \mathrm{~mm}\end{array}$ & 0.5 & 得 \\
\hline \multirow{3}{*}{$\mathrm{T}$} & \multirow{3}{*}{$\begin{array}{c}\text { Bissonnette, } \\
\text { Pigeon e } \\
\text { Vaysburd (2007) }\end{array}$} & ondulada & $\begin{array}{l}l_{f}=30 \mathrm{~mm} \\
d_{f}=0.50 \mathrm{~mm}\end{array}$ & 0.5 & हो \\
\hline & & ondulada & $\begin{array}{l}l_{f}=30 \mathrm{~mm} \\
d_{f}=0.50 \mathrm{~mm}\end{array}$ & 1 & 德3 \\
\hline & & $\begin{array}{l}\text { extremidade em } \\
\text { gancho. }\end{array}$ & $\begin{array}{l}l_{f}=30 \mathrm{~mm} \\
d_{f}=0.50 \mathrm{~mm}\end{array}$ & 0.5 & 得 \\
\hline
\end{tabular}

\footnotetext{
${ }^{1}$ Tipo de solicitação: C - Compressão, F - Flexão e T - Tração

${ }^{2}$ Ensaio de flexão em vigas de concreto com armadura longitudinal.

${ }^{3}$ Desempenho comparado ao obtido com a adição de $0.5 \%$ de fibra ondulada.
} 


\subsection{Interação entre os fenômenos de fluência e de fraturamento}

A redistribuição de tensões provocada pela fluência certamente é o principal elo entre a dependência dos mecanismos de fraturamento com tempo. Desta forma, pode-se dizer que a fluência domina a resposta de elementos de concreto fissurados ou não, submetidos a baixas taxas de carregamento, ou à aplicação de um carregamento constante.

Sendo assim, encontram-se na literatura basicamente três formas de avaliação experimental: a primeira delas está relacionada à variação da taxa de carregamento, ou seja, a duração do ensaio até a carga máxima (BAZANT; GETTU, 1992; ZHOU, 1992; WITTMANN et al. 1987); a segunda trata da avaliação da relaxação das tensões, em ensaios com controle de deslocamento, depois de atingido certo nível de carregamento no trecho póspico (BAZANT e GETTU, 1992 e ZHOU, 1992); e a terceira trata da avaliação da fluência sob carga mantida no trecho pré-pico de resistência (WITTMANN; ZAITSEV, 1972; LIU et. al., 1989; HANSEN, 1991), ou pós-pico (CARPINTERI et al., 1997). Uma descrição resumida de alguns dos trabalhos mencionados consta em Shah, Swartz e Ouyang (1995); Bazant (1993); Zhou (1993); Gettu e Garcia-Álvarez (1993). Contudo os aspectos mais relevantes de algumas destas publicações serão apresentados a seguir.

\subsubsection{Ensaios de carga mantida}

Os ensaios de carga mantida em corpos-de-prova entalhados realizados por Liu et. at. (1989) e Hansen (1991) indicam haver acréscimo da energia de fraturamento ao longo do tempo devido a fluência, ao passo que os resultados de Zhou (1992) indicam ocorrer o contrário (decréscimo de $G_{f}$ ).

Liu realizou ensaios de flexão em três pontos em vigas entalhadas mantendo a carga constante para vários níveis de tensão aplicada (65\% a 95\%), sendo observado o tempo para se atingir o colapso e a evolução das curvas CMOD-tempo e LPD-tempo, sendo LPD o deslocamento da linha de carga (Load Point Displacement), para cada nível de tensão.

Baseado na MFEL os autores definiram uma expressão, função do tempo, para $G_{f}$, de forma que o tempo de colapso por fluência pudesse ser estimado. Contudo, o colapso devido à carga mantida só ocorreu para força aplicada superior a 80\% da carga máxima. A expressão apresentada pelos autores indica aumento da energia de fraturamento com o tempo.

Já Hansen submeteu vigas entalhadas, em balanço, a diferentes períodos de força 
mantida a $90 \%$ da carga de pico. Seus resultados mostram que quanto maior o período de carga mantida, maior a energia de fraturamento, o que está de acordo com os resultados de Liu et. al. (1989). Hansen também concluiu, a partir das leituras do CMOD, que em decorrência da carga mantida há um aumento na largura da zona de processos inelásticos. Ou seja, os efeitos da fluência, somados a uma fissuração subcrítica, estariam alterando tanto a largura da ZPI quanto o valor de $\mathrm{G}_{\mathrm{f}}$. Estes ensaios foram realizados para duas séries, aos 28 dias e aos 90 dias após a moldagem. Foi observada a interferência da idade do concreto, de forma que aos 28 dias houve aumento de $23 \%$ de $G_{f}$, ao passo que aos 90 dias esse aumento foi de apenas $6 \%$.

Por outro lado, os resultados de Zhou para ensaios de carga mantida indicaram haver um decaimento da energia de fratura para $95,4 \%$ do valor obtido no ensaio estático, quando a carga mantida foi de $76 \%$ da força máxima, o que está em desacordo com os resultados anteriores. Contudo, o formato das curvas de fluência deslocamento-tempo é equivalente aos dos outros pesquisadores.

Wittman e Zaitsev (1972) ensaiaram prismas de pasta endurecida de cimento, com entalhe central, submetidos a carregamento de tração uniaxial. Observou-se que quando as cargas foram mantidas, as tensões à frente da ponta da fissura decresceram com o tempo. Foi proposto pelos pesquisadores que os mecanismos de fluência causam redistribuição das tensões, aliviando a concentração de tensões devido à fissura, proporcionando um "efeito de fortificação".

Desta forma, em vista a escassa bibliografia encontrada, e dos resultados divergentes, nota-se a necessidade de mais ensaios do gênero.

\subsubsection{Efeito da taxa de carregamento}

Uma vez que as propriedades de fraturamento dependem da taxa de propagação da fissura, e esta, por sua vez é função da taxa de carregamento, pode-se afirmar que o processo de fraturamento é sensível à taxa em que a carga é aplicada (BAZANT E GETTU, 1992). No concreto, espera-se que a sensibilidade à taxa de carregamento seja mais significativa em virtude da fluência do material na zona de processos inelásticos, assim como em toda a estrutura.

Desta forma, quando se aplica o carregamento a taxas muito baixas, de forma que a carga total seja atingida em períodos entre 1 hora ou vários dias, os efeitos da fluência se 
refletem na sensibilidade a taxa de carregamento. O conhecimento desta interação certamente colabora para previsão da fissuração ao longo do tempo e de ruína de vários tipos de estruturas de concreto.

Wittman et. al. (1987) realizaram ensaios de flexão em três pontos em vigas entalhadas variando a taxa de deslocamento imposta. O tempo para se atingir a carga máxima variou entre 1 segundo e 4 horas. Ao diminuir a taxa de carregamento, observou-se uma diminuição da energia de fraturamento, o que foi atribuído pelos autores a uma amplificação da zona de processos inelásticos.

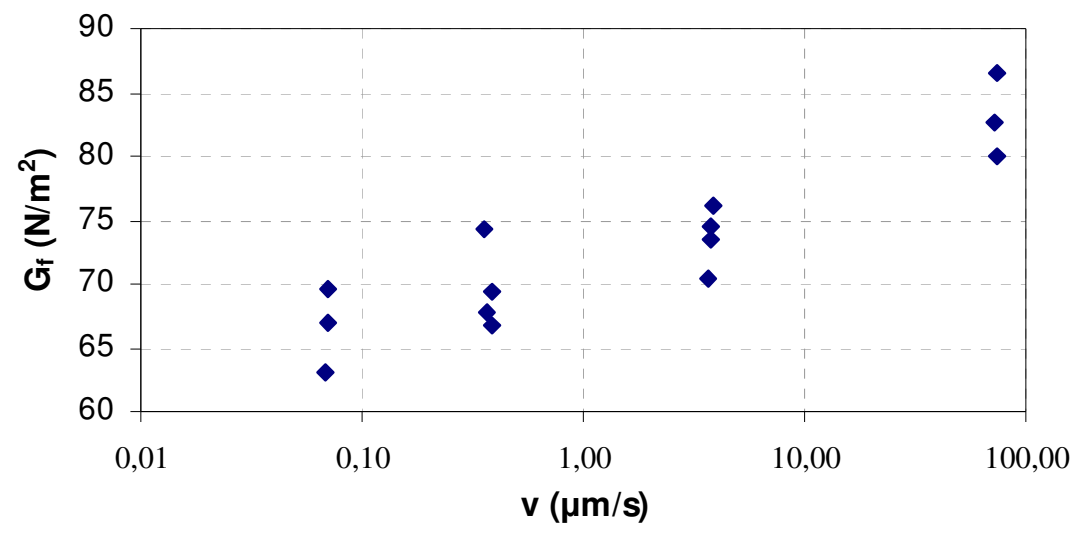

Fig. 4.14: Efeito da taxa de carregamento na energia ao fraturamento. Resaultados de Zhou F. P. adaptados de Shah, S. P.; Swartz S. E.; Ouyang C. (1995).

Bazant, Z. P. e Gettu R. (1992) também realizaram o mesmo tipo de ensaios, contudo o tempo para se atingir a carga máxima variou entre 1 segundo e 2,5 dias. Curvas ilustrativas dos resultados são apresentadas na Fig. 4.15. Nota-se que além do acréscimo de "resistência" há diferenças no trecho pós-pico. Enquanto a curva Força-CMOD para ambas as taxas de carregamento são similares, a curva força-flecha apresentou formato bastante diferente.

Para o ensaio mais rápido, a curva força-flecha apresenta uma inclinação do trecho pós-pico bastante acentuada, ao passo que no ensaio mais lento a queda da carga é gradual, e mais próxima de um comportamento dúctil. De acordo com os autores, esta diferença pode ser atribuída à fluência no volume do corpo-de-prova, uma vez que o deslocamento da linha de carga reflete uma resposta cumulativa de todo o corpo-de-prova, enquanto que o CMOD é afetado fundamentalmente pelas deformações da fissura e da zona de processos inelásticos.

Zhou (1992) também realizou ensaios em que o tempo para se atingir a carga máxima variou entre $5 \mathrm{~s}$ e $5000 \mathrm{~s}$, sendo utilizadas taxas de deslocamento de $50 \mu \mathrm{m} / \mathrm{s}$ e $0,05 \mu \mathrm{m} / \mathrm{s}$. Para estes extremos, foram obtidos, respectivamente, os seguintes valores para a energia de 
fraturamento: 67 e $87 \mathrm{~N} / \mathrm{m}$. Ou seja, $G_{f}$ decresceu $25 \%$ ao diminuir a taxa de carregamento em 1000 vezes, confirmando as opiniões anteriores.
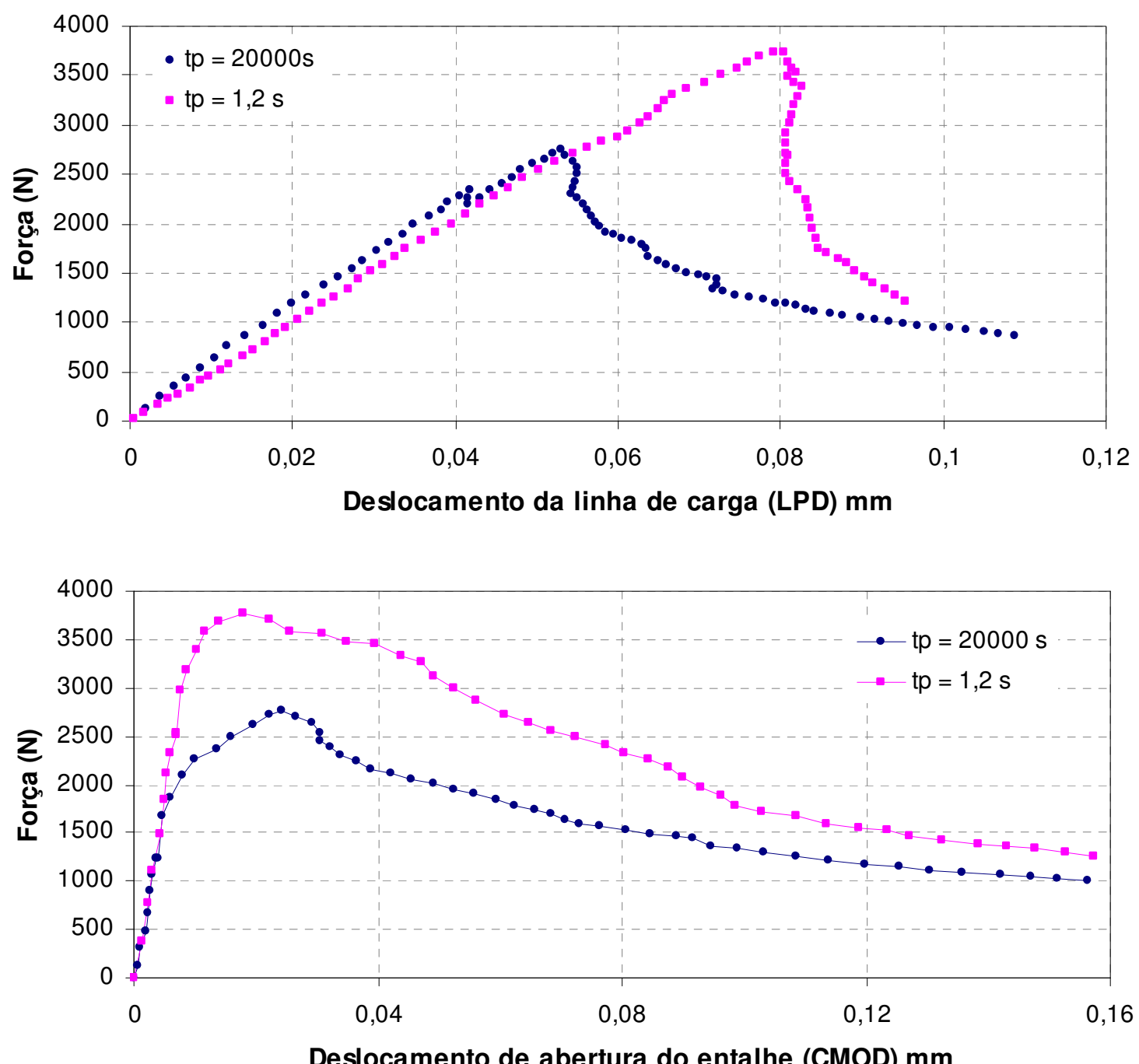

Fig. 4.15: Efeito da taxa de carregamento. Adaptação dos resultados de Bazant e Gettu, 1992.

\subsubsection{Ensaios de Relaxação (Deformação mantida)}

De acordo com os resultados de Bazant e Gettu (1992), observou-se que a relaxação das tensões à frente da ponta da fissura ocasiona uma distribuição da zona de processos inelásticos o que provoca diminuição da extensão da zona de processos inelásticos, da energia de fraturamento e da tenacidade ao fraturamento. Conforme se observa na Fig. 4.16, torna-se evidente que ao longo do tempo pode ocorrer uma mudança no comportamento do material, o qual passa a se tornar mais frágil, o que é preocupante.

Este gráfico, adaptado de Bazant e Gettu (1992) mostra de forma combinada os resultados de quatro grupos de vigas entalhadas, ensaiadas para análise segundo o Modelo do 
efeito de escala. Desta forma, cada grupo consiste em 3 subgrupos de tamanhos diferentes, com similaridade geométrica em duas dimensões, conforme prescrito pelo Modelo, entretanto a taxa de abertura da fissura, imposta para cada grupo foi variável, de modo que a duração do ensaio até se atingir a carga máxima $\left(\mathrm{t}_{\mathrm{p}}\right)$ variou de rápido a muito lento.

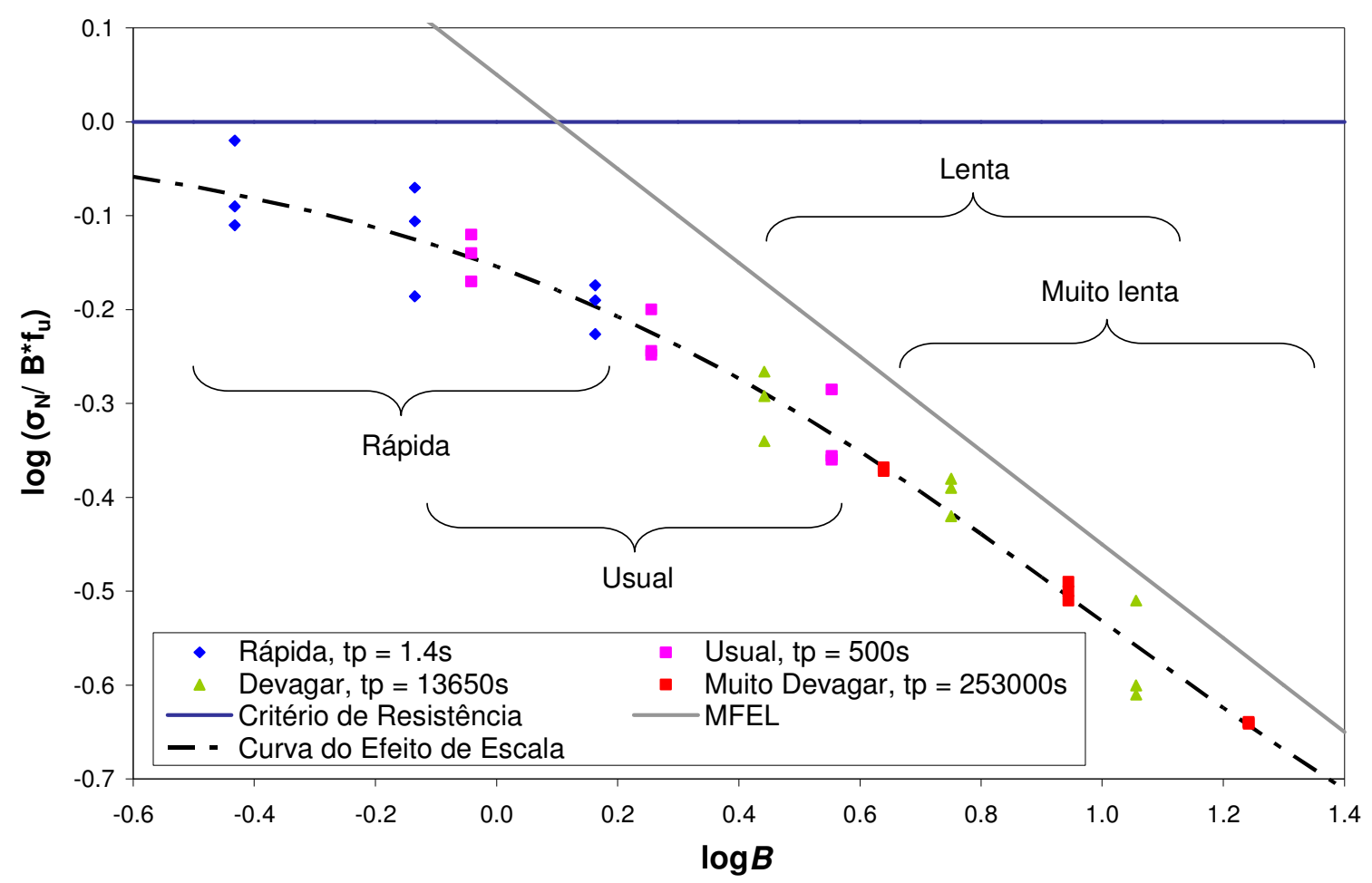

Fig. 4.16: Mudança no modo de ruptura com a taxa de carregamento. Adaptado de Bazant e Gettu (1992).

A consideração do efeito viscoelástico do concreto no cálculo da energia de fraturamento e da tenacidade ao fraturamento, foi feita substituindo o módulo de elasticidade $E$ pelo módulo efetivo $E_{f f}$ correspondente à duração do carregamento $t_{p}$. Para determinar $E_{f f}$ foi utilizado no modelo BP para previsão da fluência de Bazant e Panula.

\subsubsection{Resumo}

Há uma forte interação entre fratura e fluência no concreto, o que é evidente a partir dos ensaios do efeito da taxa de carregamento e ensaios de carga ou deformação mantida, realizados em corpos-de-prova entalhados. O conhecimento dos mecanismos de fraturafluência é importante para previsão do colapso de estruturas fissuradas assim como para a análise em serviço, já que a fluência interfere significativamente na capacidade de carga de elementos fissurados. 
No item 4.5.1, foram apresentados alguns resultados da literatura para avaliação dos mecanismos de fratura-fluência através de ensaios de carga mantida. Dentre os parâmetros medidos têm-se deslocamentos (LPD e CMOD), tempo até a ruptura, e energia de fraturamento. $\mathrm{O}$ formato das curvas deslocamentos-tempo foi similar, entretanto Liu et. al. (1989) e Hansen (1991) encontraram $G_{f}$ crescente com o tempo, ao passo que Zhou (1992) observou o contrário.

Nos ensaios para avaliação da taxa de carregamento, em todos os casos observou-se um decréscimo da energia ao fraturamento com a duração da aplicação do carregamento. Os ensaios realizados por Bazant e Gettu (1992), aplicando diferentes taxas de carregamento ao modelo do efeito de escala, indicam comportamento mais frágil para aplicação mais lenta do carregamento. Já os ensaios de relaxação efetuados pelos autores indicam que a relaxação das tensões à frente da ponta da fissura provoca diminuição da extensão da zona de processos inelásticos, da energia de fraturamento e da tenacidade ao fraturamento.

Além dos trabalhos experimentais, inúmeros pesquisadores têm se dedicado na elaboração de modelos de propagação de fissura que levem em conta a fluência. A esse respeito Bazant e Li (1997) apresentam uma interessante retrospectiva dos avanços realizados. Barpi e Valente (2003 e 2004) apresentam modelo já implementado numericamente, conduzindo a bons resultados.

A maioria dos ensaios de carga mantida comentados neste texto foi realizada para níveis de tensão fora do intervalo normalmente utilizado em projeto. Além disso, houve também a necessidade de utilizar uma máquina para aplicação e manutenção da carga. Desta forma, pode-se considerar como pioneira parte do programa experimental desta pesquisa, onde foram avaliados ao longo do tempo os deslocamentos (flecha e CMOD) de vigas entalhadas, submetidas a tensões máximas de tração dentro da fase elástica e solicitadas apenas pelo peso-próprio. 


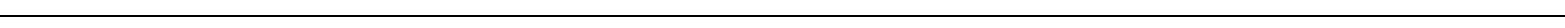




\section{CONSIDERAÇÕES NORMATIVAS}

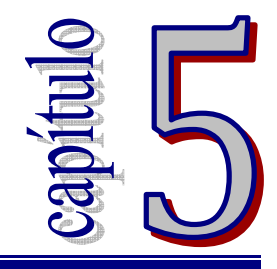

Tanto a fluência como a retração do concreto são fenômenos importantes, que ocorrem ao longo do tempo e podem acarretar vários tipos de problemas patológicos nas estruturas, diminuindo sua vida útil. Em estruturas de concreto protendido, as deformações causadas por esses fenômenos ocasionam perda de protensão; enquanto em estruturas de concreto armado, deve-se considerar as deformações ocasionadas por fluência e retração como ações indiretas, para evitar flechas excessivas.

Em virtude da comparação feita neste trabalho dos resultados experimentais com as curvas obtidas pelo modelo de previsão da NBR 6118:2003 e da simulação numérica realizada no software DIANA ${ }^{\circledR}$, que utiliza o modelo de previsão do ACI 209:1992, julgou-se de interesse apresentar de forma detalhada e comparativa as recomendações destas normas relacionadas à previsão do fenômeno. Isto foi feito tanto em termos de deformações (elementos de concreto solicitados à ação de compressão, como em peças protendidas) como em termos de deslocamentos (elementos estruturais fletidos, tais como vigas e lajes). Neste capítulo também é apresentada a metodologia experimental para caracterização do comportamento visco-elástico do concreto, sendo, para tanto, descritas as recomendações da norma americana e brasileira.

\subsection{Previsão das deformações}

Quando não há impedimento à livre deformação do concreto, e a ele é aplicada, no tempo $t_{0}$, uma tensão constante no intervalo $t-t_{0}$, sua deformação total, no tempo t, vale:

$$
\varepsilon_{c}(t)=\varepsilon_{c i}\left(t_{0}\right)+\varepsilon_{c c}(t)+\varepsilon_{c s}(t)
$$

Onde:

$\mathcal{E}_{c i}\left(t_{0}\right)$ é a deformação imediata, por ocasião do carregamento; 
$\mathcal{E}_{c c}(t)$ é a deformação por fluência, no intervalo de tempo $\left(t, t_{0}\right)$;

$\mathcal{E}_{c s}(t)$ é a deformação por retração, no intervalo de tempo $\left(t, t_{0}\right)$.

Desconsiderando por ora as deformações por retração, a previsão das deformações ao longo do tempo pode ser realizada pelo conhecimento da função de fluência, conforme já se comentou no item 4.1.4 do Capítulo 4. Esta função é expressa em termos da soma de uma parcela elástica e de uma parcela viscosa, sendo esta representada pelo coeficiente de fluência. As considerações de cada norma para o cálculo da deformação elástica inicial e das deformações por fluência serão apresentadas a seguir.

\subsubsection{NBR 6118/2003}

A formulação da NBR para o cálculo dos efeitos do tempo no concreto estrutural foi baseada no código do CEB- FIB de 1978. A função de fluência é dada pela expressão 5.2. Nota-se que a parcela referente à deformação elástica é obtida a partir do módulo de elasticidade calculado para a idade de aplicação da carga $\left(t_{0}\right)$. Já a parcela viscosa é expressa em termos do coeficiente de fluência $\phi\left(t, t_{0}\right)$ e do módulo de elasticidade aos 28 dias, calculado segundo a equação 5.3.

$$
\begin{array}{r}
J\left(t, t_{0}\right)=\frac{1}{E_{c i}\left(t_{0}\right)}+\frac{\phi\left(t, t_{0}\right)}{E_{c i}(28)} \\
E_{c i}(28)=5600 \cdot \sqrt{f_{c k}}
\end{array}
$$

A norma disponibiliza duas maneiras para a determinação do coeficiente de fluência: a forma simplificada para cálculo do coeficiente de fluência (item 8.2.11 da norma) e o método chamado de preciso (anexo A da norma).

\subsubsection{Forma Simplificada (item 8.2.11 da norma)}

Em casos onde não é necessária grande precisão, o valor final do coeficiente de fluência $\varphi\left(t_{\infty}, t_{0}\right)$ do concreto, submetido a tensões menores que $0,5 f_{c}$ quando do primeiro carregamento, podem ser obtidos, por interpolação linear, a partir dos valores da Tabela 5.1. Os valores dessa tabela são relativos a temperaturas do concreto entre $10^{\circ} \mathrm{C}$ e $20^{\circ} \mathrm{C}$, podendo admitir-se temperaturas entre $0^{\circ} \mathrm{C}$ e $40^{\circ} \mathrm{C}$, e para concretos plásticos de Cimento Portland Comum. 
O valor de $\phi\left(t_{\infty}, t_{0}\right)$ é dado em função da umidade ambiente e da espessura equivalente, conforme apresentado a seguir (página 110).

Tabela 5.1: Valores característicos superiores da deformação específica de retração $\varepsilon\left(t_{\infty}, t_{0}\right)$ e do coeficiente de fluência $\phi\left(t_{\infty}, t_{0}\right)$.

\begin{tabular}{|c|c|c|c|c|c|c|c|c|c|c|}
\hline \multirow{2}{*}{\multicolumn{3}{|c|}{$\begin{array}{l}\text { Umidade ambiente }(\%) \\
\text { Espessura fictícia } 2 \mathrm{~A}_{\mathrm{c}} / \mathrm{u}_{\mathrm{ar}} \\
\mathrm{cm}\end{array}$}} & \multicolumn{2}{|c|}{40} & \multicolumn{2}{|c|}{55} & \multicolumn{2}{|c|}{75} & \multicolumn{2}{|c|}{90} \\
\hline & & & \multirow{2}{*}{$\frac{20}{4,4}$} & \multirow{2}{*}{$\begin{array}{l}60 \\
3,9 \\
\end{array}$} & \multirow{2}{*}{$\frac{20}{3,8}$} & \multirow{2}{*}{$\begin{array}{l}60 \\
3,3 \\
\end{array}$} & \multirow{2}{*}{$\frac{20}{3,0}$} & \multirow{2}{*}{$\frac{60}{2,6}$} & \multirow{2}{*}{$\frac{20}{2,3}$} & \multirow{2}{*}{$\frac{60}{2,1}$} \\
\hline \multirow{3}{*}{$\phi\left(t_{\infty}, t_{0}\right)$} & \multirow{6}{*}{$\begin{array}{c}\mathrm{t}_{0} \\
\text { dias }\end{array}$} & 5 & & & & & & & & \\
\hline & & 30 & 3,0 & 2,9 & 2,6 & 2,5 & 2,0 & 2,0 & 1,6 & 1,6 \\
\hline & & 60 & 3,0 & 2,6 & 2,2 & 2,2 & 1,7 & 1,8 & 1,4 & 1,4 \\
\hline \multirow{3}{*}{$\varepsilon_{c s}\left(t_{\infty}, t_{0}\right)$} & & 5 & $-0,44$ & $-0,39$ & $-0,37$ & $-0,33$ & $-0,23$ & $-0,21$ & $-0,10$ & $-0,09$ \\
\hline & & 30 & $-0,37$ & $-0,38$ & $-0,31$ & $-0,31$ & $-0,20$ & $-0,20$ & $-0,09$ & $-0,09$ \\
\hline & & 60 & $-0,32$ & $-0,36$ & $-0,27$ & $-0,30$ & $-0,17$ & $-0,19$ & $-0,08$ & $-0,09$ \\
\hline
\end{tabular}

\subsubsection{Método preciso (Anexo A da norma NBR-6118)}

De acordo com a norma, a fluência do concreto é composta por uma parcela de deformação irreversível e outra reversível. Além disso, a parcela irreversível é ainda subdividida entre a fluência irreversível rápida, que ocorre durante as primeiras $24 \mathrm{~h}$ após a aplicação da carga que a originou, e a parcela irreversível lenta. Desta forma, o coeficiente de fluência é representado pela soma de três parcelas, conforme a expressão a seguir:

$$
\left.\phi\left(t, t_{0}\right)=\phi_{a}+\phi_{f \infty} \mid \beta_{f}(t)-\beta_{f}\left(t_{0}\right)\right\rfloor+\phi_{d \infty} \cdot \beta_{d}\left(t-t_{0}\right)
$$

Sendo:

$\phi_{a}$ - coeficiente de fluência rápida;

$\phi_{f \infty}$ - valor final do coeficiente de deformação lenta irreversível;

$\beta_{f}(t)-\beta_{f}\left(t_{0}\right)$ - coeficiente relativo à deformação irreversível;

$\phi_{d \infty}$ - valor final do coeficiente de deformação lenta reversível, igual a 0,4;

$\beta_{d}\left(t-t_{0}\right)$ - coeficiente relativo à deformação lenta reversível;

Além da espessura fictícia e da umidade, o método preciso considera ainda como parâmetros de entrada diversos fatores intervenientes ao fenômeno referentes às 
características do concreto fresco. Para o cálculo dos efeitos da fluência, quando as tensões no concreto são as de serviço, admitem-se as seguintes hipóteses:

a) A deformação por fluência $\varepsilon_{c c}$ varia linearmente com a tensão aplicada;

b) Princípio de superposição de efeitos;

c) A fluência rápida produz deformações constantes o longo do tempo; o valor do coeficiente é função da relação entre a resistência do concreto no momento da aplicação da carga e a sua resistência final.

d) O coeficiente de deformação lenta reversível depende apenas da duração do carregamento; o seu valor final e o seu desenvolvimento ao longo do tempo são independentes da idade do concreto no momento de aplicação da carga.

e) O coeficiente de deformação lenta irreversível depende dos seguintes fatores: umidade relativa do ambiente; consistência do concreto no lançamento (slump); espessura fictícia da peça; idade fictícia do concreto no instante da aplicação da carga e idade fictícia do concreto no instante considerado.

f) As curvas de deformação lenta irreversível em função do tempo, correspondentes a diferentes idades de carregamento para o mesmo concreto, são obtidas, umas em relação às outras, por deslocamento paralelo ao eixo das deformações.

Com relação à função utilizada pela norma para obtenção da deformação lenta irreversível, ao admitir o paralelismo entre as curvas de deformação no tempo, a norma considera que para qualquer tempo avaliado, o comportamento da curva é o mesmo. Entretanto, sabe-se que o concreto continua ganhando resistência com o tempo, e que, portanto, para correta caracterização do comportamento do material, as curvas de deformação não poderiam ser paralelas.

\subsection{Cálculo do coeficiente de fluência}

\section{- Cálculos preliminares}

- Espessura fictícia

$$
\mathrm{h}_{\text {fic }}=\gamma \frac{2 \cdot \mathrm{A}_{\mathrm{c}}}{\mathrm{u}_{\mathrm{ar}}}
$$




$$
\gamma=1+e^{(-7,8+0,1 . U)}
$$

Sendo $\mathrm{A}_{\mathrm{c}}$, a área de concreto e $\mathrm{U}_{\mathrm{ar}} \mathrm{o}$ perímetro da seção em contato com o ar.

A interferência da espessura fictícia do elemento do concreto sobre o coeficiente de fluência é ilustrada graficamente na Fig. 5.1. Nota-se que quanto menor o teor de umidade no ambiente, mais pronunciado é o efeito da espessura fictícia. Para determinação do coeficiente de fluência deste exemplo foram utilizados os dados referentes à segunda série de ensaios de fluência efetuada nesta pesquisa, variando a umidade relativa ( Tabela 5.6).

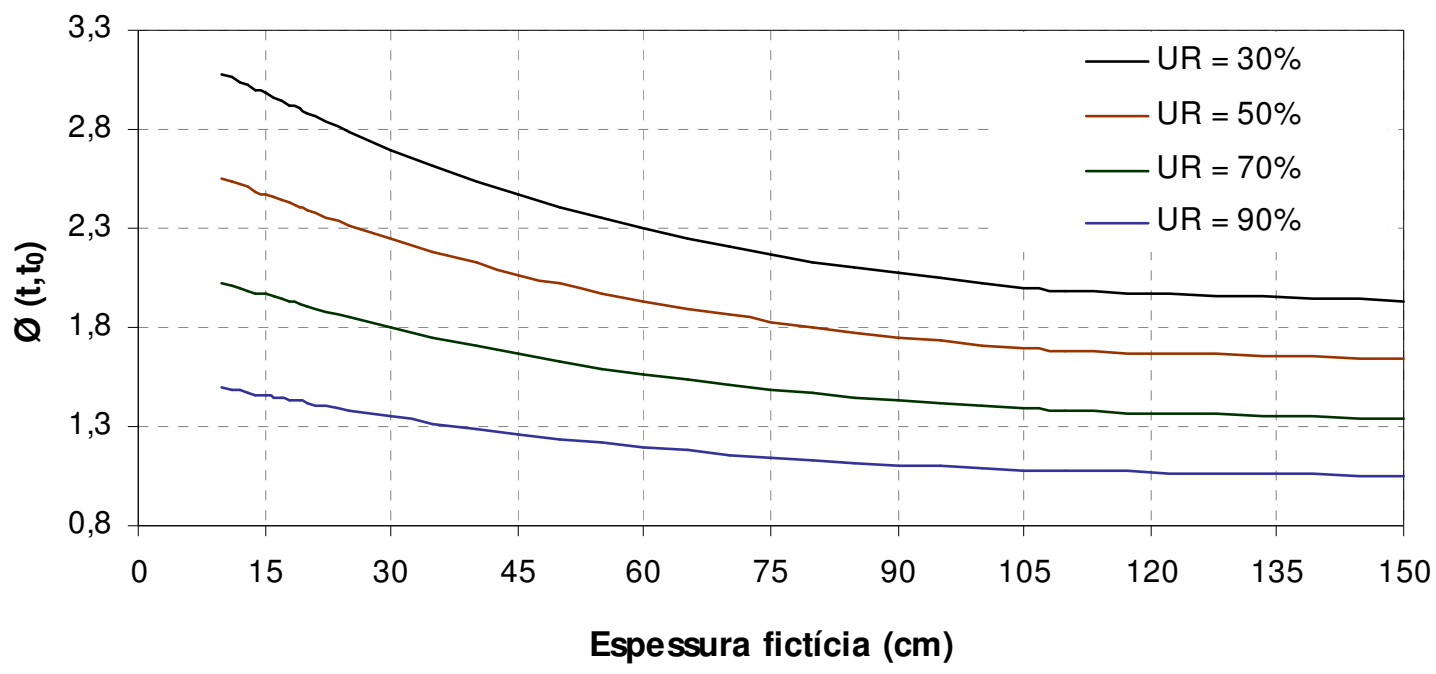

Fig. 5.1: Exemplo da variação do coeficiente de fluência com a espessura fictícia do elemento de concreto e da umidade relativa.

- Idade fictícia

$$
\mathrm{t}=\alpha \cdot \sum_{\mathrm{i}} \frac{\mathrm{T}_{\mathrm{i}}+10}{30} \cdot \Delta \mathrm{t}_{\mathrm{ef}, \mathrm{i}}
$$

$\alpha$ - coeficiente dependente da velocidade de endurecimento do cimento;

$\mathrm{T}_{\mathrm{i}}$ - Temperatura média diária do ambiente $\left({ }^{\circ} \mathrm{C}\right)$;

$\Delta T_{e f j}$ - período em dias, durante o qual a temperatura média diária do ambiente, Ti, pode ser admitida constante.

\section{- Cálculo do Coeficiente de fluência rápida}

$$
\phi_{a}=0,8 .\left[1-\frac{f_{c}\left(t_{0}\right)}{f_{c}\left(t_{\infty}\right)}\right]
$$


Sendo:

$$
\begin{aligned}
& \frac{\mathrm{f}_{\mathrm{c}}\left(\mathrm{t}_{0}\right)}{\mathrm{f}_{\mathrm{c}}\left(\mathrm{t}_{\infty}\right)} \text {, função de crescimento da resistência do concreto com a idade } \\
& f_{c}=\beta_{1} \cdot f_{c 28} \text { e } \beta_{1}=\exp \left\lfloor s \cdot(1-28 / t)^{0,5}\right\rfloor
\end{aligned}
$$

O fator $s$ na expressão de $f_{c}$ leva em consideração o tipo de cimento. Para cimentos tipo CPIII e CPIV, $\mathrm{s}=0,38$; para cimento tipo CPI e CPII, $\mathrm{s}=0,25$; e para cimento CPV-ARI, $\mathrm{s}=$ 0,20. O coeficiente de fluência rápida é o único em que se utiliza o tempo efetivo ao invés da idade fictícia.

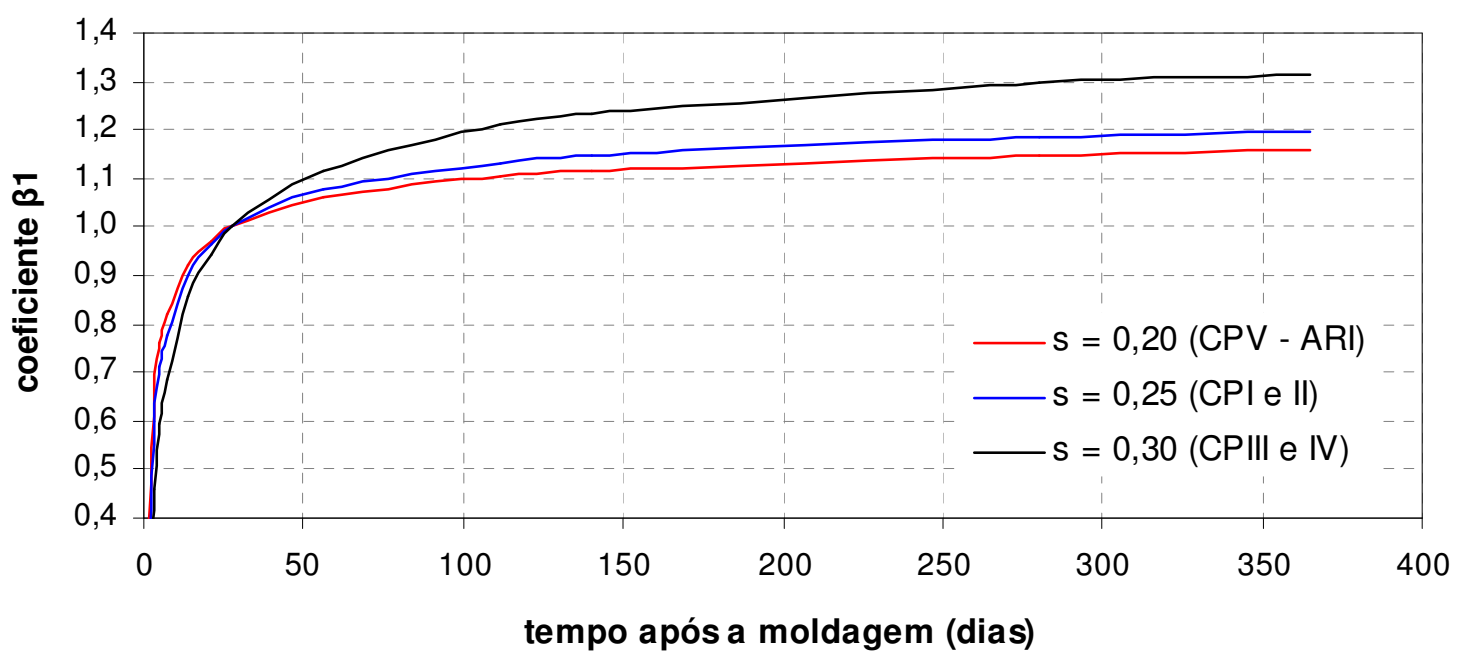

Fig. 5.2: Evolução da resistência à compressão, com referência à resistência à compressão estimada aos 28 dias.

A variação do coeficiente $\beta_{1}$ de acordo com o tipo de cimento e com o tempo efetivo após a moldagem é representada graficamente na Fig. 5.2. Nota-se que a expressão descreve de forma satisfatória o que se observa na prática: conforme mais rápido o endurecimento do cimento utilizado maior a resistência inicial e mais rápida a estabilização do ganho de resistência.

\section{- Cálculo do coeficiente de fluência irreversível}

$$
\begin{array}{r}
\phi_{f \infty o}=\phi_{1 c} \cdot \phi_{2 c} \\
\phi_{1 c}=4,45-0,035 \cdot U \\
\phi_{2 c}=\frac{42+h_{f i c}}{20+h_{f i c}}
\end{array}
$$


Para slump entre 5 e $9 \mathrm{~cm}$ e $U \leq 90 \%$, o coeficiente $\emptyset_{1 \mathrm{c}}$ é obtido pela expressão abaixo. Para slump entre 0 e $4 \mathrm{~cm}$ o valor é minorado em $25 \%$, já para slump entre 10 e $15 \mathrm{~cm}$ o valor é majorado em $25 \%$. Já o coeficiente $\emptyset_{2 c}$ é calculado a partir da espessura fíctícia (dada em centímetros), sendo esta obtida conforme apresentado anteriormente (página 110).

Nos casos em que são utilizados aditivos superplastificantes ou superfluidificantes deve ser considerado o slump que seria obtido para o traço sem o aditivo.

A variação de $\varnothing_{1 \mathrm{c}}$ com a umidade relativa, para as três faixas de slump consideradas na tabela A1 da norma, está representada na Fig. 5.3. Já na Fig. 5.4 tem-se a variação do coeficiente $\emptyset_{2 c}$ com a espessura fictícia.

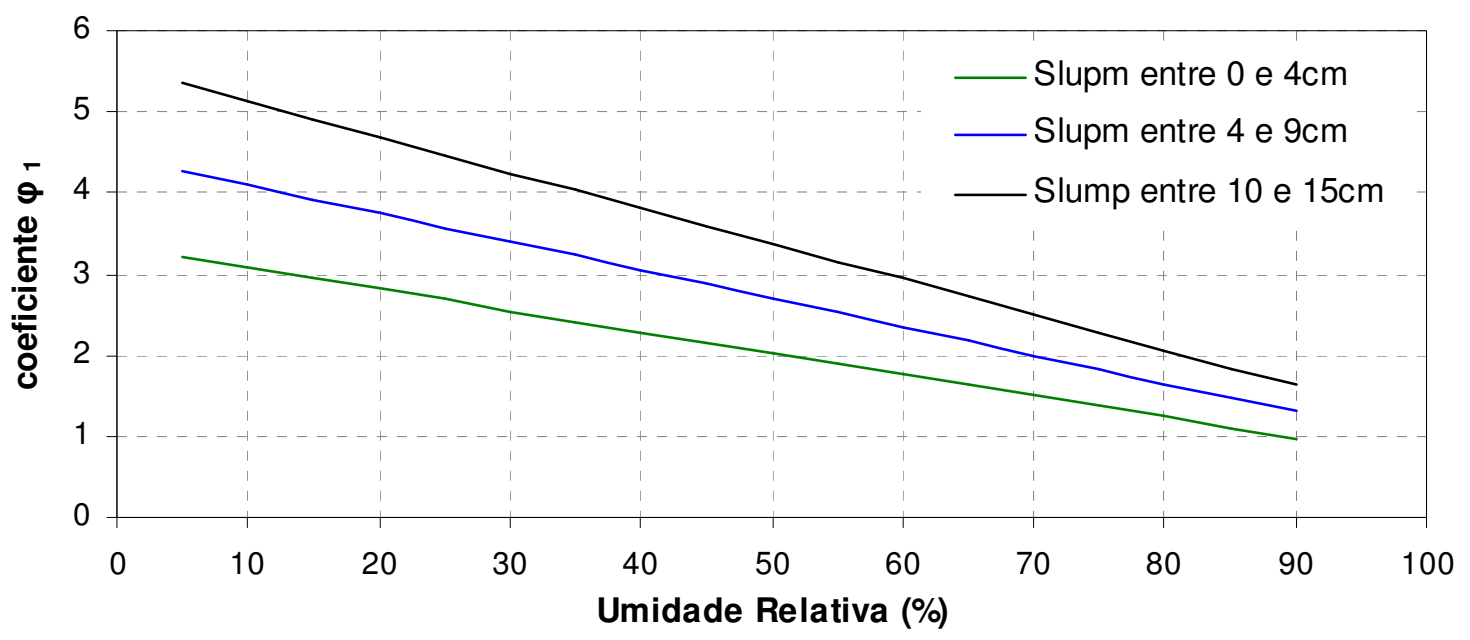

Fig. 5.3: Coeficiente $\emptyset_{1}$ em função do slump e da umidade relativa.

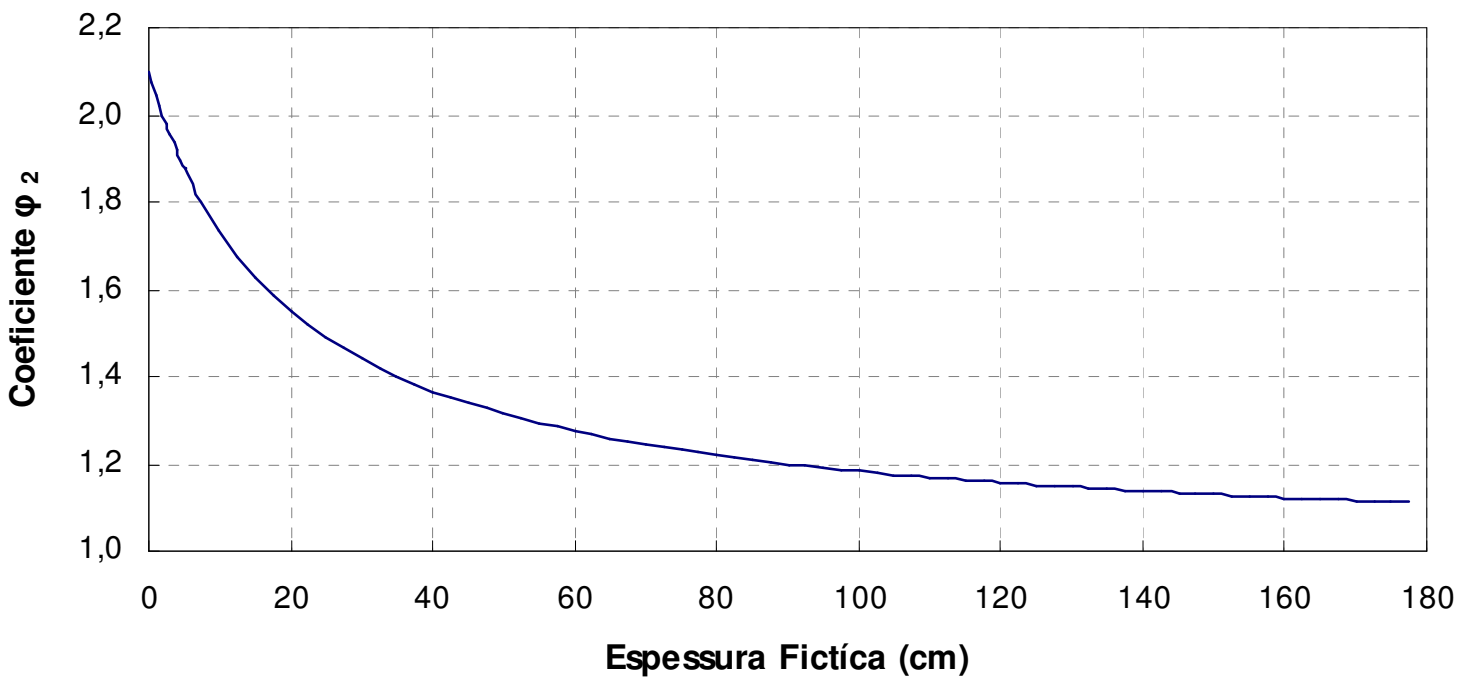

Fig. 5.4: Variação de $\emptyset_{2}$ com a espessura fictícia. 


\section{- Cálculo do coeficiente relativo à deformação lenta irreversível}

Este coeficiente corresponde ao valor de $\left(\beta_{f}(t)-\beta_{f}\left(t_{0}\right)\right)$ sendo que os valore de $\beta(t)$ e $\beta\left(t_{0}\right)$ determinados graficamente (Fig. 5.5) ou analiticamente, seguindo as expressões a seguir. Importante lembrar que se utiliza a idade fictícia do concreto, correspondentes às idade efetivas, conforme apresentado anteriormente (página 111).

$$
\beta_{f}(t)=\frac{t^{2}+A \cdot t+B}{t^{2}+C \cdot t+D}
$$

Sendo:

$$
\begin{array}{ll}
A=42 . h_{f i c}^{3}-350 . h_{f i c}^{2}+588 . h_{f i c}+113 & 5.14 \\
B=768 . h_{f i c}^{3}-3060 . h_{f i c}^{2}+3234 . h_{f i c}-23 & 5.15 \\
C=-200 \cdot h_{f i c}^{3}+13 \cdot h_{f i c}^{2}+1090 . h_{f i c}+183 & 5.16 \\
D=7579 . h_{f i c}^{3}-31916 . h_{f i c}^{2}+35343 . h_{f i c}+1931 & 5.17
\end{array}
$$

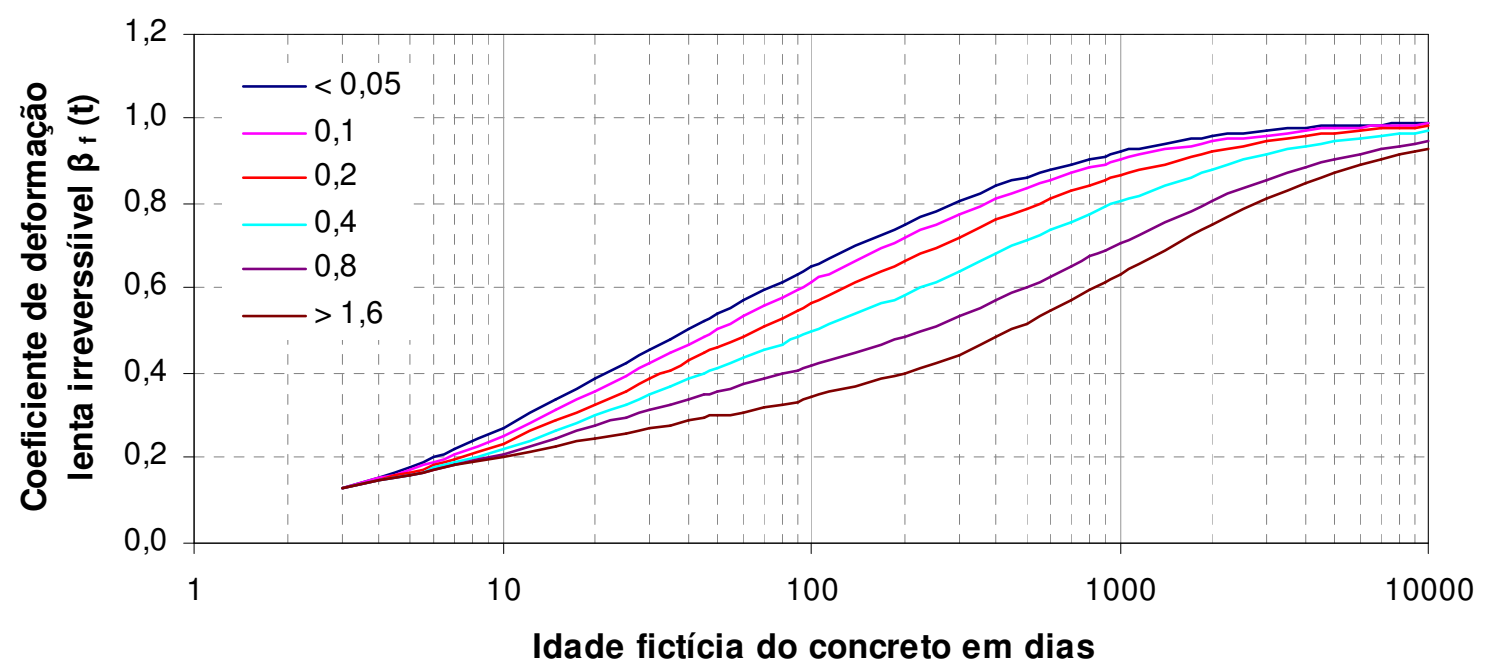

Fig. 5.5: Variação de $\beta_{f}(t)$ com a espessura fictícia e com o tempo.

- Cálculo do coeficiente de fluência reversível

$$
\begin{array}{r}
\varphi_{d_{\infty}}-\text { considerado igual a } 0,4 \\
\beta_{d}=\frac{t-t_{0}+20}{t-t_{0}+70}
\end{array}
$$


A variação de $\beta_{d}$ com a duração do carregamento é ilustrada na Fig. 5.6. Para o cálculo deste coeficiente também deve ser utilizada a idade fictícia do concreto, conforme as expressões apresentadas anteriormente (página 111).

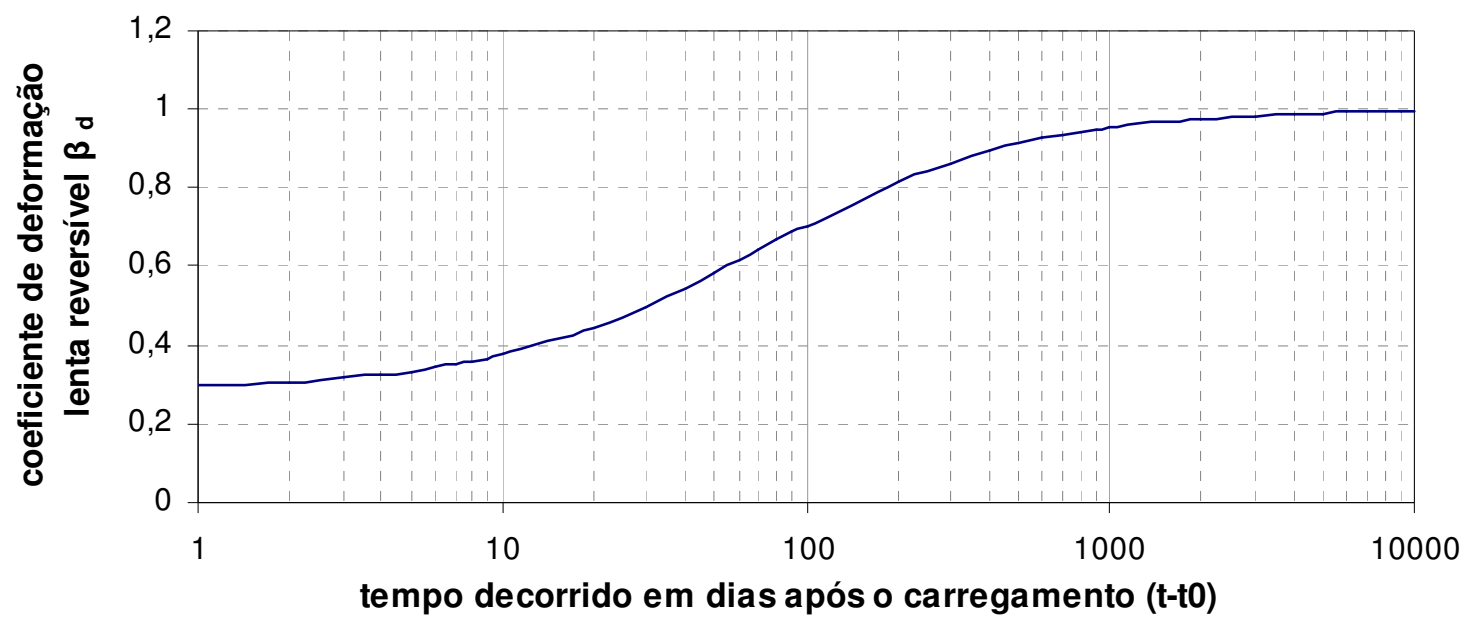

Fig. 5.6: Coeficiente de fluência reversível.

\subsubsection{ACI 209/ 1982}

No Comitê técnico 209 do ACI, a função de fluência é expressa de acordo com a expressão 5.2. A expressão é função do módulo de elasticidade variável no tempo $E_{c}(t)$ e do coeficiente de fluência, representado por $\phi\left(t, t_{0}\right)$, considerando carregamento em $t_{0}$.

$$
\begin{array}{r}
J\left(t, t_{0}\right)=\frac{1}{E_{c}\left(t_{0}\right)}\left[1+\phi\left(t, t_{0}\right)\right] \\
E_{c}\left(t_{0}\right)=0,043 \cdot \sqrt{w^{3} \cdot\left(f_{c}\right)_{t_{0}}} \\
\left(f_{c}\right)_{t_{0}}=\frac{t}{\alpha+\beta \cdot t}\left(f_{c}\right)_{28}
\end{array}
$$

Sendo:

$w$ é o peso do concreto em $\mathrm{kg} / \mathrm{m}^{3}$;

$\left(f_{c}\right)_{t_{0}}$ é a resistência característica no carregamento, em MPa.

$\left(f_{c}\right)_{28}$ é a resistência característica aos 28 dias e $\mathrm{t}_{0}$ é a idade de carregamento em dias, e $\alpha$ e $\beta$ são constantes que dependem dos tipos de cura e cimento utilizado, em dias (ver tabela 5.2). 
Diferentemente da norma brasileira, tanto a parcela elástica quanto a parcela viscosa da função de fluência são calculadas com base no módulo de elasticidade estimado na ocasião do carregamento.

Tabela 5.2: Constantes $\alpha, \beta$ dependentes do tipo de cura e cimento.

\begin{tabular}{c|c|c}
\hline Tipo de Cimento & $\boldsymbol{\alpha}$ & $\boldsymbol{\beta}$ \\
\hline Para cura úmida e cimento CP I & 4,00 & 0,85 \\
\hline Para cura úmida e cimento CP V & 2,30 & 0,92 \\
\hline Para cura a vapor e cimento CP I & 1,00 & 0,95 \\
\hline Para cura a vapor e cimento CP V & 0,70 & 0,98 \\
\hline
\end{tabular}

\subsubsection{Previsão do coeficiente de fluência}

As principais variáveis que afetam a retração e a fluência do concreto estão resumidas na Tabela 5.4. A aproximação apresentada para cálculo tanto da retração quanto da fluência refere-se às condições comuns. O Comitê 209 do ACI indica a seguinte expressão para se estimar o coeficiente de fluência do concreto, após cura úmida de 7 dias quando carregado na idade de 7 dias:

$$
\phi\left(t, t_{0}\right)=\left[\frac{\left(t-t_{0}\right)^{0,6}}{10+\left(t-t_{0}\right)^{0,6}}\right] \cdot\left(C_{\text {Idade }} C_{U R} C_{E s p} C_{S} C_{P A M} C_{A r} C_{V / S} \phi_{u}\right)
$$

Onde $t$ é o tempo, em dias, após o início do carregamento ( $t>7$ dias $)$, e $\phi_{u}$ é o valor último do coeficiente de fluência igual a 2,35. Pelo formato da expressão 5.21, nota-se que o termo relativo à duração do carregamento é descrito por uma função do tipo hiperbólica, como aquela proposta por Ross (ver item 4.1.5).

Se as condições da estrutura (período de cura e idade de carregamento) forem diferentes daquelas necessárias para aplicação da expressão anterior devem-se utilizar os fatores de correção, apresentados nos subitens a seguir.

\section{- Coeficiente de correção da idade de carregamento $C_{\text {Idade }}$}

Para idades de carregamento $\left(t_{0}\right)$ acima de 7 dias, deve-se usar o coeficiente abaixo:

$$
\begin{gathered}
C_{\text {Idade }}=1,25\left(t_{0}\right)^{-0,118} \text {, para cura úmida } \\
C_{\text {Idade }}=1,13\left(t_{0}\right)^{-0,095} \text {, para cura a vapor }
\end{gathered}
$$


- Coeficiente da umidade relativa do ambiente $C_{U R}$

$$
C_{U R}=1,27-0,0067 U \text {, para } U \geq 40 \% \text {. }
$$

\section{- Coeficiente da espessura fictícia da peça}

São disponíveis pela norma duas maneiras de se computar a influência do tamanho do elemento de concreto sobre o coeficiente de fluência. A primeira delas consiste em determinar o coeficiente da espessura mínima, $C_{E s p}$, e a outra consiste em considerar o coeficiente da relação do volume sobre a área, $C_{V / S}$.

No método da espessura média corresponde a valores do CEB de 1970 para o cálculo da espessura fictícia (expressões também próximas daquelas previstas pela NBR 6118:2003) e resulta em valores maiores do coeficiente de correção, quando comparado com o método da relação volume sobre área.

Independentemente do método utilizado, a coeficiente de correção decorrente do tamanho do elemento de concreto não deve ser inferior a 0,2 .

O DIANA ${ }^{\circledR}$ utiliza o método da relação volume sobre área (V/S). Entretanto, de acordo com o manual Materials Library pode-se considerar que V/S seja equivalente à metade da espessura fictíca, calculada da mesma forma como discreto anteriormente no modelo da NBR:

$$
h=\frac{2 A_{C}}{U_{a r}}
$$

Sendo:

$U_{a r}$ o perímetro da seção transversal em contato com a atmosfera

$A_{C}$ a área da seção transversal

No caso da determinação do coeficiente de fluência realizado para a obtenção das flechas diferidas e das demais curvas de fluência (fluência específica e deformação-tempo) optou-se por utilizar o método da relação volume sobre área. Isto porque algumas destas curvas foram comparadas com as curvas decorrentes da simulação numérica efetuada no DIANA $^{\circledR}$, e, portanto a escolha do mesmo método para obtenção do coeficiente de correção do tamanho do elemento estrutural fornece uma base de comparação mais adequada. 
- Método da espessura média

Para espessura média $d$ menor do que $150 \mathrm{~mm}$ utilizam-se os valores da Tabela 5.3. Para espessura média entre 150 e $380 \mathrm{~mm}$,

$$
\begin{aligned}
& C_{e s p}=1,14-0,00091 \cdot d \text {, para }\left(t-t_{0}\right) \leq 1 \text { ano } \\
& C_{e s p}=1,10-0,00067 \cdot d \text {, para }\left(t-t_{0}\right)>1 \text { ano }
\end{aligned}
$$

Tabela 5.3: Coeficiente da espessura mínima.

\begin{tabular}{c|c|c}
\hline \multirow{2}{*}{$\begin{array}{c}\text { Espessura } \\
\text { média }(\mathbf{m m})\end{array}$} & \multicolumn{2}{|c}{ Valores de $C_{E s p}$} \\
\cline { 2 - 3 } & Tempo $\leq 1$ ano & Tempo $\geq \mathbf{1}$ ano \\
\hline 50 & 1,30 & 1,30 \\
\hline 75 & 1,17 & 1,17 \\
\hline 100 & 1,11 & 1,11 \\
\hline 125 & 1,04 & 1,04 \\
\hline 150 & 1,00 & 1,00 \\
\hline 200 & 0,96 & 0,96 \\
\hline 250 & 0,91 & 0,93 \\
\hline 300 & 0,86 & 0,90 \\
\hline 380 & 0,80 & 0,85 \\
\hline
\end{tabular}

- Método da relação volume sobre área

$$
C_{V / S}=2 / 3[1+1,13 \exp (-0.54 \cdot V / S)] \geq 0,2
$$

- Coeficiente da consistência ("slump") do concreto no lançamento $C_{S}$

$$
C_{S}=0,82+0,00264 S \text {, onde o slump S é medido em } \mathrm{mm} \text {. }
$$

\section{- Coeficiente do percentual de agregado miúdo no concreto $\mathbf{C}_{\mathrm{PAM}}$}

$$
C_{P A M}=0,88+0,0024 P_{A M}
$$

$P_{A M}$ é a razão do peso de agregado miúdo em relação ao peso total de agregados (\%).

- Coeficiente do teor de ar incorporado no concreto $\mathrm{C}_{\mathrm{Ar}}$.

$$
C_{A r}=0,46+0,08 P_{A r} \leq 1 \text {, onde } P_{A r} \text { é o percentual de ar incorporado. }
$$


Tabela 5.4: Fatores que influenciam a fluência e a retração, de acordo com o ACI 209:1982.

\begin{tabular}{|c|c|c|c|c|}
\hline \multicolumn{3}{|r|}{ Fatores } & Variáveis Consideradas & $\begin{array}{l}\text { Condiçõoes } \\
\text { Padrão }\end{array}$ \\
\hline \multirow{10}{*}{ 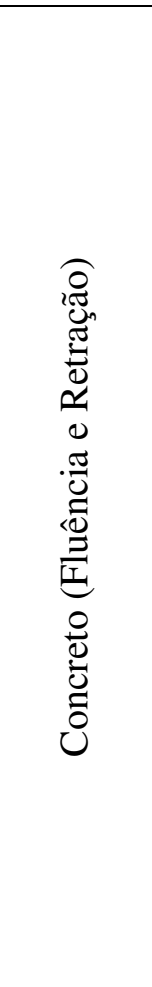 } & \multirow{5}{*}{ 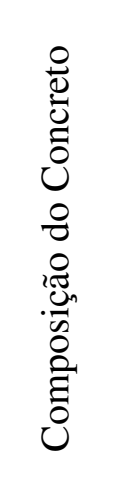 } & $\begin{array}{c}\text { Conteúdo de Pasta de } \\
\text { Cimento }\end{array}$ & Tipo de Cimento & Tipo I e III \\
\hline & & Razão Água-Cimento & Slump & $70 \mathrm{~mm}$ \\
\hline & & Proporções de Mistura & Conteúdo de Ar & $\leq 6 \%$ \\
\hline & & $\begin{array}{c}\text { Características do } \\
\text { Agregado }\end{array}$ & $\begin{array}{c}\text { Porcentagem do Agregado } \\
\text { Fino }\end{array}$ & $50 \%$ \\
\hline & & Grau de Compactação & Conteúdo de Cimento & 279 a $446 \mathrm{~kg} / \mathrm{m}^{3}$ \\
\hline & \multirow{5}{*}{ 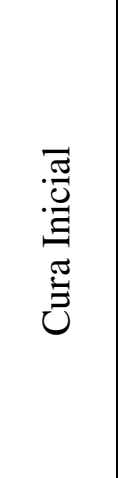 } & \multirow{2}{*}{ Tempo de Cura Inicial } & Cura Úmida & 7 dias \\
\hline & & & Cura no Vapor & $1-3$ dias \\
\hline & & \multirow{2}{*}{ Temperatura de Cura } & Cura Úmida & $23 \pm 2^{\circ} \mathrm{C}$ \\
\hline & & & Cura no Vapor & $\leq 100^{\circ} \mathrm{C}$ \\
\hline & & Umidade de Cura & Umidade Relativa & $\geq 95 \%$ \\
\hline \multirow{4}{*}{ 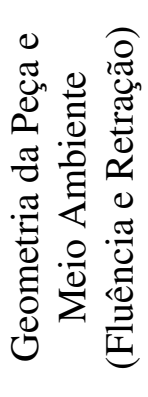 } & \multirow{2}{*}{ 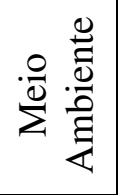 } & Temperatura do Concreto & Temperatura do Concreto & $23 \pm 2^{\circ} \mathrm{C}$ \\
\hline & & $\begin{array}{c}\text { Conteúdo de Água no } \\
\text { Concreto }\end{array}$ & Umidade Relativa do Ar & $40 \%$ \\
\hline & \multirow{2}{*}{ 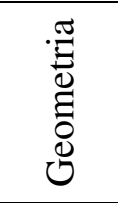 } & \multirow{2}{*}{ Tamanho e Forma } & $\begin{array}{c}\text { Razão Volume-Superfície } \\
(\mathrm{v} / \mathrm{s})\end{array}$ & $\mathrm{v} / \mathrm{s}-38 \mathrm{~mm}$ \\
\hline & & & Espessura Mínima & $150 \mathrm{~mm}$ \\
\hline \multirow{5}{*}{ 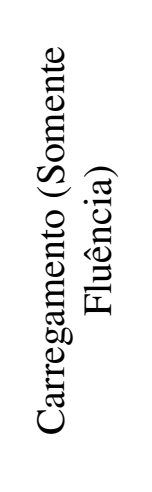 } & \multirow{3}{*}{ 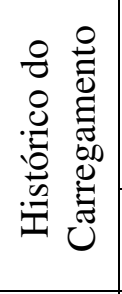 } & \multirow{2}{*}{$\begin{array}{l}\text { Idade do Concreto e } \\
\text { Aplicação do } \\
\text { Carregamento }\end{array}$} & Cura Úmida & 7 dias \\
\hline & & & Cura no Vapor & $1-3$ dias \\
\hline & & $\begin{array}{l}\text { Duração do Período de } \\
\text { Carregamento }\end{array}$ & Carregamento Contínuo & Carregamento Contínuo \\
\hline & \multirow{2}{*}{ 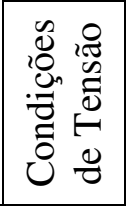 } & $\begin{array}{c}\text { Tipo de Tensão e } \\
\text { Distribuição pela Seção }\end{array}$ & Tensão de Compressão & Compressão Axial \\
\hline & & $\begin{array}{c}\text { Razão } \\
\text { Tensão/Resistência } \\
\end{array}$ & $\begin{array}{c}\text { Razão } \\
\text { Tensão/Resistência } \\
\end{array}$ & $\leq 0,50$ \\
\hline
\end{tabular}




\subsubsection{Comparação}

Com base na descrição dos modelos de previsão da fluência das normas americana e brasileira, percebe-se claramente a maior facilidade em realizar os cálculos para obtenção do coeficiente de fluência de acordo com o ACI 209, do que seguindo as recomendações da NBR 6118. O modelo do ACI, baseado nos trabalhos de Branson et. al. $(1970,1971)$ certamente é um dos mais simples para previsão da fluência (BAZANT, 1988). Este modelo é descrito no formato produtório, ou seja, a função de fluência é dada pela multiplicação de duas funções, uma que considera a idade de carregamento, e outra que considera a duração das tensões.

Já a norma brasileira, baseada na idéia de reversibilidade da deformação, utiliza um modelo somatório para descrever o coeficiente de fluência. Bazant (1988) chama a atenção para os seguintes aspectos do modelo somatório adotado pelo CEB- FIB 1978 (a partir do qual, foi desenvolvido o modelo da norma brasileira):

- A definição de uma única função para representar tanto o efeito do envelhecimento, como da duração do carregamento na parcela viscosa da fluência, não está de acordo com resultados experimentais, mesmo que o termo de fluência rápida seja apresentado separadamente da fluência;

- A componente reversível da função de fluência foi calibrada pelo ajuste de curvas de recuperação da fluência obtidas a partir do princípio da superposição pra recuperar dados experimentais também tem sido questionado. A superposição linear não se assegura no caso de descarregamento, o que tem sido demonstrado por resultados de ensaios;

- A umidade relativa e a dimensão do elemento aparecem apenas no termo irreversível, o que está em contradição com resultados experimentais.

De acordo com diversos dados da literatura, pode-se afirmar que nem sempre o modelo mais complexo, ou que leve em consideração uma maior quantidade de fatores, é necessariamente o mais preciso. Isto está relacionado com o erro que se tem na determinação (ou estimativa) dos dados de entrada. A maioria dos fatores considerados pelos modelos, possui inerentemente uma variação aleatória, representada por coeficientes de variação na ordem de 15 a 20\%, na melhor das hipóteses (ACI 209R-92).

Ou seja, além das dificuldades de calibração dos modelos por problemas de amostragem (dados de ensaios de fluência confiáveis); há também erros embutidos nos parâmetros de entrada dos modelos, o que fornece um cunho fortemente estatístico à boa 
previsão da fluência.

Apesar do procedimento de cálculo da NBR ser mais trabalhoso, exige menos parâmetros de entrada, principalmente no que diz respeito à dosagem. Isto de certa forma é um ponto positivo do modelo da NBR 6118:2003, levando em consideração o desconhecimento durante a fase de projeto de informações precisas sobre o traço e sobre o concreto no estado fresco. Uma comparação dos parâmetros de entrada, para previsão da fluência, requisitados por cada norma está apresentada na Tabela 5.5.

Tabela 5.5: Parâmetros de entrada exigidos pelos modelos estudados para previsão das deformações ao longo do tempo, considerando o fenômeno da fluência.

\begin{tabular}{l|c|c}
\hline \multicolumn{1}{c|}{ Parâmetro considerado } & ACI 209:1982 & NBR 6118:2003 \\
\hline Resistência do concreto aos 28 dias & $\checkmark$ & $\checkmark$ \\
Módulo de elasticidade na idade de carregamento & $\checkmark$ & $\times$ \\
Tipo de cimento & $\checkmark$ & $\checkmark$ \\
Tipo de cura & $\checkmark$ & $\times$ \\
Umidade Relativa & $\checkmark$ & $\checkmark$ \\
Idade do concreto no carregamento & $\checkmark$ & $\checkmark$ \\
Relação volume/área & $\checkmark$ & $\times$ \\
Abatimento do tronco de cone (slump) & $\checkmark$ & $\times$ \\
Percentagem de agregados finos em peso & $\checkmark$ & $\times$ \\
Percentagem em volume de ar aprisionado & $\checkmark$ & $\times$ \\
Densidade do concreto & $\times$ & $\checkmark$ \\
Área da seção transversal & $\times$ & $\checkmark$ \\
Parâmetro da seção transversal em contato com o ar & & $\times$ \\
\hline
\end{tabular}

De acordo com o comitê europeu do concreto de 1990, quando o modelo do CEB 1978 foi aplicado a um vasto banco de dados, foram encontrados coeficiente de variação de 39,9\% para o coeficiente de fluência e 25,5\% para a função de fluência. Esta diminuição do erro para a função de fluência é reflexo da estimativa do módulo de elasticidade proposta pelo modelo. Notou-se também que o erro na previsão torna-se maior conforme o aumento na duração do carregamento (CEB-199, 1990).

A maior ou menor confiabilidade de um ou outro modelo de previsão da fluência é relativa. Entretanto, é possível notar tendências nos resultados da literatura, sendo que em praticamente todos os casos a norma americana subestima as deformações por fluência. 
Trabalhos cujos resultados de ensaios de fluência efetuados no Brasil são comparados com as previsões da NBR 6118 e outras normas demonstram que a NBR fornece curvas de deformação-tempo e flecha-tempo superiores aos dos modelos do CEB-FIB 1990 (Sampaio C. D. C., 2004; Reis A. P. A., 2003).

De acordo com o trabalho de Fanourakis G. C. e Ballim Y. de 2006, para ensaios realizados nas condições da África do Sul, os modelo do CEB- FIB 1978 foi o que forneceu pior aproximação com os resultados experimentais, conduzindo a um coeficiente de variação de $96 \%$. As curvas de fluência específica versus tempo sob carga, obtidas por este modelo partiram de um valor inicial muito superior ao medido, superestimando o fenômeno. Já o modelo do ACI subestimou as deformações em qualquer situação.

Goel ET. AL. (2007) realizaram a comparação das curvas de fluência específica versus tempo (idade do concreto), obtidas segundo nove modelos de previsão com resultados experimentais do banco de dados da RILEM. Foi observado que na maioria dos os casos, as previsões do ACI 209:1192 e do CEB- FIB 1990 (após reformulação do CEB- FIB de 1978) subestimaram a fluência. Interessante comentar que em 1990, o modelo do comitê europeu para previsão da fluência passou a ser formulado segundo um modelo produtório, assemelhando-se ao código americano.

Ao aplicar os dados das duas séries de ensaios realizadas nesta pesquisa para se determinar o coeficiente de fluência segundo as normas descritas neste capítulo (NBR e ACI), notou-se a mesma tendência observada na literatura: as curvas do ACI são inferiores às curvas fornecidas pela NBR (ver Fig. 5.8).

Os cálculos foram realizados em planilha do Excel. Os dados de entrada utilizados estão apresentados na Tabela 5.6. Todas as informações sobre o programa experimental estão apresentadas de forma detalhada no Capítulo 7. O cálculo da percentagem de finos foi feito com base no traço utilizado em cada série (ver Tabelas 7.2 e 7.5). Já o teor de ar incorporado foi estimado pela diferença entre a massa obtida na pesagem das vigas e a massa teórica, calculada pela soma dos materiais de mistura seguindo as proporções de dosagem.

Como já comentado na apresentação do trabalho, na análise dos resultados as curvas experimentais foram comparadas com aquelas obtidas teoricamente pelas expressões normativas da NBR 6118:2003 e do ACI 209:1982. 
Tabela 5.6: Parâmetros de entrada utilizados para determinação do coeficiente de fluência.

\begin{tabular}{c|lcc}
\hline \multicolumn{2}{c}{ Descrição dos dados de entrada } & Série 1 & Série2 \\
\hline & Idade do concreto no carregamento (dias) & 60 & 14 \\
& Temperatura média do ambiente ${ }^{\circ} \mathrm{C}$ & 25,9 & 24,5 \\
Fatores comuns & Umidade Relativa do ar (\%) & 57 & 72,8 \\
entre NBR & Tipo de cimento utilizado & $\mathrm{CP}$ II & $\mathrm{CP} \mathrm{II}$ \\
6118:2003 e ACl & Área da seção transversal $\left(\mathrm{cm}^{2}\right)$ & 450 & 450 \\
209:1982 & Perímetro em contato com o ar $(\mathrm{cm})$ & 90 & 90 \\
& Abatimento do tronco de cone - slump $(\mathrm{cm})$ & 200 & 75 \\
\hline \multirow{2}{*}{ Fatores utilizados } & Percentagem de agregado miúdo $(\%)$ & 39 & 44 \\
apenas pelo ACl & Percentagem de ar incorporado $(\%)$ & $0,26 \%$ & $1,31 \%$ \\
$209: 1978$ & Espessura média (mm) & 100 & 100 \\
& Tipo de cura & úmida & úmida \\
\hline
\end{tabular}

Dentre todos os parâmetros exigidos pelo ACI certamente o mais difícil de prever é o teor de ar incorporado. Normalmente seu valor não é mensurado in loco, e também dificilmente faz-se uma estimativa por diferenças entre as massas, de forma que a tendência é utilizar o valor "default" ou padrão de 7\%. Entretanto esse é um dado de entrada importante, e o uso de $7 \%$ pode superestimar a fluência, o que em projeto ocasiona uma situação a favor da segurança, porém antieconômica.

Partindo-se de uma situação inicial cujo ar incorporado seja 6\%, o coeficiente de fluência chega a ser 9\%, 18\%, 27\%, 36\%, 45\% e 59\% maior para teores de ar incorporado de $5 \%, 4 \%, 3 \%, 2 \%, 1 \%$ e $0 \%$. A Fig. 5.7 permite a visualização do impacto destas variações, considerando os demais dados de entrada da Tabela 5.6, para a Série 2.

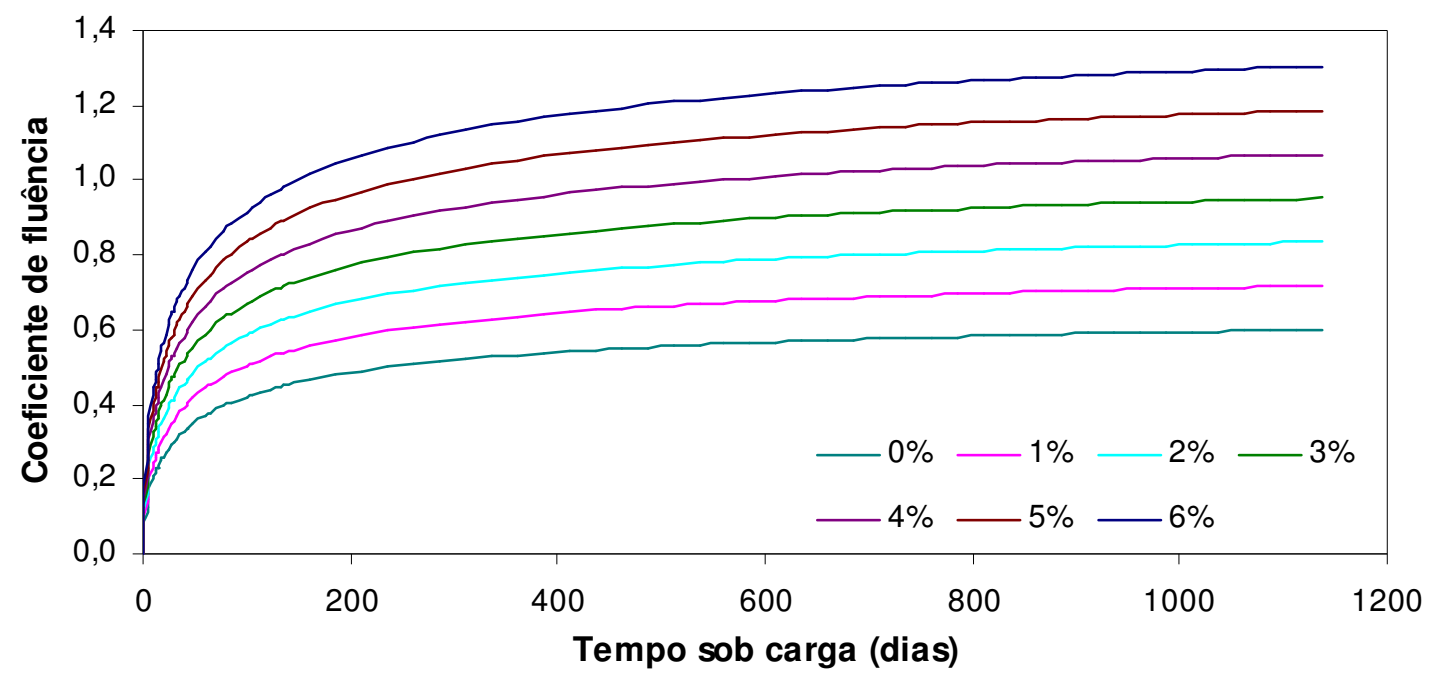

Fig. 5.7: Variação de $\emptyset\left(t, t_{0}\right)$ em função do teor de ar incorporado. 
Na Fig. 5.8 são apresentados três gráficos da variação do coeficiente de fluência no tempo, considerando as duas normas (ACI e NBR), aplicadas aos dados das duas séries de ensaio (desta forma, o número que segue a identificação da norma refere-se à série correspondente).
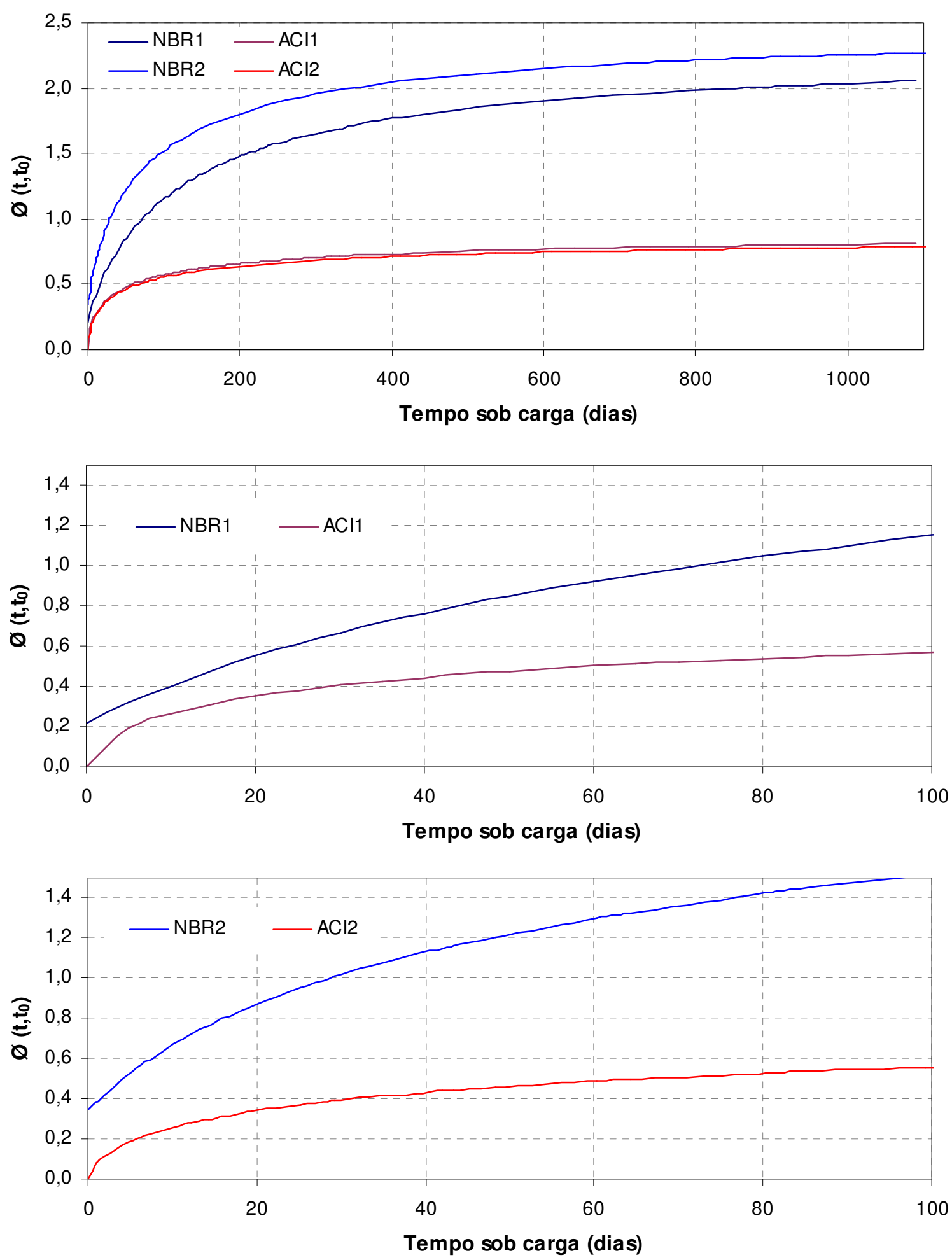

Fig. 5.8: Comparação entre as previsões normativas para variação de $\emptyset\left(t, \mathrm{t}_{0}\right)$ no tempo. 
Nota-se que, mesmo considerando o instante imediatamente após a aplicação do carregamento (ou seja, para $\left(\mathrm{t}-\mathrm{t}_{0}\right)=0$ ), de acordo com a norma brasileira, há uma parcela de fluência não desprezível, que chega a equivaler a aproximadamente $20 \%$ do total nos primeiros meses. Já segundo a norma americana, imediatamente após a aplicação da carga o coeficiente de fluência é nulo, ou seja, a deformação é a própria deformação elástica.

Torna-se bastante clara a diferença entre as duas formulações, principalmente para períodos de duração do carregamento de até 400 dias (ou próximos a um ano). Como já observado em diversas publicações, a norma americana subestima a fluência em comparação ao modelo do CEB de 1978, no qual é baseado o modelo brasileiro. No caso deste exemplo, as diferenças chegam a valores próximos de $60 \%$. Nota-se também que as curvas derivadas do ACI estabilizam-se em idades muito inferiores aquelas obtidas pela NBR.

Ainda com relação à Fig. 5.8 se observa pouca diferença, para um mesmo modelo de previsão, entre os dados das duas séries. Apesar disso, observa-se um aumento do coeficiente de fluência ao comparar as curvas NBR1 e NBR2, ao passo que segundo o ACI nota-se o oposto.

Apesar da discussão anterior em termos do coeficiente de fluência, deve-se ressaltar que este não é o parâmetro mais utilizado para caracterizar a fluência. Quando se objetiva comparar modelos de previsão, o mais adequado é representar o fenômeno em termos da função de fluência $J\left(t, t_{0}\right)$. Isto porque nesta função são consideradas as expressões para estimativa do módulo de elasticidade, e, além disso, é esta função que correlaciona tensões e deformações dentro do comportamento viso-elástico do concreto, sendo efetivamente utilizada, por exemplo, em uma modelagem numérica.

Desta forma, outra questão relevante na previsão da fluência refere-se à precisão com que os modelos normativos estimam o módulo de elasticidade, já que este valor é empregado diretamente nas expressões da função de fluência, tanto na parcela referente a deformação elástica inicial, quanto na parcela referente para estimativa das deformações dependentes do tempo.

De acordo com o que foi apresentado neste capítulo, a estimativa do módulo de elasticidade na idade de carregamento $\left(E_{c}\left(t_{0}\right)\right)$ pode ser efetuada utilizando-se as expressões 5.3, no caso da NBR, e 5.20, para o ACI. Entretanto nota-se que, através das expressões 5.9 e 5.21, as quais refletem a "lei de evolução" da resistência do concreto de acordo com a NBR e o ACI, respectivamente; o valor de $E_{c}\left(t_{0}\right)$ pode ser calculado conhecendo-se um valor de 
resistência ou mesmo do módulo de elasticidade em uma idade qualquer.

Certamente o valor usual a ser empregado na fase de projeto é o $f_{c k}$ (resistência à compressão característica aos 28 dias). Contudo, conforme será visto a seguir, tem-se uma estimativa mais correta ao empregar um valor de módulo de elasticidade, por exemplo, aos 28 dias. As figuras 5.9 e 5.10 ilustram as curvas de função de fluência obtidas através das formulações da NBR (equação 5.2) e do ACI (equação 5.19).

Na Fig. 5.9 o módulo de elasticidade na idade de aplicação do carregamento foi calculado a partir do valor experimental médio da resistência á compressão aos 28 dias (ver Tabela 5.7). Na Fig. 5.10 o valor de $E_{c}, t_{0}$ foi calculado a partir do módulo de elasticidade médio obtido experimentalmente aos 28 dias (Tabela 5.8). Comparando as duas figuras, notase claramente que o valor considerado no cálculo, afeta sobremaneira o resultado final.

Nota-se que na primeira situação (Fig. 5.9) há uma diferença entre as curvas da primeira e da segunda série (de $10 \%$ comparando NBR1 com NBR2, e de 22\% comparando ACI1 com ACI2). Por outro lado, ao utilizar como referência o valor de $E_{c, \text { exp. }}$ (28), as curvas das duas séries após cerca de 1 ano praticamente desaparecem. Desta forma parece ser mais conveniente calcular $E_{c}, t_{0}$ a partir do módulo aos 28 dias (o que já é feito no DIANA ${ }^{\circledR}$ ).

Tabela 5.7: Estimativa do módulo de elasticidade em $t_{0}$ a partir de $f_{c, \text { exp }}(28)$.

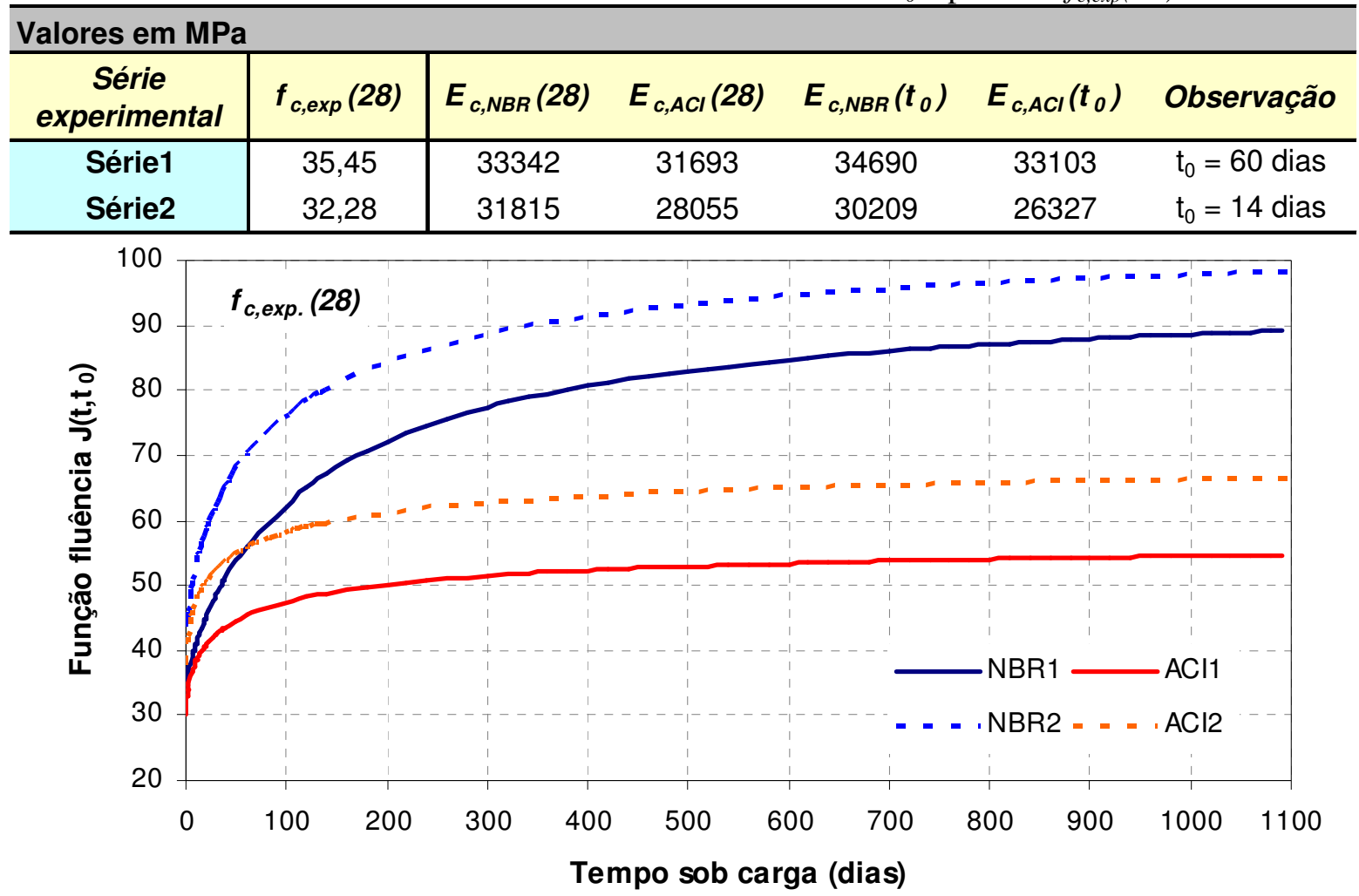

Fig. 5.9: Função de fluência. Módulo de elasticidade em $t_{0}$ obtido a partir da resistência á compressão experimental aos 28 dias $\left(f_{c, \exp }(28)\right)$. 
Tabela 5.8: Estimativa do módulo de elasticidade em $t_{0}$ a partir de $E_{c, \text { exp }}(28)$.

\begin{tabular}{c|c|ccc}
\hline $\begin{array}{c}\text { Valores em MPa } \\
\begin{array}{c}\text { Série } \\
\text { experimental }\end{array}\end{array}$ & $E_{c, \exp }(\mathbf{2 8})$ & $E_{c, N B R}\left(t_{0}\right)$ & $E_{c, A C I}\left(t_{0}\right)$ & Observação \\
\hline Série1 & 31489 & 32761 & 32889 & $\mathrm{t}_{0}=60$ dias \\
Série2 & 32838 & 31181 & 30814 & $\mathrm{t}_{0}=14$ dias \\
\hline
\end{tabular}

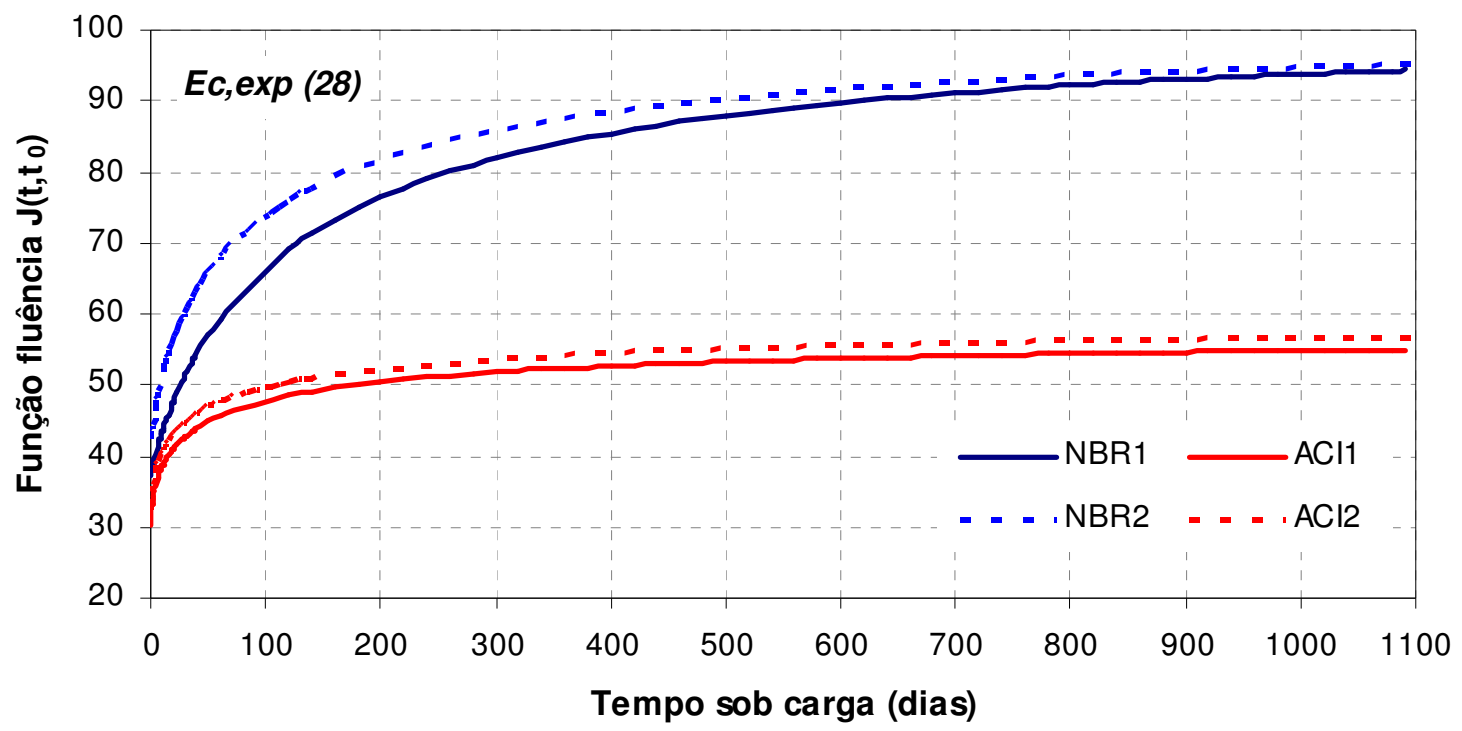

Fig. 5.10:Função de fluência. Módulo de elasticidade em t0 obtido a partir do módulo de elasticidade experimental aos 28 dias $\left(E_{c, \text { exp. }}(28)\right)$.

Ainda com relação à interferência das previsões do módulo e da função de fluência, Fanourakis e Ballim (2006) não encontraram uma correlação direta entre a boa previsão do módulo de elasticidade e do coeficiente de fluência, sendo que o modelo CEB-FIP (1970), o qual forneceu a melhor previsão para a fluência específica foi também o modelo que forneceu a pior previsão do módulo. Contudo, se os autores tivessem juntado essas informações para construção da curva função de fluência, possivelmente haveria alterações no ranking encontrado para os melhores modelos de previsão.

Considerando os códigos de norma mais utilizados (normas americana, inglesa, da áfrica do sul, européia e australiana), parece que há previsão do módulo de elasticidade mais precisas quando se tratam de concretos de menores resistências, ao passo que as deformações por fluência são estimadas de forma mais precisa para concretos de elevada resistência o trabalho de Fanourakis e Ballim (2006).

Já a Figura 5.11 ilustra como a consideração do dado de referência (se a resistência ou o módulo) para a estimativa do módulo de elasticidade na idade de carregamento afeta de forma distinta os dois modelos de previsão. 

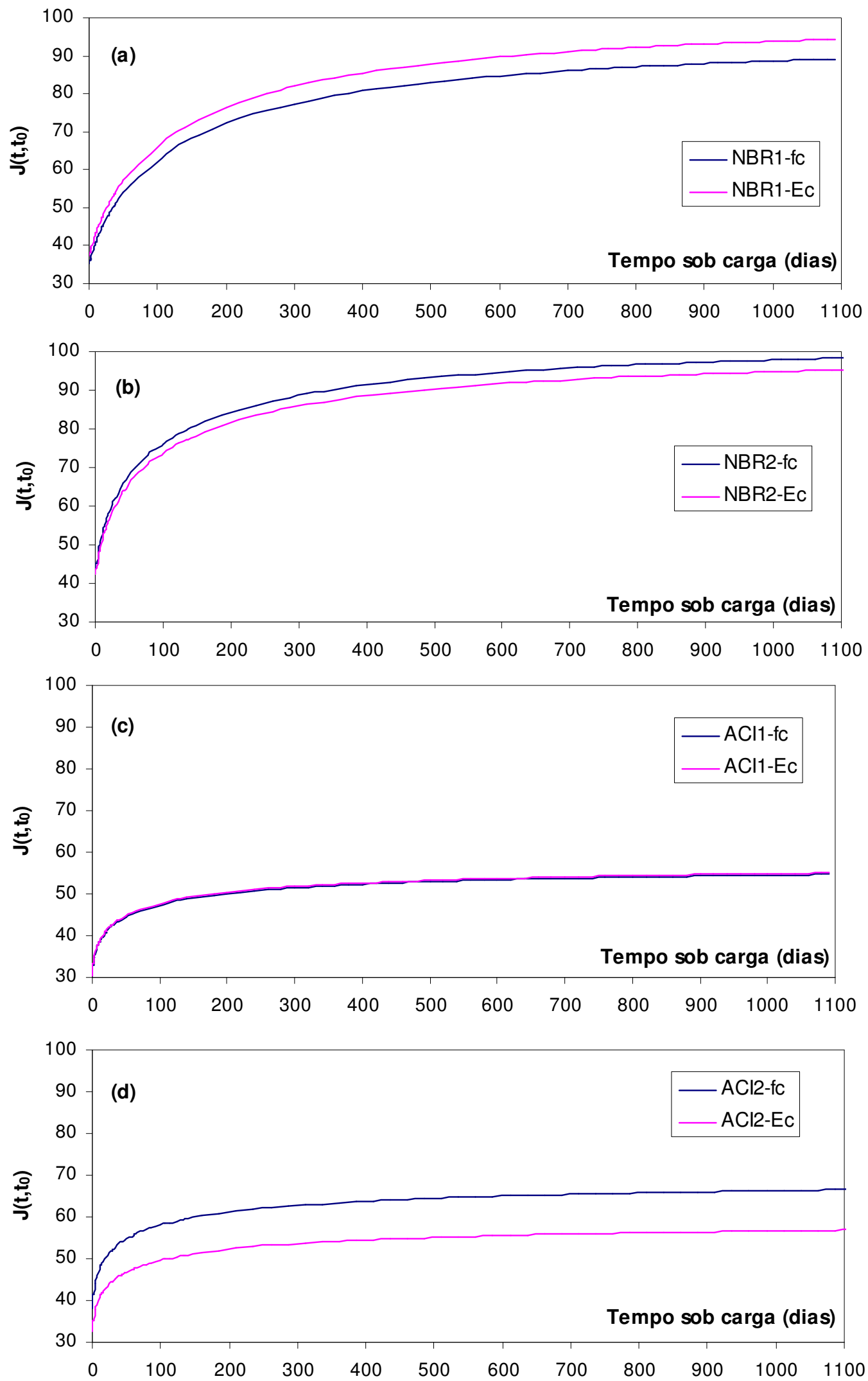

Fig. 5.11: Interferência da estimativa de $E_{c}, t_{o}$. 
Nota-se que a sensibilidade do modelo do ACI é bem maior, sendo que a diferença na determinação da função de fluência pode chegar a 17\% (gráfico d). Ainda referente ao ACI nota-se que esta sensibilidade, ao mesmo tempo, está relacionada à idade de carregamento, ou seja, à expressão 5.21, a qual define a lei de evolução da resistência do concreto segundo esta norma. Desta forma, observando as curvas referentes à NBR (gráficos a e b) percebe-se que a diferença entre a utilização de $f_{c}$ ou $E_{c}$ praticamente se mantêm constante, independente da idade de carregamento, sendo aproximadamente de 3\% (gráfico a) e 6\% (gráfico b).

Para completar a análise comparativa dos modelos, resta avaliar as resposta de cada um variando a idade de carregamento. Neste sentido, a Fig. 5.12 ilustra as curvas do coeficiente de fluência versus tempo sob carga para três diferentes datas de carregamento (14, 28 e 60 dias), sendo considerados os dados da série 1 (conforme a Tabela 5.6).

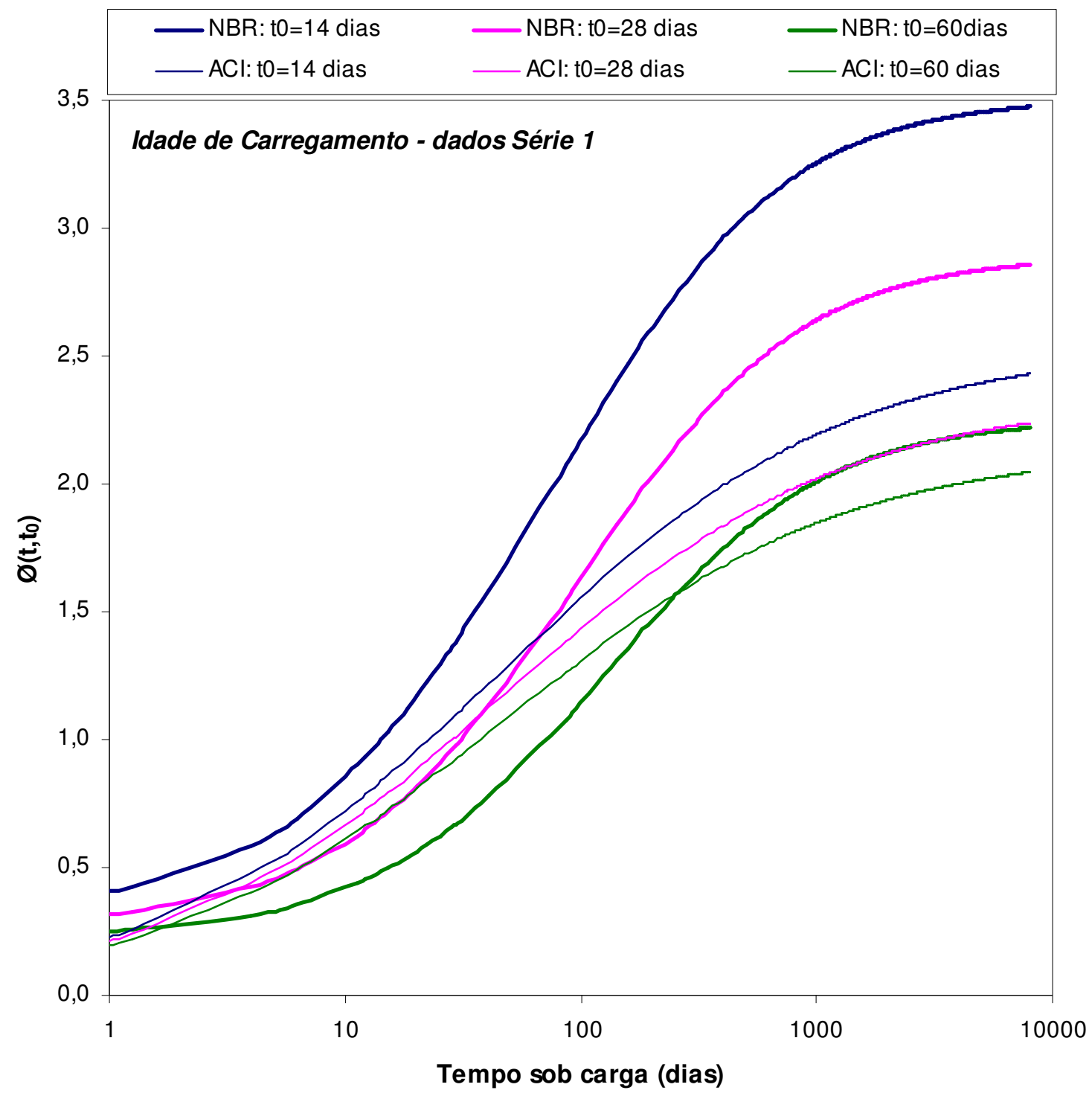

Fig. 5.12: Comparação entre os modelos para diferentes idades de carregamento. 
Nota-se que a idade de carregamento parece afetar de forma mais significativa o coeficiente de fluência nas primeiras idades no modelo da NBR do que do ACI. O formato das curvas obtidas por cada modelo é muito semelhante, entretanto percebe-se que a formulação da NBR 6118:2003 é muito mais sensível a deste parâmetro.

A idade de carregamento no modelo do ACI é considerada apenas co cálculo do coeficiente $C_{\text {idade }}$, o qual é função do tipo de cimento e da cura. Já segundo a NBR a idade de carregamento afeta o valor do coeficiente de fluência rápida, sendo este função do tipo de cimento. Entretanto, deve-se lembrar que a idade de carregamento teve um papel importante na calibração de cada modelo.

\subsection{Fluência em termos de deslocamentos}

Normalmente, após um tempo $t$ da aplicação do carregamento, a flecha diferida é definida com relação à flecha elástica inicial. A expressão padrão para o cálculo da flecha inicial de um elemento fletido não fissurado é dada pela equação 5.23, onde $M_{\text {máx }}$ é o momento máximo, que ocorre no vão $S ; \kappa_{\delta}$ é um fator que depende do tipo de carregamento e da vinculação, $E$ é o módulo de elasticidade e $I_{c}$ é o momento de inércia da seção transversal (em relação ao cntro de gravidade).

$$
\delta_{i}=\frac{\kappa_{\delta} \cdot M_{\text {maxx }} \cdot S^{2}}{E \cdot I_{c}}
$$

Para o caso de uma viga simplesmente apoiada, a flecha elástica decorrente da atuação de carregamento uniformemente distribuído ou carga concentrada aplicada no meio do vão, é obtida através das equações 5.24 e 5.25 respectivamente (desconsiderando o alívio dos balanços).

$$
\begin{gathered}
\delta_{i}=\frac{5 \cdot w \cdot S^{4}}{384 \cdot E \cdot I_{c}} \\
\delta_{i}=\frac{P \cdot S^{3}}{48 \cdot E \cdot I_{c}}
\end{gathered}
$$

Contudo, como não é costume projetar estruturas no estádio I (onde a máxima tensão de tração do concreto não foi ultrapassada), e, portanto trabalha-se com peças fissuradas, deve-se considerar a perda de rigidez do elemento através da inércia equivalente. 
Uma maneira esquemática de mostrar a relação momento curvatura $M-\Phi$ de uma viga se encontra na Fig. 5.13. Abaixo do momento de fissuração $M_{c r}$ a inclinação da relação $M-\Phi$ representa a rigidez à flexão de uma seção não fissurada, $(\mathrm{EI})_{1}$. A partir do instante em que o momento aplicado ultrapassa $M_{c r}$, existe uma transição linear até que toda a seção encontre-se fissurada, situação que corresponde ao momento $M_{y}$. A rigidez de transição é definida como $(\mathrm{EI})_{\mathrm{e}}$, conhecida como rigidez equivalente.

De acordo com a NBR 6118:2003, nos estados limites de serviço, as estruturas trabalham parcialmente no estádio I e parcialmente no estádio II, sendo que a separação entre essas duas partes é definida pelo momento de fissuração, o qual pode ser calculado de acordo com a expressão a seguir.

$$
M_{r}=\frac{\alpha \cdot f_{c t} \cdot I_{c}}{y_{t}}
$$

Na equação 5.21, $\alpha$ é o fator que correlaciona aproximadamente a resistência à tração na flexão com a resistência à tração direta (valendo 1,5 para seção retangular); $y_{t}$ é a distância do centro de gravidade da seção à fibra mais tracionada; $I_{c}$ é o momento de inércia da seção bruta de concreto e $f_{c t}$ é a resistência à tração direta do concreto. Calculados o momento máximo e o momento de fissuração, é possível prever sob qual reta a relação momentocurvatura estará (Fig. 5.13).

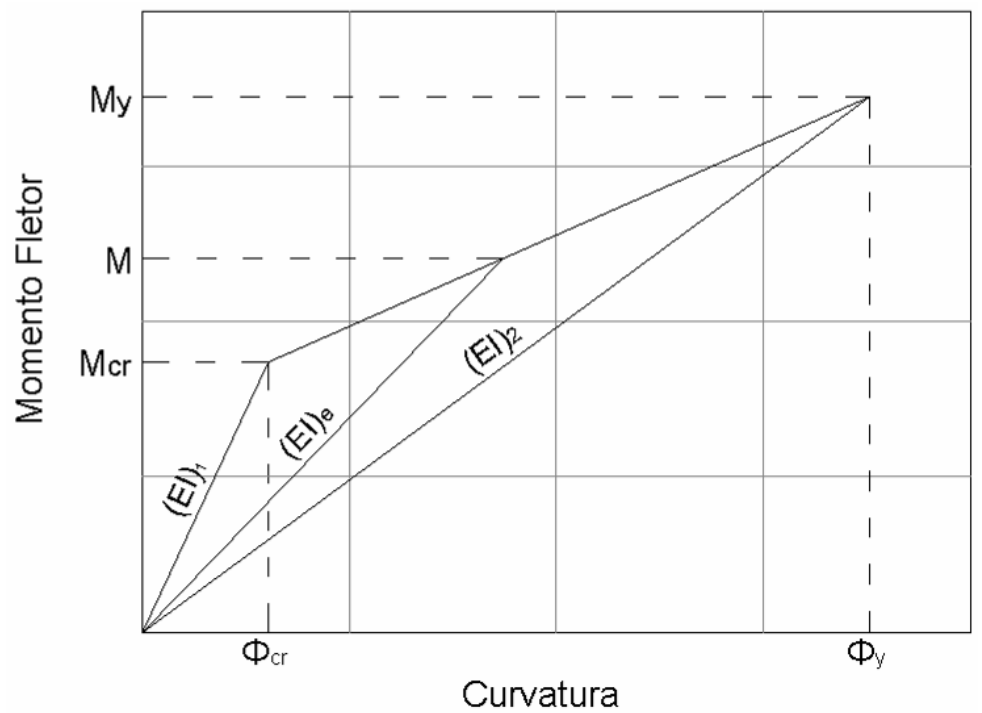

Fig. 5.13: Representação esquemática da relação momento curvatura de uma viga.

Experimentalmente, a resistência à tração pode ser obtida de forma indireta (à flexão e 
à compressão diametral), por meio de ensaios relativamente simples. Contudo, na falta de valores experimentais, para o cálculo do momento de fissuração recomenda-se deduzir o valor de $f_{c t}$ conhecida a resistência característica à compressão (itens 17.3.1 e 8.2.5 da norma):

$$
f_{c t}=0,21 \cdot\left(f_{c k}\right)^{2 / 3}
$$

Para uma viga de concreto armado submetida a solicitações normais, algumas seções estão fissuradas, enquanto outras permanecem em estado íntegro. Para levar em consideração a variação da rigidez das seções ao longo do elemento assim como o efeito das forças de tração no concreto entre as regiões fissuradas, deve-se utilizar um momento de inércia equivalente.

$$
(E I)_{e q}=E_{c s}\left\{\left(\frac{M_{r}}{M_{a}}\right)^{3} \cdot I_{c}+\left[1-\left(\frac{M_{r}}{M_{a}}\right)^{3}\right] I_{I I}\right\} \leq E_{c s} \cdot I_{c}
$$

A NBR 6118:2003, baseada na expressão inicialmente proposta por Branson, recomenda o uso da equação 5.28, a qual depende do momento máximo aplicado $\left(M_{a}\right)$, do momento de fissuração, dos momentos de inércia nas situações íntegra $\left(I_{c}\right)$ e fissurada $\left(I_{I I}\right)$ e do módulo de elasticidade secante $\left(E_{c s}\right)$.

\subsubsection{Cálculo da flecha diferida no tempo para vigas de concreto armado}

O equacionamento para cálculo das flechas diferidas segundo as duas normas (NBR 618:2003 e ACI 318:2002) é praticamente idêntico. A flecha adicional diferida, decorrente das cargas de longa duração em função da fluência, pode ser calculada de maneira aproximada pela multiplicação da flecha imediata pelo fator $1+\alpha_{f}$, sendo $\alpha_{f}$ dado pela expressão:

$$
\alpha_{f}=\frac{\Delta \xi}{1+50 \rho^{\prime}}
$$

Onde:

$$
\rho^{\prime}=\frac{A_{s}{ }^{\prime}}{b \cdot d}
$$

$\xi$ é um coeficiente função do tempo, que pode ser obtido diretamente na Tabela 5.9 ou ser calculado pelas expressões seguintes: 


$$
\begin{gathered}
\Delta \xi=\xi(t)-\xi\left(t_{0}\right) \\
\xi(t)=0,68 \cdot\left(0,996^{t}\right) \cdot t^{0,32} \text { para } t \leq 70 \text { meses } \\
\xi(t)=2 \text { para } t \geq 70 \text { meses }
\end{gathered}
$$

Sendo:

$t$ é o tempo, em meses, quando se deseja o valor da flecha diferida;

$t_{0}$ é a idade, em meses, relativa à data de aplicação da carga de longa duração.

Tabela 5.9: Valores do coeficiente $\xi$ em função do tempo.

\begin{tabular}{c|c|c|c|c|c|c|c|c|c|c|c}
\hline Tempo (t) meses & 0 & 0,5 & 1 & 2 & 3 & 4 & 5 & 10 & 20 & 40 & $\geq 70$ \\
\hline Coeficiente $\xi(t)$ & 0 & 0,54 & 0,68 & 0,84 & 0,95 & 1,04 & 1,12 & 1,36 & 1,64 & 1,89 & 2 \\
\hline
\end{tabular}

No caso de parcelas da carga de longa duração ser aplicadas em idades diferentes, pode-se tomar para $t_{0}$ o valor médio ponderado obtido pela equação 5.31 , na qual $P_{i}$ representa as parcelas de carga, e $t_{0}$ a idade em que se foi aplicada cada parcela $P_{i}$, em meses.

$$
t_{0}=\frac{\sum P_{i} t_{0 i}}{\sum P_{i}}
$$

O valor da flecha total deve ser obtido multiplicando a flecha imediata por $\left(1+\alpha_{f}\right)$, ou seja, $\delta(t)=\delta_{i} \cdot\left(1+\alpha_{f}\right)$. Esta formulação é baseada na expressão proposta por Branson para o cálculo de flechas diferidas, considerando acréscimos da curvatura decorrentes tanto da fluência como da retração (Neville 1982):

$$
\delta\left(t, t_{0}\right)=\delta_{i} \cdot K_{\phi, s h} \cdot \phi\left(t, t_{0}\right)
$$

Sendo :

$\phi\left(t, t_{0}\right)=$ coeficiente de fluência.

$K_{\phi, s h}=$ coeficiente de redução dependente da razão entre as armaduras de tração e compressão. Se houver apenas fluência, $K_{\phi, s h}$ vale 0,85 . Ocorrendo retração simultaneamente, o coeficiente passa a valer 1 . 
É interessante ressaltar nas expressões normativas, o coeficiente de fluência da expressão de Branson, representado pela função $\xi(t)$, não leva em considerações informações sobre importantes fatores intervenientes do fenômeno (características do concreto fresco, e endurecido e das condições de exposição). Esta simplificação grosseira pode ocasionar diferenças significativas entre os valores previstos e as flechas reais de algumas estruturas. (como aquelas com taxa mínima de armadura). Melhor seria se ao invés de $\xi(t)$, fosse utilizado o coeficiente de fluência obtido segundo os modelos para previsão da fluência apresentados neste capítulo. Conforme se apresenta no Capítulo 8 esta consideração foi realizada neste trabalho, conduzindo a melhores aproximações.

\subsection{Determinação Experimental da Fluência}

O objetivo de ambas as normas, americana (ACI 512/2002) e brasileira (NBR 8224/1983) é prescrever uma metodologia padrão para determinação experimental da deformação do concreto, devido ao fenômeno da fluência.

Nos dois casos, recomenda-se a utilização de corpos-de-prova cilíndricos submetidos à tensão mantida de compressão uniforme. Entretanto, existem algumas diferenças a respeito das dimensões dos corpos-de-prova, cálculo das deformações, idade de carregamento e condições de exposição.

A norma americana comenta não haver dados disponíveis que possam assegurar a extrapolação dos resultados dos ensaios (sob compressão uniforme) a elementos de concreto solicitados por outros estados de tensão, como tração pura e torção.

\subsubsection{Corpos-de-prova}

\subsubsection{Quantidade de corpos-de-prova}

De acordo com as duas recomendações, deve-se moldar no mínimo 6 corpos-de-prova para cada idade de carregamento, a saber:

a) dois corpos-de-prova para os ensaios de resistência à compressão;

b) dois corpos-de-prova para os ensaios de fluência.

c) dois corpos-de-prova de controle, idênticos aos anteriores.

Os corpos-de-prova de controle deverão ser munidos com dispositivos de medição de 
deformação, e permanecerão descarregados durante todo período de ensaio. Suas leituras indicarão as variações volumétricas devido a outras causas, diferentes do carregamento.

Apesar de não utilizar a terminologia fluência básica, a NBR traz recomendações muito semelhantes às do ACI com respeito da preparação de corpos-de-prova selados, recomendando que, para minorar as deformações devido à retração, podem-se utilizar corposde-prova revestidos, de forma a impedir perda de umidade. A jaqueta de revestimento pode ser colocada na face interna do molde antes da moldagem do corpo-de-prova, ou então ser colocado imediatamente após a desforma. O material deste revestimento pode ser borracha ou filme plástico. A borracha deve ser colada ao concreto do corpo-de-prova e aos discos metálicos com resina epoxídica. O filme plástico deve ficar aderido firmemente ao corpo-deprova, devendo ser utilizadas pelo menos cinco camadas de filme.

\subsubsection{Dimensões dos corpos-de-prova}

A esse respeito, a norma americana recomenda a utilização de corpos-de-prova cilíndricos com $150 \mathrm{~mm}$ de diâmetro e 300 milímetros de altura, sendo que os ensaios só podem ser realizados se a dimensão máxima do agregado for inferior a $50 \mathrm{~mm}$. Para concretos com agregados de dimensão máxima característica maior que $50 \mathrm{~mm}$ poderão ser utilizados corpos-de-prova de $(150 \times 300) \mathrm{mm}$, moldados com a fração desses concretos que passa na peneira de 2 polegadas.

Tabela 5.10: Limite para corpos-de-prova

\begin{tabular}{c|c}
\hline Diâmetro $(\mathbf{m m})$ & $\boldsymbol{d}_{\boldsymbol{a , \boldsymbol { m a ́ x }} \boldsymbol{1 9}} \mathbf{( m m )}$ \\
\hline 150 & 19 \\
\hline 150 & 38 \\
\hline 250 & 76 \\
\hline 450 & 152 \\
\hline
\end{tabular}

A norma brasileira também recomenda a utilização de corpos-de-prova cilíndricos, entretanto o diâmetro é tabelado de acordo com a dimensão máxima do agregado graúdo (ver Tabela 5.10), mantendo a relação entre a altura e o diâmetro igual ou maior do que dois. No caso de concretos com agregados de dimensão máxima característica maior que $38 \mathrm{~mm}$ poderão ser utilizados corpos-de-prova de $(150 \times 300) \mathrm{mm}$, moldados com a fração desses

\footnotetext{
${ }^{19}$ Dimensão máxima característica do agregado graúdo.
} 
concretos que passa na peneira ABNT $38 \mathrm{~mm}$.

Recomenda-se utilizar o mesmo concreto para moldagem de todos os corpos-de-prova, sendo que eles devem ser submetidos a condições de cura idênticas.

\subsubsection{Cura e Estocagem}

Para a cura-padrão, antes da desforma, os corpos-de-prova deverão ser guardados em uma sala com temperatura de $(23,0 \pm 2,0)^{\circ} \mathrm{C}$, segundo a NBR, e $(23,0 \pm 1,7)^{\circ} \mathrm{C}$, segundo o ACI, e cobertos com material que evite a evaporação recomendando-se o uso de plástico ou filme plástico. Os corpos-de-prova deverão ser desformados após um período não inferior a 20 horas nem superior a 48 horas após a modelagem.

Segundo a NBR, após a desforma, que deve ser feita de preferência dentro da câmara úmida, os corpos-de-prova deverão ser mantidos na câmara úmida, à temperatura de $(23,0 \pm$ $2,0)^{\circ} \mathrm{C}$ até a idade de ensaio e umidade relativa não inferior a $95 \%$, sendo o seu valor indicado no relatório. O ACI também recomenda a permanência dos corpos-de-prova em câmara úmida, à mesma temperatura de cura, por 7 dias.

Comenta-se que poderão ser especificadas outras condições de cura e estocagem, em função das necessidades do projeto e da obra. Essas condições deverão, entretanto, ser detalhadas de modo preciso no relatório.

\subsubsection{Execução do ensaio}

\subsubsection{Idade de aplicação do carregamento}

De acordo com o ACI, quando o propósito é comparar a fluência do concreto para diferentes traços, devem-se iniciar os ensaios aos 28 dias. Já a NBR, não estabelece uma data específica, desde que, logicamente, todos os corpos-de-prova sejam carregados no mesmo dia.

Contudo, quando o intuito é caracterizar a fluência de um determinado traço, recomenda-se a moldagem de corpos-de-prova a serem carregados em diferentes idades. $\mathrm{O}$ ACI prevê pelo menos 5 idades: 2, 7, 28, 90 e 365 dias; e a NBR sugere 4 idades: 7, 28, 180 e 365 dias, chamando atenção para o fato de que nos ensaios de fluência para carregamento em idades maiores não é permitida a utilização de corpos-de-prova que já foram utilizados nos ensaios a idades menores e cujo período de carregamento tenha sido encerrado. 
A norma americana é mais enfática com relação ao respeito das idades de carregamento recomendadas, sendo que "se mais informações são desejadas para outras idades de carregamento, deve-se incluir esta idade no relatório". A norma brasileira é mais flexível: "as idades de carregamento deverão ser escolhidas em função das necessidades do projeto estrutural".

\subsubsection{Aparelhagem}

A máquina de ensaio deverá ser capaz de aplicar e manter a carga especificada para o ensaio durante todo o período de realização do ensaio, não devendo ter erro de exatidão maior que $2 \%$. Será composta dos seguintes elementos:
a) célula hidráulica de carregamento;
b) mola de reação;
c) rótula de apoio.

No dispositivo de carregamento que utiliza células hidráulicas existem várias estruturas que podem ser carregadas simultaneamente, por meio de uma unidade central de manutenção de carga. O ajuste desta carga é feito por meio de reguladores e de leitura em manômetros. Existe também a possibilidade de ajuste automático das variações de carga por meio de reguladores a uma fonte de pressão. Para maiores informações a esse respeito, sugere-se consultar a bibliografia.

\subsubsection{Precisão}

No item 5.2 da NBR 8224, consta que:

\footnotetext{
"Os aparelhos ou instrumentos destinados à medição das deformações deverão apresentar precisão de leitura de no mínimo $20 \times 10^{-6} \mathrm{~m}$ (ou seja, 20 milésimos de milímetros)".
}

Uma interpretação rigorosa da frase permite observar um equívoco: normalmente, os instrumentos destinados às leituras medem comprimento e não deformação. A obtenção das deformações é feita indiretamente, de forma manual. Mesmo que o aparelho faça a leitura em deformações, sua precisão deveria ser representada em unidade de deformação.

O ACI, no item 4.3, recomenda que um dispositivo adequado para medição das deformações tenha precisão de aproximadamente $10 \times 10^{-6}$, devendo ser capaz de realizar as medições durante 1 ano, sem que haja alteração na calibração. 


\subsubsection{Condições de exposição durante o ensaio}

A esse respeito cabe comentar que a norma brasileira não é muito clara sobre a condição de umidade relativa do ambiente. No item 4.2 da NBR 8224 consta que:

"Se especificada para o ensaio a cura nas condições da umidade interna do concreto, os corpos-de-prova deverão ser selados com revestimento à prova d'água... Os corpos de prova revestidos deste modo estarão protegidos quanto à perda de umidade, e conseqüentemente menos sujeitos às deformações devidas à retração por secagem durante o período de estocagem e de ensaio"

Mais adiante, no item 6 da referida norma (que trata da execução do ensaio) nenhuma menção é feita sobre a umidade relativa do ambiente, havendo apenas recomendações sobre a temperatura. Ora, se os corpos-de-prova de controle podem estar sujeitos à secagem, considerar que as deformações dos mesmos referem-se apenas às deformações autógenas é um equívoco, haja vista a definição de deformação autógena encontrada da literatura.

De acordo com a NBR, a temperatura ambiente durante o ensaio deverá ser a especificada pelo solicitante e deverá ser rigorosamente mantida no intervalo de variação de \pm $2^{\circ} \mathrm{C}$. Qualquer variação de temperatura acima ou abaixo dos valores limites poderá provocar variações volumétricas significativas, que deverão ser corrigidas após serem calculadas e analisadas.

A norma americana estabelece que após a cura, os corpos-de-prova devem ser armazenados à temperatura de $23,0 \pm 1,1^{\circ} \mathrm{C}$ e à umidade relativa do ambiente de $50 \pm 4 \%$ até o término dos ensaios.

\subsubsection{Aplicação do Carregamento}

Ambas as normas definem:

a) Tensão limite $40 \%$ da resistência à compressão (determinada imediatamente antes do ensaio).

b) Variação máxima de tensão aplicada em $2 \%$.

c) Para a determinação da tensão de carregamento, os corpos-de-prova complementares deverão ser ensaiados à resistência à compressão, imediatamente antes do ensaio.

Entretanto a norma americana permite a escolha de tensões que respeitem este limite, 
enquanto que a brasileira estabelece a aplicação de $40 \%$ da resistência à compressão.

A norma brasileira ainda recomenda que o carregamento deve ser feito a uma velocidade tal que a carga total seja aplicada no corpo-de-prova durante um período o mais próximo possível de 30 segundos; e ainda que antes do carregamento definitivo devam ser realizados dois ciclos iniciais de carregamento e descarregamentos nos corpos-de-prova, até a carga estabelecida nos ensaio. Deve também ser feita uma leitura nos aparelhos medidores de deformação imediatamente antes do carregamento definitivo (leitura de referência).

\subsubsection{Intervalos de Leitura}

Tabela 5.11: Intervalos de Leituras

\begin{tabular}{|c|c|}
\hline Recomendações da NBR 8224/1993 & Recomendações do ACI 512/2002 \\
\hline a) 30 segundos após o carregamento; & a) imediatamente após o carregamento; \\
\hline b) 510 e 30 minutos após o carregamento; & b) depois de decorridas de 2 a 6 horas; \\
\hline c) 12 e 5 horas após o carregamento; & c) diariamente até completar uma semana; \\
\hline d) diariamente por uma semana; & d) semanalmente até completar um mês; \\
\hline $\begin{array}{l}\text { e) duas vezes por semana até completar um } \\
\text { mês; }\end{array}$ & e) mensalmente até completar um ano. \\
\hline f) semanalmente até completar o ensaio. & \\
\hline
\end{tabular}

Os intervalos entre as leituras subsequientes à aplicação do carregamento sugeridos por cada norma são semelhantes. Observando os valores dispostos na Tabela 5.11, nota-se, porém que o número de leituras, após o primeiro mês de ensaios, previsto pela NBR é 4 vezes maior do que o recomendado pelo ACI.

\subsubsection{Resultados}

Tanto a NBR quanto o ACI recomendam a apresentação dos resultados em termos da fluência específica, parâmetro obtido pela divisão das deformações por fluência pela tensão aplicada.

Independente da recomendação que se esteja seguindo há a necessidade de serem moldados corpos-de-prova equivalentes, sendo parte deles carregados e parte não solicitados por carregamento algum. Desta forma, após um tempo $t$ - $t_{0}$ da aplicação da carga, a deformação por fluência é obtida pela diferença entre a deformação média dos corpos-de- 
prova carregados subtraída da deformação média encontrada para os corpos-de-prova não carregados. Como já comentado anteriormente, a rigor, existem duas situações de ensaio possíveis para o caso de se avaliar a fluência básica ou a fluência por secagem.

No primeiro caso, tanto os corpos-de-prova carregados como aqueles não carregados deverão ser selados. A deformação do primeiro grupo representa a deformação total e a do segundo grupo refere-se às deformações por retração autógena. Sendo assim, a determinação da parcela de fluência é feita com a seguinte conta:

$$
\varepsilon_{c c}=\varepsilon_{t}-\varepsilon_{i}-\varepsilon_{s}
$$

Onde:

$\varepsilon_{c c}$ : deformação por fluência;

$\varepsilon_{t}$ : deformação total a partir da leitura de referência, nos corpos-de-prova sob carregamento, na idade considerada;

$\varepsilon_{i}$ : deformação imediata medida no ato de aplicação da carga;

$\varepsilon_{s}$ : deformação média dos corpos-de-prova complementares não submetidos a carregamento (deformação autógena).

No segundo caso, há ainda mais duas possibilidades: determinação apenas da fluência total, ou determinação das parcelas de fluência por secagem e fluência básica. Para determinação da fluência total utiliza-se a expressão 5.33, com a ressalva de que a deformação dos corpos-de-prova não carregados representa na realidade não só a deformação por retração autógena, mas também as deformações por variação térmica e retração por secagem. Por outro lado, se o usuário desejar conhecer as parcelas da fluência (básica e por secagem) será necessário carregar corpos-de-prova selados e não selados.

A NBR não traz nenhuma indicação específica com respeito ao ajuste dos dados experimentais. Já o ACI comenta que, se conveniente, pode-se lançar em gráfico a deformação total por unidade de tensão no eixo das ordenadas, e nas abscissas, o tempo em escala logarítmica, para determinar a taxa de fluência a partir da expressão:

$$
\varepsilon=(1 / E)+F(K) \ln (t+1)
$$


Sendo:

$t: \quad$ tempo após carregamento.

$\varepsilon: \quad$ deformação total em um tempo t;

E : módulo elástico instantâneo;

$F(K)$ : taxa de fluência, calculada como a inclinação da reta representativa da curva de fluência;

No item 3.4 desta norma comenta-se que a indicação de uma expressão logarítmica não implica que a relação entre a deformação por fluência e o tempo seja necessariamente uma função logarítmica exata. Contudo, para o período de um ano, essa expressão (conforme comentado no capítulo 4) aproxima o comportamento à fluência do concreto de forma suficientemente precisa, possibilitando o cálculo de parâmetros úteis (como a taxa de fluência, por exemplo) para o propósito de comparação entre diferentes concretos.

\subsubsection{Relatório de ensaio}

A duas normas alertam seus usuários para importância de documentar todos os dados e cuidados experimentais que interfiram nos resultados. Desta forma, é interessante conhecer as informações sobre a composição da mistura, caracterização dos materiais, confecção do concreto, moldagem, condições de exposição, etc.

\subsubsection{Validação dos resultados}

A norma americana recomenda que os resultados de ensaios executados pelo mesmo operador a partir de material proveniente da mesma massada, não devem diferir mais do que $6 \%$ do valor médio. Resultados de ensaios executados pelo mesmo operador a partir de material proveniente de diferentes massadas não devem diferir mais do que $13 \%$ do valor médio. A norma brasileira não faz considerações a esse respeito. 


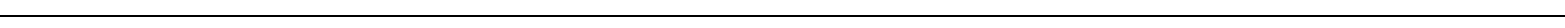




\subsection{Considerações gerais}

Neste Capítulo são tecidos alguns comentários a respeito dos procedimentos adotados nas simulações numéricas efetuadas com auxílio do software DIANA ${ }^{\circledR}$. Em uma primeira etapa, anterior à realização dos ensaios, as simulações tiveram importância para prever, mesmo que de forma aproximada, o que aconteceria no programa experimental. Ou seja, se com o nível de solicitação empregado realmente não haveria fissuração, qual a ordem de grandeza dos valores dos deslocamentos, e se seria possível observar alguma tendência de comportamento após 3 meses (tempo a princípio estipulado).

Concluídas as séries experimentais, e estando os modelos numéricos definidos, foi feito um simples ajuste dos dados de entrada, sendo neste momento utilizadas as informações retiradas dos ensaios, para que as curvas numéricas fossem comparadas com as curvas de tendência (experimentais) e com as curvas teóricas, obtidas pelos modelos de previsão apresentados no Capítulo 5.

\subsection{Descrição da simulação}

A análise numérica computacional deste trabalho está baseada no Método dos Elementos Finitos (MEF), que é um poderoso instrumento para a solução de problemas da Engenharia, particularmente na análise do comportamento estrutural.

O comportamento das vigas ensaiadas à fluência na flexão foi simulado através de uma análise não-linear, utilizando-se o programa computacional de elementos finitos DIANA $^{\circledR}$ versão 9.1, o qual vem sendo desenvolvido e aperfeiçoado por engenheiros civis da TNO Building and Construction Research, na Holanda, desde 1972. 
Para modelar estruturas de concreto, ou estruturas de materiais com comportamento quase-frágil em geral, o programa computacional DIANA ${ }^{\circledR}$ oferece uma vasta possibilidade de tipos de elementos. O comportamento constitutivo dos materiais quase-frágeis é caracterizado pela fissuração à tração, esmagamento à compressão e efeitos de longa duração, como retração e fluência.

Nesta pesquisa, basicamente dois modelos foram realizados: um para simulação da fluência nas vigas entalhadas (VE), submetidas ao carregamento do peso-próprio, e outro para as vigas sem entallhe (VSE), submetidas ao peso-próprio e uma carga concentrada de 4,87 kN no meio do vão. Como as simulações foram realizadas para as duas séries de ensaio, o número posterior à identificação do "tipo" de viga representa a série em questão, por exemplo: VSE1 (Viga sem entalhe da série1).

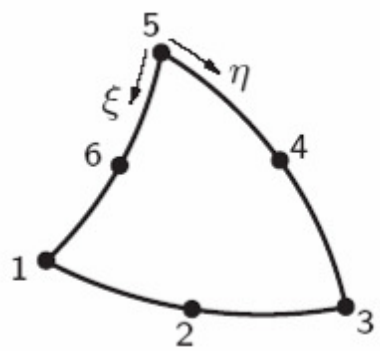

Fig. 6.1: Elemento Finito utilizado.

Foi utilizado o elemento triangular CT12M (ver Fig. 6.1), adequado para esse problema (estado plano de tensões). Trata-se de um elemento triangular de seis nós, baseado em interpolação quadrática e integração de área. A função polinomial que descreve os deslocamentos $u_{x}$ e $u_{y}$ pode ser expressa como:

$$
u_{i}(\xi, \eta)=a_{0}+a_{1} \cdot \xi+a_{2} \cdot \eta+a_{3} \cdot \xi \cdot \eta+a_{4} \cdot \xi^{2}+a_{5} \cdot \eta^{2}
$$

Tipicamente, esta função polinomial conduz a variações aproximadamente lineares das deformações nas direções $x$ e $y$. Como padrão o software realiza a integração em 3 pontos de Gauss.

As Figuras 6.2 e 6.3 ilustram a geometria e a malha de elementos finitos para cada modelo (VSE e VE). Nota-se que foi realizada uma discretização diferenciada da malha na região central de ambos os modelos, sendo que na região próxima ao entalhe, a malha foi bastante refinada. Estas figuras também apresentam o teste da qualidade da malha. Tem-se que para os dois modelos a qualidade da malha, no que diz respeito à distribuição e ao formato dos elementos, está satisfatória. 

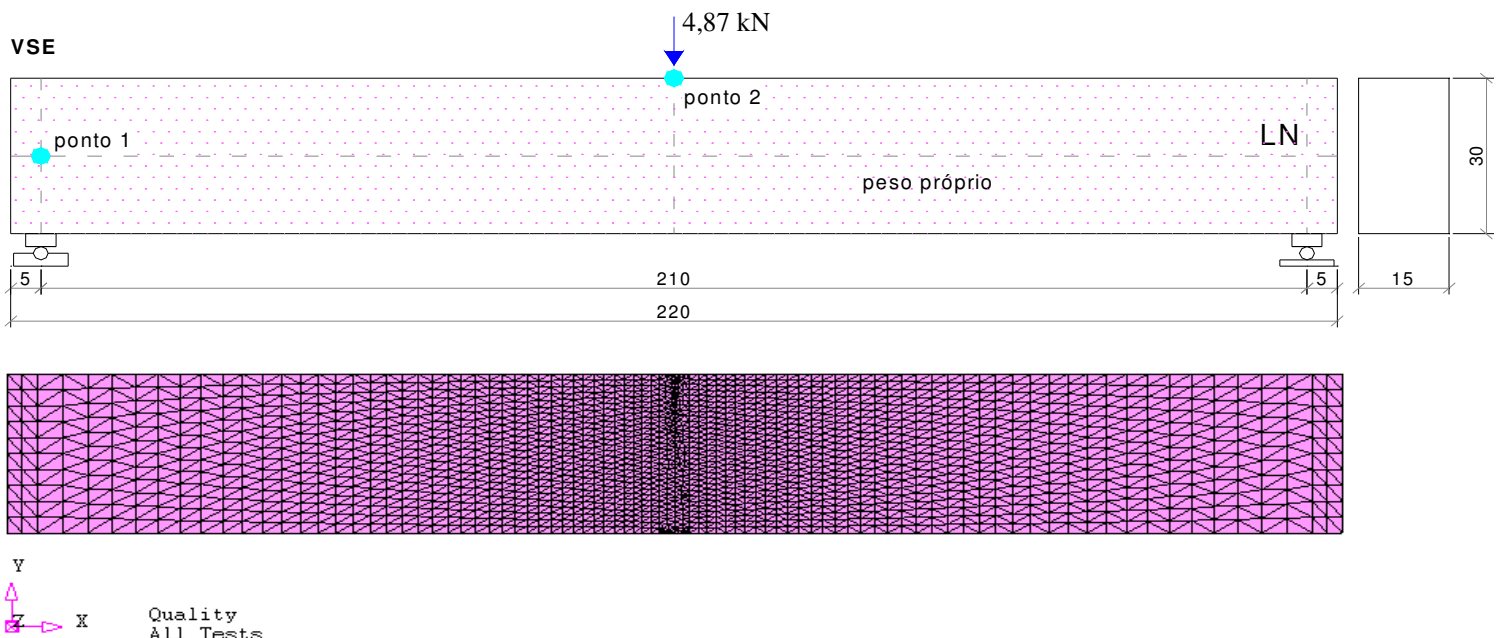

- PASS

Fig. 6.2:Viga sem entalhe (VSE): geometria e malha utilizada.
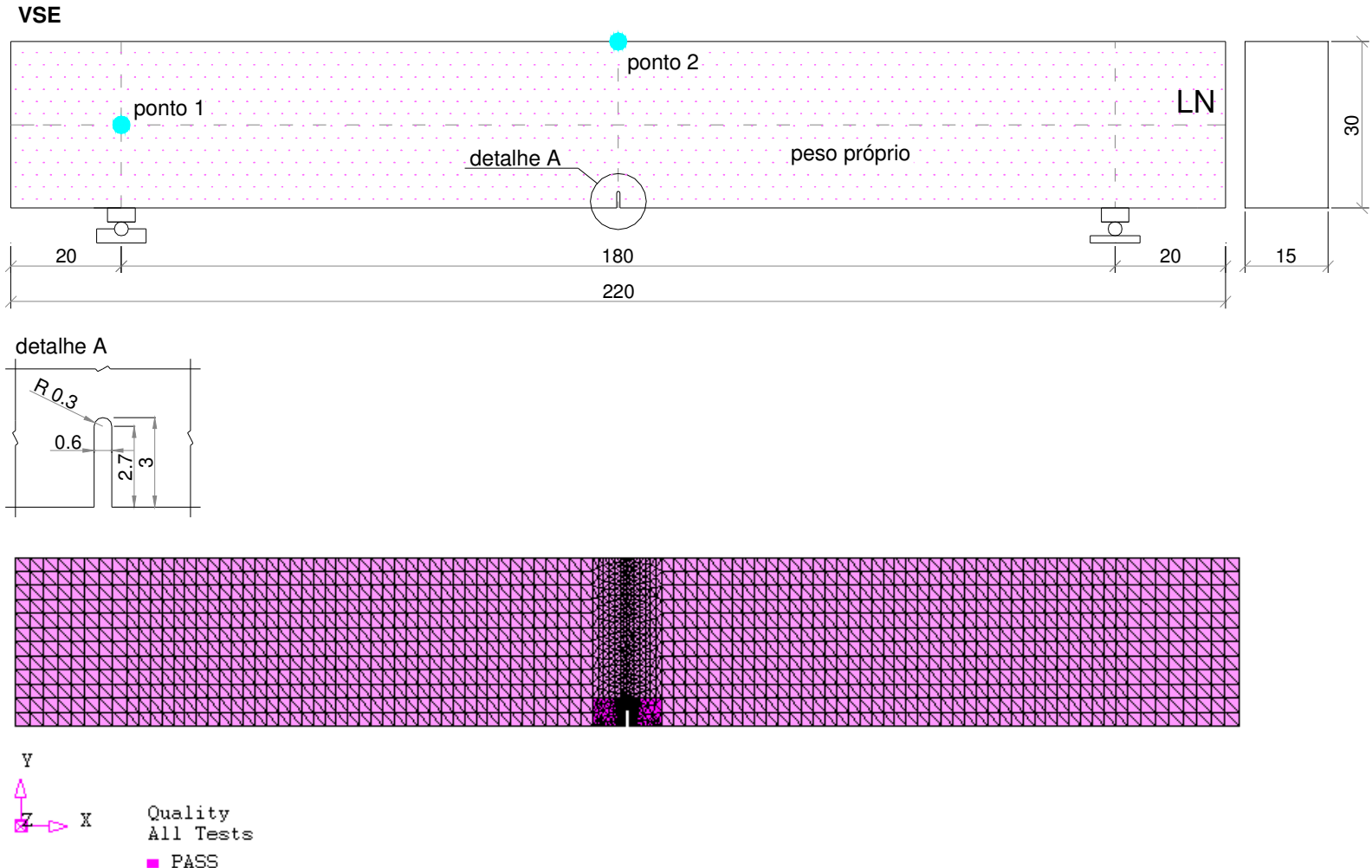

Fig. 6.3: Viga entalhada (VE): geometria e malha utilizada.

\subsubsection{Fissuração}

O modelo de fissuração utilizado nos exemplos das vigas foi o Multi-directional Fixed Crack que caracteriza um modelo de fissuração distribuída (Smeared cracking). Nesse modelo, o material quando danificado ainda é considerado como um meio contínuo e as notações de tensão e deformação podem ser aplicadas sem a necessidade de se construir uma nova malha enquanto as fissuras se propagam. 
Os parâmetros relacionados com a Mecânica da Fratura introduzidos no modelo de fissuração distribuída são a energia de fraturamento e a banda de fissuras. A Fig. 6.4 mostra a caixa de diálogo do DIANA ${ }^{\circledR}$ para definição do modelo de fissuração adotado. A seguir serão detalhadas as considerações para iniciação e propagação da fissura, de acordo com o modelo escolhido.

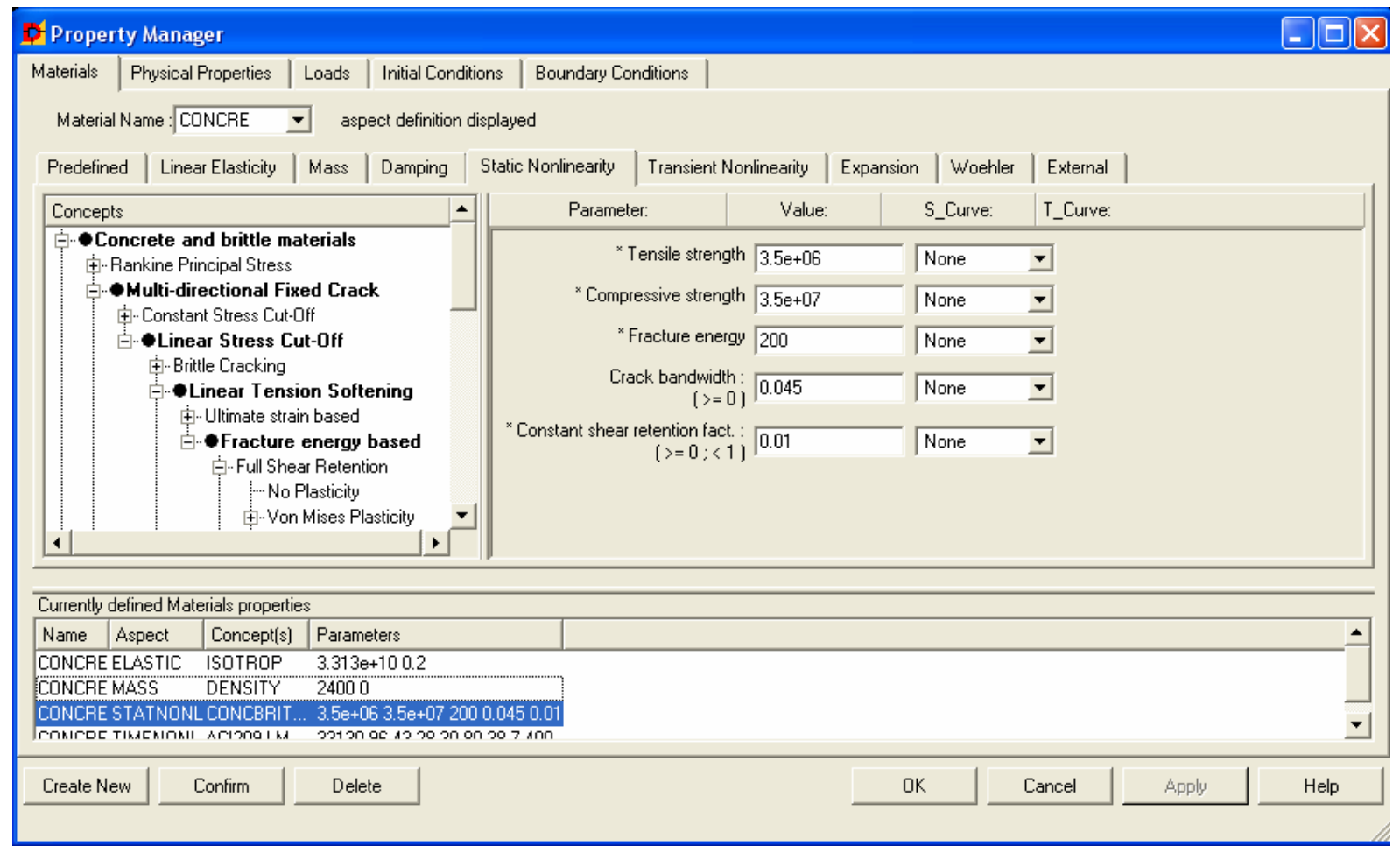

Fig. 6.4: Modelo de Fissuração utilizado na simulação numérica.

\subsubsection{Critério de Propagação de fissura}

A formação de uma fissura é governada pelo critério de tensão limite definido como cut-off e pelo ângulo entre duas fissuras consecutivas. Desta forma, para que se inicie o processo de propagação de fissuras, o programa DIANA ${ }^{\circledR}$ aplica os seguintes critérios, os quais devem ser satisfeitos simultaneamente:

- A tensão principal de tração viola a condição de tensão máxima.

- O ângulo entre a fissura existente e a tensão principal de tração excede o valor de $\alpha_{T D}$. Para este ângulo foi utilizado o valor de $60^{\circ}$, default do programa

Um inconveniente deste critério de propagação de fissuras relaciona-se com a possibilidade da tensão de tração temporariamente atingir valores maiores do que três vezes a resistência à tração, enquanto a condição relacionada ao ângulo $\alpha_{T D}$ (threshold angle) não 
seja violada. Há dois critérios de resistência (tension cut-off) disponíveis, o constante, no qual é necessário conhecer apenas a resistência à tração, e o linear, o qual depende da resistência na compressão e na tração (ver Fig. 6.5). Neste trabalho foi utilizado o critério cut-off linear (identificado como CRACK 2), sendo para tanto fornecidos os valores de resistência à compressão e à tração obtidos experimentalmente na idade de carregamento.
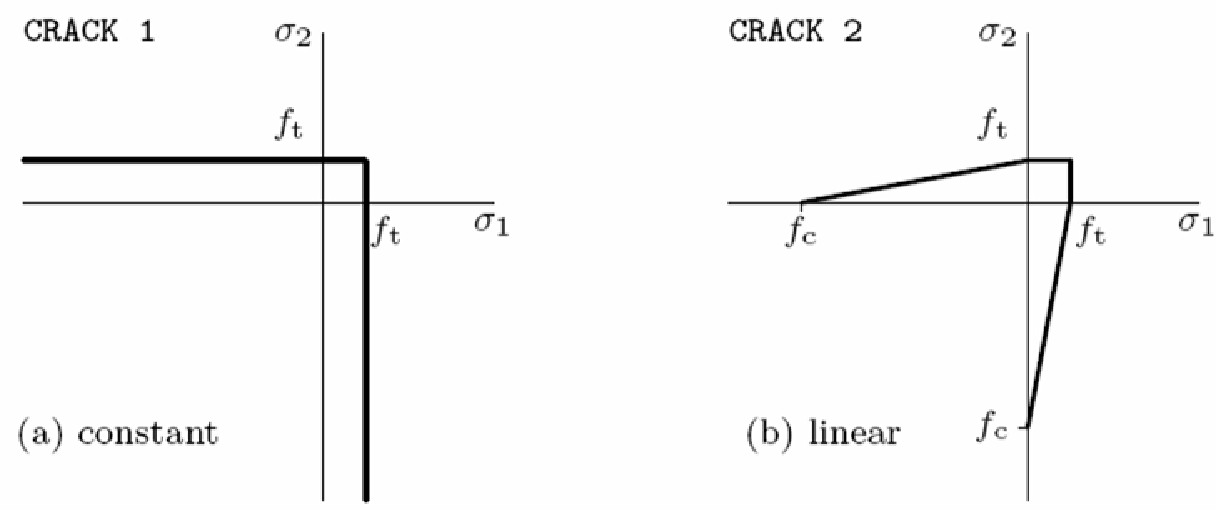

Fig. 6.5: Critérios cut-off disponíveis no espaço de duas tensões principais.

\subsubsection{Amolecimento (esmagamento do concreto)}

Para o esmagamento do concreto (tension softening) foi utilizado um modelo que caracterize ruptura frágil (brittle cracking), que descreve o trecho descendente do diagrama tensão-deformação. O software disponibiliza várias funções para descrever esse trecho (linear, multilinear, e duas funções não lineares).

Neste caso foi utilizado o modelo de amolecimento linear (Fig. 6.6). Como estava previsto um baixo nível de solicitação (ou seja, tensões máximas em torno de $30 \%$ da resistência), e, portanto a relação tensão-deformação encontra-se dentro do regime elástico linear, acredita-se que a escolha de outro de esmagamento não exerceria influência significativa sobre os resultados.

Observando a Fig. 6.6 tem-se que a deformação última (na situação fissurada) é dada pela seguinte expressão a seguir.

$$
\varepsilon_{n n . u l t}^{c r}=2 \cdot \frac{G_{f}^{I}}{h \cdot f_{t}}
$$

Sendo:

$G_{f}^{I}$ : energia de fratura para fraturamento no Modo I; 
$h:$ largura da banda de fissura;

$f_{t}$ : resistência à tração.

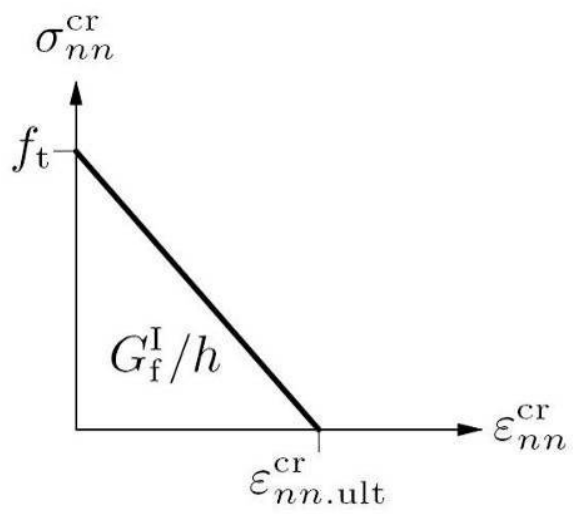

Fig. 6.6: Aproximação linear para trecho de amolecimento.

Na realidade, a idéia empregada neste modelo de fissuração distribuída partiu do Modelo da Banda de Fissuração, brevemente comentado no Capítulo 3. Nele comentou-se que o valor razoável para a largura da banda de fissura é 3 vezes o diâmetro do agregado. Contudo aqui a largura da banda de fissura, $h$, está relacionada à área A do elemento finito:

$$
h=\sqrt{2 \cdot A}
$$

Desta forma pode-se dizer que este parâmetro é dependente da malha. Isto é relevante para grandes estruturas não armadas. Nestes casos as dimensões dos elementos e da largura da banda de fissura tornam-se muito grandes, e o diagrama de amolecimento torna-se muito íngreme. O manual recomenda que seja refinada a malha até se ter certeza de que a deformação última é maior do que $f_{t} / E$.

\subsubsection{Retenção ao Cisalhamento}

Devido à fissuração do material, a rigidez ao cisalhamento é usualmente reduzida. Esta redução é normalmente conhecida como retenção do cisalhamento. São disponíveis duas situações para retenção do cisalhamento: retenção completa ou constante. A diferença é que na primeira não há redução do módulo de elasticidade transversal por conta da fissuração, ao passo que na segunda este módulo é reduzido por um fator maior do que zero e menor ou igual a um. Neste trabalho foi considerada retenção completa. 


\subsubsection{Modelo de Fluência do concreto}

Efeitos de longa duração, como a fluência, podem ser modelados com um dos três modelos viscoelásticos disponíveis: Power Law, Maxwell-Chain and a Kelvin-Chain.

O programa computacional DIANA ${ }^{\circledR}$ também pode gerar os parâmetros nos modelos em série de Maxwell e Kelvin para a fluência, onde os dados de entrada podem ser uma função discreta de fluência ou relaxação, ou utilizar a formulação de um código internacional. Podem estar disponíveis os modelos de acordo com o Comitê Euro-Internacional do Concreto (CEB-FIB 1990), o Instituto Americano do Concreto (ACI 209) e a norma holandesa (DutchNEN). No software disponível para utilização está disponível o modelo do ACI 209.

Nos ensaios de fluência, uma tensão é aplicada a um tempo inicial e as deformações são medidas em função do tempo. Desta forma, pode-se obter a função de fluência, que relaciona as deformações de fluência com a tensão aplicada no tempo e utilizá-la no modelo numérico.

Se a função de fluência é conhecida, por exemplo, utilizando a formulação de um código normativo disponível no software, as deformações podem ser determinadas considerando os modelos viscoelásticos e o princípio da superposição a um histórico de tensões conhecido.

No programa computacional DIANA ${ }^{\circledR}$, o comportamento viscoelástico pode ser descrito por uma função de fluência $J\left(t_{0}, t\right)$. Sendo esta função conhecida (obtida, por exemplo, pelos códigos de norma), a relação entre as tensões e as deformações é dada por:

$$
\varepsilon(t)=\int_{-\infty}^{t} J(t, \tau) \bar{C} \dot{\sigma}(\tau) d \tau
$$

Para materiais isotrópicos a matriz $\bar{C}$ é adimensional e descrita em função do coeficiente de Poisson $v$ :

$$
\bar{C}=\left[\begin{array}{cccccc}
1 & -v & -v & 0 & 0 & 0 \\
-v & 1 & -v & 0 & 0 & 0 \\
-v & -v & 1 & 0 & 0 & 0 \\
0 & 0 & 0 & 2(1+v) & 0 & 0 \\
0 & 0 & 0 & 0 & 2(1+v) & 0 \\
0 & 0 & 0 & 0 & 0 & 2(1+v)
\end{array}\right]
$$


A aplicação da deformação por fluência nas vigas modeladas no DIANA ${ }^{\circledR}$ foi feita usando o modelo do ACI 209:1982 disponível no software, e o aplicando ao respectivo material requerido. Isto foi feito utilizando o comando que gerencia as propriedades dos materiais (property manager) e definindo esta "propriedade" para o material definido (concreto). A Fig. 6.7 ilustra a caixa de diálogo do DIANA ${ }^{\circledR}$ para definição do modelo de fluência.

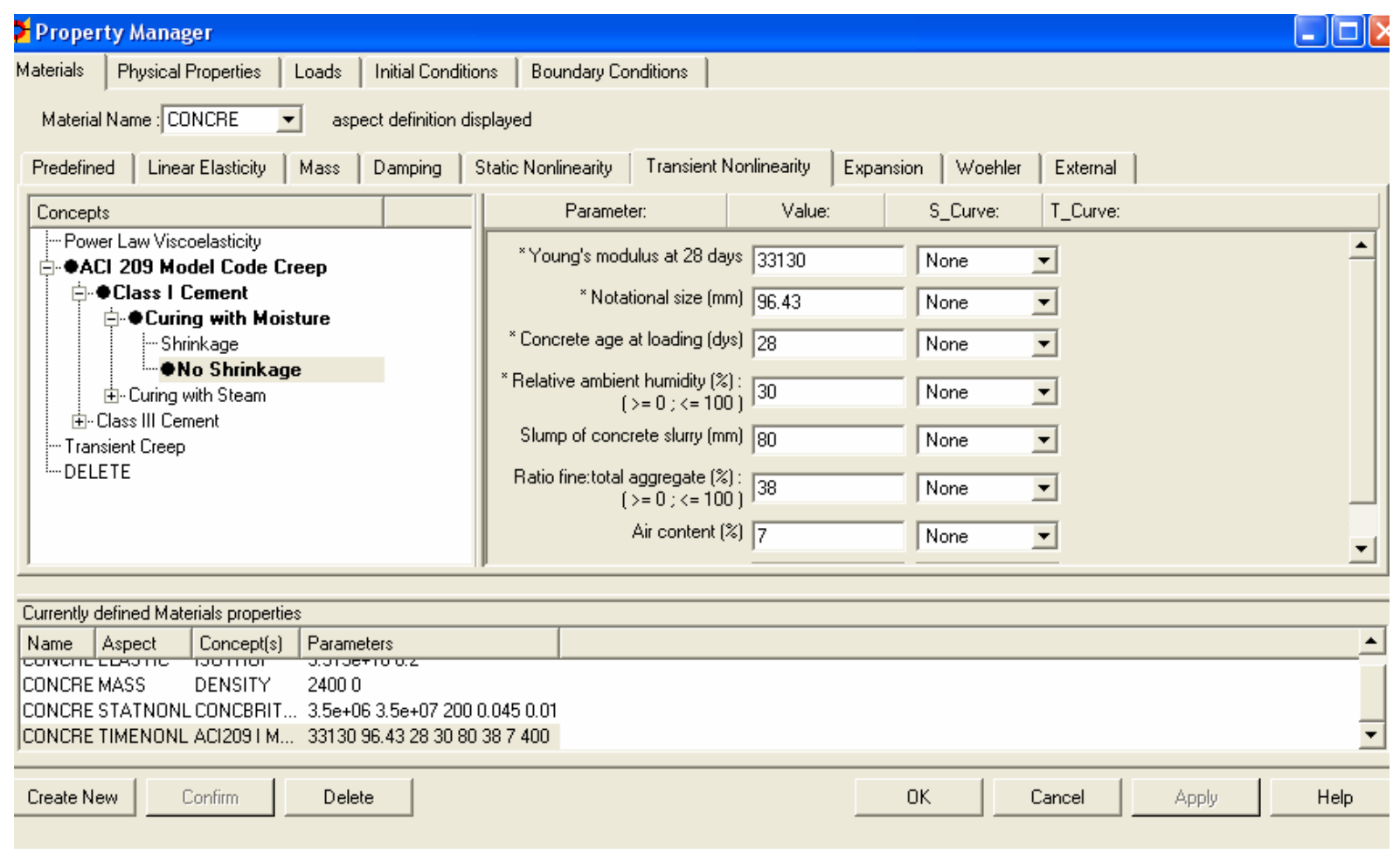

Fig. 6.7: Modelo de fluência utilizado na simulação numérica.

\subsubsection{Análise não linear-passos de tempo}

A análise não linear foi feita em duas etapas: na primeira o carregamento foi aplicado em passos de carga, sendo considerado o modelo de fissuração; na segunda foram aplicados passos de tempo, sendo considerado tanto a fissuração como a fluência.

Os intervalos de tempo ("passos”) utilizados na análise não-linear da fluência seguem os intervalos de medida dos deslocamentos recomendados pela NBR8224, a saber:

a) 30 segundos após o carregamento (deformação imediata);

b) 5, 10 e 30 minutos após o carregamento;

c) 1, 2 e 5 horas após o carregamento;

d) diariamente por uma semana; 
e) duas vezes por semana até completar um mês;

f) semanalmente até completar o ensaio.

Desta forma, estimando um período total de observações de 1 ano, tem-se, em segundos, os seguintes instantes: 30, 270, 300, 1200, 1800, 3600, 10800, 68400, 86400(6), 345600(4), 432000, 604800(48), totalizando 67 passos.

\subsubsection{Parâmetros utilizados para simulação da fluência}

Os parâmetros de entrada estão apresentados na Tabela 6.1. Os dados estão dispostos da mesma ordem com que devem ser preenchidos na caixa de diálogo, conforme a Fig. 6.7.

Foi considerada apenas a fluência (portanto sem retração), sendo adotada cura úmida, o que está compatível com a cura utilizada nas séries de ensaio, descrita no Capítulo 7. Informações sobre slump, percentagem de finos e consumo de cimento estão apresentadas também no Capítulo 7 (ver Tabelas 7.2 e 7.5). Já o teor de ar incorporado foi estimado pela diferença entre a massa obtida na pesagem das vigas e a massa teórica, calculada pela soma dos materiais de mistura seguindo as proporções de dosagem (ver Tabela 8.1 e Tabela 8.9).

Para determinação da espessura média das vigas entalhadas foi considerada a seção transversal que contem o entalhe. Os valores do módulo de elasticidade (Fig. 8.2 e Fig. 8.36) e umidade relativa, obtidos das séries experimentais, podem ser consultados no Capítulo 8.

Tabela 6.1: Dados de entrada para análise da fluência.

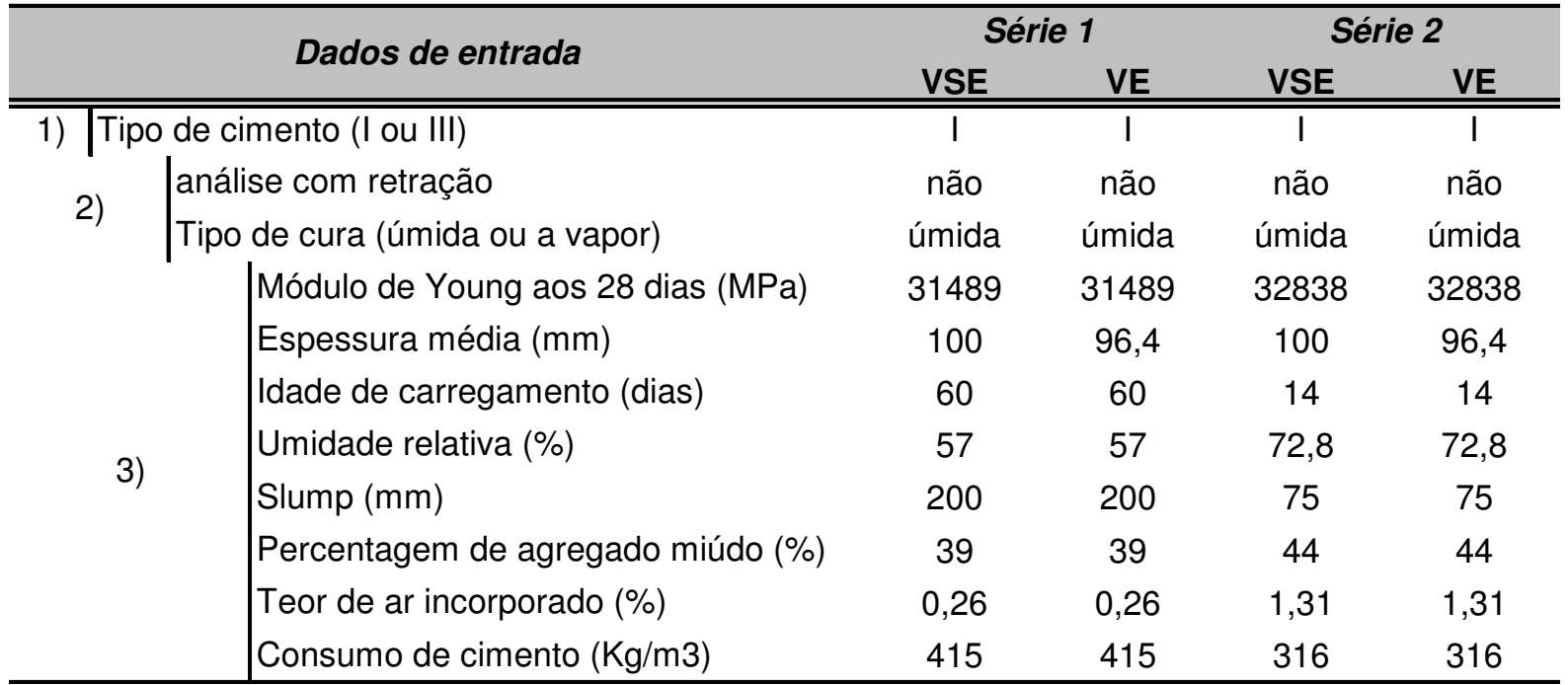




\subsubsection{Equívocos encontrados no modelo de fluência do DIANA ${ }^{\circledR}$.}

Durante a realização de diversos testes, assim como das simulações finais, foi possível perceber dois equívocos na aplicação do modelo de fluência do ACI 209:1982 pelo sofware.

O primeiro deles, que nem é tão grave, refere-se à entrada do consumo de cimento, mesmo quando o usuário deseja considerar apenas a fluência. Conforme já apresentado no Capítulo 5, no cálculo do coeficiente de fluência pelo modelo do ACI não se utiliza, em nenhum momento, o consumo de cimento. Esse parâmetro só necessário para a estimativa das deformações por retração, o que é inclusive descrito no manual Material Library do DIANA $^{\circledR}$.

Para constatar se esse dado de entrada realmente não interferia nos resultados, (quando não se considera a retração), fez-se um teste. Foram processados dois arquivos com exatamente os mesmos dados, entretanto, em um deles foi considerado o triplo do consumo de cimento. Os resultados, como se esperava, mostram que o modelo é indiferente ao consumo de cimento. Sendo assim, melhor seria se este dado de entrada fosse requerido apenas quando realmente necessário, como no caso da consideração das deformações por retração.

Outro equívoco, porém este mais grave, refere-se a outro dado de entrada, o teor de ar incorporado. De acordo com a descrição do modelo de fluência do ACI, a percentagem de ar incorporado pode variar de $0 \%$ a $6 \%$, o que leva a uma variação do coeficiente $C_{a r}$ entre 0.46 e 1, tendo em vista a expressão para o cálculo deste coeficiente:

$$
C_{A r}=0,46+0,09 P_{A r} \geq 1 \text {, onde } P_{A r} \text { é o percentual de ar incorporado. }
$$

Ou seja, a redução de $C_{a r}$ de $6 \%$ para $0 \%$ ocasiona uma redução do coeficiente de fluência de $54 \%$, uma vez que se trata de um modelo produtório. Sabendo que o coeficiente de fluência interfere na função de fluência (ver equação 5.19), pode-se estimar o impacto da variação do coeficiente $C_{a r}$ sobre as deformações. Desta forma, utilizando, por exemplo, os demais dados da série 2 (Tabela 6.1), observa-se que ao variar o teor de ar incorporado de $6 \%$ a $0 \%$, a redução na função de fluência (e conseqüentemente nas deformações) chega a $30 \%$.

Foram realizados alguns testes no DIANA ${ }^{\circledR}$ variando-se apenas este parâmetro dentro e fora dos limites estipulados pelo ACI, e os resultados são, no mínimo, estranhos. Para variações entre $0 \%$ e $6 \%$, ou seja, dentro do intervalo limite aceito pelo ACI, não ocorre nenhuma alteração nos deslocamentos. Pelo cálculo simples apresentado no parágrafo anterior imagina-se que alguma diferença deveria ser observada. 
Por outro lado, ao utilizar valores maiores que $6 \%$ para a percentagem de ar incorporado, como $7 \%$ e $80 \%$, ocorrem grandes alterações. Ou seja, o DIANA ${ }^{\circledR}$ não limita o coeficiente $C_{a r}$ no valor da unidade, contrariando o modelo de fluência no qual está embasado. Imagina-se que para valores fora do intervalo o programa deveria alertar o usuário. Estas comparações estão apresentadas no gráfico da Fig. 6.8. Ou seja, parece que o programa despreza teores de ar incorporado quando estes estão dentro do limite recomendado, e por outro lado considera valores fora deste limite.

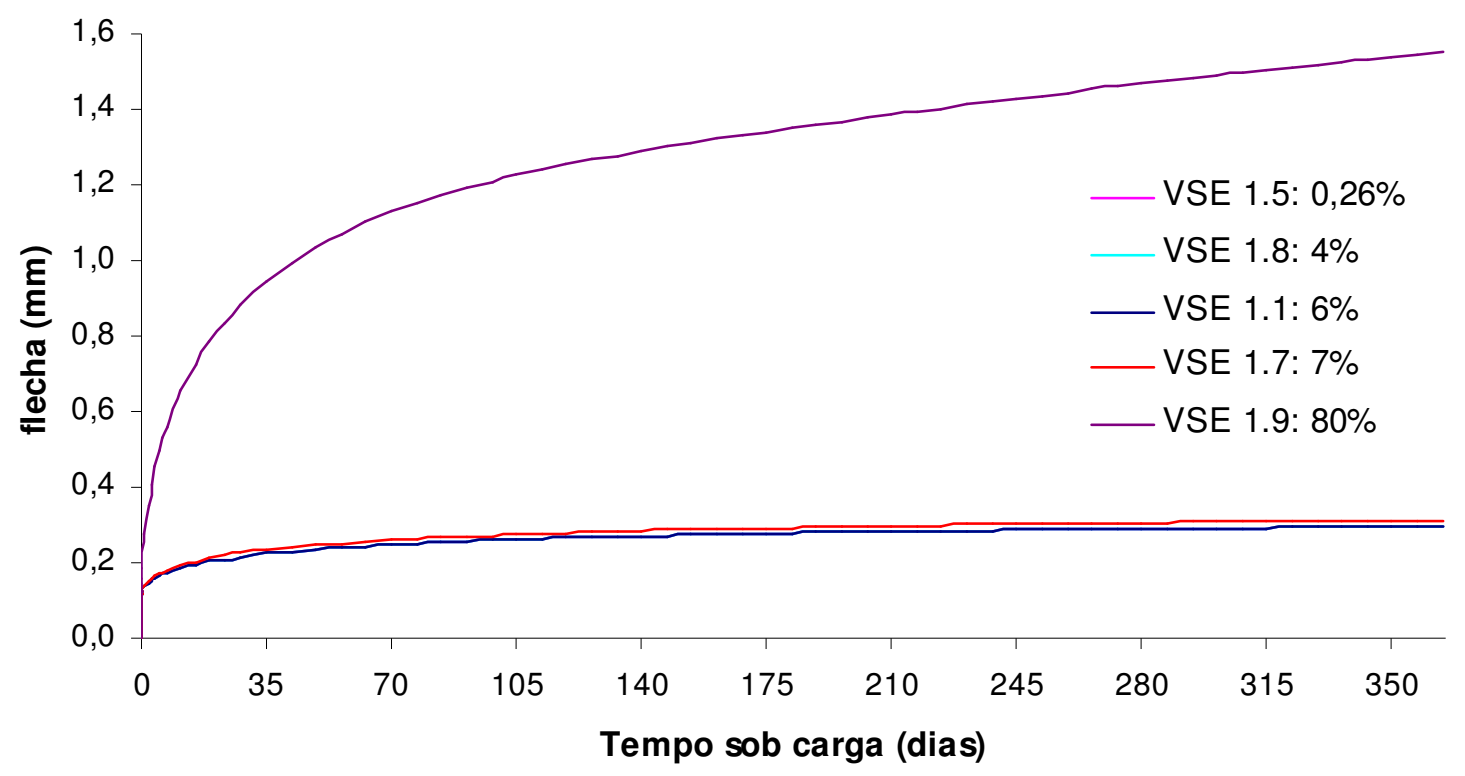

Fig. 6.8: Influência do teor de ar incorporado na simulação.

\subsection{Resultados}

Para construção das curvas de deslocamentos-tempo, foram tabulados os deslocamentos dos nós da malha de elementos finitos, correspondentes às posições geométricas de interesse para cada modelo. Em destaque na Fig. 6.2, para as vigas sem entalhe, e na Fig. 6.3, para as vigas entalhadas, estão os pontos em que foram considerados os deslocamentos verticais para o cálculo das flechas (deslocamento do ponto 2 menos o do ponto 1).

Para análise global das vigas foram gerados arquivos do tipo Femview para visualização dos resultados utilizando o iDIANA ${ }^{\circledR}$. Para tratar os resultados tabulados, fez-se uso de uma rotina escrita em linguagem Fortran. A partir dos arquivos gerados por essa rotina, foram traçadas as curvas de deslocamento ao longo do tempo que caracterizam o fenômeno da fluência. Conforme se esperava não houve fissuração em nenhum caso. 


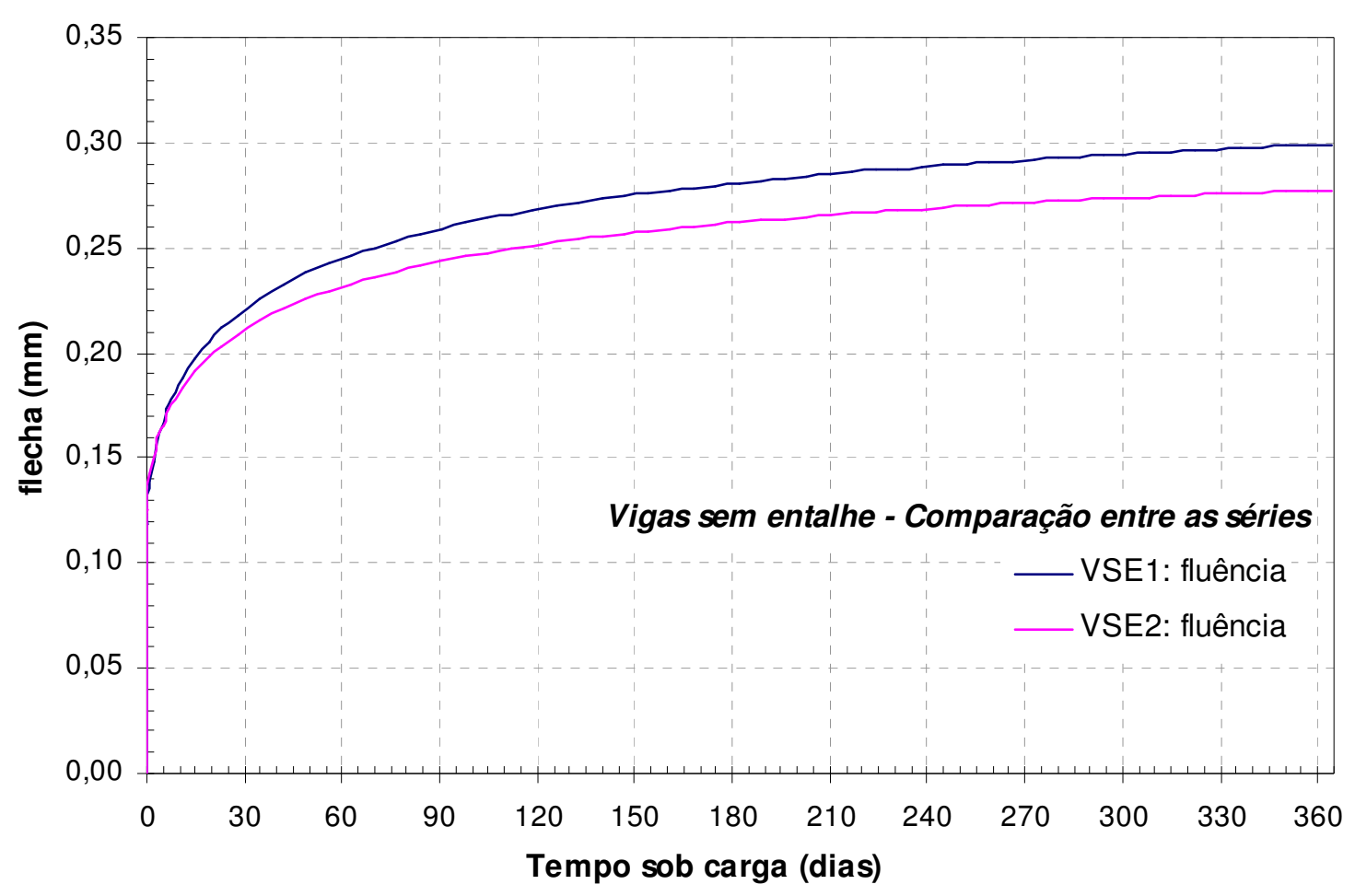

Fig. 6.9: Resultado da simulação flecha-tempo: Vigas sem entalhe.

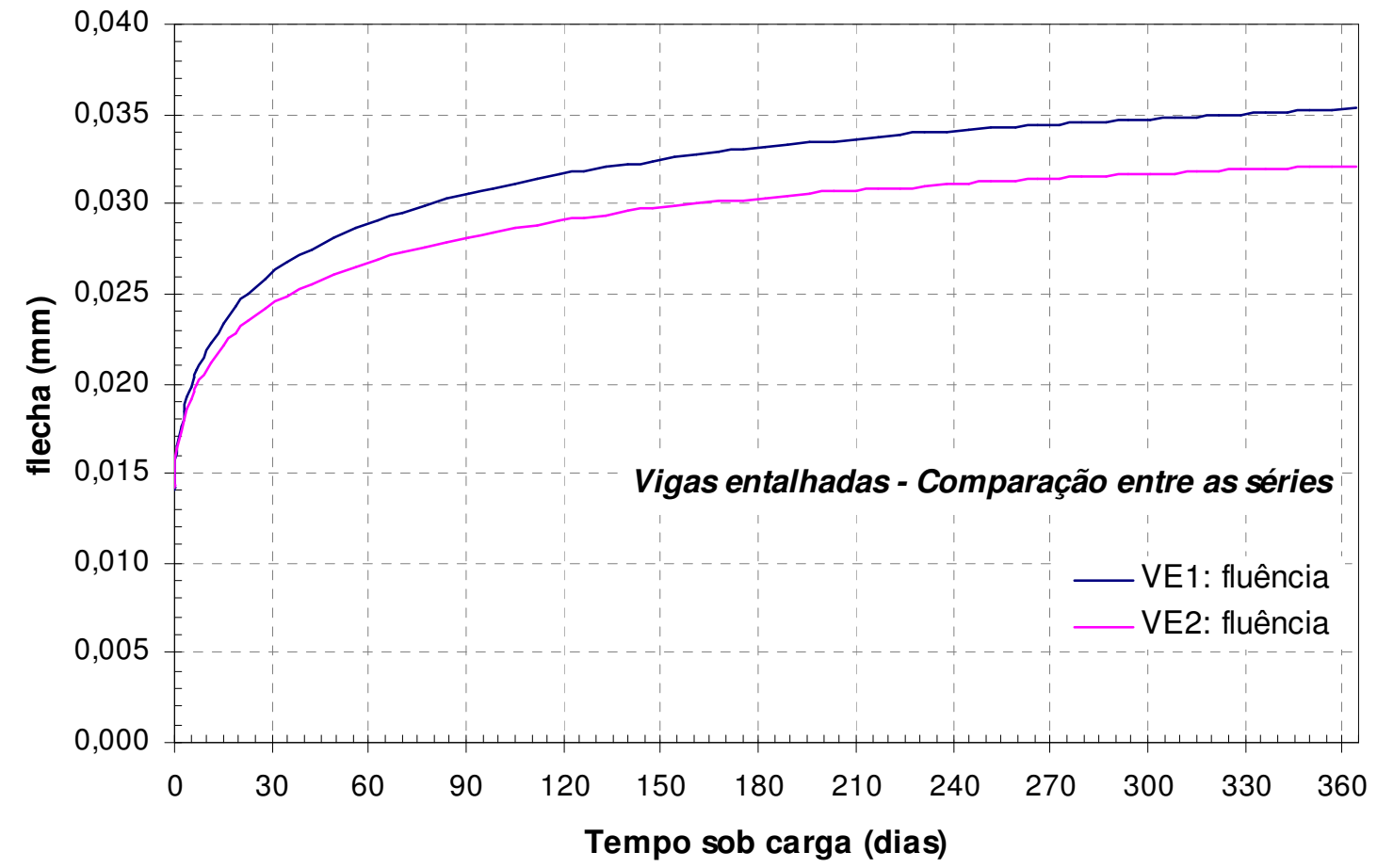

Fig. 6.10: Resultados simulação flecha-tempo: Vigas entalhadas. 


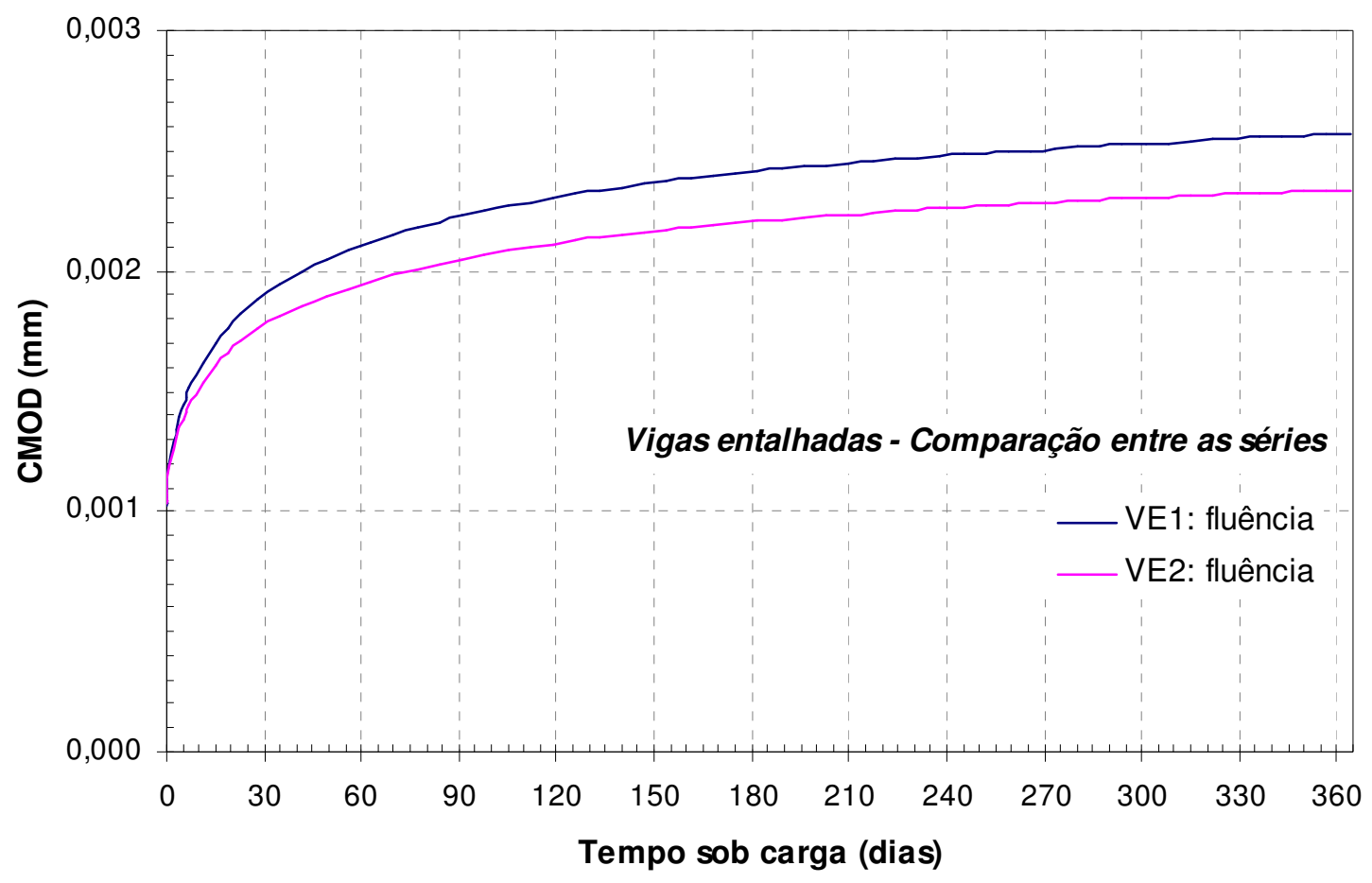

Fig. 6.11: Resultados simulação CMOD-tempo: Vigas entalhadas.

As Figuras 6.9-6.11 ilustram os resultados das simulações. Nota-se que, mesmo a idade de carregamento da Série 1 ter sido maior do que da Série 2, as curvas primeira série são superiores. Conforme a Tabela 6.1 nota-se que os parâmetros que mais destoam entre as duas séries são a umidade relativa e o slump, sendo que estes dois fatores tiveram valores mais desfavoráveis à fluência no caso da Série 1. De qualquer forma a diferença entre as curvas é pequena (em torno de $8 \%$ ).

Nota-se também que a diferença na ordem de grandeza das flechas estimadas para as vigas VSE e VE: a flecha da viga sem entalhe é praticamente 10 vezes à da viga entalhada. A esse respeito é interessante notar também as variações do CMOD (Fig. 6.11). De acordo com estas estimativas, haveria apenas dois valores diferentes de leitura, para cada série, e desta forma, a curva do programa experimental deveria ser composta por duas retas (ou seja, ter-seiam dois pontos de leitura), já que a sensibilidade do aparelho de medição é de $1 \mu m$.

A título de ilustração, a Fig. 6.12 traz a comparação das curvas flecha-tempo entre a situação em que se considera apenas a fluência e aquela em que se considera tanto a fluência como a retração. Ao considerar a retração há um acréscimo da flecha diferida após um ano em torno de $150 \%$. 
Considerando a retração nas duas séries e comparando-as entre si (ver Fig. 6.13) notase que a diferença entre as curvas cresce de forma mais pronunciada ao longo do tempo, sendo que após 1 ano atinge $25 \%$.

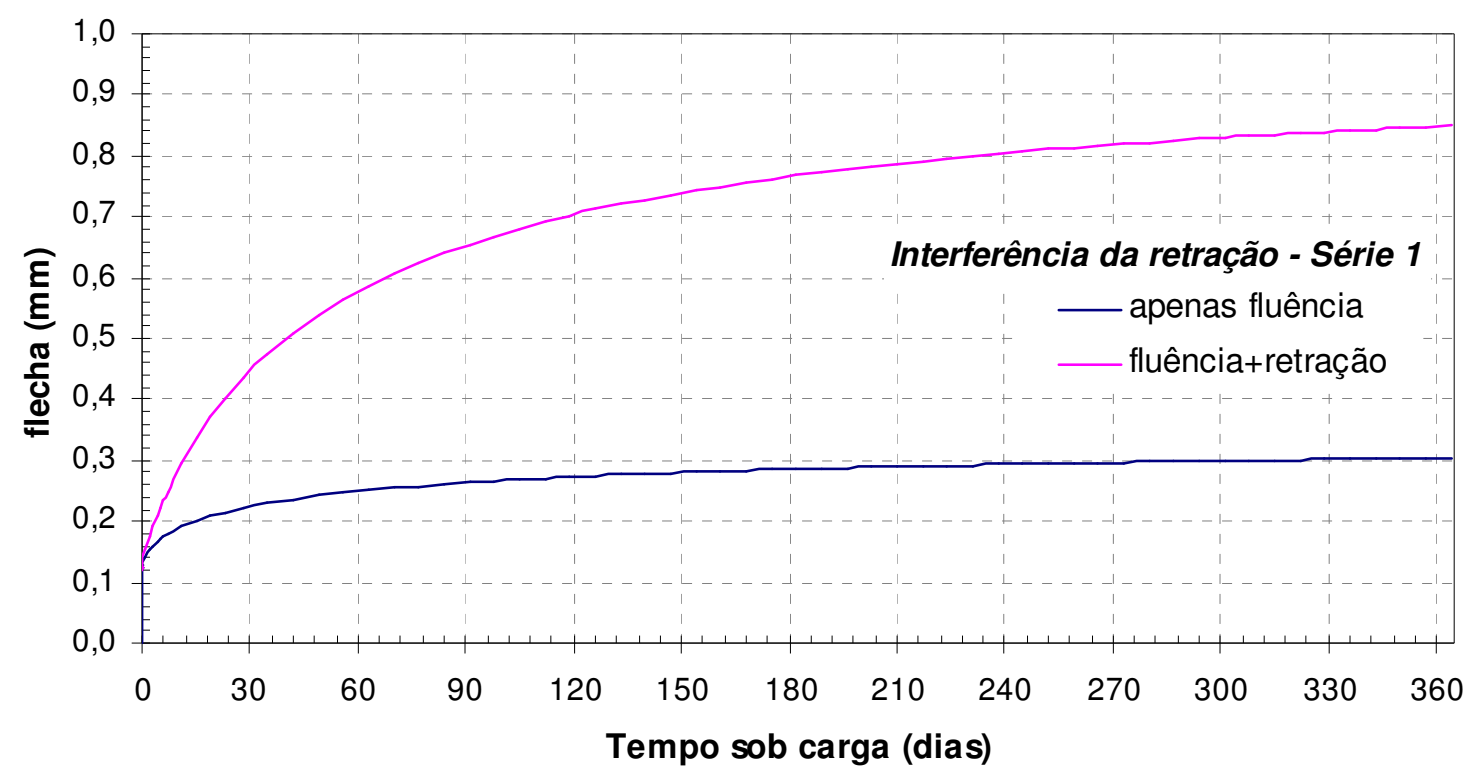

Fig. 6.12: Acréscimo da flecha por retração.

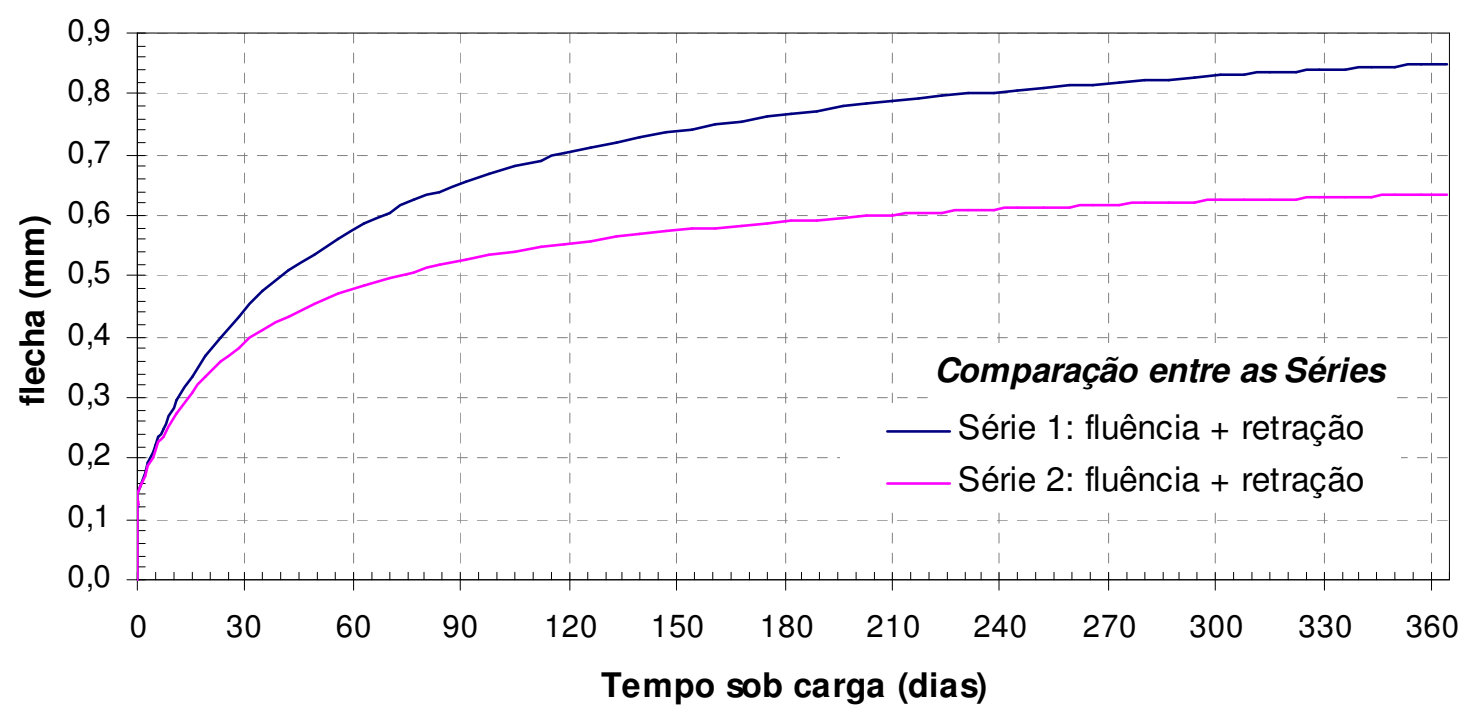

Fig. 6.13: Comparação entre as séries: fluência e retração. 
A avaliação experimental da fluência contou com duas séries de ensaios: Série Piloto, com duração de 45 dias, e a Série Definitiva com duração de 135 dias. A princípio, seria realizada apenas uma série de ensaios de duração maior (em torno de 90 dias); entretanto, em virtude de contratempos que prejudicaram a primeira série, julgou-se conveniente a realização de uma nova série, repetindo-se os ensaios. A seguir são apresentadas as principais diferenças entre as séries, cuja interferência foi direta sobre os resultados do comportamento do concreto à fluência:

- Origem do concreto utilizado na matriz dos três materiais avaliados: na primeira série, o concreto foi moldado in loco, e na segunda série foi utilizado concreto usinado (moldado em central);

- Data de carregamento: na primeira série os ensaios de longa duração tiveram início aos 60 dias após a moldagem; já na segunda série deu-se início aos ensaios de longa duração aos 14 dias;

- Condição de exposição anterior ao início dos ensaios: na primeira série, não propositalmente, os modelos passaram por uma exposição a condições climáticas variáveis durante um mês após sua desfôrma. Na segunda série após 2 dias da desfôrma, os modelos foram colocados na câmara climatizada para início dos ensaios de longa duração.

Houve também outras medidas relacionadas à instrumentação e aos ensaios relacionados, com o intuito de melhorar a qualidade dos resultados, a saber:

- Monitoramento do CMOD: com base nos resultados da primeira série, foram realizadas alterações construtivas nos "clip-on-gauges" desenvolvidos no laboratório, de forma que a precisão das leituras fosse mantida ao longo do tempo. Na série definitiva, além dos "clips" foi também utilizado um equipamento mecânico (Tenso-Tast) para medição da abertura do entalhe. 
- Ensaios de caracterização: na segunda série de ensaios foi moldada uma quantidade maior de corpos-de-prova, de forma que a evolução das propriedades mecânicas do concreto pudesse ser avaliada de maneira mais confiável.

- Ensaios de fraturamento: na segunda série foram moldados prismas para determinação de parâmetros de fraturamento $\left(G_{f}\right.$ e $K_{I C}$ ), não previstos na primeira série. A energia de fraturamento é um dos dados de entrada na simulação computacional no DIANA ${ }^{\circledR}$.

As principais dificuldades encontradas que levaram à realização da nova série estão apresentadas no item 7.6 deste trabalho. Ressalta-se que tais dificuldades interferiram nos resultados dos ensaios, sendo que as justificativas para sua repetição estão incluídas na apresentação e discussão dos resultados primeira série. Cada série envolveu, na realidade, um grupo de ensaios. Na Tabela 7.1 constam informações sobre os tipos de ensaios e os corposde-prova utilizados para cada material.

\subsection{Materiais Estudados}

Foram avaliados três materiais: concreto simples (matriz), concreto reforçado com fibras de aço (CRFA convencional) e compósito híbrido (concreto com adição de fibras e microfibras de aço). Os traços utilizados para confecção do concreto de referência de cada série de ensaios estão apresentados no item 7.4.

Para a composição do CRFA, foi adicionado à matriz um teor de $1 \%\left(80 \mathrm{~kg} / \mathrm{m}^{3}\right) \mathrm{de}$ fibras de aço com gancho de extremidade, fornecidas pela Maccaferri, especificadas como tipo Wirand FS8. Trata-se de fibras de aço de baixo teor de carbono com comprimento (l) igual a $25 \mathrm{~mm}$, diâmetro (d) da ordem de $0,75 \mathrm{~mm}$ e razão de aspecto (1/d) igual a 33 .

Para obtenção do compósito híbrido, foi adicionado a esse CRFA um teor de 1\% (80 $\left.\mathrm{kg} / \mathrm{m}^{3}\right)$ de microfibras de aço de formato reto com gancho na extremidade $(\mathrm{l}=13 \mathrm{~mm}, \mathrm{~d}=0,5$ $\mathrm{mm}$ e $1 / \mathrm{d}=26$ ), fornecidas pelo mesmo fabricante. A Fig. 7.1 ilustra os dois tipos de fibras metálicas utilizados. Ao longo do texto, a identificação dos materiais será feita pelas siglas:

○ CONC : concreto (matriz de referência);

○ $\mathrm{CF}$ :concreto reforçado com fibras de aço $(25 \mathrm{~mm})$;

○ CFMF : concreto reforçado com fibras de aço $25 \mathrm{~mm}$ e de $13 \mathrm{~mm}$. 

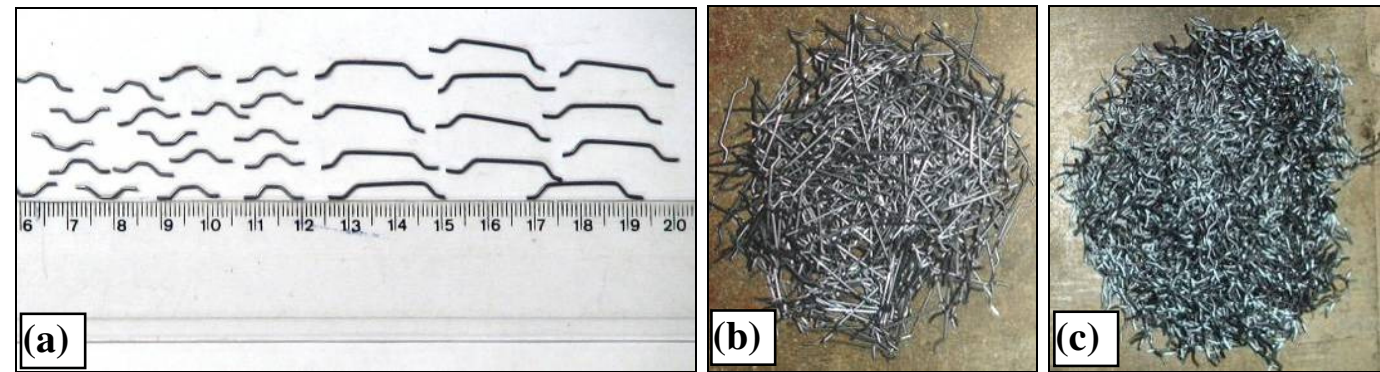

Fig. 7.1: Fibras utilizadas na confecção dos materiais compósitos. (a) comparação dimensional. (b) fibras de $25 \mathrm{~mm}$. (c) fibras de $13 \mathrm{~mm}$.

O teor de $1 \%$ de fibras foi adotado com base nos resultados de Ferreira, Hanai e Ferrari (2007); Ferrari (2007) e Ferreira (2007). De acordo com esses pesquisadores, a utilização das quantidades referidas das fibras RC e ZC levou ao comportamento ótimo dos materiais compósitos, para os traços avaliados por eles, no que diz respeito ao ganho de resistência à tração e tenacidade à flexão e capacidade de carga à flexão.

\subsection{Corpos-de-prova e ensaios correlacionados}

A avaliação experimental da fluência realizada nesta pesquisa contou com a realização de inúmeros ensaios correlacionados. De forma resumida, a Tabela 7.1 traz a terminologia adotada para cada ensaio, sua finalidade, assim como as dimensões e quantidade de corposde-prova necessários para cada material avaliado.

\subsubsection{Fôrmas utilizadas}

Os corpos-de-prova utilizados nos ensaios de caracterização foram moldados em fôrmas cilíndricas metálicas padronizadas (Fig. 7.2). Para moldagem dos prismas (15x30x100 $\mathrm{mm}$ ) foram reaproveitadas fôrmas de madeira existentes no laboratório (Fig. 7.3:a). Já para as vigas foram confeccionadas fôrmas de madeira (Fig. 7.3: b-d), elaborada para moldagem de duas vigas em cada etapa de concretagem. Detalhes das fôrmas de madeira são apresentados na Fig. 7.4.

Ao todo foram feitas 5 fôrmas: 1 fôrma simples e 1 fôrma dupla, destinadas às vigas sem entalhe (uma viga de cada material), e três fôrmas duplas destinadas às vigas entalhadas (cada uma para um tipo de material). Nestas fôrmas foi feita uma ranhura para acomodar a placa de inserção, colocada logo após a concretagem, necessária para realização do entalhe. Conforme se apresenta nos itens 7.4.1 e 7.4.2, essa placa foi de madeira (Fluência Série 1) ou 
de aço (Fluência-Série 2). Os dois tipos de furação indicados na vista lateral (Furação VE e Furação VSE) referem-se ao posicionamento dos varões-roscados passantes necessários à sustentação da instrumentação para medição das flechas, conforme se comenta em 7.5.1 e 7.6.4.

Tabela 7.1: Quadro resumo do grupo de ensaios para avaliação experimental da fluência.

\begin{tabular}{|c|c|c|}
\hline $\begin{array}{l}\text { Terminologia } \\
\text { utilizada para o ensaio }\end{array}$ & Corpos-de-prova & Resultados (Finalidades) \\
\hline $\begin{array}{c}\text { Ensaios de } \\
\text { caracterização. }\end{array}$ & $\begin{array}{l}\text { Cilindros } \\
(10 \times 20 \mathrm{~cm})\end{array}$ & $\begin{array}{l}\text { Determinação em várias idades da resistência à } \\
\text { tração, módulo de Young e resistência à } \\
\text { compressão. }\end{array}$ \\
\hline Flecha Inicial & Todas as vigas & Flecha elástica experimental. \\
\hline Ensaios de retração. & $\begin{array}{c}1 \text { Prisma } \\
(15 \times 30 \times 100 \mathrm{~cm})\end{array}$ & $\begin{array}{c}\text { Deformações volumétricas devido à retração } \\
\text { autógena, retração por secagem e variação } \\
\text { térmica. }\end{array}$ \\
\hline \multirow[b]{2}{*}{ Ensaios de fluência. } & $\begin{array}{l}1 \text { Viga sem entalhe. } \\
(15 \times 30 \times 220 \mathrm{~cm})\end{array}$ & $\begin{array}{l}\text { Evolução das flechas diferidas ao longo do } \\
\text { tempo. }\end{array}$ \\
\hline & $\begin{array}{l}2 \text { Vigas Entalhadas. } \\
(15 \times 30 \times 220 \mathrm{~cm})\end{array}$ & $\begin{array}{l}\text { Evolução das flechas diferidas e do } \\
\text { deslocamento de abertura do entalhe ao longo } \\
\text { do tempo. }\end{array}$ \\
\hline Ensaios dinâmicos. & $\begin{array}{l}\text { Vigas utilizadas nos } \\
\text { ensaios de fluência. }\end{array}$ & Módulo de elasticidade dinâmico. \\
\hline $\begin{array}{c}\text { Ensaios de } \\
\text { Fraturamento }\end{array}$ & $\begin{array}{c}\text { Prismas } \\
(15 \times 15 \times 50 \mathrm{~cm})\end{array}$ & Determinação de parâmetros de fraturamento. \\
\hline
\end{tabular}

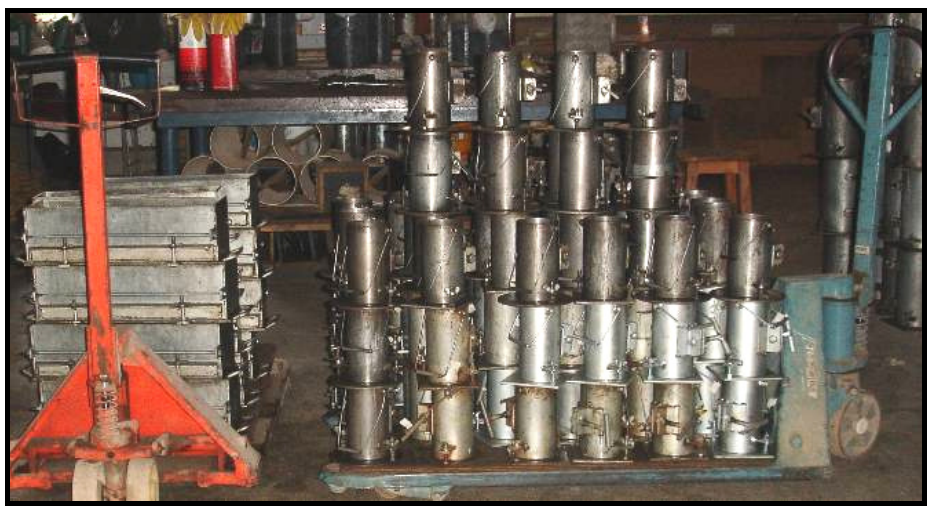

Fig. 7.2: Fotos das fôrmas metálicas: (a) $\mathrm{cp}(\mathrm{s})$ cilíndricos, (b) prismas.

\footnotetext{
${ }^{20}$ Os ensaios de fraturamento foram realizados apenas na segunda série de ensaios.
} 

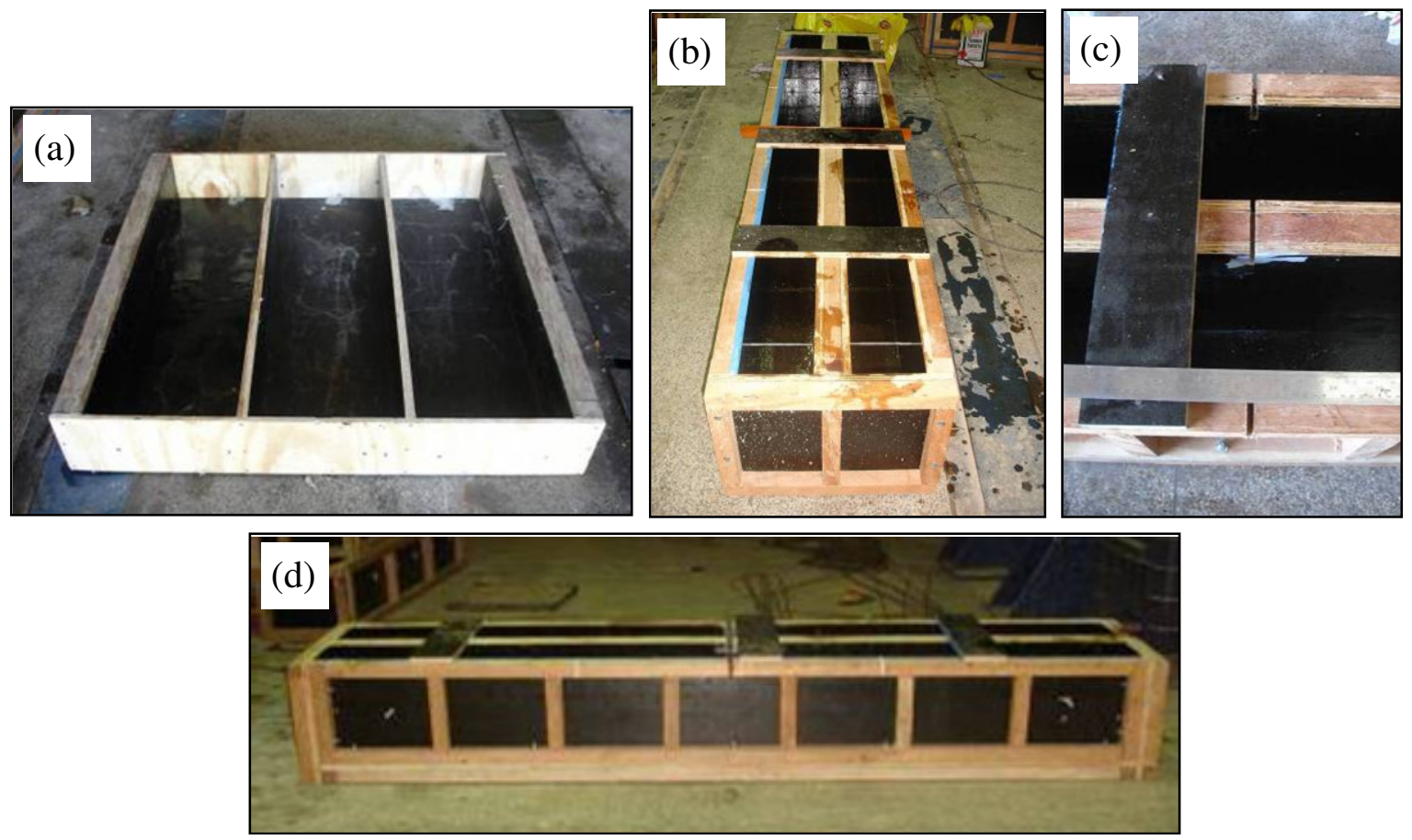

Fig. 7.3: Fotos das fôrmas de madeira: (a) prismas, (b-d) vigas.

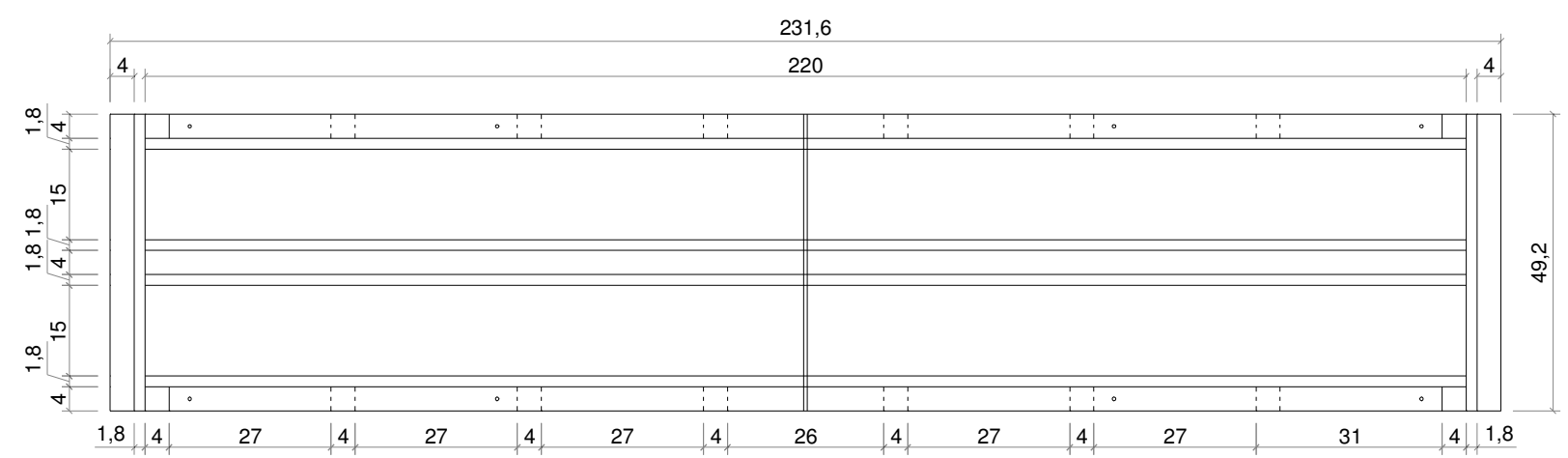

Fôrma Vigas: Vista em Planta
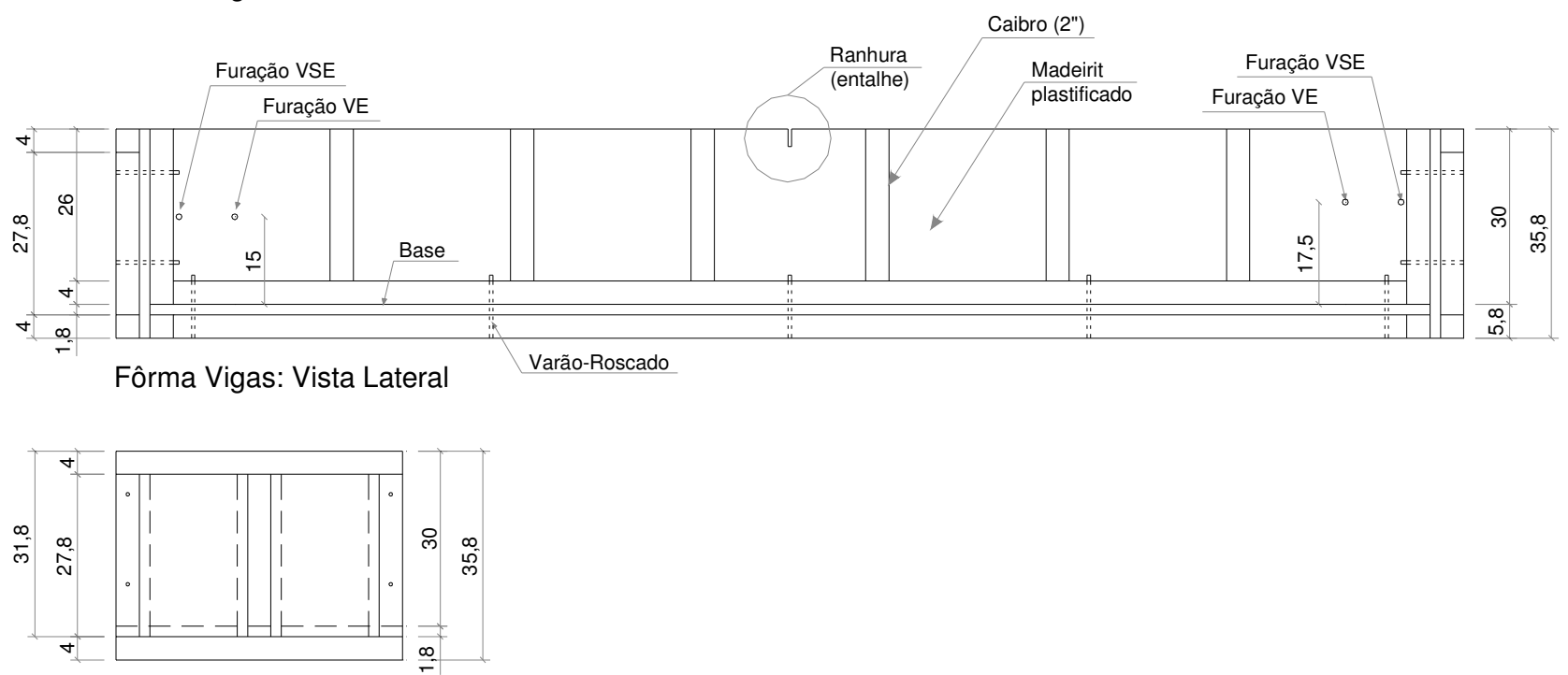

Fôrma Viga: Vista Frontal

Fig. 7.4: Detalhamento das fôrmas das vigas. 


\subsection{Condições de aclimatação dos corpos-de-prova}

Durante os ensaios de longa duração, todos os corpos-de-prova que faziam parte do programa experimental permaneceram na câmara climatizada do Laboratório de Estruturas, em condições de exposição ambiental controlada.

A câmara climatizada tem $4 \mathrm{~m}^{2}(2 \mathrm{~m} \times 2 \mathrm{~m})$, é vedada com paredes tipo sanduíche com núcleo de poliestireno expandido (placas de $6 \mathrm{~cm}$ ), e foi projetada para trabalhar em faixas de temperatura e umidade relativa entre 15 e $40^{\circ} \mathrm{C}$ e 20 e $80 \%$, respectivamente. $\mathrm{O}$ controle das condições ambientais é feito de forma automática pelo software SIMPLE Ambiental.

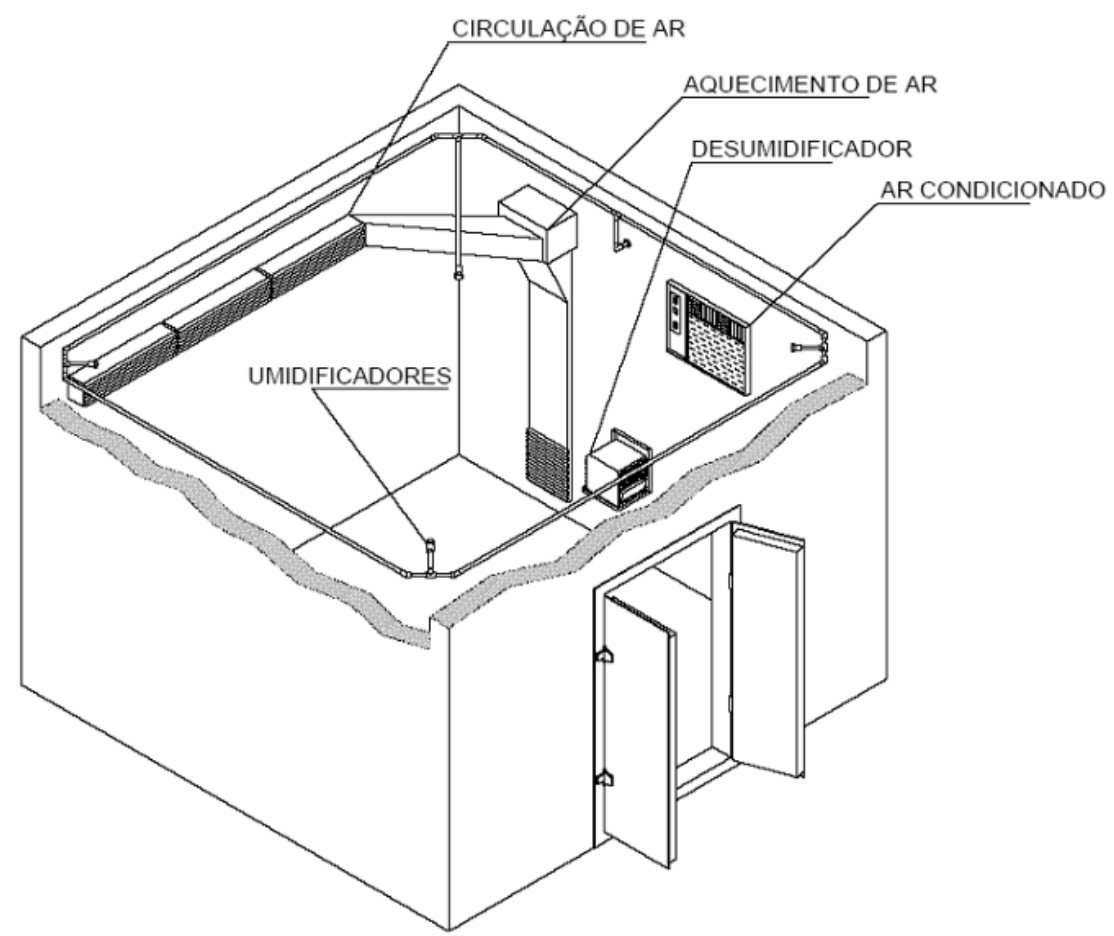

Fig. 7.5: Disposição dos equipamentos no interior da câmara climatizada.

Conforme ilustra a Fig. 7.5, a câmara dispõe de aparelho de ar condicionado, para refrigeração do ar; sistema de aquecimento de ar (resistências elétricas localizadas no duto de circulação de ar), sistema de umidificação por aspersão; desumidificador, além de sensores de temperatura (5 no total) e umidade relativa (um).

\subsubsection{Dimensionamento da geometria do entalhe e do peso-morto}

A aplicação da Mecânica do Fraturamento no estudo da fluência foi efetuada na comparação do comportamento das vigas entalhadas (referenciadas ao longo do texto por VE) e das vigas sem entalhe (consideradas de "referência", identificadas no texto por VSE). 
O dimensionamento da geometria do entalhe e da carga a ser aplicada no meio do vão foi realizado de forma que a máxima tensão de tração, à ponta do entalhe, fosse $40 \%$ do valor da resistência (conforme recomendação da NBR 8224:1982), sendo consideradas as seguintes propriedades para o concreto: resistência à compressão de $35 \mathrm{MPa}$, resistência à tração de 3.5 MPa, módulo de elasticidade igual a $33130 \mathrm{MPa}$ e peso específico de $25 \mathrm{kN} / \mathrm{m}^{3}$.

O carregamento dentro do limite elástico do material é importante para assegurar que os incrementos nas flechas decorram apenas da fluência e de outras deformações não dependentes da tensão aplicada (retração autógena, retração por secagem e variações térmicas). Se este limite é ultrapassado, os resultados podem ser mascarados devido ao processo simultâneo de propagação subcrítica de fissuras.

\subsubsection{Geometria do entalhe}

Considerando a concentração de tensões proporcionada pela presença do entalhe, o dimensionamento das vigas entalhadas foi realizado, com auxílio de simulações numéricas utilizando o programa Franc2DL ${ }^{21}$ (WAWRZNEK; INGRAFFEA, 1987), de maneira a submetê-las apenas ao carregamento devido ao peso próprio.

O Franc2DL foi desenvolvido pelos membros do "Cornell Fracture Group” da Universidade de Cornell nos Estados Unidos e permite visualizar como uma descontinuidade geométrica gera uma região com concentração de tensões. Esse programa simula o fraturamento de estruturas por meio de rotinas interativas de regeneração automática de malhas, empregando-se a Mecânica da Fratura Elástica Linear (MFEL) e o Método dos Elementos Finitos.

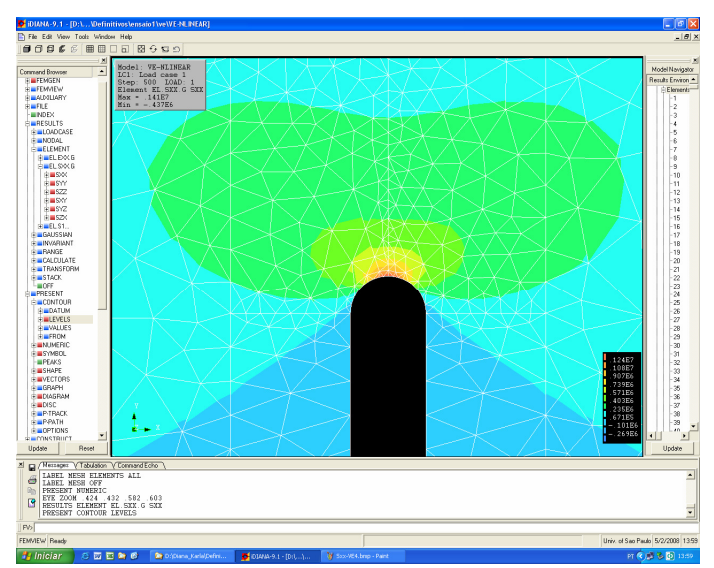

Fig. 7.6: Distribuição das tensões $S_{x x}$ (perpendicular ao carregamento) à frente da ponta do entalhe.

\footnotetext{
${ }^{21}$ Disponível para acesso em: <http://www.cfg.cornell.edu/software/franc2dl.htm>
} 


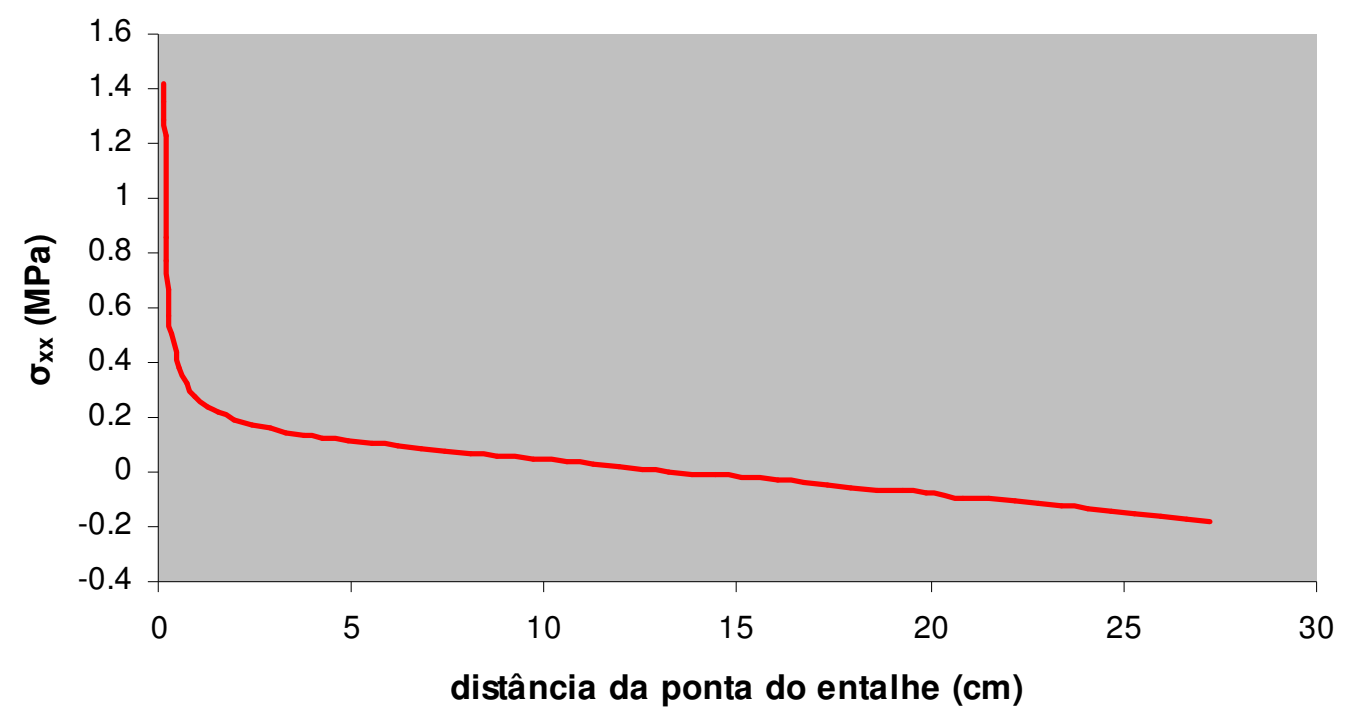

Fig. 7.7: Distribuição das tensões $S_{x x}$ ao longo da seção transversal da viga (da esquerda para direta: ponta do entalhe até a face superior).

Após definida esta geometria, foi elaborado o modelo no DIANA ${ }^{\circledR}$ para simulação do processo de fluência. A Fig. 7.7 ilustra a distribuição das tensões ao longo da seção transversal que contem o entalhe, partindo-se da ponta deste, sendo a máxima tensão de tração igual a 1.4 MPa. Já na Fig. 7.6 tem-se a configuração do campo de tensões à frente da ponta do entalhe. $\mathrm{O}$ entalhe especificado têm $3 \mathrm{~cm}$ de profundidade, $6 \mathrm{~mm}$ de largura e ponta arredondada no formato de um semi-círculo de $3 \mathrm{~mm}$ de raio.

\subsubsection{Determinação da carga concentrada (peso-morto)}

Nas vigas sem entalhe, o valor do peso-morto utilizado, como carga aplicada no meio do vão, foi definido considerando que a tensão de tração da fibra mais tracionada fosse equivalente à tensão de tração na ponta do entalhe (40\% da tensão de compressão adotada), conforme o equacionamento a seguir (desprezando o alívio dos balanços):

$$
\sigma_{\text {máx }}=f_{t}^{e}=\sigma^{P P}+\sigma^{F} \Rightarrow f_{t}^{e}=\frac{3}{4} \gamma \frac{S^{2}}{W}+\frac{3}{2} \frac{F S}{B W^{2}}
$$

Onde:

$\sigma^{P P} \quad$ : tensão de tração devida ao peso próprio;

$\sigma^{F} \quad$ : tensão de tração devida força aplicada;

$f_{t}^{e} \quad$ : tensão de tração na fase resiliente;

$\gamma \quad:$ peso específico $\left(\mathrm{N} / \mathrm{m}^{3}\right)$ 
$S \quad$ : vão livre entre apoios;

$B \quad$ : largura da viga;

F $\quad$ : força concentrada aplicada no meio do vão;

Para o carregamento das vigas foram utilizados como peso morto blocos de concreto de 32x50x122 cm, suspensos por cabos de aço uma polegada de diâmetro. Esta solução foi a mais viável, em razão do custo e da adequação da geometria das massas ao espaço disponível na câmara climatizada.

\subsection{Características das misturas, moldagem e armazenamento.}

\subsubsection{Fluência - Série 1 (Piloto)}

Nesta série foi utilizado concreto moldado in-loco. Em virtude da quantidade de material necessária, foi necessário realizar um plano de concretagem em etapas. Em razão das condições do laboratório (capacidade da betoneira, armazenamento de material seco e pesagem dos materiais), optou-se por realizar três etapas de concretagem, sendo cada uma delas destinada à moldagem dos corpos-de-prova relativos a um dos três materiais avaliados. Em cada etapa de concretagem foram realizadas 2 massadas para moldar todos os modelos.

Desejava-se iniciar os ensaios aos 28 dias, sendo que nesta idade a resistência à compressão do concreto deveria ser de $35 \mathrm{MPa}$ (para que os níveis de tensão à tração não ultrapassassem $40 \%$ da resistência). Foram testados alguns traços encontrados em trabalhos acadêmicos do Departamento de Engenharia de Estruturas. Na Tabela 7.2 constam as proporções em massa dos materiais e informações sobre o traço final adotado. Procurou-se um traço fluido, que permitisse a mistura das fibras com boa trabalhabilidade.

Tabela 7.2: Traço Fluência-Série 1

\begin{tabular}{c|c|c|c}
\hline Cimento $(\mathrm{CPII})$ & Areia Média & Brita 01 & água/cimento \\
\hline 1 & 1,75 & 2,75 & 0,52 \\
\hline \hline $\begin{array}{c}\text { Consumo de } \\
\text { cimento }\left(\mathbf{k g} / \mathrm{m}^{3}\right)\end{array}$ & $\begin{array}{c}\text { teor de } \\
\text { argamassa }(\%)\end{array}$ & $\begin{array}{c}\text { cimento/ } \\
\text { agregados }\end{array}$ & $\begin{array}{c}\text { água/ materiais } \\
\text { secos }\end{array}$ \\
\hline 410 & 0,50 & 4,50 & 9,45 \\
\hline
\end{tabular}

Foi utilizado cimento CPII da marca Itaú, areia média e brita $01\left(\mathrm{~d}_{\text {máx }}=19 \mathrm{~mm}\right)$ provenientes da região de São Carlos. Na definição do tipo de cimento foi levada em 
consideração a interferência da velocidade de hidratação, função do tipo de cimento, sobre o comportamento do concreto à fluência. Optou-se pelo uso de brita 01 como agregado graúdo devido sua utilização usual em obras que empregam concreto de resistência intermediária.

\subsubsection{Concretagem}

Nesta série foram moldados 60 corpos-de-prova cilíndricos (destinados aos ensaios de caracterização), 3 prismas para os ensaios de retração e 9 vigas para os ensaios de fluência, conforme especificado na Tabela 7.1. Já a Tabela 7.3 resume o plano de concretagem dos corpos-de-prova.

Tabela 7.3: Plano de concretagem: Fluência-Série1

\begin{tabular}{|c|c|c|c|}
\hline Data & Material & Primeira massada & Segunda massada \\
\hline $13 / 07 / 07$ & $\begin{array}{l}\text { Concreto sem } \\
\text { fibras }\end{array}$ & $\begin{array}{c}10 \text { cilindros } 10 \times 20 \\
1 \text { viga entalhada } \\
\text { (VE-CONC1); } \\
\text { Viga sem entalhe (VSE-CNC). }\end{array}$ & $\begin{array}{l}10 \text { cilindros } 10 \times 20 ; \\
1 \text { viga entalhada } \\
\text { (VE-CONC2); } \\
1 \text { Prisma. }\end{array}$ \\
\hline $17 / 07 / 07$ & $\begin{array}{l}\text { Concreto com } \\
\text { firas }(25 \mathrm{~mm})\end{array}$ & $\begin{array}{c}10 \text { cilindros } 10 \times 20 \\
1 \text { viga entalhada } \\
\text { (VE-CONC1); } \\
\text { Viga sem entalhe (VSE-CNC). }\end{array}$ & $\begin{array}{l}10 \text { cilindros } 10 \times 20 ; \\
1 \text { viga entalhada } \\
\text { (VE-CONC2); } \\
1 \text { Prisma. }\end{array}$ \\
\hline $18 / 07 / 07$ & $\begin{array}{l}\text { Concreto com } \\
\text { fibras }(25 \mathrm{~mm}) \\
\text { e microfibras } \\
(13 \mathrm{~mm})\end{array}$ & $\begin{array}{c}10 \text { cilindros } 10 \times 20 ; \\
1 \text { viga entalhada } \\
\text { (VE-CONC1); } \\
\text { Viga sem entalhe (VSE-CNC). }\end{array}$ & $\begin{array}{l}10 \text { cilindros } 10 \times 20 ; \\
1 \text { viga entalhada } \\
\text { (VE-CONC2); } \\
1 \text { Prisma. }\end{array}$ \\
\hline
\end{tabular}

As concretagens foram realizadas sempre no início da manhã, de forma a minimizar a interferência das variações climáticas que ocorrem ao longo do dia e permitir a realização do acabamento nos modelos com concreto ainda no estado fresco. Conforme se observa na Tabela 7.3, há uma diferença de 4 dias entre o primeiro e o segundo dia de concretagem. $\mathrm{O}$ ideal seria ter efetuado as concretagens em dias consecutivos, entretanto, por conta de um contratempo com a balança utilizada na pesagem dos materiais e à chuva que ocorreu no período, houve um atraso com relação aos prazos desejados.

A Fig. 7.10 ilustra todas as etapas da concretagem desta primeira série de ensaios. Nas fotos $a$ e $b$ tem-se os materiais devidamente dosados para mistura referente a uma etapa de concretagem. O slump-test foi realizado para todas as massadas (foto $c$ ), sendo os valores 
encontrados tabelados (ver Tabela 7.4). Nesta tabela constam também informações sobre a temperatura e umidade relativa para cada dia de concretagem.
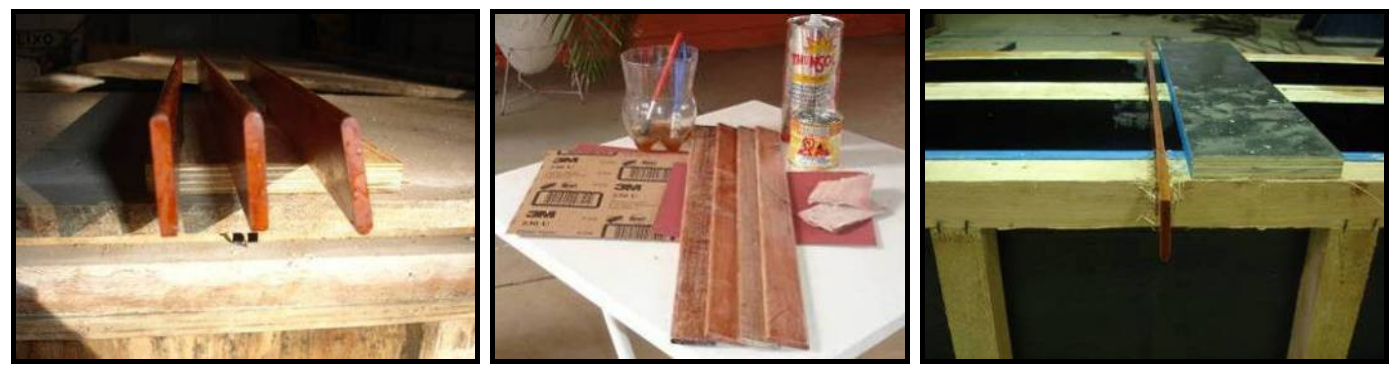

Fig. 7.8: Peça de inserção em madeira para confecção do entalhe.

Tabela 7.4: Concretagem Fluência-Série1: Slump (mm) e condições ambientais.

\begin{tabular}{c|c|c|c|c}
\hline Material & $\begin{array}{c}\text { Primeira } \\
\text { massada }\end{array}$ & $\begin{array}{c}\text { Segunda } \\
\text { massada }\end{array}$ & $\begin{array}{c}\text { Temperatura } \\
\left({ }^{\circ} \boldsymbol{C}\right)\end{array}$ & $\begin{array}{c}\text { Umidade } \\
\text { Relativa (\%) }\end{array}$ \\
\hline Concreto sem fibras & 200 & 200 & 21.6 & 54 \\
\hline Concreto com fibras & 185 & 195 & 16.2 & 80 \\
\hline Concreto com fibras e microfibras & 180 & 170 & 16.5 & 86 \\
\hline
\end{tabular}

Nas duas séries, o entalhe nas vigas foi realizado durante a concretagem, pela utilização de placas de inserção passantes nas fôrmas. Nesta primeira série foram utilizadas placas de madeira. A madeira foi cuidadosamente cortada na espessura de $6 \mathrm{~mm}$, tendo um de seus lados abaulados, de modo que sua geometria ficasse a mais próxima possível da especificada. Essas peças foram lixadas e envernizadas três vezes para impedir que a madeira absorvesse umidade (Fig. 7.8). Nesta série foi também efetuada a concretagem dos blocos de concreto utilizados como peso morto para carregar as vigas de seção íntegra (Fig. 7.9). Para tanto foi utilizado parte de um concreto usinado excedente de outra pesquisa realizada no departamento.

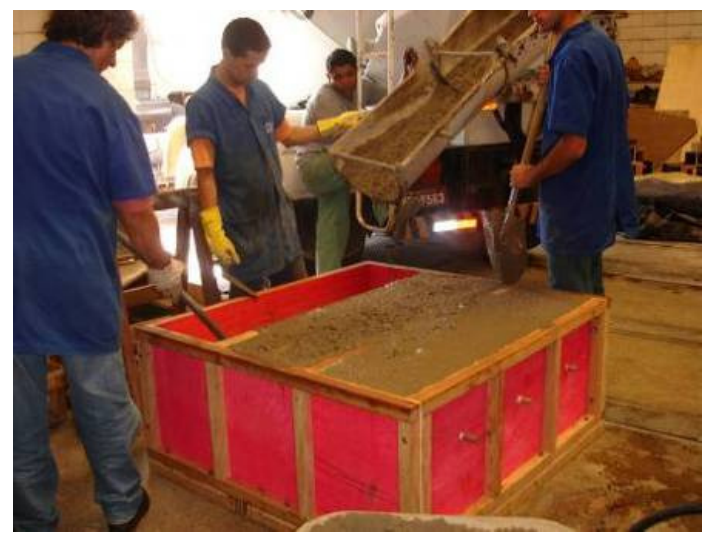

Fig. 7.9: Concretagem dos pesos mortos. 

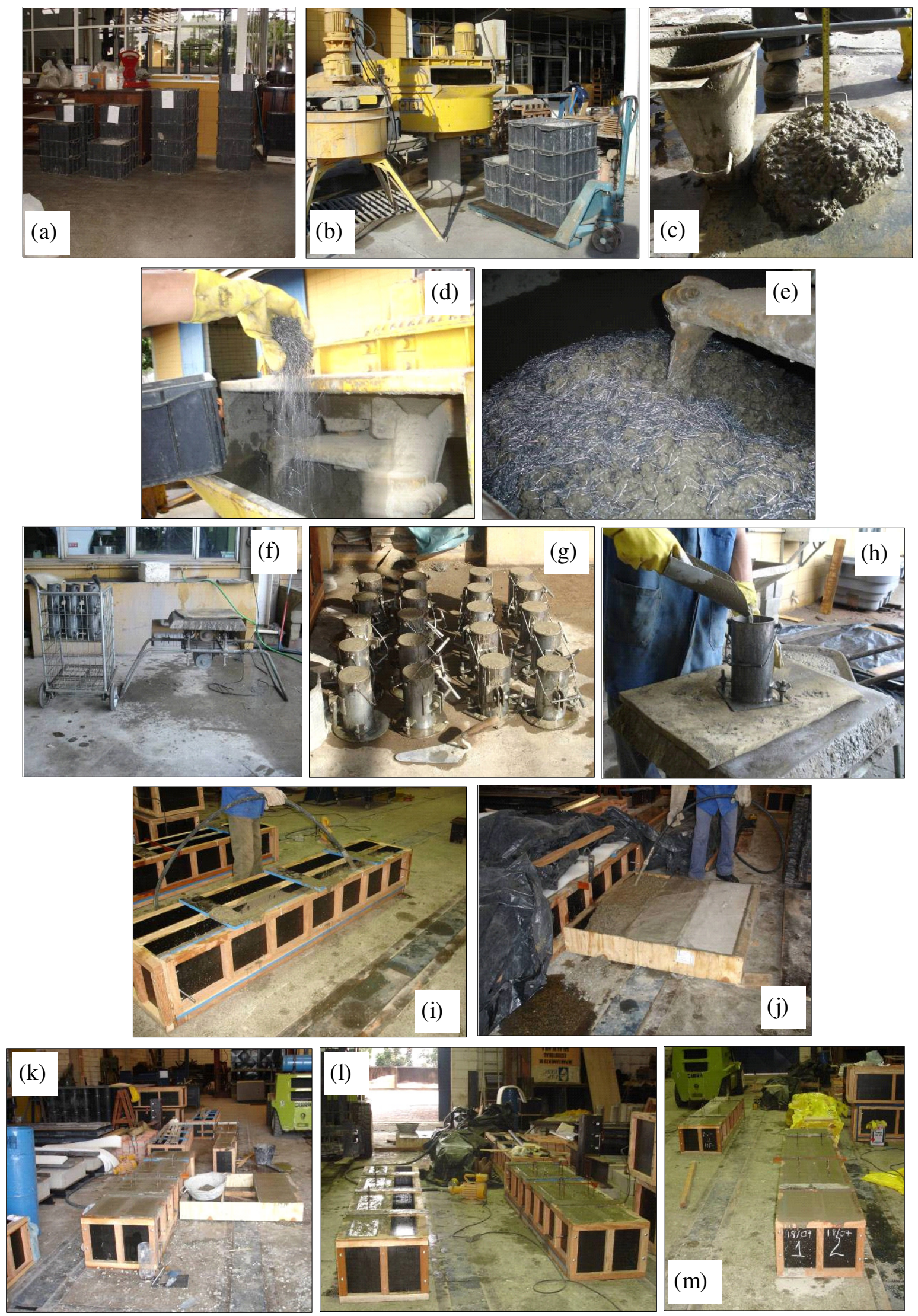

Fig. 7.10: Painel de concretagem - Série 1. 
As fibras foram adicionadas aos poucos sobre a mistura de concreto, de forma a evitar o embolamento e a formação de "ouriços" (Fig. 7.10, fotos d-e). Os corpos-de-prova cilíndricos $(10 \times 20 \mathrm{~cm})$ foram moldados em duas camadas e adensados em mesa vibratória. Já as vigas e os prismas, também moldados em camadas (2 a 3 camadas), foram adensados com mangote vibratório (Fig 7.10, fotos h, i, j).

As fotos de $k$ - $m$ da Fig. 7.10. ilustram o final de cada dia de concretagem, embora as etapas sejam mais nítidas na foto $j$, em que a diferença na coloração dos modelos revela sua moldagem em ocasiões distintas. Nota-se que foram deixados ganchos de ferro de construção de $8 \mathrm{~mm}$ dobrados para permitir o içamento e a desfôrma das vigas.

\subsubsection{Cura e Armazenamento}

Os modelos foram curados e armazenados no galpão de ensaios. Os corpos-de-prova cilíndricos foram desformados após 24 horas da concretagem, já as vigas e os prismas foram desformados apenas em data próxima ao início dos ensaios. Durante todo período de cura e armazenagem os corpos-de-prova foram molhados diariamente. Para controlar ao máximo a evaporação de água, foram colocadas espumas sobre as vigas e os prismas, sendo os eles também cobertos com lona plástica.
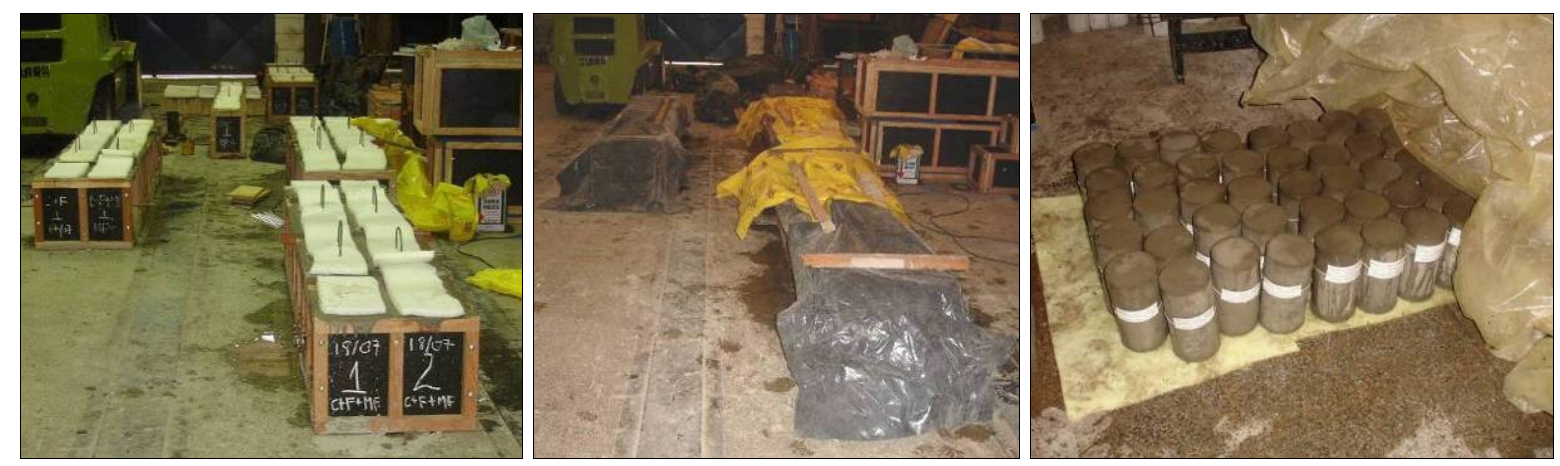

Fig. 7.11: Cura e Armazenamento: Fluência-Série 1.

Os corpos-de-prova cilíndricos foram mantidos em condições semelhantes. Conforme ilustra a Fig. 7.11, estes foram colocados sobre uma camada de espuma e cobertos com lona plástica. Nota-se que todos os corpos-de-prova foram devidamente identificados.

\subsubsection{Preparação dos modelos}

A preparação dos modelos consistiu basicamente na limpeza, furação (para fixação dos componentes da instrumentação), pesagem e corte dos ganchos de içamento (sendo esta última atividade designada apenas para as vigas entalhadas). 
Para a pesagem das vigas, assim como das massas (pesos mortos) foi acoplada ao gancho da ponte rolante uma célula de carga de capacidade de $15 \mathrm{kN}$ (marca Eletrolink), conectada a um indicador de extensometria (modelo TMDE, da Transdutec), de forma que ao içar os modelos, fosse determinado seu peso (Fig. 7.12 e Fig. 7.13).

No caso das vigas entalhadas, o corte dos ganchos deixados para desmoldagem foi necessário devido a questões operacionais. Como estas vigas foram moldadas em posição invertida (por conta do entalhe), os ganchos atrapalhariam o armazenamento, transporte e ensaios dos modelos.

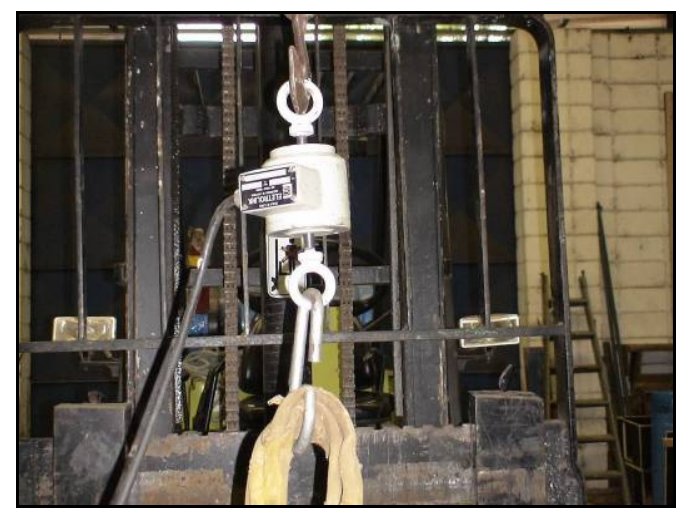

Fig. 7.12: Célula de carga acoplada à ponte rolante.
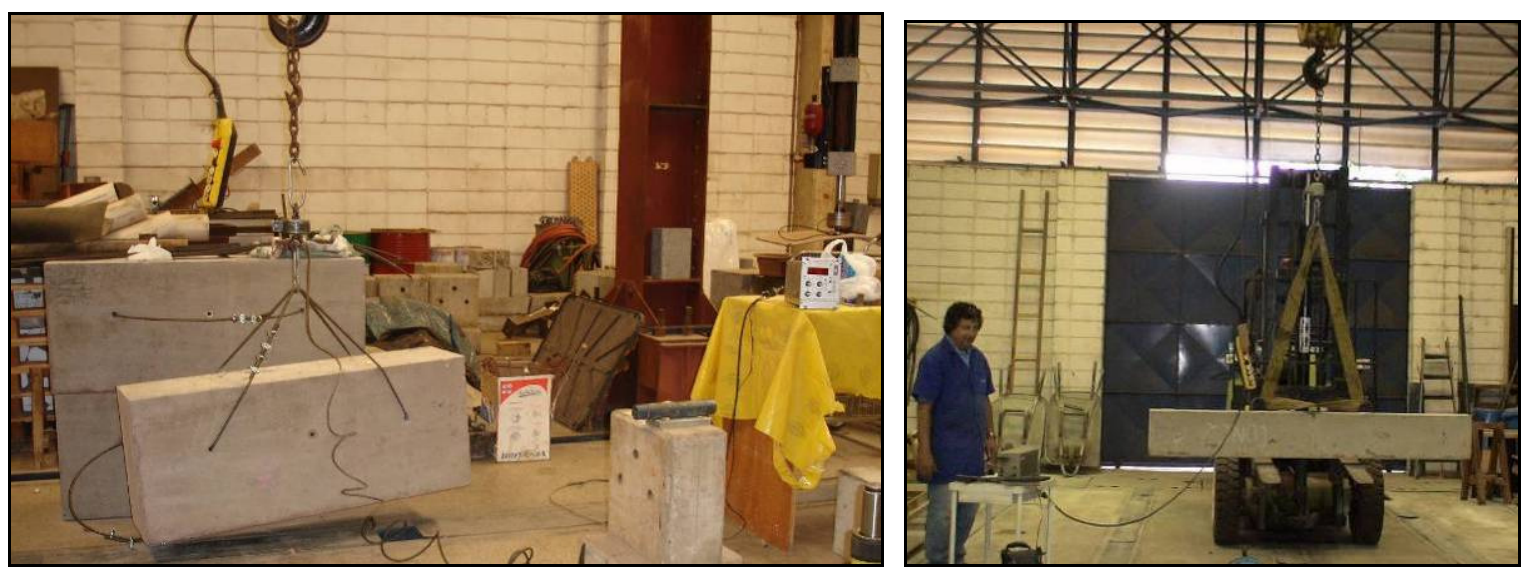

Fig. 7.13: Pesagem dos modelos (vigas e peso-morto) - Série 1

\subsubsection{Fluência - Série 2 (Definitivo)}

Nesta série foi utilizado concreto usinado, e sendo assim, todos os corpos-de-prova foram moldados no mesmo dia. As proporções da mistura utilizada para o concreto, informadas pela empresa fornecedora do concreto, são apresentadas na Tabela 7.5.

Foi utilizado cimento CPII da marca LIZ, brita 01, areia média e pedrisco, aditivo 
retardador de pega da marca Cryso. Para viabilizar a mistura das fibras, foi utilizado superplastificante Glenium 51, a um teor de $1 \%$ do consumo em massa de cimento.

Tabela 7.5: Traço Fluência - Série 2

\begin{tabular}{c|c|c|c|c|c}
\hline $\begin{array}{c}\text { Cimento } \\
(\text { CPII })\end{array}$ & Areia Média & Pedrisco & Brita 01 & Aditivo Glenium & $\begin{array}{c}\text { águal } \\
\text { cimento }\end{array}$ \\
\hline 1 & 2,73 & 1,38 & 2,07 & $0,5 \%$ & 0,41 \\
\hline \hline \multirow{3}{*}{} & $\begin{array}{c}\text { Consumo de } \\
\text { cimento }\left(\mathbf{k g} / \mathbf{m}^{3}\right)\end{array}$ & $\begin{array}{c}\text { teor de } \\
\text { argamassa }\end{array}$ & $\begin{array}{c}\text { cimento/ } \\
\text { agregados }\end{array}$ & $\begin{array}{c}\text { água/materiais } \\
\text { secos }\end{array}$ & \\
\cline { 2 - 5 } & 316 & 0,52 & 6,17 & 5,78 & \\
\hline
\end{tabular}

\subsubsection{Concretagem}

Os procedimentos de mistura das fibras e adensamento dos corpos-de-prova foram análogos aos descritos para a concretagem da primeira série, não sendo, portanto, necessário repeti-los. Nesta série foi utilizada uma placa de inserção metálica, ao invés da de madeira utilizada anteriormente (Fig. 7.15), com o intuito de facilitar sua remoção. A Fig. 7.14 ilustra o concreto sendo descarregado do caminhão diretamente na betoneira do laboratório e alguns modelos já concretados.
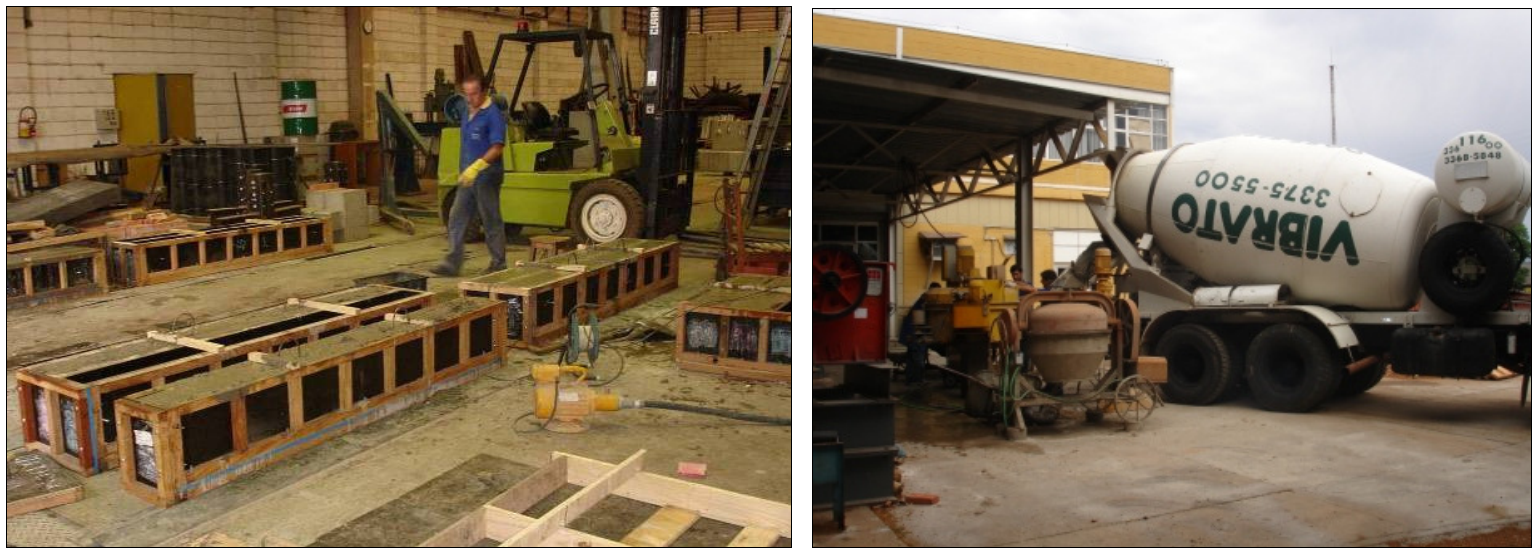

Fig. 7.14: Concretagem - Série 2.

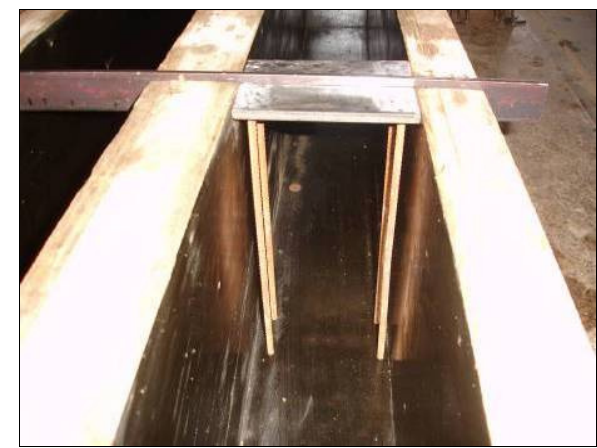

Fig. 7.15: Placa de inserção e chapa metálica. 
Sabe-se que o teor de fibras utilizado é função do volume de concreto. Logo, para garantir que a quantidade de fibras separada para cada massada correspondesse ao teor estipulado na dosagem, a quantidade de concreto transferida do caminhão para a betoneira deveria ser conhecida e/ou controlada. Para tanto, o volume interno da betoneira foi previamente medido, de forma a estipular a altura referente à betoneira que conduzisse ao volume de concreto desejado. Desta forma, a betoneira era preenchida gradativamente, ligada algumas vezes para homogeneizar a distribuição do concreto em seu interior, até certa altura, delimitada por marcações nas paredes internas da betoneira e também por uma barra de controle (ou seja, de altura conhecida).

Foi solicitado concreto com slump $10 \pm 1(\mathrm{~cm})$, contudo o material entregue tinha slump de $8 \pm 1(\mathrm{~cm})$, o que prejudicou a trabalhabilidade para adição das fibras. Após a concretagem dos modelos de referência (ou seja, sem fibras), deram-se início as operações de mistura das fibras descritas anteriormente. Novamente foi medido o abatimento do tronco de cone, o qual já havia caído para $6 \mathrm{~cm}$. Após a colocação do superplastificante, o slump subiu para $15 \mathrm{~cm}$.

Durante a concretagem, realizada logo no início da manhã, o clima estava nublado e bastante úmido, sendo que no final da moldagem teve início uma chuva fina. Desta forma, acredita-se que não houve interferência das condições ambientais sobre o concreto fresco utilizado nos últimos modelos, e se esta existiu, foi positiva.

\subsubsection{Cura e Armazenamento}

Da mesma forma que para a Série 1, os modelos foram curados e armazenados no galpão de ensaios. Os corpos-de-prova cilíndricos foram desformados após 24 horas da concretagem, já as vigas e os prismas foram desformados apenas em data próxima ao início dos ensaios (13 dias após a moldagem). Durante todo período de cura e armazenagem os corpos-de-prova foram molhados diariamente. Para controlar ao máximo a evaporação de água, foram colocadas espumas sobre as vigas e os prismas, sendo eles também cobertos com lona plástica.

\subsubsection{Preparação dos modelos}

A preparação dos modelos consistiu basicamente na limpeza, furação (para fixação dos componentes da instrumentação), pesagem e corte dos ganchos de içamento (sendo esta última atividade designada apenas para as vigas entalhadas). Os procedimentos envolvidos 
nestas atividades foram realizados de forma daquela descrita anteriormente, com a vantagem de que, devido à prática adquirida com a Série Piloto, o tempo despedido foi muito menor.

\subsection{Ensaios}

\subsubsection{Série 1 (Piloto)}

\subsubsection{Ensaios de Caracterização}

Foram moldados 2 corpos-de-prova para cada ensaio (conforme recomendado pela NBR 8224:1982), sendo previstas inicialmente 5 idades de ensaio. Considerando os três materiais e a realização de ensaios de compressão axial e diametral, foram moldados ao todo 60 corpos-de-prova. Contudo, os ensaios foram realizados apenas em 4 idades (por conta da duração dos ensaios de fluência ser menor do que o esperado), a saber: 14, 28, 60 (início dos ensaios de fluência) e 105 (término dos ensaios de fluência). Deste modo, na última idade (105 dias) foram ensaiados 4 corpos-de-prova por vez.

- Compressão Axial

A partir dos ensaios de compressão axial, além da resistência à compressão foram obtidos também os valores do módulo de elasticidade em diversas idades. Para a realização destes ensaios foram observadas as recomendações das normas NBR 5739:1994, para determinação da resistência à compressão e NBR 8522: 2003, para determinação do módulo de elasticidade.

Os ensaios realizados aos 14 dias foram feitos na máquina de ensaios ELE, controlada por computador, com capacidade de 200 toneladas à compressão. Não foi necessário retificar as extremidades dos corpos-de-prova, sendo utilizados discos de neuprene. Já aos 28 e 60 dias após a moldagem, os ensaios foram realizados na máquina de ensaios servo-hidráulica Instron, modelo 8506, com capacidade de 250 toneladas à compressão, utilizando capeamento de enxofre para regularizar os corpos-de-prova. Aos 105 dias após a moldagem, foi utilizada a máquina de ensaios universal da marca Instron, modelo 5595, servo-hidráulica, de capacidade de 150 toneladas, utilizando corpos-de-prova capeados com enxofre. As Figuras Fig. 7.16 e Fig. 7.17 ilustram os ensaios realizados nas diferentes máquinas.

Para medição de deslocamentos lineares longitudinais, utilizaram-se transdutores de 
deslocamento à base de extensômetros elétricos, apoiados nas duas laterais do CP. Os transdutores foram colocados na região central dos $\operatorname{cp}(\mathrm{s})$, a fim de evitar o efeito de confinamento das extremidades. Como a superfície do corpo-de-prova não é completamente lisa, foram utilizados dois transdutores; desta forma, utiliza-se a média das medidas e minimizam-se possíveis erros. Os transdutores utilizados têm base de medida de $200 \mathrm{~mm}$, sensibilidade de $0,001 \mathrm{~mm}$ e capacidade de $10 \mathrm{~mm}$.

Nos ensaios realizados na Instron, os deslocamentos eram aplicados segundo a taxa de $0,005 \mathrm{~mm} / \mathrm{s}$ e registrados pelo sistema 5000 de aquisição de dados, juntamente com os valores das forças, a cada 1 segundo. Nos ensaios executados na máquina ELE, a carga era aplicada à velocidade de $0,94 \mathrm{kN} / \mathrm{s}$, e os valores de força e deslocamento do transdutor anotados manualmente a cada $10 \mathrm{kN}$. Nestes ensaios, foi utilizado apenas um transdutor.
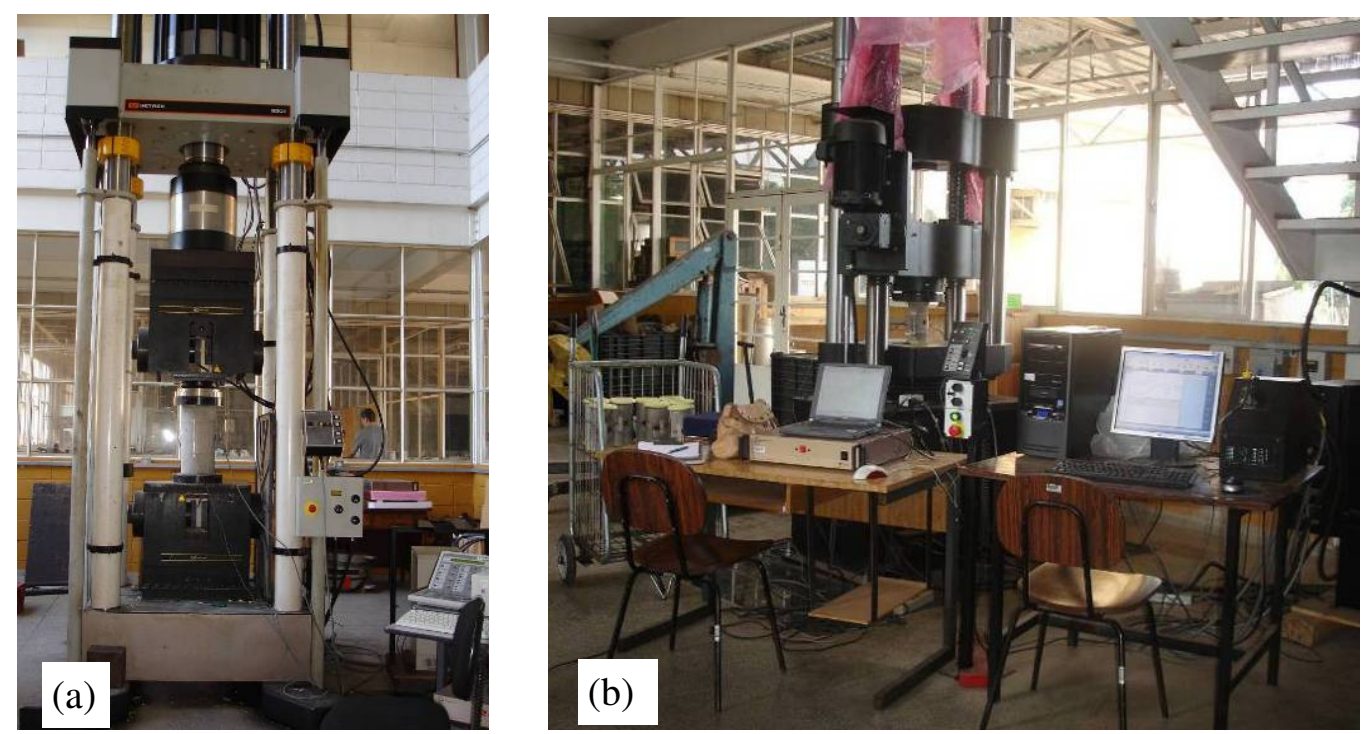

Fig. 7.16: Compressão axial: (a) Instron - 8506 (250 ton.) (b) Instron - 5595 (150 ton.).

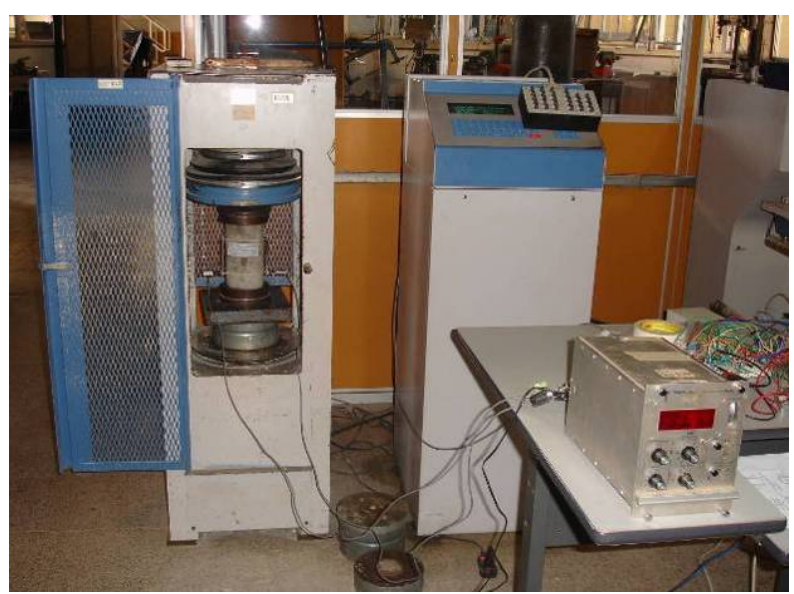

Fig. 7.17: Compressão Axial - Máquina de ensaios ELE. 
Nos ensaios realizados à idade de 28 dias após a moldagem, foi também determinado, para cada série, em cada corpo-de-prova ensaiado à compressão axial, o valor do coeficiente de Poisson. O conhecimento deste parâmetro do material é necessário para a simulação numérica. Além disso, desejava-se avaliar se haveria alteração desta propriedade entre os materiais estudados. Para medir as deformações transversais, foram colados extensômetros diametralmente opostos na região central dos corpos-de-prova.

- Compressão Diametral

A resistência à tração foi determinada por ensaios de compressão diametral, em corpos-de-prova 10x20 cm, observando as recomendações prescritas na NBR 7222:1994. Os ensaios foram realizados na máquina de ensaios ELE (Fig. 7.18), com taxa de aplicação do carregamento de 2,4 kN/s, adequada às dimensões dos corpos-de-prova. Sabe-se que a resistência à tração obtida por compressão diametral $\left(f_{t, d}\right)$ é em torno de $90 \%$ da resistência à tração direta $\left(f_{t}\right)$, entretanto, foram adotados nesta pesquisa os valores de $f_{t, d}$ nos cálculo, sem correção.
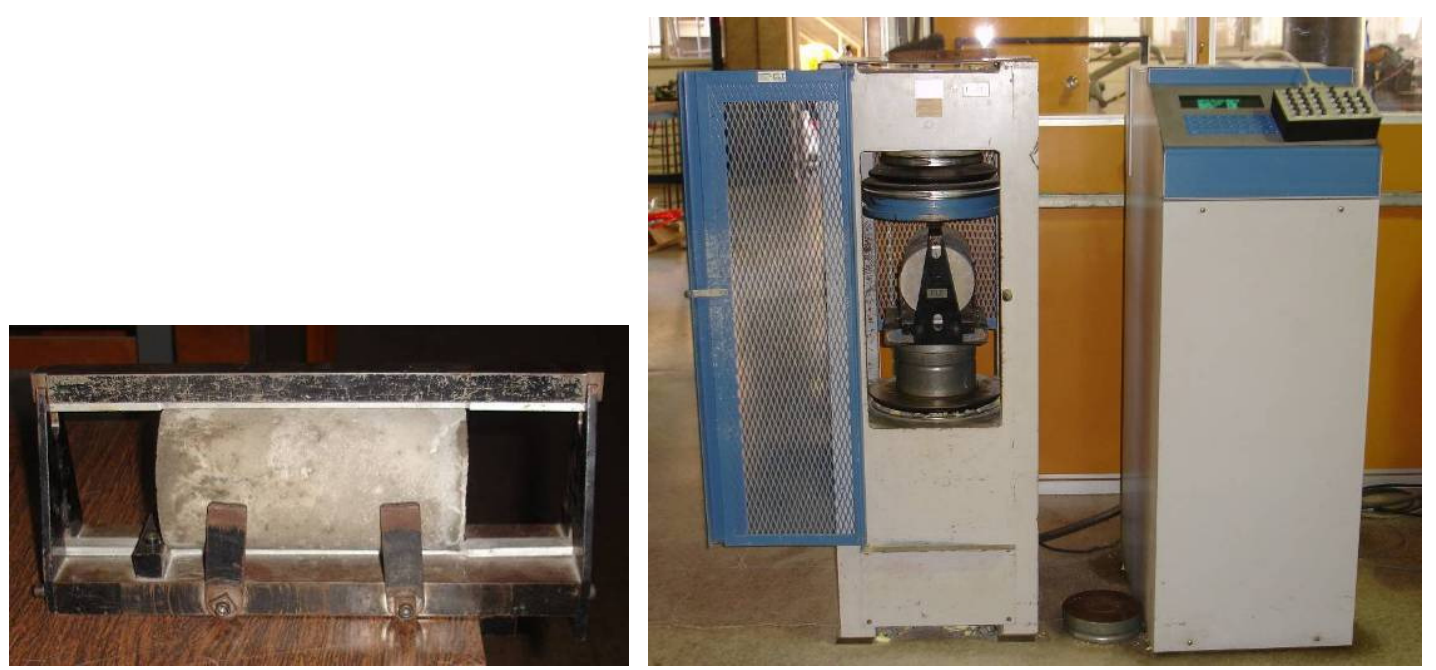

Fig. 7.18: Compressão diametral - máquina de ensaios ELE.

\subsubsection{Flecha Inicial}

As vigas foram bi-apoiadas com vãos de $1,8 \mathrm{~m}$ e 2,0 $\mathrm{m}$ para as vigas entalhadas e não entalhadas, respectivamente. Um dos apoios restringe a translação nas direções vertical e horizontal, enquanto que o outro restringe apenas movimentos verticais, evitando que as peças ficassem hipostáticas. Para garantir a prática desta vinculação, foram utilizados:

- Roletes de aço de 2 polegadas de diâmetro $(5,08 \mathrm{~cm})$ e $9 \mathrm{~cm}$ de comprimento, 
banhados com zinco;

- Peças de suporte para apoio fixo (4x6 in), com encaixe para os roletes, de ferro zincado;

- Peças de suporte para apoio móvel (4x6 in), de ferro banhadas com zinco;

- Peças de transição para apoio, de ferro banhadas com zinco, $(5 \times 15 \mathrm{~cm})$.

Essas peças estão ilustradas no esquema da Fig. 7.36 e podem também ser identificadas nas fotografias dos ensaios (Fig. 7.20 e Fig. 7.44). A colocação da peça de transição na face inferior das vigas sobre os apoios objetiva distribuir melhor as tensões nesta região, evitando o esmagamento do concreto. Essas peças foram fixadas às vigas com massa plástica, durante a preparação dos modelos anterior aos ensaios. O banho de zinco aplicado às peças permite maior durabilidade, pois protege o aço da corrosão superficial.

Estes ensaios foram realizados para determinação da flecha elástica inicial de todas as vigas, de ambas as séries, devido ao peso próprio e também devido à carga aplicada (no caso das vigas sem entalhe). Trata-se de ensaios rápidos, mas, por conta das manobras envolvidas com transporte e posicionamento das vigas, a duração para completar o conjunto das nove vigas gira em torno de 1 a 1,5 dias. Desta forma, sua realização preferencialmente teve início alguns dias antes da previsão de início dos ensaios de longa-duração.

Contudo, na primeira série de ensaios, por conta de adaptação do sistema de instrumentação, estes ensaios foram realizados, repetidas vezes, durante um período de 15 dias, até se obter a instrumentação mais adequada (conforme descrito no item 7.6.4). Na segunda série, com a resolução dos problemas encontrados na primeira, os prazos previstos foram cumpridos, sendo estes ensaios realizados aos 15 dias após a moldagem.

Definida a instrumentação das vigas, a realização deste ensaio é bastante simples. Inicialmente as vigas são posicionadas sob as condições de contorno dos ensaios de longa duração. Para medição dos deslocamentos foram utilizados relógios comparadores das marcas Käfer e Huggenberger, ambos com curso de $5 \mathrm{~mm}$ e previsão de 0,001 mm.

Para não correr o risco de danificar os relógios, ou mesmo a régua metálica, o transporte e posicionamento das vigas eram feito sem a instrumentação. Entretanto, imediatamente após o posicionamento, a flecha devida ao peso próprio já havia ocorrido, sem seu devido registro. 
CARREGAMENTO: PESO PRÓPRIO

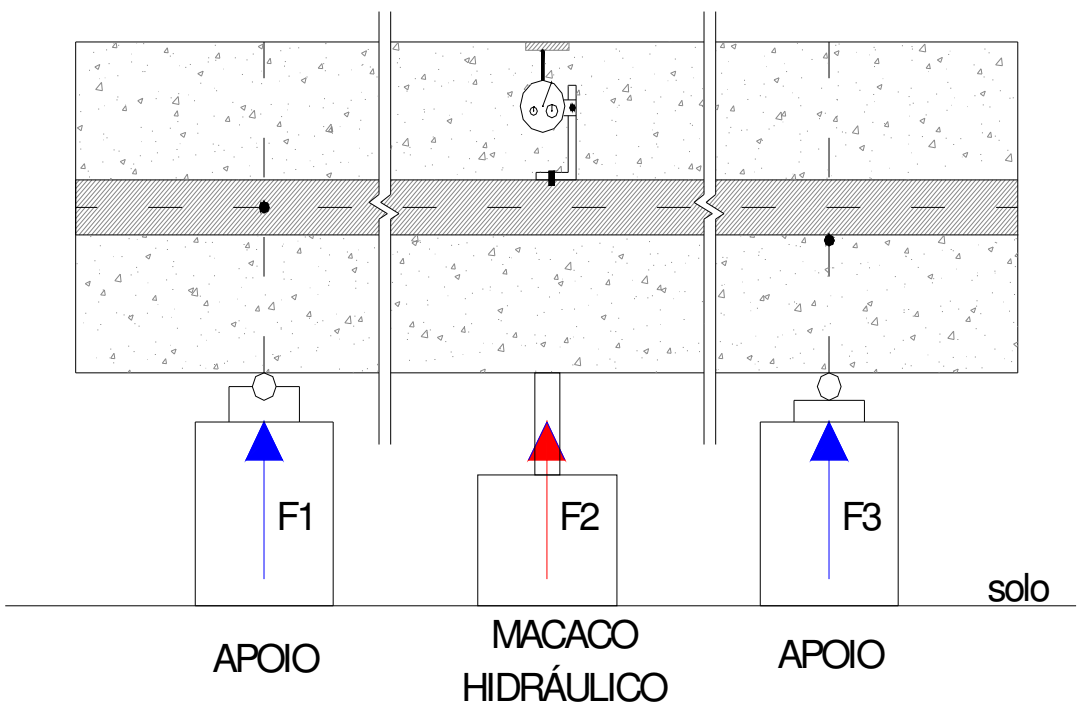

Fig. 7.19: Determinação da flecha inicial devida ao peso-próprio.

Para correta medição desta flecha, a viga deveria estar nivelada e instrumentada para posterior "aplicação" do carregamento (o peso próprio). Desta forma, depois de posicionadas e instrumentadas, o nivelamento foi realizado utilizando um macaco hidráulico, localizado sob o meio do vão. A carga era aplicada até atingir o valor limite equivalente à reação de um terceiro apoio, central (reação F2 da Fig. 7.19). Conhecidas as massas de cada viga (todas as vigas foram pesadas conforme apresentado na página 169), determinaram-se os valores das reações com auxílio do programa Ftool. No caso da determinação da flecha inicial devida à carga concentrada aplicada, o procedimento adotado foi semelhante. Após a colocação da viga sobre os apoios, o bloco de concreto (peso morto) era posicionado sob o ponto de aplicação com auxílio da empilhadeira. Os cabos de aço de sustentação eram devidamente presos, a viga instrumentada e então se abaixavam lentamente os braços da empilhadeira, evitando aplicação da carga de forma abrupta.
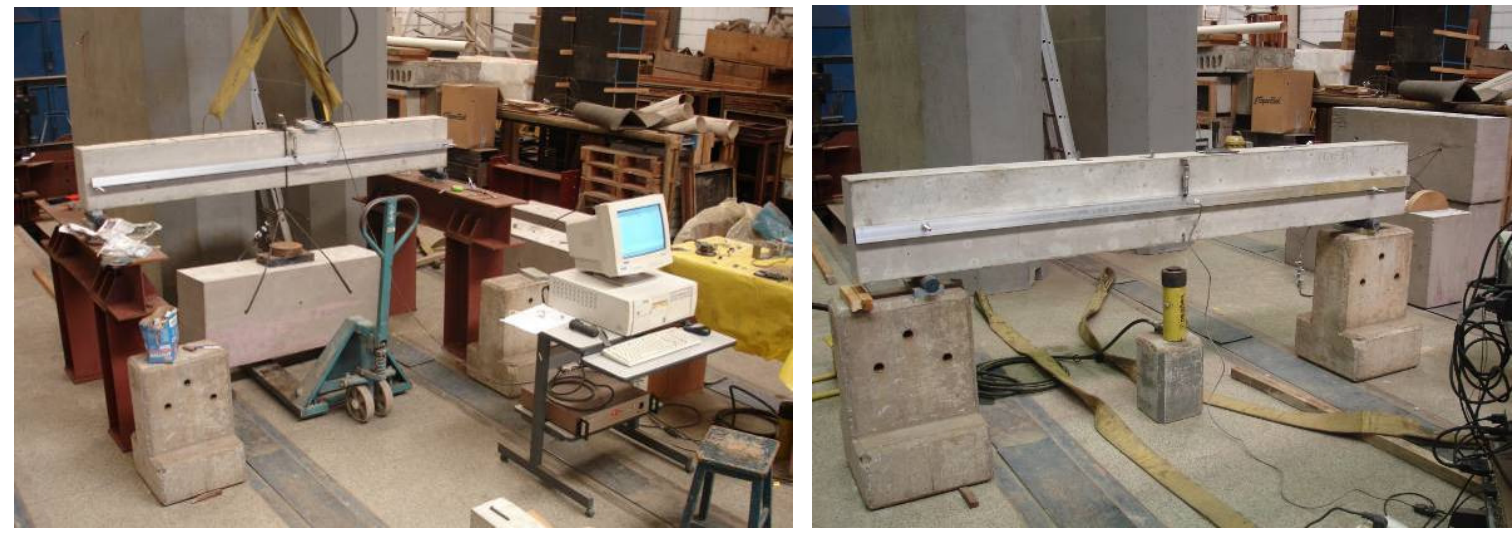

Fig. 7.20: Ensaios de flecha inicial - Série 1 (Piloto). 


\subsubsection{Ensaios de Retração}

O objetivo dos ensaios de retração foi avaliar ao longo do tempo, as deformações em prismas de concreto decorrentes da retração autógena, retração por secagem e variação de temperatura. Os prismas tinham a mesma seção transversal das vigas utilizadas nos ensaios de fluência, entretanto, o comprimento era menor. Estes corpos-de-prova foram colocados no piso, sem aplicação de carregamento algum. As medidas das deformações iniciaram-se juntamente com os ensaios de fluência, logo após a colocação dos modelos na câmara climatizada. Os ensaios de retração iniciaram-se juntamente com os de fluência (aos 60 dias).

O equipamento utilizado nas leituras de deslocamento foi um relógio comparador eletrônico marca Mitutoyo, com precisão de $1 \mu \mathrm{m}(0,001 \mathrm{~mm})$ e curso de $\pm 5 \mathrm{~mm}$. O usuário pode ajustar os cursos do relógio referentes a medidas de prolongamento (dilatação) ou encurtamento (retração), sendo a medida de referência uma haste metálica padrão de $30 \mathrm{~cm}$ que acompanha o relógio.

Para encaixe do relógio, foram coladas à superfície do concreto, em linha reta, peças triangulares de alumínio, à distância que permitisse o posicionamento do relógio. A superfície era previamente limpa com pano úmido em solução de álcool isopropílico e demarcada. Para fixação destas peças, foi utilizado nesta série adesivo de cura rápida a base de cianoacrilato, da marca Super-Bonder. Este adesivo promove uma aplicação limpa e rápida além de permitir maior precisão do posicionamento da peça, porém, com o tempo algumas peças se soltaram.

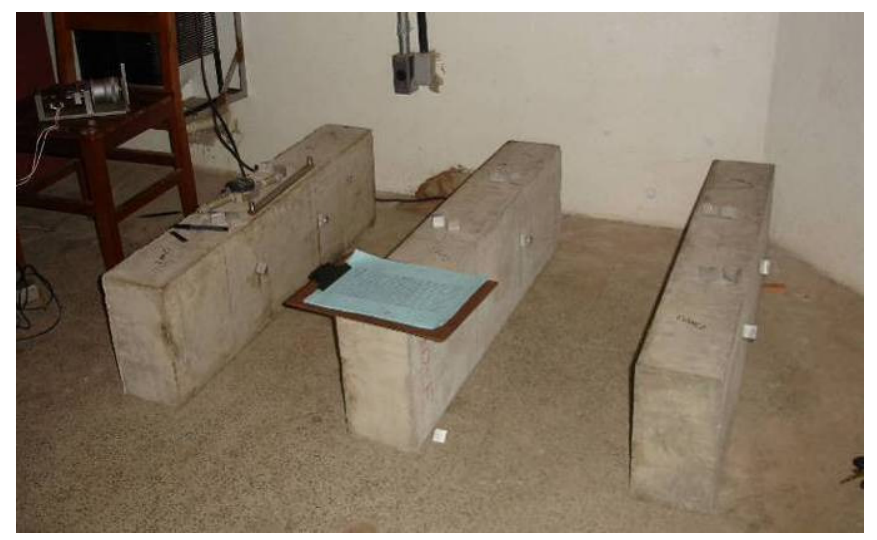

Fig. 7.21: Ensaio de Retração - Série 1

Nesta primeira série foram feitas leituras nas duas laterais, e duas leituras na face superior do prisma. Contudo, notou-se que as leituras feitas na face superior são mais confiáveis do que aquelas realizadas nas faces laterais, de forma estas últimas leituras não foram utilizadas para análise dos resultados. Isto decorre dos fatores: escorregamento das 
peças de encaixe durante sua fixação, incorreto posicionamento do relógio devido à ação de seu peso próprio (verificou-se que a tentativa de sustentar o relógio com as mãos pode acarretar variações nas leituras).

Tanto a haste, como o relógio, permaneceram na câmara climatizada todo o tempo. Desta forma, eventuais alterações no funcionamento do conjunto devidas a variações de temperatura são descartadas. A seguir é apresentado o roteiro realizado para realização das leituras: o relógio era ligado, com o curso livre, posteriormente posicionado na haste e zerado, em seguida realizava-se a leitura. Para cada ponto de leitura esse procedimento foi repetido 3 vezes.

\subsubsection{Ensaios de Fluência}

Os ensaios de fluência são análogos aos de flecha inicial. Entretanto, além da leitura do deslocamento vertical da linha de carga, foi feito um monitoramento da abertura do entalhe, utilizando para tanto os extensômetros elétricos de resistência do tipo "clips-on-gage" desenvolvidos no laboratório para medição do CMOD e ponte de balanceamento portátil da Transdutec-Brasil. As leituras dos deslocamentos foram feitas de acordo com os seguintes intervalos de tempo: a cada 12 horas, até completar uma semana; diariamente, até o término dos ensaios (após 45 dias).

Conforme já foi comentado, os ensaios de fluência foram realizados no interior da câmara climatizada do LE. Durante a Série 1 de ensaios o software SIMPLE Ambiental não estava instalado, e, portanto, não havia um sistema de controle acionado. Entretanto, dado o isolamento térmico das paredes sanduíche, a temperatura e a umidade não sofreram grandes variações sendo $25,9^{\circ} \mathrm{C}$ e $57,1 \%$ os valores médios, e $0,8^{\circ} \mathrm{C}$ e $4,8 \%$ os desvios padrão, respectivamente.

O principal fator de viabilização destes ensaios diz respeito à questão operacional envolvida no transporte e posicionamento de todas as vigas no interior da Câmara. Esta questão está adequadamente apresentada no item 7.6.3, em Dificuldades encontradas.

Outra dificuldade encontrada durante esta primeira série foi o monitoramento da abertura do entalhe. Por problemas construtivos do clip (não identificados nos testes realizados até então), houve a necessidade de realizar vários outros testes visando à construção de um dispositivo mais confiável para leituras de longa duração (ver item 7.6.5, de Dificuldades encontradas). Apesar de quantitativamente os resultados serem inválidos, 
qualitativamente foram úteis, como se discute no Capítulo 7. Possivelmente o fato da porta da câmara ser aberta inúmeras vezes durante o período de testes do dispositivo de medição do CMOD contribuiu para as alterações na umidade relativa do ar em seu interior.

As vigas carregadas foram apoiadas sobre estruturas metálicas pertencentes ao laboratório, de acordo com configuração ilustrada na Fig. 7.23-b. Já as vigas entalhadas, foram mantidas em uma prateleira metálica, especialmente projetada de forma a permitir o posicionamento dos modelos por etapas. O processo envolvido na montagem destes ensaios está apresentado passo a passo no painel fotográfico da Fig. 7.34. A Fig. 7.23-a ilustra a configuração final da prateleira, de três patamares (cada um abrigando duas vigas do mesmo material). Para medição dos deslocamentos foram utilizados relógios comparadores das marcas Käfer e Huggenberger, ambos com curso de $5 \mathrm{~mm}$ e previsão de 0,001 mm.

Para realização das leituras foi utilizado o aparelho "Ponte de balanceamento em zero", do tipo portátil, de fabricação nacional da firma brasileira Transdutec (Fig. 7.23-b). Neste aparelho a primeira providência antes de se iniciar a medição, é a obtenção e o registro da leitura de referência: após a conexão do extensômetro (clip) ao aparelho e o ajuste do fator do extensômetro, ajusta-se o potenciômetro do circuito de balanceamento até que o galvanômetro indique o valor zero; o valor indicado nesse momento no mostrador do potenciômetro é a leitura de referência. Ocorrendo uma deformação no extensômetro (clip), a indicação do galvanômetro sairá do zero, faz-se então uma nova operação de ajustar o potenciômetro do circuito de balanceamento para zerar novamente o galvanômetro, e registrase a leitura no mostrador.
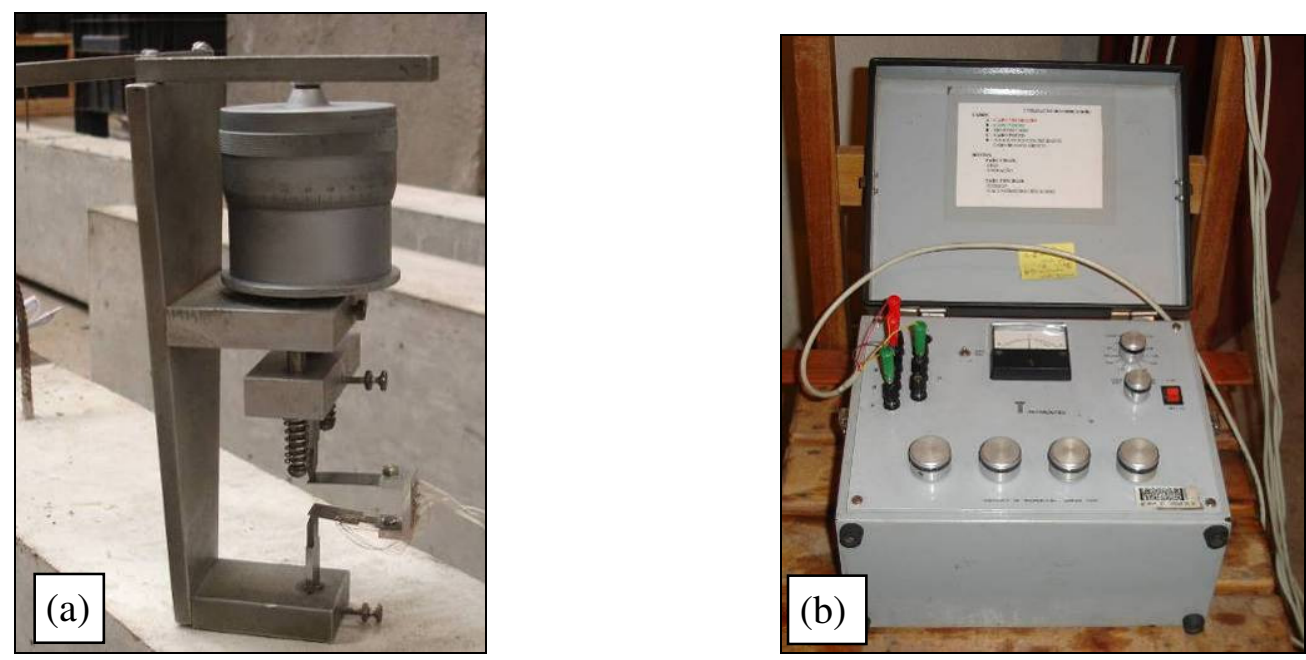

Fig. 7.22: Equipamentos utilizados em conjunto com os clips: (a) Micrômetro, para calibração, (b) Ponte de balanceamento no zero. 

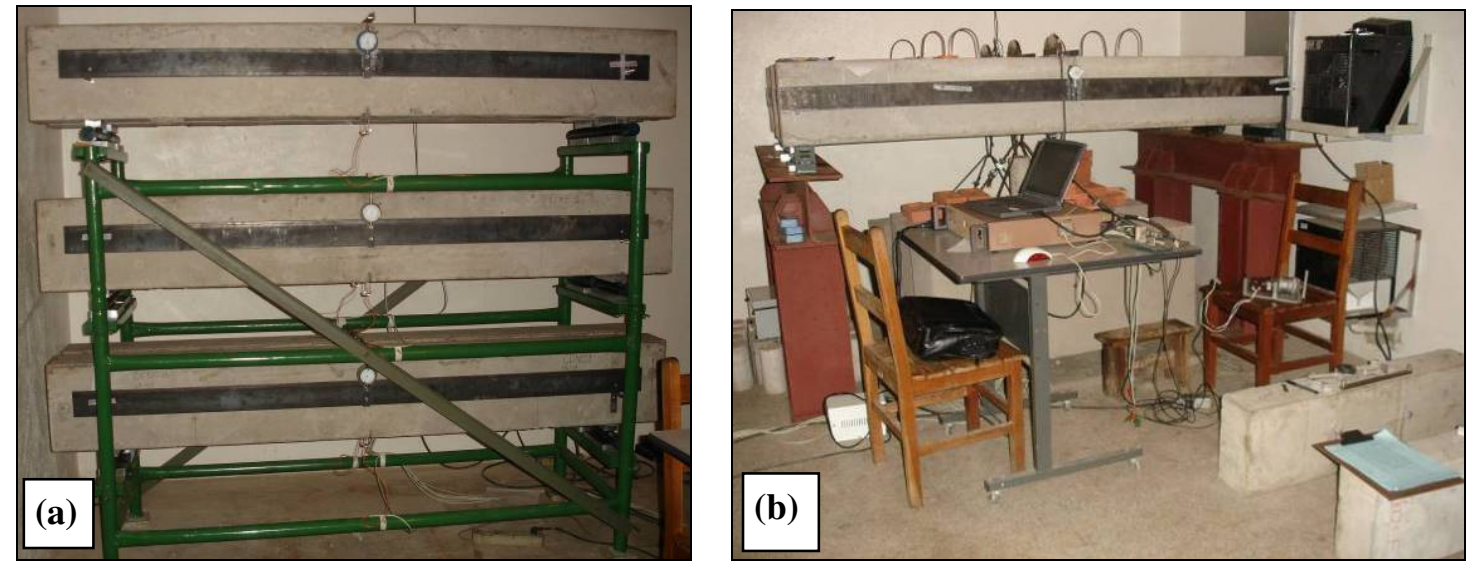

Fig. 7.23: Medição de flechas diferidas (Série 1): (a) Vigas entalhadas, (b) Vigas carregadas.

Apesar de o procedimento parecer trabalhoso, este aparelho oferece maior liberdade aos usuários, no sentido de que, entre leituras sucessivas, pode ser desconectado e utilizado em outro ensaio sem problemas. Além disso, pequenas variações da tensão de excitação não afetam as leituras, uma vez que elas resultam da diferença entre a tensão de saída da ponte de extensômetros e a ponte de referência interna, conferindo confiabilidade em medições de longa duração (Takeya, 2003).

O valor da abertura do entalhe em um tempo t após o início do ensaio, em um tempo $\mathrm{t}_{0}$, portanto, é obtida através da diferença entre as leituras feitas em $\mathrm{t}$ e $\mathrm{t}_{0}$, dividida pela constante de calibração de cada clip. Essa constante e a responsável pela conversão das medidas de tensão (Volts) em deslocamento $(\mathrm{mm})$. A calibração dos clips foi feita com auxílio de um micrômetro, conforme ilustra a Fig. 7.23-a.

\subsubsection{Ensaios Dinâmicos}

Os ensaios dinâmicos de vibração livre foram efetuados em todas as vigas, após 27 dias da moldagem (anteriormente aos ensaios de fluência) e aos 107 dias (depois de finalizados os ensaios de fluência). Para tanto, as vigas foram penduradas por cabos de aço (5/16" de diâmetro) pelos pontos nodais do primeiro modo de vibração (condição livre-livre). Para o primeiro modo de vibração, os pontos nodais situam-se a 0,224L de cada extremidade, sendo L o comprimento do prisma.

Anteriormente à realização dos primeiros ensaios dinâmicos, a partir do módulo de elasticidade obtido nos ensaios de caracterização e dados da geometria e densidade das vigas, foram estimadas as frequiências naturais de vibração do modo I, a fim de verificar se os equipamentos disponíveis seriam adequados para realização dos ensaios. 
Esta estimativa foi feita através da expressão:

$$
f=\frac{K_{n}}{2 \cdot \pi} \sqrt{\frac{E \cdot I}{m \cdot L^{3}}}
$$

Na qual:

$f \quad$ : freqüência fundamental transversal $(\mathrm{Hz})$;

E : módulo de elasticidade do material $\left(\mathrm{N} / \mathrm{m}^{2}\right)$;

I : : momento de inércia da seção $\left(\mathrm{m}^{4}\right)$;

M : massa total da amostra $(\mathrm{kg})$;

L : comprimento da amostra (m);

$\mathrm{K}_{\mathrm{n}} \quad$ : coeficiente que depende das condições de contorno e do modo de vibração. Para sistemas contínuos, viga livre-livre, $\mathrm{K}_{\mathrm{n}}=22,3733$ para o primeiro modo de vibração.

Após esta verificação, os ensaios foram realizados seguindo o esquema da Fig. 7.24, sendo utilizados os seguintes equipamentos: martelo de impacto (marca Endevco); sistema de aquisição System 6000 (marca Vishay Measurements Groups), sistema de aquisição de dados para acelerometria (marca Data-Physics) e acelerômetro piezoelétrico (marca Endevco).

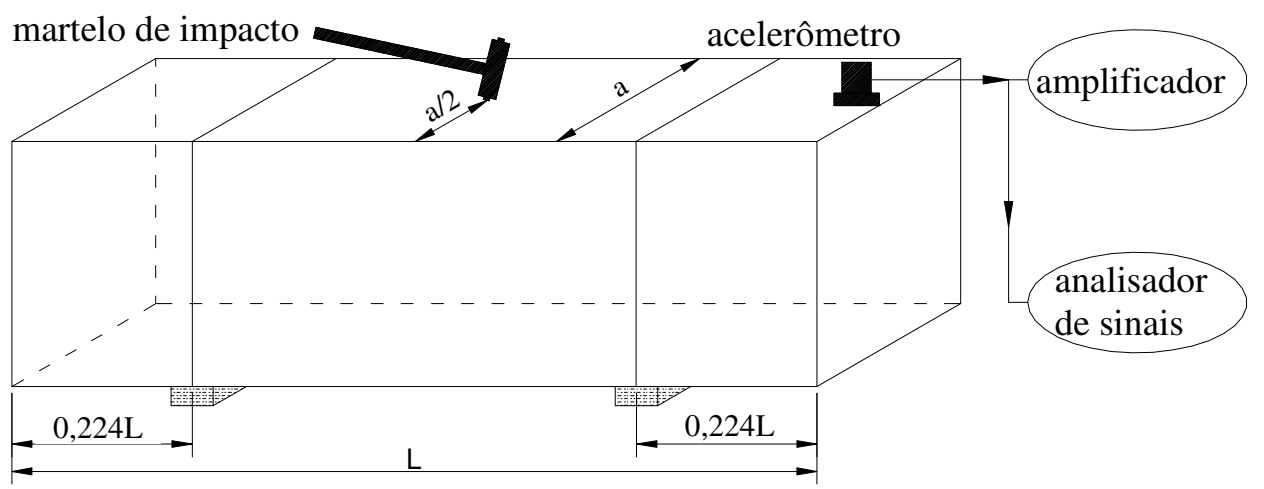

Fig. 7.24: Esquema de ensaio dinâmico para determinação da freqüência fundamental no modo I.

Para cada viga foram feitas duas medidas (uma referente à metade do comprimento e a outra na extremidade oposta ao acelerômetro). Na Fig. 7.26 têm-se a Função de Resposta em Frequiência (FRF) obtida durante os ensaios. A Fig. 7.25 ilustra a realização dos ensaios dinâmicos das peças ainda no estado íntegro, ou seja, anteriormente aos ensaios de longa duração. 


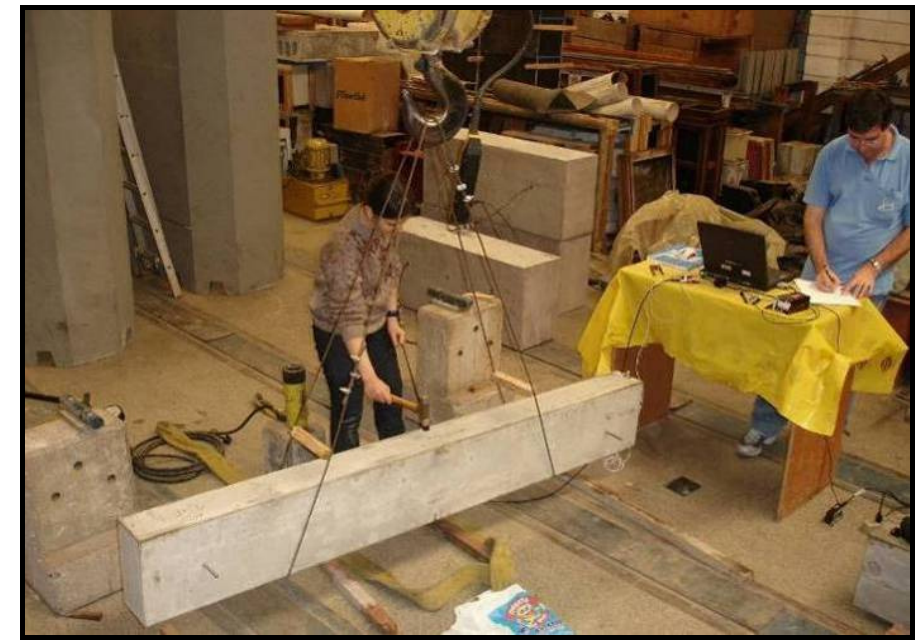

Fig. 7.25: Ensaios dinâmicos - Série 1

Sabe-se que a posição dos pontos nodais para corpos-de-prova prismáticos entalhados não é a mesma definida para aqueles de seção íntegra (ou seja, sem entalhe), visto que, dada a variação da rigidez na posição central, ocorre a tendência das coordenadas dos pontos nodais "migrarem" em direção ao entalhe. Apesar de deduzidas para outra geometria, as expressões propostas por Ferreira, et. al. (2007) foram utilizadas para estimar os pontos nodais das vigas entalhadas. As coordenadas encontradas distariam apenas $1,5 \mathrm{~cm}$ daquelas normalmente utilizadas, representando uma diferença mínima de 3\%. Desta forma, foram utilizadas para todas as vigas as mesmas coordenadas nodais $(0,224 L)$.

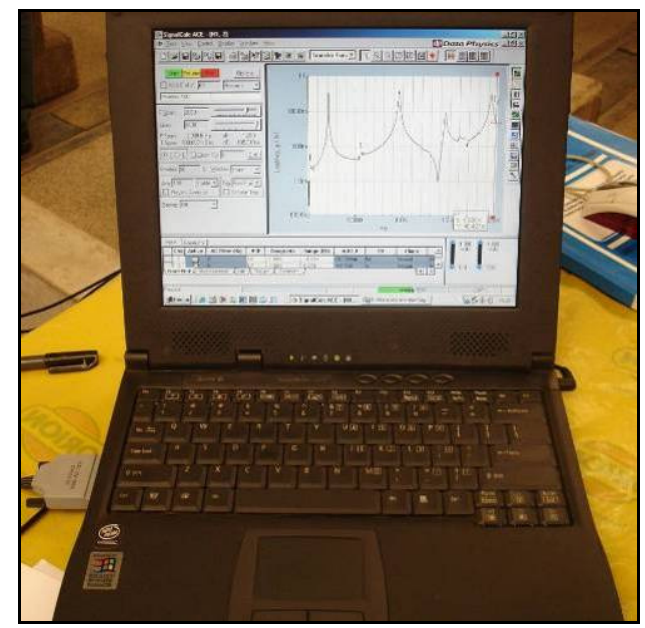

Fig. 7.26: FRF obtida pelo sistema de aquisição. 


\subsubsection{Série 2 (Definitivo)}

\subsubsection{Ensaios de Caracterização}

Foram moldados $3 \mathrm{cp}(\mathrm{s})$ para cada ensaio, sendo previstas inicialmente 4 idades de ensaio. Considerando os três materiais e a realização de ensaios de compressão axial e diametral, seriam necessários $72 \mathrm{cp}(\mathrm{s})$, entretanto foram moldados ao todo 81 (9 a mais, utilizados para determinação da resistência à compressão aos 7 dias). Até o momento, foram efetuados ensaios aos 7, 14 e 28 dias.

- Compressão Axial

Os ensaios de compressão axial para determinação da resistência à compressão e do módulo de elasticidade foram feitos seguindo os mesmos procedimentos da primeira série, sendo realizados na máquina de ensaios Instron-5595 (Fig. 7.16-b).

Os corpos-de-prova ensaiados aos 28 dias foram instrumentados com extensômetros elétricos de resistência para obtenção do coeficiente de Poisson.

\section{- Compressão Diametral}

Da mesma forma que descrito para a Série 1, os ensaios de compressão diametral foram realizados na máquina de ensaios ELE (capacidade de 300 toneladas), nas idades de 14 e 28 dias (Fig. 7.18).

\subsubsection{Flecha Inicial}

Os procedimentos, equipamentos e instrumentação utilizados na realização destes ensaios são equivalentes aos já descritos para a primeira série. Contudo nesta série de ensaios não houve atraso na realização destes ensaios, sendo que sua execução ocorreu dois dias após a desmoldagem (diferença devida à preparação), e um dia antes de se iniciarem os ensaios de fluência e retração, ou seja, aos 15 dias após a moldagem. As figuras ilustram a determinação da flecha inicial para a viga carregada.

A única diferença, que não interfere em nada nos resultados, refere-se ao apoio utilizado em cada série. Na primeira, foram empregadas peças de concreto para apoio das vigas entalhadas (Fig. 7.20); e na segunda, estruturas metálicas foram utilizadas como apoio de todas as vigas (Fig. 7.27). Para medição dos deslocamentos foram utilizados relógios 
comparadores de sensibilidade de $0,001 \mathrm{~mm}$ e curso de $5 \mathrm{~mm}$, das marcas Käfer e Huggenberger.

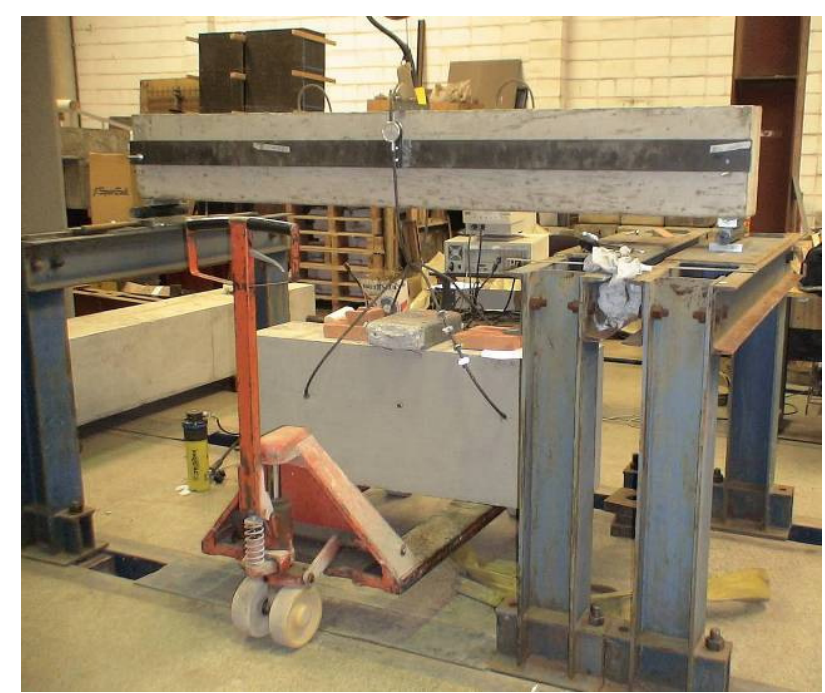

Fig. 7.27: Medição da flecha inicial - Série 2.

\subsubsection{Ensaios de Retração}

Estes ensaios iniciaram-se juntamente com os ensaios de fluência, ou seja, aos 16 dias após a moldagem. Os procedimentos, equipamentos e instrumentação utilizados na realização destes ensaios são equivalentes aos já descritos para a primeira série.

Contudo desta vez, ao invés de adesivo instantâneo marca Super-Bonder, foi utilizado adesivo epóxi da marca Araldite. A aplicação deste adesivo é mais demorada e o correto posicionamento das peças é difícil, contudo aparentemente não houve ressecamento do adesivo. Contudo, houve desprendimento de uma peça. Para cada prisma foram realizadas duas leituras na face superior.
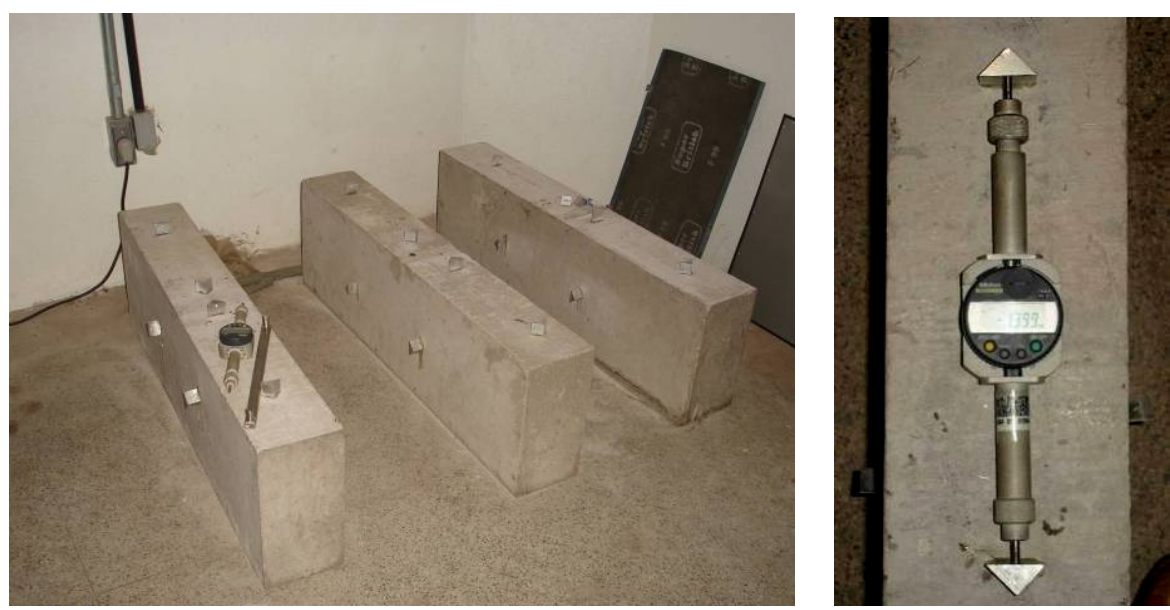

Fig. 7.28: Ensaio de retração - Série 2. 


\subsubsection{Ensaios de Fluência}

Estes ensaios tiveram início na data prevista (15 dias após moldagem), sendo que a operação de montagem do ensaio na câmara climatizada ocorreu de forma mais ágil e tranqüila do que da primeira vez, haja vista o conhecimento adquirido na realização das tarefas. Os procedimentos, equipamentos e instrumentação utilizados na realização destes ensaios são equivalentes aos já descritos para a primeira série (com exceção do clip-on-gage).

A Fig. 7.29 ilustra a disposição dos modelos. Para medição dos deslocamentos foram utilizados relógios comparadores de precisão de $0,001 \mathrm{~mm}$ e curso de $5 \mathrm{~mm}$, das marcas Käfer e Hggenberger.
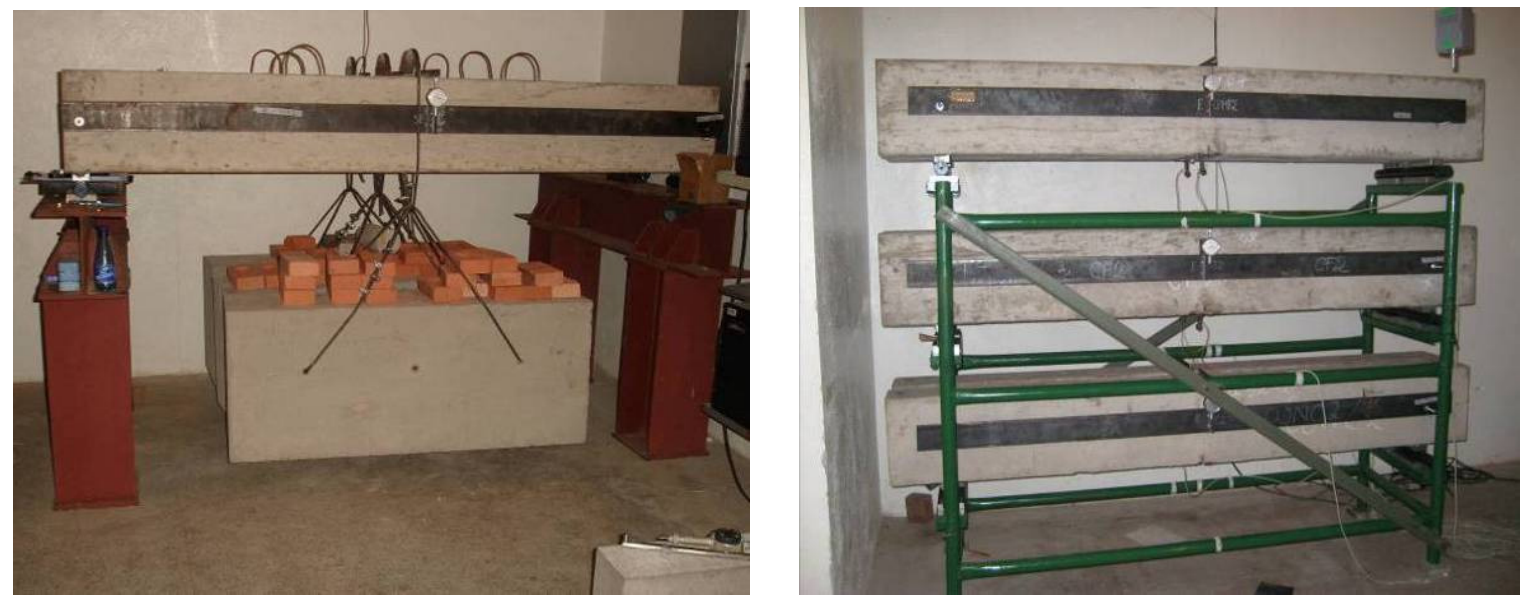

Fig. 7.29: Disposição das vigas nos ensaios de fluência - Série 2.

Nesta série, foi utilizado outro dispositivo para medição do CMOD. O novo "clip" desenvolvido para estes ensaios consiste da mesma lâmina de aço mola instrumentada, do clip anterior, fixa em uma peça de ferro bastante rígida (ferro chato de $3 \mathrm{~mm}$ de espessura). Desse modo, para o mesmo deslocamento imposto, a tensão na região instrumentada é maior, o que elevou a sensibilidade do dispositivo. Diferentemente da Série 1, o clip foi fixado em uma chapa metálica, "embutida" nas vigas durante a concretagem.

Além do clip-on-gage, foi também utilizado outro dispositivo, de funcionamento mecânico, para o monitoramento da abertura do entalhe. Trata-se do extensômetro removível Tenso-Tast, da marca Huggenberger, com relógio comparador de sensibilidade de 0,001 mm. Foi utilizada base de $50 \mathrm{~mm}$ (sensibilidade de 20 $\mu$ ). Apesar da sensibilidade em deformação não ser adequada, nota-se que as variações medidas são qualitativamente coerentes com aquelas observadas pelo clip. 

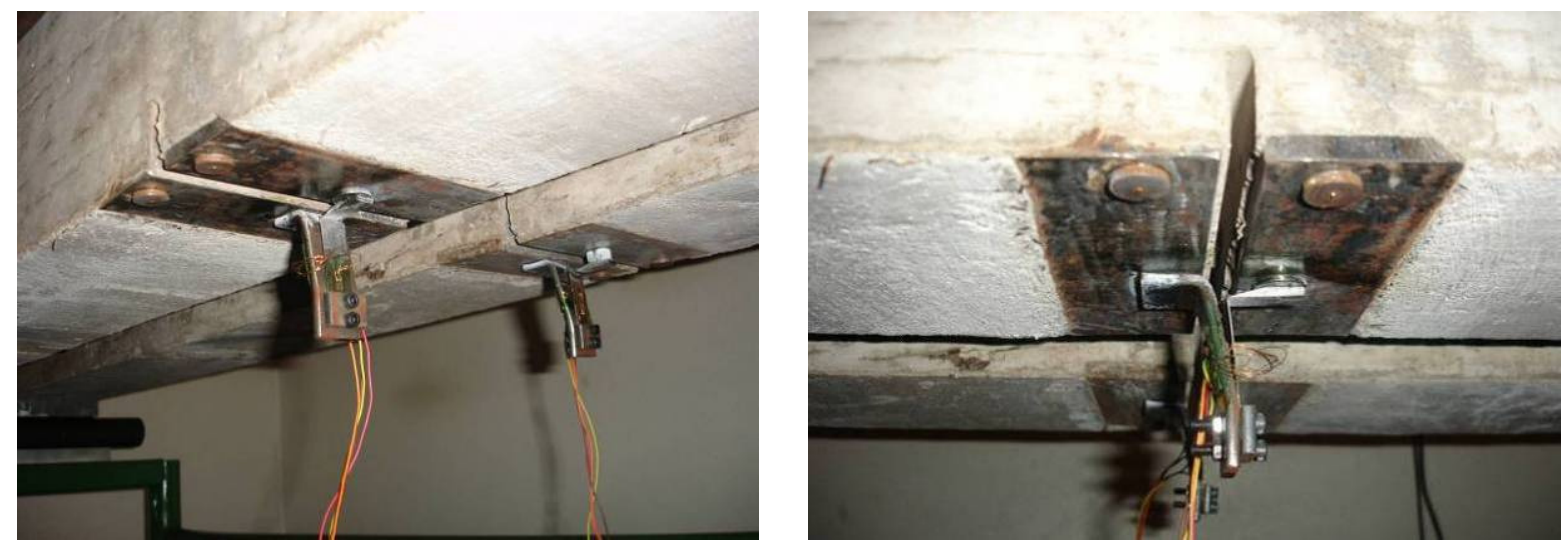

Fig. 7.30: Clip-on-gage utilizado na Série 2.

As peças de encaixe do extensômetro (rodelas de aço, visualizadas na Fig. 7.30) foram coladas na chapa metálica com adesivo do tipo super-bonder, sendo que a distância entre as peças foi demarcada segundo a base de medida do conjunto deste aparelho $(50 \mathrm{~mm})$. Como ilustra a Fig. 7.31, para realização das leituras, o extensômetro é encaixado, e as leituras são comparativas. O maior problema de precisão deste dispositivo relaciona-se ao seu correto encaixe na base de medida. Dependendo da pressão utilizada pelo usuário, podem ocorrer variações significativas nas leituras. Além disso, não foi possível garantir o perfeito alinhamento de algumas chapas metálicas em que as peças de encaixe foram fixadas, o que também diminui a qualidade dos resultados.

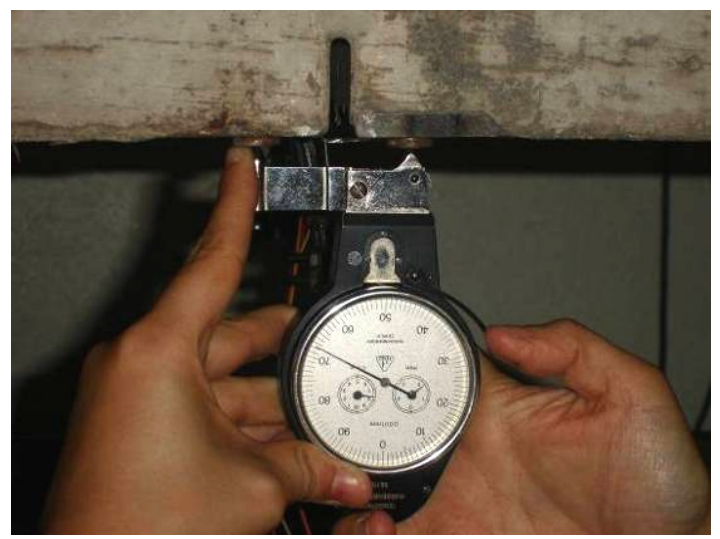

Fig. 7.31: Dispositivo de leitura Tenso-Tast.

\subsubsection{Ensaios Dinâmicos}

Os ensaios dinâmicos foram realizados aos 15 dias, sendo utilizados os mesmos procedimentos, equipamentos e instrumentação da Série 1. A Fig. 7.32 ilustra a realização destes ensaios. 

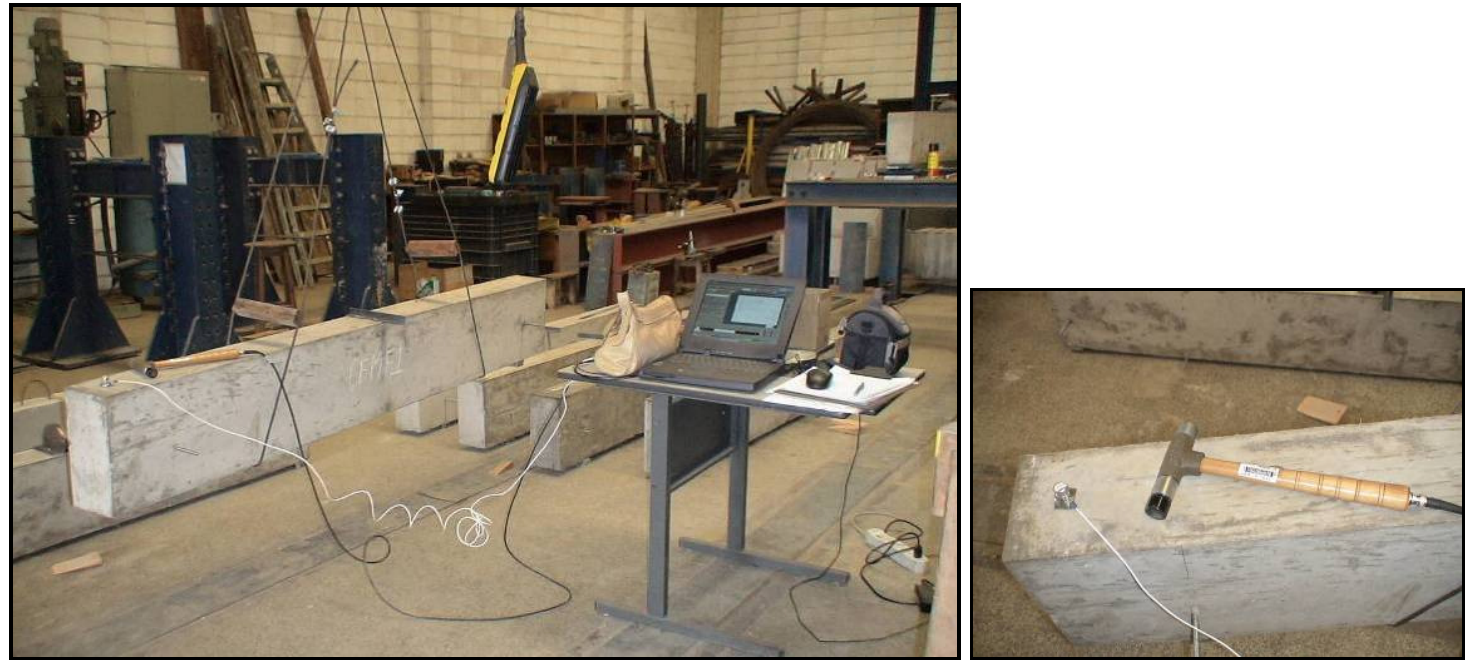

Fig. 7.32: Ensaios dinâmicos - Série 2

\subsubsection{Ensaios de Fraturamento}

Nesta série foram previstos ensaios de fraturamento para determinação da energia de fratura e da tenacidade ao fraturamento da matriz de concreto utilizada. Para tanto, foram ensaiados prismas de dimensões (150x150x500 mm), bi-apoiados com vão livre de $450 \mathrm{~mm}$, com entalhe central passante de $30 \mathrm{~mm}$ de extensão. Apesar de ser necessária aos cálculos a aquisição dos valores de força e deslocamento vertical, o ensaio foi feito com controle de abertura da fissura, o que fornece maior estabilidade (a taxa utilizada foi de $0,00015 \mathrm{~mm} / \mathrm{s}$ ). A Fig. 7.33 ilustra a realização destes ensaios, efetuada após 40 dias da data de moldagem.
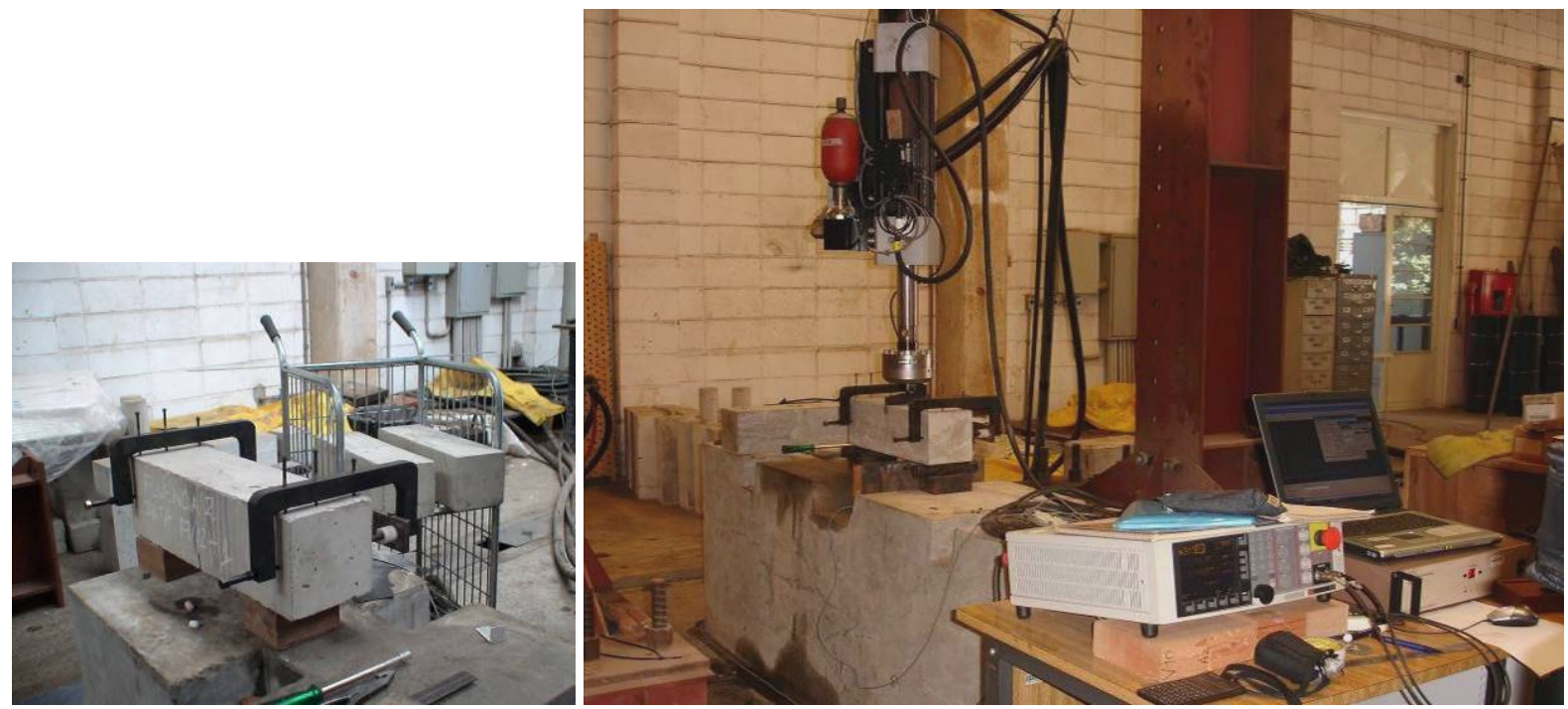

Fig. 7.33: Ensaio de Fraturamento - Série 2: corpos-de-prova e execução do ensaio. 


\subsection{Dificuldades Encontradas}

\subsubsection{Condições de Exposição}

Como já se comentou na Revisão da Bibliografia, a umidade relativa e a temperatura do ambiente têm influência significativa sobre os processos de fluência e de retração. Por esse motivo, recomenda-se "descartar" essas variáveis, adotando como padrão a avaliação da fluência básica e da retração autógena em corpos-de-prova selados, em pelo menos 3 corposde-prova iguais (Bazant, Z. P.; 1988). Esta medida que pode ser facilmente aplicada em modelos pequenos, como é o caso da maioria das pesquisas que tratam da avaliação de deformações lentas em corpos-de-prova cilíndricos submetidos à compressão.

A princípio, idealizou-se realizar os ensaios de fluência à flexão em vigas submersas, justamente para evitar a variável imposta pela umidade relativa do ambiente. Entretanto, em virtude das dimensões e quantidades de vigas necessárias para a avaliação experimental desta pesquisa, essa idéia se tornou inviável. Sendo assim, optou-se por efetuar os ensaios na câmara climatizada do Laboratório do Departamento de Engenharia de Estruturas (LE-EESC).

Durante a Série 1, além do inconveniente de iniciar os ensaios de fluência com o dobro da idade prevista, os $\mathrm{cp}(\mathrm{s})$ ficaram expostos às variações climáticas durante um mês (apesar de armazenados no galpão de ensaios, protegidos da chuva), o que ocasionou uma présecagem das vigas. Como a grandeza esperada para as variações dos deslocamentos das vigas já era pequena, a diminuição do conteúdo de água evaporável, decorrente tanto das reações de hidratação, mas principalmente da condição de exposição anterior aos ensaios, contribuíram para dificultar a observação da fluência nestes modelos.

Durante a Série 2 de ensaios, apesar de o software estar instalado, o aparelho de arcondicionado permaneceu em manutenção durante o primeiro mês e um novo sistema de umidificação foi adquirido. Porém, o novo umidificador foi entregue após o início dos ensaios, o que inviabilizou sua instalação. Em decorrência da manutenção dada aos equipamentos da câmara, houve grandes variações da umidade relativa $(72,8 \pm 8,8 \%)$. Os valores de temperatura e umidade relativa foram anotados juntamente com todas as leituras, sendo possível tirar algumas conclusões a respeito de alteração da tendência das deformações lentas no tempo. 


\subsubsection{Preservação das características da matriz de concreto nos compósitos estudados}

Um dos objetivos do trabalho foi avaliar experimentalmente a influência das fibras e micro-fibras no processo de fluência. Para identificar e quantificar tal influência, obviamente, é necessário comparar os materiais compósitos com a matriz de referência. Quando o volume total dos modelos é pequeno (admitindo como pequeno um volume inferior à capacidade da betoneira), pode-se, de certa forma, garantir que a permanência das características da matriz de concreto que será utilizada em diferentes composições com fibras.

Nesta pesquisa, para cada material estudado (matriz de concreto, CFRA com teor de $1 \%$ de fibras de $25 \mathrm{~mm}$, e concreto reforçado com teor de $1 \%$ de fibras de $25 \mathrm{~mm}$ e de 13 $\mathrm{mm}$ ), utilizou-se por volta de $0,45 \mathrm{~m}^{3}$ de concreto, totalizando $1,35 \mathrm{~m}^{3}$. Na Série 1 de ensaios, optou-se por misturar o concreto no laboratório, acreditando-se que assim haveria maior controle sobre sua confecção e sobre os materiais utilizados. Em decorrência do volume elevado, frente à capacidade da betoneira disponível no LE-EESC $\left(0,25 \mathrm{~m}^{3}\right)$, necessariamente a moldagem foi efetuada em 3 dias (um material por dia), com 2 massadas por dia (2 massadas de 230 litros). Desta forma, não se garantiu a uniformidade da matriz de concreto, haja vista alterações climáticas e na realização da mistura.

Na Série 2 de ensaios, com o intuito de garantir que a matriz de concreto fosse o mais uniforme possível, utilizou-se concreto usinado (dosado em central e misturado no caminhão betoneira). Os modelos referentes apenas à matriz foram moldados com concreto retirado diretamente do caminhão. Para obtenção dos materiais compósitos foi necessário repetir em 4 etapas a mistura de 240 litros de concreto retirados do caminhão a quantidade de fibras correspondente. Para garantir boa trabalhabilidade na mistura das fibras, foi solicitado concreto com slump $10 \pm 1 \mathrm{~cm}$, entretanto o concreto foi recebido com slump $8 \pm 1 \mathrm{~cm}$. O tempo gasto na concretagem e na mistura das fibras ocasionou evaporação de água e conseqüente diminuição do slump.

Desta forma, nas quatro massadas em que foram misturadas as fibras foi necessário utilizar o superplastificante Glenium 51, para melhorar a trabalhabilidade. Novamente, de certa forma, restaram dúvidas quanto à possibilidade de comparação das características do concreto e do concreto reforçado com fibras e micro-fibras.

O fabricante do Glenium 51 afirma que este aditivo pode elevar a resistência e o 
módulo de elasticidade ${ }^{22}$. Tal afirmação parece óbvia quando se utiliza este aditivo para reduzir a quantidade de água no traço do concreto; entretanto, entende-se que sua utilização apenas para melhorar a trabalhabilidade não altera as propriedades mecânicas do concreto, nem seu comportamento ao longo do tempo ou as deformações por retração (Brooks J. J.; 1989). Foram encontrados na literatura trabalhos em que, para mistura das fibras, foi adicionado aditivo superplastificante ao concreto (mantidas as proporções do traço) para melhorar a trabalhabilidade. Entretanto, na análise dos resultados esse fato não levado em consideração (BISSONNETTE; PIGEON, 1995).

As duas possibilidades de estratégia de moldagem foram testadas, e pôde-se concluir que para a quantidade de material utilizada na pesquisa é não é possível garantir uma melhor uniformidade da matriz de concreto para todos os materiais estudados.

\subsubsection{Viabilização dos Ensaios na Câmara Climatizada}

A decisão de utilizar a câmara climatizada para controle das condições ambientais ocasionou um novo desafio. Projetar o layout e planejar o transporte e posicionamento de todos os modelos dentro da câmara não foi uma tarefa simples. As vigas chegam a pesar cada uma, por volta de $240 \mathrm{~kg}$, cada peso morto aproximadamente 0,5 ton. $(5 \mathrm{kN})$, e ainda havia o agravante do transporte das peças entalhadas: estas tiveram de ser transportados sempre biapoiadas nos terços-de-vão a fim de evitar tensões de tração elevadas na ponta do entalhe que induzisse à fissuração. Inúmeros layouts foram idealizados, e concluiu-se que não havia espaço suficiente para o posicionamento das vigas em um mesmo nível (todas na mesma altura).

Desta forma, a única saída seria "empilhar" as vigas entalhadas em uma prateleira (já que estas não receberiam carregamento externo). Todavia, o posicionamento na prateleira também não foi simples, dado o peso das vigas, a necessidade de carregá-las nos terços-devão, e a distância entre os apoios e as faces laterais $(20 \mathrm{~cm})$. A viabilização do uso da prateleira surgiu com a idéia de projetar uma prateleira de patamares encaixáveis, ou seja, primeiro seriam posicionadas as vigas do primeiro patamar, depois seria encaixado os segundo patamar para posicionamento das vigas correspondentes e assim sucessivamente.

\footnotetext{
${ }^{22}$ BASF Construction Chemicals Brasil. Disponível em: < http://www.degussa-cc.com.br>. Acesso em 10 dez. 2007.
} 

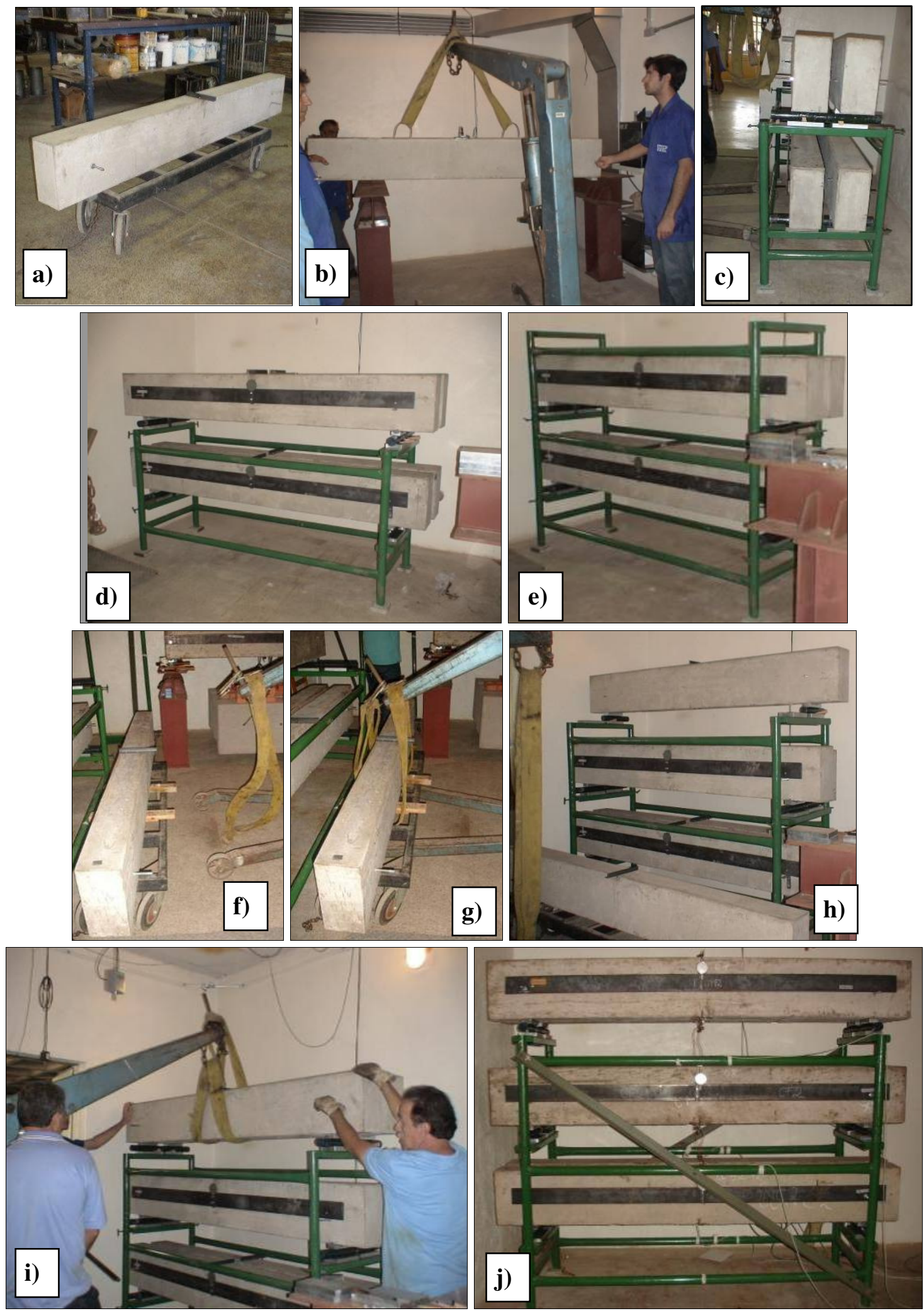

Fig. 7.34: Processo de acomodação dos modelos para ensaios de longa duração na câmara climatizada.

As etapas de "montagem" dos ensaios de fluência constituem o painel fotográfico da Fig. 7.34. As vigas foram transportadas do galpão até a câmara em um carrinho constituído por travessas metálicas, de modo a não solicitar as peças (Fig. 7.34-a). Já com o carrinho no 
interior da câmara, as vigas eram içadas por uma fita de tecido resistente com auxílio de um guincho e então posicionadas sobre seus apoios (Fig. 7.34-f-i). A Fig. 7.34-b mostra o posicionamento das vigas carregadas, com a utilização do guincho. A Fig. 7.34 (fotos de $c$ a e) ilustra a montagem a prateleira (colocação o último patamar), e por fim têm-se todas as vigas posicionadas na prateleira (Fig. 7.34-j)

\subsubsection{Definição da Instrumentação das Vigas}

Com o intuito de minimizar erros de leitura decorrentes da instrumentação, foi idealizado um sistema semelhante ao Yoke utilizado nos ensaios de fraturamento (ver Fig. 7.35). Este dispositivo permite que as medidas de deslocamento sejam feitas com referência ao próprio corpo-de-prova, evitando que movimentações externas alterem os resultados. O correto posicionamento do Yoke, sobre a linha dos apoios à meia-altura (ou seja, passando pela linha neutra) também evita interferência de seu peso próprio no carregamento do corpode-prova.

Observando a Fig. 7.35, nota-se também que o LVDT é fixado a uma régua metálica por meio de uma cantoneira. Em uma extremidade, a régua é presa à meia altura, podendo realizar movimentos de rotação em relação ao seu eixo perpendicular, sendo que na extremidade oposta, ela seria apenas apoiada, permitindo movimentos de translação na direção de seu comprimento.
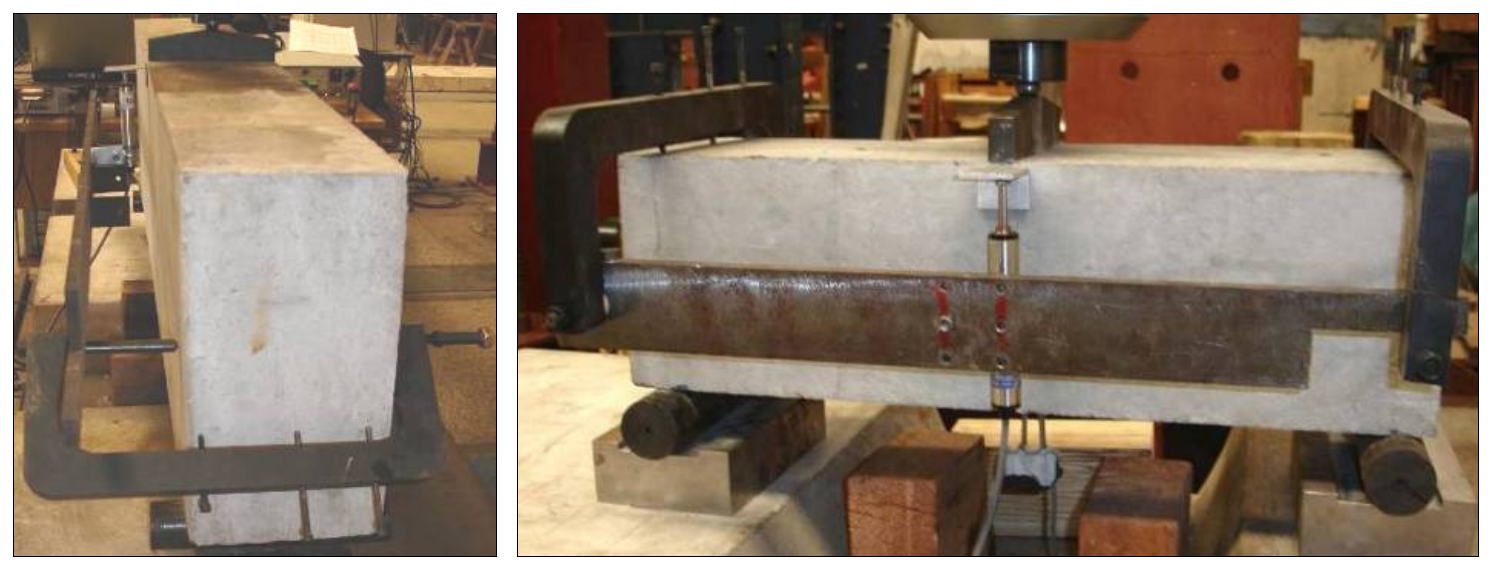

Fig. 7.35: Fotos do dispositivo Yoke, utilizado nos ensaios de fraturamento.

Inicialmente, foram utilizados relógios mecânicos comparadores (micrômetros) para medição das flechas. Esta escolha baseou-se na disponibilidade destes aparelhos, com precisão de $1 \mu m$, na quantidade necessária para a pesquisa, e também na maior confiabilidade no uso de aparelhos de funcionamento mecânico em ensaios de longa duração. 
Para sustentação dos relógios o "Yoke" adaptado para as dimensões das vigas está esquematizado na Fig. 7.36. Como se pode observar em analogia à Fig. 7.35, as leituras são efetuadas com referência a uma cantoneira de alumínio colada na face lateral da viga, o micrômetro é fixado à régua por cantoneira de alumínio, e ao invés dos ganchos ajustáveis, o apoio da régua é efetuado por varões-roscados fixadas à própria viga, no momento da concretagem. A Fig. 7.44-a ilustra o ensaio realizado com esse conjunto de instrumentação.

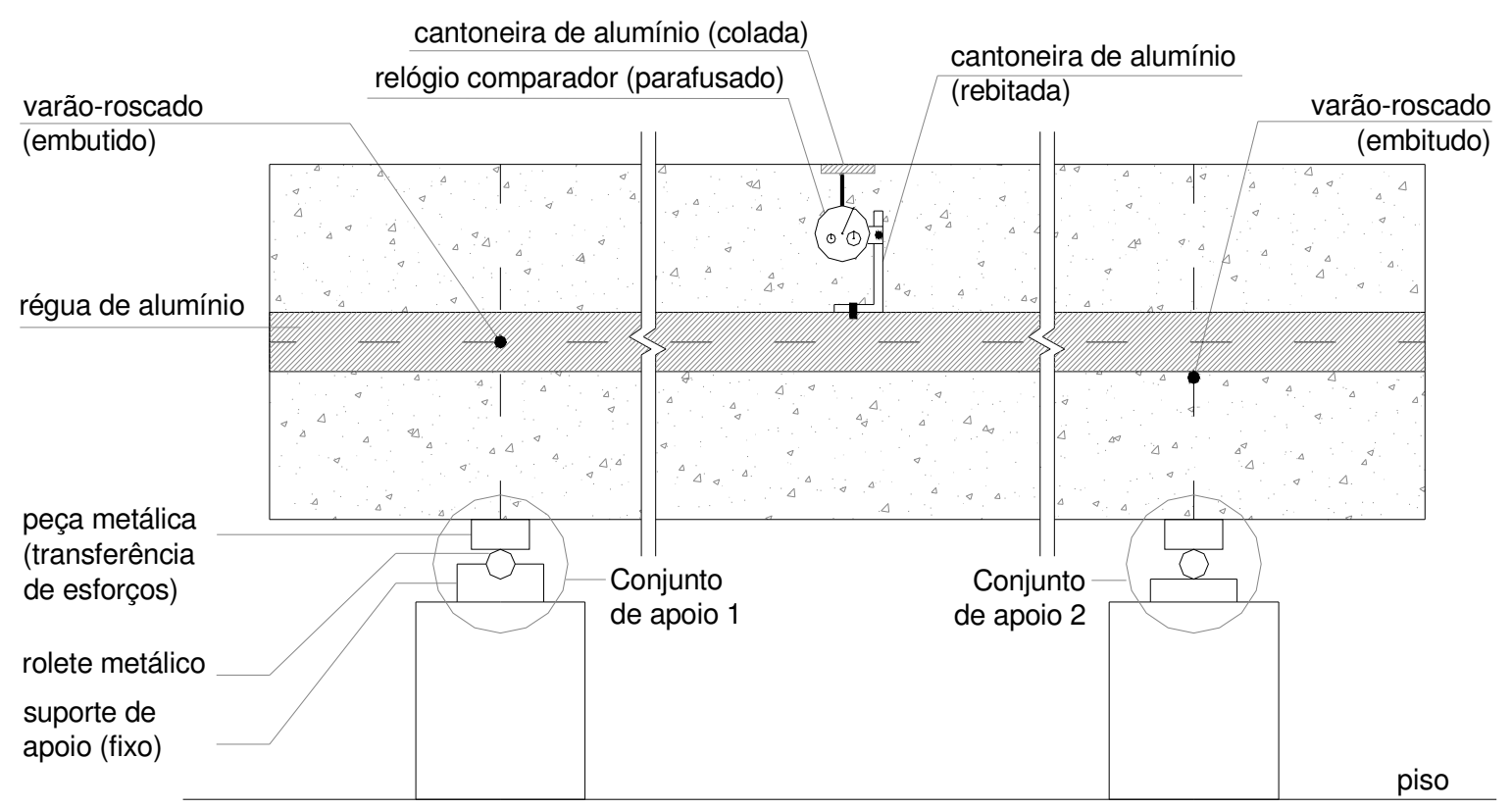

Fig. 7.36: Instrumentação idealizada.

A escolha da utilização da régua de alumínio (comercialmente encontrada como régua de pedreiro) justificou-se por seu baixo peso, baixo custo e fácil disponibilidade frente outras soluções. Entretanto, ao mesmo tempo em que é leve o alumínio também é muito deformável (seu módulo de elasticidade, $70 \mathrm{GPa}$, é aproximadamente 1/3 do módulo de elasticidade do aço, $210 \mathrm{GPa}$ ). Em decorrência disto, houve um comportamento inesperado do sistema de instrumentação quando da tentativa de mensurar a flecha inicial nas vigas da série 1 .

Ao realizar estes ensaios, algo curioso acontecia, o relógio comparador não acusava nenhuma leitura (apesar de pequeno, o valor teórico da flecha inicial das vigas entalhas é da ordem de décimos de milímetros). Algumas hipóteses sugiram: problema no método de ensaio, micrômetro defeituoso, ou falha na sustentação do relógio comparador. A conclusão foi de que as três hipóteses mostraram-se verdadeiras.

Em primeiro lugar detectou-se certa "dureza" nos mecanismos do relógio, o que foi rapidamente resolvido com sua limpeza e uso de óleo spray. Contudo o problema não foi 
solucionado. Entretanto, essa observação chamou a atenção para outra questão: a deformabilidade da régua de fixação. Por conta da baixa rigidez da régua, a força necessária para deformá-la seria inferior à força necessária para vencer o atrito estático dos mecanismos do relógio comparador; e sendo assim, ao invés de acusar a flecha da viga, este "empurrava" a régua. Um exemplo esquemático deste comportamento é apresentado na Fig. 7.37.

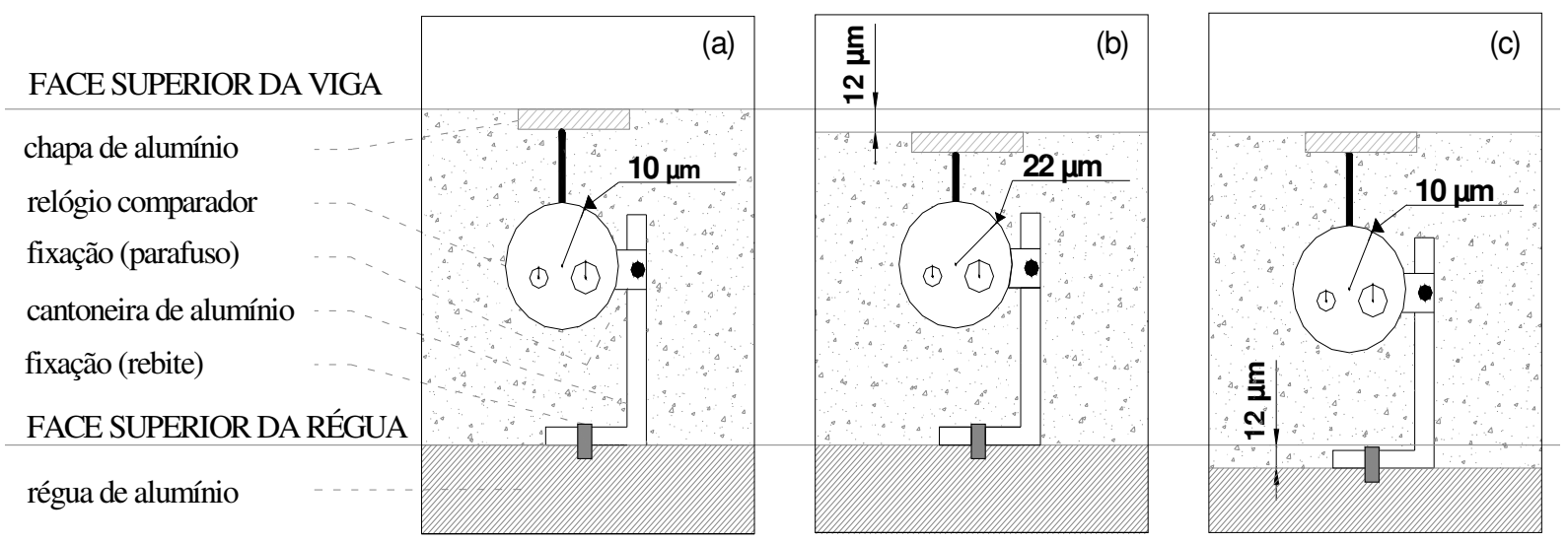

Fig. 7.37: Problemas da instrumentação das vigas (esquema fora de escala).

Nesta figura, a situação inicial (ou seja, viga nivelada, não submetida a carregamento) é apresentada na Fig. 7.37-(a). Após a aplicação do carregamento, decorrente da flexão a viga, observa-se, por exemplo, uma flecha de $12 \mu \mathrm{m}$, devidamente registrada pelo relógio comparador (a diferença entre as leituras do relógio da situação (a) e (b) indica a flecha sofrida). O último quadro, situação (c), reflete o comportamento ocorrido durante o ensaio: a régua sofre um deslocamento equivalente ao da viga, impossibilitando a leitura (o relógio comparador nesta situação tem a mesma marcação da situação inicial (a)).

Para melhorar a instrumentação, portanto, foram testados sistemas com régua de maior rigidez e equipamentos mais sensíveis. A fim de tentar aproveitar as réguas adquiridas, a primeira providência a ser tomada foi grautear uma régua, o que conduziu a uma rigidez 5 vezes superior (ver Fig. 7.38). Em seguida foram testados 4 instrumentos para medição dos deslocamentos:

- Relógio mecânico comparador das marcas Huggenberger, curso de $5 \mathrm{~mm}$ e sensibilidade de 0,001 mm, e Käspér, com curso de $4 \mathrm{~mm}$ e sensibilidade de $0,001 \mathrm{~mm}$.

- Transdutor de deslocamentos resistivo, da marca Vishay, Modelo H525, com sensibilidade de $0,001 \mathrm{~mm}$ e curso de $25 \mathrm{~mm}$; 
- Dois extensômetros elétricos de resistência, do tipo "clip-on-gage";

Um dos clips foi fornecido pela empresa MSI (Microsensores Industriais Ltda.), confeccionado com uma lâmina dobrada de uma liga de Bronze Fosforoso instrumentado com ponte completa, sendo denominado Clip-BF (Bronze Fosforoso); e o outro foi confeccionado no Laboratório de Estruturas a partir de duas hastes flexíveis de aço mola (aço 1070 temperado), parafusadas em um perfil $U$ de alumínio, também instrumentado com ponte completa, denominado Clip-LE1 (Laboratório de Estruturas). O Clip-LE1 foi desenvolvido para ser utilizado nos ensaios de fluência para o monitoramento da abertura do entalhe no tempo. A fixação destes instrumentos de medição à régua foi feita por meio de peças metálicas (de ferro ou alumínio) adaptadas de acordo com a especificidade de cada um, conforme se observa na Fig. 7.44.

Tabela 7.6: Testes realizados na instrumentação das vigas: Fluência - Série 1.

\begin{tabular}{c|c|c|c}
\hline Data & Instrumentação & $\begin{array}{c}\text { Idade do } \\
\text { concreto }\end{array}$ & Fotos de referência \\
\hline $17 / 08 / 07$ & Relógio comparador mecânico & 28 dias & Fig. 7.44: (a) \\
\hline $20 / 08 / 07$ & Transdutor de deslocamentos (LVDT) & 31 dias & Fig. 7.44: (b) \\
\hline $\begin{array}{c}21 / 08 / 07 \text { e } \\
22 / 08 / 07\end{array}$ & CLIP LE1 & 33 dias & Fig. 7.44: (c) \\
\hline $23 / 08 / 07$ & CLIP LE1; & 35 dias & Fig. 7.44: (e) e (f) \\
\hline $03 / 09 / 07$ & Transdutor de deslocamentos (LVDT) & 46 dias & Fig. 7.44: (d) \\
\hline $05 / 09 / 07$ & CLIP BF & 47 dias & Fig. 7.41 \\
\hline
\end{tabular}

A Tabela 7.6 resume cronologicamente os testes realizados até chegar à combinação final entre régua, dispositivo para medição das flechas que compôs o sistema de instrumentação utilizado. O painel fotográfico da Fig. 7.44 ilustra os testes realizados, assim como os diferentes equipamentos utilizados para medição das flechas. Deve-se ressaltar que a utilização destes diferentes equipamentos de medição foi realizada tanto para as vigas entalhadas (fotos a-d) como para as vigas sem entalhe (fotos e-f), na determinação das flechas elásticas devidas ao peso-próprio e ao carregamento de 0,5 ton nas vigas de concreto. 


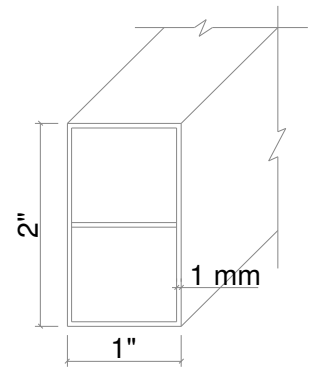

(a) régua de alumínio (régua de pedreiro)

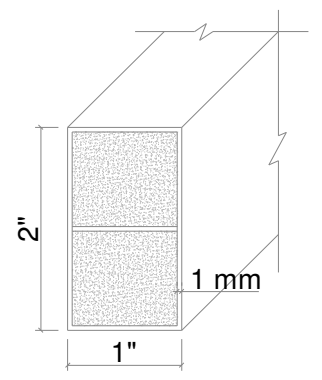

(b) régua de alumínio grauteada

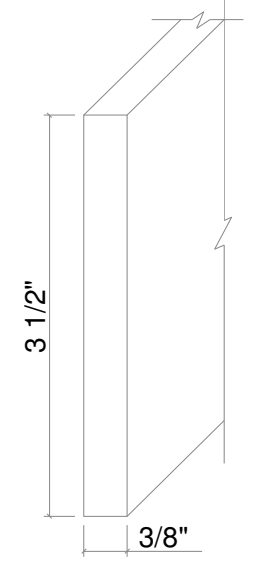

(c) régua de ferro chato

Fig. 7.38: Réguas utilizadas como testes para instrumentação das vigas.

Os primeiros testes (Fig. 7.44-a) realizados após 28 dias da moldagem utilizando relógio comparador forneceram resultados insatisfatórios (tanto para as flechas devidas ao peso-próprio como para aquelas devido à carga concentrada). Apesar da rigidez da régua grauteada ter sido aumentada em 5 vezes, ainda havia problemas na montagem da instrumentação:

- As medidas eram feitas com referência a uma cantoneira de alumínio de abas desiguais colada com adesivo da marca Super-Bonder, estando sujeita às deformações que mascaravam os resultados, da mesma forma que a régua de alumínio;

- O relógio comparador era fixado a uma cantoneira de alumínio que por sua vez estava rebitada à régua. Entretanto, por conta da altura da viga, foi necessário utilizar um prolongador. Observou-se que o uso do prolongador não é confiável, já que pode haver escorregamento, alterando os resultados.

Desta forma, concluiu-se que para o uso adequado deste micrômetro como instrumento de medição, todo o conjunto que engloba a montagem da instrumentação deveria ser enrijecido. 


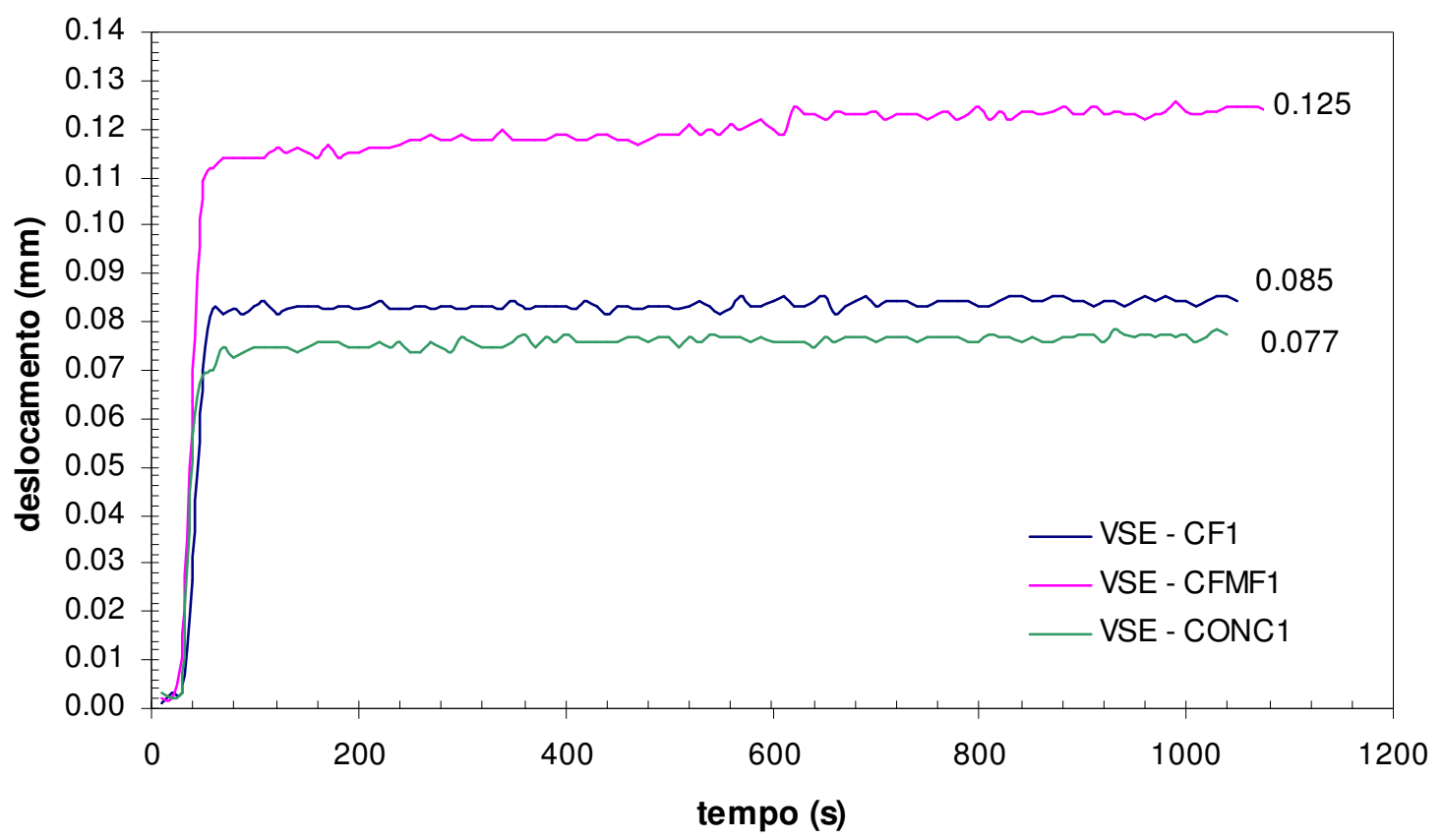

Fig. 7.39: Flechas imediatas devidas ao carregamento concentrado de 4.87 kN ( Fluência série1).

Para os demais instrumentos de medição testados, prolongou-se o ensaio em 15 minutos para avaliar as variações no resultado ao longo do tempo. Dos testes realizados com os clips e com o Transdutor concluiu-se que:

- O clip-on-gage de bronze fosforoso é inadequado. Notou-se que este clip é extremamente sensível a variações de temperatura (o coeficiente de dilatação térmica do bronze é cerca de $50 \%$ maior do que o do aço), além de ser muito instável;

- Tanto o clip-on-gage desenvolvido no laboratório quanto o transdutor conduziram a bons resultados, sendo a precisão do primeiro superior. A Fig. 7.39 ilustra os resultados do deslocamento vertical da linha de carga utilizando o CLIP-LE1, para a determinação das flechas imediatas devidas à carga de $4,87 \mathrm{kN}$ (os valores destacados são da flecha imediata).

A sensibilidade do CLIP-BF à temperatura foi comprovada ao ser realizado em teste comparativo com o CLIP-LE1. Nesse teste os dois clips foram zerados e mantidos com a lâmina na posição indeformada, ou seja, sem nenhuma solicitação, durante um período de 2 horas (entre o fim da manhã e o início da tarde). As leituras, aquisitadas a cada 1 min., demonstram o comportamento dos dispositivos (ver Fig. 7.40). 


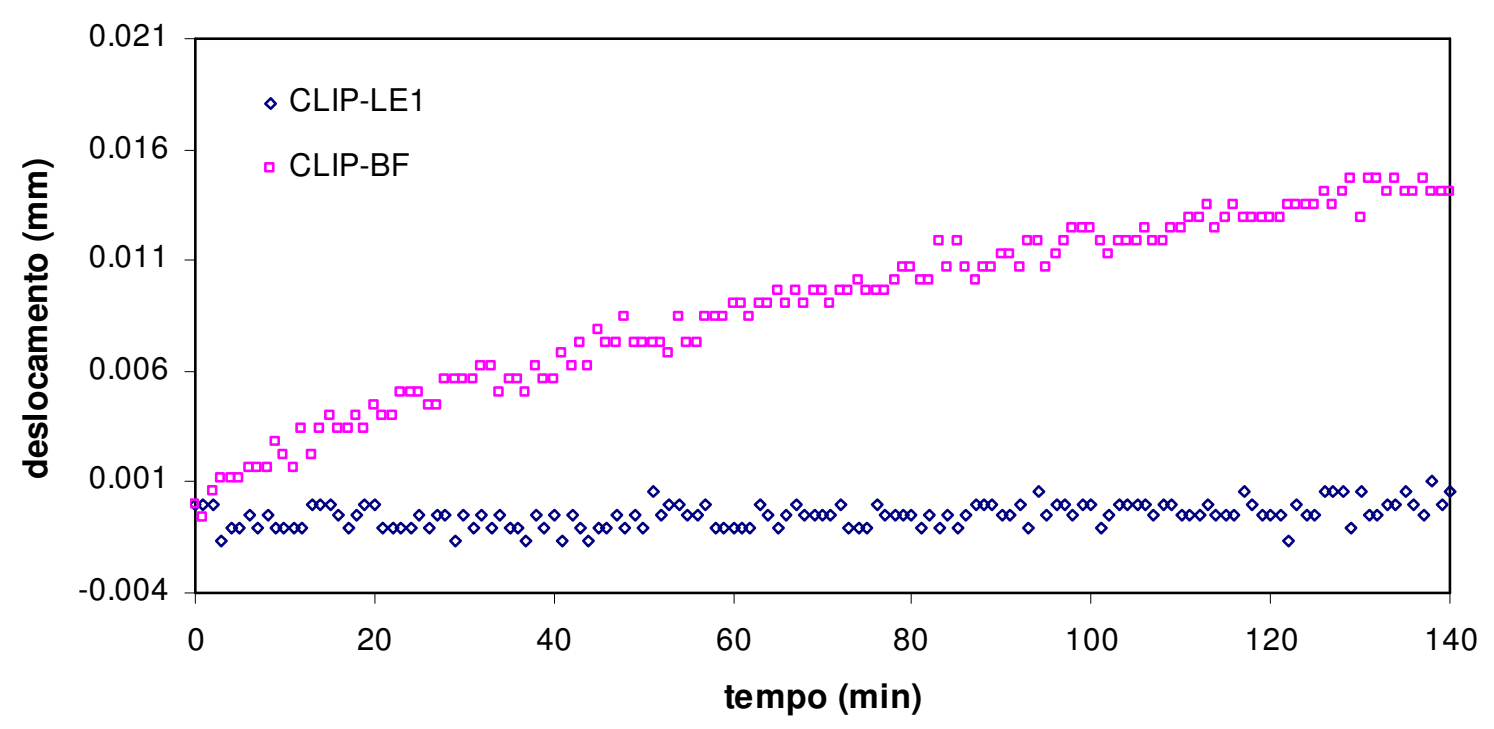

Fig. 7.40: Teste Comparativo - clips

Apesar dos bons resultados apresentados pelo transdutor e pelo clip desenvolvido no laboratório, a utilização destes aparelhos tornou-se inviável após levantar o custo de aquisição e principalmente o tempo necessário para entrega (no mínimo 2 meses no caso dos transdutores) e elaboração (no mínimo 1 mês) no caso do CLIP-LE1. Desta forma, foi necessário buscar uma solução mais rápida e, se possível, de baixo custo.

Partiu-se então para outro caminho, o enrijecimento de todo o conjunto que compõe a instrumentação. Sendo assim, no último teste realizado, foram utilizados:

- Régua metálica de ferro chato, de medidas comerciais $(3 / 8$ × $31 / 2$ in), cuja rigidez é 15 vezes à da régua de alumínio utilizada inicialmente;

- Cantoneiras de ferro de abas iguais de (1 in $\mathrm{x} 1$ in) e $3 \mathrm{~mm}$ de espessura (medidas comerciais) na fixação do micrômetro à régua assim como referência das medidas (ver Fig. 7.41). Em ambos os casos foram efetuadas duas furações, para evitar qualquer tipo de movimentação.

A utilização do relógio comparador em conjunto com esse sistema forneceu resultados muito próximos dos valores esperados. Tendo em vista a maior viabilidade, tanto em termos de custo como de tempo, adotou-se essa instrumentação para todos os ensaios de flexão nas vigas (flecha inicial e fluência).

Para correta aplicação da carga relativa ao peso morto foi confeccionada uma peça em aço, que permite a distribuição desse carregamento em toda largura da viga sem esmagamento das laterais (ver Fig. 7.41). Trata-se de uma roldana, de $15 \mathrm{~cm}$ de diâmetro, cortada ao meio. 
Para garantir sua estabilidade foram soldadas em suas laterais duas cantoneiras metálicas. Essa peça também foi parafusada nas vigas.
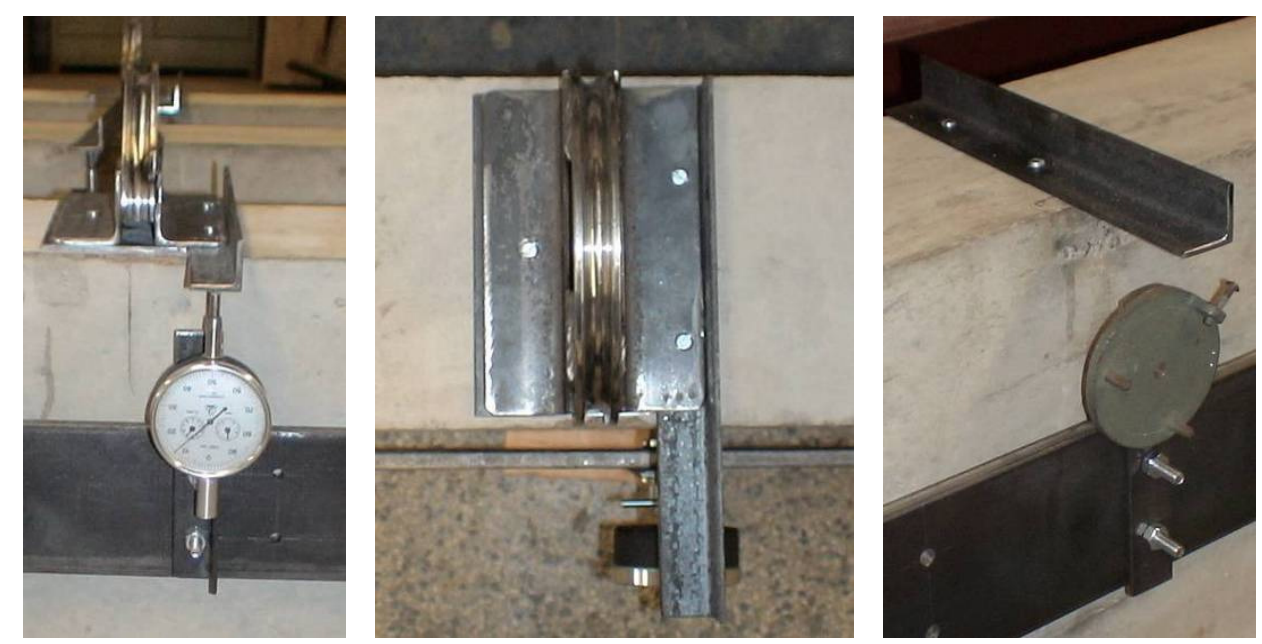

Fig. 7.41: Fixação dos componentes da instrumentação (ensaios de flexão).

\subsubsection{Monitoramento da abertura do entalhe}

O monitoramento do CMOD ao longo do tempo foi uma ferramenta necessária para avaliação do processo de fluência nas vigas entalhadas, garantindo a verificação da inexistência de crescimentos subcríticos de fissuras. Com os resultados das simulações realizadas no DIANA ${ }^{\circledR}$, já havia estimativas da evolução da abertura da fissura. Se fosse observado um crescimento anormal do CMOD, em correspondência às curvas numéricas, provavelmente o processo de propagação de fissura estaria presente, inviabilizando a avaliação da fluência do concreto nas vigas entalhadas submetidas à ação do peso próprio.

Para medição do CMOD foram desenvolvidos para esta pesquisa extensômetros elétricos de resistência do tipo “clip-on-gages", pela equipe técnica do laboratório de estruturas. A versão inicial deste clip, utilizada na primeira série de ensaios e denominada de CLIP-LE1 foi construída a partir de duas hastes flexíveis de aço mola (lâmina de 0,52 mm de espessura de aço 1070 temperado), parafusadas em um perfil U de alumínio, instrumentado com ponte completa de Wheatstone (ver Fig. 7.42).

O CLIP-LE1 foi também utilizado nos ensaios de flecha inicial da primeira serie de ensaios, para os quais forneceu bons resultados. Entretanto, durante as leituras do CMOD, percebeu-se a ineficiência de seu funcionamento ao longo do tempo para leitura de menores grandezas. As curvas obtidas demonstram deslocamentos irreais, logo após as primeiras 24 horas. 
A taxa de crescimento dessas leituras foi totalmente incompatível com as leituras do deslocamento vertical da linha de carga, indicando claramente problemas construtivos do clip.
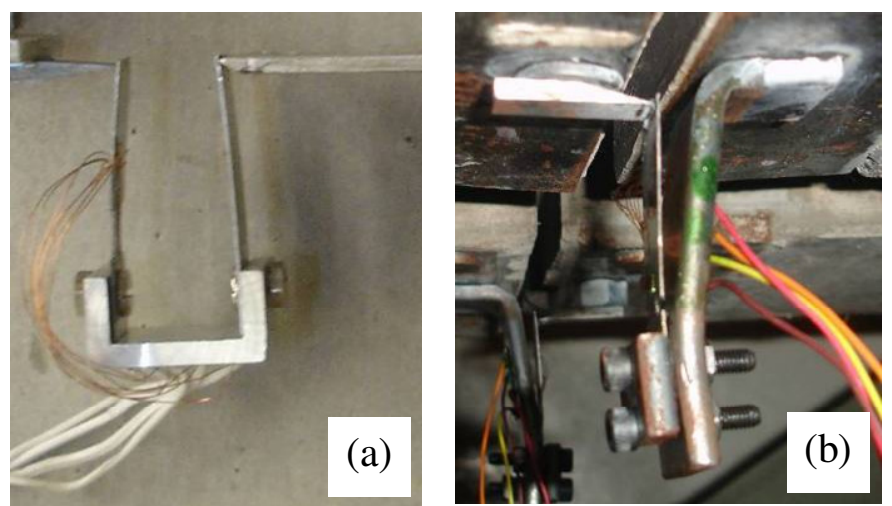

Fig. 7.42: Clips utilizados nos ensaios: (a) Série 1, (b) Série 2.

Sendo assim, após 7 dias dois clips foram desativados, sendo utilizados em uma serie de testes realizados na câmara climatizada. Os resultados de alguns testes estão apresentados no gráfico da Fig. 7.43.

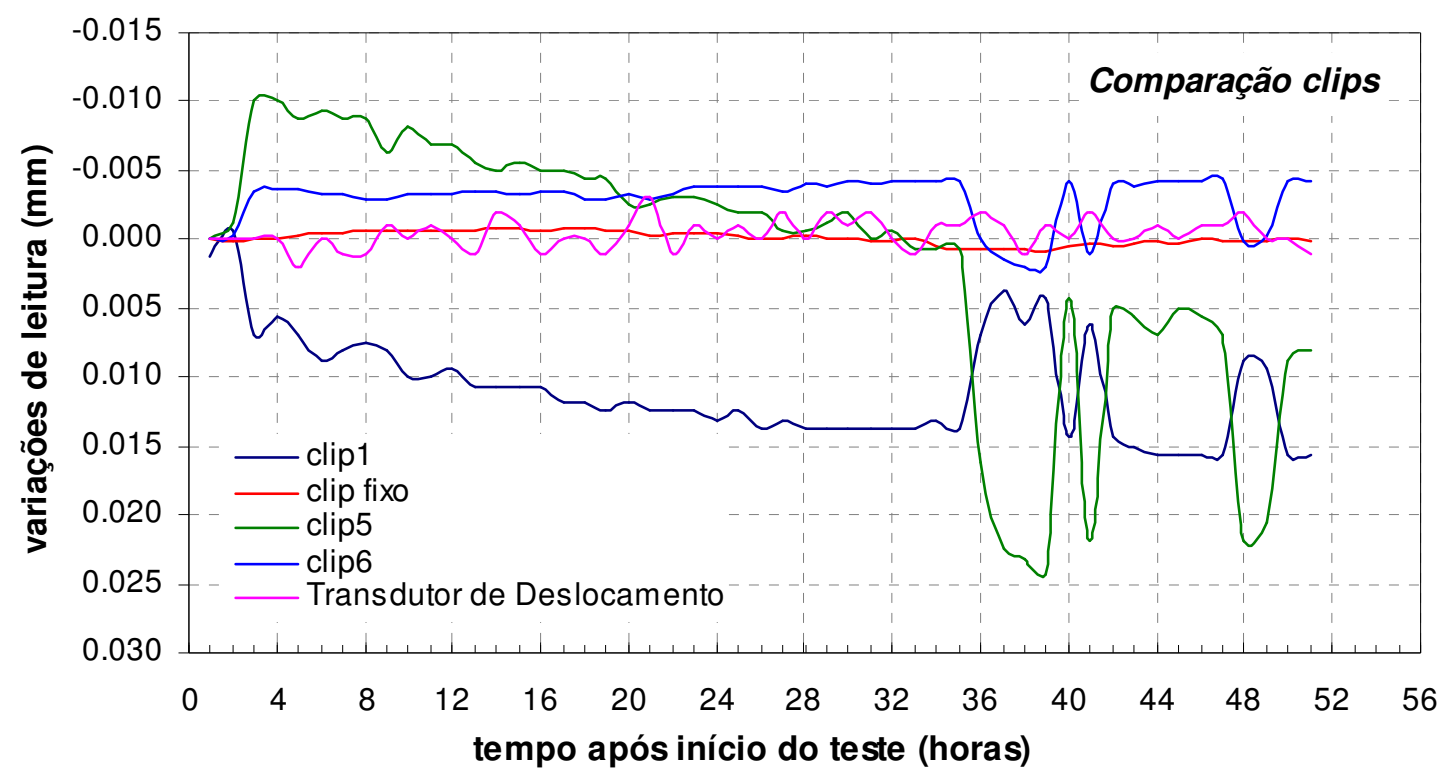

Fig. 7.43: Resultados de testes de diferentes dispositivos de medição.

Observa-se que mesmo o transdutor de deslocamentos (marca Vishay), apresentou variações superiores aos valores de medida teóricos, entretanto nota-se, pela tendência da curva certa estabilidade. A partir desses resultados notou-se que um caminho para melhorar o desempenho dos clips consistia em elevar a sensibilidade, aumentando construtivamente, a rigidez da região não instrumentada. Dessa forma, para a segunda série de ensaios foi confeccionado o clip ilustrado na Fig. 7.42-b. As lâminas instrumentadas foram reaproveitadas, entretanto, para o mesmo deslocamento imposto, aumentou-se a tensão na região onde foram colados os extensômetros. 

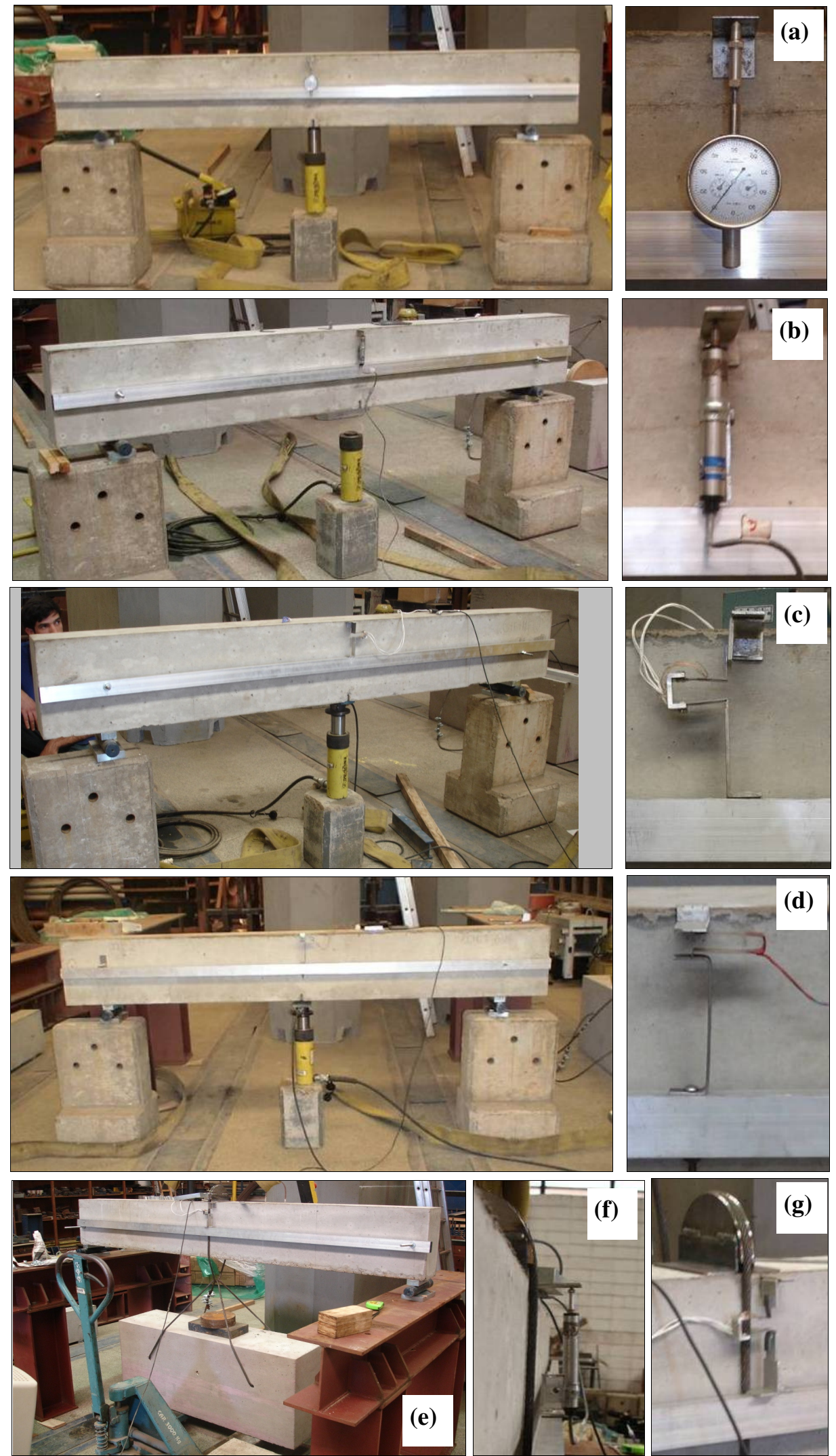

Fig. 7.44: Testes instrumentação. Vigas entalhadas: (a) relógio comparador, (b) transdutor de deslocamentos, (c) Clip-BF, (d) Clip-LE1. Vigas sem entalhe: (e) transdutor de deslocamentos, (f) Clip-LE1 e dispositivo para aplicação da carga concentrada. 


\subsection{Série 1 (Piloto)}

\subsubsection{Ensaios de Caracterização}

As Figuras 8.1-8.4 apresentam os resultados obtidos a partir dos ensaios de compressão axial e diametral efetuados em diversas idades. Para cada ensaio, foram utilizados dois $\mathrm{cp}(\mathrm{s})$, sendo que em alguns casos constataram-se diferenças significativas nos resultados. A planilha com todos os resultados consta no Apêndice A.

O módulo de elasticidade foi calculado considerando o trecho elástico linear situado entre $10 \%$ e $30 \%$ da tensão de ruptura (conforme apresentado no gráfico da Fig. 2.3). O cálculo da resistência à tração foi feito considerando a expressão da norma NBR 7222:1994.

Independentemente da idade avaliada, observou-se que a adição de $1 \%$ das fibras de $25 \mathrm{~mm}$ proporcionou resistência à compressão em torno de $11 \%$ menores do que o concreto de referência, módulo de elasticidade $3 \%$ menor e resistência à tração cerca de $6 \%$ maior. Já as propriedades do concreto reforçado com fibras e microfibras apresentaram diferenças mais significativas com relação à matriz: resistência à compressão $28 \%$ menor, módulo de elasticidade $23 \%$ menor e resistência à tração $2 \%$ maior.

Segundo o manual para utilização de concreto reforçado com fibras da Maccaferri, fornecedora das fibras utilizadas, com a incorporação de fibras metálicas a teores inferiores a $2 \%$ em volume, praticamente não se observa alteração no módulo de elasticidade e no coeficiente de Poisson, sendo que para teores de até 1,5\% pode-se observar algum incremento na resistência à compressão.

Considerando as diferenças da ordem de $10 \%$ das propriedades mecânicas avaliadas, para o caso do material CF em relação ao concreto de controle (denominado CONC), admitese que para as características da mistura e dos ensaios efetuados, o emprego de $1 \%$ da fibra de 
25 mm não alterou o desempenho do concreto quanto às propriedades mecânicas.

De acordo com a Regra das Misturas, esperava-se que, ao aumentar a quantidade de fibras, adicionando as micro-fibras, a deformabilidade do material fosse diminuída e os parâmetros de resistência elevados, principalmente a resistência à tração, já que está sendo acrescentado um material de módulo muito maior $\left(E_{a c ̧ o}=210 \mathrm{GPa}\right)$ e resistência á tração maior (cerca de $400 \mathrm{MPa}$ ). Entretanto, como explicar a expressiva piora no desempenho do compósito CFMF frente às propriedades da matriz?

Provavelmente a resposta para esta pergunta esteja no fato de que a incorporação de fibras pode ocasionar um aumento da porosidade da matriz, associado a um maior teor de ar incorporado. Por uma simples comparação entre massas, esta hipótese foi de certa forma, comprovada nesta pesquisa.

A Tabela 7.2 traz o consumo de cimento e as proporções entre os materiais utilizados para a confecção da matriz. Desta forma, conhecido o volume de uma viga $\left(0,099 \mathrm{~m}^{3}\right)$, determina-se facilmente qual deveria ser a massa teórica de cada modelo. No caso dos compósitos reforçados com fibras, basta acrescentar a quantidade em massa de fibras necessária para o volume do modelo (para cada viga do material reforçada com $1 \%$ de fibras, por exemplo, são necessários 7,92 kg, ou seja $80 \mathrm{~kg} / \mathrm{m}^{3}$ vezes $0,099 \mathrm{~m}^{3}$ ).

Conforme se comentou no Capítulo 7 , todas as vigas foram pesadas, a fim de se determinar a massa real, a qual foi utilizada no cálculo do módulo dinâmico. Ora, havendo diferença entre a massa teórica e a real, obtida por pesagem, essa diferença só pode ser devida à incorporação de ar.

Tabela 8.1: Cálculo do teor de ar incorporado - Série 1.

\begin{tabular}{ccccc} 
Material & $\begin{array}{c}\text { massa teórica: } \\
\text { traço }(\mathbf{K g})\end{array}$ & $\begin{array}{c}\text { massa real: } \\
\text { pesagem }(\mathbf{K g})\end{array}$ & $\begin{array}{c}\text { diferença } \\
(\mathbf{K g})\end{array}$ & $\begin{array}{c}\text { teor de ar } \\
\text { incorporado }(\%)\end{array}$ \\
\hline CONC & 247,3 & 246,7 & 0,6 & $0,26 \%$ \\
CF & 255,3 & 247,0 & 8,3 & $3,23 \%$ \\
CFMF & 263,2 & 240,7 & 22,5 & $8,54 \%$
\end{tabular}

De acordo com a Tabela 8.1 nota-se que para a matriz praticamente não houve diferença entre as massas (teórica e pesada), o que demonstra que os materiais foram dosados corretamente e que o concreto foi bem adensado por vibrações mecânicas. Já o material CF apresentou uma diferença de $3,23 \%$, que apesar de pequena já é significativa. Contudo, ao adicionar as fibras e microfibras essa diferença, que aqui está sendo considerada como teor de ar incorporado, disparou para 8,54\%. 
Certamente que esse acréscimo de porosidade tornou a matriz dos materiais reforçados menos resistente e mais deformável, o que se refletiu nos resultados de todos os ensaios de caracterização, assim como nos ensaios de fluência, cujos resultados serão comentados adiante (página 214).

Portanto, pode-se dizer que há uma relação muito estreita entre fibras e porosidade, a qual funciona como os pesos de uma balança para determinar se haverá melhora ou piora no desempenho de um CRFA, quando comparado com a matriz de referência (sem fibras).

Esta relação entre fibras e ar incorporado já havia sido cogitada por Bissonnette e Piegon (1995). Os autores comentam que as microfibras (no caso, com diâmetro da ordem de micro-metros) podem se interligar formando uma espécie de tela, o que prejudica a expulsão de água e de ar, e promove ao concreto maior porosidade na matriz.

Outro fator que pode ter influenciado refere-se à quantidade de fibras incorporada. Os teores de fibras utilizados na composição dos materiais CF e CFMF foram adotados de acordo com os resultados de outras pesquisas concluídas no departamento (Ferrari, 2007 e Ferreira, 2007). Nestes trabalhos obteve-se que a incorporação de $1 \%$ da fibra de $25 \mathrm{~mm} 1 \%$ da microfibra $(13 \mathrm{~mm})$ conduziria a um comportamento ótimo do compósito. Entretanto, sabe-se que o desempenho do concreto reforçado com fibras depende de diversos fatores, dentre eles:

- Geometria, fator de forma, teor, orientação e distribuição das fibras;

- Resistência da matriz e dimensão máxima dos agregados;

- Interface fibra-matriz;

- Dimensões e geometria dos corpos-de-prova;

- Metodologia de ensaio.

Desta forma, mesmo que mantidas as características relativas às fibras, certamente o teor ótimo encontrado para uma determinada situação não pode ser generalizado. Ou seja, mesmo trabalhando com a mesma classe de resistência do concreto, inúmeros fatores que interferem nas características da matriz podem afetar, por exemplo, a interface fibra-matriz. Também é certo que o acréscimo na porosidade discutido anteriormente também deve ser um fator muito importante na determinação do teor ótimo de fibras para um determinado traço.

Sendo assim, o ideal seria se neste trabalho tivesse sido realizado um estudo de dosagem das fibras, para determinar o teor ótimo relacionado ao traço efetivamente utilizado na avaliação experimental. 


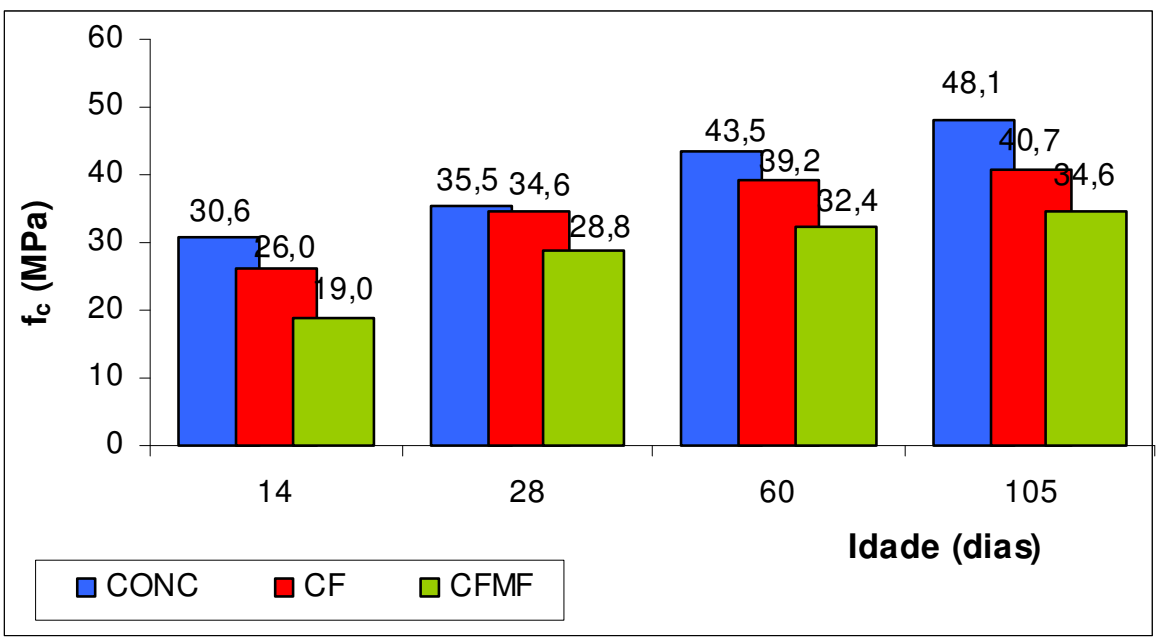

Fig. 8.1:Ensaios de Caracterização Série 1 - Resistência à Compressão.

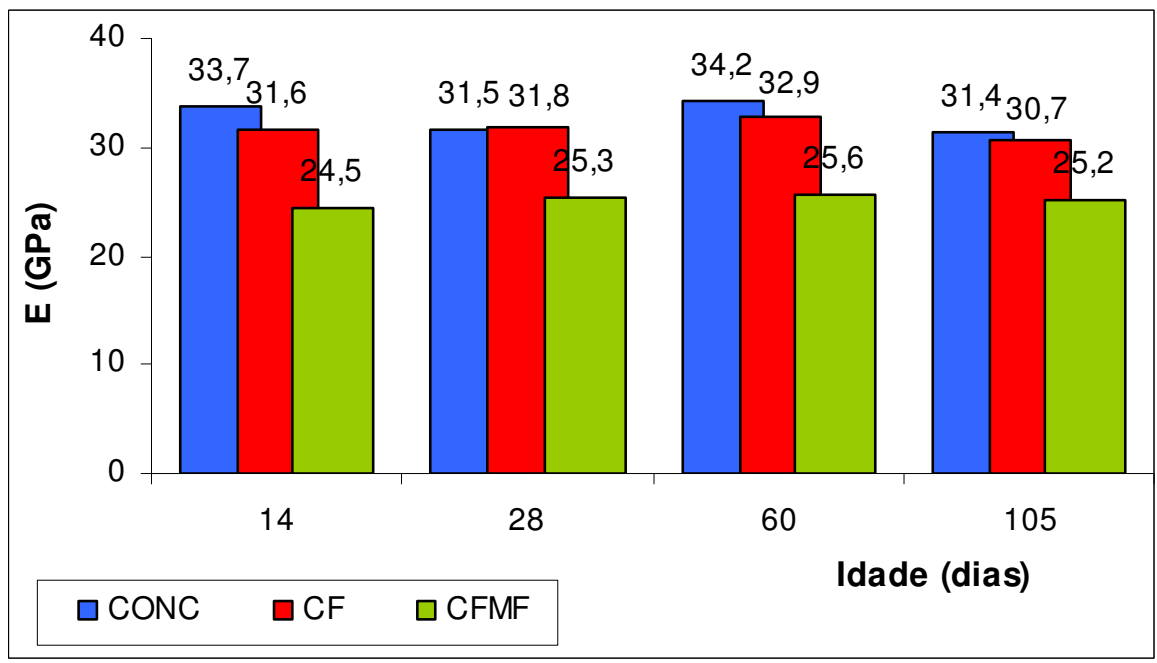

Fig. 8.2: Ensaios de Caracterização Série 1 - Módulo de elasticidade.

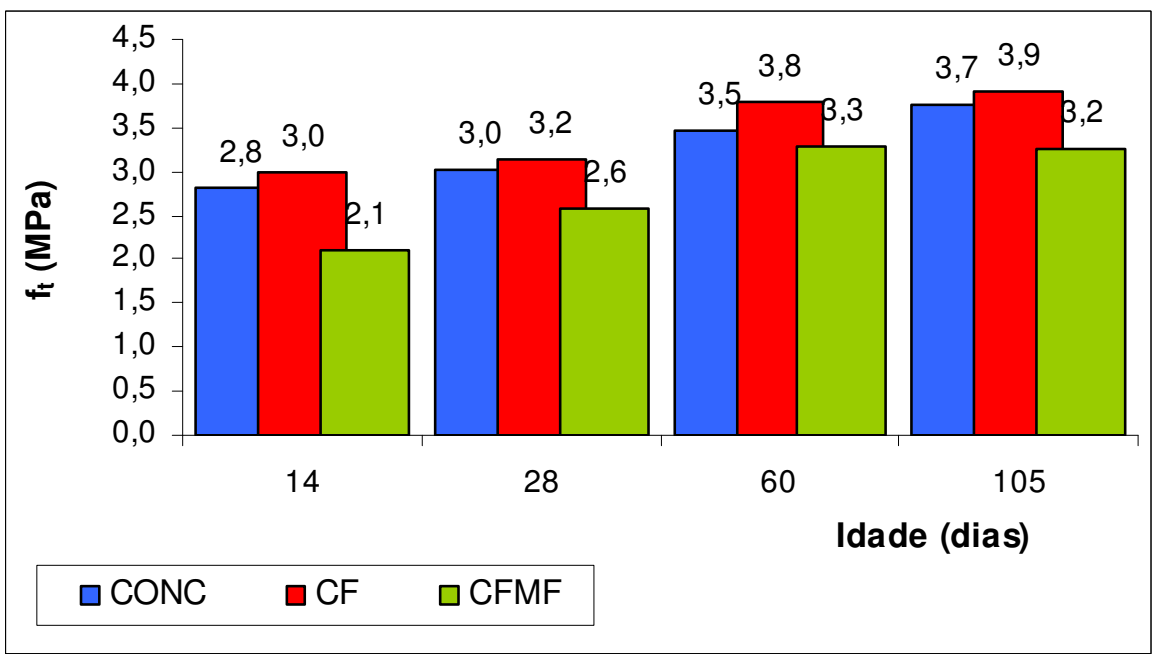

Fig. 8.3: Ensaios de Caracterização Série 1 - Resistência à Tração Indireta (Compressão diametral). 
Outra possibilidade para o baixo desempenho do material CFMF relaciona-se ao fato de que nesta série de ensaios piloto as concretagens referentes aos três materiais foram realizadas em dias diferentes, com concreto misturado in loco. Nesse sentido não se descartou a hipótese de ter havido alguma falha na dosagem dos materiais. Esta hipótese fortaleceu a repetição dos ensaios.

A partir dos ensaios de compressão axial efetuados aos 28 dias foram também obtidos os valores do coeficiente de Poisson para cada material, sendo encontrados valores de 0,16 , 0,16 e 0,24 para a matriz, o concreto com fibras (CF) e para o concreto com fibras e microfibras (CFMF), respectivamente. Novamente os resultados demonstram que a incorporação das fibras e microfibras tornou o compósito mais deformável.

A Fig. 8.4-a ilustra a variação da relação entre as deformações transversal e longitudinal de acordo com a tensão aplicada. Esta é uma forma de visualizar o coeficiente de Poisson. Neste trabalho, essa propriedade foi determinada a partir do coeficiente angular da reta reproduzida em um gráfico $\varepsilon_{\text {tranversal }}$ versus $\varepsilon_{\text {longitudinal }}$ para a resposta elástica linear, ou seja, dentro do intervalo considerado para tensões aplicadas entre $10 \%$ e $30 \%$ de $\sigma_{\text {máx }}$ (ver Fig. 8.4-b), sendo que a deformação transversal é dada pelo do valor médio dos dois extensômetros utilizados.
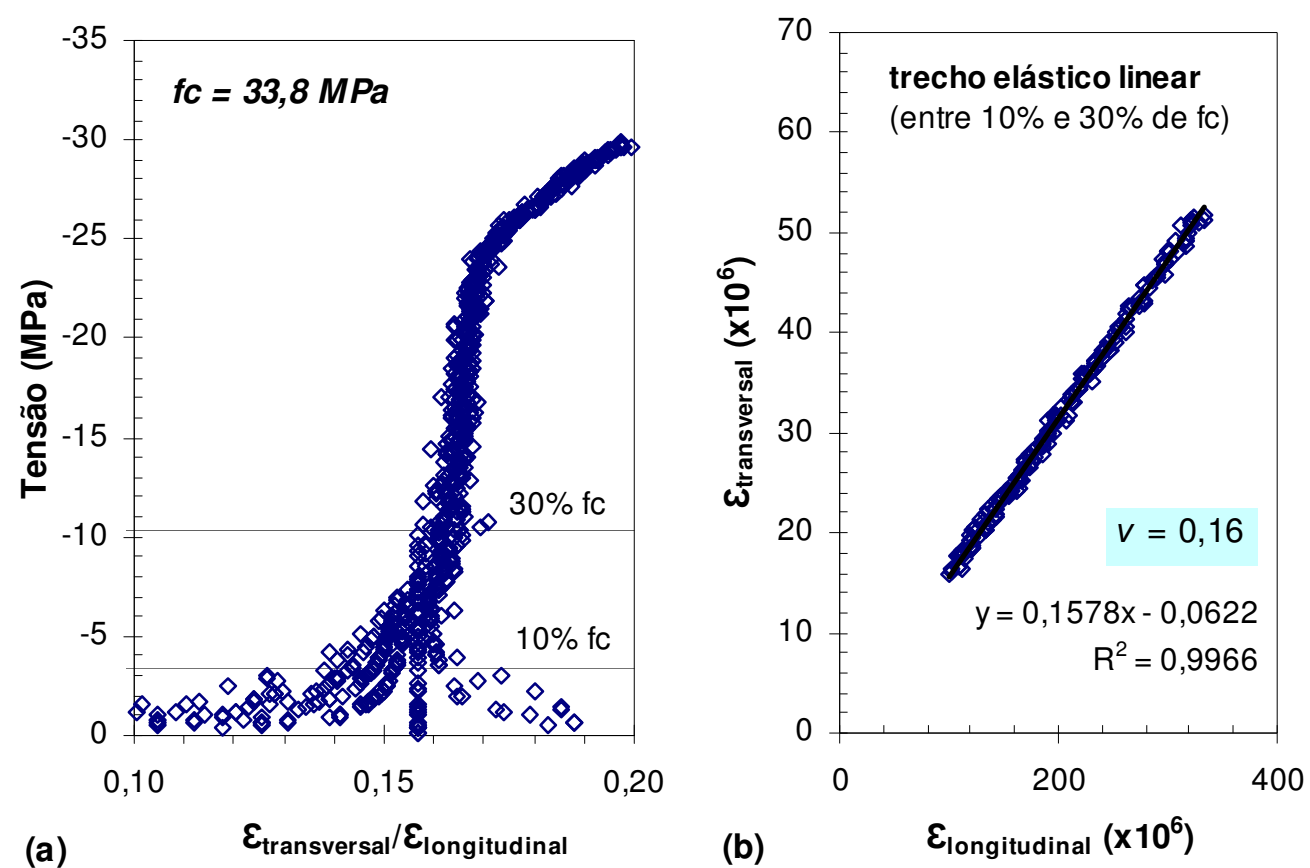

Fig. 8.4: Determinação do coeficiente de Poisson (cp cilíndrico-CONC1). 
Conforme demonstra a Fig. 8.5-a, os extensômetros utilizados para o corpo-de-prova em questão forneceram leituras muito próximas. Entretanto, muitas vezes as leituras são discrepantes, dificultando a obtenção de um valor confiável para o coeficiente de Poisson.

Isto porque o extensômetro pode ser fixado em uma região desfavorável, como por exemplo, sobre uma brita ou um poro, ou ainda por ocorrer microfissuras próximas que mascaram os resultados. Desta forma, na Fig. 8.5-b tem-se um caso em que não foi possível determinar o coeficiente de Poisson.

Se o concreto fosse um material homogêneo, certamente que o uso de extensômetros para representar seu comportamento poderia ser realizado com maior tranqüilidade, ainda mais quando se utilizam poucos pontos de leitura (no caso apenas dois, diametralmente opostos). Os valores do coeficiente de Poisson determinado para cada corpo-de-prova ensaiado estão apresentados na Tabela 8.2.
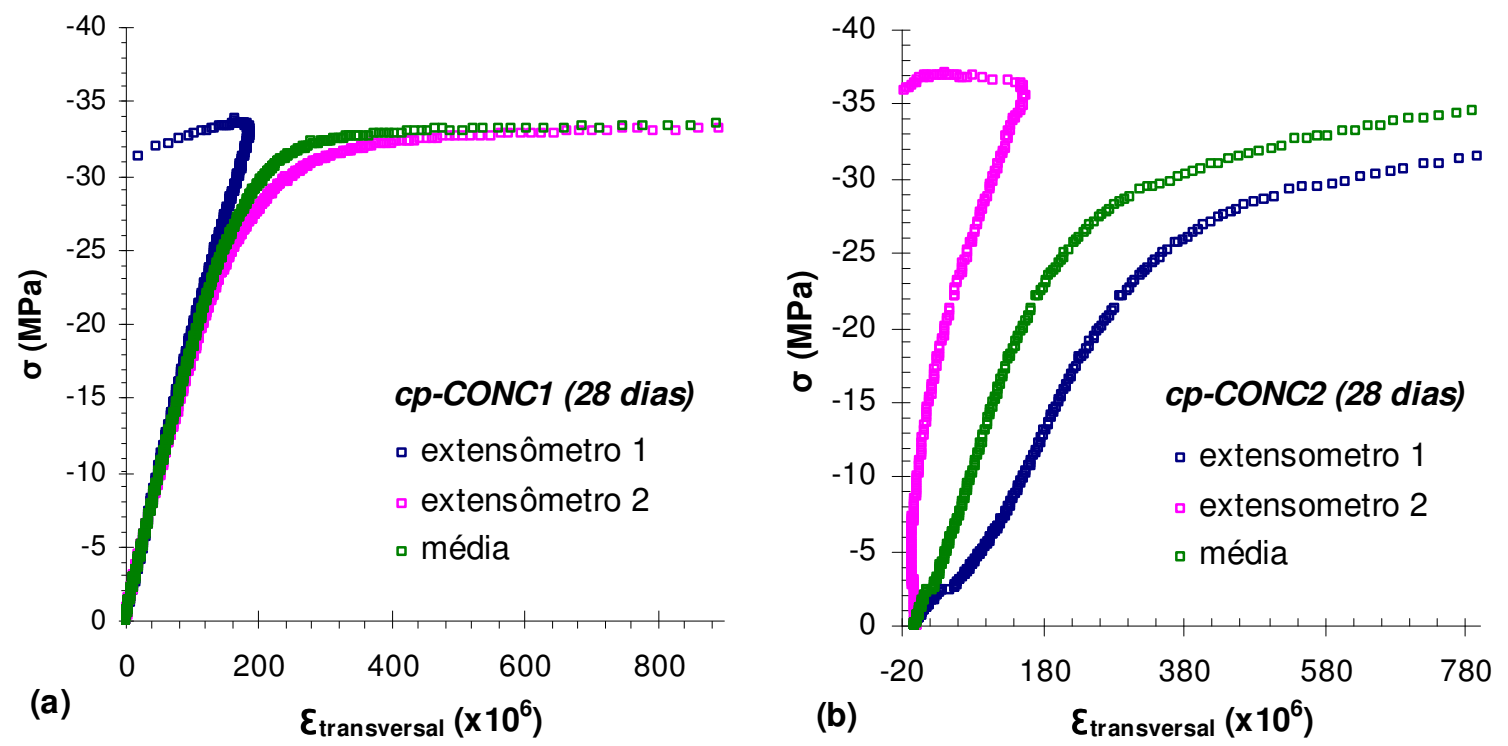

Fig. 8.5: Leituras de deformação transversal.

Tabela 8.2: Valores do coeficiente de Poisson.

\begin{tabular}{cccccc}
\hline Corpo-de-prova & $\begin{array}{c}\text { Poisson } \\
\text { (ext. 1) }\end{array}$ & $\begin{array}{c}\text { Poisson } \\
\text { (ext. 2) }\end{array}$ & média & $\begin{array}{c}\text { valor } \\
\text { assumido }\end{array}$ & $\begin{array}{c}\text { valor representativo } \\
\text { do material }\end{array}$ \\
\hline CONC1 & 0,16 & 0,16 & 0,16 & 0,16 & 0,16 \\
CONC2 & $-0,56$ & 0,02 & 0,25 & descartado & 0,16 \\
\hline CF1 & 0,13 & 0,42 & 0,27 & 0,13 & 0,24 \\
CF2 & 0,14 & 0,23 & 0,19 & 0,19 & \\
\hline CFMF1 & 0,23 & 0,26 & 0,24 & 0,24 & 0,25 \\
CFMF2 & 0,19 & 0,31 & 0,25 & 0,
\end{tabular}


Com relação à evolução das propriedades ao longo do tempo nota-se que, no final dos ensaios (concreto com idade de 105 dias) houve acréscimos de 36\%, 28\% e 20\% da resistência à compressão, comparativamente aos valores encontrados aos 28 dias. Consideram-se esses valores elevados, uma vez que pela norma (NBR 6118:2003), para o concreto de referência, dever-se-ia esperar algo em torno de $13 \%$.

Interessante notar que à medida que se adicionaram as fibras, os percentuais de aumento da resistência foram menores. Já com relação à resistência à tração, foram obtidos, em média, valores aos 105 dias 25\% maiores do que aqueles encontrados aos 28 dias.

A resistência à compressão e o módulo de elasticidade aumentam com a idade, mas com diferentes taxas de crescimento. Certas características do concreto, tais como a zona de transição, o estado de umidade e o grau de hidratação, influenciam ambas as propriedades de forma diferente. Conforme se observa na Fig. 8.6, praticamente em todos os casos as propriedades aumentaram com o tempo, contudo dois comportamentos atípicos chamam a atenção.

Nota-se que as curvas para a resistência à compressão sofrem um crescimento mais acentuado dos 14 aos 28 dias, diferentemente da tendência observada dos 28 dias em diante. Lembrando as informações do capítulo anterior, aos 14 dias foram utilizados discos de neuprene. Sabe-se que a utilização destes discos, ao invés do capeamento com enxofre, pode implicar em resistências menores, o que explica os saltos observados.

Já as curvas do módulo de elasticidade apresentam pouca diferença entre 28 e 60 dias, sendo que entre 60 e 105 dias, alguns materiais apresentaram queda do módulo de elasticidade. Isto possivelmente espelha a microfissuração devida à retração por secagem que ocorreu neste período, uma vez que os corpos-de-prova ficaram armazenados juntamente com os demais modelos (vigas e prismas) na câmara climatizada, sendo que a umidade relativa média foi de $59 \%$. Cogita-se ainda que esse comportamento esteja também vinculado à variabilidade dos resultados. 


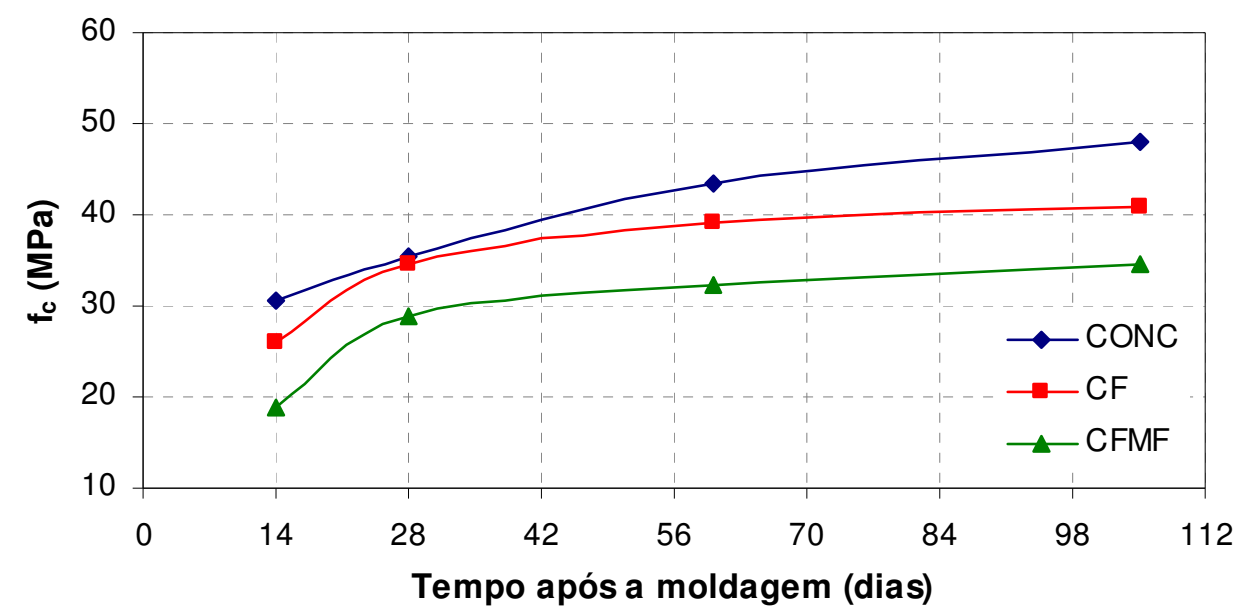

Fig. 8.6: Variação ao longo do tempo da resistência à compressão - Série 1.

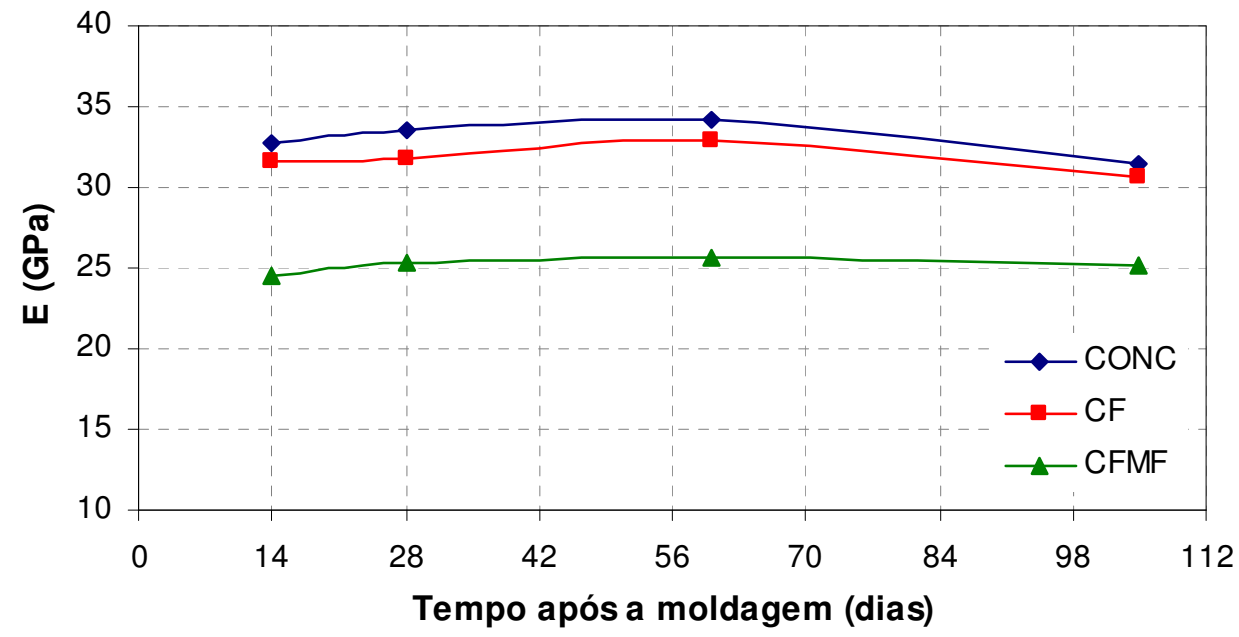

Fig. 8.7: Variação ao longo do tempo do módulo de elasticidade - Série 1.

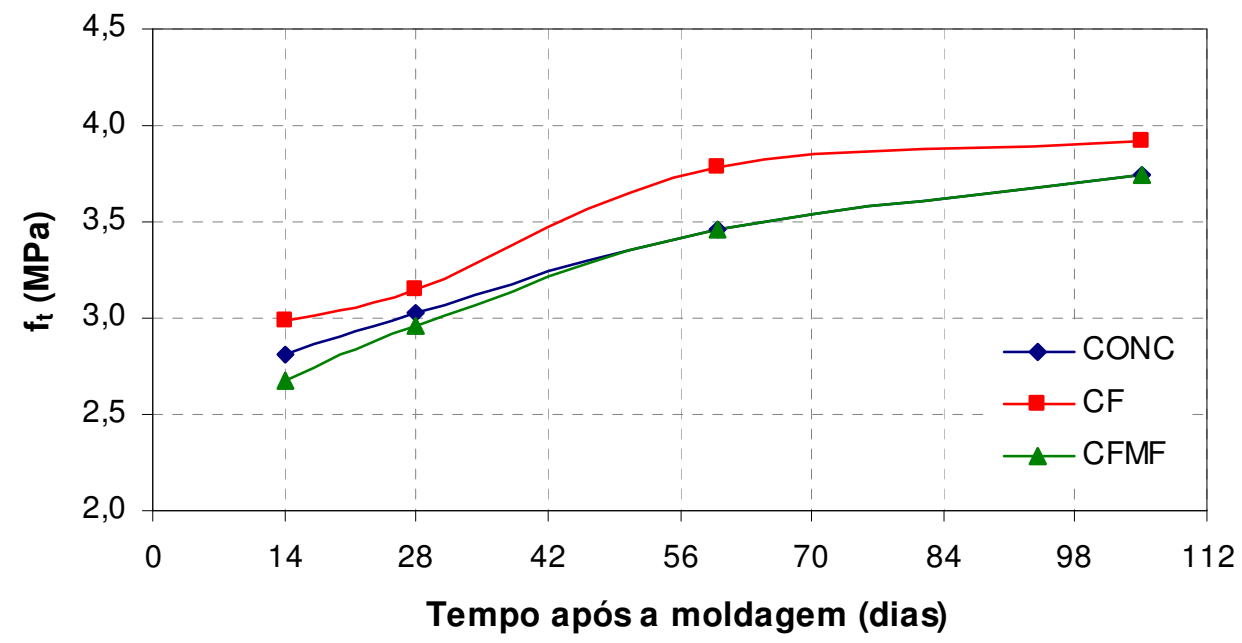

Fig. 8.8: Variação ao longo do tempo da resistência à tração (compressão diametral) - Série 1. 


\subsubsection{Ensaios de Retração}

Os valores destas deformações não foram aplicados na correção das deformações totais obtidas no ensaio de fluência, em virtude da realização destes ensaios à flexão. O principal objetivo destes ensaios foi avaliar o desempenho do material compósito, conforme será comentado adiante.

Como os corpos-de-prova foram sujeitos à pré-secagem e os ensaios se iniciaram aos 60 dias, as deformações por retração medidas foram muito pequenas, alcançando valores próximos de $50 \mu$ após 38 dias de leitura (98 dias após a moldagem).

Os dados experimentais foram ajustados a equações normalmente utilizadas na literatura: expressão exponencial e uma expressão equivalente à utilizada pelo ACI 209:1982. As equações são apresentadas a seguir, já os coeficientes e o índice de correlação $\left(\mathrm{r}^{2}\right)$ obtido por cada ajuste estão apresentados para cada material na Tabela 8.3.

Exponencial:

$$
\varepsilon_{c, s}=a\left[1-\exp \left(-b\left(t-t_{0}\right)\right)\right]
$$

ACI 209:1982:

$$
\varepsilon_{c, s}=\frac{a \cdot\left(t-t_{0}\right)}{35+b \cdot\left(t-t_{0}\right)}
$$

Tabela 8.3: Coeficientes para ajuste dos dados de retração - Série 1.

\begin{tabular}{ccccc}
\hline \multirow{2}{*}{ Ajuste } & & CONC & CF & CFMF \\
\hline \multirow{3}{*}{ Exponencial 1 } & $\mathrm{a}$ & 51,413056 & 141,60241 & 60,754785 \\
& $\mathrm{~b}$ & 0,057252 & 0,010761 & 0,044787 \\
& $\mathrm{r}^{2}$ & 0,98 & 0,97 & 0,96 \\
\hline \multirow{2}{*}{ ACI 209 } & $\mathrm{a}$ & 109,94683 & 53,36027 & 101,89246 \\
& $\mathrm{~b}$ & 1,439713 & 0,19945 & 1,109862 \\
& $\mathrm{r}^{2}$ & 0,98 & 0,97 & 0,96 \\
\hline
\end{tabular}

Os gráficos das figuras 8.7, 8.9 e 8.11 apresentam as linhas de tendências obtidas por cada ajuste para os três materiais avaliados: concreto sem fibras (CONC), concreto com fibras (CF) e concreto com fibras e microfibras (CFMF). Já as figuras 8.8, 8.10 e 8.12 ilustram a extrapolação no tempo do comportamento das linhas de tendência encontradas.

Através das Figuras 8.10, 8.11 e 8.12 nota-se que as expressões utilizadas nos ajustes representam muito bem o comportamento observado dentro do período de avaliação, o que também é comprovado pelo coeficiente de correlação encontrado para cada ajuste. 


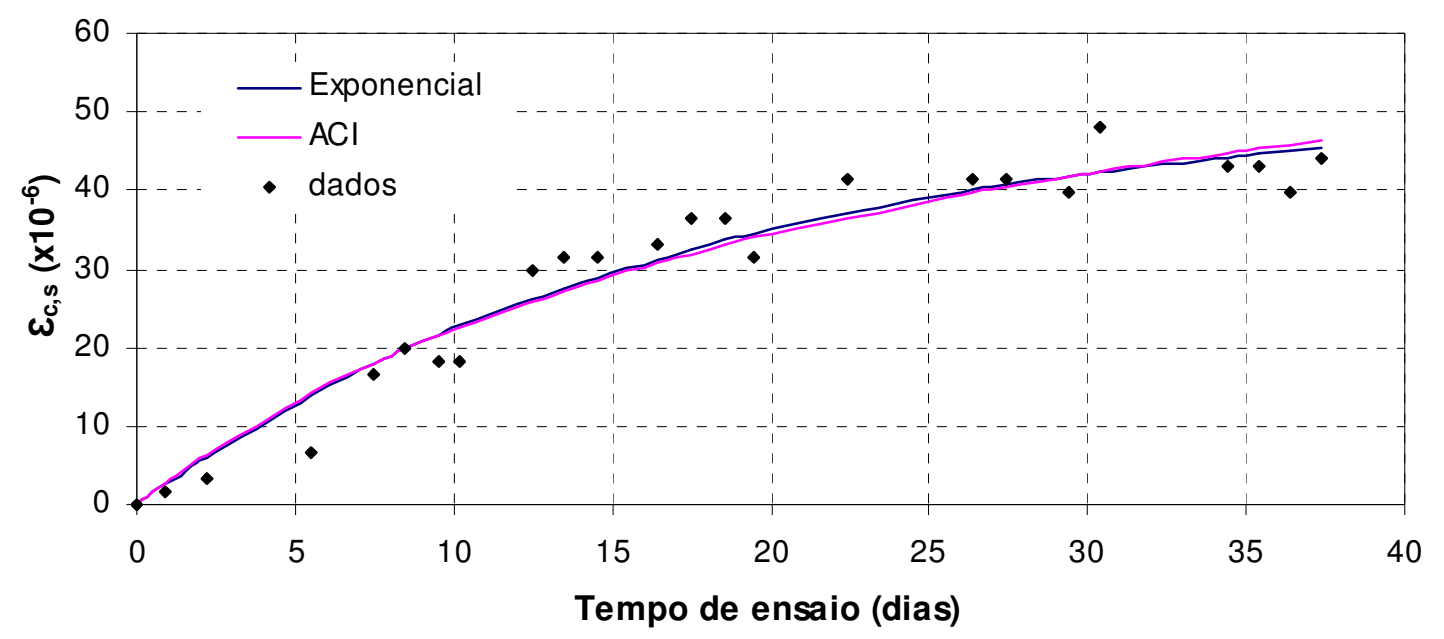

Fig. 8.9: Deformações Volumétricas - Série 1. Ajustes aos dados experimentais: CONC.

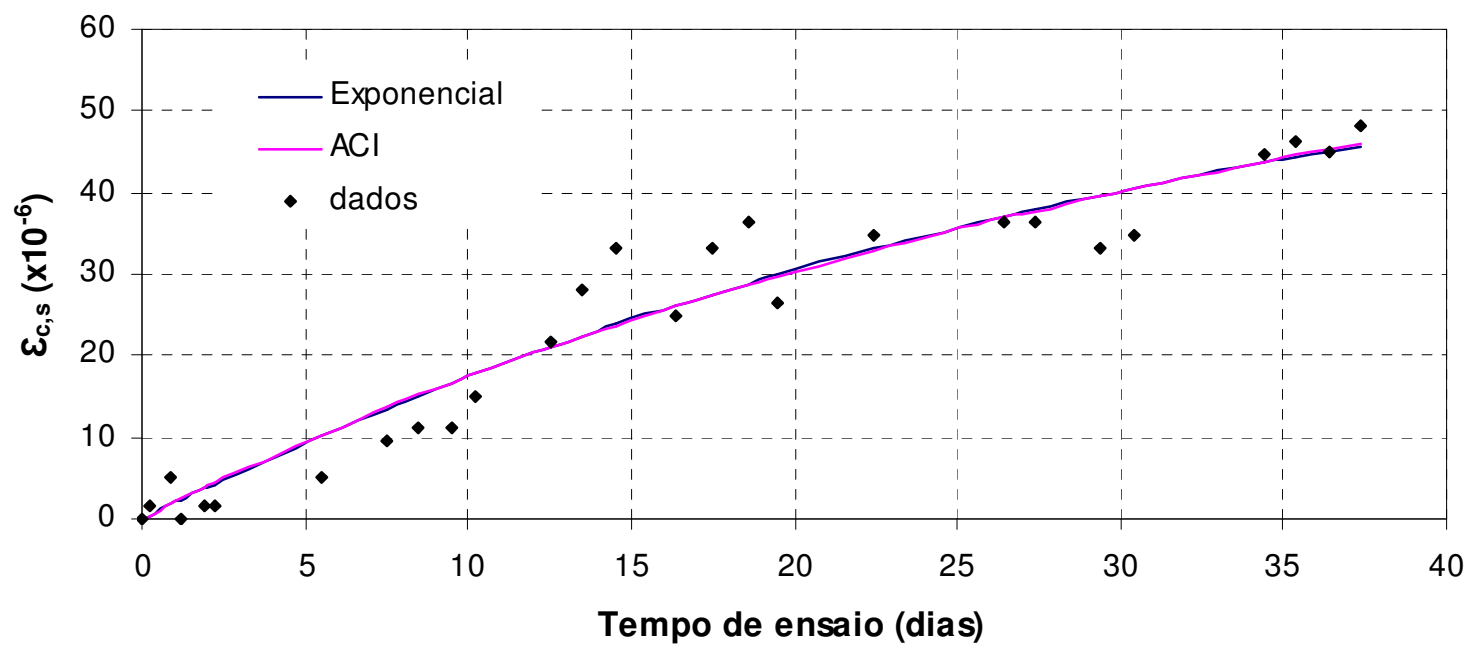

Fig. 8.10: Deformações Volumétricas - Série 1. Ajustes aos dados experimentais: CF.

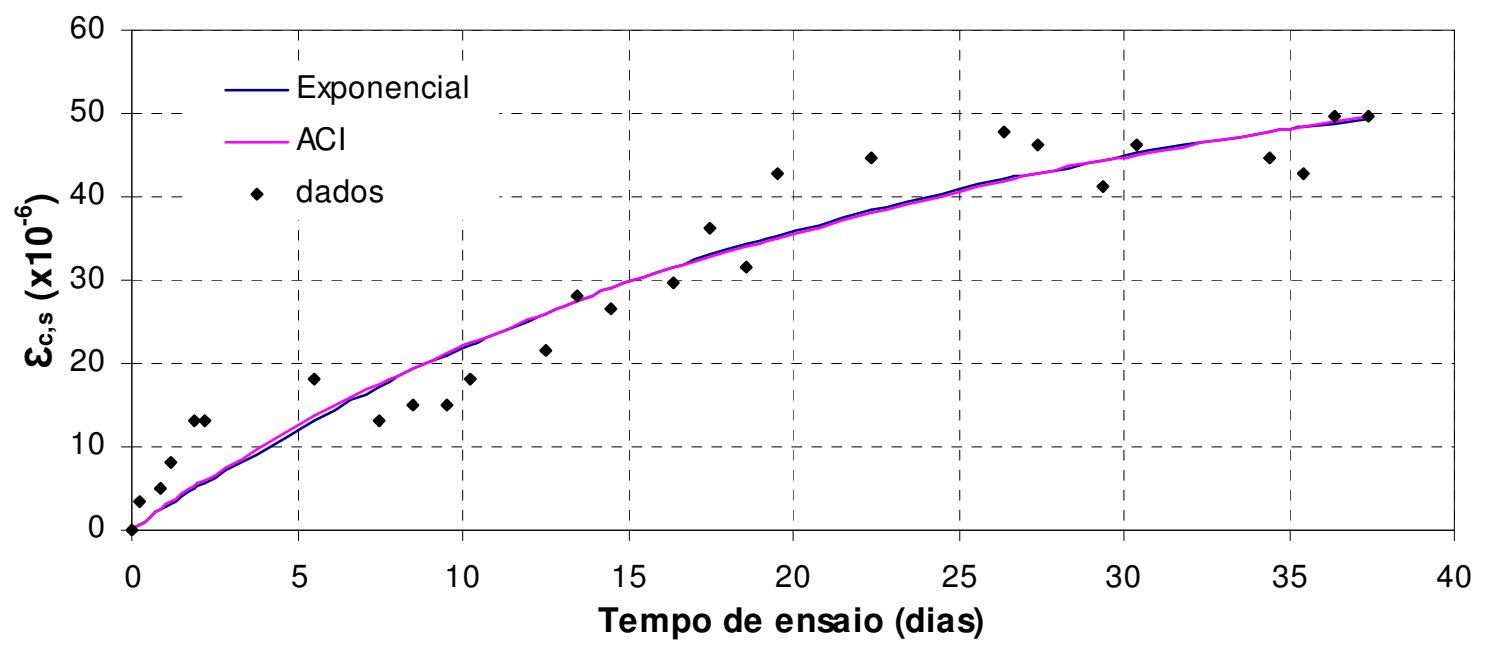

Fig. 8.11: Deformações Volumétricas - Série 1. Ajustes aos dados experimentais: CFMF. 


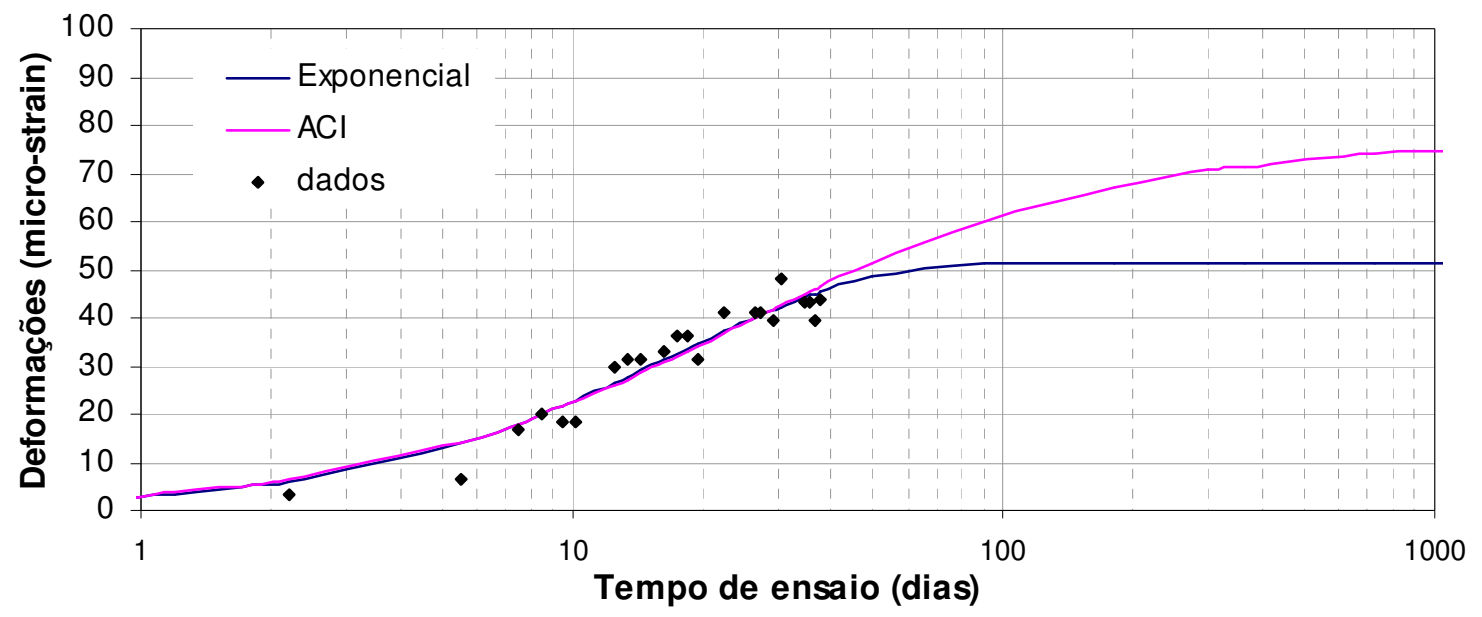

Fig. 8.12: Extrapolação das deformações por retração: CONC.

Já a Fig. 8.12 ilustra a extrapolação das curvas de tendência para períodos de tempo de até aproximadamente 3 anos (1000 dias). Este gráfico é interessante por explicitar a grande diferença na estimativa da deformação última por retração decorrente da expressão utilizada para o ajuste dos dados de ensaios de curta duração. Imagina-se que a curva do ACI represente melhor o fenômeno, uma vez que foi calibrada a partir de um vasto banco de dados e indica uma estabilização suave das deformações.

De acordo com a Figura abaixo, nota-se que até a data em que foram finalizadas as leituras, a deformação por retração experimental, de 44 microstrain, é muito próxima do valor estimado pela NBR 6118:2003 (Anexo A - Efeitos do tempo), igual a 53 microstrain. Contudo, como o período de observação foi curto percebe-se que a curva de ajuste distanciase consideravelmente da curva obtida segundo a norma.

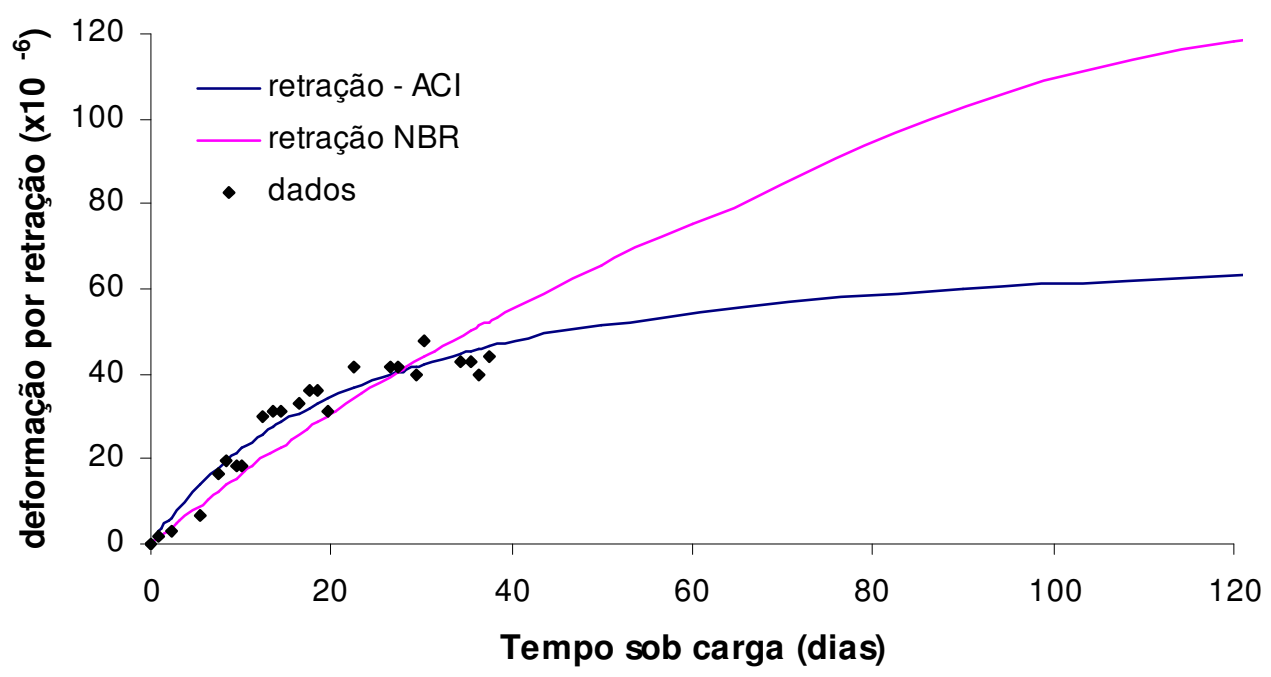

Fig. 8.13: Comparação das curvas de retração experimental e normativa. 
Para determinação das deformações por retração, a norma brasileira considera os seguintes fatores: umidade relativa do ambiente, consistência do slump no lançamento e a espessura fictícia, a qual depende das dimensões da peça. Desta forma, deve-se considerar que boa parte do distanciamento entre as curvas deve-se à pré-secagem e à idade em que foram iniciados os ensaios, já que estes são fatores que não são levados em conta por este modelo de previsão.

\subsubsection{Influência das fibras}

A Fig. 8.14, ilustra comparativamente o comportamento dos três materiais para o período de tempo avaliado, de acordo com as linhas de tendência obtidas a partir das expressões equivalentes à proposta pelo ACI. Conforme se observa, não houve diferença significativa entre os materiais avaliados. Apesar das diferenças na porosidade da matriz, prevaleceu a capacidade das fibras de restringir deformações e transmitir tensões. Imagina-se também que essas diferenças na porosidade da matriz não tenham interferido muito nestes ensaios por conta da condição de secagem à que os prismas ficaram expostas durante um mês antes do início das leituras.

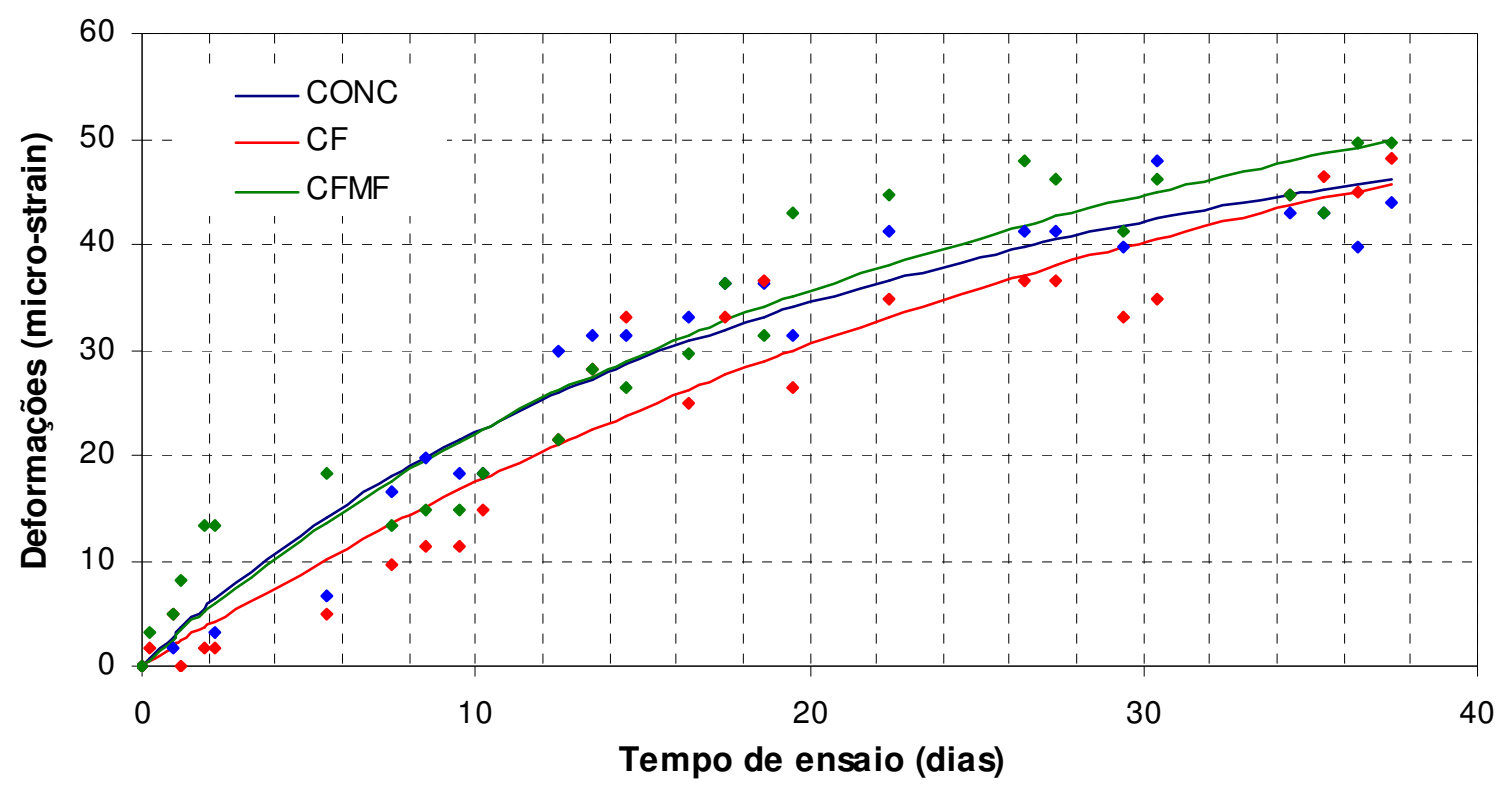

Fig. 8.14: Deformações por retração - Série 1. Período de observação.

Ressalta-se que, mesmo tomando todos os cuidados necessários durante a fixação das peças de encaixe, houve dificuldade em manter as peças, durante a colagem, exatamente na mesma posição. Desta forma, qualquer folga no encaixe do relógio contribui para menor repetibilidade das leituras, prejudicando as medições. Além disso, como os valores das 
deformações são pequenos, assim como as variações entre leituras subseqüentes, qualquer erro na instrumentação ou erro de leitura tem importância significativa.

\subsubsection{Ensaios de Fluência}

A partir das leituras dos deslocamentos verticais da linha de carga (flecha) das vigas do tipo VSE (Viga Sem Entalhe), foram realizadas inúmeras ações para análise comparativa do comportamento dos materiais, em decorrência da incorporação das fibras, e extrapolação dos dados experimentais.

Os resultados das vigas do tipo VE (Vigas Entalhadas) serão apresentados à parte no item 8.1.3.2, por conta de particularidades que ocorreram nos ensaios. Para identificação dos materiais utiliza-se a nomenclatura: CONC (concreto sem fibras), $\mathrm{CF}$ (1\% de fibras de comprimento de $25 \mathrm{~mm}$ ); e CFMF (fibras de $25 \mathrm{~mm}$ e $13 \mathrm{~mm}, 1 \%$ de cada).

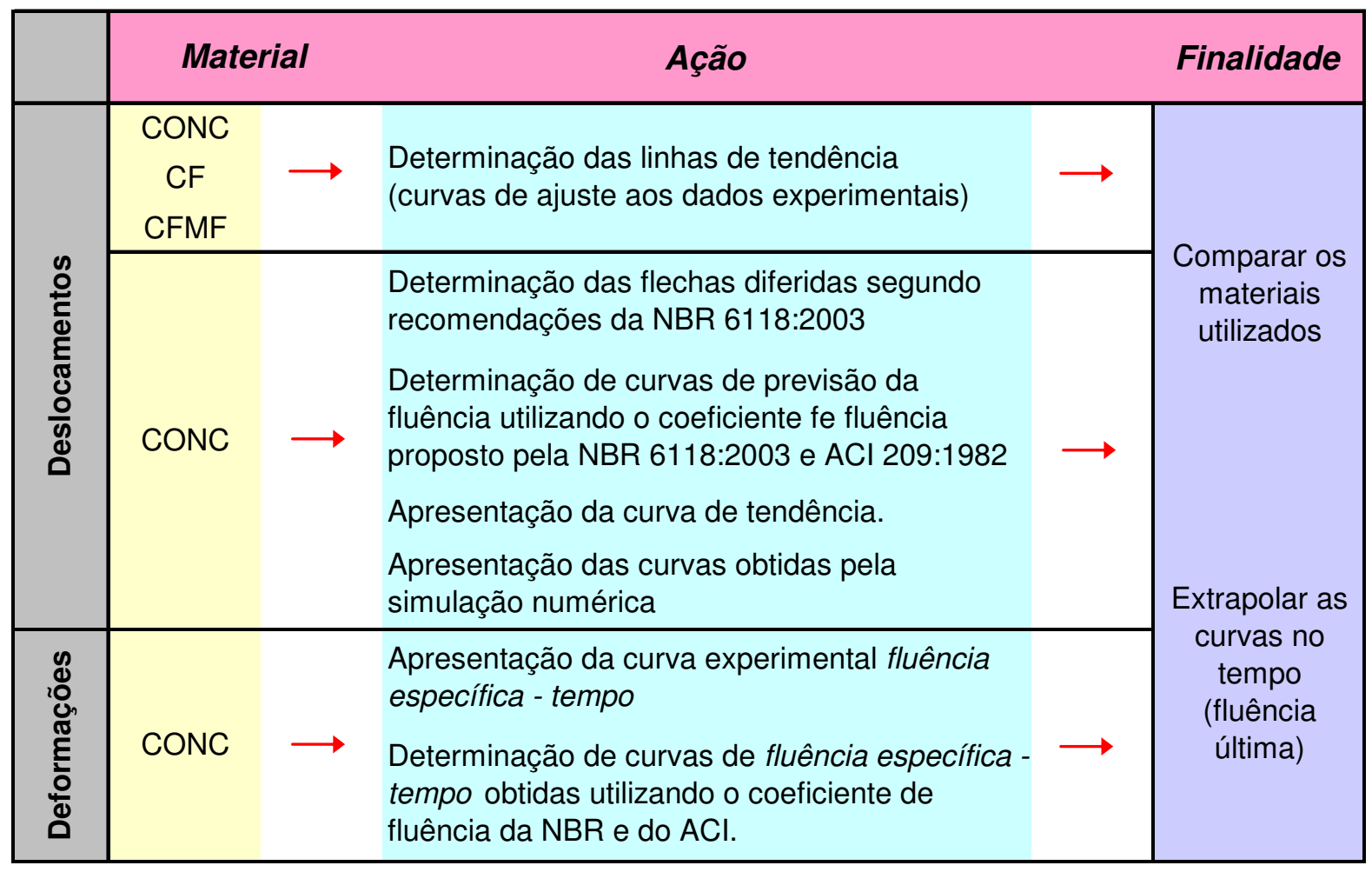

Fig. 8.15: Esquema das etapas envolvidas na análise dos resultados dos ensaios de fluência das vigas sem entalhe (VSE).

Relativamente aos ensaios de fluência, é interessante comentar sobre o nível de tensão aplicado. Tanto as vigas entalhadas quanto aquelas sem entalhe possuem tensões máximas de tração da ordem de 1,4 MPa. Desta forma, observando o valor da resistência à tração obtida aos 60 dias para cada material, tem-se que a relação tensão-resistência foi de $40 \%$. 


\subsubsection{Resultados das Vigas sem entalhe}

\subsection{Resultados em termos de deslocamentos}

\section{a) Ajuste dos dados experimentais}

Para determinação das curvas de tendência deslocamento-tempo para os dados experimentais das flechas diferidas, medidos durante o período de observação de 38 dias, foram utilizadas expressões análogas às funções fluência apresentadas no capítulo 4. Desta forma, somada à flecha inicial tem-se uma função dependente da duração do carregamento (t$\mathrm{t}_{0}$ ), cujos coeficientes foram obtidos por regressões com auxilio do software curvexpert ${ }^{23}$ (HYANS, 1997).

Foram empregadas duas expressões bastante conhecidas da literatura para definir esta função: a equação exponencial e a equação hiperbólica proposta por Ross (hipérbole de Ross), na qual se baseia o modelo de previsão de fluência da norma americana (ACI 209:1982) para estimativa da parcela da fluência específica dependente da duração do carregamento $\left(\mathrm{t}-\mathrm{t}_{0}\right)$.

A seguir são apresentadas as equações utilizadas para obtenção das curvas de tendência; já os coeficientes e o índice de correlação obtido por cada ajuste estão apresentados na tabela 8.4.

$$
\begin{array}{ll}
\text { Exponencial: } & \delta(t)=a \cdot\left[1-\exp \left(-c \cdot\left(t-t_{0}\right)\right)\right]+\delta_{i}\left(t_{0}\right) \\
\text { Hipérbole de Ross: } & \delta(t)=\frac{\left(t-t_{0}\right)}{a+b \cdot\left(t-t_{0}\right)}+\delta_{i}\left(t_{0}\right)
\end{array}
$$

Tabela 8.4: Coeficientes para ajuste dos dados de fluência - Série 1.

\begin{tabular}{cccccccc}
\hline \multirow{2}{*}{ Modelo } & \multicolumn{3}{c}{ Hipérbole de Ross } & \multicolumn{3}{c}{ Exponencial } & $\boldsymbol{\delta}_{\mathbf{i}}\left(\mathrm{t}_{\mathbf{0}}\right)$ \\
& $\mathbf{a}$ & $\mathbf{b}$ & $\mathbf{r}^{2}$ & $\mathbf{a}$ & $\mathbf{b}$ & $\mathbf{r}^{2}$ & $(\mathbf{m m})$ \\
\hline VSE - CONC & 95,964042 & 3,708794 & 0,999 & 0,183212 & 0,055967 & 0,998 & 0,109 \\
VSE - CF & 100,11994 & 2,930256 & 1,000 & 0,223544 & 0,042023 & 1,000 & 0,120 \\
VSE - CFMF & 64,770998 & 1,354032 & 1,000 & 0,461936 & 0,032109 & 1,000 & 0,148 \\
\hline
\end{tabular}

${ }^{23}$ HYANS, D. (1997). CurveExpert: a comprehensive curve fitting system for windows, ver. 1.34. Starkville, MS (USA), 1997. O software está disponível para download em: <http://www.ebicom.net/ dhyams/cmain.htm> 


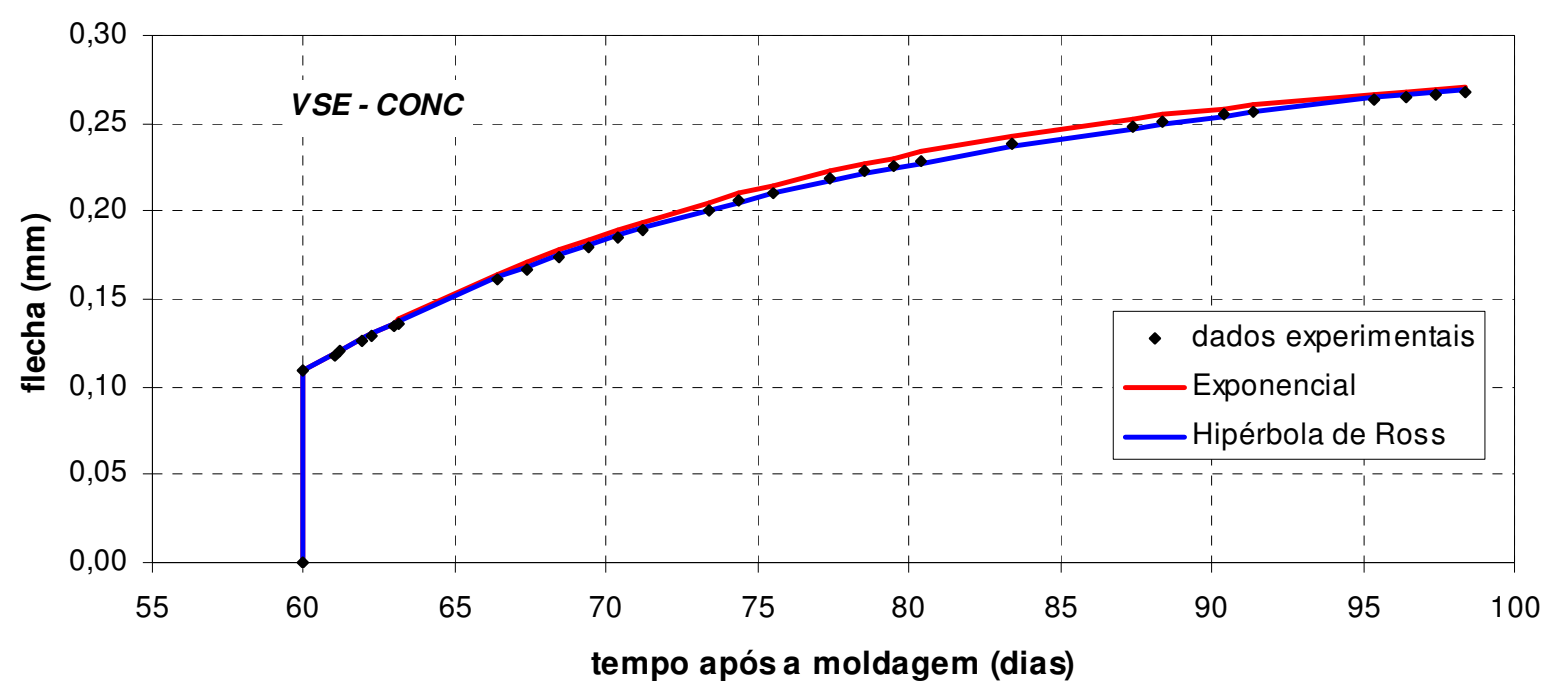

Fig. 8.16: Flechas diferidas VSE - Série 1. Ajustes aos dados experimentais: CONC.

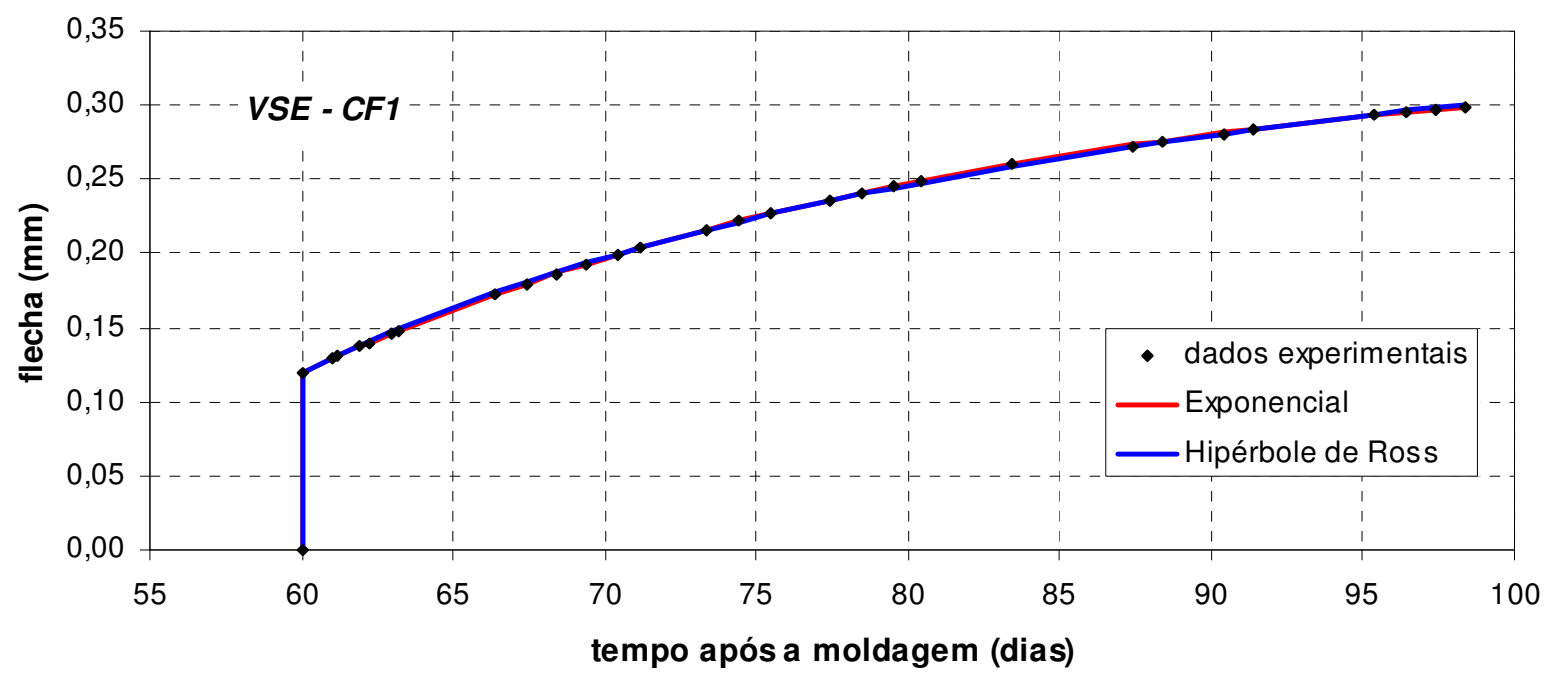

Fig. 8.17: Flechas diferidas VSE - Série 1. Ajustes aos dados experimentais: CF.

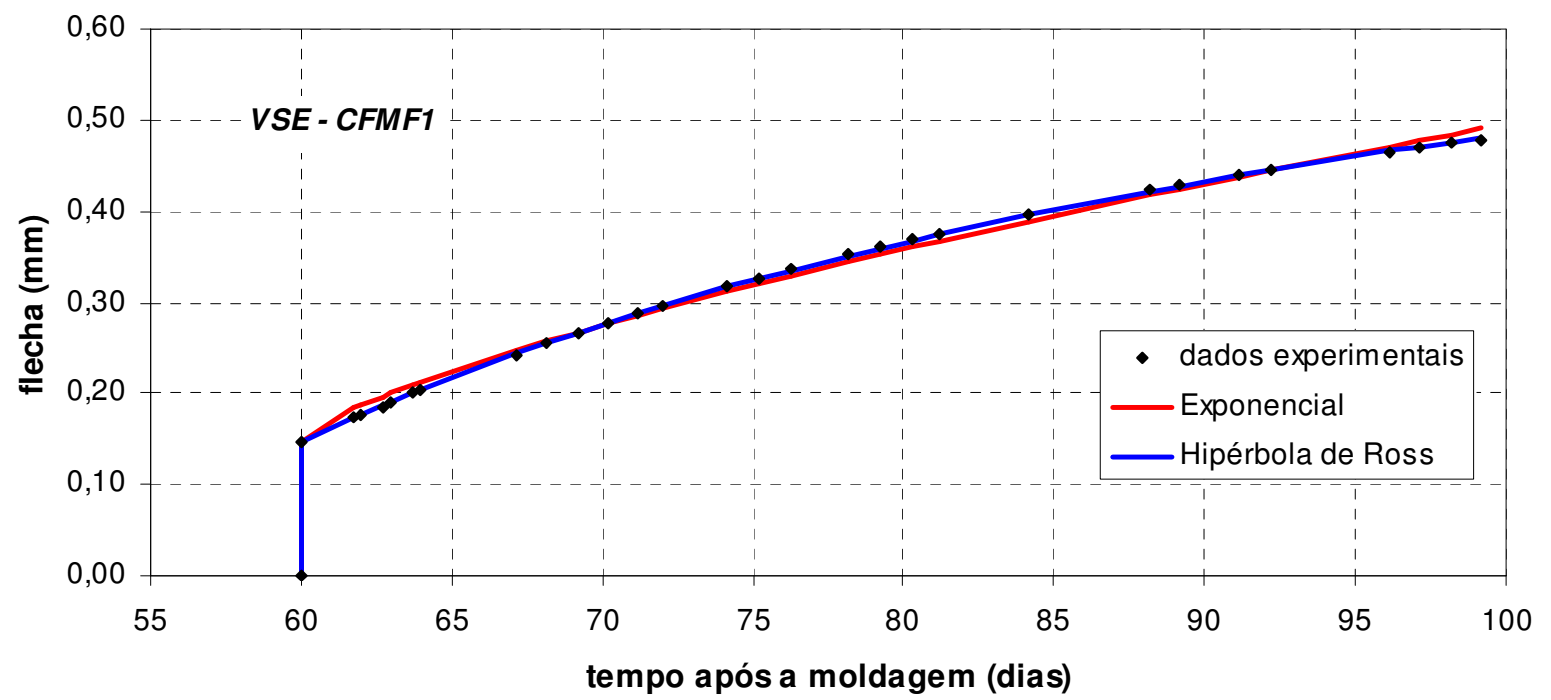

Fig. 8.18: Flechas diferidas VSE - Série 1. Ajustes aos dados experimentais: CFMF. 
Os gráficos das figuras $8.16,8.17$ e 8.18 apresentam as linhas de tendências obtidas por cada ajuste para os três materiais avaliados: concreto sem fibras (CONC), concreto com fibras (CF) e concreto com fibras e microfibras (CFMF). Nota-se que dentro do período de observação os dois ajustes retratam muito bem o comportamento dos materiais, o que também é refletido pelos coeficientes de correlação encontrados (praticamente igual a 1 em todos os casos).

Já o gráfico da Fig. 8.19 fornece a extrapolação no tempo das curvas de tendência, apenas com o intuito de comparar as estimativas fornecidas pelos dois ajustes para períodos maiores de tempo. Nota-se que as expressões de ajuste fornecem resultados bastante diferentes, sendo a curva derivada da Hipérbole de Ross mais suave e com comportamento mais próximo do esperado.

Esta análise é interessante por expor claramente a importância da precisão na estimativa da fluência a partir de ensaios de curta duração. Ou seja, deve-se estar atento de que apesar de aparentemente haver excelente ajuste dentro do período de observação, os critérios adotados na extrapolação dos resultados devem ser rigorosos. A esse respeito, há algumas considerações em Neville (1982).

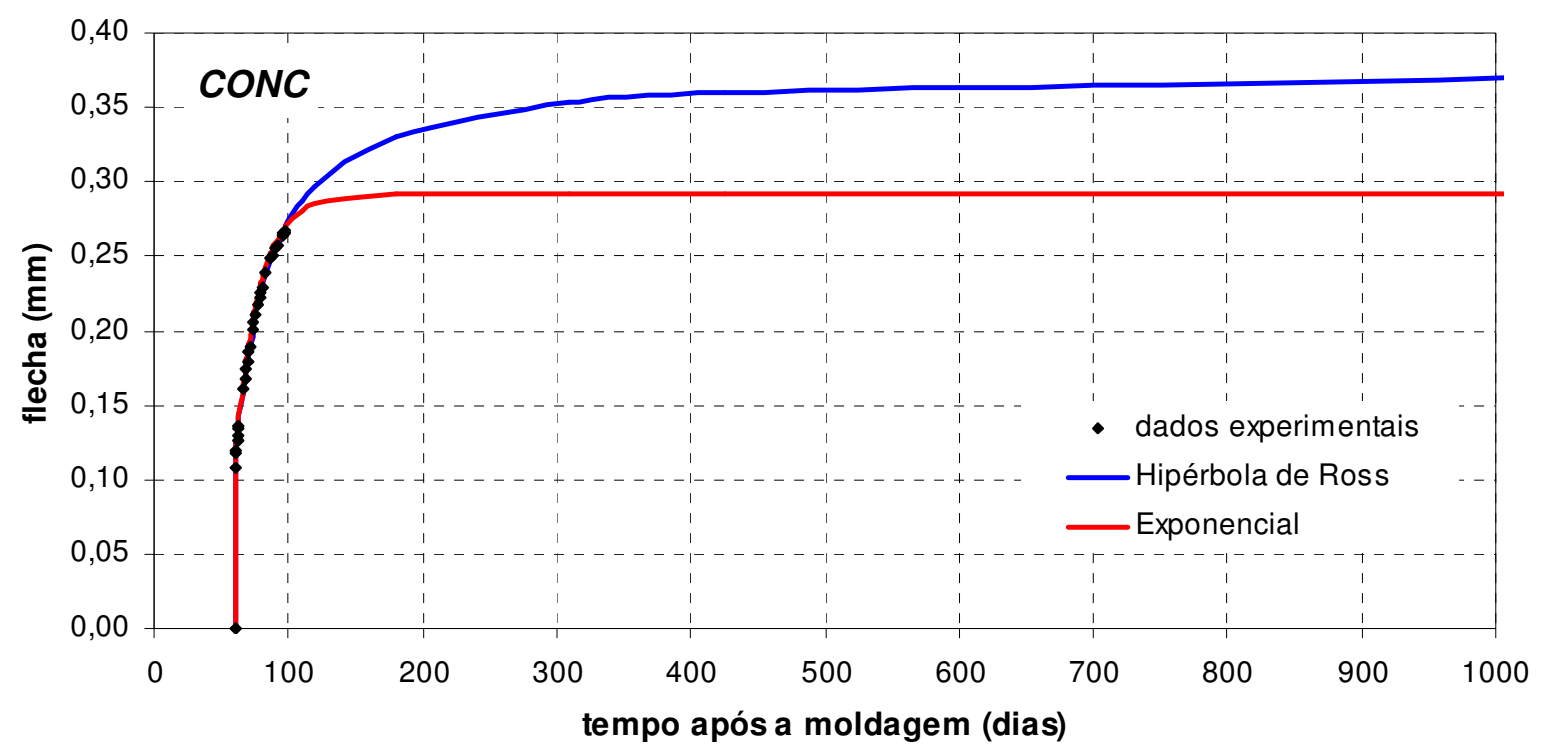

Fig. 8.19: Extrapolação das curvas de tendência.

\section{b) Influência das fibras}

O comportamento comparativo dos materiais é apresentado na Fig. 8.20, através das curvas de tendência obtidas pela equação para o intervalo de avaliação experimental. Percebe- 
se que o concreto reforçado apenas com as fibras de $25 \mathrm{~mm}$ (cujas propriedades, módulo e resistência eram próximas do concreto de referência) não apresentou alteração significativa, embora os deslocamentos referentes a esse material sejam levemente superiores (aproximadamente 12\%).

Contudo, a adição das microfibras ao CRFA conduziu a um desempenho muito pior, sendo que no término dos ensaios, a flecha medida para este material foi aproximadamente $80 \%$ superior àquela medida para a matriz. Certamente que em grande parte esse desempenho ruim dos materiais compósito está relacionado com o aumento do teor de ar incorporado proporcionado pela incorporação das fibras.

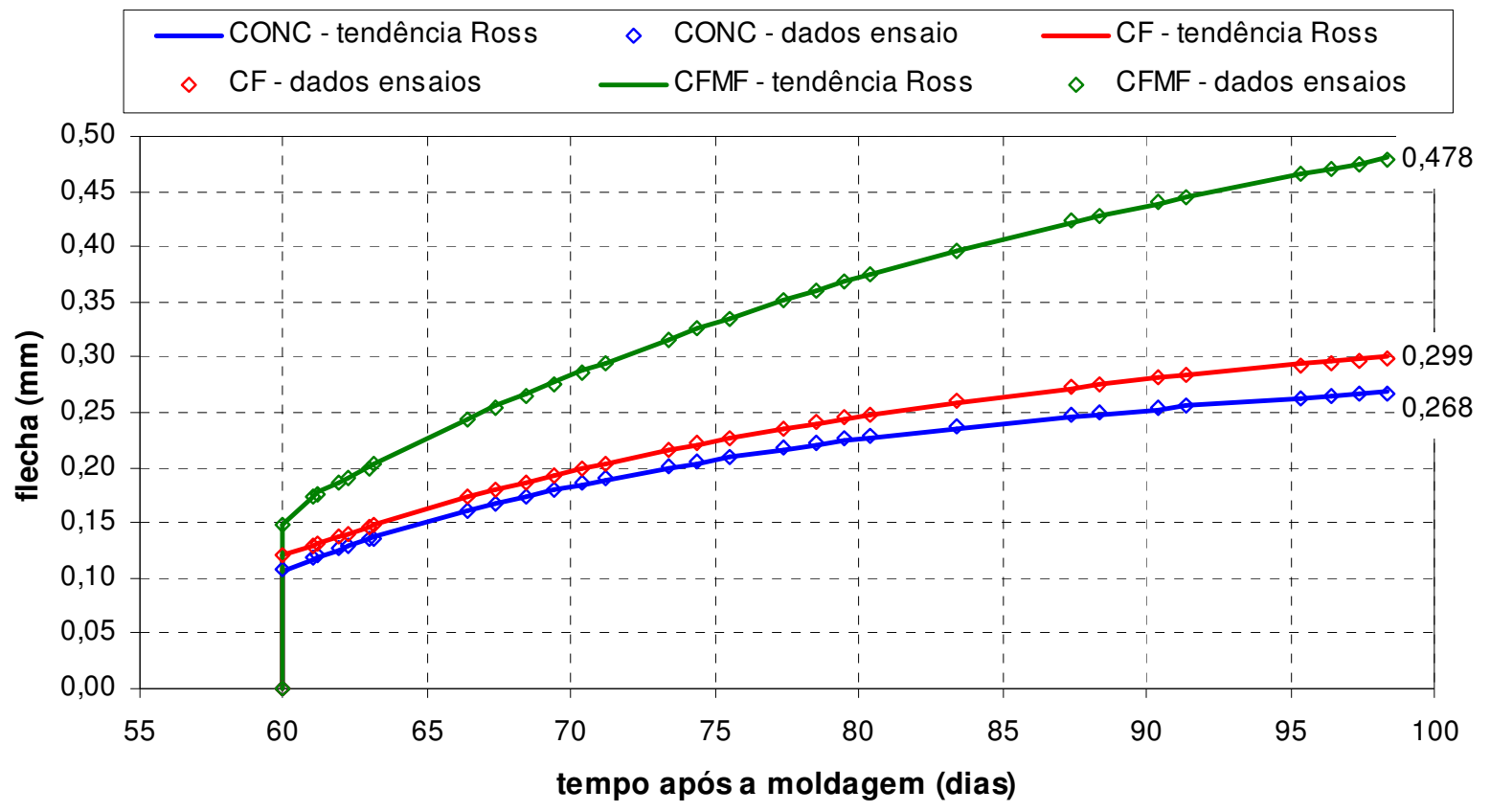

Fig. 8.20: Flechas diferidas VSE: comparação entre os materiais.

Apesar da avaliação experimental desta pesquisa ter sido efetuada em flexão, considera-se que a resposta global da viga seja determinada por sua resistência à tração, principalmente por não haver armadura longitudinal. Em outras palavras, o processo de fissuração, o qual é responsável pela perda de rigidez e está intimamente relacionado ao aumento da deformabilidade da viga, ocorre no banzo tracionado e é determinado pela resistência à tração do concreto. Estas considerações são interessantes no sentido de comparar o comportamento observado com os resultados de outros autores.

Conforme já comentado no capítulo 4, em publicação de 1995, Bissonnette e Piegon observaram o mesmo desempenho para materiais compósitos reforçados com microfibra de 
aço, contudo em sua pesquisa tratava-se realmente de microfibras, cujo diâmetro era de $25 \mu m$. Nesta publicação comentou-se sobre a possibilidade deste comportamento decorrer de uma maior quantidade de ar aprisionado, em consequiência da adição de fibras.

Novamente, desta vez em publicação mais recente (agosto de 2007), Bissonnette et al. avaliaram a fluência de concreto reforçado com fibras, entretanto, comparando matriz e compósitos com as mesmas propriedades mecânicas e teor de ar incorporado. Os autores concluem que o formato da fibra, a quantidade de fibras e a porosidade na interface fibramatriz são fundamentalmente os fatores que definem o impacto da incorporação de fibras metálicas sobre a fluência (mais detalhes foram apresentados no Capítulo 4).

Voltando à Fig. 8.20, isto também ajuda a explicar o fato do aumento na quantidade de fibras (no caso pela adição das microfibras) ter piorado o desempenho do compósito, uma vez que, com base nos resultados dos ensaios de retração, não houve grande diferença entre os compósitos no que diz respeito à restrição de deformações. Ou seja, além de aumentar a porosidade da matriz, pode ter havido também um aumento na porosidade na região de interface entre as fibras e a matriz.

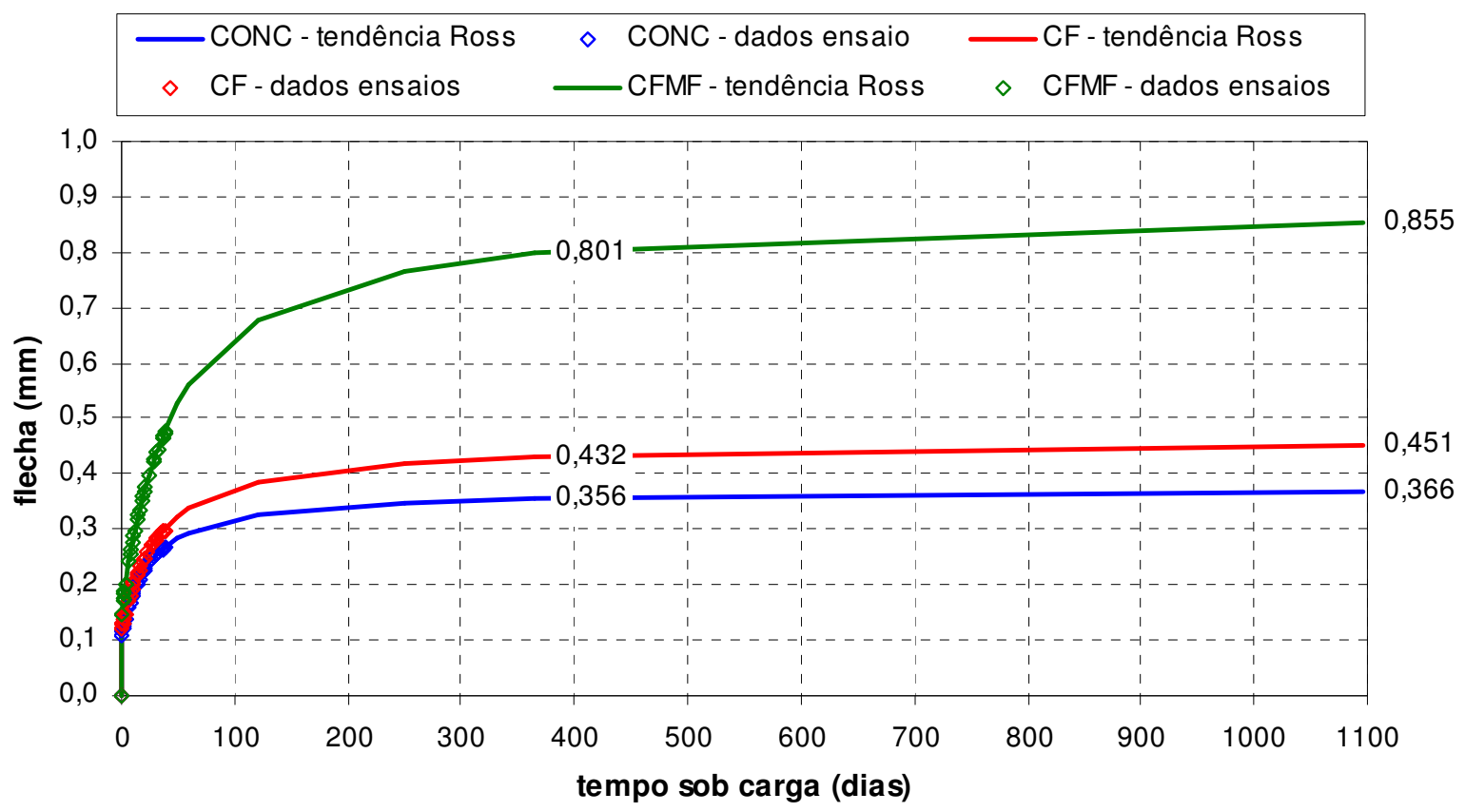

Fig. 8.21: Extrapolação das curvas deslocamento-tempo.

A Fig. 8.21 ilustra o comportamento comparativo dos materiais avaliados para períodos de tempo de até 3 anos. É interessante notar que as curvas do concreto de referência (CONC) e do concreto reforçado com as fibras de $25 \mathrm{~mm}(\mathrm{CF})$ apresentam uma tendência à 
estabilização após um ano, o que por outro lado não ocorre para o material derivado da adição das fibras e microfibras (CFMF). São apresentados no gráfico os valores das flechas diferidas após um ano e 3 anos sob carga.

Relativamente a esses valores tem-se que, após um ano, a adição das fibras $(l=25 \mathrm{~mm})$ conduziria a acréscimos de aproximadamente $20 \%$ na flecha diferida, ao passo que a adição das microfibras ao CRFA conduziria a flechas $125 \%$ maiores do que os valores obtidos com o concreto de referência. Após 3 anos a diferença entre os materiais CONC e CF se mantém; sendo que a diferença entre as flechas diferidas dos materiais CFMF e CONC aumentaria em torno de $10 \%$.

\section{c) Comparações entre curvas numéricas, teóricas e experimentais.}

Neste item a curva de tendência da viga VSE-CONC, é comparada com as curvas obtidas por expressões normativas e também com a curva proveniente da simulação numérica efetuada no DIANA ${ }^{\circledR}$. A seguir está descrito o procedimento seguido para a obtenção das curvas teóricas que são apresentadas na Fig. 8.22.

- $\quad N B R 1$

A construção desta curva foi realizada empregando as expressões apresentadas no Capítulo 5 (item 5.2.1). Para tanto foram utilizados: tempo $t_{0}$ igual à idade de aplicação do carregamento (60 dias), tempo $t_{n}$ variável e taxa de armadura igual a zero.

Para determinação da flecha elástica inicial foram utilizados: o valor de $E_{c, N B R}\left(t_{0}\right)$ da Tabela 5.8, a expressão 5.24, para o cálculo da flecha devida ao peso próprio $\left(\delta_{p p}\right)$ e a expressão 5.25, para o cálculo da flecha devida à carga concentrada. Os demais dados necessários para estes cálculos são:

- $\quad$ B: $0,15 \mathrm{~m}$ (largura da viga);

- W: 0,30 m (altura da viga);

- $\quad$ S: 2,1m (vão livre entre apoios);

- g: $9,81 \mathrm{~m} / \mathrm{s}^{2}$ (aceleração da gravidade);

- $\quad \gamma: 2491,6 \mathrm{~kg} / \mathrm{m}^{3}$ (densidade, Tabela 8.1);

- PM: 4,87 kN (peso morto de 487,4 kg aplicado no meio do vão). 
- $\quad N B R 2$

A curva NBR2 foi construída considerando-se que em um tempo $t$, posterior à aplicação do carregamento, a flecha diferida $\delta\left(t, t_{0}\right)$ pode ser obtida multiplicando-se a flecha elástica inicial $\delta_{i}\left(t_{0}\right)$ por $\left(1+\phi\left(t, t_{0}\right)\right)$, sendo $\phi\left(t, t_{0}\right)$ o coeficiente de fluência calculado a partir do método preciso para previsão da fluência (ver Capítulo 5, item 5.1.1.2). A flecha elástica inicial utilizada foi a mesma calculada para a curva anterior. Os dados de entrada empregados no modelo de fluência estão apresentados na Tabela 5.6.

- $A C I$

A curva denominada $A C I$ foi determinada de forma análoga à curva $N B R 2$, entretanto o coeficiente de fluência foi estimado aplicando os dados dos ensaios às expressões de previsão do ACI 209:1992 (conforme apresentado no item 5.1.2.1 do Capítulo 5). Os dados de entrada do modelo constam na Tabela 5.6. A flecha elástica inicial foi calculada conforme descrito anteriormente, sendo utilizado o valor de $E_{c, A C I}\left(t_{0}\right)$, apresentado na Tabela 5.8.

A curva denominada DIANA refere-se à curva proveniente da simulação numérica. Neste caso os dados de entrada (em essência os mesmos utilizados para a curva $A C I$ ) estão apresentados na Tabela 6.1, na ocasião em que foi descrito os procedimentos da simulação.

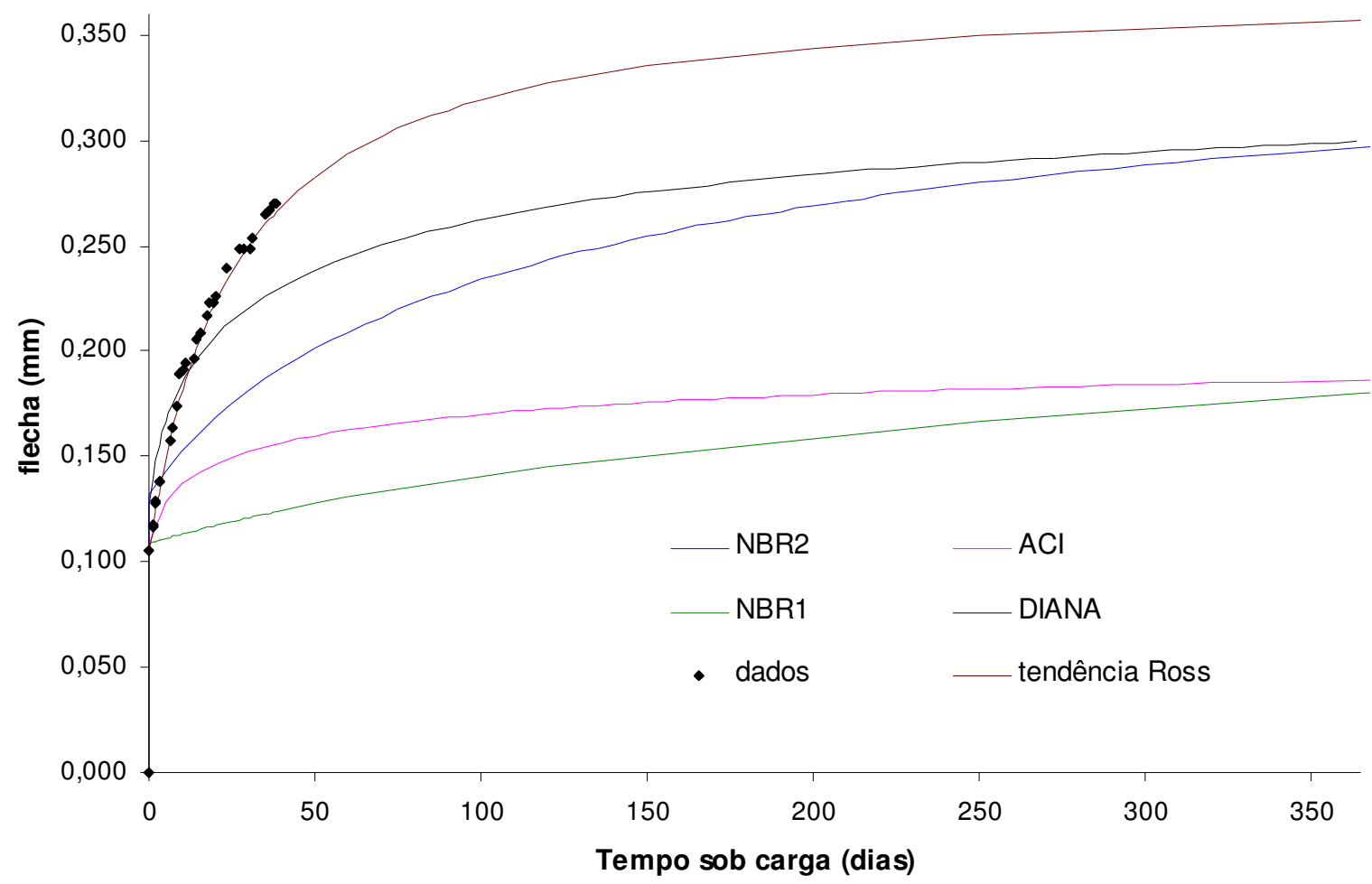

Fig. 8.22: Flechas diferidas: comparações normativas. 
Dentre as curvas teóricas a NBR2 é a que fornece melhor estimativa. Nas primeiras idades após a aplicação do carregamento nota-se que a "taxa de fluência" desta curva é inferior à curva de tendência. Ao término das leituras, a NBR2 forneceu uma flecha diferida cerca de $30 \%$ inferior ao resultado experimental. Extrapolando estas curvas no tempo, estimase que esta diferença após um ano seja de $17 \%$, o que pode ser considerado razoável.

Por outro lado, a curva NBR1 foi a que apresentou o prior comportamento, aproximando-se de uma reta, frente aos resultados experimentais. Como já comentado no Capítulo 5, trata-se de uma estimativa muito pobre da fluência, já que as únicas variáveis são o tempo e a taxa de armadura (esta igual à zero, no caso). Certamente essas expressões foram calibradas a partir de dados experimentais de flechas diferidas de vigas com armadura longitudinal, o que proporciona maior inércia da seção bruta e também uma colaboração menos expressiva dos deslocamentos que por ventura possam ocorrer em decorrência da microfissuração no deslocamento total.

A Tabela 8.5 fornece, para cada uma das curvas, os acréscimos à flecha elástica inicial experimental ao término das leituras (45 dias) e após 365 dias. Nota-se quão abaixo está esta previsão das flechas diferidas comparativamente aos outros métodos. Desta forma, fica clara a não adequação das expressões da NBR para flechas diferidas de elementos fletidos, quando estes são não possuem armadura. É indiscutível a melhora da previsão do fenômeno utilizando ao invés do fator $\left(1+\alpha_{f}\right)$ o fator $(1+\phi)$, conforme foi feito para construção da curva NBR2, ainda que as expressões para determinação do coeficiente de fluência não tenham sido, em essência, elaboradas para o caso de elementos fletidos. Neste sentido, a norma apenas cite que o modelo de fluência possa ser aplicado para tração.

Já a curva ACI apresentou valores aproximadamente $45 \%$ inferiores dos da curva de tendência, subestimando os deslocamentos em comparação também à curva NBR2. Tendo em vista as considerações efetuadas no Capítulo 5, este comportamento já era esperado. Entretanto, o que chama atenção é sua inconsistência com a curva DIANA. Uma vez que as duas são baseadas no mesmo modelo de fluência, deveriam fornecer curvas muito próximas.

Parte desta diferença reside no parâmetro de entrada relativo ao teor de ar incorporado. Como já comentado no Capítulo 6, depois de efetuados vários testes, constatou-se que o modelo numérico considera teor de ar incorporado de $6 \%$ independentemente do valor arbitrado pelo usuário (deste que seja menor do que 6\%). 
Outro fator que justifica a distância entre estas curvas refere-se à diferença nos valores da flecha elástica inicial utilizados por uma e por outra. Conforme os dados da Tabela 8.5, nota-se que a flecha inicial utilizada pelo DIANA ${ }^{\circledR}$ é aproximadamente $9 \%$ maior do que a teórica utilizada na curva $A C I$, ainda que o módulo de elasticidade empregado seja o mesmo.

Aparentemente, isto está em desacordo com a própria natureza do método numérico utilizado (elementos finitos), cujos resultados deveriam refletir um comportamento mais rígido do material. Apesar de a relação constitutiva ser elástica linear durante a aplicação do carregamento, este foi aplicado de forma incremental, através de um procedimento não-linear. Este procedimento gerou uma acumulação de resíduos em deslocamentos, que justifica o valor superior ao esperado para a flecha "elástica inicial".

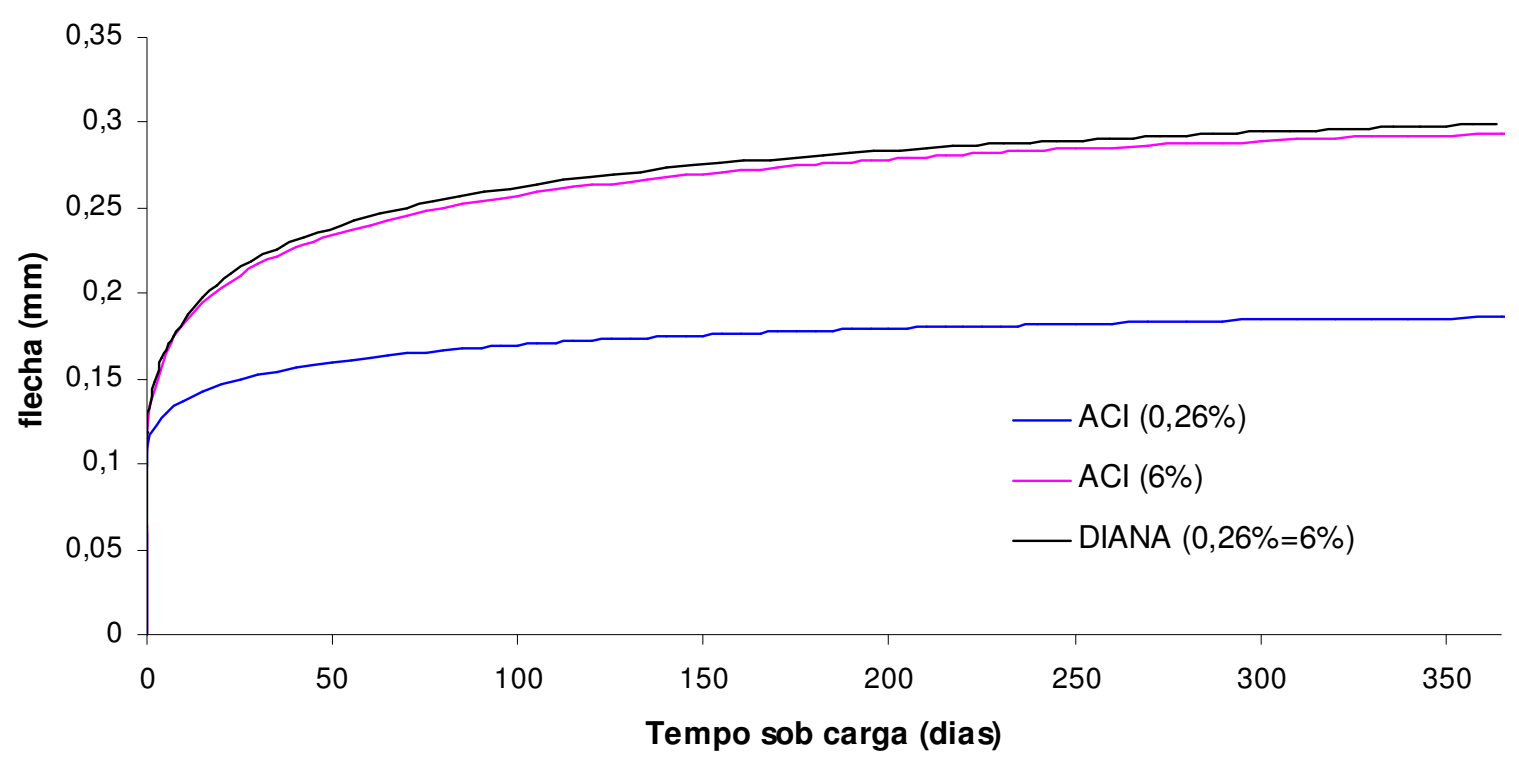

Fig. 8.23: Flechas diferidas: Curva numérica (DIANA) e curva ACI modificada

Sendo assim, ao reconstruir a curva $A C I$, agora utilizando um teor de ar incorporado de $6 \%$ e a flecha inicial extraída da simulação, tem-se praticamente a sobreposição das curvas (Fig. 8.23). De certa forma isto demonstra a falta de confiabilidade nos resultados da simulação e dispensa maiores comentários sobre a curva numérica.

Conforme comentado no Capítulo 4 (item 4.1.4), a base de dados para calibração dos modelos de previsão de fluência empregados nos códigos de normas refere-se na grande maioria dos casos a resultados experimentais de ensaios de fluência em elementos de concreto solicitados à compressão. Em partes, isto explica a diferença encontrada entre as curvas teóricas NBR2 e ACI e a curva experimental (Tendência), tanto em termos quantitativos (diferenças de valores) quanto em termos qualitativos (formato das curvas). 
Um resumo comparativo entre os valores fornecidos pelas curvas comentadas neste item é apresentado na Tabela 8.5.

Foi calculado também o momento de fissuração $M_{r}$ a partir da expressão 5.26. Em todos os casos o valor encontrado de $M_{r}$ foi muitas vezes inferior ao momento máximo, o que garante a consideração de seção íntegra, ou melhor, não fissurada (ver Tabela B.1 no Apêndice B).

Tabela 8.5: Valores comparativos das Flechas - Série 1.

\begin{tabular}{|c|c|c|c|c|c|c|}
\hline $\begin{array}{l}\text { Tempo } \\
\text { (dias) }\end{array}$ & $\begin{array}{l}\text { Deslocamento } \\
\text { (flecha) em } \mathrm{mm}\end{array}$ & $\begin{array}{l}\text { Hipérbole } \\
\text { Ross }\end{array}$ & NBR1 & NBR2 & $\mathrm{ACl}$ & DIANA \\
\hline$t_{0}$ & $\delta_{i}$ & 0,105 & 0,109 & 0,109 & 0,108 & 0,118 \\
\hline \multirow{3}{*}{$\left(\mathrm{t}-\mathrm{t}_{0}\right)=40$} & $\delta\left(\mathrm{t}-\mathrm{t}_{0}\right)$ & 0,266 & 0,124 & 0,192 & 0,156 & 0,232 \\
\hline & $\delta_{c}\left(t-t_{0}\right)$ & 0,161 & 0,015 & 0,083 & 0,048 & 0,114 \\
\hline & $\varnothing\left(\mathrm{t}-\mathrm{t}_{0}\right)$ & 1,533 & 0,138 & 0,761 & 0,444 & 0,966 \\
\hline \multicolumn{3}{|c|}{ diferença com relação à tendência } & $53 \%$ & $28 \%$ & $41 \%$ & $13 \%$ \\
\hline \multirow{3}{*}{$\left(\mathrm{t}-\mathrm{t}_{0}\right)=365$} & $\delta\left(t-t_{0}\right)$ & 0,357 & 0,180 & 0,297 & 0,186 & 0,299 \\
\hline & $\delta_{c}\left(t-t_{0}\right)$ & 0,252 & 0,071 & 0,188 & 0,078 & 0,181 \\
\hline & $\varnothing\left(\mathrm{t}-\mathrm{t}_{0}\right)$ & 2,400 & 0,651 & 1,725 & 0,722 & 1,534 \\
\hline \multicolumn{3}{|c|}{ diferença com relação à tendência } & $50 \%$ & $17 \%$ & $48 \%$ & $16 \%$ \\
\hline
\end{tabular}

\subsection{VSE - Resultados em termos de deformações}

Pode-se dizer que a transformação das medidas de deslocamento da linha de carga $(\delta)$ na direção $y$ em deformação na direção $x\left(\varepsilon_{x x}\right)$ baseou-se de duas operações: primeiro, considerando relações de geometria, encontrou-se para cada valor de flecha diferida a curvatura correspondente; a seguir, conhecida a curvatura, foram obtidas as deformações $\varepsilon_{x x}$ a partir de expressões da Teoria de Vigas. A seguir são apresentadas passo a passo as deduções necessárias para o equacionamento, sendo todo o procedimento extraído de Timoshenko S. P. (1971).

Para o problema representado na Fig. 8.24, tem-se que a curva elástica é um arco de círculo de raio $r$ e $D B$ é um cateto do triângulo retângulo $D O B$, onde $O$ é o centro de curvatura. Portanto:

$$
\overline{D B^{2}}=r^{2}-(r-\delta)^{2}=2 r \delta-\delta^{2}
$$

Considerando que $\delta$ é muito pequena em comparação com o raio $\mathrm{r}$, a quantidade $\delta^{2}$ pode ser desprezada na equação anterior. Substituindo $D B^{2}=S / 2$, então: 


$$
r=\frac{(S / 2)^{2}}{2 \cdot \delta} \rightarrow \frac{1}{r}=\frac{2 \cdot \delta}{(S / 2)^{2}}
$$

Sabendo-se que $\varepsilon_{x x}=y / r$ (ver Fig. 8.24-b), sendo y um eixo vertical com origem no CG da seção transversal da viga, para determinar a relação entre a flecha medida e a deformação ao longo da direção x (longitudinal) da fibra mais tracionada de uma viga com seção transversal simétrica, basta substituir $y=h / 2$, sendo $h$ a altura da seção transversal, e o valor da curvatura deduzido anteriormente:

$$
\varepsilon_{x x}\left(t, t_{0}\right)=\frac{(h / 2)}{(S / 2)^{2}} \cdot 2 \cdot \delta\left(t, t_{0}\right)
$$

Ou seja, para cada leitura da flecha diferida realizada em um tempo $t$ após aplicação do carregamento em $t_{0}$, se obtém pela expressão anterior a deformação $\varepsilon_{x x}$ correspondente. Subtraindo destes valores a deformação elástica inicial $\varepsilon_{c, i}$ tem-se as deformações por fluência, e assim pode-se construir a curva $C\left(t, t_{0}\right)$-tempo (fluência específica versus tempo), como é usual encontrar na literatura.

Como o programa experimental tratou de elementos fletidos, imagina-se que as deformações por retração sejam insignificantes. Desta forma considerou-se que as deformações obtidas através da expressão 8.5 refiram-se apenas à fluência.
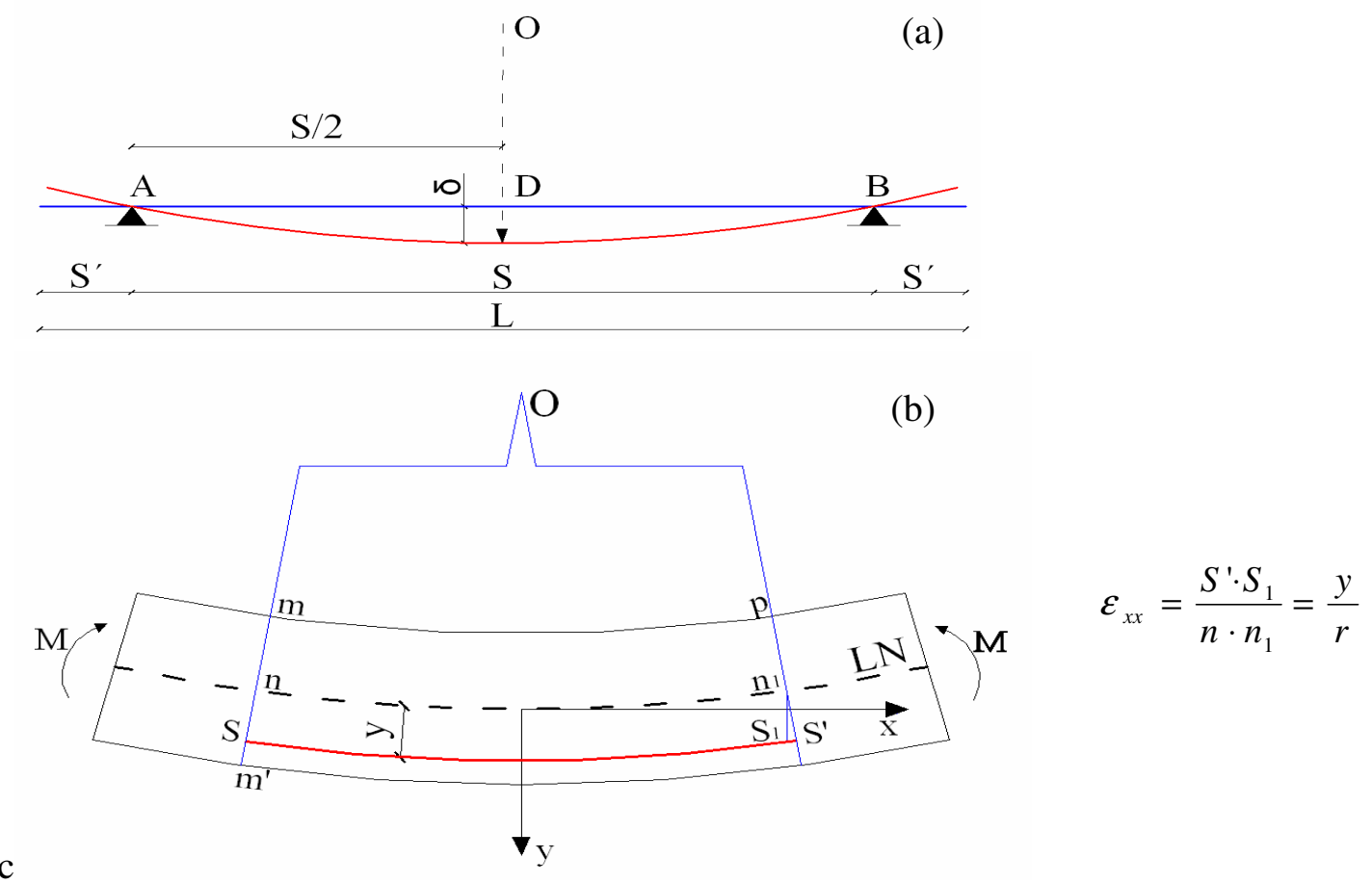

Fig. 8.24: Dedução geométrica da relação entre $\delta$ e $\varepsilon_{x x}$. 
Na Fig. 8.25 a curva de tendência, agora em termos de deformações, é comparada com as curvas obtidas pela NBR e pelo ACI. Para tanto foram utilizadas as funções fluência de cada uma das normas (expressões 5.2 e 5.19), empregando o módulo de elasticidade experimental aos 28 dias para o cálculo de $E_{c}, t_{0}$ (ver Tabela 5.8). O procedimento e os dados utilizados para a obtenção das curvas de função de fluência foram apresentados detalhadamente no Capítulo 5. Conhecida a função de fluência, basta multiplicá-la pela tensão aplicada (no caso 1,4 MPa) para determinar a deformação em um tempo $t$ qualquer. Conforme esperado, a NBR (baseada no CEB 1978) superestima as deformações, ao passo que o ACI subestima.

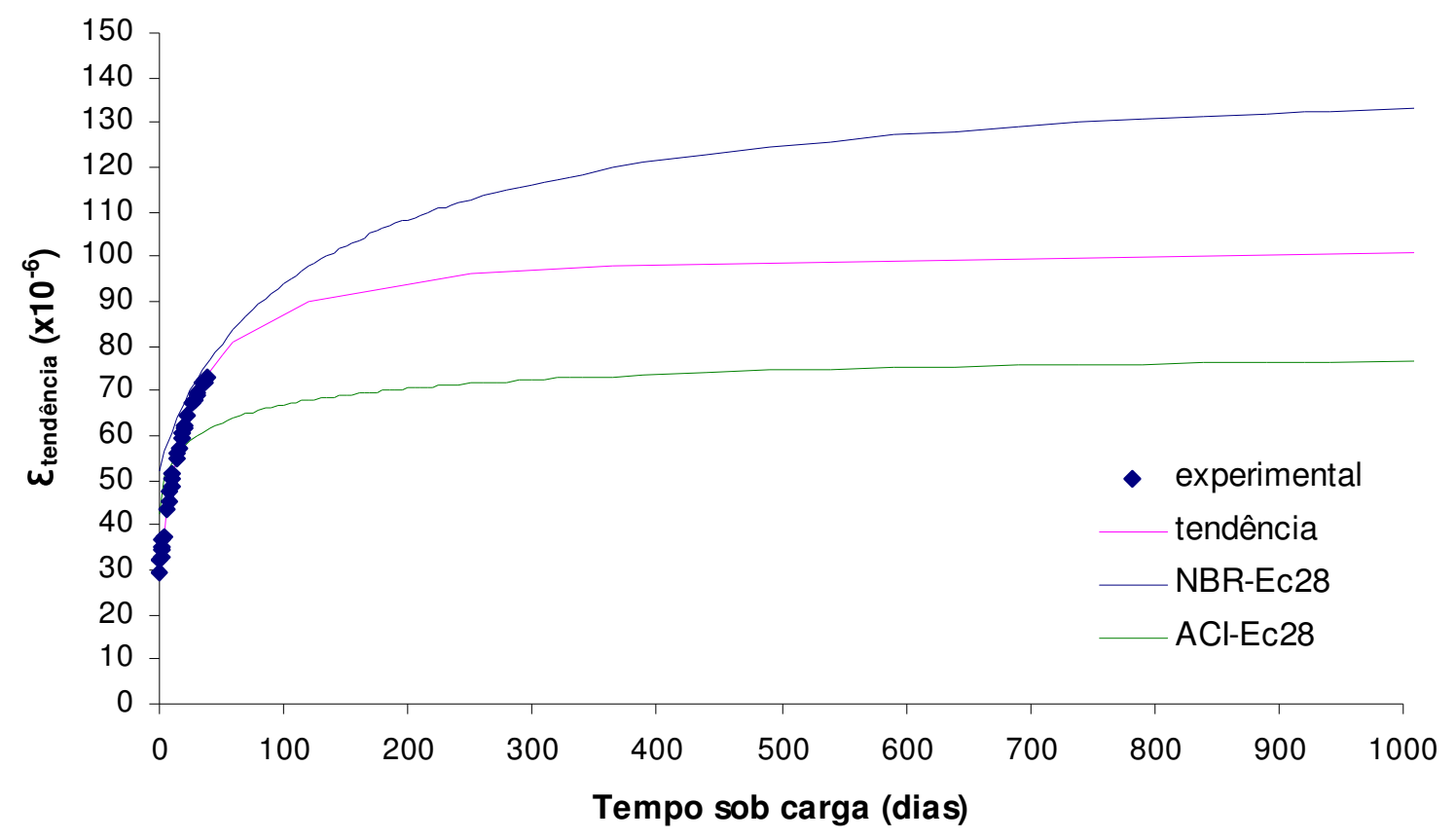

Fig. 8.25: Deformações por fluência Série 1 - VSE-CONC.

A fim de descartar o efeito da deformação elástica inicial na análise das deformações lentas por fluência, torna-se interessante avaliar os dados apresentados nas curvas de fluência específica versus tempo sob carga, o que é ilustrado na Fig. 8.26. Por este gráfico percebe-se uma grande proximidade da curva obtida a partir da NBR da curva de tendência, ao passo que a distância entre esta e a curva obtida a partir do ACI se eleva. A partir das figuras Fig. 8.25 e Fig. 8.26 é interessante notar como a análise pode mudar em função do tipo de curva que se esteja utilizando.

A respeito da relação entre boa previsão do módulo de elasticidade e confiabilidade do modelo de previsão de fluência, Fanourakis e Ballim (2007) comentam que aparentemente não se trata de uma relação de dependência. 
Ou seja, mesmo que a previsão do módulo seja ruim, o que poderia transladar a curva de fluência para cima ou para baixo, ao longo do eixo y, em certos casos, o próprio modelo empregado para previsão das deformações lentas (coeficiente de fluência) se encarrega de compensar a falta. Desta forma, para períodos longos de tempo, pode-se obter um resultado satisfatório.

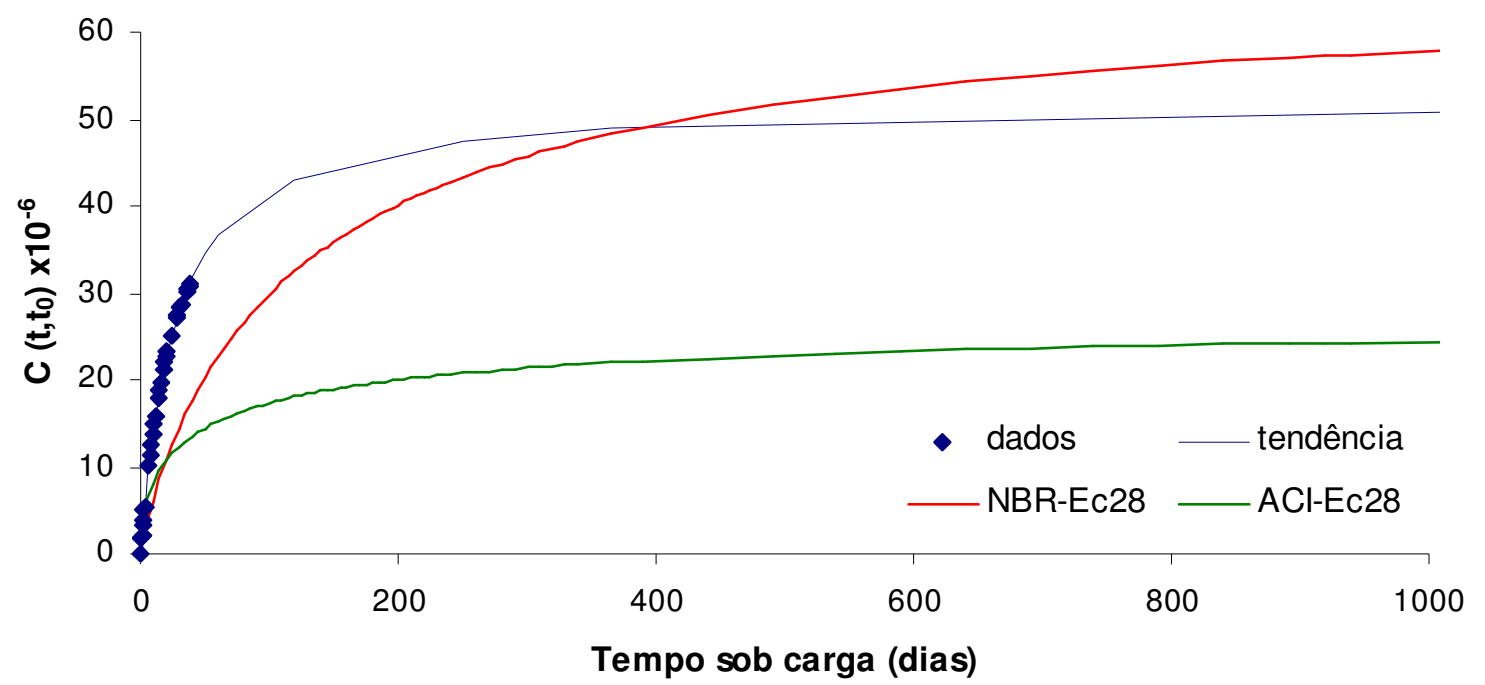

Fig. 8.26: Fluência específica. VSE-CONC: Série 1.

Através das curvas de fluência específica pode-se também comparar o comportamento dos três materiais. De acordo com a figura abaixo nota-se que a incorporação das fibras praticamente não proporcionou diferença alguma na fluência específica, durante o período de ensaio (até 40 dias), e segundo as curvas de tendência, após 3 anos chegaria a 25\%. Entretanto o concreto reforçado com fibras e microfibras apresenta valores muito superiores: $106 \%$ no término dos ensaios e 170\% após 3 anos (1100 dias).

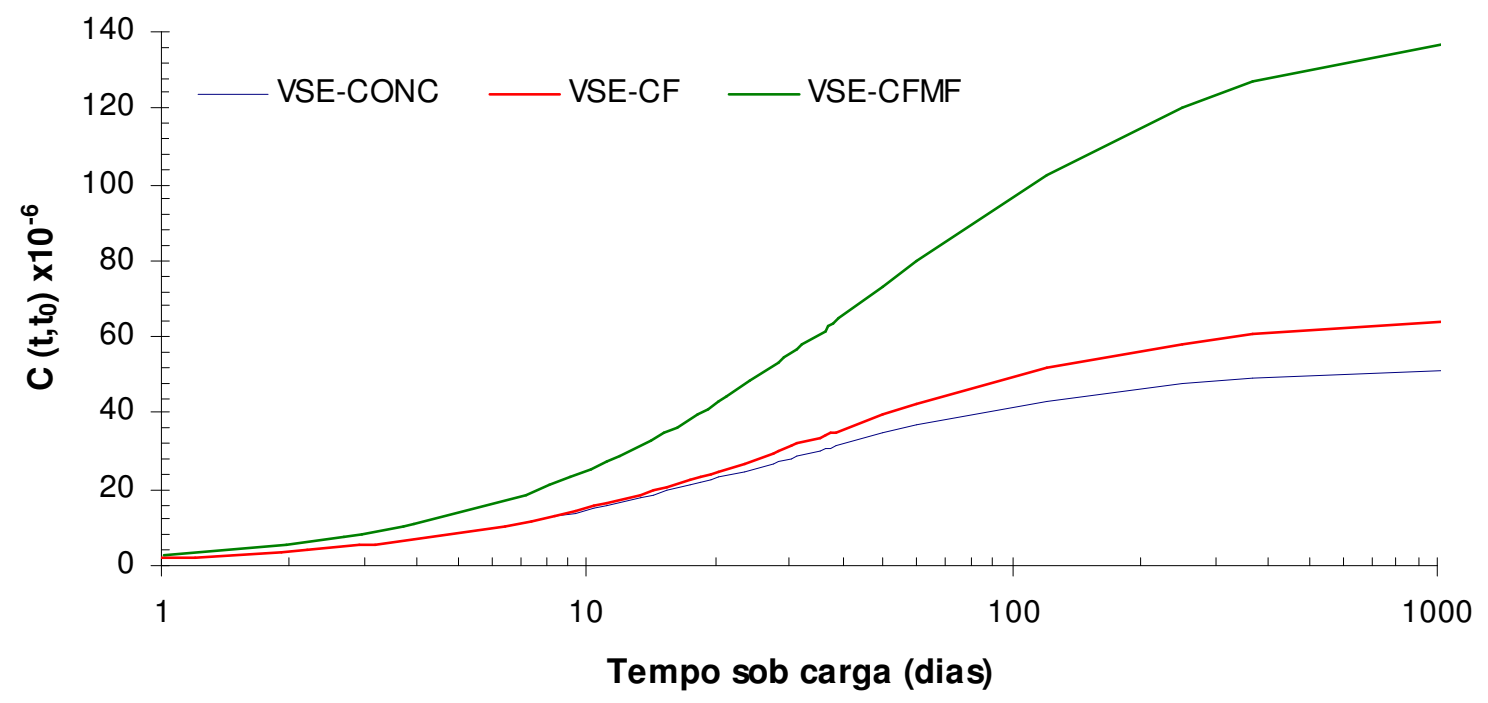

Fig. 8.27: Curvas $\mathrm{C}(\mathrm{t}, \mathrm{t} 0)$-tempo para os três materiais avaliados (Série 1). 


\subsubsection{Vigas Entalhadas}

Com relação às flechas diferidas das vigas entalhadas (solicitadas apenas ao peso próprio), foram construídas as curvas deslocamento-tempo apresentadas na Fig. 8.28. A curva tracejada representa a evolução das flechas segundo a simulação do DIANA ${ }^{\circledR}$, de modo que após 45 dias de ensaio, seria esperado um acréscimo das flechas de praticamente $100 \%$. Contudo, deve-se ressaltar que os incrementos de deslocamentos entre os passos de tempo são muito pequenos (menos de 5 milésimos), o que tornou o ensaio extremamente susceptível a qualquer interferência externa.
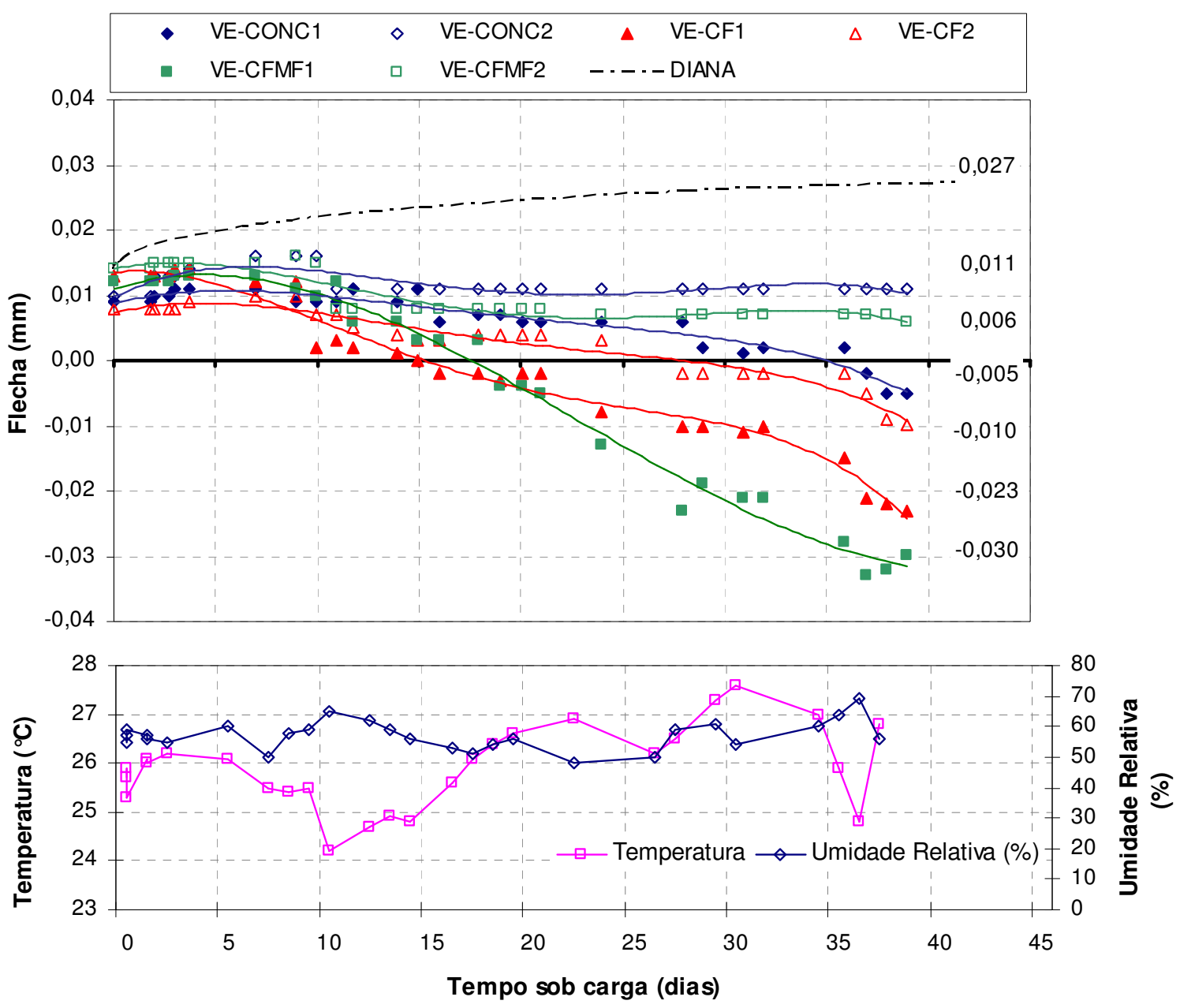

Fig. 8.28: Flechas Diferidas - Vigas entalhadas (Série 1). Linhas de tendência obtidas por expressões polinomiais completas de terceiro e quarto grau.

Deste modo, contribuiu sobremaneira para o comportamento obtido, a exposição à pré-secagem durante o período em que foi definida a instrumentação, a idade avançada em que se deu o início dos ensaios (a fluência é inversamente proporcional à idade de carregamento) e a variação de umidade e temperatura no interior da câmara (que apesar de 
pequenas, foram significativas). As condições ambientais no interior da câmara consistiram em temperatura e umidade relativa do ar de $25,9 \pm 0,8^{\circ} \mathrm{C}$ e $57,1 \pm 4.8 \%$.

Nota-se que algumas vigas, de certo modo, permaneceram estáveis enquanto que outras apresentaram uma redução da flecha ao longo do tempo. Entretanto, não é possível distinguir tendências diferentes de comportamento para as vigas de concreto, das vigas reforçadas com fibras. Sabe-se que a fluência ocasiona uma redistribuição das tensões, em todo o volume do corpo-de-prova, refletindo em uma diminuição da zona de processos inelásticos.

Devido ao baixo nível de tensões em que foram iniciados os ensaios (tensão máxima de tração igual a $40 \%$ da resistência à tração), e também por conta dos baixos valores de deslocamentos incrementais, imagina-se que houve relaxação das tensões na viga, contribuindo para a verificação de recuperação das flechas. Ora, se as tensões que já eram baixas tornaram-se ainda menores, o que deixou as vigas muito mais suscetíveis aos inúmeros fatores externos que contribuíram para que os deslocamentos fossem menores do que o esperado.

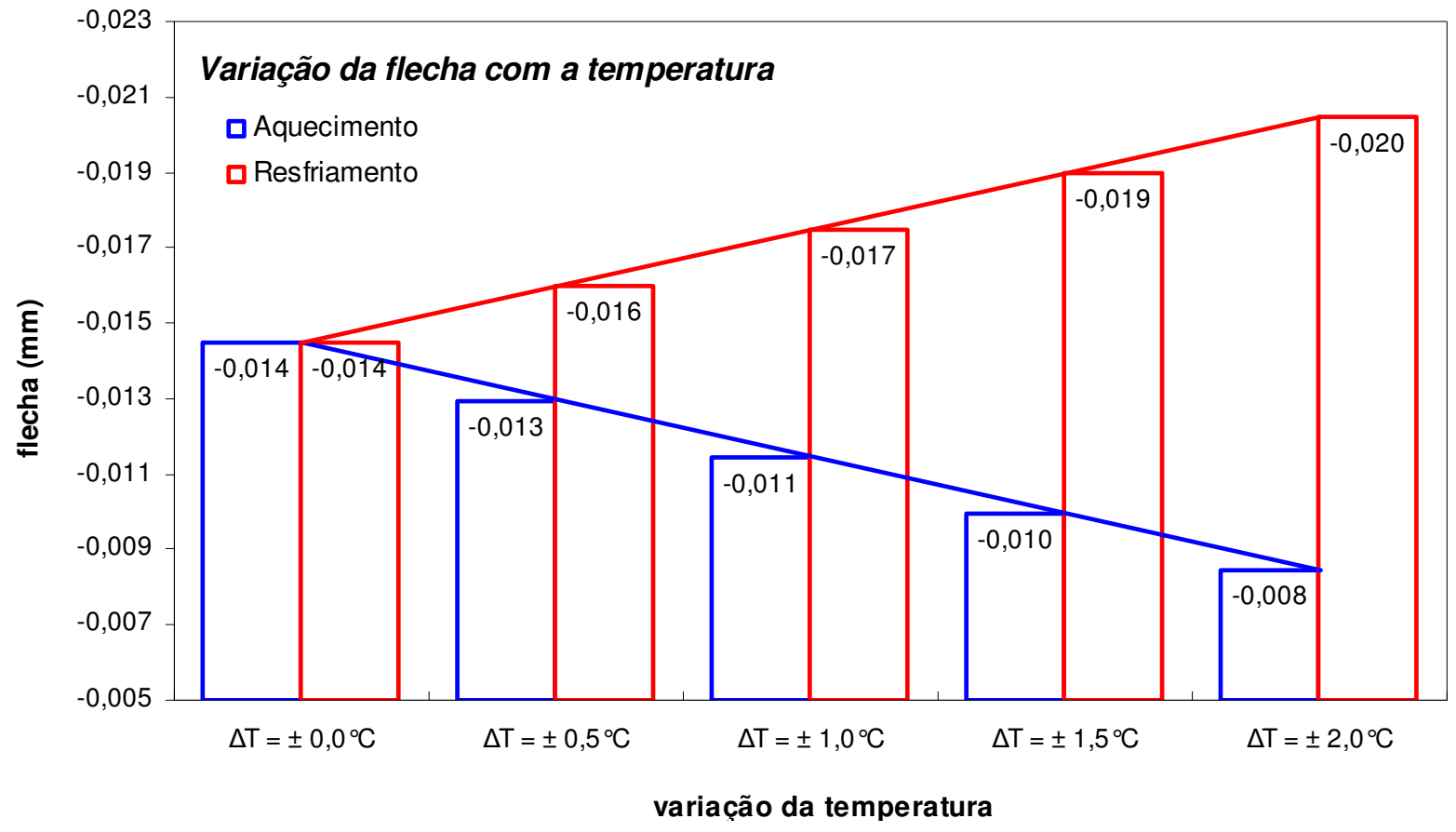

Fig. 8.29: Variação da flecha com a temperatura - simulação no Franc2dl.

Foi feita uma simulação no Franc2Dl, em que foi modelada a geometria da viga entalhada, solicitada ao seu peso próprio e a carregamentos relacionados a variações térmicas. 
Obteve-se que uma variação da temperatura de $2{ }^{\circ} \mathrm{C}$ pode ocasionar uma variação na flecha de 6 milésimos de milímetro. Apesar de não parecer, essa variação é bastante significativa, posto que, de acordo com a simulação do DIANA ${ }^{\circledR}$, após 45 dias o acréscimo na flecha elástica deveria ser de 13 milésimos de milímetro. Ou seja, essa variação da temperatura, normalmente aceitável, ocasionaria uma redução da flecha esperada de 50\%. Isso ocorreria considerando-se somente a interferência da temperatura.

Certamente se fosse possível uma análise conjunta da variação da umidade, retração, etc., essa redução poderia ser maior do que a própria flecha elástica, como se o modelo fosse submetido a uma contraflecha. Observando a Fig. 8.28 percebe-se que a redução mais pronunciada das flechas ocorre entre o décimo e o trigésimo quinto dias sob carga, justamente o período que sofreu elevação da temperatura. De acordo com a simulação comentada no parágrafo anterior, uma elevação da temperatura (que implica na dilatação da viga), incorre em redução da flecha e aumento do CMOD. Por outro lado, uma diminuição da temperatura (que implica na contração da viga) incorre em acréscimo da flecha e redução do CMOD.

$\mathrm{Na}$ realidade a percepção desta interferência da temperatura ocorreu por conta da maneira com que foi fixada a instrumentação das vigas. Conforme descrito no Capítulo anterior, a régua metálica que sustenta o relógio foi fixada na própria viga, sobre a linha neutra, sendo que o ponto de referência para as medições do relógio situa-se na face superior da viga. Desta forma, se por dilatação térmica e a viga se expandir, a face superior ocupará uma nova posição acima da anterior, entretanto, como a régua não varia (pois está sobre eixo neutro), haverá um aumento no curso do relógio, o que significa em uma redução da leitura.

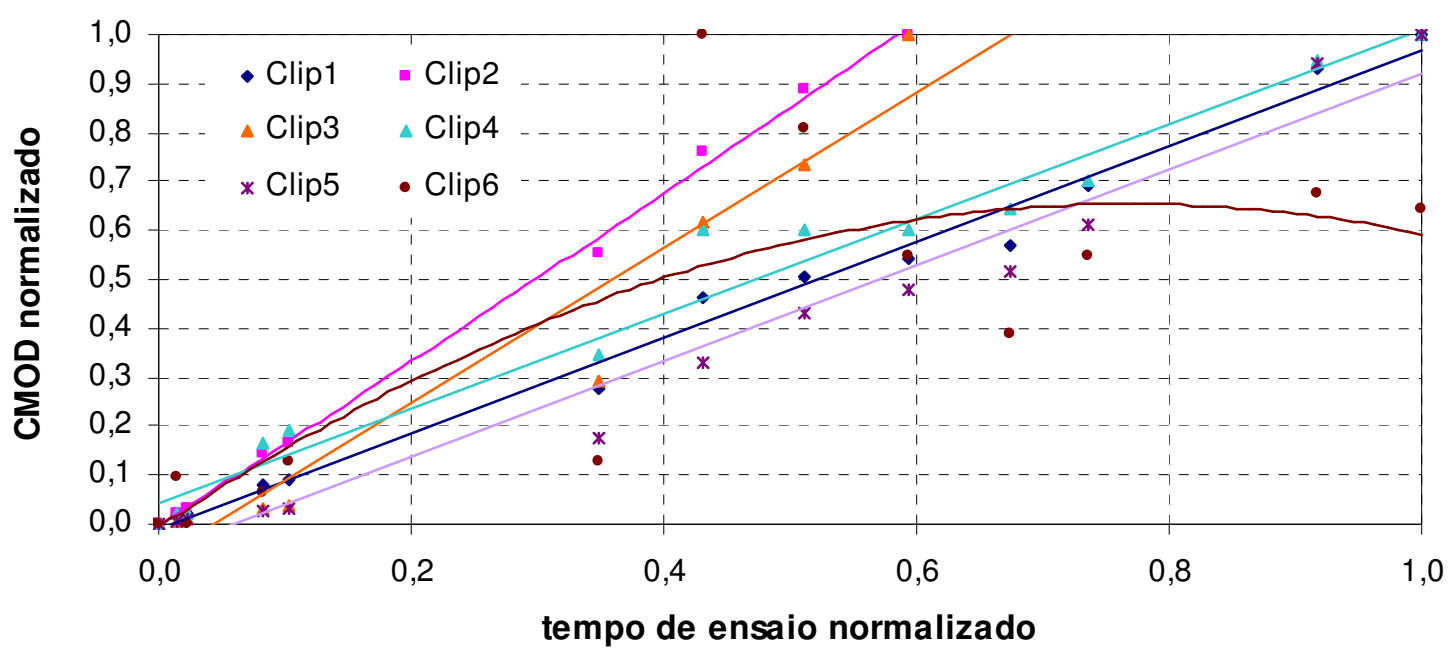

Fig. 8.30: Gráfico normalizado - CMOD versus Tempo de ensaio (Série 1). Linhas de tendência obtidas por ajuste polinomial. 
Com relação ao monitoramento da abertura do entalhe, houve problemas nas leituras dos clips (ver mais detalhes em no item 7.6.5), de forma que o aumento no CMOD registrado por eles não correspondia aos valores esperados (se fossem reais, as vigas teriam se rompido).

A menos de um clip (de número 6) todos os outros apresentaram comportamento parecido, como se observa na Fig. 8.30. Todos os clips apresentaram a tendência de abertura do entalhe, em concordância com a avaliação da temperatura feita anteriormente, entretanto por conta da grandeza dos valores medidos estes foram desconsiderados, sendo atribuídos por mau funcionamento dos dispositivos.
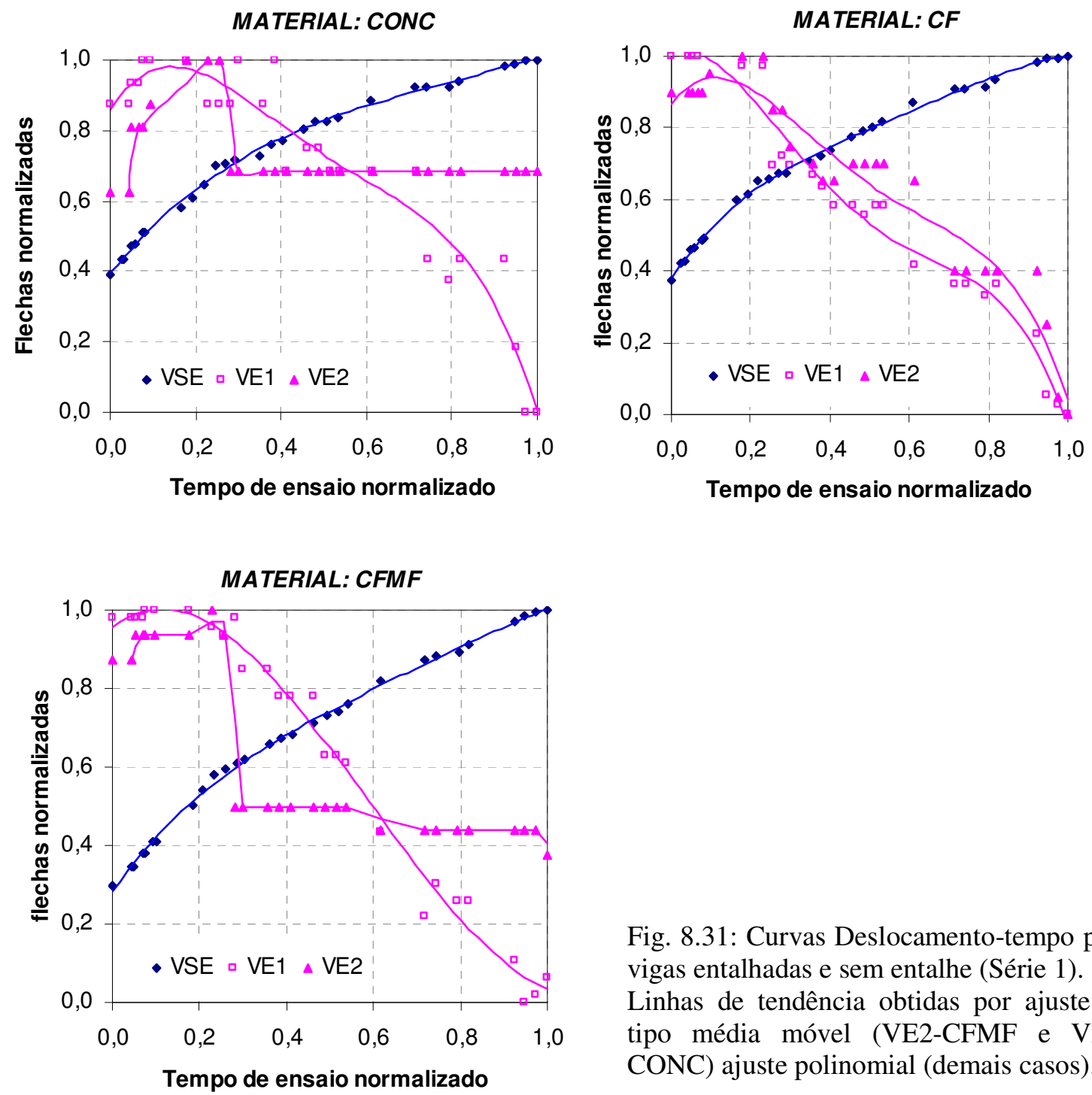

Fig. 8.31: Curvas Deslocamento-tempo para vigas entalhadas e sem entalhe (Série 1). Linhas de tendência obtidas por ajuste do tipo média móvel (VE2-CFMF e VE2CONC) ajuste polinomial (demais casos).

Vale ressaltar a importância em avaliar corretamente a abertura do entalhe. Valores de CMOD próximos àqueles oriundos da simulação numérica indicam que não estaria ocorrendo processo de propagação da fissura, e conseqüentemente, a análise feita com base nestas 
leituras seria decorrente apenas da fluência. Caso contrário, a variação dos deslocamentos ( $\delta$ e CMOD) no tempo seria composta por duas parcelas: uma proveniente da fluência e outra proveniente da fissuração, sem que fosse possível o desacoplamento delas para a correta avaliação da fluência.

Os gráficos da Fig. 8.31 demonstram o comportamento para cada material, quanto ao deslocamento vertical, através da normalização dos resultados das vigas entalhadas e das vigas sem entalhe. Nota-se que duas vigas entalhadas (VE-CONC2 e VE-CFMF2) após um pequeno aumento das flechas, sofreram uma redução, seguida da estabilização dos resultados. Esta "paralisação" da flecha pode também estar associada a algum tipo de travamento que possa ter ocorrido nos mecanismos dos relógios comparadores. Já as demais vigas entalhadas apresentaram reduções das flechas logo no início dos ensaios.

Apesar dos bons resultados para as vigas não entalhadas, não foi possível trabalhar com os resultados das vigas entalhadas desta série. Acredita-se que basicamente dois fatores tenham contribuído para este insucesso: a idade de carregamento e a pré-secagem dos modelos. Como um dos objetivos, que era justamente avaliar a fluência das vigas utilizando a formulação da Mecânica da Fratura, não foi cumprido, foi decidido realizar uma nova série de ensaios, evitando todos os problemas que ocorreram.

\subsubsection{Ensaios Dinâmicos}

O cálculo do módulo de elasticidade dinâmico foi feito utilizando-se as expressões da norma ASTM C-512:1991, conforme apresentado no Capítulo 2, empregando os valores de frequiências naturais encontradas nos ensaios de vibração livre. As freqüências naturais obtidas para as vigas entalhadas foram muito próximas da freqüência obtida para a correspondente viga sem entalhe. Isto permitiu comparar os três materiais, sem distinção da geometria das vigas. No Capítulo 7, item 7.5.1.5, consta alguns comentários sobre a consideração de equivalência entre as vigas com e sem entalhe para efeito de cálculo e posição dos pontos nodais.

De acordo com a expressão 2.1, considerando que para a mesma série de ensaios todos os modelos possuem os mesmos parâmetros de geometria, os parâmetros variáveis entre as vigas ensaiadas são: a freqüência natural de vibração, a massa, e o coeficiente de Poisson.

A Tabela 8.6 apresenta os valores do módulo dinâmico encontrados para cada viga, o valor médio de cada grupo representativo de um material e o coeficiente de variação. Nota-se 
que houve pouca variabilidade dos resultados, considerando coeficientes de variação (cv) variando entre 0,5 e $7,2 \%$.

Os valores da freqüência e massa foram considerados individualmente (ou seja, valores obtidos para cada viga), ao passo que com relação ao coeficiente de Poisson ( $v$ ) foi utilizado o valor médio obtido para cada material nos ensaios de compressão axial efetuado aos 28 dias. Nota-se ainda que para as duas situações avaliadas (antes e depois dos ensaios de fluência) foram utilizados os mesmos valores das massas e do coeficiente de Poisson (por esta razão estes estão identificados na tabela como dados de entrada comuns).

Sabe-se que, devido à utilização de cimento CPII, as reações de hidratação prolongamse muito além do período de cura, o que leva ao aumento da resistência e do módulo de elasticidade com o tempo. Certamente também ocorre variação do coeficiente de Poisson, entretanto, de acordo com resultados de outras pesquisas (K. K. Sideris et. al. 2004) imaginase que essa variação entre o período considerado (28 e 105 dias) não seja significativa frente aos erros experimentais inerentes à determinação experimental deste coeficiente.

Tabela 8.6: Determinação do módulo dinâmico - Série 1.

\begin{tabular}{|c|c|c|c|c|c|c|}
\hline \multicolumn{3}{|c|}{ dados de entrada comuns } & \multicolumn{2}{|c|}{ antes (28 dias) } & \multicolumn{2}{|c|}{ depois (105 dias) } \\
\hline Modelo & $\operatorname{Massa}(K g)$ & $\mathbf{v}$ & $f\left(H_{z}\right)$ & $E_{d, A S T M}(G P a)$ & $f\left(H_{z}\right)$ & $E_{d, A S T M}(G P a)$ \\
\hline$\overline{V S E}-\mathrm{CONC}$ & $\overline{245}$ & (0,16 & 242,5 & "40,5 & 232,5 & 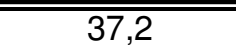 \\
\hline$V E-C O N C 1$ & 248 & 0,16 & 235,0 & 38,5 & 225,0 & 35,3 \\
\hline$V E-C O N C 2$ & 247 & 0,16 & 233,8 & 37,9 & 223,8 & 34,8 \\
\hline média & 246,7 & 0,16 & 237,1 & 39,0 & 227,1 & 35,8 \\
\hline$c v$ & $0,6 \%$ & & $2,0 \%$ & $3,5 \%$ & $2,1 \%$ & $3,6 \%$ \\
\hline$V S E-C F$ & 243 & 0,23 & 230,0 & 36,3 & 218,8 & 32,8 \\
\hline$V E-C F 1$ & 249 & 0,23 & 226,3 & 36,0 & 213,8 & 32,1 \\
\hline$V E-C F 2$ & 249 & 0,23 & 226,3 & 36,0 & 213,8 & 32,1 \\
\hline média & 247,0 & 0,23 & 227,5 & 36,1 & 215,4 & 32,3 \\
\hline$c v$ & $1,4 \%$ & & $1,0 \%$ & $0,5 \%$ & $1,3 \%$ & $1,3 \%$ \\
\hline VSE - CFMF & 236 & 0,25 & 211,3 & 29,8 & 192,5 & 24,7 \\
\hline$V E-C F M F 1$ & 243 & 0,25 & 212,5 & 31,0 & 196,3 & 26,5 \\
\hline VE - CFMF2 & 243 & 0,25 & 216,3 & 32,1 & 203,8 & 28,5 \\
\hline média & 240,7 & 0,25 & 213,3 & 31,0 & 197,5 & 26,6 \\
\hline$c v$ & $1,7 \%$ & & $1,2 \%$ & $3,8 \%$ & $2,9 \%$ & $7,2 \%$ \\
\hline
\end{tabular}

No ensaio de compressão axial, utilizam-se normalmente dois extensômetros colados em posições diametralmente opostas, para medir as deformações na direção transversal à aplicação da carga. Sendo o concreto um material heterogêneo, medidas extremamente pontuais podem gerar grande dispersão. Ou seja, o extensômetro não representa bem o que ocorre com o material, já que a localização de poros e agregado graúdo sob o ponto em que 
foi colado o extensômetro, ou mesmo o processo de fissuração próximo, alteram significativamente os resultados.

O ideal seria utilizar uma quantidade maior de extensômetros para obter resultados mais confiáveis. Contudo, este procedimento tornaria a montagem do ensaio e a análise dos resultados muito mais trabalhosa, além da elevação do custo do ensaio por corpo-de-prova (o que é problemático quando se necessita ensaiar inúmeros corpos-de-prova). Ressalta-se que não há considerações a respeito na NBR 6118:2003. Também não há uma norma brasileira para padronização da determinação experimental desta propriedade do concreto.

Com relação à re-pesagem das vigas, a questão também reflete o problema da precisão das leituras. Claro que por conta do processo de secagem ocorre perda de água e possivelmente fissuração, dois fatores que contribuem para diminuição da massa de cada viga. Contudo, imagina-se que a perda de massa que ocorreu entre o período avaliado seja inferior à precisão com que foi efetuada a pesagem. Como descrito no Capítulo 7, item 7.4.1.3, foi utilizada uma célula de carga acoplada a um indicador de extensometria, de forma que a precisão das medidas foi de $1 \mathrm{~kg}$.

Tabela 8.7: Idades em que foram realizados os ensaios dinâmicos - Série 1.

\begin{tabular}{|c|c|c|c|}
\hline Data & Atividade & Modelo & Idade (dias) \\
\hline $13 / 8 / 2007$ & Desforma & $\begin{array}{l}\text { Todos os } \mathrm{cp}(\mathrm{s}) \text { do tipo CONC } \\
\text { Todos os } \mathrm{cp}(\mathrm{s}) \text { do tipo CF } \\
\text { Todos os } \mathrm{cp}(\mathrm{s}) \text { do tipo CFMF }\end{array}$ & $\begin{array}{l}31 \\
28 \\
27\end{array}$ \\
\hline $16 / 8 / 2007$ & Ensaios & $\begin{array}{l}\text { VSE - CONC } \\
\text { VSE - CF } \\
\text { VSE - CFMF }\end{array}$ & $\begin{array}{l}34 \\
31 \\
30\end{array}$ \\
\hline 17/8/2007 & Dinâmicos & $\begin{array}{l}\text { VE - CONC1/ VE - CONC2 } \\
\text { VE - CF1/ VE - CF2 } \\
\text { VE - CFMF1/ VE - CFMF2 }\end{array}$ & $\begin{array}{l}35 \\
32 \\
31\end{array}$ \\
\hline $17 / 9 / 2007$ & Ensaios de & $\begin{array}{l}\text { VE - CONC1/ VE - CONC2 } \\
\text { VE - CF1/ VE - CF2 } \\
\text { VE - CFMF1/ VE - CFMF2 }\end{array}$ & $\begin{array}{l}66 \\
63 \\
62\end{array}$ \\
\hline 18/9/2007 & fluência & $\begin{array}{l}\text { VSE - CONC } \\
\text { VSE - CF } \\
\text { VSE - CFMF }\end{array}$ & $\begin{array}{l}67 \\
64 \\
63\end{array}$ \\
\hline
\end{tabular}

Como nesta série a concretagem foi realizada em etapas, as idades em que foram efetuados os ensaios dinâmicos são as apresentadas na Tabela 8.7. Entretanto, como os resultados foram comparados com os ensaios estáticos realizados efetivamente aos 28 dias de idade para cada material, por questão de conveniência estipulou-se a identificação de 28 dias como a data anterior aos ensaios de fluência em que foram realizados os ensaios dinâmicos. Considera-se que essa aproximação não seja grave, imaginando-se que uma diferença de 4 
dias, após os 28 dias, não implicaria em ganhos significativos de resistência e módulo de elasticidade.

As Figuras 8.32 e 8.33 ilustram os valores médios, para cada material, do módulo de elasticidade estático obtidos a partir do ensaio de compressão axial $\left(E_{\text {est.,CA }}\right)$ e do módulo de elasticidade dinâmico $\left(E_{d, A S T M}\right)$, para as duas situações avaliadas (antes e depois das vigas serem submetidas à carga mantida). Destacados nos gráficos estão os valores percentuais das diferenças entre os módulos, com referência àquele de menor valor.

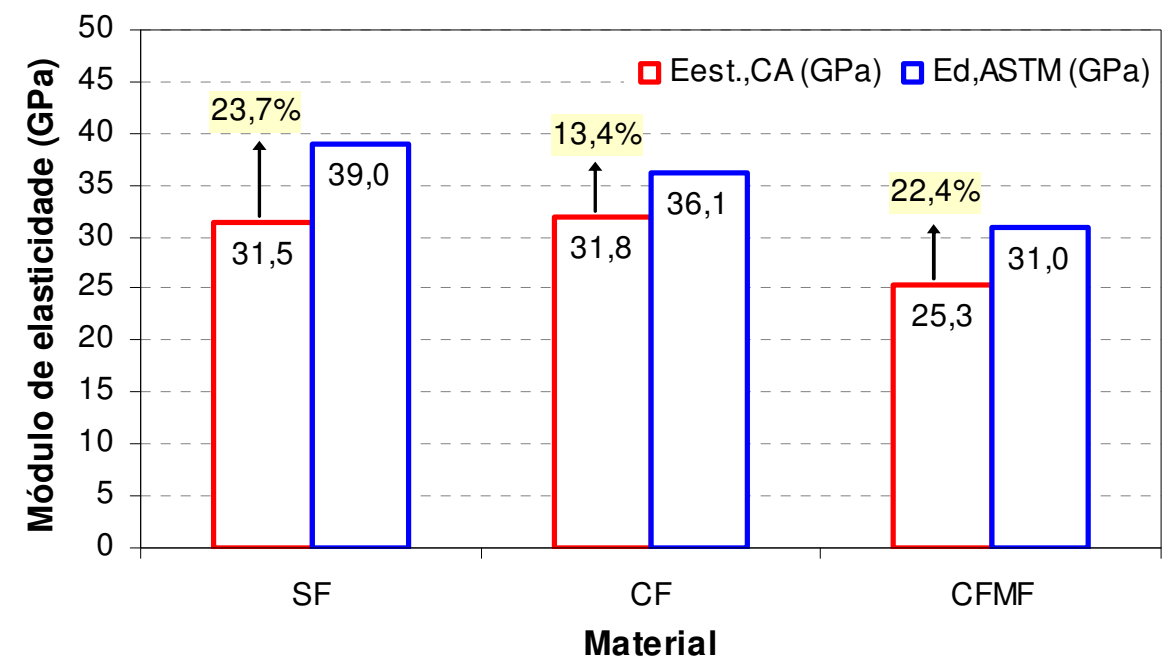

Fig. 8.31: Comparação entre os módulos dinâmico e estático. Idade de ensaio: 28 dias (anterior ao carregamento).

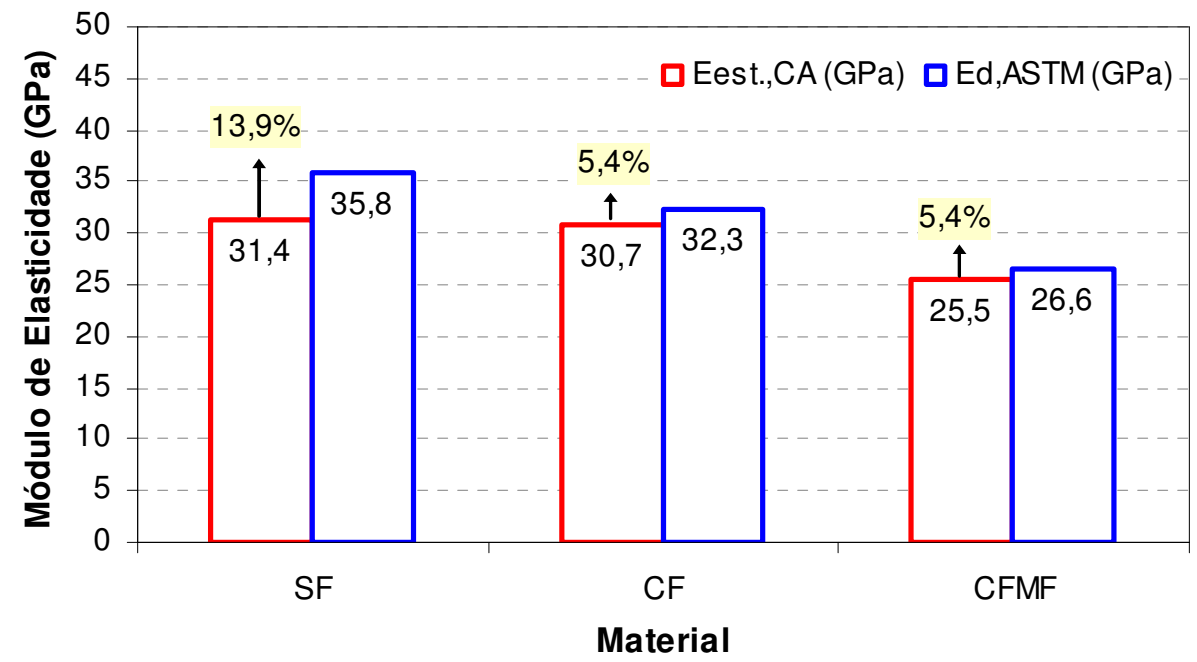

Fig. 8.32: Comparação entre os módulos dinâmico e estático. Idade de ensaio: 105 dias (posterior ao carregamento).

Como esperado, o módulo dinâmico foi maior do que o estático, sendo que para a matriz a diferença foi de $24 \%$, considerando o corpo-de-prova íntegro. Ao adicionar as fibras 
houve uma diminuição desta diferença, que passou a valer 13,4\%. Contudo, ao adicionar as microfibras, a diferença aumenta, retornando a $24 \%$; entretanto, não se sabe o motivo deste comportamento. Conforme discutido no item 8.1.1, constatou-se que as diferenças no teor de ar incorporado entre os materiais avaliados refletiram-se diretamente nas propriedades mecânicas dos concretos, principalmente no módulo de elasticidade. Entretanto, no caso do módulo dinâmico parece não haver relação entre as quantidades de ar incorporado com a

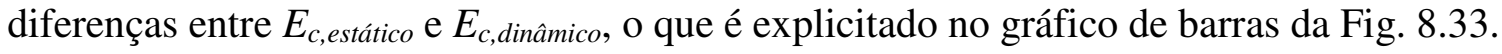

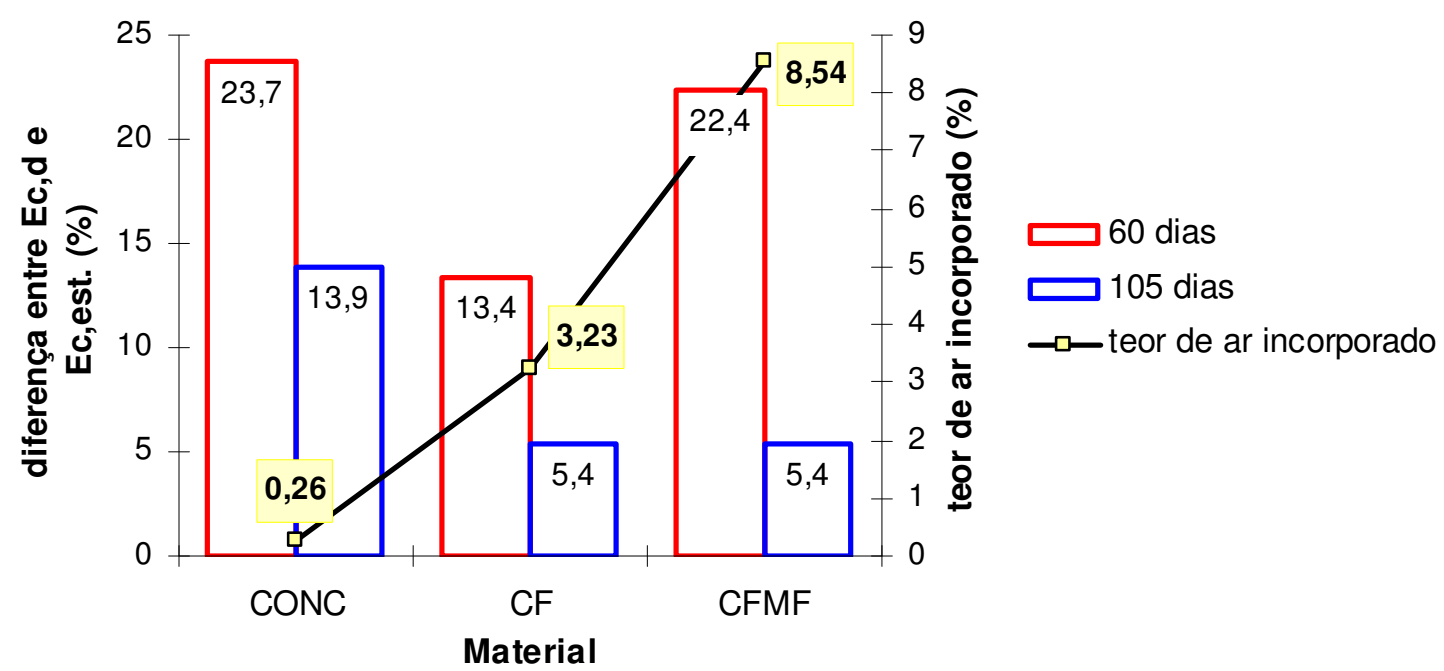

Fig. 8.33: Relação entre o teor de ar incorporado e as diferenças entre $E_{c, d}$ e $E_{c, \text { est }}$.

Contudo, deve-se ressaltar a interferência do teor de ar incorporado no valor do módulo dinâmico obtido para cada material. O teor de ar incorporado interfere no valor da

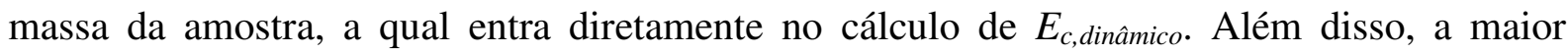
porosidade da matriz (proporcional à quantidade de ar aprisionado) pode ocasionar maior amortecimento, o que de certa forma, pode interferir na freqüência natural obtida. Desta forma, a diminuição do módulo dinâmico com a incorporação das fibras, está intimamente relacionada à elevação do teor de ar incorporado (ver Tabela 8.1).

Segundo Metha e Monteiro (1994), geralmente o módulo dinâmico é maior que o estático em aproximadamente $20 \%, 30 \%$ ou até $40 \%$, variando de acordo com a resistência (alta, média e baixa). Considerando a resistência à compressão média aos 28 dias da matriz igual 35,5 MPa, a diferença entre os módulos estático e dinâmico de $24 \%$ está próximo da literatura.

Certamente o gráfico mais interessante desta seção é aquele ilustrado na Fig. 8.34. Neste gráfico são comparados os valores do módulo de elasticidade dinâmico obtidos antes e 
após os ensaios de fluência. Os valores percentuais da queda no módulo são apresentados em destaque, calculados relativamente aos valores iniciais (28 dias).

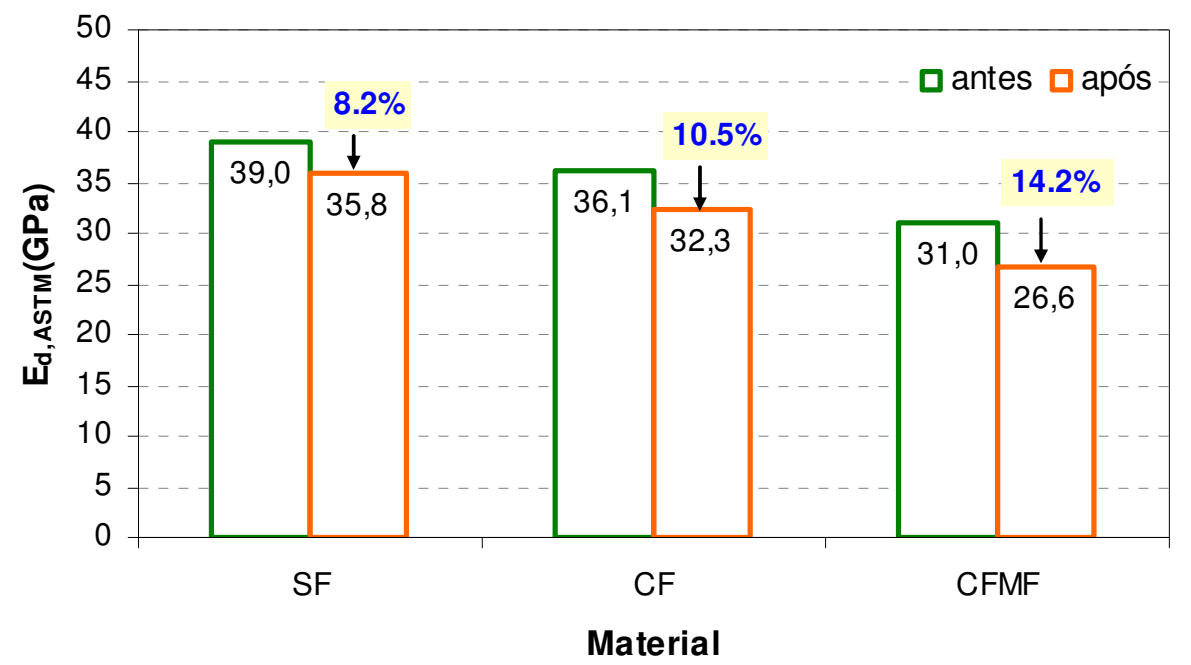

Fig. 8.34: Valores do módulo dinâmico $\left(E_{d}\right)$ antes e após os ensaios de fluência.

De acordo com a Fig. 8.34, nota-se que houve perda de rigidez em todas as vigas. Entretanto percebe-se que a danificação das vigas foi proporcional à quantidade de fibras, o que é coerente com os resultados dos ensaios de fluência. Ora, os materiais que apresentaram maiores valores de fluência específica certamente teriam maior perda de rigidez.

Contudo, deve-se salientar que esta perda de rigidez está associada não só à fluência, mas também à retração por secagem que ocorreu antes e durante os ensaios de fluência, e possivelmente a algum processo de microfissuração associado à retração. Entre a realização dos ensaios dinâmicos e o início dos ensaios de fluência houve um período relativamente grande em que as vigas ficaram expostas às condições de exposição ambientais (no interior do galpão de ensaios), por conta dos imprevistos que ocorreram na definição do sistema de instrumentação (ver datas dos ensaios na Tabela 8.7).

Apesar de tanto as vigas sem entalhe como as vigas entalhadas estarem submetidas à mesma tensão máxima de tração, entende-se que a fluência foi menor nas vigas entalhadas. Considerando que a deformação por fluência é dependente da tensão, apesar da forte concentração de tensões na ponta do entalhe, o restante do volume destes modelos estava solicitado por tensões significativamente menores do que as vigas sem entalhe, às quais foi aplicada uma força concentrada de quase $5 \mathrm{kN}$. Desta forma, imaginava-se que haveria maior danificação destas últimas, contudo, pelos resultados da Tabela 8.6 praticamente não houve diferença entre as vigas. 


\subsection{Série 2 (Definitiva)}

\subsubsection{Ensaios de Caracterização}

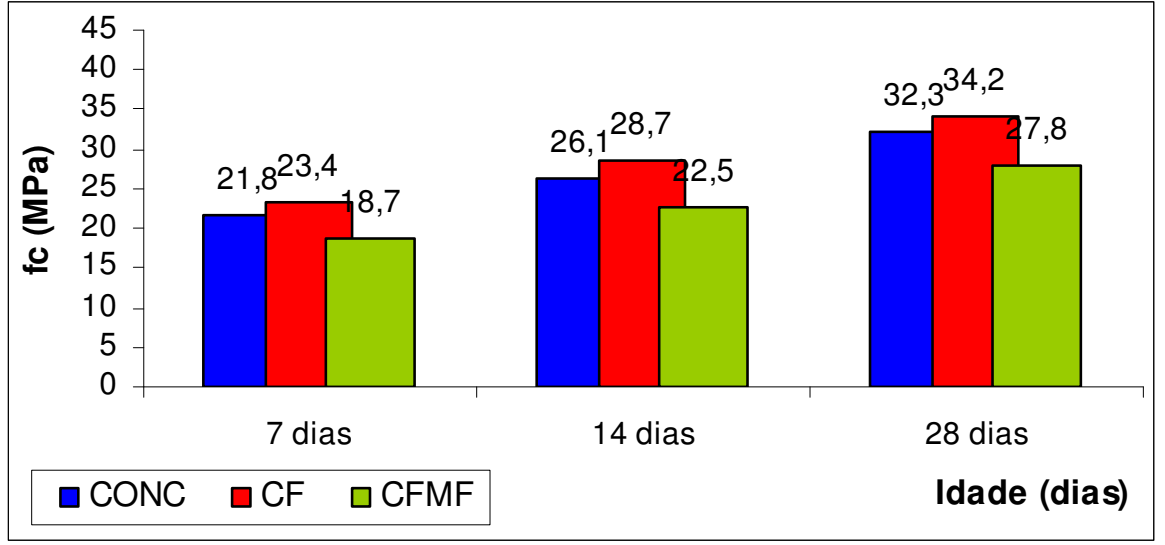

Fig. 8.35:Ensaios de Caracterização Série 2 - Resistência à Compressão.

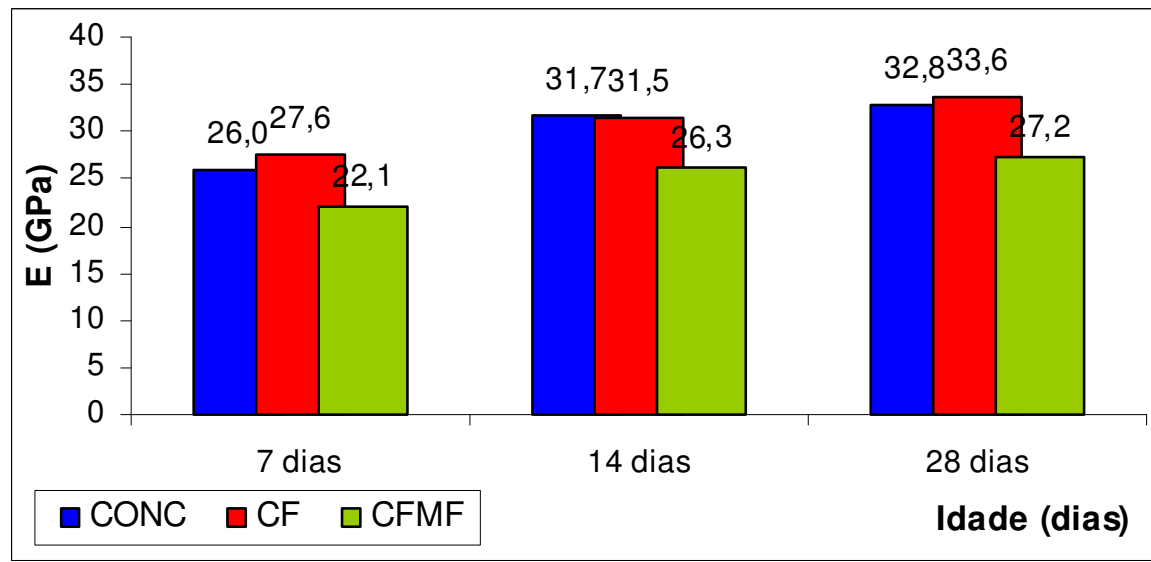

Fig. 8.36:Ensaios de Caracterização Série 2 - Módulo de Elasticidade.

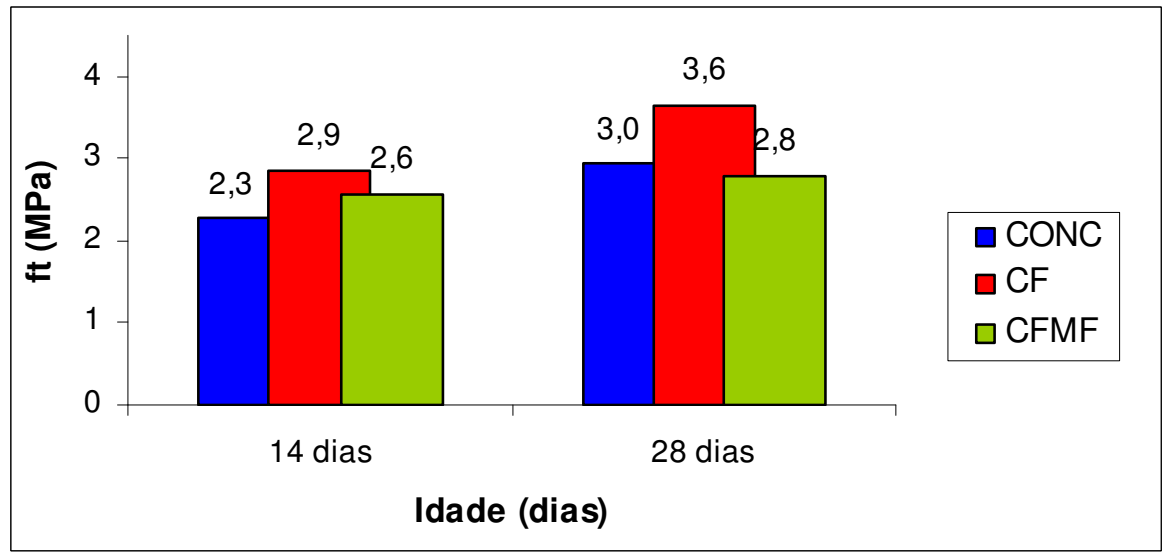

Fig. 8.37:Ensaios de Caracterização Série 2 - Resistência à Tração Indireta por compressão diametral. 
Os resultados dos ensaios de caracterização são apresentados nas Figuras 8.32, 8.33 e 8.34 e representam o valor médio de três corpos-de-prova. Como nesta série foi utilizado concreto usinado, houve pouca variabilidade dos resultados, sendo que de uma forma geral, o coeficiente de variação manteve-se entre $0,5 \%$ e $10 \%$. As planilhas com os resultados de todos os ensaios constam no Apêndice A.

Em média, a adição das fibras de $25 \mathrm{~mm}$ proporcionou valores de resistência à compressão e à tração cerca de $8 \%$ e $19 \%$ superiores, respectivamente, aos da matriz; não sendo observadas variações significativas no módulo de elasticidade. Entretanto ao adicionar as microfibras ao CRFA houve queda na resistência à compressão de aproximadamente 14\%, e no módulo, de 17\%. Quanto à resistência à tração, dependendo da idade do ensaio, ora o valor médio foi menor, maior ou próximo. Possivelmente isto esteja relacionado ao ganho de aderência entre as fibras e a matriz com o tempo, assim como com a variação inerente dos resultados experimentais. A Tabela 8.8 apresenta para cada idade avaliada as diferenças percentuais entre os valores médios das propriedades mecânicas encontradas para os materiais compósitos com relação aos valores obtidos para o concreto de referência.

Tabela 8.8: Acréscimos nas propriedades mecânicas relativos às propriedades da matriz.

\begin{tabular}{cccc}
\hline & $\boldsymbol{f}_{\boldsymbol{c}}$ (MPa) & $\boldsymbol{E}_{c}(\mathbf{M P a})$ & $\boldsymbol{f}_{\boldsymbol{t}}(\mathbf{M P a})$ \\
\hline Idade: $\mathbf{9}$ dias & & & \\
$\mathbf{C F}$ & $7 \%$ & $6 \%$ & $7 \%$ \\
$\mathbf{C F M F}$ & $-14 \%$ & $-15 \%$ & $-14 \%$ \\
Idade: $\mathbf{1 4}$ dias & & & \\
CF & $10 \%$ & $-1 \%$ & $25 \%$ \\
CFMF & $-14 \%$ & $-17 \%$ & $13 \%$ \\
Idade: $\mathbf{2 8}$ dias & & & \\
CF & $6 \%$ & $2 \%$ & $23 \%$ \\
CFMF & $14 \%$ & $-17 \%$ & $-5 \%$ \\
\hline
\end{tabular}

Novamente nota-se uma ligação entre o desempenho do concreto reforçado com fibras e o teor de ar incorporado. Da mesma forma que na série anterior, o cálculo deste parâmetro foi realizado através da diferença entre as massas das vigas. Para o cálculo das massas teóricas foram utilizadas as informações do traço do concreto desta série apresentadas na Tabela 7.5. Já as massas reais foram obtidas por pesagem dos modelos, e constam na tabela a seguir. 
Tabela 8.9: Determinação do teor de ar incorporado - Série 2.

\begin{tabular}{ccccc}
\hline Material & $\begin{array}{c}\text { massa teórica: } \\
\text { traço }(\mathbf{K g})\end{array}$ & $\begin{array}{c}\text { massa real: } \\
\text { pesagem }(\mathbf{K g})\end{array}$ & $\begin{array}{c}\text { diferença } \\
(\mathbf{K g})\end{array}$ & $\begin{array}{c}\text { teor de ar } \\
\text { incorporado (\%) }\end{array}$ \\
\hline CONC & 237,6 & 234,5 & 3,1 & $1,31 \%$ \\
CF & 245,5 & 239,8 & 5,7 & $2,33 \%$ \\
CFMF & 253,4 & 241,1 & 12,3 & $4,87 \%$ \\
\hline
\end{tabular}

De acordo com a Tabela 8.9, percebe-se que, ao adicionar as fibras houve um aumento do teor de ar incorporado. Entretanto, como a dosagem do concreto desta série forneceu uma mistura mais seca do que o da série anterior (slump da série 2 de $7,5 \mathrm{~cm}$ contra $20 \mathrm{~cm}$ da série 1), houve uma variação do teor de ar incorporado de 3,5\% (na série anterior a variação foi $8,5 \%$ ). Nota-se inclusive, talvez por coincidência, que a adição de $1 \%$ de fibras, proporcionou o um aumento em duas vezes deste teor (variação total de 3,5\%). Ora, se as fibras "atrapalham" a expulsão de água durante o adensamento, faz sentido que quanto menor a quantidade de água da mistura, menor será também a quantidade retida pelas fibras.

Imagina-se que se fosse possível obter um compósito com $1 \%$ de fibras de $25 \mathrm{~mm}$ e $1 \%$ de microfibras de $13 \mathrm{~mm}$, sem alterar de forma significativa as características da matriz, obviamente que as propriedades mecânicas deste compósito seriam superiores às do concreto de referência.

A partir dos ensaios de compressão axial efetuados aos 28 dias foram também obtidos os valores do coeficiente de Poisson para cada material, sendo encontrados valores de 0,21, para a matriz, e 0,20 para o concreto com fibras (CF) e para o concreto com fibras e microfibras (CFMF). O procedimento efetuado para o cálculo desta propriedade foi o mesmo descrito para a Série 1. Os valores do coeficiente de Poisson determinado para cada corpo-deprova ensaiado estão apresentados na Tabela 8.10. Com relação à influência das fibras, a diferença entre os materiais compósitos e a matriz foi insignificante. Ou seja, nesta série, o coeficiente de Poisson não sofreu influência da adição de fibras.

Além destes ensaios foram também realizados, aos 56 dias, ensaios de flexão em três pontos nos prismas entalhados, moldados com concreto sem fibras. A partir das curvas $P$ - $\delta$ obteve-se a energia ao fraturamento $\mathrm{G}_{\mathrm{f}}$. $\mathrm{O}$ procedimento de cálculo e de ensaio são aqueles recomendados pela RILEM de 1990 (conforme apresentado no Capítulo 3). Foi utilizado o programa TENAC, de autoria de Ferreira, L. E. T. (Ferreira, Hanai e Bittencourt 2008), para determinação desta propriedade. O valor médio de Gf obtido foi de $181 \mathrm{~N} / \mathrm{m}$, sendo que o coeficiente de variação encontrado foi de $5 \%$. 
A Fig. 8.38 ilustra as curvas $\sigma-\varepsilon$ obtidas a partir dos ensaios de compressão axial aos 28 dias. Visualmente percebe-se que os materiais CF e CONC apresentaram um trecho prépico de resistência muito próximo o que se reflete nos valores do módulo de elasticidade, ao passo que o material CFMF apresentou maior deformabilidade. É possível notar também o ganho de tenacidade pela adição das fibras, apesar dos corpos-de-prova do tipo CFMF terem alcançado valores menores de $f_{c}$. É interessante observar que conforme o material torna-se mais poroso, e, portanto mais heterogêneo, os resultados tornam-se mais dispersos, como não poderia deixar de ser.

Tabela 8.10: Determinação do coeficiente de Poisson - Série 2.

\begin{tabular}{cccccc}
\hline Corpo-de-prova & $\begin{array}{c}\text { Poisson } \\
\text { (ext. 1) }\end{array}$ & $\begin{array}{c}\text { Poisson } \\
\text { (ext. 2) }\end{array}$ & média & $\begin{array}{c}\text { valor } \\
\text { assumido }\end{array}$ & $\begin{array}{c}\text { valor representativo } \\
\text { do material }\end{array}$ \\
\hline CONC1 & 0,2091 & 0,1946 & 0,2018 & 0,2018 & \\
CONC2 & 0,2127 & 0,1956 & 0,2042 & 0,2042 & 0,2055 \\
CONC3 & 0,2357 & 0,1856 & 0,2106 & 0,2106 & \\
\hline CF1 & 0,2222 & 0,2224 & 0,2223 & 0,2223 & 0,2016 \\
CF2 & 0,2145 & 0,1820 & 0,1983 & 0,1983 & \\
CF3 & 0,1842 & 0,1452 & 0,1647 & 0,1842 & \\
\hline CFMF1 & 0,2688 & $-0,0871$ & 0,1780 & descartado & \\
CFMF2 & 0,2907 & 0,1887 & 0,2397 & 0,1887 & \\
CFMF3 & 0,1266 & 0,2140 & 0,1703 & 0,2140 & \\
\hline
\end{tabular}

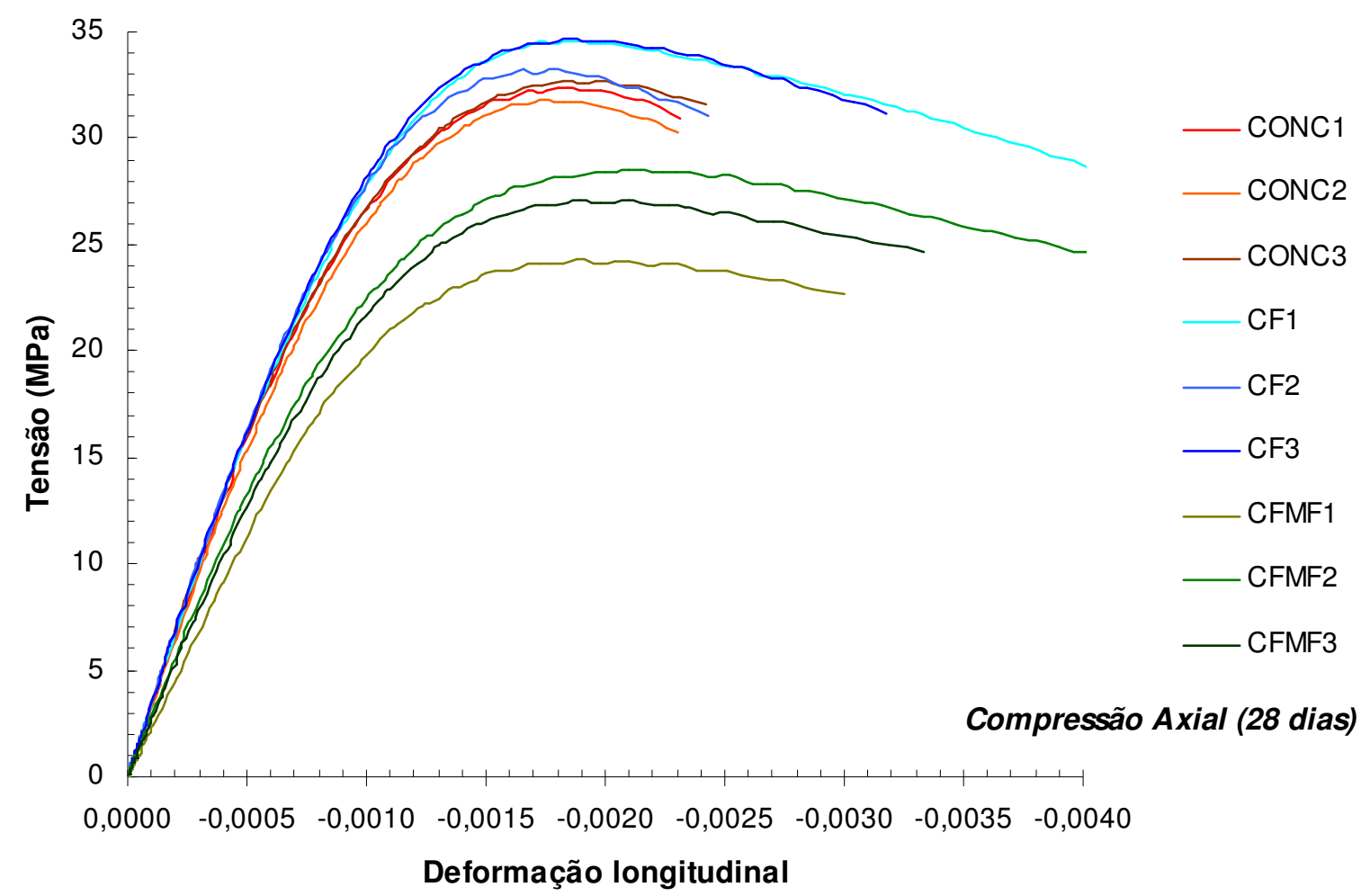

Fig. 8.38: Curvas tensão-deformação obtidas dos ensaios de compressão axial aos 28 dias. 


\subsubsection{Ensaios Dinâmicos}

Os resultados dos ensaios dinâmicos realizados antes da aplicação da carga mantida estão apresentados na Tabela 8.11. O cálculo do módulo de elasticidade dinâmico foi feito através das expressões da norma ASTM C-512: 1991, utilizando-se os valores de frequiências naturais encontradas nos ensaios de vibração livre. A frequiência natural obtida para as vigas entalhadas foi muito próxima da correspondente viga sem entalhe, o que permitiu comparar os três materiais sem distinção da geometria das vigas.

Tabela 8.11: Resultados ensaios dinâmicos (Série 2).

\begin{tabular}{|c|c|c|c|c|}
\hline Modelo & Massa (Kg) & Poisson & $f(H z)$ & $E_{d, A S T M}(M P a)$ \\
\hline VSE - CONC & 237 & 0,21 & 221,5 & 32,8 \\
\hline VE - CONC1 & 234,8 & 0,21 & 220,0 & 32,0 \\
\hline VE - CONC2 & 231,8 & 0,21 & 220,0 & 31,6 \\
\hline média & 234,5 & 0,21 & 220,5 & 32,1 \\
\hline cV & $1,1 \%$ & & $0,4 \%$ & $1,8 \%$ \\
\hline$V S E-C F$ & 239,8 & 0,20 & 222,5 & 33,4 \\
\hline$V E-C F 1$ & 244,8 & 0,20 & 227,5 & 35,7 \\
\hline$V E-C F 2$ & 234,8 & 0,20 & 225,0 & 33,5 \\
\hline média & 239,8 & 0,20 & 225,0 & 34,2 \\
\hline$c v$ & $2,1 \%$ & & $1,1 \%$ & $3,8 \%$ \\
\hline VSE - CFMF & 242,8 & 0,20 & 213,8 & 31,2 \\
\hline VSE - CFMF1 & 239,8 & 0,20 & 210,0 & 29,8 \\
\hline VSE - CFMF2 & 240,8 & 0,20 & 215,0 & 31,3 \\
\hline média & 241,1 & 0,2 & 212,9 & 30,8 \\
\hline$c v$ & $0,6 \%$ & & $1,2 \%$ & $2,8 \%$ \\
\hline
\end{tabular}

Considerando que para a mesma série de ensaios todos os modelos possuem os mesmos parâmetros de geometria, são apresentadas na Tabela 8.9 as três variáveis entre os materiais no cálculo do módulo dinâmico: a freqüência natural de vibração, a massa, e o coeficiente de Poisson. Os dois primeiros são considerados individualmente para cada viga, ao passo que para o coeficiente de Poisson é levado em conta o valor representativo de cada material.

Através da Tabela 8.11 nota-se uma grande homogeneidade nos resultados de cada material, sendo que o coeficiente de variação para os valores de freqüência encontrados situou-se em torno de $1 \%$. Nesta série de ensaios não foram realizados os ensaios dinâmicos depois de finalizadas as leituras de fluência. 
Na Fig. 8.39 são comparados os valores dos módulos estático e dinâmico, sendo que a diferença percentual entre eles (com relação ao maior) é representada em destaque. Observase que para as vigas moldadas com concreto simples (sem fibras), o módulo de elasticidade dinâmico foi muito próximo do módulo estático (variação de apenas 1\%). Entretanto, ao adicionar as fibras, a diferença entre os módulos estático e dinâmico aumentou para 9\% (CF) e 17\% (CFMF). Coincidentemente ou não, o aumento nesta diferença foi proporcional aos incrementos do teor de ar incorporado.

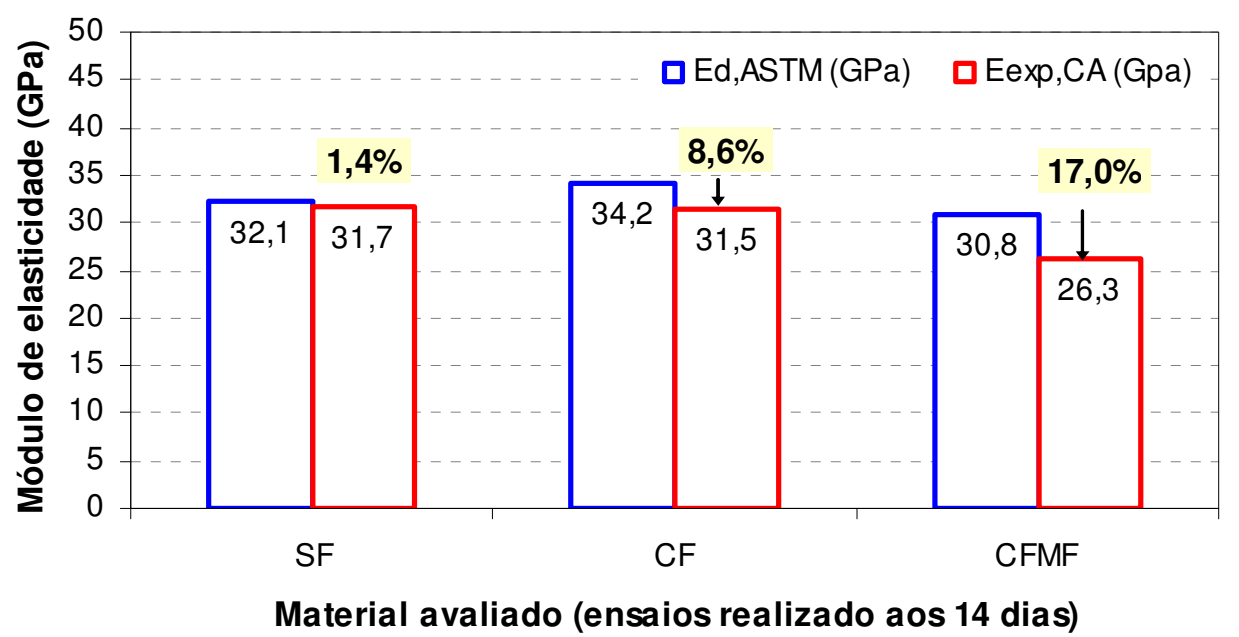

Fig. 8.39: Comparação entre os módulos dinâmico e estático. Idade de ensaio: 27 dias.

Nesta série houve um melhor controle sobre as características da matriz, uma vez que foi utilizado concreto usinado. Conseqüentemente houve menos dispersão dos resultados, sendo que para determinação do módulo estático aos 14 dias, o coeficiente de variação manteve-se em tono de $4 \%$. Também já foi comentado a respeito da boa repetibilidade dos ensaios dinâmicos e de sua maior confiabilidade, o que é refletido em coeficientes de variação igualmente baixos.

A conclusão a que se quer chegar com esta discussão é que os resultados dos ensaios desta série (principalmente os destrutivos) foram, de uma forma geral, mais confiáveis; e sendo assim, a análise do gráfico da Fig. 8.39 parece indicar que a porosidade afeta quantitativamente de forma diferente a determinação experimental do módulo estático e do módulo dinâmico. 


\subsubsection{Temperatura e Umidade na Câmara}

As Figuras Fig. 8.40 e Fig. 8.41 ilustram a variação da temperatura e da umidade relativa do ar no interior da câmara climatizada durante a realização da segunda série de ensaios de fluência. Apesar de o software estar instalado, o aparelho de ar-condicionado permaneceu em manutenção durante o primeiro mês e um novo sistema de umidificação foi adquirido. Porém, o novo umidificador foi entregue somente após o início dos ensaios, o que inviabilizou sua instalação. Em decorrência da manutenção dada aos equipamentos da câmara, e também de fortes chuvas que ocorreram no período, houve grandes variações da umidade relativa $\left(25,4 \pm 0,8^{\circ} \mathrm{C}\right.$ e $\left.72,8 \pm 25,4 \%\right)$.

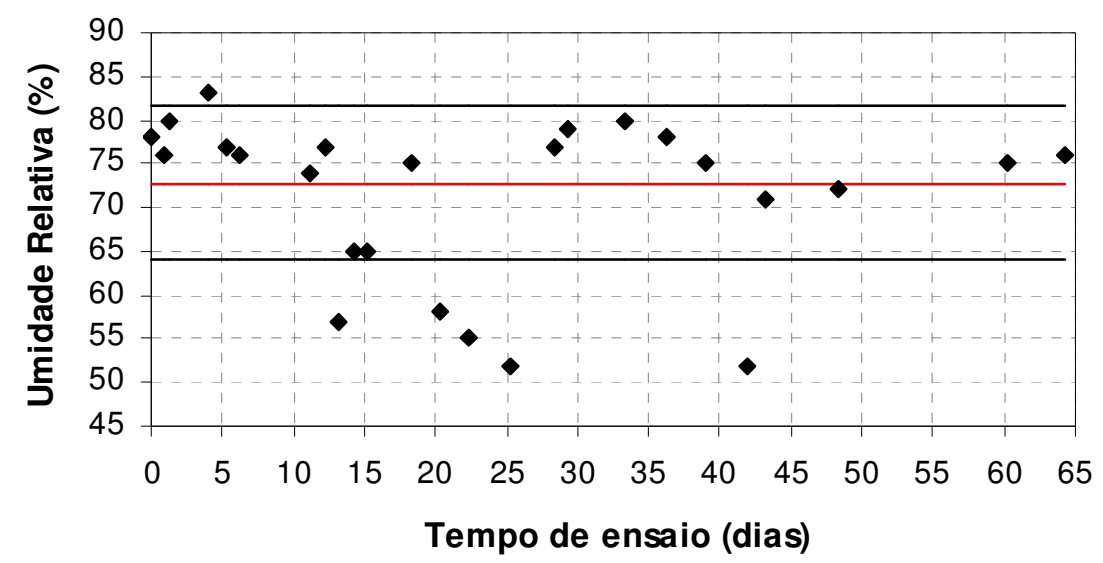

Fig. 8.40: Variação da umidade relativa (Série 2).

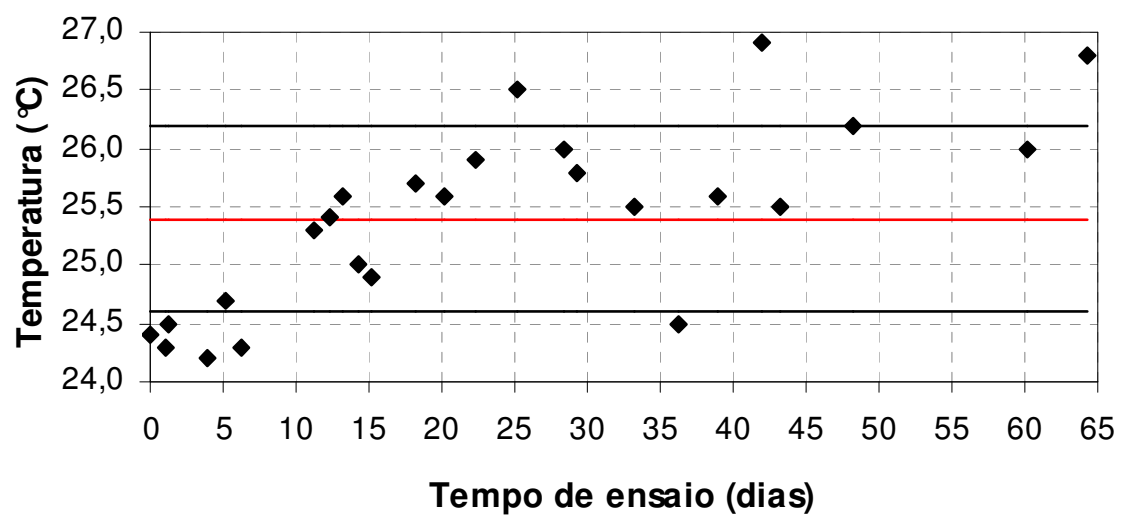

Fig. 8.41: Variação da Temperatura (Série 2).

\subsubsection{Ensaios de Retração}

Como os prismas estão apoiados no piso, sem nenhum tipo de solicitação e não foram selados, na realidade a deformação medida é resultado da ação conjunta de alguns fenômenos, 
como retração autógena, retração por secagem e dilatação térmica. Contudo, refere-se ao longo do texto apenas à retração.

Da mesma forma que na Série 1, os dados experimentais foram ajustados a equações normalmente utilizadas na literatura: equação exponencial e uma expressão equivalente à utilizada pelo ACI 209:1982. Por facilitar a leitura, as equações são novamente apresentadas a seguir. Os coeficientes e o índice de correlação obtido por cada ajuste estão apresentados na Tabela 8.12.

Exponencial:

$$
\varepsilon_{c, s}=a\left[1-\exp \left(-b\left(t-t_{0}\right)\right)\right]
$$

Equação ACI:

$$
\varepsilon_{c, s}=a \cdot\left(t-t_{0}\right) /\left(35+b \cdot\left(t-t_{0}\right)\right)
$$

Tabela 8.12: Coeficientes para ajuste dos dados de retração - Série 2.

\begin{tabular}{c|ccc|ccc}
\hline \multirow{2}{*}{ Material } & \multicolumn{3}{|c|}{ Exponencial } & \multicolumn{3}{c}{ ACl } \\
& $\mathbf{a}$ & $\mathbf{b}$ & $\mathbf{r}^{2}$ & $\mathbf{a}$ & $\mathbf{b}$ & $\mathbf{r}^{2}$ \\
\hline \hline CONC & 365,588740 & 0,027664 & 0,98 & 422,607270 & 0,884838 & 0,98 \\
CF & 274,575300 & 0,048044 & 0,98 & 609,385520 & 1,841286 & 0,99 \\
CFMF & 236,343640 & 0,025201 & 0,96 & 245,181240 & 0,782084 & 0,97 \\
\hline
\end{tabular}

Os gráficos das figuras 8.37 a 8.39 apresentam as linhas de tendências obtidas por cada ajuste para os três materiais avaliados: concreto sem fibras (CONC), concreto com fibras (CF) e concreto com fibras e microfibras (CFMF). Já as figuras 8.40 a 8.42 ilustram a extrapolação no tempo do comportamento das linhas de tendência encontradas.

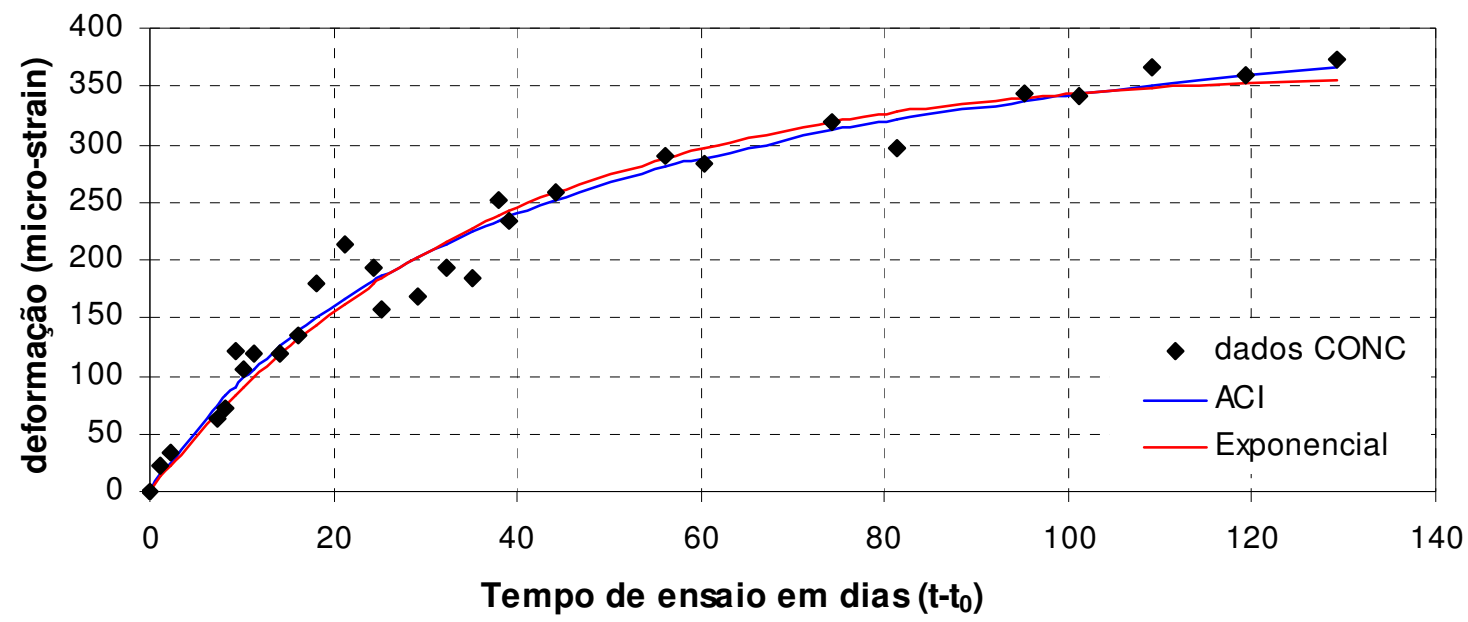

Fig. 8.42: Deformações Volumétricas - Série 2. Ajustes aos dados experimentais: CONC. 


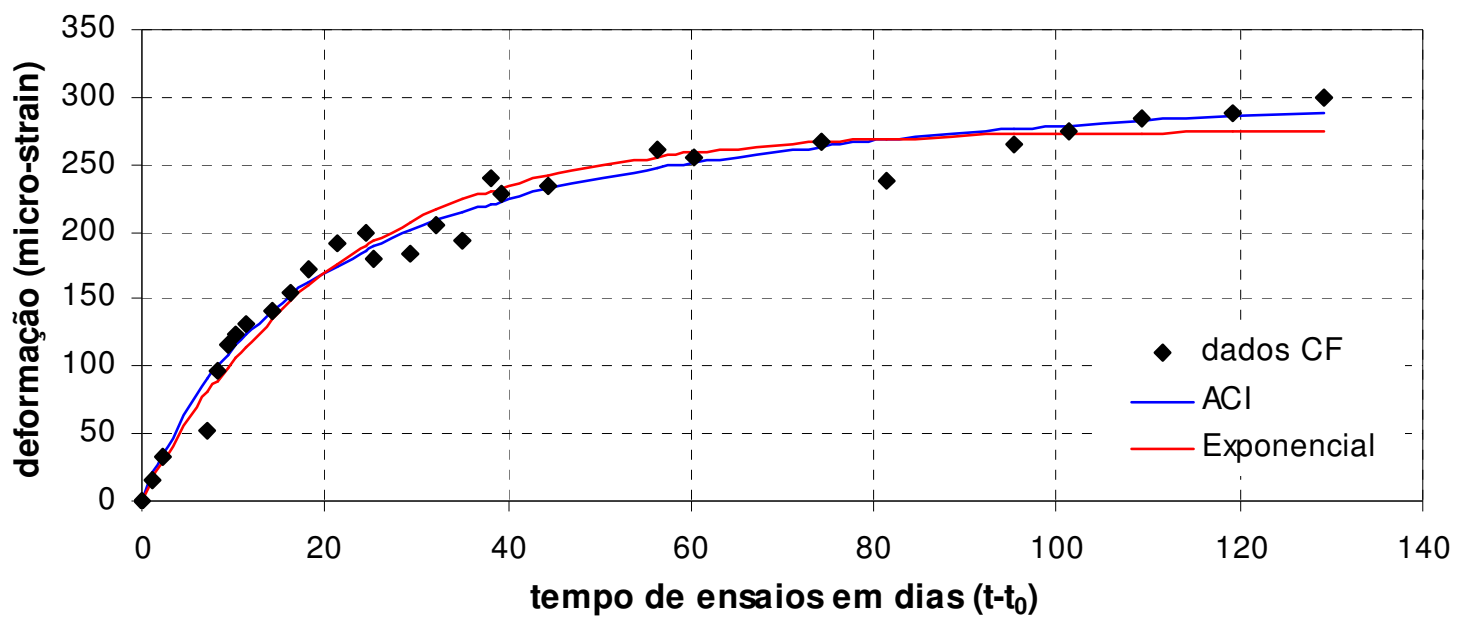

Fig. 8.43: Deformações Volumétricas - Série 2. Ajustes aos dados experimentais: CF.

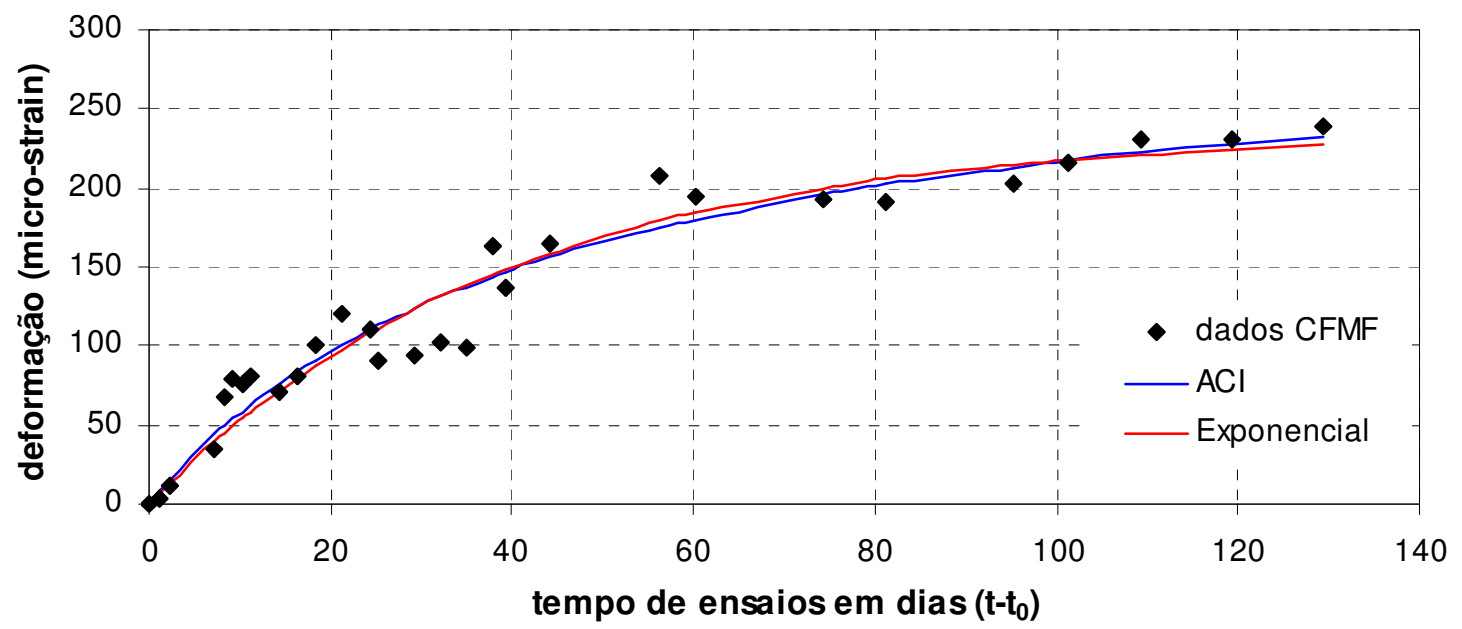

Fig. 8.44: Deformações Volumétricas - Série 2. Ajustes aos dados experimentais: CFMF.

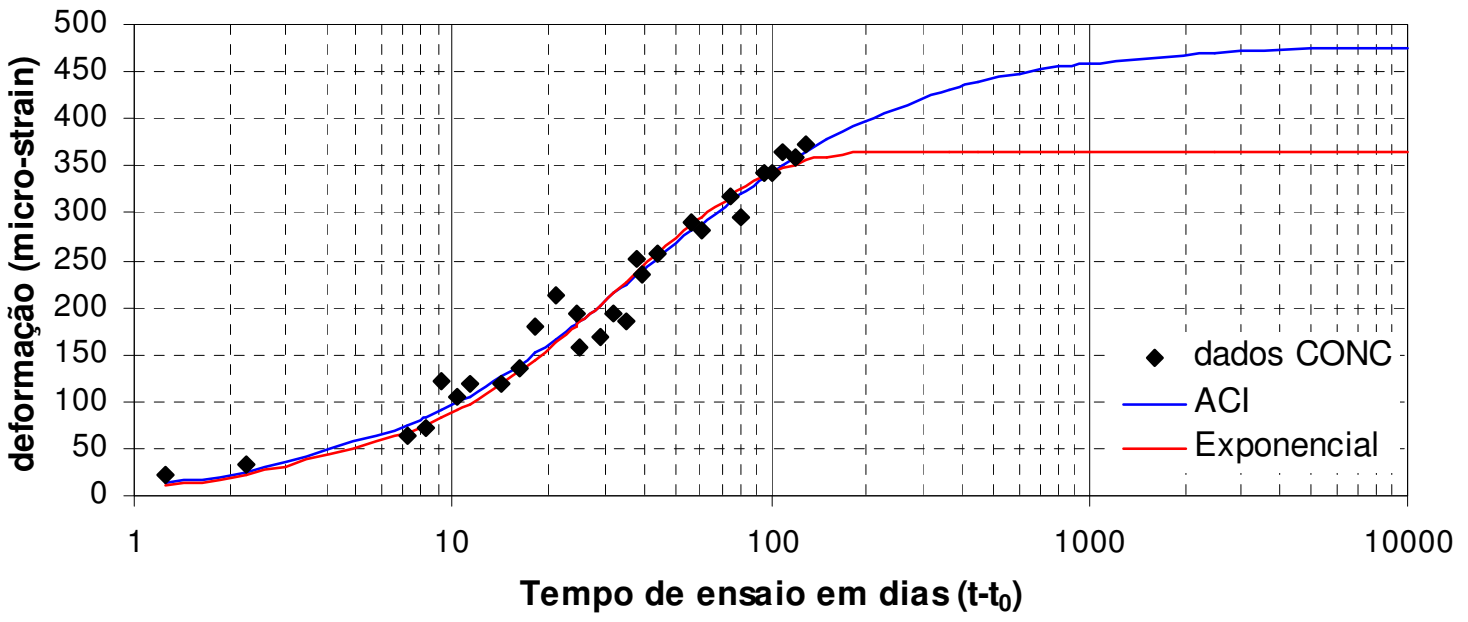

Fig. 8.45: Deformações Volumétricas - Série 2. Extrapolação das deformações por retração: CONC. 


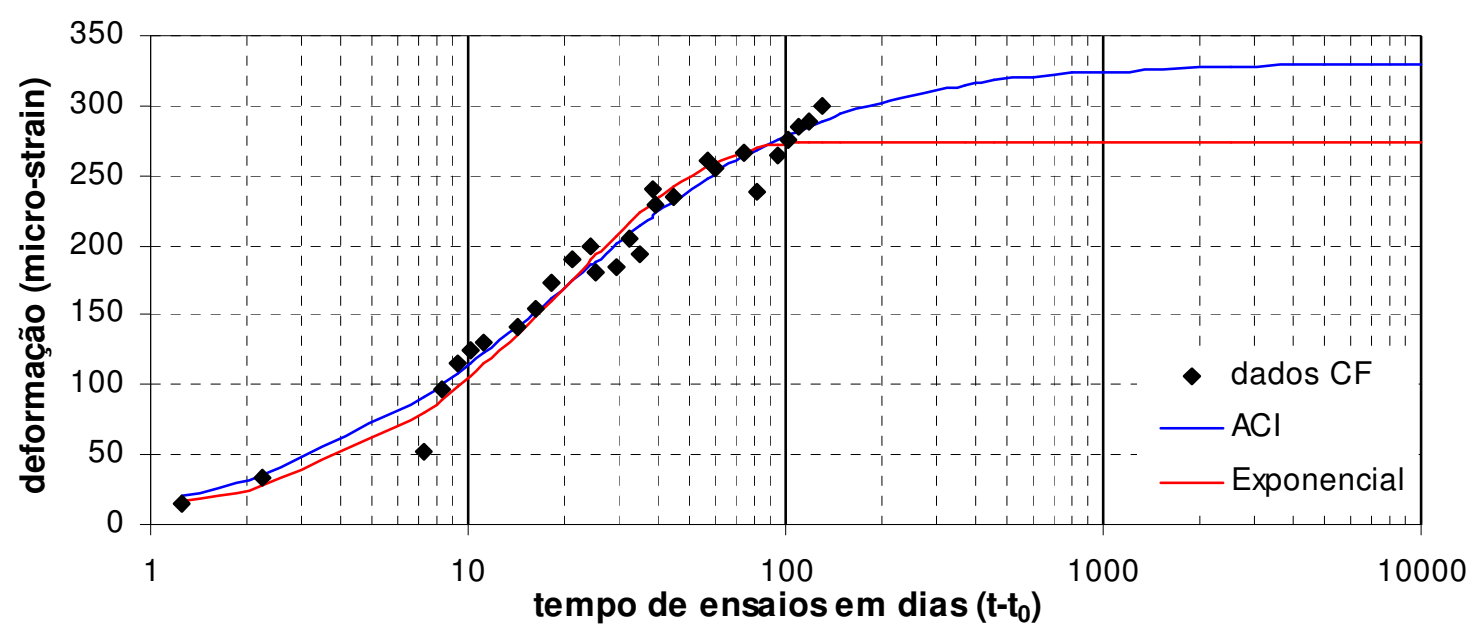

Fig. 8.46: Deformações Volumétricas - Série 2. Extrapolação das deformações por retração: CF.

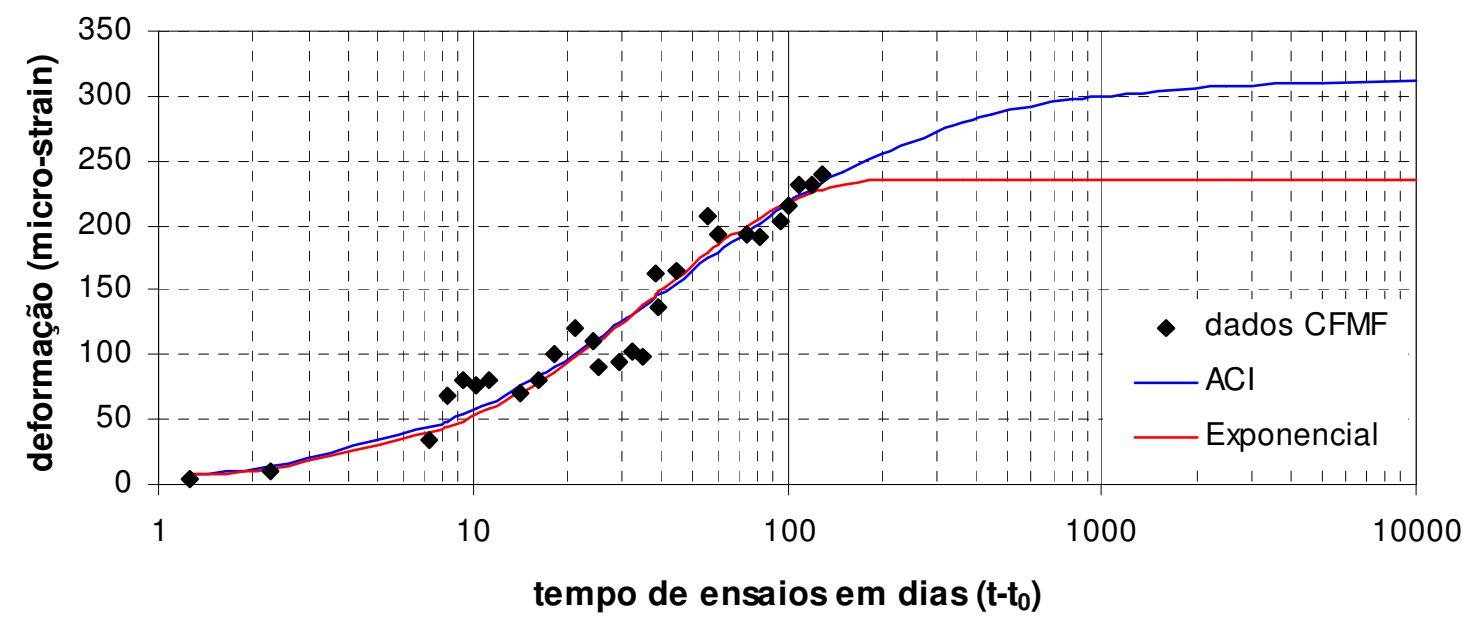

Fig. 8.47: Deformações Volumétricas - Série 2. Extrapolação das deformações por retração: CFMF.

Nota-se que as expressões utilizadas nos ajustes representam bem o comportamento observado dentro do período de avaliação, independentemente do material avaliado. Isto pode ser percebido visualmente e também está constatado pela boa correlação encontrada entre o ajuste e os dados experimentais (de acordo com os coeficientes de correlação da Tabela 8.12, $r^{2} \geq 0,96$ ). Observa-se também que os formatos das curvas são bastante próximos.

Ao extrapolar as curvas de tendência para períodos sob carga de até 27 anos, nota-se que, a partir dos dados destes ensaios a estabilização das deformações utilizando ajuste exponencial ocorre após 200 dias, já utilizando a expressão para ajuste denominada ACI, a estabilização ocorre praticamente após 6 anos (2500 dias). Deve-se considerar ainda a diferença significativa entre os valores finais oriundos de cada expressão de ajuste (aproximadamente igual a 20\%). 


\subsubsection{Influência da Umidade Relativa do Ambiente}

Como já foi mencionado, as deformações medidas nestes ensaios denominados ensaios de retração refletem na realidade o produto do conjunto de várias deformações: deformação por retração autógena, retração por secagem e dilatação térmica. Considerando a retração por secagem, fenômeno associado à perda de água adsorvida, certamente ao elevar a umidade relativa do ambiente ocorrerá uma recuperação das deformações, analogamente ao que ocorre com a parcela de fluência por secagem quando o corpo-de-prova submetido à carga mantida é exposto a condições de maior e menor umidade relativa.

A influência da variação da umidade relativa do meio é explicitada no gráfico da Fig. 8.48. Neste gráfico estão apresentados os valores normalizados ao longo do tempo (também normalizado) das deformações volumétricas (retração) e da umidade relativa no interior da câmara climatizada. É interessante notar o rebatimento das curvas, principalmente nos períodos em que houve maior variação da umidade (entre 0 e 0,3 da duração total dos ensaios). Claro que um aumento na umidade relativa provoca um "inchamento" do corpo-deprova, causando uma recuperação de parte da deformação por retração.

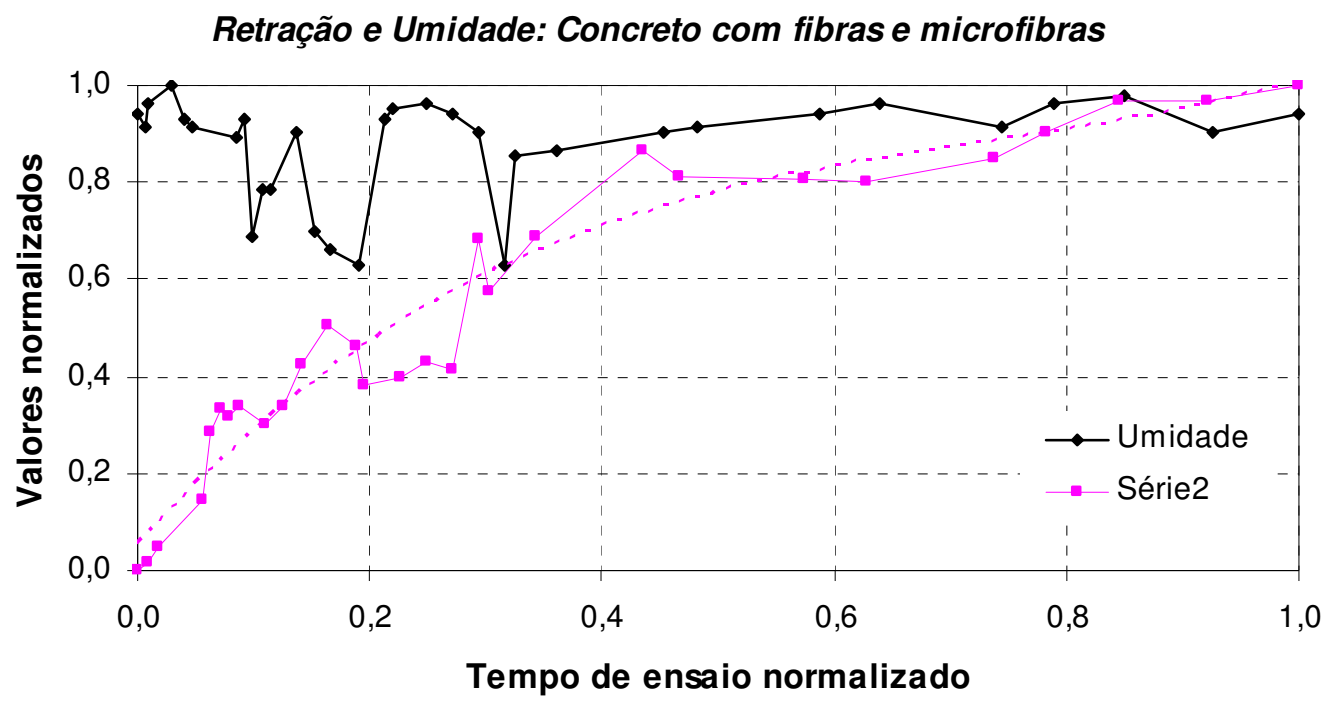

Fig. 8.48: Influência da umidade relativa nas leituras dos ensaios de retração.

\subsubsection{Influência das fibras}

De acordo com o gráfico da Fig. 8.49, para esta série de ensaios, a adição de fibras metálicas proporciona maior restrição às deformações por retração, sendo que esta restrição foi mais proeminente para o concreto reforçado com fibras e microfibras de aço. 
Ao final dos ensaios, os prismas de concreto simples apresentaram deformações em torno de $370 \mu e$, ao passo que o prisma CF apresentou deformação de $300 \mu e$ ( $18 \%$ menor) e o prisma CFMF apresentou deformação de $238 \mu$ (36\% menor).

Os valores medidos de retração não foram utilizados para corrigir as deformações de fluência, posto que os ensaios de fluência foram realizados à flexão. Entretanto, os resultados obtidos foram interessantes por permitirem observar a melhoria do comportamento do concreto reforçada com fibras e microfibras frente aos outros dois materiais.

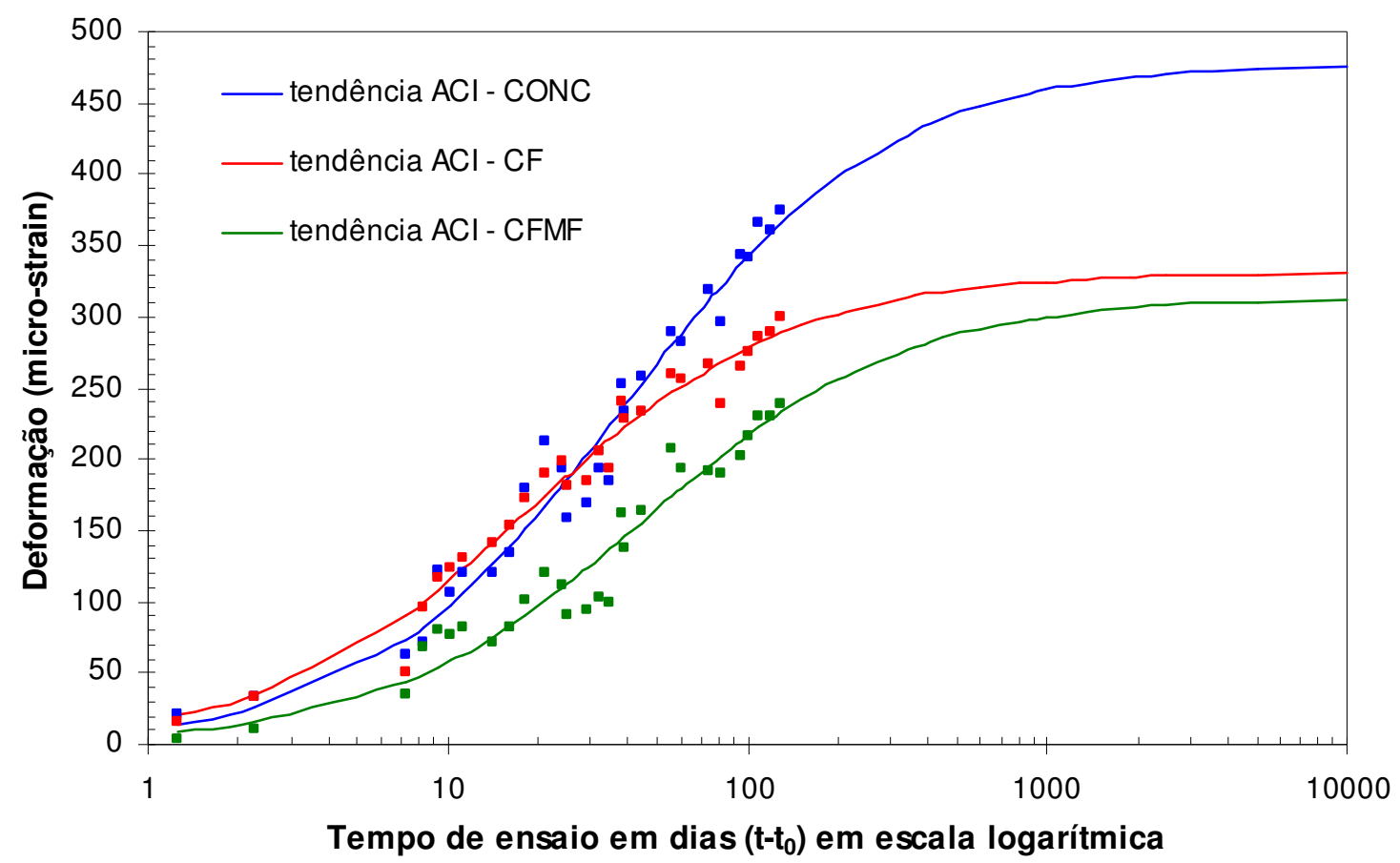

Fig. 8.49: Influência das fibras nas deformações por retração.

\subsubsection{Ensaios de Fluência}

Para o tratamento dos dados dos ensaios de fluência foram realizadas as mesmas ações esquematizadas na Fig. 8.15.

Nesta série foi utilizada a mesma geometria do entalhe, para as vigas entalhadas e o mesmo peso-morto para aplicação da carga concentrada mantida no meio do vão das vigas sem entalhe. Desta forma, as máximas tensões de tração, devido a solicitações são as mesmas que da série anterior e correspondem a 1,4 MPa.

Entretanto, ao observar os valores da resistência à tração obtida para cada material na idade de carregamento (14 dias), tem-se que as relações tensão-resistência utilizadas nos ensaios de fluência foram de $0,61,0,48$ e 0,54 para as vigas de concreto, concreto reforçado 
com fibras e concreto reforçado com fibras e microfibras, respectivamente.

\subsubsection{Resultados das Vigas Sem Entalhe (VSE)}

\subsection{Resultados em termos de deslocamentos}

\section{a) Ajuste dos dados experimentais}

Para obtenção das curvas de tendência para os três modelos ensaiados, com o intuito de permitir uma avaliação comparativa mais correta, os dados experimentais foram ajustados a diversas expressões, de forma análoga ao realizado para os dados da primeira série.

Para tanto, considerou-se que a flecha $\delta(t)$ em uma determinada data $t$, após a aplicação do carregamento em $t_{0}$ é constituída de duas parcelas: a flecha elástica inicial (que ocorreu em $t_{0}$ ) e o deslocamento devido à fluência durante o período em que a peça ficou sob carga $\left(t-t_{0}\right)$, definido aqui como $\delta_{c}(t)$, onde o subscrito $c$ refere-se à inicial de creep (fluência em inglês). Portanto:

$$
\delta(t)=\delta_{i}\left(t_{0}\right)+\delta_{c}\left(t-t_{0}\right)
$$

Sabe-se que o comportamento à fluência é variável, e que conseqüentemente precisariam ser definidas funções para descrever corretamente os acréscimos da flecha por conta do fenômeno. Desta forma, foram utilizadas funções bastante conhecidas da literatura por descrever satisfatoriamente bem o comportamento do concreto à fluência a partir de ensaios de curta duração, como as expressões exponencial, hiperbólica e de potência já apresentadas no Capítulo 4.

$\mathrm{Na}$ época em que estas expressões foram largamente utilizadas (décadas de 60 e 70) não havia os recursos computacionais que existem hoje. Sendo assim, havia a necessidade de serem utilizadas expressões cuja obtenção dos coeficientes não exigisse cálculos complexos, o que era feito, muitas vezes, graficamente. Informações a esse respeito são apresentadas em Neville, 1982. Neste trabalho a obtenção dos coeficientes das expressões foi efetuada utilizando o software curvexpert.

Ressalta-se que a maioria dos estudos experimentais, para os quais tais funções funcionavam bem, tratava-se da fluência à compressão. Sendo assim, buscou-se também verificar se a fluência à flexão teria comportamento semelhante, sendo "modelada" segundo o 
mesmo "formato" que no caso da compressão.

Nesta série foram também empregadas outras duas expressões: uma adaptação da norma americana ACI 209:1982 e a equação MMF. A expressão da norma americana ACI 209:1982 para estimativa do coeficiente de fluência (apresentada no Capítulo 5) é uma função hiperbólica de potência, podendo ser considerada uma variação da hipérbole de Ross. De acordo com Neville, apesar de subestimarem a fluência nas primeiras idades, estas expressões fornecem bons resultados a longo prazo, sendo comumente utilizadas.

A expressão MMF recebe este nome em homenagem a Morgan, Mercer e Flodin, e é um modelo não linear de crescimento bastante conhecido. Apesar de não ter sido encontrado constatações do uso desta expressão para fluência, em todos os corpos-de-prova (inclusive da série 1) esta expressão forneceu os valores de $\mathrm{r}^{2}$ mais próximos de 1.

Ressalta-se também a boa adequação desta expressão com os dados de deslocamento fornecidos pela simulação numérica efetuada no DIANA ${ }^{\circledR}$. Observando com atenção nota-se que esta boa correlação é fundamentada no forte parentesco que esta expressão possui com aquela adotada pelo ACI. Na realidade pode-se dizer que a expressão do ACI é uma forma simplificada do MMF, o que justifica a excelente correlação desta expressão com a simulação.

A Tabela 8.13 traz a relação de todas as expressões utilizadas. Apesar de algumas delas já terem sido apresentadas anteriormente, julgou-se conveniente reescrevê-las aqui, facilitando a leitura.

Na Tabela 8.14 constam os valores dos coeficientes encontrados para cada ajuste e das flechas elásticas utilizadas. Nesta tabela, para cada modelo avaliado, as expressões de ajuste estão apresentadas em ordem decrescente do coeficiente $\mathrm{r}^{2}$ encontrado (ou seja, do melhor ao pior ajuste segundo o coeficiente de correlação). Os dados da tabela também ilustram algo um tanto óbvio: a diminuição do número de coeficientes a serem ajustados implica em um maior erro. Ou seja, quanto mais geral a expressão, maior o erro. Nos piores casos obteve-se $\mathrm{r}^{2}$ igual a 0,95 e erro de $8 \%$. 
Tabela 8.13: Expressões de ajuste para as flechas diferidas - Série 2.

Exponencial: $\quad \delta(t)=a \cdot\left[1-\exp \left(-c \cdot\left(t-t_{0}\right)\right)\right]+\delta_{i}\left(t_{0}\right)$

Hipérbole de Ross: $\quad \delta(t)=\frac{\left(t-t_{0}\right)}{a+b \cdot\left(t-t_{0}\right)}+\delta_{i}\left(t_{0}\right)$

Potência:

$$
\delta(t)=a \cdot\left(t-t_{0}\right)^{b}+\delta_{i}\left(t_{0}\right)
$$

MMF:

$$
\delta(t)=\frac{a \cdot b+c \cdot\left(t-t_{0}\right)^{d}}{b+\left(t-t_{0}\right)^{d}}+\delta_{i}\left(t_{0}\right)
$$

ACI adaptado:

$$
\delta(t)=\frac{a \cdot\left(t-t_{0}\right)^{0.6}}{10+\left(t-t_{0}\right)^{0.6}}+\delta_{i}\left(t_{0}\right)
$$

\begin{tabular}{|c|c|c|c|c|c|c|}
\hline & a & $\boldsymbol{b}$ & $c$ & $d$ & $\begin{array}{c}\text { Correlation } \\
\text { coeficient }\end{array}$ & $\begin{array}{c}\text { Standard } \\
\text { error }\end{array}$ \\
\hline \multicolumn{7}{|l|}{ VSE - CONC } \\
\hline \multicolumn{7}{|l|}{$\delta \mathrm{i}, \mathrm{t}_{0}(\mathrm{~mm})=0.085$} \\
\hline MMF & 0,043182 & 51,006520 & 0,465569 & 1,281009 & 0,989162 & $1,912 \%$ \\
\hline Hipérbole de Ross & 40,871723 & 2,003558 & & & 0,985861 & $2,345 \%$ \\
\hline Exponencial & 0,413227 & 0,044672 & & & 0,982477 & $2,345 \%$ \\
\hline ACI modificado & 0,668870 & & & & 0,980543 & $2,430 \%$ \\
\hline Potência & 0,080490 & 0,361298 & & & 0,972486 & $2,931 \%$ \\
\hline \multicolumn{7}{|l|}{ VSE - CF } \\
\hline \multicolumn{7}{|l|}{$\delta \mathrm{i}, \mathrm{t}_{0}(\mathrm{~mm})=0.103$} \\
\hline MMF & 0,046720 & 90,782220 & 0,556182 & 1,422372 & 0,994074 & $1,773 \%$ \\
\hline Hipérbole de Ross & 41,358191 & 1,583205 & & & 0,991137 & $2,093 \%$ \\
\hline Exponencial & 0,508074 & 0,037712 & & & 0,991040 & $2,105 \%$ \\
\hline ACI modificado & 0,781505 & & & & 0,973725 & $3,530 \%$ \\
\hline Potência & 0,079633 & 0,403261 & & & 0,974729 & $3,520 \%$ \\
\hline \multicolumn{7}{|l|}{ VSE - CFMF } \\
\hline \multicolumn{7}{|l|}{$\delta \mathrm{i}, \mathrm{t}_{0}(\mathrm{~mm})=0.096$} \\
\hline MMF & 0,006171 & 113,555260 & 0,883718 & 1,497498 & 0,997779 & $1,910 \%$ \\
\hline Hipérbole de Ross & 32,435067 & 0,917287 & & & 0,992714 & $3,338 \%$ \\
\hline Exponencial & 0,837921 & 0,031130 & & & 0,992714 & $2,517 \%$ \\
\hline ACI modificado & 1,202571 & & & & 0,949109 & $8,582 \%$ \\
\hline Potência & 0,092813 & 0,472557 & & & 0,967093 & $7,047 \%$ \\
\hline
\end{tabular}

Tabela 8.14: Informações sobre ajustes realizados para o modelo VSE-CONC. Série 2. 
Os gráficos das figuras $8.50,8.51$ e 8.52 apresentam as linhas de tendências obtidas por cada ajuste para os três materiais avaliados. Nota-se que dentro do período de observação de 134 dias (ver Figura 8.50) todas as expressões ajustam-se bem aos resultados, mesmo sendo estes de ensaios de flexão. Através da análise visual, percebe-se melhor aproximação aos dados segundo a expressão hipérbole de Ross.

Já nas figuras 8.53 a 8.55 fornecem a extrapolação no tempo das curvas de tendência, apenas com o intuito de comparar as estimativas fornecidas pelos ajustes para períodos de tempo de até 10000 dias (27 anos). Através destes gráficos torna-se mais nítida as discrepâncias entre os ajustes. Esta análise, ainda que bastante superficial, expõe a importância da precisão na estimativa da fluência a partir de ensaios de curta duração.

Como já apontado na literatura, a expressão de potência não representa bem o fenômeno, superestimando-o demasiadamente. A expressão exponencial indica estabilização da flecha já aos 150 sob carga o que se sabe ser improvável. As outras três expressões (ACI adaptado, hipérbole de Ross e MMF) apresentaram curvas de tendência com comportamento bastante próximo, o que era esperado dada a semelhança analítica entre elas. Percebe-se também a semelhança entre as curvas Potência e ACI modificado nos primeiros 30 dias de ensaio, o que se deve à natureza desta última. Isto pode ser observado com maior clareza nas figuras 8.50 a 8.52 .

Nota-se que as curvas Hipérbole de Ross e $M M F$ praticamente se estabilizam após 3 anos, ao passo que a curva ACI adaptada indica taxa de fluência durante 20 anos. Os valores das flechas após 365 dias (1 ano) assim como os valores últimos (após 10000 dias) são apresentados na Tabela 8.15. Nesta tabela também é apresentada a parcela devida à fluência da flecha diferida $(\delta c)$, dada pela diferença entre a flecha total $\delta$ e a flecha elástica inicial $(\delta i)$; e o coeficiente de fluência, obtido pela razão $\delta c / \delta i$.

De acordo com a literatura, na falta de estimativas melhoras, pode-se adotar coeficiente de fluência igual a 3 para tempo "infinito", ao se tratar de concreto comprimido. Já de acordo com as recomendações normativas (NBR e ACI), considera-se que haja estabilização das flechas após 70 meses (aproximadamente 6 anos), sendo a flecha elástica inicial majorada por um coeficiente que pode variar entre 0 e 3. 


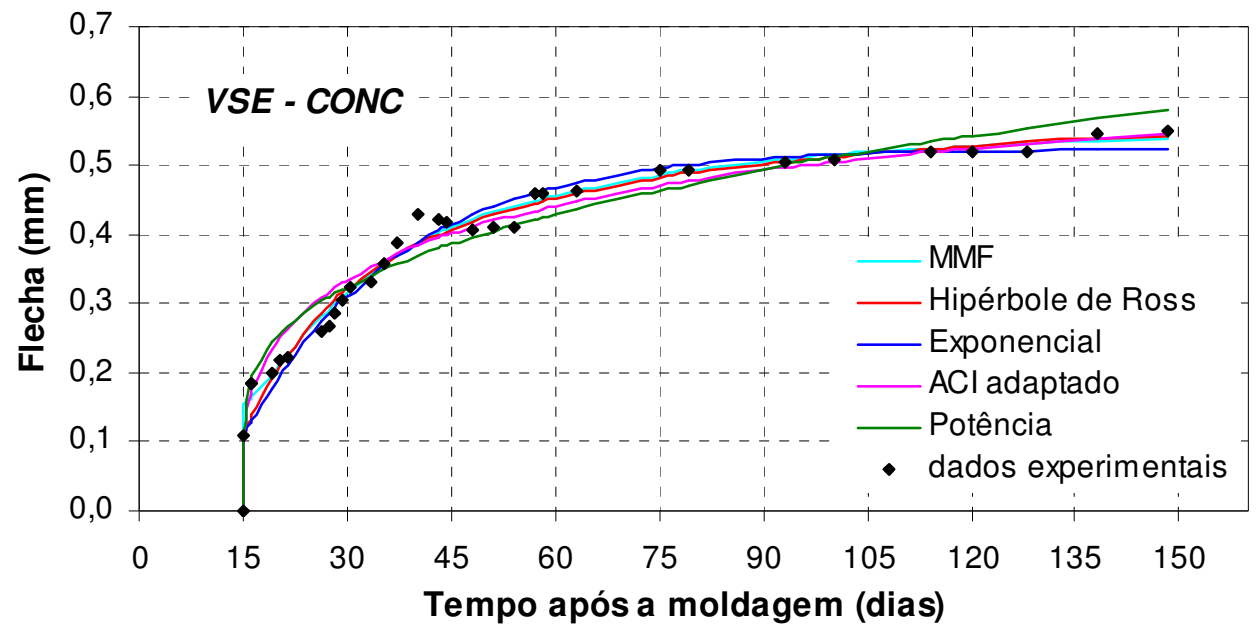

Fig. 8.50: Curvas de tendência VSE-CONC, Série 2.

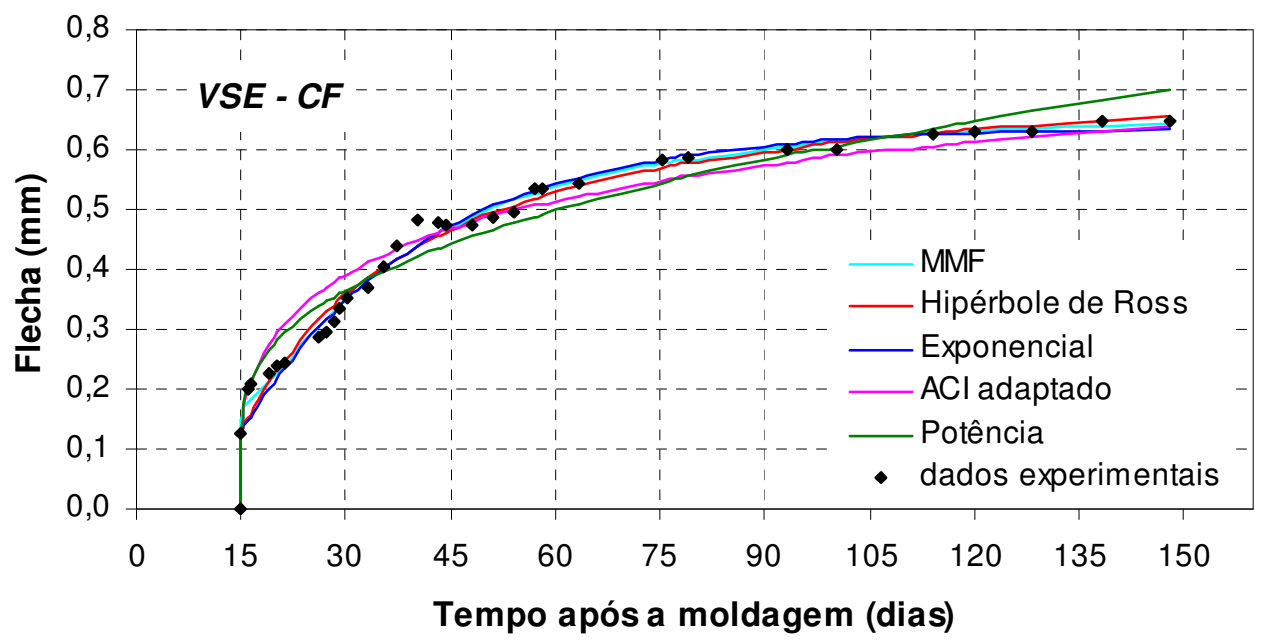

Fig. 8.51: Curvas de tendência VSE-CF, Série 2.

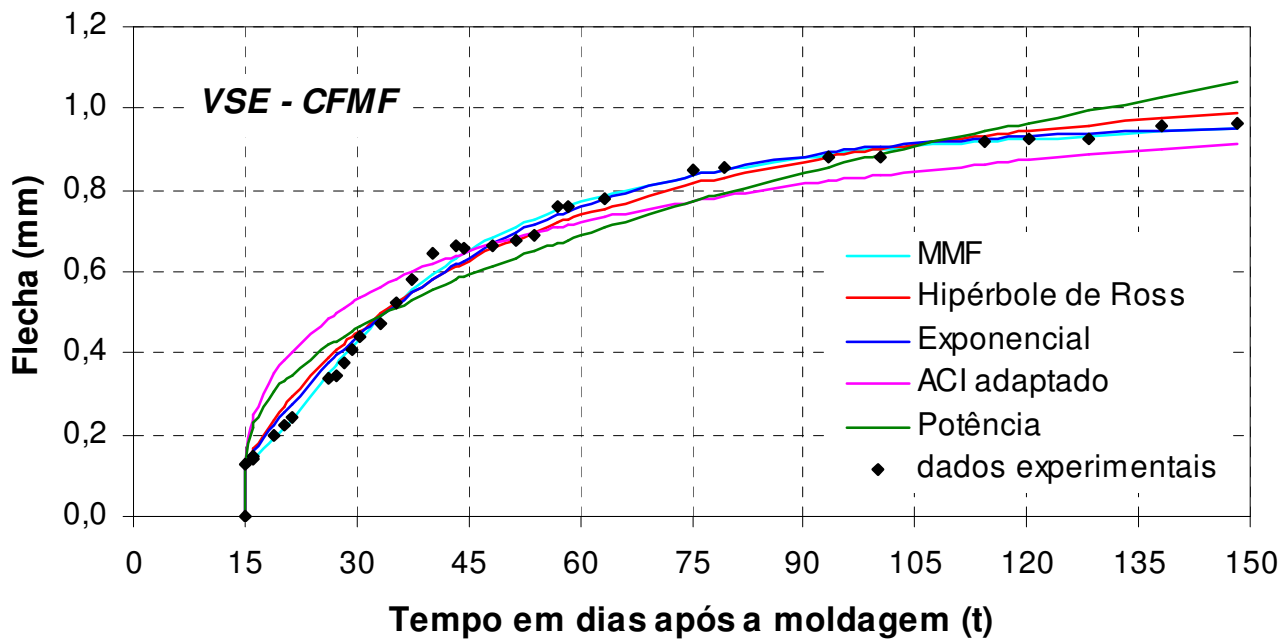

Fig. 8.52: Curvas de tendência VSE-CFMF, Série 2. 


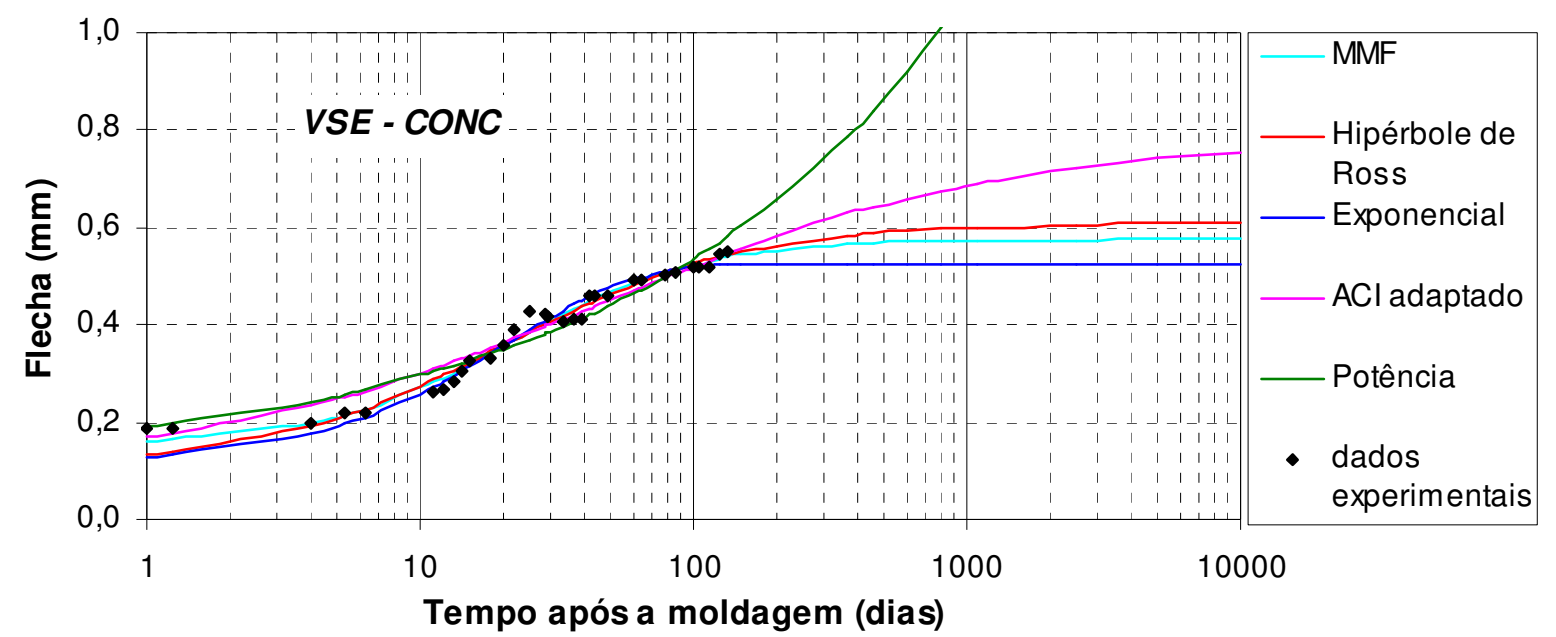

Fig. 8.53: Extrapolação das Curvas de tendência VSE-CONC, Série 2.

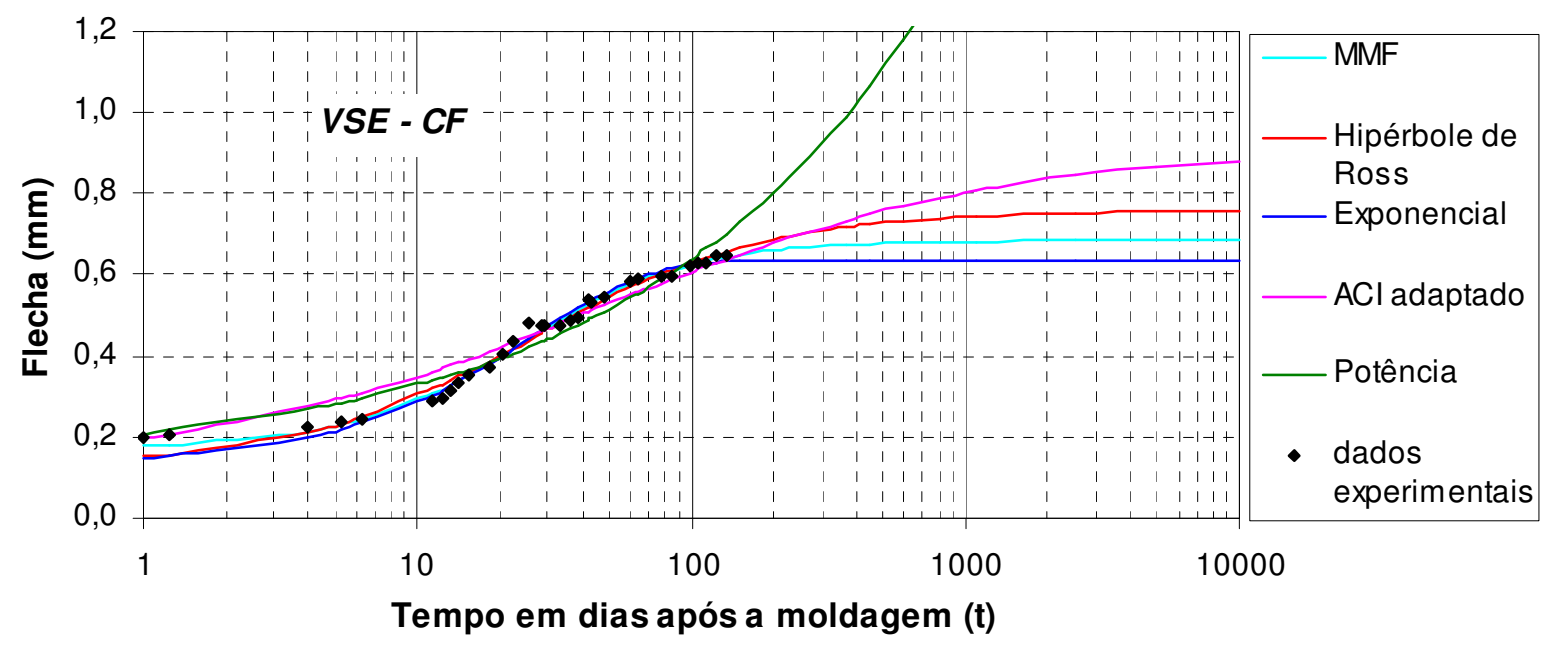

Fig. 8.54: Extrapolação das Curvas de tendência VSE-CF. Série 2.

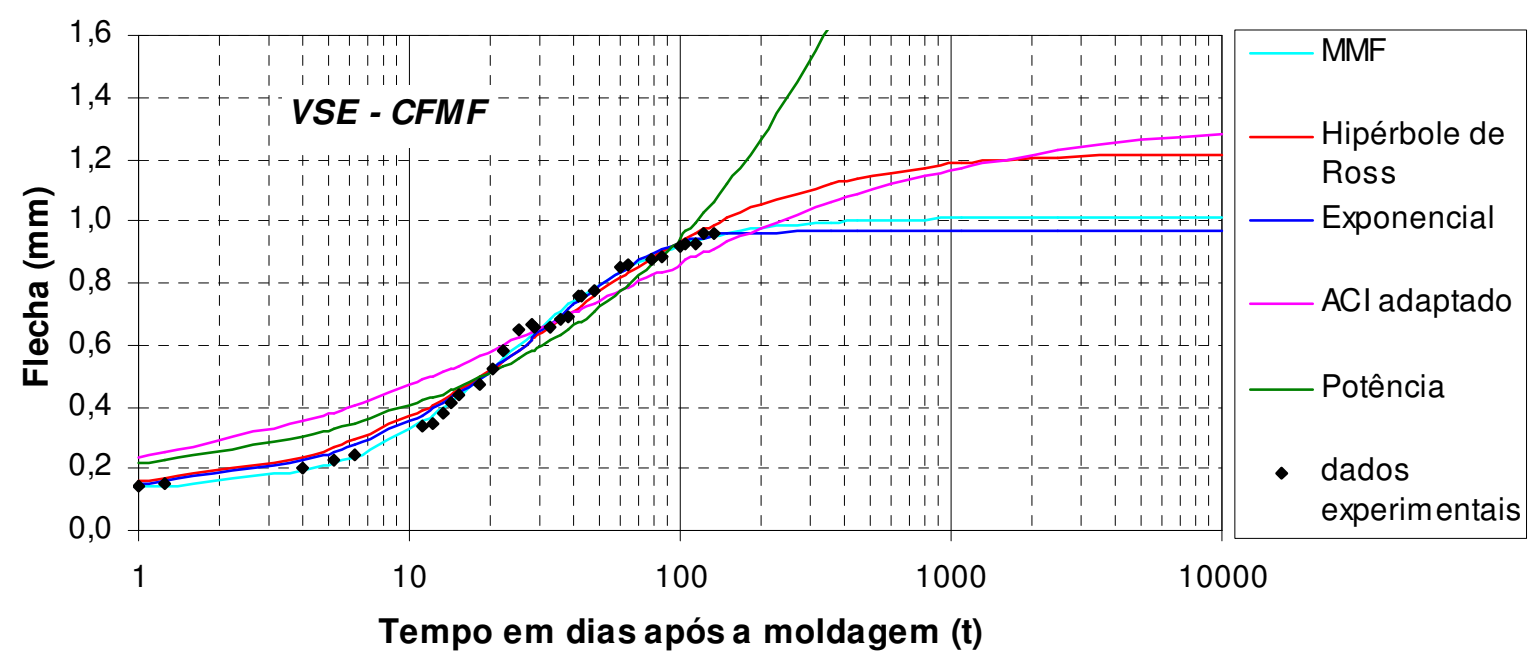

Fig. 8.55: Extrapolação das Curvas de tendência VSE-CFMF, Série 2. 
Conforme se observa na Tabela 8.15 após 1 ano, estariam previstas flechas superiores a 5 vezes a flecha elástica. Desta forma, entende-se que para elementos de concretos não armados, submetidos à flexão, a fluência causar deslocamentos em níveis muito mais críticos do que se possa estimar.

Tabela 8.15: Flechas diferidas e coeficiente de fluência - comparação entre as expressões de ajuste.

\begin{tabular}{|c|c|c|c|c|c|c|}
\hline $\begin{array}{l}\text { Tempo } \\
\text { (dias) }\end{array}$ & $\begin{array}{l}\text { Deslocamento } \\
\text { (flecha) em mm }\end{array}$ & MMF & $\begin{array}{c}\text { Hipérbole } \\
\text { de Ross }\end{array}$ & Exponencial & Potência & $\begin{array}{c}A C l \\
\text { adaptado }\end{array}$ \\
\hline \multicolumn{7}{|c|}{ VSE-CONC } \\
\hline $\mathrm{t}_{0}$ & $\delta_{i}$ & 0,110 & 0,110 & 0,110 & 0,110 & 0,110 \\
\hline \multirow{3}{*}{$\left(\mathrm{t}-\mathrm{t}_{0}\right)=365$} & $\delta\left(\mathrm{t}-\mathrm{t}_{0}\right)$ & 0,565 & 0,583 & 0,523 & 0,788 & 0,628 \\
\hline & $\delta_{c}\left(t-t_{0}\right)$ & 0,455 & 0,473 & 0,413 & 0,678 & 0,518 \\
\hline & $\varnothing\left(t-t_{0}\right)$ & 4,133 & 4,297 & 3,757 & 6,167 & 4,713 \\
\hline \multirow{3}{*}{$\left(t-t_{0}\right)=10000$} & $\delta\left(\mathrm{t}-\mathrm{t}_{0}\right)$ & 0,575 & 0,608 & 0,523 & 2,354 & 0,753 \\
\hline & $\delta_{c}\left(t-t_{0}\right)$ & 0,465 & 0,498 & 0,413 & 2,244 & 0,643 \\
\hline & $\varnothing\left(t-t_{0}\right)$ & 4,231 & 4,528 & 3,757 & 20,396 & 5,848 \\
\hline \multicolumn{7}{|c|}{ VSE-CF } \\
\hline$t_{0}$ & $\delta_{i}$ & 0,128 & 0,128 & 0,128 & 0,128 & 0,128 \\
\hline \multirow{3}{*}{$\left(\mathrm{t}-\mathrm{t}_{0}\right)=365$} & $\delta\left(\mathrm{t}-\mathrm{t}_{0}\right)$ & 0,674 & 0,717 & 0,636 & 0,988 & 0,734 \\
\hline & $\delta_{c}\left(t-t_{0}\right)$ & 0,546 & 0,589 & 0,508 & 0,860 & 0,606 \\
\hline & $\varnothing\left(t-t_{0}\right)$ & 4,265 & 4,605 & 3,969 & 6,717 & 4,732 \\
\hline \multirow{3}{*}{$\left(t-t_{0}\right)=10000$} & $\delta\left(\mathrm{t}-\mathrm{t}_{0}\right)$ & 0,684 & 0,758 & 0,636 & 3,395 & 0,880 \\
\hline & $\delta_{c}\left(t-t_{0}\right)$ & 0,556 & 0,630 & 0,508 & 3,267 & 0,752 \\
\hline & $\varnothing\left(t-t_{0}\right)$ & 4,344 & 4,922 & 3,969 & 25,523 & 5,872 \\
\hline \multicolumn{7}{|c|}{ VSE-CFMF } \\
\hline$t_{0}$ & $\delta_{i}$ & 0,127 & 0,127 & 0,127 & 0,127 & 0,127 \\
\hline \multirow{3}{*}{$\left(\mathrm{t}-\mathrm{t}_{0}\right)=365$} & $\delta\left(\mathrm{t}-\mathrm{t}_{0}\right)$ & 0,996 & 1,121 & 0,965 & 1,635 & 1,059 \\
\hline & $\delta_{c}\left(t-t_{0}\right)$ & 0,869 & 0,994 & 0,838 & 1,508 & 0,932 \\
\hline & $\varnothing\left(t-t_{0}\right)$ & 6,846 & 7,826 & 6,598 & 11,875 & 7,340 \\
\hline \multirow{3}{*}{$\left(\mathrm{t}-\mathrm{t}_{0}\right)=10000$} & $\delta\left(\mathrm{t}-\mathrm{t}_{0}\right)$ & 1,011 & 1,213 & 0,965 & 7,335 & 1,284 \\
\hline & $\delta_{c}\left(t-t_{0}\right)$ & 0,884 & 1,086 & 0,838 & 7,208 & 1,157 \\
\hline & $\varnothing\left(t-t_{0}\right)$ & 6,958 & 8,554 & 6,598 & 56,758 & 9,107 \\
\hline
\end{tabular}




\section{b) Influência das fibras}

Uma avaliação comparativa dos três materiais é feita na Fig. 8.56. Da mesma forma que na série anterior, nota-se que a incorporação das fibras, nos teores utilizados nesta pesquisa, conduziu a deslocamentos superiores àqueles medidos para a matriz.

Mesmo possuindo propriedades mecânicas bastante próximas do concreto de referência na ocasião do carregamento, a viga VSE-CF apresentou flechas cerca de $20 \%$ superiores. Já a adição das microfibras conduziu a um desempenho muito pior, sendo que no término dos ensaios, a flecha medida para este material foi em torno de $80 \%$ superior àquela medida para a matriz.

Na Fig. 8.56 estão plotados os dados experimentais e as curvas de tendência obtidas pelo ajuste da expressão do tipo hipérbole de Ross. As curvas foram extrapoladas para períodos sob carga de até 3 anos. Em destaque estão os valores das flechas totais (elástica inicial e fluência) para as vigas avaliadas em três momentos: ao término das leituras (dados experimental), após 1 ano sob carga (valor estimado) e após 3 anos sob carga (valor estimado).

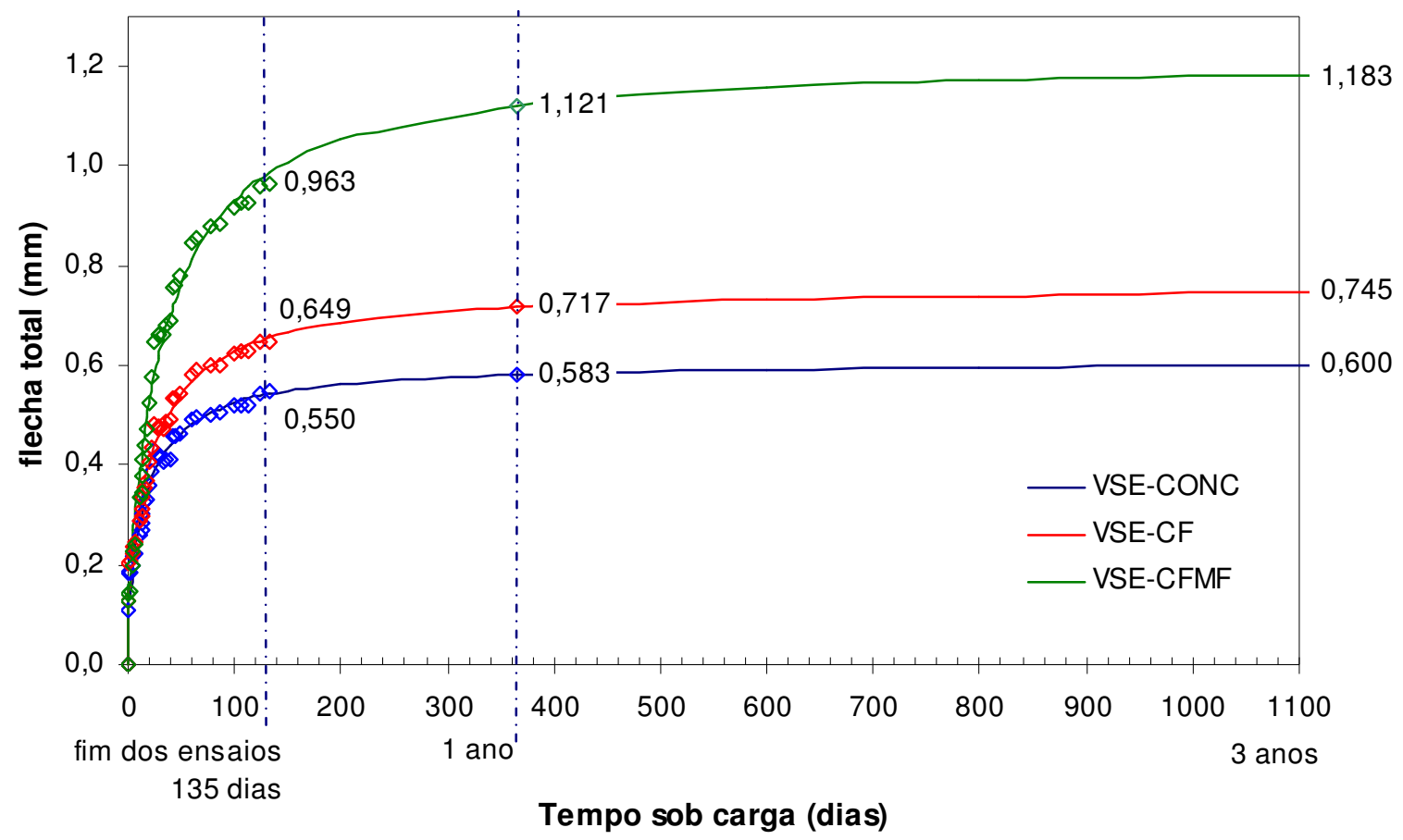

Fig. 8.56: Flechas diferidas - Comparação entre os materiais. 
Nota-se que as curvas apresentam comportamentos próximos, entretanto a taxa inicial de fluência que ocorre para o modelo VSE-CFMF e muito superior aos demais. Os valores considerados últimos segundo estas curvas de tendência representariam acréscimos de 26,8\%, $17,4 \%$ e $11 \%$ nos valores estimados após um ano de carga mantida.

Conforme já discutido para a Série 1, acredita-se que o comportamento dos materiais compósitos esteja vinculado ao aumento da porosidade na matriz, decorrente de uma maior quantidade de ar aprisionado; assim como às propriedades da região de interface entre as fibras e a matriz, na qual pode se originar boa parte da fluência.

\section{c) Comparações entre curvas numéricas, teóricas e experimentais.}

Neste item a curva de tendência da viga VSE-CONC, é comparada com as curvas obtidas por expressões normativas e também com a curva proveniente da simulação numérica efetuada no DIANA ${ }^{\circledR}$. Apesar de os prodecimentos para a obtenção das curvas teóricas serem análogos ao que já foi apresentado para a Série 1, convém repeti-los aqui.

- $\quad N B R 1$

A construção desta curva foi realizada empregando as expressões apresentadas no Capítulo 5 (item 5.2.1). Para tanto foram utilizados: tempo $t_{0}$ igual à idade de aplicação do carregamento (14 dias), tempo $t_{n}$ variável e taxa de armadura igual a zero.

Para determinação da flecha elástica inicial foram utilizados: o valor de $E_{c, N B R}\left(t_{0}\right)$ da Tabela 5.8, a expressão 5.24, para o cálculo da flecha devida ao peso próprio $\left(\delta_{p p}\right)$ e a expressão 5.25, para o cálculo da flecha devida à carga concentrada. Os demais dados necessários para estes cálculos são:

- B: 0,15 m (largura da viga);

- $\mathrm{W}: 0,30 \mathrm{~m}$ (altura da viga);

- $\quad$ S: 2,1m (vão livre entre apoios);

- g: $9,81 \mathrm{~m} / \mathrm{s}^{2}$ (aceleração da gravidade);

- $\quad \gamma: 2491,6 \mathrm{~kg} / \mathrm{m}^{3}$ (densidade, ver Tabela 8.9);

- PM: 4,87 kN (peso morto de $487 \mathrm{~kg}$ aplicado no meio do vão). 
- $\quad N B R 2$

A curva NBR2 foi construída considerando-se que em um tempo $t$, posterior à aplicação do carregamento, a flecha diferida $\delta\left(t, t_{0}\right)$ pode ser obtida multiplicando-se a flecha elástica inicial $\delta_{i}\left(t_{0}\right)$ por $\left(1+\phi\left(t, t_{0}\right)\right)$, sendo $\phi\left(t, t_{0}\right)$ o coeficiente de fluência calculado a partir do método preciso para previsão da fluência (ver Capítulo 5, item 5.1.1.2). A flecha elástica inicial utilizada foi a mesma calculada para a curva anterior. Os dados de entrada empregados no modelo de fluência estão apresentados na Tabela 5.6.

- $A C I$

A curva denominada $A C I$ foi determinada de forma análoga à curva $N B R 2$, entretanto o coeficiente de fluência foi estimado aplicando os dados dos ensaios às expressões de previsão do ACI 209:1992 (conforme apresentado no item 5.1.2.1 do Capítulo 5). Os dados de entrada do modelo constam na Tabela 5.6. A flecha elástica inicial foi calculada conforme descrito anteriormente, sendo utilizado o valor de $E_{c, A C I}\left(t_{0}\right)$, apresentado na Tabela 5.8.

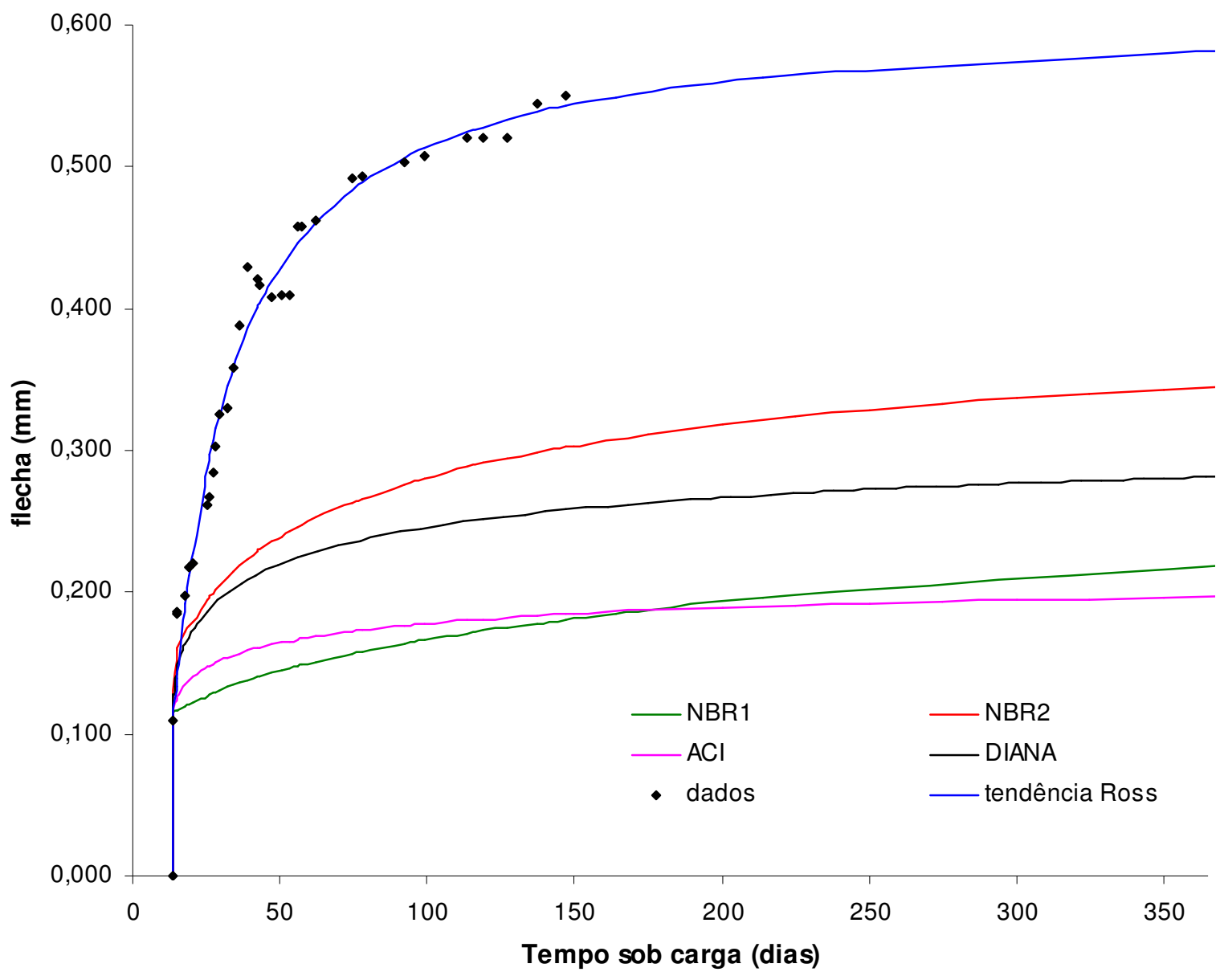

Fig. 8.57: VSE-CONC Serie 2. Comparações normativas. 
A curva denominada DIANA refere-se à curva proveniente da simulação numérica. Neste caso os dados de entrada (em essência os mesmos utilizados para a curva $A C I$ ) estão apresentados na Tabela 6.1, na ocasião em que foi descrito os procedimentos da simulação.

A partir da Fig. 8.57 nota-se que, para esta série de ensaios houve maior discrepância entre a curva experimental e as curvas teóricas, do que o observado para a série anterior. Em partes isto pode estar relacionado à data em que foi aplicada a carga, o que indica que os modelos de fluência utilizados possam ter alguma deficiência ao considerar o carregamento em idade inferior aos 28 dias.

A curva teórica $N B R 2$ é aquela que mais se aproxima da curva de tendência experimental, entretanto, a diferença entre elas permanece em torno de 40\% (ver Tabela 8.15). Já a curva $A C I$ apresentou valores muito abaixo da curva de tendência, sendo que ao término das leituras, a diferença foi de $66 \%$, tão ruim quanto à previsão pela curva $N B R 1$.

Conforme já comentado anteriormente, as expressões utilizadas para a obtenção da curva NBRl são extremamente pobres, no que diz respeito à caracterização da fluência, já que não levam em conta praticamente nenhum dos fatores intervenientes do fenômeno. Mas, de acordo com a Fig. 8.57, esta aproximação forneceu resultados próximos daqueles obtidos pelo modelo de fluência da norma americana (curva $A C I$ ), o que reforça a afirmação de que nem sempre o modelo mais complexo produz valores mais confiáveis.

Como já comentado no Capítulo 5 (ver Fig. 5.12) o modelo de fluência do ACI é menos sensível à variação da idade de carregamento do que o modelo de fluência da NBR. Isto se deve às diferentes expressões que caracterizam a evolução da resistência do concreto, fornecidas pelos dois modelos e também à consideração de parcela de fluência rápida pelo modelo da NBR.

Além da idade de carregamento há outros fatores que justificam as diferenças observadas, como por exemplo: o tipo de solicitação, o nível de carregamento e as características dos componentes do concreto.

Ainda que a norma brasileira permita a aplicação do modelo de fluência para tensões de tração, sabe-se que a grande maioria dos dados experimentais utilizados na calibração dos modelos normativos refere-se à fluência a compressão.

Com relação ao nível de carregamento tem-se a possibilidade de fissuração. Quando comparados os valores do momento de fissuração $M_{r}$ com o momento máximo, para cada viga, tem-se que teoricamente, não haveria fissuração (ver Tabela B.1 do Apêndice B). 
Apesar disso, para tensões máximas de tração em torno de $60 \%$ do valor resistente (portanto, acima do limite de linearidade considerado de 50\%), associadas às condições de exposição do concreto, imagina-se que possa ter ocorrido um processo de microfissuração no banzo tracionado, provocando perda de rigidez. Conseqüentemente, deslocamentos devidos à fissuração se somaram aqueles decorrentes da fluência, o que de certa forma pode ter mascarado os resultados (já que os incrementos na flecha elástica ao longo do tempo foram atribuídos apenas à fluência).

Outra hipótese para justificar a discrepância entre as curvas teóricas e experimentais consiste na desatualização dos modelos de fluência vinculada à evolução na composição do cimento atual quando comparado com cimentos produzidos em décadas anteriores.

Os cimentos produzidos hoje são muito mais finos e estabilizam as reações de hidratação mais rapidamente. Sendo assim, após 28 dias as variações na resistência do concreto feito com o cimento atual são menores do que aquelas que eram observadas para o concreto produzido com os cimentos antigos, conforme está representado na Fig. 8.58 (FIGUEIREDO 2004 apud SAMPAIO 2004).

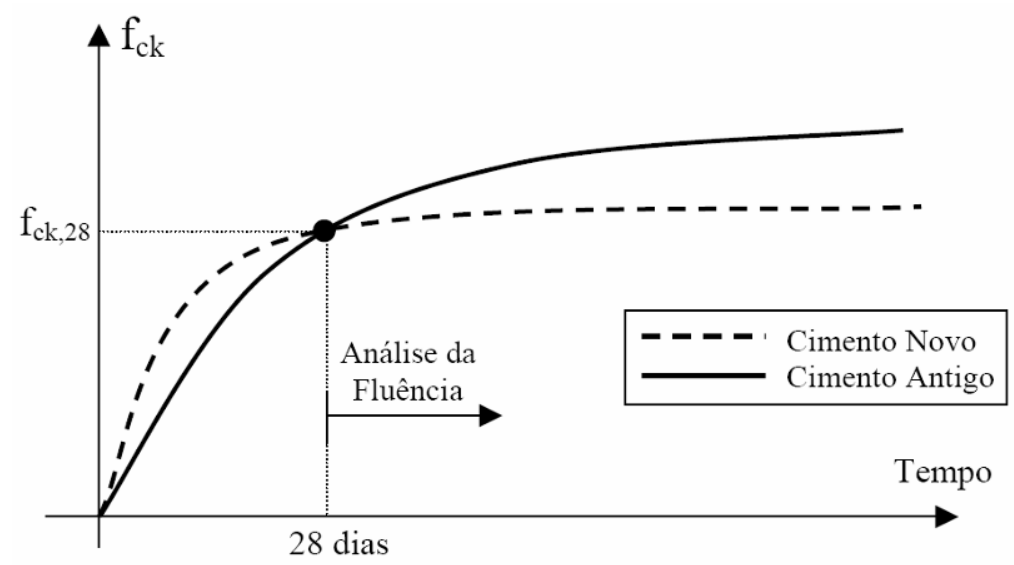

Fig. 8.58: Evolução da resistência à compressão obtida a partir de concretos produzidos a partir de cimentos novos e antigos. Fonte: Figueiredo A. D. (2004) apud Sampaio, C. D. C. (2004).

Ou seja, ao considerar que os modelos normativos utilizados ainda hoje, foram calibrados a partir de dados experimentais oriundos de concretos produzidos com cimentos antigos, é razoável que os deslocamentos e deformações de ensaios de fluência atuais sejam maiores do que os valores fornecidos por esses modelos de previsão.

Com relação à curva numérica, esta apresentou deslocamentos menores do que a curva NBR2, mesmo considerando que na simulação o teor de ar incorporado utilizado é de $6 \%$, independentemente do valor correto estipulado pelo usuário (mais detalhes constam no 
Capítulo 6). Além disso, como já comentado anteriormente para a Série 1 (página 221), a aplicação do carregamento foi feita de forma incremental, o que provoca uma acumulação de resíduos em deslocamentos, e conseqüentemente proporciona um maior valor para a flecha “elástica inicial”.

Ao reconstruir a curva $A C I$, agora utilizando um teor de ar incorporado de $6 \%$ e a flecha inicial extraída da simulação, tem-se praticamente a sobreposição desta (denominada ACI 6\%) com a curva fornecida pela simulação (Fig. 8.59). De certa forma isto demonstra, novamente, a falta de confiabilidade nos resultados da simulação e dispensa maiores comentários sobre a curva numérica. Um resumo comparativo entre os valores fornecidos pelas curvas comentadas neste item é apresentado na Tabela 8.16.

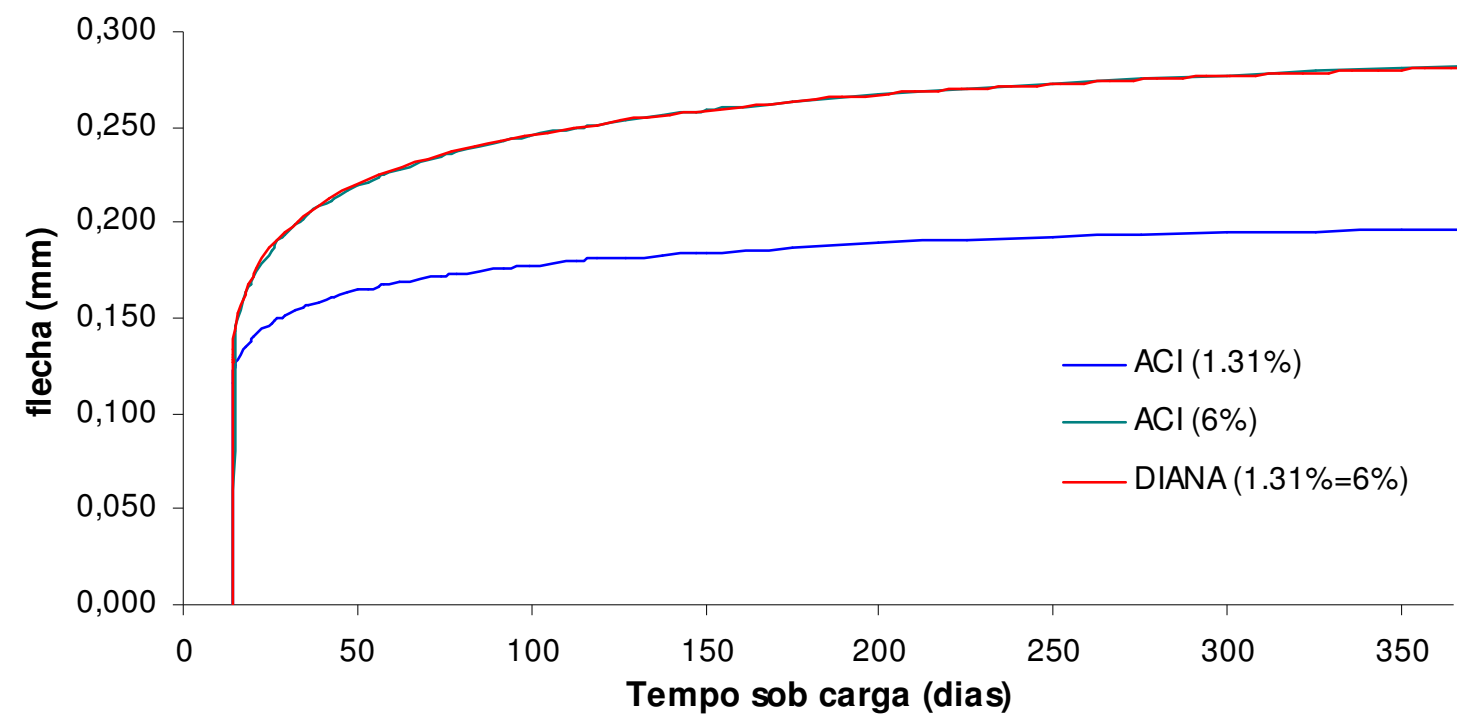

Fig. 8.59: Flechas diferidas: Curva numérica (DIANA) e curva ACI modificada.

Tabela 8.16: Valores comparativos das Flechas - Série 2.

\begin{tabular}{|c|c|c|c|c|c|c|}
\hline $\begin{array}{l}\text { Tempo } \\
\text { (dias) }\end{array}$ & $\begin{array}{l}\text { Deslocamento } \\
\text { (flecha) em } \mathrm{mm}\end{array}$ & $\begin{array}{l}\text { Hipérbole } \\
\text { Ross }\end{array}$ & NBR1 & NBR2 & $\mathrm{ACl}$ & DIANA \\
\hline \multicolumn{7}{|c|}{ VSE-CONC } \\
\hline$t_{0}$ & $\delta_{i}$ & 0,110 & 0,115 & 0,115 & 0,116 & 0,127 \\
\hline \multirow{3}{*}{$\left(\mathrm{t}-\mathrm{t}_{0}\right)=40$} & $\delta\left(\mathrm{t}-\mathrm{t}_{0}\right)$ & 0,543 & 0,181 & 0,302 & 0,184 & 0,258 \\
\hline & $\delta_{c}\left(t-t_{0}\right)$ & 0,433 & 0,066 & 0,188 & 0,068 & 0,131 \\
\hline & $\varnothing\left(\mathrm{t}-\mathrm{t}_{0}\right)$ & 3,935 & 0,578 & 1,640 & 0,591 & 1,037 \\
\hline \multicolumn{3}{|c|}{ diferença com relação à tendência } & $67 \%$ & $44 \%$ & $66 \%$ & $52 \%$ \\
\hline \multirow{3}{*}{$\left(t-t_{0}\right)=365$} & $\delta\left(\mathrm{t}-\mathrm{t}_{0}\right)$ & 0,583 & 0,220 & 0,345 & 0,197 & 0,282 \\
\hline & $\delta_{c}\left(t-t_{0}\right)$ & 0,473 & 0,106 & 0,230 & 0,081 & 0,155 \\
\hline & $\varnothing\left(\mathrm{t}-\mathrm{t}_{0}\right)$ & 4,297 & 0,924 & 2,012 & 0,700 & 1,224 \\
\hline \multicolumn{3}{|c|}{ diferença com relação à tendência } & $62 \%$ & $41 \%$ & $66 \%$ & $52 \%$ \\
\hline
\end{tabular}




\subsection{Resultados em termos de deformações}

Aqui os resultados obtidos em deslocamentos são transformados em deformações da mesma maneira que descrita anteriormente (página 264). Por esta transformação pode-se comparar a curva da viga de concreto com as previsões do ACI 209:1982 e da NBR 6118:2003, conforme é ilustrado na Fig. 8.60.

Para tanto foram utilizadas as funções fluência definidas no Capítulo 5 (expressões 5.2 e 5.19). Ressalta-se que aqui, para a construção das curvas $J\left(t, t_{0}\right)$-tempo, foi utilizado o módulo de elasticidade experimental aos vinte oito dias como parâmetro de entrada para o cálculo do módulo de elasticidade na idade de carregamento (ver Tabela 5.8). Conhecido o valor da tensão máxima de tração decorrente do carregamento em $t_{0}$, e os valores de $\mathrm{J}\left(\mathrm{t}, \mathrm{t}_{0}\right)$ mo tempo, as curvas teóricas da deformação no tempo $\left(\varepsilon_{c, \text { total }}-\right.$ tempo $)$ são facilmente obtidas pela expressão a seguir, sendo que o índice total na deformação indica que esta refere-se à deformação elástica inicial somada à deformação por fluência:

$$
\mathcal{E}_{c, \text { total }}\left(t, t_{0}\right)=\sigma_{\text {máx }}\left(t_{0}\right) \cdot J\left(t, t_{0}\right) \rightarrow \mathcal{E}_{c, \text { total }}(t, 14)=1.4 \cdot J(t, 14)
$$

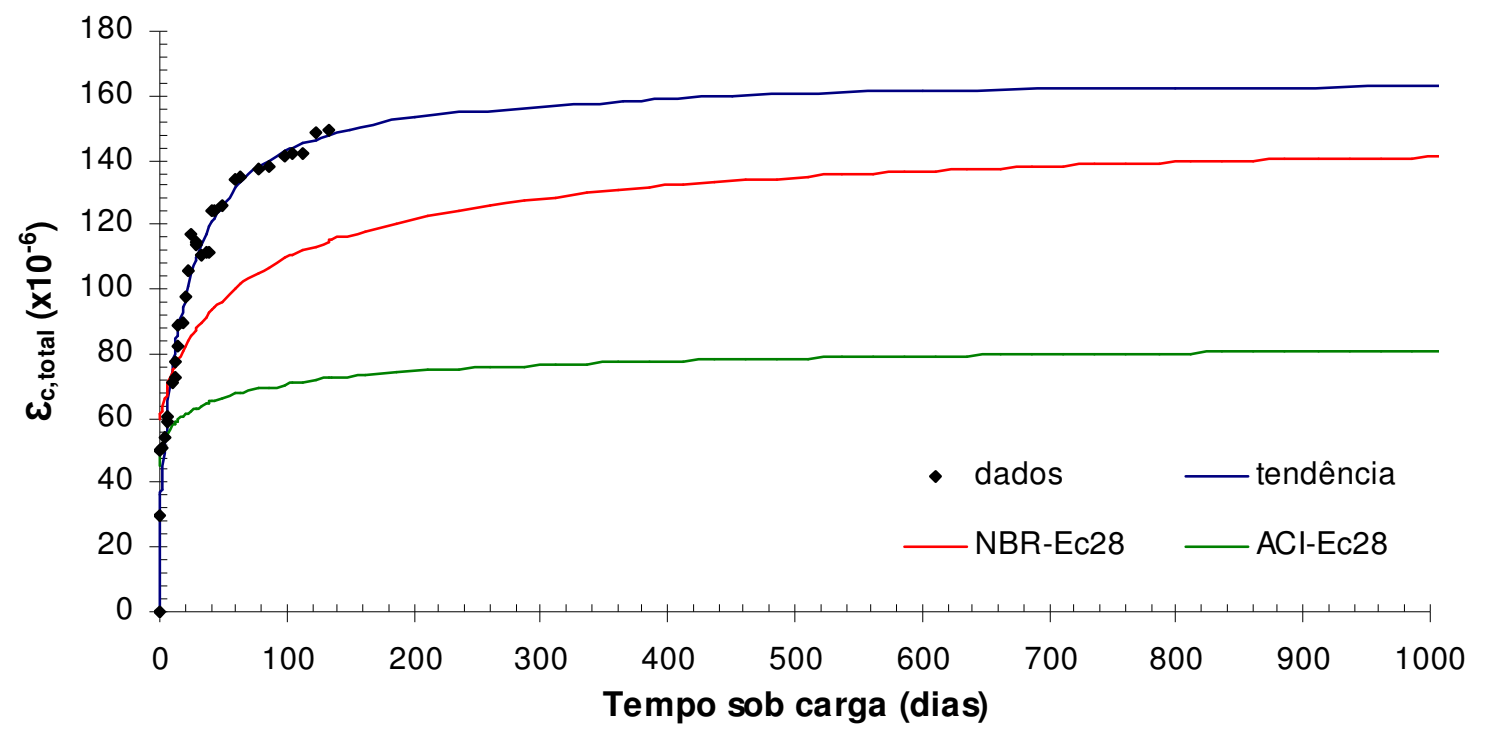

Fig. 8.60: Deformações por fluência Série 1 - VSE-CONC.

Através da Fig. 8.60 nota-se que, para esta série, ambas as normas americana e brasileira subestimaram as deformações. Contudo a norma brasileira foi a que mais se aproximou da curva experimental (no caso representado pela linha de tendência oriunda da expressão hiperbólica de Ross). A diferença mais significativa entre estas curvas situa-se nos primeiros meses após a aplicação do carregamento. 
Possivelmente isto reflita uma pior aproximação do modelo da NBR para idades de carregamento inferiores a 28 dias. Além disso, deve-se considerar que a relação entre a tensão aplicada e a tensão resistente na data de carregamento foi superior ao valor máximo recomendado pela norma (igual a 0,5). Desta forma, pode ter ocorrido um processo de microfissuração que "mascarou" a taxa de fluência. Após o término dos ensaios, a estimativa da NBR forneceu valores cerca de $20 \%$ menores do que os dados do ensaio, entretanto, de acordo com a Fig. 8.60 essa diferença tende a diminuir, chegando a valer em torno de $10 \%$ para o valor último de deformação (após 10000 dias).

Conforme já comentado anteriormente o tipo de solicitação e diferenças nos materiais empregados na confecção do concreto são fatores que interferem na distância das curvas teóricas e experimental.

Já a curva de previsão do ACI situou-se muito abaixo das demais, sendo que, em média os valores foram aproximadamente $50 \%$ menores do que aqueles da curva experimental. Nota-se também que a curva $A C I$ estabiliza-se muito rapidamente. A taxa de fluência durante os primeiros 100 dias é muito mais baixa e após esta data, o modelo apresenta valores praticamente constantes para as deformações.

Como já comentado para a série anterior, em partes as discrepâncias entre as curvas em temos das deformações ocorrem por conta da precisão com que os modelos prevêem o módulo de elasticidade na idade de carregamento, uma vez que deste valor depende diretamente o cálculo da deformação elástica inicial. No caso desta série, conforme se observa na Tabela 8.17, as duas normas forneceram valores para $E_{c}\left(t_{0}\right)$ muito próximos do valor experimental. Nesta tabela também é apresentado o módulo experimental aos 28 dias, o qual foi utilizado para valor de referência.

Tabela 8.17: Previsão do módulo de elasticidade.

\begin{tabular}{cccc}
\hline $\boldsymbol{E}_{c, \text { exp. }}(\mathbf{1 4})$ & $\boldsymbol{E}_{c, \exp }(\mathbf{2 8})$ & $\boldsymbol{E}_{c, \text { NBR }}(\mathbf{1 4})$ & $\boldsymbol{E}_{c, A C l}(\mathbf{1 4})$ \\
31532 & 32838 & 31181 & 30814 \\
Diferença relativa ao $\mathrm{E}_{c, \exp }(14)$ & $5 \%$ & $\mathbf{6 \%}$ \\
\hline
\end{tabular}

Uma forma bastante comum de se apresentar o fenômeno da fluência consiste em representar graficamente a fluência específica ao longo do tempo. A obtenção da curva $C\left(t, t_{0}\right)$-tempo a partir dos dados experimentais reduz-se a determinar a deformação por fluência em um tempo $t$ e dividi-la pela tensão aplicada, que neste caso vale 1,4 MPa. 
De acordo com a Fig. 8.61 nota-se que ao avaliar a fluência específica tem-se uma aproximação das curvas teórica e um maior distanciamento destas frente à curva experimental. Pode-se dizer que isto reflete o fato da taxa de fluência experimental ser muito superior àquela estimada pelas normas. Possivelmente o acréscimo desta taxa seja devido a fatores já discutidos como: a má representatividade dos modelos para idades de carregamento inferiores à 28 dias, microfissuração devida ao nível de carga aplicado, evolução dos materiais e tipo de solicitação. De acordo com a literatura (ver item 4.3), na tração a fluência apresenta taxa inicial superior do que na compressão e se estabiliza mais rapidamente.

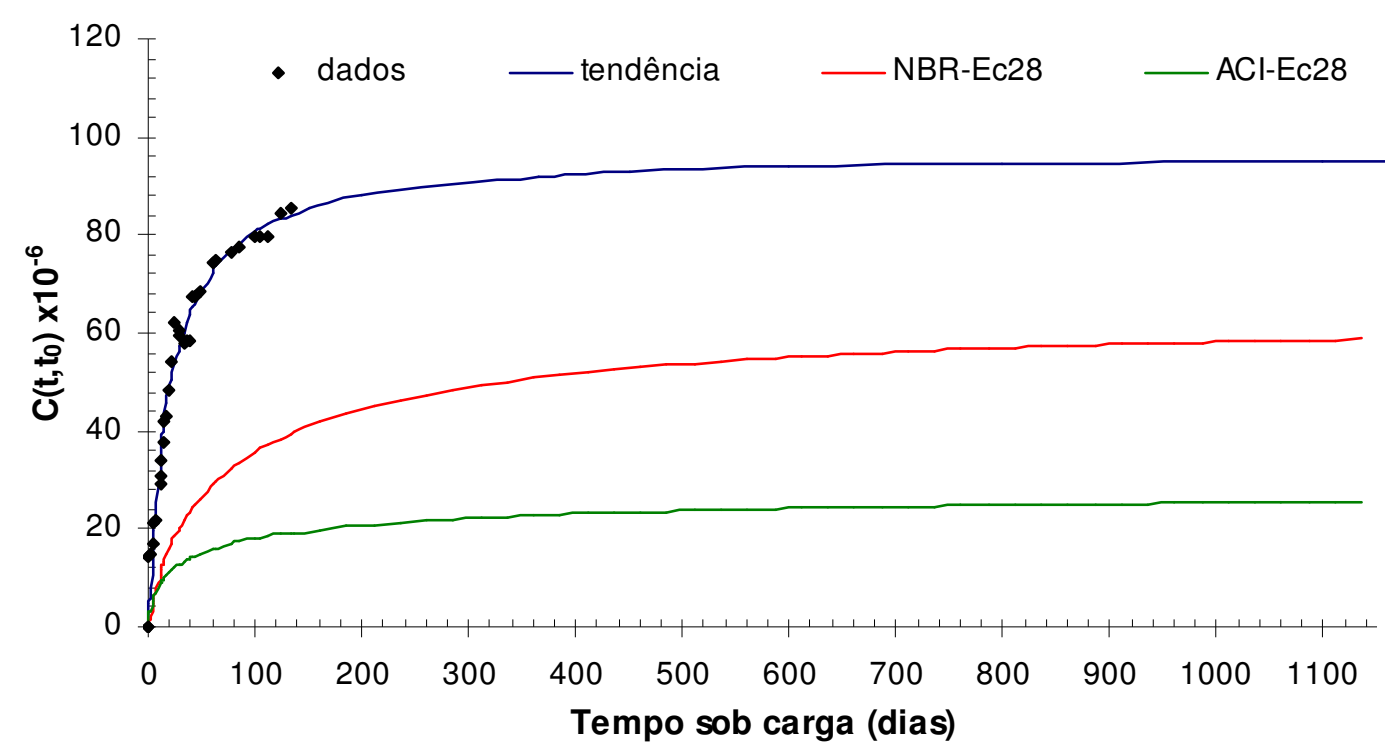

Fig. 8.61: Fluência específica Série 1 - VSE-CONC.

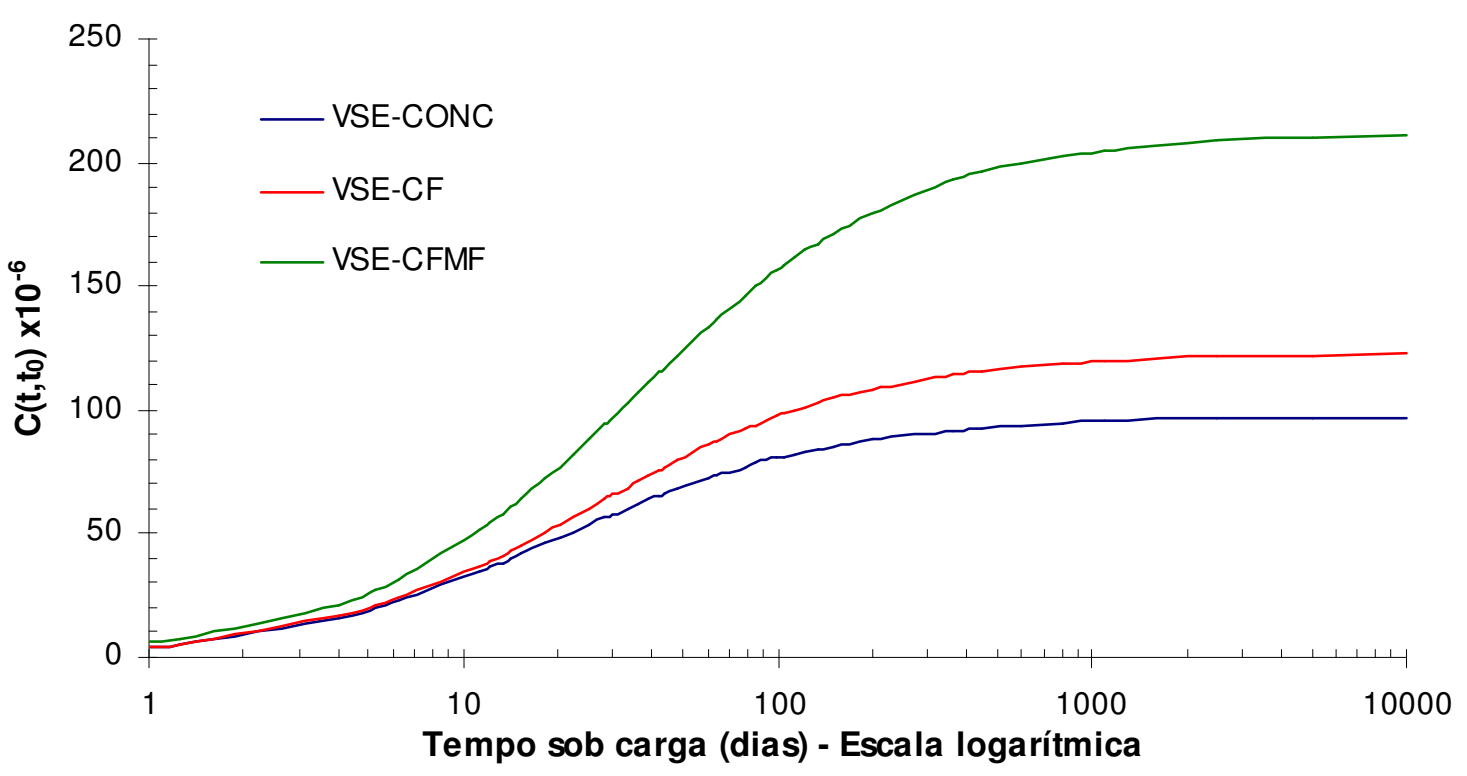

Fig. 8.62: Curvas $\mathrm{C}(\mathrm{t}, \mathrm{t} 0)$-tempo para os três materiais avaliados (Série 2). 
As curvas de fluência específicas também são úteis para comparar o comportamento dos materiais avaliados. Através da Fig. 8.62 nota-se que a diferença entre os materiais tornase evidente após uma semana sob carga. As diferenças entre as vigas VSE-CONC e VSE-CF são pequenas, sendo que após o término dos ensaios a incorporação das fibras levou a fluência específica $20 \%$ menor. Contudo, a viga moldada com concreto reforçado com fibras e microfibras apresentou o dobro da fluência específica encontrada para a viga VSE-CONC. Posteriormente este gráfico também será útil para avaliação qualitativa da fluência entre as duas séries de ensaios.

\subsubsection{Vigas Entalhadas}

Os resultados das flechas diferidas para as vigas entalhadas estão apresentados na Fig. 8.63. Das seis vigas avaliadas quatro delas (VE-CONC1, VE-CF1, VE-CF2, VE-CFMF2) apresentaram o mesmo comportamento que foi observado de forma unânime para as vigas entalhadas da série anterior, ou seja, houve "redução dos deslocamentos" ao longo do tempo.

A viga VE-CFMF1 demonstrou acréscimos na flecha inicial durante os primeiros 20 dias, sendo que a partir daí suas leituras tenderam à estabilização seguida de uma redução dos valores. O último modelo a ser comentado, VE-CONC2, foi a única dentre todas as vigas ensaiadas nas duas séries que apresentou um comportamento mais próximo do esperado. Os deslocamentos deste modelo aumentaram com o tempo, entretanto a estabilização foi rápida: praticamente após 45 dias de ensaio não se observou variações significativas nas leituras.

Uma vez que a ordem de grandeza das leituras continuou, a mesma não foi possível escapar completamente da interferência dos fatores ambientais como umidade relativa e temperatura do ambiente. Entretanto, por conta da menor idade de carregamento, maiores níveis de tensão e não exposição à pré-secagem, houve a possibilidade de realizar uma breve, porém proveitosa, discussão sobre o comportamento das vigas VE-CONC2 e VE-CFMF1.

Observando com maior atenção os pontos de leitura da viga VE-CONC2 (Fig. 8.63) nota-se que algumas variações bruscas ocorreram. Os deslocamentos crescem durante os primeiros 18 dias, depois parece haver um "patamar", no qual as leituras se mantiveram durante 10 dias, e então houve um salto. Isto possivelmente é decorrência de algum atrito interno nos mecanismos do relógio comparador de funcionamento mecânico, e não comprometeu os resultados, uma vez que os ajustes foram feitos a partir de alguns pontos deste conjunto, denominados aqui de pontos de interesse. 


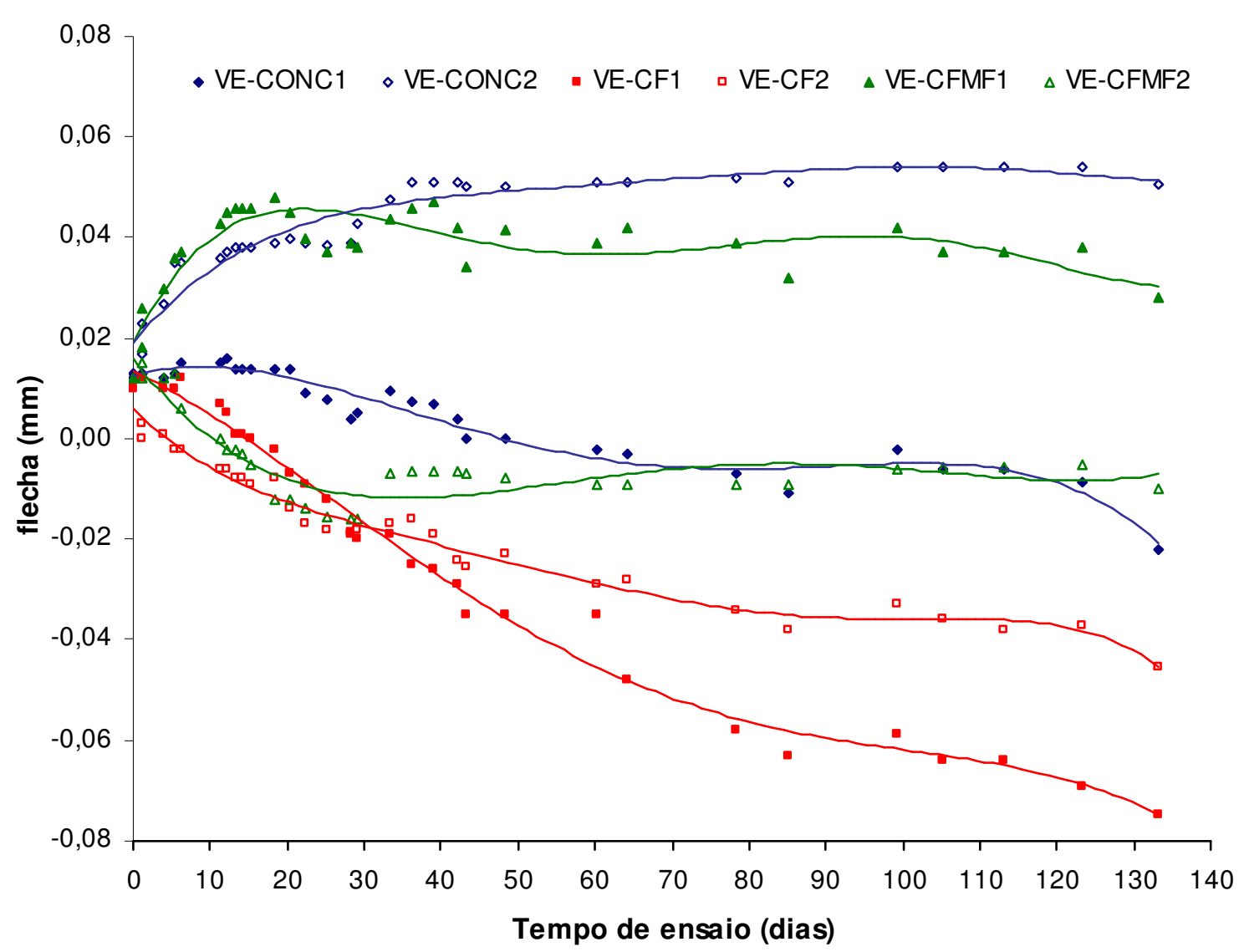

Fig. 8.63: Flecha Inicial - Vigas entalhadas (Série 2). Linhas de tendência obtidas por ajuste dos dados experimentais a funções polinomiais completas de ordem 4 e 5 .

Além da viga VE-CONC2 foi também obtida a curva $C\left(t, t_{0}\right)$-tempo para a viga VECFMF1. Entretanto, para este modelo, infelizmente teve-se que considerar apenas os dados das leituras até o décimo oitavo dia de ensaio. Certamente isto contribui para maior incerteza quanto à extrapolação da curva de tendência do modelo, porém a análise ainda assim é útil.

Repetindo a mesma seqüência efetuada para as vigas não entalhadas, os valores das flechas foram convertidos em deformações e estas foram transformadas em fluência específica. Esta última passagem baseia-se em dividir a deformação por fluência pela tensão aplicada. Já as deformações por fluência são obtidas subtraindo-se da deformação total (oriunda da flecha diferida em um instante $t$ ) a deformação elástica inicial (decorrente da flecha elástica inicial, no instante $t_{0}$ de aplicação do carregamento).

Como se trata de vigas entalhadas, a transformação dos deslocamentos em deformações não foi feita da mesma forma que a descrita anteriormente (página 225). Neste caso, faz-se necessário utilizar uma formulação específica da Mecânica da Fratura, a qual é apresentada a seguir (página 271). 
Conforme já foi comentado no Capítulo 7, foram utilizados dois dispositivos para medição do CMOD. Da mesma forma que para a Série 1, o objetivo de realizar estas leituras foi acompanhar um possível processo de fissuração. Caso, os valores de CMOD medidos fossem superiores à estimativa oriunda da simulação numérica, não seria possível atribuir os acréscimos de $\delta$ à fluência, o que comprometeria a análise, pois neste caso parte dos acréscimos na flecha seria decorrente da fissuração.

Entretanto, de acordo com as figuras 8.65 e 8.66 verifica-se que independentemente do dispositivo empregado (clip-on-gauge ou Tenso-Tast) os resultados indicam uma diminuição do CMOD no tempo.

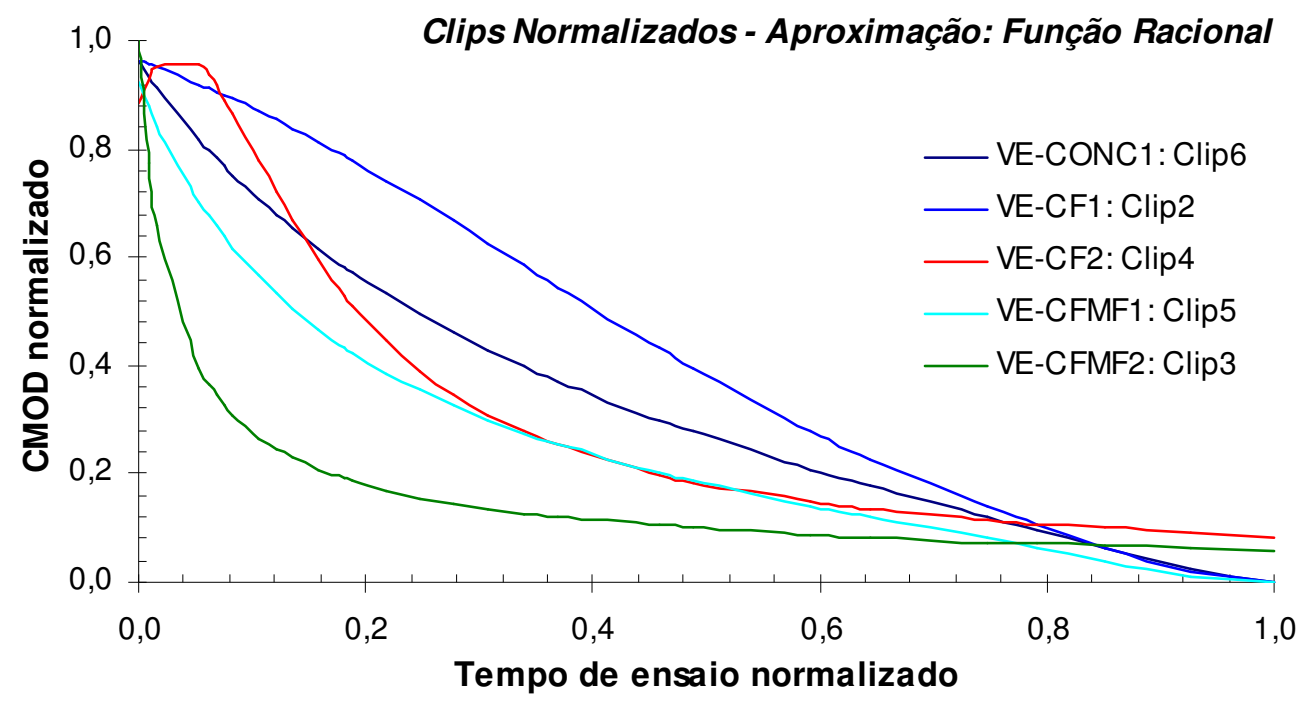

Fig. 8.64: Curvas CMOD-tempo normalizados para leituras obtidas com Clips.

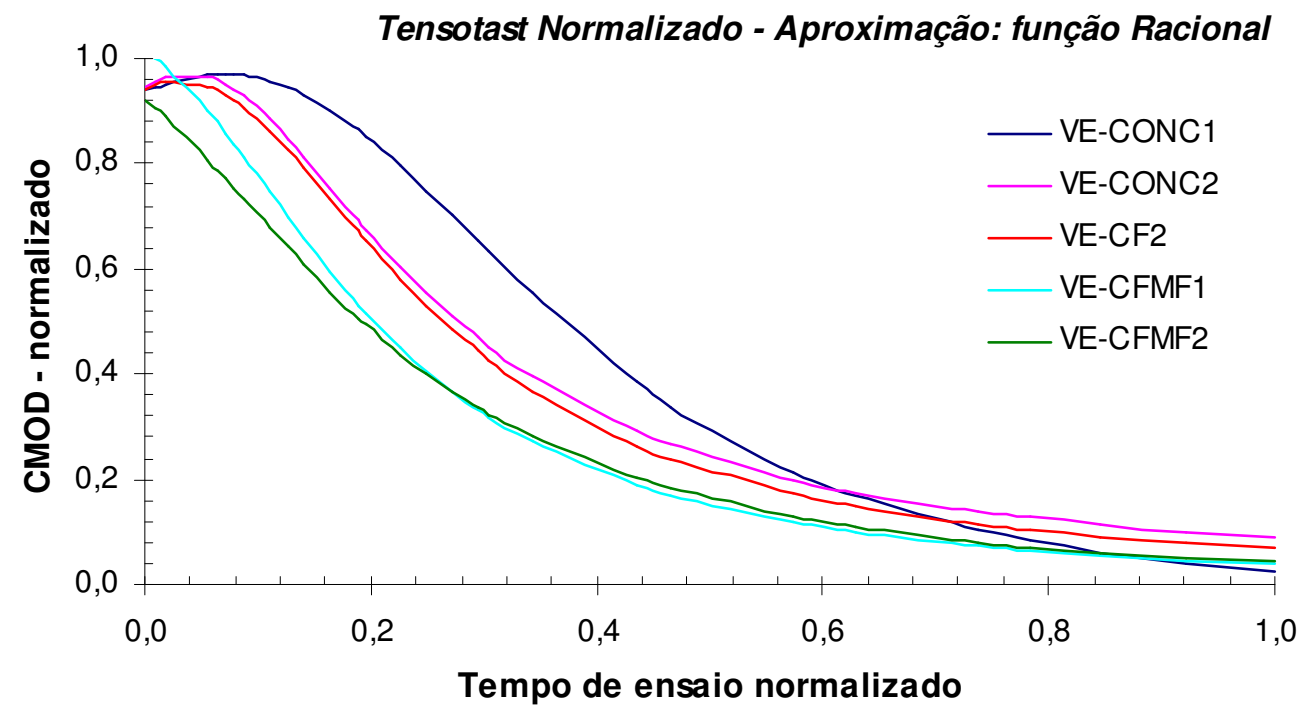

Fig. 8.65: Curvas CMOD-tempo normalizadas para as leituras obtidas com Tenso-Tast. 
A Fig. 8.64 mostra a evolução do CMOD ao longo dos ensaios, em curvas normalizadas. Nota-se que apesar de todos os cuidados na construção dos novos dispositivos, houve ainda leituras bastante discrepantes. Contudo, os resultados foram qualitativamente satisfatórios, pois indicam claramente uma tendência.

Após alguns testes efetuados com os clips, chegou-se à conclusão de que o problema não seria construtivo, nem de calibração, mas sim, estaria vinculado aos materiais utilizados em sua fabricação, principalmente a lâmina de aço-mola. Ressalta-se, todavia, que isto só se torna um problema frente à ordem de grandeza das leituras requeridas e também à natureza do ensaio de longa duração. Ou seja, se os mesmos clips fossem utilizados para medir deslocamentos de ensaios estáticos “convencionais", não haveria problema (o que de certa foi comprovado no item 7.6.4).

Os resultados obtidos com a utilização do Tenso-Tast estão apresentados na Fig. 8.65. Observa-se o mesmo comportamento encontrado com a utilização dos clips, ou seja, a redução da abertura do entalhe ao longo do tempo. As variações nestas leituras refletem dificuldades operacionais na utilização deste dispositivo, comentadas no Capítulo anterior.

Para a construção das curvas representadas nas figuras acima, os valores dos deslocamentos medidos experimentalmente foram normalizados, com relação ao maior valor encontrado durante todo intervalo de avaliação, sendo normalizado também o tempo. Em seguida buscou-se ajustar uma expressão que representasse bem os dados normalizados de cada viga. Desta forma, os dados normalizados foram ajustados à expressão do tipo Racional (dada pela divisão de um polinômio de primeiro grau por outro de segundo grau). Informações sobre os coeficientes encontrados, a precisão dos ajustes e os dados "brutos" dos ensaios constam no Apêndice $\mathrm{C}$.

De acordo com a simulação para avaliar a influência da temperatura, comentada no item 8.1.3.2, uma elevação da temperatura (que implica na dilatação da viga), incorre em redução da flecha e aumento do CMOD. Considerando as vigas em que houve redução da flecha, a redução do CMOD não faria sentido, levando-se em conta apenas a temperatura.

Na utilização dos clips houve erros na instrumentação, ao passo que com o Tenso-Tast têm-se erros vinculados à falta de precisão, decorrente de dificuldades em manipular o dispositivo. Contudo, mesmo considerando estes erros, não se sabe ao certo o motivo da tendência observada. $\mathrm{O}$ importante é que, certamente, não houve propagação de fissura, em nenhum modelo. 


\subsection{Determinação das deformações (Vigas VE-CONC2 e VE-CFMF1)}

Toda a dedução que será demonstrada a seguir é atribuída a Ferreira ${ }^{24}$ (2006), o qual investigou a influência direta da ação do peso próprio estrutural sobre o processo de fraturamento.

Para as condições de contorno e carregamento das vigas em questão, a máxima tensão de tração pode ser escrita independente da largura do corpo-de-prova:

$$
\sigma_{0}=\frac{3 \gamma S^{2}}{4 W}
$$

Desta forma, se obtêm a equação 8.7, a qual correlaciona o deslocamento da linha de carga $(\delta)$ com a propagação da fissura, parâmetros de geometria, módulo de elasticidade e carregamento.

$$
\delta=\frac{5 \gamma S^{4}}{32 E W^{2}} v_{\gamma}(\alpha)
$$

Sendo:

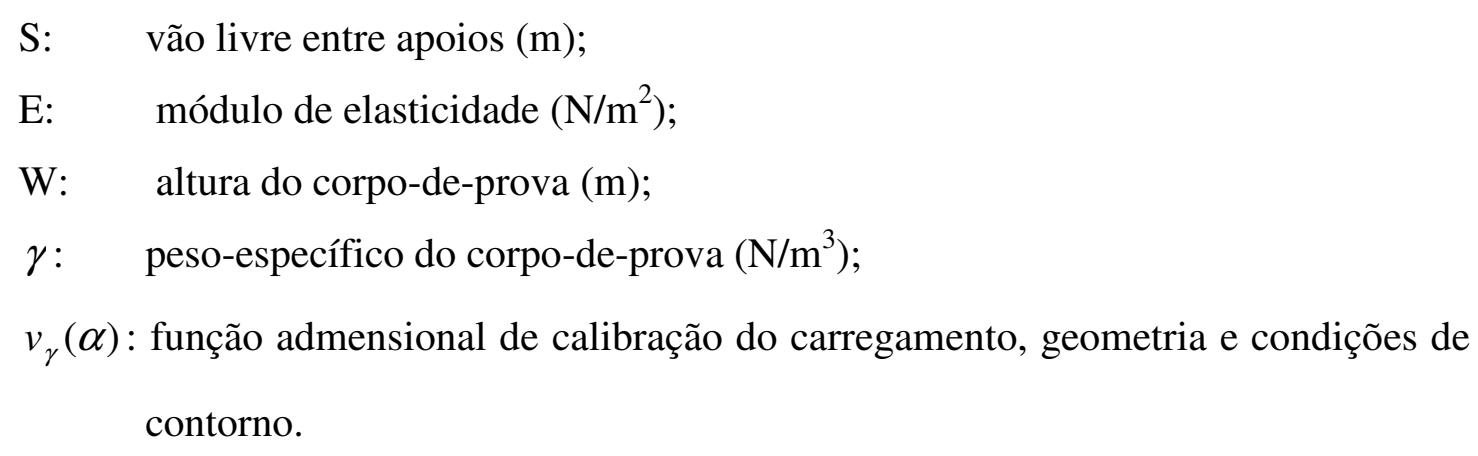

Neste caso, deve-se frisar que a função adimensional de calibração foi obtida numericamente através da simulação do processo de fraturamento de uma viga entalhada com geometria similar (mesmo S/W), cujo carregamento foi apenas o peso-próprio. Trata-se de uma função polinomial, na qual $\alpha$ representa a relação admensional entre a extensão da fissura e a altura do corpo-de-prova:

$$
v_{y}(\alpha)=a+b \alpha+c \alpha^{2}+d \alpha^{3}+e \alpha^{4}+f \alpha^{5}
$$

Os coeficientes a serem utilizados na equação acima foram determinados computacionalmente por Ferreira ${ }^{9}$ (2006), através do método dos elementos finitos, sendo

\footnotetext{
${ }^{24}$ Ferreira, L. E. T. (2006). Comunicações privadas. Departamento de Engenharia de Estruturas, Escola de Engenharia de São Carlos.
} 
que, para $\mathrm{S} / \mathrm{W}=6$, os valores são: $a=1,0025666, b=0,9894039, c=-5,6432696$, $d=40,6461320, e=-55,2832000$ e $f=47,5006615$ (Ferreira et. al., 2007).

Foi também utilizado um fator de correção da tensão nominal, $k$, para levar em consideração o alívio dos balanços. A utilização deste fator é necessária, uma vez que na simulação numérica a razão entre o balanço e o vão livre foi igual a 18. Neste trabalho, esta relação vale 9. Desta forma, o alívio causado pelos balanços considerado na simulação foi menor do que o ocorre na realidade, e para compatibilizar os cálculos multiplica-se a tensão máxima de tração considerada igual a 1,4 MPa pelo fator $k$, o qual irá minorar este valor.

Conforme Ferreira $^{25}$ (2006), esse fator de correção é dado pela expressão 8.9, sendo $n$ a relação entre o balanço, definido por $S^{\prime}$, e o vão livre entre apoios, $S,\left(n=S^{\prime} / S\right)$.

$$
k=\frac{81}{80}\left(1-\frac{4}{n^{2}}\right)
$$

Invertendo a equação 8.7 chega-se a uma expressão que define o módulo de elasticidade em função de parâmetros da geometria, carregamento e do deslocamento vertical da linha de carga. Conseqüentemente, conhecido o valor da tensão nominal, e sendo este constante, as deformações foram calculadas considerando a relação linear entre tensões e deformações (lei de Hooke).

Dentre as funções testadas para o ajuste das curvas $C\left(t, t_{0}\right)$-tempo tem-se: hipérbole de Ross, ACI, e MMF. Todas elas já foram apresentadas anteriormente e podem ser consultadas nos Capítulo 4 e 5. De acordo com as figuras a seguir, nota-se que as expressões testadas caracterizaram bem o fenômeno. Conforme já foi comentado anteriormente, o ajuste foi feito considerando pontos de interesse dentre o intervalo de dados, os quais estão explicitados nos gráficos. Os coeficientes obtidos pelos ajustes estão apresentados Tabela 8.18.

Observando as figuras nota-se que para a viga VE-CFMF1 as curvas de tendência são mais discrepantes. Isto é reflexo do menor conjunto de pontos utilizados no ajuste por conta do menor intervalo de tempo considerado. Entretanto, dentro do período de avaliação as três curvas são bastante próximas. De acordo com o gráfico do modelo VE-CONC2 percebe-se grande semelhança entre os ajustes MMF e Ross, sendo que a extrapolação no tempo demonstra a diferença do ajuste fornecido pela expressão do ACI.

\footnotetext{
${ }^{25}$ Ferreira, L. E. T. (2006). Comunicações privadas. Departamento de Engenharia de Estruturas, Escola de Engenharia de São Carlos.
} 


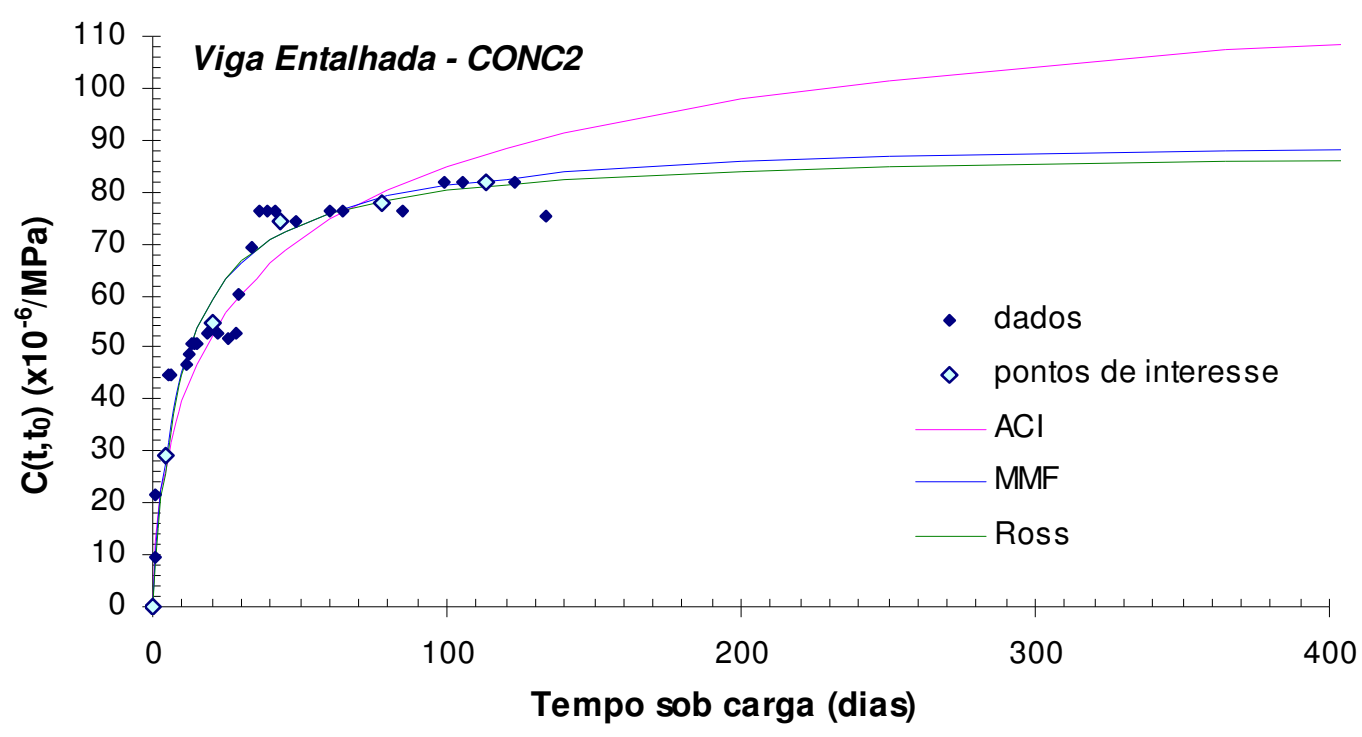

Fig. 8.66: Curvas de tendência para o modelo VE-CONC2.

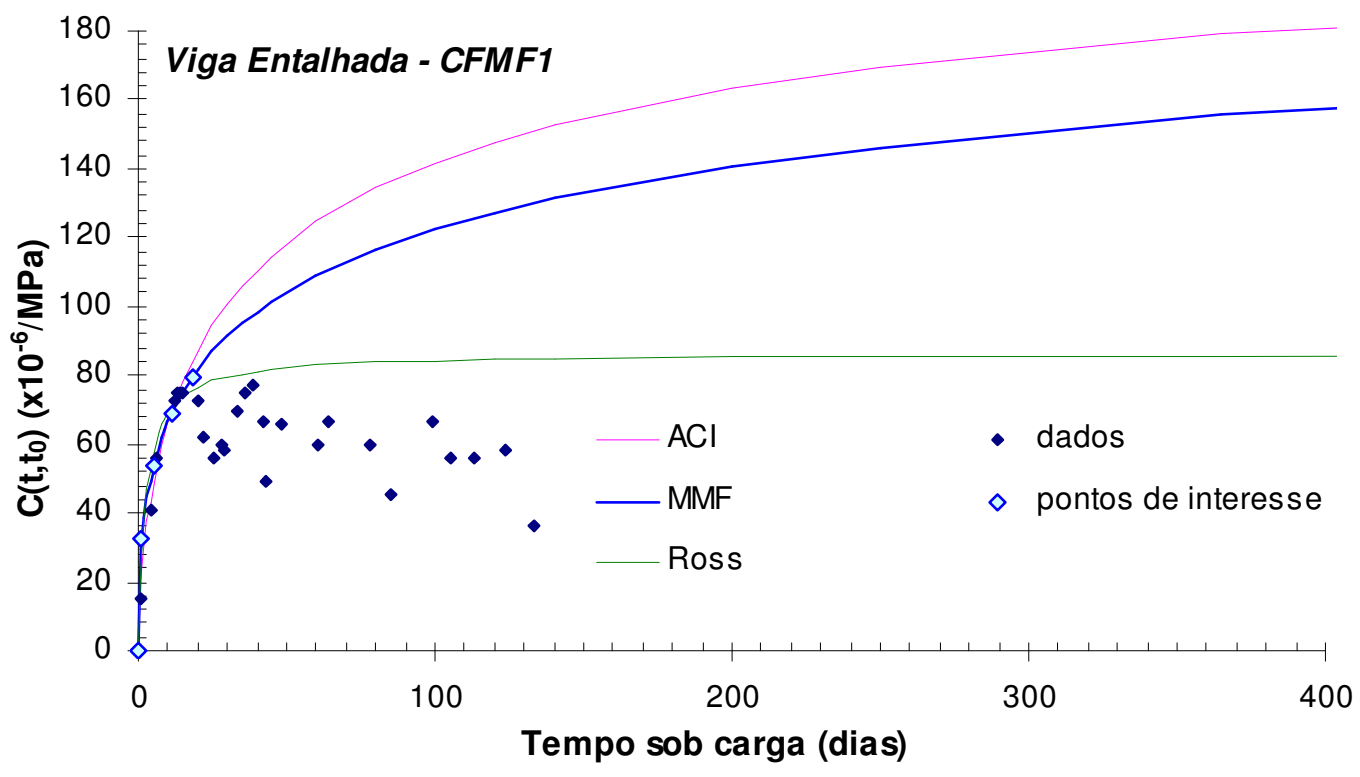

Fig. 8.67: Curvas de tendência para o modelo VE-CFMF1.

Avaliando comparativamente as duas figuras nota-se que esta expressão forneceu, para o conjunto de pontos de interesse considerado em casa caso, comportamentos mais próximos para as duas vigas.

Através da análise das curvas de fluência específicas apresentadas na Fig. 8.68, ajustadas segundo a expressão ACI, pode-se avaliar a influência das fibras sobre o comportamento das vigas entalhadas. Além disso, é possível comparar o comportamento das vigas sem entalhe correspondentes, uma vez que seja utilizada a mesma expressão de ajuste. Nota-se que a adição das fibras afetou tanto as vigas entalhadas como as vigas sem entalhe da 
mesma forma. Ressalta-se a equivalência entre as curvas obtidas para os dois tipos de vigas avaliadas, considerando o mesmo material. Praticamente foram obtidas "as mesmas" curvas.

Ao considerar a mesma tensão máxima de tração, notou-se uma incrível similaridade no comportamento viscoelástico dos modelos. Ou seja, o comportamento à fluência na viga não entalhada, a qual sofreu ação de seu peso-próprio somada a uma carga concentrada de aproximadamente $5 \mathrm{kN}$, foi praticamente o mesmo que aquele observado para uma viga entalhada, solicitada apenas por seu peso-próprio.

Nesta figura também é apresentada a curva $C\left(t, t_{0}\right)$-tempo obtida a partir da simulação feita do DIANA ${ }^{\circledR}$. Os dados de entrada utilizados já foram apresentados na Tabela 6.1 do Capítulo 6. A comparação desta curva com as demais é consistente, visto que foi utilizada nos ajustes dos dados experimentais a expressão do ACI 209:1982, modelo empregado pelo software.

Da mesma forma que na discussão das vigas sem entalhe, nota-se que o resultado da simulação subestimou a fluência. Após 140 dias (término das leituras) a curva experimental fornece uma fluência específica de $91,5 \times 10-6$, ao passo que a curva do DIANA ${ }^{\circledR}$ fornece um valor igual a 29,8×10-6, ou seja, a diferença entre os resultados é de 67\%. Conforme já discutido anteriormente, pode-se justificar esta diferença através dos seguintes fatores: erros inerentes ao próprio do modelo ACI (calibração por base de dados), tipo de solicitação, nível de carregamento e desatualização do modelo, por conta da evolução dos materiais empregados na confecção dos concretos atuais.

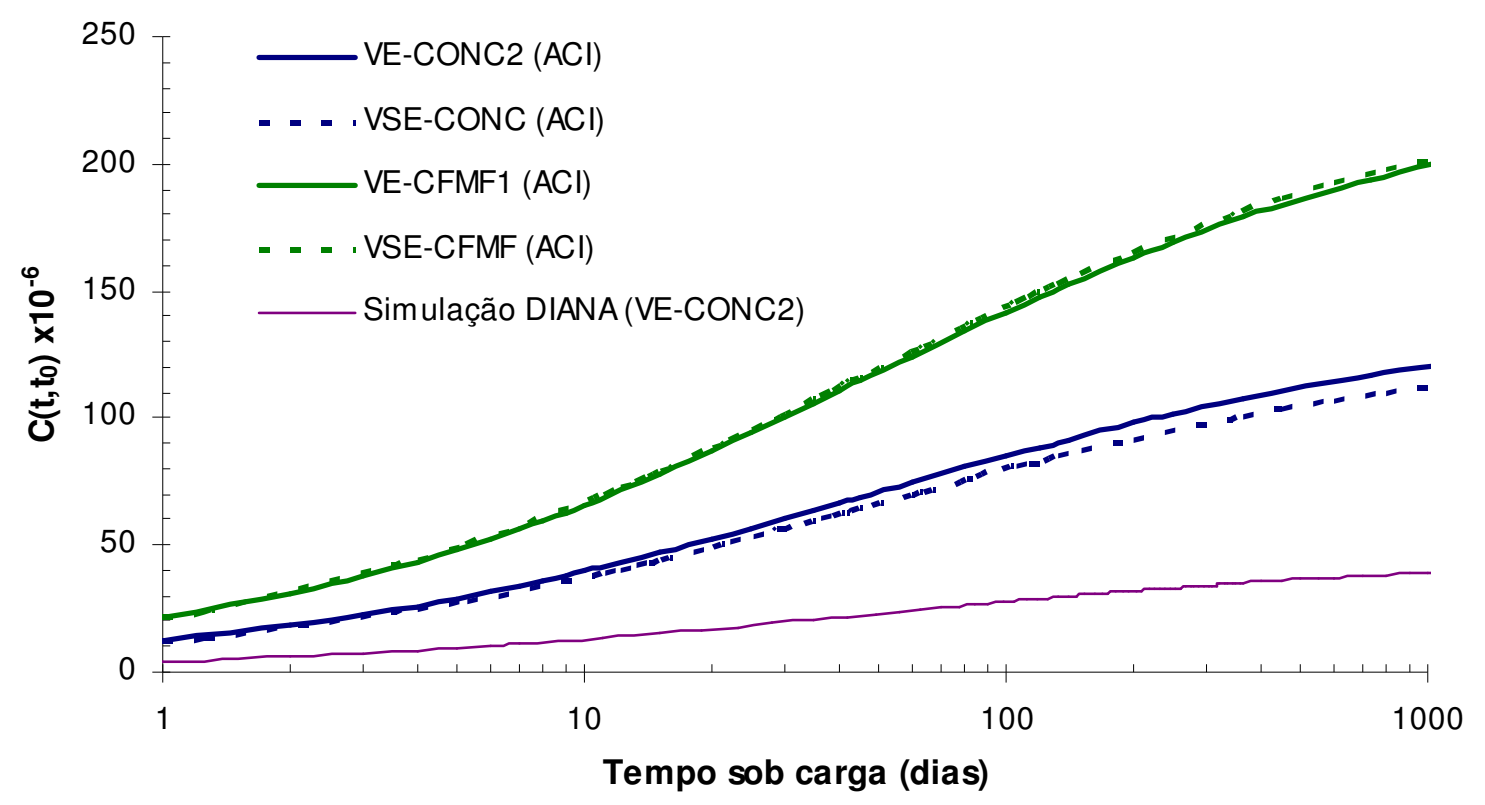

Fig. 8.68: Avaliação comparativa da fluência. 
Tabela 8.18: Expressões de ajuste para a função de fluência específica - Vigas entalhadas Série 2.

\begin{tabular}{|c|c|c|}
\hline Modelo & VE-CONC2 & VE-CFMF1 \\
\hline \multirow{2}{*}{ Hipérbole de Ross } & \multicolumn{2}{|c|}{$C\left(t, t_{0}\right) \times 10^{5}=\quad\left(t-t_{0}\right)$} \\
\hline & & $a+b \cdot\left(t-t_{0}\right)$ \\
\hline a & 1,096349 & 2,950857 \\
\hline$b$ & 0,113581 & 1,157329 \\
\hline$r^{2}$ & 0,995983 & 0,993615 \\
\hline $\mathrm{ACl}:$ & \multicolumn{2}{|c|}{$C(t+t) \times 10^{6}=a \cdot\left(t-t_{0}\right)^{0.6}$} \\
\hline ACI: & \multicolumn{2}{|c|}{$C\left(t, t_{0}\right) \times 10^{\circ}=\frac{}{10+\left(t-t_{0}\right)^{0.6}}$} \\
\hline a & 138,625180 & 231,148650 \\
\hline r2 & 0,991442 & 0,985480 \\
\hline MMF. & \multicolumn{2}{|c|}{$C\left(t, t_{0}\right) \times 10^{6}=\frac{a \cdot b+c \cdot\left(t-t_{0}\right)^{d}}{}$} \\
\hline TVIVIF: & $c\left(l, l_{0}\right) \times 10=-$ & $b+\left(t-t_{0}\right)^{d}$ \\
\hline a & 0,015603 & 0,000200 \\
\hline$b$ & 8,095291 & 7,312122 \\
\hline c & 91,646795 & 246,693290 \\
\hline$d$ & 0,898531 & 0,428481 \\
\hline$r^{2}$ & 0,999594 & 1,000000 \\
\hline
\end{tabular}

Apesar da ciência de que foram dois modelos em doze, acredita-se que esta semelhança indica a possibilidade de se estudar a fluência na flexão em prismas entalhados submetidos apenas ao peso-próprio. Além de ser um estudo inédito, facilita a avaliação em diversos aspectos.

Uma maneira de minorar os "efeitos colaterais" oriundos da grande suscetibilidade da influência de fatores externos, por conta da grandeza das variações nos deslocamentos, consiste em justamente aumentar estes valores. Para uma avaliação em que se considera apenas o peso-próprio isto seria possível, por exemplo, alterando a geometria e extensão do entalhe. Desta forma, possivelmente as tensões à frente da ponta do entalhe seriam superiores ao limite de proporcionalidade, de modo que a fluência seria avaliada conjuntamente à fissuração. Neste sentido, poderiam ser utilizadas diferentes razões entre tensão solicitante e tensão resistente e avaliar outros fatores de interesse, como tempo de colapso e parâmetros de fraturamento, seguindo a linha de trabalho de Liu et. al. (1989 apud SHAH et. al. 1995).

Entretanto, ressalta-se que em um estudo deste tipo não seria possível avaliar qual a parcela de fluência que realmente estaria ocorrendo. Isto porque ao submeter o corpo-deprova a níveis de tensão superiores a 50\% induz-se a ocorrência de fissuração subcrítica. $\mathrm{Ou}$ seja, não há como desacoplar os efeitos oriundos da fissuração subcrítica e da fluência. 


\subsection{Comparação entre as Séries - Avaliação da idade do carregamento}

Apesar de inúmeras diferenças entre as duas séries, os ensaios de caracterização na idade de carregamento forneceram valores para o módulo de elasticidade dos materiais avaliados muito próximos. O módulo de elasticidade é a propriedade mecânica de maior influência na deformabilidade do concreto, e isto justifica ao menos uma análise qualitativa entre os comportamentos observados paras as duas séries de ensaios.

A Tabela 8.19 resume os valores das propriedades mecânicas na idade de carregamento para as duas séries. As diferenças no módulo não ultrapassam 7\%. Entretanto nota-se que na primeira série a relação entre tensão solicitante e tensão resistente manteve-se em torno de $40 \%$, ao passo que para a segunda série esta relação variou entre $50 \%$ e $60 \%$.

Tabela 8.19: Propriedades mecânicas das duas séries na idade de carregamento.

\begin{tabular}{c|cccc|cccc}
\hline \multirow{2}{*}{ Modelo } & \multicolumn{3}{|c|}{ Série 1 ( $\boldsymbol{t}_{\boldsymbol{0}}=\mathbf{6 0}$ dias) } & \multicolumn{4}{c}{ Série 2 ( $\boldsymbol{t}_{\boldsymbol{o}}=\mathbf{1 4}$ dias) } \\
& $\mathrm{E}_{\mathrm{c}}(\mathrm{GPa})$ & $\mathrm{f}_{\mathrm{c}}(\mathrm{MPa})$ & $\mathrm{f}_{\mathrm{t}}(\mathrm{MPa})$ & $\sigma_{\text {máx }} / \mathrm{f}_{\mathrm{t}}$ & $\mathrm{E}_{\mathrm{c}}(\mathrm{GPa})$ & $\mathrm{f}_{\mathrm{c}}(\mathrm{MPa})$ & $\mathrm{f}_{\mathrm{t}}(\mathrm{MPa})$ & $\sigma_{\text {máx }} / \mathrm{f}_{\mathrm{t}}$ \\
\hline VSE-CONC & 34,2 & 43,5 & 3,5 & $40 \%$ & 31,7 & 26,1 & 2,3 & $61 \%$ \\
VSE-CF & 32,9 & 38,2 & 3,8 & $37 \%$ & 31,5 & 28,7 & 2,9 & $48 \%$ \\
VSE-CFMF & 25,6 & 32,4 & 3,3 & $42 \%$ & 26,3 & 22,5 & 2,6 & $54 \%$ \\
\hline
\end{tabular}

Apesar de na segunda série o concreto conter menos água (slump menor) e a umidade relativa do ar ter sido maior ( $72,8 \%$ contra $59 \%$ da primeira série), os deslocamentos obtidos pelas vigas da Série 2 foram maiores. Isto certamente reflete o peso da idade de carregamento. Além disso, na segunda série o nível de tensões foi um pouco maior e as peças não ficaram expostas à pré-secagem; dois fatores importantes que também se somam para contribuir aos maiores deslocamentos.

A Fig. 8.69 ilustra de forma conjunta os dados e as curvas de tendência em termos de deslocamentos de cada viga do tipo VSE. Nota-se que o formato das curvas, para as vigas equivalentes (da mesma categoria) é muito semelhante. Isto significa que nas duas séries de ensaios forneceram resultados confiáveis (já que o comportamento de certa forma se repetiu). Além disso, conclui-se que a idade de carregamento afeta o concreto reforçado com fibras da mesma forma que a matriz. Por esta figura pode-se dizer que nas duas séries o comportamento dos materiais foi qualitativamente semelhante.

Ao comparar as vigas de um mesmo material entre as séries, percebe-se que há certa proporção nos deslocamentos, o indica que os fatores intervenientes afetam da mesma forma os três materiais. A Fig. 8.70 traz uma análise mais minuciosa a esse respeito. 


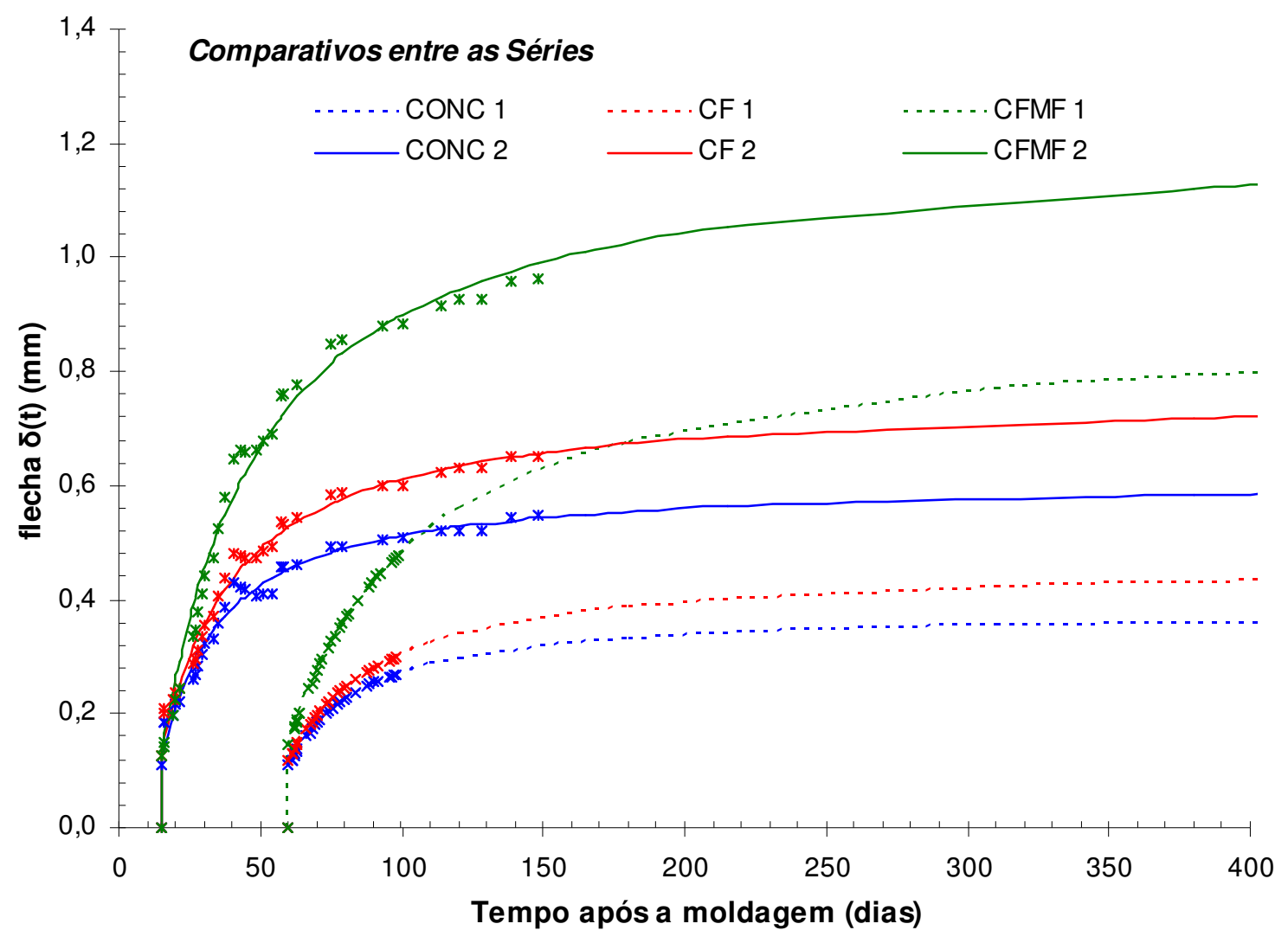

Fig. 8.69: Comparativo entre as séries em termos de deslocamentos.

\section{Após 40 dias (valores mensurados)}

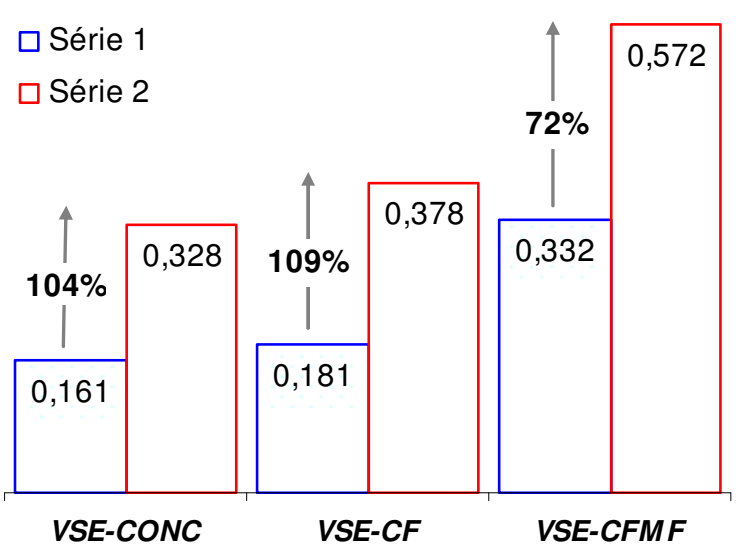

Após 10.000 dias (valores estimados)

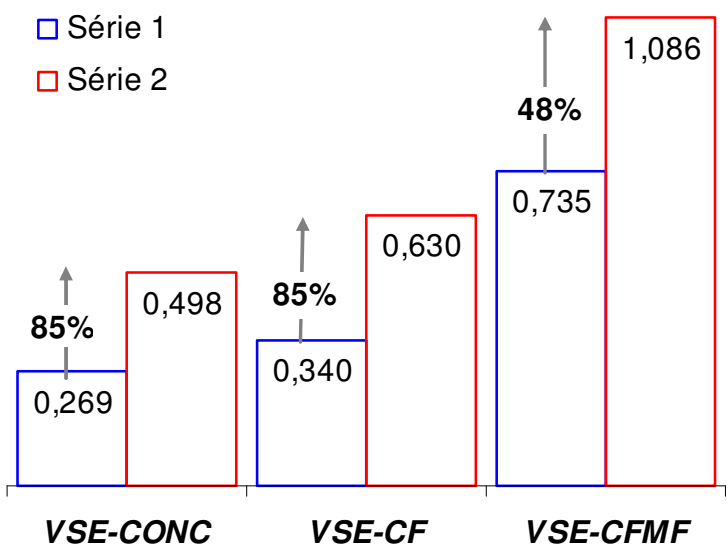

Fig. 8.70: Deslocamentos por fluência $\left(\delta(t)-\delta\left(t_{0}\right)\right)$.

Nesta figura são apresentados de forma comparativa os valores dos acréscimos em deslocamentos por fluência para os materiais avaliados, em duas situações: após 40 dias, sendo que neste caso os valores foram efetivamente medidos; e após 10000 dias, sendo que neste caso os valores foram retirados da extrapolação das curvas de tendência, traçadas a partir da expressão hiperbólica de Ross. 
Dada a constância dos fatores intervenientes (idade de carregamento, umidade relativa, slump, temperatura, etc.) em cada série esperava-se a fluência fosse também quantitativamente equivalente entre vigas de mesmo material. Nota-se que, considerando o mesmo intervalo sob carga, os materiais $C O N C$ e $C F$ apresentam valores equivalentes de majoração da fluência. Entretanto, as diferenças encontradas nos acréscimos de deslocamento por fluência foram menores no caso do concreto reforçado com fibras e microfibras.

Isto pode ser explicado pela variação não proporcional de um fator interveniente importante: o teor de ar incorporado. Conforme as tabelas 8.1 e 8.9 as diferenças entre o teor de ar incorporado dos materiais $C O N C$ e $C F$ para as duas séries foi muito pequena (1\%). Já para o concreto reforçado com fibras e microfibras essa diferença foi de $4 \%$. Desta forma, se o percentual de ar incorporado do material $C F M F$ da primeira série tivesse atingido um valor próximo de 4,5, certamente seria mantida a proporcionalidade na fluência entre as duas séries.

Outra forma de avaliar a fluência nas duas séries consiste em comparar os resultados em termos de fluência específica e coeficiente de fluência, o que é feito na Fig. 8.71 e na Tabela 8.20.

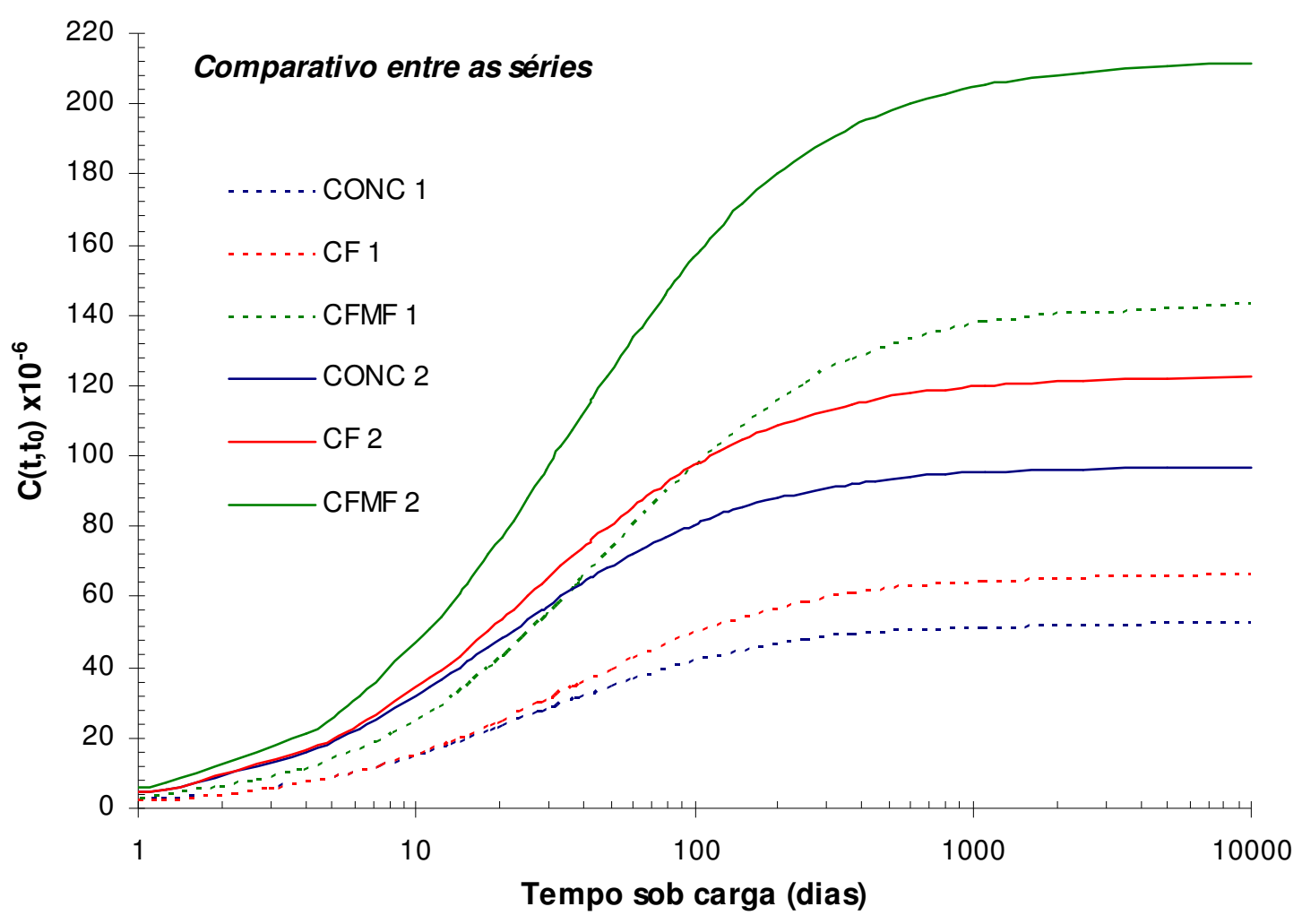

Fig. 8.71: Comparativo entre as séries em termos da fluência específica. 
Apesar das condições adversas a que as duas séries de ensaio foram submetidas, notase muita semelhança na taxa de fluência. Independente do modelo avaliado percebe-se uma tendência a estabilização da taxa de fluência após 6 meses $(\approx 200$ dias). É Interessante observar os valores do coeficiente de fluência encontrados, apresentados na Tabela 8.20.

Tabela 8.20: Comparação entre os coeficientes de fluência $\emptyset\left(t, t_{0}\right)$

\begin{tabular}{cccccccc}
\hline \multirow{2}{*}{$\begin{array}{c}\text { Tempo após a aplicação } \\
\text { do carregamento (dias) }\end{array}$} & \multicolumn{3}{c}{ Série $\mathbf{1}\left(\boldsymbol{t}_{\boldsymbol{f}}=\mathbf{4 0}\right.$ dias) } & \multicolumn{3}{c}{ Série $\mathbf{2}\left(\boldsymbol{t}_{\boldsymbol{f}}=\mathbf{1 3 5}\right.$ dias) } \\
\hline CONC & CF & CFMF & CONC & CF & CFMF \\
\hline Término dos ensaios $\left(\mathrm{t}_{\mathrm{f}}\right)$ & 1,5 & 1,5 & 2,3 & 3,9 & 4,1 & 6,8 \\
365 (valores estimados) & 2,4 & 2,6 & 4,4 & 4,3 & 4,6 & 7,8 \\
10000 (valores estimados) & 2,6 & 2,8 & 5,0 & 4,5 & 4,9 & 8,6 \\
\hline
\end{tabular}

Para a primeira série, ainda que as peças tenham sido carregadas aos 60 dias e submetidas à pré-secagem, o coeficiente último de fluência (para um tempo "infinito", no caso igual a 10000 dias) para os materiais $C O N C$ e $C F$ estão próximos de valores normalmente adotados. Contudo o material CFMF forneceu um valor bem acima do que normalmente se utiliza. Quando se observa os coeficientes da segunda série, nota-se que ,independente do material avaliado, os valores são muito superiores aqueles indicados na literatura, mesmo considerando a viga de concreto simples.

Esta discussão reforça os seguintes aspectos:

- A fluência na flexão, para peças de concreto não armado, ocorre a taxas iniciais superiores do que no caso da fluência na compressão. Além disso, a estabilização da taxa de fluência é mais rápida. No caso dos ensaios efetuados neste trabalho, estima-se que após um ano já tenha ocorrido praticamente toda fluência (cerca de 90\%).

- Através dos dados da tabela 8.19, percebe-se indícios de que quanto antes ocorre o carregamento, maiores as taxas de fluência inicial e mais rápida a estabilização.

- A incorporação de fibras deve ser feita com muito cuidado em elementos de concreto que estejam solicitados à flexão. Conforme os resultados deste trabalho, a incorporação de $1 \%$ de fibras e $1 \%$ de microfibras conduziu, após 4 meses e meio de observações, deslocamentos 8 vezes maiores do que o inicial. 


\section{CONSIDERAÇÕES FINAIS}

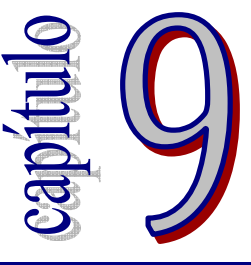

Neste trabalho foram estudadas várias vertentes sobre o material concreto reforçado com fibras de aço: suas propriedades mecânicas, o comportamento sob carga mantida na flexão, aplicação da Mecânica da Fratura e recomendações normativas para estimativa da fluência.

Com relação à adição de fibras metálicas, os resultados desta pesquisa indicam que, ao adicionar as fibras, principalmente as fibras curtas, ocorre um aumento no teor de ar incorporado do compósito relativamente à matriz. Conseqüentemente observa-se que, para solicitações na fase pré-pico de resistência, ocorre uma piora no desempenho do concreto reforçado.

Verificou-se que, para os traços utilizados nas duas séries de ensaios, ao adicionar $1 \%$ em volume das fibras metálicas de $25 \mathrm{~mm}$, praticamente não houve alteração das propriedades mecânicas. Houve um pequeno aumento dos deslocamentos por fluência e também certo ganho na resposta do material à retração.

Entretanto, ao adicionar a esse concreto reforçado $1 \%$ em volume de fibras curtas $(l=13 \mathrm{~mm})$, notou-se um aumento bastante significativo no teor de ar incorporado. Desta forma, este compósito mostrou-se menos resistente e mais deformável. Nas duas séries a taxa de fluência deste material foi muito superior à dos outros dois (matriz de referência e CRFA).

Quanto à retração, este material apresentou restrições razoáveis a esta deformação. $\mathrm{Na}$ primeira série de ensaios, não foi possível avaliar restrições significativas por conta da idade de início das leituras e da pré-secagem a que os modelos ficaram expostos. Entretanto, os resultados da segunda apontam que, ao final das leituras, a incorporação de $1 \%$ das fibras longas $(l=25 \mathrm{~mm})$ forneceu deformações $18 \%$ menores e a incorporação de $1 \%$ das fibras curtas $(l=13 \mathrm{~mm})$ forneceu deformações $36 \%$ menores.

Os resultados dos ensaios de fluência indicam que o fenômeno, quando avaliado na flexão, pode ser bem representado por expressões conhecidas da literatura, comumente 
aplicadas aos resultados de estudos experimentais de fluência na compressão. Ou seja, apesar de a taxa inicial de fluência ser bem maior na flexão, o comportamento é qualitativamente o mesmo. Notou-se também que essa taxa foi maior para os concretos reforçados, o que está relacionado com as variações no módulo de elasticidade, decorrentes aumento no teor de ar incorporado.

Além da questão da taxa de fluência, maior na flexão que na compressão, verificou-se uma estabilização mais rápida do fenômeno do que o normalmente esperado para corpos-deprova comprimidos, o que está de acordo com informações da literatura sobre o assunto.

Por conta da semelhança no módulo de elasticidade dos materiais ensaiados na primeira e na segunda série, avaliou-se a influência da idade de carregamento. Comparando as curvas de modelos de um mesmo material, ensaiados em idades distintas, percebe-se que o formato das curvas é muito semelhante, indicando um comportamento qualitativamente equivalente. Claro que para aplicação da carga aos 14 dias os acréscimos nos deslocamentos por fluência nas primeiras idades de observação foram muito maiores.

As curvas de tendência obtidas para as vigas de seção íntegra (sem entalhe), moldadas com concreto de referência (sem fibras), foram comparadas com curvas obtidas por recomendações normativas e também com aquelas provenientes das simulações. Independentemente da idade de carregamento, as prescrições para flechas-diferidas das normas americana e brasileira foram muito ruins, sendo que as diferenças entre estas e as curvas experimentais chegou a aproximadamente $70 \%$. Pode ser que esta grande discrepância decorra do fato de que as vigas ensaiadas nesta pesquisa não possuíam barras de armadura longitudinal.

De qualquer modo, pode-se dizer que as expressões para estimativa das flechasdiferidas por fluência são muito pobres, já que não levam em consideração, ao menos na formulação, praticamente nenhum fator interveniente do fenômeno, além da idade de carregamento. Com certeza melhores resultados são obtidos se ao invés do coeficiente $\alpha_{f}$ fosse utilizado o coeficiente $\phi\left(t, t_{0}\right)$. Esta comparação foi feita e comprovada na discussão dos resultados.

Com relação à simulação da fluência no DIANA ${ }^{\circledR}$, foram feitas algumas críticas no Capítulo 6. No caso das vigas de seção íntegra moldadas com o concreto de referência, ao comparar as curvas provenientes das simulações àquelas obtidas pela modelo de fluência do ACI, quando considerados os mesmos parâmetros de entrada, obtém-se praticamente a 
sobreposição das curvas. Como o modelo da norma americana é bastante simples, tem-se que a simulação, neste caso, é desnecessária. Entretanto, de acordo com a comparação dos resultados do modelo VE-CONC2 da segunda série de ensaios com a simulação numérica, notou-se que houve uma diferença significativa entre a curva de fluência específica experimental e aquela proveniente da simulação. Neste caso, a simulação não representou bem o comportamento, subestimando os resultados.

Destaca-se a possibilidade de avaliar os resultados em termos de deformações. No caso das vigas de seção íntegra, a transformação de deslocamentos em deformações é simples, baseada em uma expressão puramente geométrica, que atualiza o raio de curvatura com o aumento da flecha no tempo. Esta transformação permite a construção de curvas de fluênciaespecífica versus tempo, além de permitir uma comparação mais consistente com os modelos normativos de previsão da fluência.

A parir das curvas $C(t, t 0)$-tempo verifica-se de forma mais nítida a fluência dos materiais, uma vez que considera-se apenas as deformações por fluência, "descartando" a interferência da deformação elástica inicial.

Como esperado, o modelo de fluência da norma brasileira NBR 6118:2003, o qual foi baseado no modelo do CEB de 1978, forneceu estimativas mais próximas dos resultados experimentais. Já o modelo da norma americana subestimou os resultados, em todos os casos.

Entretanto, apesar de afirmar que a NBR forneceu estimativas melhores, convém ponderar que as diferenças entre os valores teóricos e experimentais não foram satisfatórias. Ao término dos ensaios, a norma brasileira forneceu valores cerca de $30 \%$ e $40 \%$ menores, considerando a primeira e a segunda série de ensaios, respectivamente. Já a norma americana forneceu valores $45 \%$ e $66 \%$ menores. Em partes, estas diferenças são oriundas da precisão de cada modelo, contudo foram considerados outros fatores que também possam contribuir. Dentre eles tem-se o tipo de solicitação e a desatualização dos modelos de fluência por conta da evolução na composição do cimento.

Ainda com relação aos modelos de fluência destas normas, foram feitas no Capítulo 5 diversas comparações, relativamente à deformação elástica inicial e à idade de carregamento. Notou-se que a norma americana é muito menos sensível à idade de carregamento. Isto pode ser reflexo do tipo de cimento utilizado na confecção de concreto, e também dos agregados.

Além dos ensaios de caracterização, de fluência e retração, foram efetuados ensaios dinâmicos de vibração livre. Para a primeira série, os ensaios dinâmicos forneceram módulo 
de elasticidade em torno de $20 \%$ superior ao módulo estático (aos 28 dias), o que está de acordo com dados da literatura. Na segunda série de ensaios, os ensaios dinâmicos foram realizados aos 15 dias, e praticamente não houve diferença entre o módulo estático e o dinâmico, no caso da matriz. Contudo não se sabe o motivo que levaram a valores tão próximos, diferentemente do observado para a série anterior.

Desta forma, não foi possível identificar uma relação clara entre o módulo estático e o módulo dinâmico, considerando os diferentes materiais avaliados. Porém, de acordo com a discussão sobre o assunto efetuada no Capítulo 8, imagina-se que interfiram na relação $\left(E_{c, d} / E_{c, \text { est. }}\right)$ diversos fatores, dentre eles: a porosidade do material, as condições de exposição e grau de hidratação da matriz (idade de realização do ensaio).

Os ensaios dinâmicos da Série 1, realizados antes e depois dos ensaios de fluência, permitiram avaliar a perda de rigidez em todas as vigas. A danificação das vigas foi proporcional à quantidade de fibras, o que é coerente com os resultados dos ensaios de longa duração. Ora, os materiais que apresentaram maiores valores de fluência específica certamente teriam maior perda de rigidez. Contudo, deve-se salientar que esta perda de rigidez está associada não só à fluência, mas também à retração por secagem que ocorreu antes e durante os ensaios de fluência, e possivelmente a algum processo de microfissuração associado à retração.

Com relação à intenção de se estudar a fluência em prismas entalhados submetidos apenas à solicitação de seu peso-próprio, apesar das dificuldades em mensurar os dados, alguns resultados da segunda série ensaios foram bastante interessantes. As flechas diferidas de dois modelos foram convertidas em deformações, empregando-se formulações da Mecânica da Fratura. Para tornar a avaliação do fenômeno mais consistente, estas deformações foram transformadas em fluência específica.

A comparação das curvas de fluência específica versus tempo, obtidas para as vigas não entalhadas e aquelas entalhadas, indica a possibilidade de se estudar a fluência a partir da metodologia de ensaios proposta neste trabalho.

\subsection{Sugestões para trabalhos futuros}

Tendo em vista as dificuldades encontradas durante o programa experimental, assim como as inúmeras possibilidades de novos estudos que complementem este trabalho, são colocadas a seguir algumas sugestões para trabalhos futuros. 
Com relação à avaliação da fluência em concreto reforçado com fibras de aço, com base na revisão da bibliografia e também com nos resultados experimentais deste trabalho pode-se dizer que o conhecimento sobre o assunto é incipiente. Desta forma um estudo interessante seria uma avaliação experimental da fluência sob diferentes solicitações considerando uma maior variedade de materiais:

a) Para aproveitar toda a experiência adquirida neste trabalho poderiam ser efetuados novos ensaios na flexão. Tendo em vista o grande número de trabalhos de fluência em elementos comprimidos, seria interessante efetuar ensaios de fluência na compressão, os quais serviriam como base de comparação. Este tipo de avaliação conjunta permitiria correlacionar os resultados em termos de coeficiente de fluência e fluência específica, sob diferentes solicitações, o que pode ser de grande interesse para a previsão correta dos acréscimos de deslocamentos de elementos fletidos. Ressalta-se a inexistência de estudos deste tipo;

b) Tendo em vista a influência da matriz e também da região de interface entre a fibra e a matriz no desempenho dos concretos reforçados com fibras metálicas, seria interessante avaliar matrizes de características diferentes. Para isto seria conveniente o estudo prévio de traços de concreto que fornecessem pelo menos três faixas de resistência (baixa, moderada e alta);

c) Para cada matriz, definir, por exemplo, dois teores de fibras longas (possivelmente 0,5\% e $1 \%$ ), e no caso de compósitos híbridos formados pela associação de fibras metálicas longas e curtas, variar-se as combinações (ou seja, adicionar ao CRFA comum, diferentes teores de fibra curta).

d) Com relação à fluência de compósitos híbridos, poderiam ser avaliados materiais provenientes da combinação de fibras de materiais diferentes, por exemplo, fibras metálicas associadas a fibras de carbono. O excelente desempenho deste compósito relatado por trabalhos apresentados no Capítulo 2 indica um grande potencial de aplicação, e certamente o conhecimento de seu comportamento ao longo do tempo é de interesse;

e) Analisar a porosidade dos materiais e determinar de forma mais consistente o teor de ar incorporado quando da adição das fibras, o que torna o estudo mais completo e facilita a correta análise dos resultados. A esse respeito, constitui-se de particular interesse e a identificação no processo de mistura do fator que contribui para o 
aumento no teor de ar incorporado;

f) Para concretos reforçados também seria interessante a avaliação das características no estado fresco de acordo com as recomendações do ACI 544R.3 (1993).

Como já foi mencionado, por conta da ordem de grandeza das leituras, houve grandes dificuldades experimentais em realizar a avaliação da fluência em vigas entalhadas submetidas apenas ao peso-próprio. Desta forma, uma maneira de minimizar imprecisões seria aumentar os valores dos deslocamentos, o que pode ser conseguido elevando o nível da solicitação. No caso das vigas entalhadas, isto pode ser feito alterando a geometria da viga, o vão livre entre os apoios, ou ainda a geometria do entalhe. Poderiam ser idealizados modelos de menores dimensões, visando facilitar diversas etapas envolvidas no programa experimental, como: concretagem, desforma, transporte e locação dos modelos. Também seria interessante trabalhar com corpos-de-prova selados e corpos-de-prova não-selados, o que permitiria a avaliação da fluência básica e da fluência por secagem. Neste caso, mesmo que houvesse variações bruscas na umidade relativa do meio, esta variável não interferiria na avaliação da fluência básica (modelos selados). Estas são maneiras de viabilizar a repetição de parte dos ensaios realizados nesta pesquisa, porém com maior probabilidade de resultados satisfatórios.

Entretanto, um inconveniente em se elevar o nível de tensão consiste em agregar nos deslocamentos medidos uma parcela de acréscimo de deslocamento por conta da fissuração, a qual não se consegue desacoplar da parcela de deslocamento que efetivamente ocorre por fluência. Contudo, este tipo de avaliação é interessante, principalmente havendo a possibilidade de as peças serem solicitadas apenas por seu peso-próprio, não sendo necessário dispor de um sistema complexo para aplicação e controle de carga. Ao final dos ensaios de fluência poderiam ser efetuados ensaios de fraturamento, e desta forma correlacionar os efeitos do tempo ao o nível de solicitações e também a parâmetros de fraturamento de interesse $\left(\mathrm{K}_{\mathrm{IC}}\right.$ e $\left.\mathrm{G}_{\mathrm{f}}\right)$. 


\section{REFERÊNCIAS}

ALEXANDER, M. G. (1996). Aggregates and Deformation Properties of Concrete. ACI Materials Journal. V. 93, No. 6, November-December.

ALMEIDA, S. F. (2005). Análise dinâmica experimental da rigidez de elementos de concreto submetidos à danificação progressiva até a ruptura. Dissertação (Mestrado). Engenharia de Estruturas, Escola de Engenharia de São Carlos, Universidade de São Paulo.

ALTHUN, F.; HAKTANIR, T.; ARI, K. (2007). Effects of steel fiber addition on mechanical properties of concrete and RC beams. Construction and Building Materials. Vol. 21, p. 654661.

ALTOUBAT, S. A.; LANGE, D. A. (2001). Creep, Shrinkage, and cracking of Restrained Concrete at Early Age. ACI Materials Journal. Vol. 98, No. 4, July-August.

AMERICAN CONCRETE INSTITUTE (2004). ACI 544.1R-96: State-of-theart report on fiber reinforced concrete. In: Manual of concrete Practice. Detroit, Michigan. Vol. 5.

AMERICAN CONCRETE INSTITUTE (2002). ACI 318-02: Building code requirements for structural concrete and commentary. Reported by ACI Committee 318. Detroit, Michigan.

AMERICAN CONCRETE INSTITUTE (1998). ACI 506.1R-98: Committee Report on Fiber Reinforced Shotconcrete: Reported by Committee 506-ACI. Detroit, Michigan.

AMERICAN CONCRETE INSTITUTE (1992). ACI 209R-92: Prediction of creep, shrinkage, and temperature effects in concrete structures: Reported by Committee 209-ACI. Detroit, Michigan.

AMERICAN CONCRETE INSTITUTE (1988). ACI 544.2R-88: Measurements of properties of fiber reinforced concrete. Detroit, Michigan.

AMERICAN CONCRETE INSTITUTE (1993). ACI 544.3R-93: Guide for specifying, proportioning, mixing, placing, and finishing steel fiber reinforced concrete. Detroit, Michigan.

AMERICAN CONCRETE INSTITUTE (1988). ACI 544.4R-88: Design considerations for steel fiber reinforced concrete. Detroit, Michigan.

AMERICAN SOCIETY FOR TESTING AND MATERIALS (2002). C512-2002: Standard test method for creep of concrete in compression. Detroit, USA.

AMERICAN SOCIETY FOR TESTING AND MATERIALS. (1991). C215-91: Standard test method for fundamental transverse, longitudinal and torsional frequencies of concrete specimens. Philadelphia.

ANDERSON, T. L. (1991). Fracture Mechanics: Fundamentals and applications. CRC Press, Boca Raton, Florida, USA. 
ARAÚJO, D. L. (2002). Taxa de armadura longitudinal mínima em vigas de concreto de alta resistência com fibras de aço. Tese (doutorado). Engenharia de Estruturas, Escola de Engenharia de São Carlos, Universidade de São Paulo.

ASSOCIAÇÃO BRASILEIRA DE NORMAS TÉCNICAS. (2003). NBR 6118: Projeto de estruturas de concreto. Rio de Janeiro.

ASSOCIAÇÃO BRASILEIRA DE NORMAS TÉCNICAS. (1994). NBR 5739: Ensaio de compressão de corpos-de-prova cilíndricos. Rio de Janeiro.

ASSOCIAÇÃO BRASILEIRA DE NORMAS TÉCNICAS. (2004). NBR 5738: Modelagem e cura de corpos-de-prova cilíndricos. Rio de Janeiro.

ASSOCIAÇÃO BRASILEIRA DE NORMAS TÉCNICAS. (1994). NBR 7222: Argamassa e concreto - determinação da resistência à tração por compressão diametral de corpos-de-prova cilíndricos. Rio de Janeiro.

ASSOCIAÇÃO BRASILEIRA DE NORMAS TÉCNICAS. (1983). NBR 8224: Concreto Endurecido - Determinação da Fluência. Rio de Janeiro.

BAKOOS, S. L.; GILBERT, R. I.; FAULKES, K. A.; PULMANO, V. A. (1982). Long-Term deflections of reinforced concrete beams. Magazine of concrete research. Vol. 34, No. 121, p. 203-212.

BALAGURU, P.; RAMAKRISHNAN, V. (1988). Properties of Fiber Reinforced Concrete: Workability, Behavior under Long-Term Loading, and Air-Void Characteristics. ACI Materials Journal. Vol. 85, No. 3, May/June, p. 189-196.

BANTHIA, N.; GUPTA, R. (2004). Hybrid fiber reinforced concrete (HyFRC): fiber synergy in high strength matrices. Materials and Structures. Vol. 37, December 2004, p. 707-716.

BANTHIA, N.; SHENG, J. (1996). Fracture Toughness of Micro-Fiber Reinforced Cements. Special Issue, Int. Journal of Cement and Concrete Composites. Vol. 18, p. 251-269.

BANTHIA, N., NANDAKUMAR, N. (2003). Crack growth resistance of hybrid fiber reinforced cement composites, Cement and Concrete Composites. Vol. 25, p. 3-9.

BARPI, F.; VALENTE, S. (2004). A fractional order rate approach for modeling concrete structures subjected to creep and fracture. International Journal of Solids and Structures. Vol. 41, p. $2607-2621$.

BARPI, F.; VALENTE, S. (2004). Creep and fracture in concrete: a fractional order rate approach. Engineering Fracture Mechanics. Vol. 70, p. 611-623.

BARSON, R. (1977). Fracture and fatigue control in structures: applications of fracture mechanics. Prentice Hall, Inc. New Jersey.

BAZANT, Z. P (2001). Prediction of concrete creep and shrinkage: past, present and future. Nuclear Engineering and Design. 203, p. 27-38. 
BAZANT, Z. P.; ASCE, F.; CANER, F. C.; ADLEY, M. D.; AKERS, S. A. (2000). Fracturing Rate Effect and Creep in Microplane Model for Dynamics. Journal of Engineering Mechanics. September 2000. p. 962-970.

BAZANT, Z. P.; LI, Y. N. (1997). Cohesive crack with rate-dependent opening and viscoelasticity: I. mathematical model and scalling. International Journal of Fracture. Vol. 86 , p. 247-265.

BAZANT, Z. P.; PLANAS, J. (1997). Fracture and Size Effect in Concrete and Other Quasi Brittle Materials. CRC Press, Boca Raton, Florida USA.

BAZANT, Z. P.; BAWEJA, S (1995). Justification and refinements of model B3 for concrete creep and shrinkage. Materials and Structures. Paris, Vol. 28, p. 415-430.

BAZANT, Z. P. (1993). Current status and advances in the theory of creep and interaction with fracture. In: Bazant, Z. P.; Carol, I. (Ed.). Creep and Shrinkage of Concrete. London: E \& FN Spon, p. 291-309.

BAZANT, Z. P.; GETTU, R. (1992). Rate Effects and Load Relaxation in Static Fracture of Concrete. ACI Materials Journal, Vol. 89, No. 5, p. 456-468.

BAZANT, Z. P. (1988). Mathematical modeling of creep and shrinkage of concrete. John Wiley \& Sons Ldt, 459 p.

BAZANT, Z. P.; PRAT, P. C. (1988). Effect of Temperature and Humidity on Fracture Energy of Concrete. ACI Materials Journal. No. 85, M32.

BAZANT, Z. P., PFEIFFER, P. A. (1987). Determination of fracture energy from size effect and brittleness number. ACI Materials Journal. Vol. 84, No. 6, p. 463-480.

BAZANT, Z. P. (1984). Size Effect in blunt fracture: concrete, rock, metal. Journal of Engineering Mechanics (ASCE). Vol. 110, No. 4, p. 518-35.

BAZANT, Z. P.; OH, B. H. (1983). Crack band theory fracture of concrete. Materials and Structures. Vol. 16, No. 93, p. 155-177.

BARR, B. I. G.; HASS E. B. D.; WEISS V. J. (1986). Effect of specimen and aggregate sizes upon the fracture characteristics of concrete. The International Journal of Cement Composites and Lighteight Concrete. Vol. 8, No. 2.

BENTUR, A.; MINDESS, S. (1990). Fibre Reiforced Cementitious Composites. Elservier App. Science, London.

BISSONNETTE, B. B.; PIGEON, M.; VAYSBURD, A. M. (2007). Tensile Creep of Concrete: Study of Sensitivity to Basic Parameters. ACI Materials Journal. V.104, No.4, p. 360-368.

BISSONNETTE, B. B.; PIGEON, M. (1995). Tensile creep at early ages of ordinary, silica fume and fiber reinforced concretes. Cement and Concrete Research. Vol.25, No.5, p. 10751085 . 
BITTENCOURT, T. (1999). Fraturamento do Concreto Estrutural: Aspectos Teóricos, Computacionais e Experimentais e suas aplicações. 240f. Tese (livre-docência). Escola Politécnica da Universidade de São Paulo, São Paulo.

BLAKE, A. (1996). Practical fracture mechanics in design. New York : M. Dekker.

BRANDT, A. M. (1995). Cement-Based Composites: materials, mechanical properties and performance - E \& FN Spon, London.

BROEK, D. (1986). Elementary Engineering Fracture Mechanics. Martinus Nijhoff Publishers, Dordrecht, the Netherlads.

BROOKS, J. J. (1989). Influence of mix proportions, plasticizers and superplasticizers on creep and drying shrinkage of concrete. Magazine of Concrete Research. Vol. 41, No. 148, p. 145-153.

BUENO, E. M. R. (1999). Simulação bi-dimensional de fraturamento coesivo por meio do método dos elementos finitos. 162 p. Dissertação (mestrado). Escola Politécnica da Universidade de São Paulo, São Paulo.

CABRERA, J. G.; BROOKS, J. J.; BERENJIAN, J. (1993). The effect of creep and drying shrinkage on the micromorphology of cement paste containing superplasticizers. In: Bazant, Z. P.; Carol, I. (Ed.). Creep and Shrinkage of Concrete. London: E \& FN Spon, p. 115-121.

CARPINTERI A.; CHIAIA B. (1996). Size effects on concrete fracture energy: dimensional transition from order to disorder. Materials and Structures, v.29, p. 259-266.

CARPINTERI, A; VALENTE, S.; ZHOU, F. P.; FERRARA, G.; G. MELCHIORRI. (1997). Tensile and flexural creep rupture tests on partially-damaged concrete specimens. Materials and Structures. Vol. 30, june 1997, p. 269-276.

COMITE EURO-INTERNATIONAL DU BETON (1990). Evaluation of the time dependent behavior of concrete. Bulletin d'Information $\mathrm{n}^{\circ}$ 199. Paris.

CHEN, L.; LIU, J. (2004). Contribution of hybrid fibers on the properties of the high-strengh lightweight concrete having good workability. Cement and Concrete Research. Vol. 35, p. 913-917.

CHERN, J. C.; YOUNG, C. H. (1989). Compressive creep and shrinkage of steel fiber reinforced concrete. The International Journal of Cement Composites and Lightweight Concrete. Vol. 11, No. 4, p. 205-214.

CHRISTIANSEN, K. (1988). Eight-year deformation tests on reinforced concrete beams. Materials and Structures. Vol. 21, p. 172-178.

CYR, M. F.; PELED, A.; SHAH, S. P. (2001). Extruded hybrid fiber reinforced cementitious composites. In: Mansur, M.A.; Ong, K.C.G. Seventh International Symposium on Ferrocement and Thin-Reinforced Composites. National University of Singapore, p. 199-207.

DIANA FINITE ELEMENT ANALYSIS. User's manual release 9. TNO DIANA: The Netherlands, 2005. 
DUAN K.; HU X.; WITTMANN F. H. (2007). Size effect on specific fracture energy of concrete. Engineering Fracture Mechanics. Vol. 74, p. 87-96.

DUAN K.; HU X.; WITTMANN F. H. (2003). Boundary effect on concrete fracture and nonconstant fracture energy distribution. Engineering Fracture Mechanics. Vol. 70, p. 22572268.

ELICES, M.; GUINEA, G. V.; PLANAS, J. (1992). Measurement of the fracture energy using three-point bend tests: Part 3 - Influence of cutting the $P-\delta$ tail. Materials and Structures. Vol. 25, p. 327-334.

FANOURAKI, G. C.; BALLIM, Y. (2006). An assessment of the accuracy of nine design models for predicting creep in concrete. Journal of the South African Institution of Civil Engineering. Vol. 48, No. 4, p. 2-8.

FERRARI, V. J. (2007). Reforço à flexão de vigas de concreto armado com manta de polímero reforçado com fibras de carbono (PRFC) aderido a substrato de transição constituído por compósito cimentício de alto desempenho. 328p. Tese (Doutorado), Escola de Engenharia de São Carlos, Universidade de São Paulo.

FERREIRA, L. E. T; HANAI, J. B.; BITTENCOURT, T. N. (2008). Computational evaluation of flexural toughness of FRC and fracture properties of plain concrete. Materials and Structures, v. 41, n. 2, p. 391-405.

FERREIRA, L. E. T.; HANAI, J. B.; FERRARI, V. J. (2007). Otimização de concretos híbridos de alta resistência reforçados com fibras de aço. $49^{\circ}$ Congresso Brasileiro do Concreto, Instituto Brasileiro do Concreto, IBRACON, Bento Gonçalves, RS.

FERREIRA, L. E. T.; HANAI, J. B.; SOUSA, J. L. A. O.; VAREDA, L. V.; ALMEIDA, S. F.; SILVA, A. I. (2007). Determination of concrete fracture toughness from the modal dynamic response of notched beams. Fracture Mechanics of Concrete and Concrete Structures: New Trends in Fracture Mechanics of Concrete. In: Carpinteri, A., Gambarova, P., Ferro, G., Plizzari, G. (Eds), London: Taylor \& Francis Group, Vol. 1, p. 309-315.

FERREIRA, L. E. T. (2007). Comportamento ao fraturamento de compósitos híbridos a base de cimento Portland reforçados com micro e macrofibras de aço. Pesquisa de PósDoutoramento, Escola de Engenharia de São Carlos, USP. (texto disponibilizado pelo autor através do e-mail leferrei@uol.com.br).

FERREIRA, L. E. T. (2002). Sobre a resistência ao fraturamento do concreto e do concreto reforçado com fibras de aço. Tese (Doutorado), Escola Politécnica da Universidade de São Paulo, São Paulo, 2002.

FERREIRA, L. E. T. (1997). Análise de parâmetros de tenacidade ao fraturamento de concretos obtidos em ensaios de flexão de vigas. 268f. Dissertação (mestrado). Faculdade de Engenharia Civil da Universidade Estadual de Campinas, Campinas.

FERRO, G., 2006. On dissipated energy density in compression for concrete. Engineering Fracture Mechanics. Vol. 73, p. 1510-1530. 
FIGUEIREDO, A. D. (2000). Concreto com Fibras de Aço. Boletim Técnico - Série BT/PCC/260, Escola Politécnica de São Paulo, São Paulo.

GAO, J.; SUN, WEI; MORINO, K. (1997). Mechanical Properties of steel fiber-reinforced, high-strength, lightweight concrete. Cement and Concrete Composites. Vol. 19, No. 4 (August), p. 307-313.

GETTU, R.; GARCIA-ÁLVAREZ, V. O. (1993). Interaction of creep and fracture in concrete. In: Bazant, Z. P.; Carol, I. (Ed.). Creep and Shrinkage of Concrete. London: E \& FN Spon, p. 291-309.

GOEL, R.; KUMAR, R.; PAUL, D. K. (2007). Comparative study of various creep and shrinkage prediction models for concrete. Journal of Materials in Civil Engineering (C) ASCE. Vol. 19, No. 3, March 1.

GOPALARATNAN, V. S., GETTU, R., CARMONA, S., JAMET, D. (1995). Characterization of the toughness of fiber reinforced concretes using the Load-CMOD response. Fracture Mechanics of Concrete Structures, Proc. of FRANCOS2, Ed. F.H.Wittmann, p. 769-782.

GUINEA G. V. (1995). Modelling the fracture of concrete: the cohesive crack. Materials and Structures. Vol. 28, p. 187-194.

GUINEA G. V.; PLANAS J.; ELICES M. (1992). Measurement of the fracture energy using three-point bend tests: Part 1 - Influence of experimental procedures. Materials and Structures. Vol. 25, p. 327-334.

HILlERBORG, A., MORDEER, M., PETERSSON, P. E. (1976). Analysis of a crack formation and crack growth in concrete by means of fracture mechanics and finite elements. Cement and Concrete Research, Vol.6, p. 773-782.

HILLERBORG, A (1985). The theoretical basis of a method to determine the fracture energy Gf to concrete. Materials and Structures. Vol. 18, p. 291-296.

HOLLANDA, K. M. A. (2002). Análise dos mecanismos resistentes e das similaridades de efeitos da adição de fibras de aço na resistência e na ductilidade à punção de lajes-cogumelo $e$ ao cisalhamento de vigas de concreto. Tese (Doutorado). Engenharia de Estruturas, Escola de Engenharia de São Carlos, Universidade de São Paulo.

HU X. Z.; WITTMANN F. H. (1992). Fracture energy and fracture process zone. Materials and Structures. Vol. 25, p. 319-26.

HYANS, D. (1997). CurveExpert: a comprehensive curve fitting system for windows, ver. 1.34. Starkville, MS (USA).

JAMET, D.; GETTU, R.; GOPALARATNAM, V. S.; AGUADO, A. (1995). Toughness of Fiber-Reinforced High-Strength Concrete from Notched Beam Tests. Testing of Fiber Reinforced Concrete, ACI SP-155. American Concrete Institute. Detroit, USA, p. 23-39.

JENQ Y. S.; SHAH S. P. (1985). Two parameters fracture model for concrete. ASCE Journal of Engineering Mechanics Division. Vol. 111, No. 10, p. 1227-1241. 
JENQ Y. S.; SHAH S. P. (1985a). A fracture toughness criterion for concrete. Engineering Fracture Mechanics, Vol. 21, No. 5, p. 1055-1069.

JO, B. W.; SHON, Y. H.; KIM, Y. J. (2001). The evaluation of elastic modulus for steel fiber reinforced concrete. Russian Journal of Nondestructive Testing. Vol. 37, No. 2, p. 152-161.

KAGE, T.; MASUDA, Y.; TANANO, Y.; SATO, K. (1995). Long_term Deflection of continuous fiber reinforced concrete beams. Non-metallic (FRP) Reinforcement for Concrete Structures. L. Taerwe. (C) RILEM, London. p. 251-258.

KARIHALOO B. L. (1995). Fracture mechanics \& Structural concrete. London, Addison Wesley Longman Limited.

KARIHALOO B. L.; NALLATHAMBI P. (1988). An improved effective crack model for the determination of fracture toughness of concrete. Cement and Concrete Research. Vol. 19, p. 603-610.

KUPERMAN, S. C. (2007). Considerações sobre fluência de concretos. Revista Téchne. São Paulo. Pini. Edição 125. p. 52-58.

LAWLER, J. S.; ZAMPINI, D.; SHAH, S. P. (2005). Microfiber and macrofiber hybrid fiberreinforced concrete. Journal of Materials in Civil Engineering (C) ASCE. Vol. 17, No. 5, October 1, p. 595-603.

LOPES, M. M. (2005). Substituição parcial de armadura de flexão por fibras de aço em vigas de concreto. Dissertação (mestrado). Rio de Janeiro. COPPE/UFRJ.

MANGAT, P. S., AZARI, M. M. (1985). A Theory for the creep of steel fiber reinforced cement matrices under compression. Journal of Materials Science. Vol. 20, p. 1119-1133.

MANGAT, P. S., AZARI, M. M. (1986). Compression creep behavior of steel fiber reinforced cement composites. Materials and Structures. Vol. 19, No. 113, p. 361-370.

MANASEER, A. A.; NASSER, K. W. (1986). Creep of Concrete Containing Fly Ash and Superplasticizer at Different Stress/Strengh Ratios. ACI Journal. No. 86-62. July-August.

MEHTA, P. K.; MONTEIRO, P. J. M. (1994). Concreto: Estrutura, Propriedades e Materiais. São Paulo: Pini, 573 p.

MÜLLER, H. S.; PRISTL, M. (1993). Creep and shrinkage of concrete at variable ambient conditions. In: Bazant, Z. P.; Carol, I. (Ed.). Creep and Shrinkage of Concrete. London: E \& FN Spon. (p. 15-27).

NALLATHAMBI P.; KARIHALOO B. L.; HEATON B. S. (1985). Various Size Effects in Fracture of Concrete. Cement and Concrete Research. Vol. 15, p. 117-126.

NEVILLE, A. M.; DILGER, W. H. and BROOKS, J. J. (1983). Creep of Plain and Structural Concrete. Construction Press, Longman Group, London.

NEVILLE, A. M. (1981). Propriedades do Concreto. $3^{\text {a }}$ Ed. São Paulo: Pini, 738 p. 
NEVILLE, A. M.; DILGER, W. H. (1970). Creep of Concrete: Plain, Reinforced and Prestressed. North-Holland Publishing Company, Amsterdam.

NEVILLE, A. M. (1964). Creep of concrete as a function of its cement past content. Mag. Concr. Res. Vol. 16, No. 46, p. 21-30.

OLIVEIRA, S. L. (2005). Taxa de armadura longitudinal mínima em vigas de concreto de alta resistência com fibras de aço. 134p. Dissertação (mestrado). COPPE/UFRJ.

OYAMADA, R. N. (1998). Análise estrutural de barras sujeitas a fluência. 97p. Dissertação (Mestrado). Engenharia de Estruturas, Escola Politécnica - Universidade de São Paulo, 1998.

PLANAS J.; ELICES M.; GUINEA G. V. (1992). Measurement of the fracture energy using three-point bend tests: Part 2 - Influence of bulk energy dissipation. Materials and Structures. Vol. 25, p. 327-334.

PURKISS, J. A.; BIAGOJEVIĆ, P. (1993). Comparison between the short and long term behaviour of fibre reinforced and unreinforced concrete beams. Composite Structures. Vol. 25, p. $45-49$.

REINHARDT, H. W.; RINDER, T. (2006). Tensile creep of high-strength concrete. Journal of Advanced Concrete Technology. Vol. 4, No. 2, June 2006, p. 227-283.

REIS, A. P. A. (2003). Reforço de vigas de concreto armado submetidas a pré-carregamento $e$ ações de longa duração com aplicação de concretos de alta resistência e concretos com fibras de aço. 355 p. São Carlos. Tese (Doutorado). Engenharia de Estruturas, Escola de Engenharia de São Carlos - Universidade de São Paulo.

RILEM (1985). Technical Committee - 50 - FMC - Determination of the fracture energy of mortar and concrete by means of the three-point bend test on notched beams. Draft Recommendation - Materials and Structures. Vol. 18, p. 291-296.

RILEM (1990). Technical Committee - 89 - FMTM - Determination of fracture parameters $\left(K_{I c}^{S}\right.$ and $C T O D_{C}$ ) of plain concrete using three-point bend tests. Materials and Structures. Vol. 23, p. 457-460.

RILEM (1990a). Technical Committee - 89 - FMTM - Size-effect method for determining fracture energy and process zone size of concrete. Draft Recommendation - Materials and Structures. Vol. 23, p. 461-465.

ROUSE, J. M.; BILLINGTON, S. L. (2007). Creep and Shrinkage of High-Performance Fiber-Reinforced Cementitious Composite. ACI Materials Journal. 104-M15, March-April, p. 129-136.

SAMPAIO, C. D. C. (2004). Comparação entre a modelagem numérica e experimental da deformação por fluência em vigas de concreto armado. Dissertação (mestrado). Escola Politécnica da Universidade de São Paulo, São Paulo, 2004.

SCANDIUZZI, L.; ANDRIOLO, F. R (1946). Concreto e seus materiais: propriedades e ensaios. São Paulo, PINI. 
SHAH, S. P.; SWARTZ S. E.; OUYANG C. (1995). Fracture mechanics of concrete: Applications of Fracture Mechanics to concrete, rock and other quasi-brittle materials. New York. John Wiley \& Sons.

SMERDA, Z.; KRISTEK, V. (1988). Creep and shrinkage of concrete elements and structures. Amsterdam; New York : Elsevier: Distribution for the U.S.A. and Canada, Elsevier Science Pub. Co. 296 p. (Translation of: Dotvarování a smérsítování betonovâych prvkêu a konstrukcí).

SOLANKI, H.; SABNIS, G. M. (1987). Long-term deflections of reinforced concrete structures. Indian Concrete Journal. Vol. 61, No. 4, Apr, p. 107-110.

SORELLI, L. G.; MEDA, A.; PLIZZARI, G. A. (2005). Bending and uniaxial tensile tests on crete reinforced with hybrid steel fibers. Journal of Materials in Civil Engineering (C) ASCE. Vol. 17, No. 5, October 1, p. 519-527.

SOUZA, R. A. (2001). Análise de fraturamento em estruturas de concreto utilizando programas de análise estrutural. 273f. Dissertação (mestrado). Universidade Estadual de Campinas, Campinas, 2001.

SUN, W.; CHEN, H.; LUO, X.; QUIAN, H. (2000). The effect of hybrid fibers and expansive agent on the shrinkage and permeability of high-performance concrete. Cement and Concrete Research. Vol. 31, p. 595-601.

TAN, K. H.; PARAMASIVAM, P.; TAN, K. C. (1994). Creep and shrinkage deflections of RC beams with steel fibers. Journal of Materials in Civil Engineering. Vol. 6, No. 4, November. P. 474-494.

TIMOSHENKO, S. P.; GOODIER, J. N. (1970). Teoria da Elasticidade. Guanabara dois, Rio de Janeiro.

TIMOSHENKO, S. P. (1971). Resistência dos Materiais. Vol. 1. Rio de Janeiro: Pan Americana. p. 107-152.

THOMAS, J. RAMASWAMY, A. (2007). Mechanical properties of steel fiber-reinforced concrete. Journal of materials in civil engineering ${ }^{\circledR}$ ASCE. Vol. 19, No. 5, p. 385-392.

VANDEWALLE, L. et al. (2000a), "RILEM TC162-TDF : Test and Design Methods for Steel Fiber Reinforced Concrete : Bending Test", "Technical Recommendation" , Materials and Structures, Vol. 33, January - February, 2000, p. 3-5.

VANDEWALLE, L. et al. (2000b). RILEM TC162-TDF: Test and Design Methods for Steel Fibre Reinforced Concrete: Design Method, Technical Recommendation, Materials and Structures, Vol. 33, March, 2000, p.75-81.

ZHOU, F. P. (1993). Cracking analysis and size effect in creep rupture of concrete. In: Bazant, Z. P.; Carol, I. (Ed.). Creep and Shrinkage of Concrete. London: E \& FN Spon, p. 407-413. 
WAWRZYNEK, P. A.; INGRAFFEA, A. R (1987). Interactive Finite Element Analysis of Fracture Processes: An Integrated Approach. Theoretical and Applied Fracture Mechanics. Vol. 8, p. 137-150.

WU, Y.; LI, J.; WU, K. (2003). Mechanical properties of hybrid fiber-reinforced concrete at low fiber volume fraction. Cement and Concrete Research. Vol. 33, p. 27-30. 


\section{APÊNDICE A - Ensaios de Caracterização}

Série 1 (Piloto)

Tabela A.1: Material: CONC

\begin{tabular}{|c|c|c|c|}
\hline \multirow{2}{*}{ Idade (dias) } & \multicolumn{3}{|c|}{ concreto sem fibras } \\
\cline { 2 - 4 } & $\mathrm{f}_{\mathrm{c}}(\mathrm{MPa})$ & $\mathrm{E}(\mathrm{GPa})$ & $\mathrm{f}_{\mathrm{t}}(\mathrm{MPa})$ \\
\hline \multirow{2}{*}{14} & 30.60 & 33.70 & 2.54 \\
& 32.80 & 33.79 & 2.81 \\
\hline valor assumido & $\mathbf{3 0 . 6 0}$ & $\mathbf{3 3 . 7 0}$ & $\mathbf{2 . 8 1}$ \\
\hline \hline \multirow{2}{*}{28} & 33.80 & 29.90 & 2.89 \\
& 37.10 & 31.50 & 3.03 \\
\hline valor assumido & $\mathbf{3 5 . 4 5}$ & $\mathbf{3 1 . 5 0}$ & $\mathbf{3 . 0 3}$ \\
\hline \hline \multirow{2}{*}{60} & 43.45 & 32.34 & 2.98 \\
& 51.44 & 34.24 & 3.95 \\
\hline \hline \multirow{2}{*}{105} & $\mathbf{4 3 . 4 5}$ & $\mathbf{3 4 . 2 4}$ & $\mathbf{3 . 4 6}$ \\
\hline & 47.88 & 31.70 & 3.55 \\
& 42.55 & 31.46 & 4.46 \\
& 48.39 & 31.18 & 3.39 \\
& 52.79 & 32.59 & 3.59 \\
\hline valor assumido & $\mathbf{4 8 . 1 4}$ & $\mathbf{3 1 . 4 4}$ & $\mathbf{3 . 7 5}$ \\
\hline
\end{tabular}

Tabela A.2: Material: CF

\begin{tabular}{|c|c|c|c|}
\hline \multirow{2}{*}{ Idade (dias) } & \multicolumn{3}{|c|}{ concreto + fibra $(25 \mathrm{~mm})$} \\
\cline { 2 - 4 } & $\mathrm{f}_{\mathrm{c}}(\mathrm{MPa})$ & $\mathrm{E}(\mathrm{GPa})$ & $\mathrm{f}_{\mathrm{t}}(\mathrm{MPa})$ \\
\hline \multirow{2}{*}{14} & 25.32 & 31.59 & 2.98 \\
& 26.00 & 33.41 & 3.10 \\
\hline valor assumido & $\mathbf{2 6 . 0 0}$ & $\mathbf{3 1 . 5 9}$ & $\mathbf{2 . 9 8}$ \\
\hline \hline \multirow{2}{*}{28} & 27.57 & 30.80 & 2.93 \\
& 34.60 & 31.79 & 3.15 \\
\hline valor assumido & $\mathbf{3 4 . 6 0}$ & $\mathbf{3 1 . 7 9}$ & $\mathbf{3 . 1 5}$ \\
\hline \multirow{2}{*}{60} & 39.16 & 32.88 & 3.78 \\
& 41.14 & 30.04 & 4.14 \\
\hline \hline \multirow{2}{*}{105} & $\mathbf{3 9 . 1 6}$ & $\mathbf{3 2 . 8 8}$ & $\mathbf{3 . 7 8}$ \\
& 40.61 & 30.25 & 4.19 \\
& 37.80 & 31.15 & 3.31 \\
& 40.85 & 31.07 & 4.34 \\
& 43.40 & 28.55 & 3.82 \\
\hline valor assumido & $\mathbf{4 0 . 7 3}$ & $\mathbf{3 0 . 6 6}$ & $\mathbf{3 . 9 2}$ \\
\hline
\end{tabular}


Tabela A.3: Material: CFMF.

\begin{tabular}{|c|c|c|c|}
\hline \multirow{2}{*}{ Idade (dias) } & \multicolumn{3}{|c|}{ concreto + fibra $(25 \mathrm{~mm})+$ microfibra $(13 \mathrm{~mm})$} \\
\cline { 2 - 4 } & $\mathrm{f}_{\mathrm{c}}(\mathrm{MPa})$ & $\mathrm{E}(\mathrm{GPa})$ & $\mathrm{f}_{\mathrm{t}}(\mathrm{MPa})$ \\
\hline \multirow{2}{*}{14} & 18.75 & 24.45 & 1.95 \\
& 19.00 & 25.34 & 2.10 \\
\hline valor assumido & $\mathbf{1 9 . 0 0}$ & $\mathbf{2 4 . 4 5}$ & $\mathbf{2 . 1 0}$ \\
\hline \hline \multirow{2}{*}{28} & 25.00 & 25.29 & 2.00 \\
& 28.80 & 27.96 & 2.59 \\
\hline \hline \multirow{2}{*}{60} & $\mathbf{2 8 . 8 0}$ & $\mathbf{2 5 . 2 9}$ & $\mathbf{2 . 5 9}$ \\
\hline \multirow{2}{*}{ valor assumido } & 29.70 & 23.63 & 2.98 \\
& 32.40 & 25.59 & 3.28 \\
\hline \hline \multirow{2}{*}{105} & $\mathbf{3 2 . 4 0}$ & $\mathbf{2 5 . 5 9}$ & $\mathbf{3 . 2 8}$ \\
& 34.78 & 25.66 & 2.75 \\
& 34.51 & 24.71 & 2.76 \\
& 29.26 & 24.69 & 3.13 \\
\hline valor assumido & $\mathbf{3 4 . 6 5}$ & $\mathbf{2 5 . 1 9}$ & $\mathbf{3 . 2 4}$ \\
\hline
\end{tabular}

Série 2 (Definitiva)

Tabela A.4: Resultados aos 9 dias para os três materiais.

\begin{tabular}{ccccc}
\multicolumn{5}{c}{$\mathbf{9}$ dias } \\
\hline & $\mathbf{f}_{\mathrm{c}}$ (MPa) & $\mathbf{E}$ (MPa) & $\mathrm{E}_{\mathrm{NBR}}$ (MPa) & $\mathbf{f}_{\mathbf{t}}$ (MPa) \\
\hline CONC1 & 20.94 & 24843 & 21784 & 1.68 \\
CONC2 & 21.72 & 25493 & 22183 & 1.74 \\
CONC3 & 22.81 & 27633 & 22733 & 1.82 \\
média & $\mathbf{2 1 . 8 2}$ & $\mathbf{2 5 9 9 0}$ & $\mathbf{2 2 2 3 3}$ & $\mathbf{1 . 7 5}$ \\
cV & $4.3 \%$ & $5.6 \%$ & $2.1 \%$ & $4.3 \%$ \\
\hline CF1 & 23.05 & 25735 & 22852 & 1.84 \\
CF2 & 24.02 & 27724 & 23329 & 1.92 \\
CF3 & 23.18 & 29215 & 22918 & 1.85 \\
média & $\mathbf{2 3 . 4 2}$ & $\mathbf{2 7 5 5 8}$ & $\mathbf{2 3 0 3 3}$ & $\mathbf{1 . 8 7}$ \\
cV & $2.3 \%$ & $6.3 \%$ & $1.1 \%$ & $2.3 \%$ \\
\hline CFMF1 & 18.83 & 21790 & 20657 & 1.51 \\
CFMF2 & 18.72 & 22045 & 20597 & 1.50 \\
CFMF3 & 18.58 & 22523 & 20516 & 1.49 \\
média & $\mathbf{1 8 . 7 1}$ & $\mathbf{2 2 1 1 9}$ & $\mathbf{2 0 5 9 0}$ & $\mathbf{1 . 5 0}$ \\
cv & $0.7 \%$ & $1.7 \%$ & $0.3 \%$ & $0.7 \%$ \\
\hline
\end{tabular}


Tabela A.5: Resultados aos 14 dias para os três materiais.

14 dias

\begin{tabular}{|c|c|c|c|c|c|}
\hline & $\mathrm{f}_{\mathrm{c}}(\mathrm{MPa})$ & $E$ (MPa) & $\mathrm{E}_{\mathrm{NBR}}(\mathrm{MPa})$ & $f_{t}(M P a)$ & $\% f_{t} / f_{c}$ \\
\hline CONC1 & 25.25 & 33101 & 23917 & 2.16 & $8.6 \%$ \\
\hline CONC2 & 25.57 & 30317 & 24071 & 2.41 & $9.4 \%$ \\
\hline CONC3 & 27.62 & 31718 & 25018 & 2.29 & $8.3 \%$ \\
\hline média & 26.15 & 31712 & 24335 & 2.29 & $8.8 \%$ \\
\hline$c v$ & $4.9 \%$ & $4.4 \%$ & $2.5 \%$ & $5.3 \%$ & $6.7 \%$ \\
\hline CF1 & 28.29 & 30743 & 25317 & 2.85 & $10.1 \%$ \\
\hline CF2 & 28.86 & 32102 & 25571 & 2.84 & $9.8 \%$ \\
\hline CF3 & 29.05 & 31750 & 25656 & 2.89 & $10.0 \%$ \\
\hline média & 28.73 & 31532 & 25515 & 2.86 & $10.0 \%$ \\
\hline$c V$ & $1.4 \%$ & $2.2 \%$ & $0.7 \%$ & $1.0 \%$ & $1.1 \%$ \\
\hline CFMF1 & 22.61 & 26050 & 22634 & 2.71 & $12.0 \%$ \\
\hline CFMF2 & 22.37 & 25253 & 22511 & 2.40 & $10.7 \%$ \\
\hline CFMF3 & 22.66 & 27471 & 22661 & 2.64 & $11.6 \%$ \\
\hline média & 22.55 & 26258 & 22602 & 2.58 & $11.4 \%$ \\
\hline$c V$ & $0.7 \%$ & $4.3 \%$ & $0.4 \%$ & $6.4 \%$ & $5.8 \%$ \\
\hline
\end{tabular}

Tabela A.6: Resultados aos 28 dias para os três materiais.

28 dias

\begin{tabular}{|c|c|c|c|c|c|c|}
\hline & fc (MPa) & E (MPa) & $\mathrm{E}_{\mathrm{NBR}}(\mathrm{MPa})$ & Poisson & ft (MPa) & $\% f t / f c$ \\
\hline CONC1 & 32.34 & 32394 & 27069 & 0.20 & 3.30 & $10.2 \%$ \\
\hline CONC2 & 31.78 & 31725 & 26834 & 0.20 & 2.66 & $8.4 \%$ \\
\hline CONC3 & 32.71 & 34396 & 27225 & 0.21 & 2.90 & $8.9 \%$ \\
\hline média & 32.28 & 32838 & 27042 & 0.21 & 2.96 & $9.2 \%$ \\
\hline$c v$ & $1.5 \%$ & $4.2 \%$ & $0.7 \%$ & $2.2 \%$ & $11.0 \%$ & $10.4 \%$ \\
\hline CF1 & 34.59 & 33347 & 27995 & 0.22 & 3.54 & $10.2 \%$ \\
\hline CF2 & 33.20 & 34074 & 27425 & 0.20 & 3.34 & $10.1 \%$ \\
\hline CF3 & 34.67 & 33447 & 28028 & 0.16 & 4.04 & $11.7 \%$ \\
\hline média & 34.15 & 33623 & 27816 & 0.19 & 3.64 & $10.7 \%$ \\
\hline $\mathrm{cv}$ & $2.4 \%$ & $1.2 \%$ & $1.2 \%$ & $14.9 \%$ & $9.9 \%$ & $8.2 \%$ \\
\hline CFMF1 & 27.45 & 27543 & 24939 & 0.18 & 2.68 & $9.7 \%$ \\
\hline CFMF2 & 28.49 & 27881 & 25408 & 0.22 & 2.69 & $9.5 \%$ \\
\hline CFMF3 & 27.06 & 26542 & 24763 & 0.16 & 3.04 & $11.2 \%$ \\
\hline média & 27.78 & 27212 & 25037 & 0.19 & 2.80 & $10.1 \%$ \\
\hline$c v$ & $3.6 \%$ & $3.5 \%$ & $1.3 \%$ & $16.4 \%$ & $7.3 \%$ & $9.4 \%$ \\
\hline
\end{tabular}


Tabela A.7: Evolução das propriedades no tempo.

Resistência à compressão $f_{c}(\mathrm{Mpa})$

\begin{tabular}{|c|c|c|c|c|c|}
\hline grupo & 7 dias & 14 dias & ganho & 28 dias & ganho \\
\hline CONC & 21.8 & 26.1 & $19.8 \%$ & 32.3 & $23.4 \%$ \\
\hline CF & 23.4 & 28.7 & $22.7 \%$ & 34.2 & $18.9 \%$ \\
\hline CFMF & 18.7 & 22.5 & $20.5 \%$ & 27.8 & $23.2 \%$ \\
\hline média & 21.3 & 25.8 & $21.0 \%$ & 31.4 & $21.8 \%$ \\
\hline$c V$ & $11 \%$ & $12 \%$ & $7 \%$ & $10 \%$ & $12 \%$ \\
\hline \multicolumn{6}{|c|}{ Módulo de Young E (Gpa) } \\
\hline grupo & 7 dias & 14 dias & ganho & 28 dias & ganho \\
\hline CONC & 26.0 & 31.7 & $22.0 \%$ & 32.8 & $3.6 \%$ \\
\hline CF & 27.6 & 31.5 & $14.4 \%$ & 33.6 & $6.6 \%$ \\
\hline CFMF & 22.1 & 26.3 & $18.7 \%$ & 27.2 & $3.6 \%$ \\
\hline média & 25.2 & 29.8 & $18.4 \%$ & 31.2 & $4.6 \%$ \\
\hline$c v$ & $11 \%$ & $10 \%$ & $21 \%$ & $11 \%$ & $38 \%$ \\
\hline \multicolumn{4}{|c|}{ Resistência à tração $f_{t}(G p a)$} & & \\
\hline grupo & 14 dias & 28 dias & ganho & & \\
\hline SF & 2.3 & 3.0 & $29.3 \%$ & & \\
\hline CF & 2.9 & 3.6 & $27.3 \%$ & & \\
\hline CFMF & 2.6 & 2.8 & $8.6 \%$ & & \\
\hline média & 2.6 & 3.1 & $21.7 \%$ & & \\
\hline$c v$ & $11 \%$ & $14 \%$ & $53 \%$ & & \\
\hline
\end{tabular}




\section{APÊNDICE B - Momento de Fissuração/ Flecha elástica}

Tabela B.1: Determinação mo momento de fissuração e da flecha elástica inicial.

\begin{tabular}{|c|c|c|c|c|c|}
\hline & & VE - série1 & VSE - série 1 & VE - série2 & VSE - série 2 \\
\hline \multirow{10}{*}{ 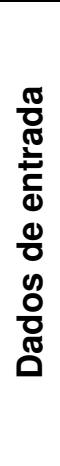 } & $b(m)$ & 0.15 & 0.15 & 0.15 & 0.15 \\
\hline & $h(m)$ & 0.3 & 0.3 & 0.3 & 0.3 \\
\hline & $L(m)$ & 2.2 & 2.2 & 2.2 & 2.2 \\
\hline & $S(m)$ & 1.8 & 2.1 & 1.8 & 2.1 \\
\hline & $\mathrm{E}_{\mathrm{c}, \text { experimental (28) }}(\mathrm{N} / \mathrm{m} 2)$ & $3.40 \mathrm{E}+10$ & $3.40 \mathrm{E}+10$ & $3.17 \mathrm{E}+10$ & 3.17E+10 \\
\hline & $P(N)$ & & 4874 & & 4874 \\
\hline & densidade $(\mathrm{Kg} / \mathrm{m} 3)$ & 2491.6 & 2491.6 & 2370 & 2370 \\
\hline & $\alpha$ & 1.5 & 1.5 & 1.5 & 1.5 \\
\hline & $\mathrm{f}_{\mathrm{c}}(\mathrm{MPa})$ & 43 & 43 & 26 & 26.0 \\
\hline & $\mathrm{f}_{\mathrm{t}}(\mathrm{MPa})$ & 3.15 & 3.15 & 2.07 & 2.07 \\
\hline \multirow{10}{*}{ 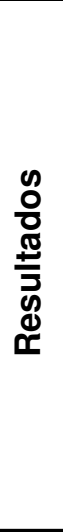 } & \multirow{10}{*}{$\begin{array}{l}\text { Tensão máx (MPa) } \\
\text { flecha-pp }(\mathrm{mm}) \\
\text { flecha-P }(\mathrm{mm}) \\
\text { flecha elástica total }(\mathrm{mm})\end{array}$} & 3.38E-04 & 3.38E-04 & $3.38 \mathrm{E}-04$ & 3.38E-04 \\
\hline & & 0.099 & 0.099 & 0.099 & 0.099 \\
\hline & & $1.15 \mathrm{E}+07$ & $1.15 \mathrm{E}+07$ & $1.07 \mathrm{E}+07$ & 1.07E+07 \\
\hline & & 1099.92 & 1099.92 & 1046.24 & 1046.24 \\
\hline & & 445.5 & 3165.2 & 423.7 & 31356 \\
\hline & & 10631.3 & 10631.3 & 6986.3 & 6986.3 \\
\hline & & & 1.41 & & 1.39 \\
\hline & & 0.013 & 0.024 & 0.013 & 0.025 \\
\hline & & 0.000 & 0.082 & 0.000 & 0.088 \\
\hline & & 0.013 & 0.106 & 0.013 & 0.113 \\
\hline
\end{tabular}




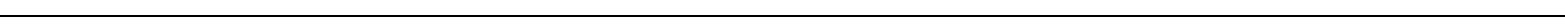




\section{Apêndice C - Leituras CMOD}

A seguir são apresentados os dados relativos ao deslocamento de abertura do entalhe, obtidos a partir das leituras dos clips e do Tenso-Tast para a segunda série de ensaios.

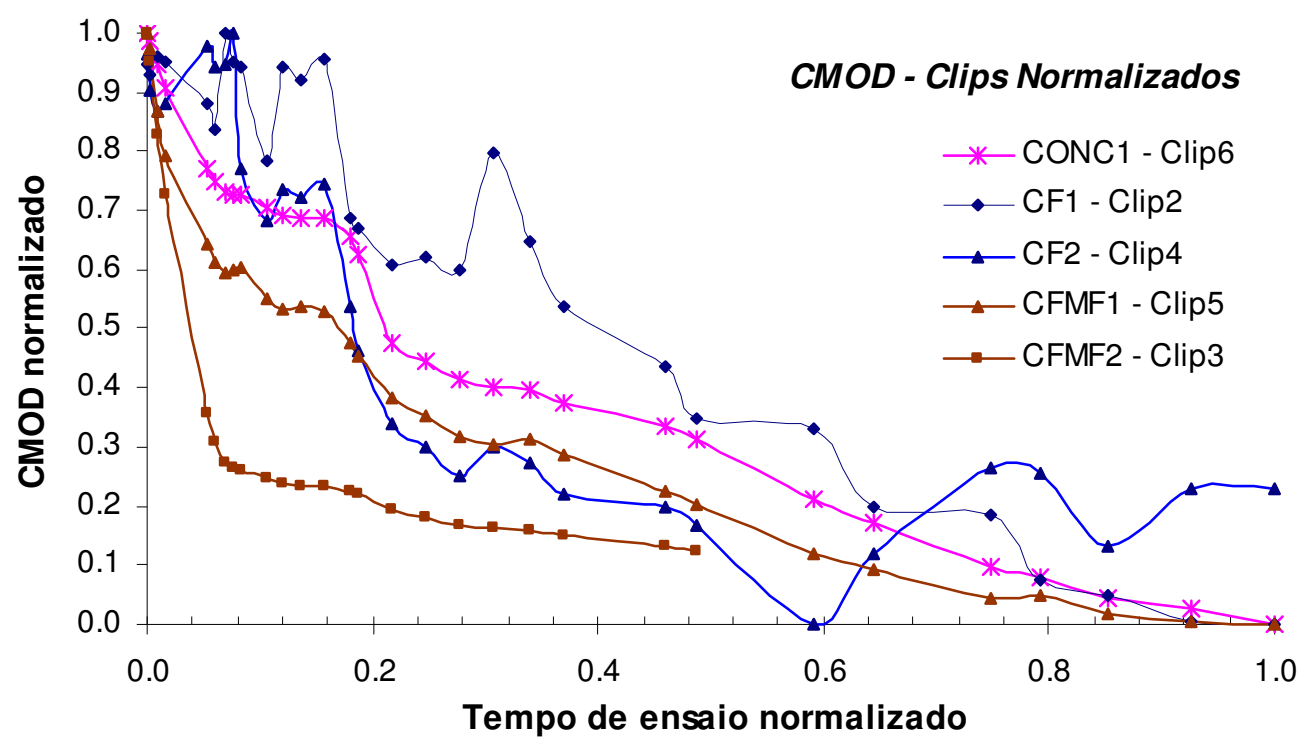

Fig. C.1: Curva normalizada CMOD-tempo. Dados obtidos pelos clips.

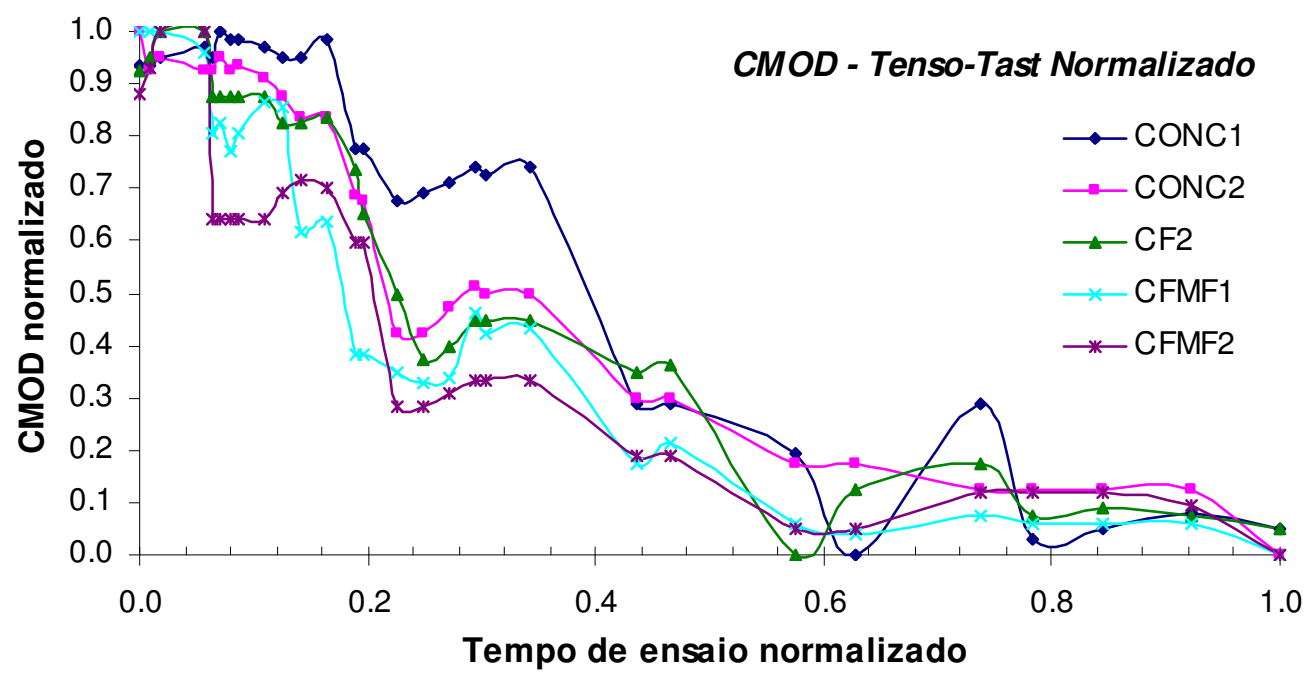

Fig. C.2: Curva normalizada CMOD-tempo. Dados obtidos pelo Tenso-Tast. 
Tabela C.1: Informações sobre o ajuste das leituras do CMOD obtidas através do Tenso-Tast.

\begin{tabular}{|c|c|c|c|c|c|}
\hline \multicolumn{4}{|c|}{ Normalização - Aproximação - função racional (Tenso-Tast) } & \multicolumn{2}{|c|}{$\left[(a+b \cdot x) /\left(1+c \cdot x+d \cdot x^{2}\right)\right]$} \\
\hline$r^{2}$ & 0.98 & 0.99 & 0.98 & 0.97 & 0.95 \\
\hline a & 0.9394 & 0.9453 & 0.9399 & 1.0121 & 0.9226 \\
\hline $\mathrm{b}$ & -0.7908 & 0.9001 & 0.2756 & -0.2124 & -0.3066 \\
\hline c & -1.7651 & -0.5964 & -0.8323 & 0.9409 & 1.4954 \\
\hline d & 6.9482 & 20.3686 & 17.8367 & 18.2584 & 11.9759 \\
\hline Tempo & VE-CONC1 & VE-CONC2 & VE-CF2 & VE-CFMF1 & VE-CFMF2 \\
\hline 0.00 & 0.939 & 0.945 & 0.940 & 1.012 & 0.923 \\
\hline 0.01 & 0.947 & 0.958 & 0.949 & 0.999 & 0.906 \\
\hline 0.02 & 0.953 & 0.965 & 0.953 & 0.987 & 0.891 \\
\hline 0.06 & 0.970 & 0.966 & 0.946 & 0.901 & 0.807 \\
\hline 0.06 & 0.971 & 0.960 & 0.939 & 0.880 & 0.789 \\
\hline 0.07 & 0.971 & 0.951 & 0.930 & 0.859 & 0.771 \\
\hline 0.08 & 0.970 & 0.941 & 0.919 & 0.837 & 0.752 \\
\hline 0.09 & 0.968 & 0.929 & 0.907 & 0.814 & 0.734 \\
\hline 0.11 & 0.958 & 0.884 & 0.862 & 0.746 & 0.678 \\
\hline 0.13 & 0.946 & 0.849 & 0.828 & 0.700 & 0.642 \\
\hline 0.14 & 0.931 & 0.811 & 0.791 & 0.656 & 0.606 \\
\hline 0.16 & 0.902 & 0.753 & 0.732 & 0.593 & 0.556 \\
\hline 0.19 & 0.864 & 0.692 & 0.671 & 0.532 & 0.506 \\
\hline 0.20 & 0.853 & 0.675 & 0.655 & 0.516 & 0.493 \\
\hline 0.23 & 0.795 & 0.602 & 0.581 & 0.449 & 0.437 \\
\hline 0.25 & 0.748 & 0.552 & 0.530 & 0.404 & 0.399 \\
\hline 0.27 & 0.703 & 0.510 & 0.487 & 0.368 & 0.368 \\
\hline 0.29 & 0.654 & 0.468 & 0.444 & 0.333 & 0.336 \\
\hline 0.30 & 0.633 & 0.452 & 0.428 & 0.319 & 0.324 \\
\hline 0.34 & 0.553 & 0.394 & 0.369 & 0.271 & 0.280 \\
\hline 0.44 & 0.385 & 0.291 & 0.264 & 0.189 & 0.201 \\
\hline 0.47 & 0.338 & 0.265 & 0.238 & 0.169 & 0.181 \\
\hline 0.57 & 0.213 & 0.198 & 0.171 & 0.118 & 0.128 \\
\hline 0.63 & 0.168 & 0.174 & 0.148 & 0.100 & 0.109 \\
\hline 0.74 & 0.103 & 0.138 & 0.113 & 0.074 & 0.081 \\
\hline 0.78 & 0.082 & 0.127 & 0.102 & 0.065 & 0.072 \\
\hline 0.85 & 0.061 & 0.113 & 0.090 & 0.056 & 0.061 \\
\hline 0.92 & 0.040 & 0.100 & 0.077 & 0.047 & 0.051 \\
\hline 1.00 & 0.024 & 0.089 & 0.068 & 0.040 & 0.043 \\
\hline
\end{tabular}


Tabela C.2: Informações sobre o ajuste das leituras do CMOD obtidas através dos clip.

\begin{tabular}{|c|c|c|c|c|c|}
\hline \multicolumn{4}{|c|}{ Normalização - Aproximação - função racional (Clips) } & \multicolumn{2}{|c|}{$\left[(a+b \cdot x) /\left(1+c \cdot x+d \cdot x^{2}\right)\right]$} \\
\hline $\mathbf{r}^{2}$ & 0.98 & 0.99 & 0.96 & 0.99 & 0.99 \\
\hline $\mathbf{a}$ & 0.9629 & 1.0023 & 0.8830 & 0.9253 & 0.9628 \\
\hline b & -0.9961 & 4.1286 & 5.8151 & -0.9786 & -0.9938 \\
\hline c & -0.2807 & 36.4593 & 0.3634 & 4.7021 & 2.1613 \\
\hline d & 1.4188 & 48.5902 & 79.4480 & -3.7677 & -1.3784 \\
\hline Tempo & $\begin{array}{l}\text { VE-CF1: } \\
\text { Clip2 }\end{array}$ & $\begin{array}{c}\text { VE-CFMF2: } \\
\text { Clip3 }\end{array}$ & $\begin{array}{l}\text { VE-CF2: } \\
\text { Clip4 }\end{array}$ & $\begin{array}{c}\text { VE-CFMF1: } \\
\text { Clip5 }\end{array}$ & $\begin{array}{c}\text { VE-CONC1: } \\
\text { Clip6 }\end{array}$ \\
\hline 0.00 & 0.963 & 1.002 & 0.883 & 0.925 & 0.963 \\
\hline 0.00 & 0.962 & 0.946 & 0.893 & 0.915 & 0.957 \\
\hline 0.01 & 0.956 & 0.775 & 0.927 & 0.878 & 0.935 \\
\hline 0.02 & 0.950 & 0.660 & 0.953 & 0.844 & 0.914 \\
\hline 0.05 & 0.919 & 0.395 & 0.957 & 0.703 & 0.818 \\
\hline 0.06 & 0.913 & 0.368 & 0.939 & 0.680 & 0.800 \\
\hline 0.07 & 0.906 & 0.345 & 0.917 & 0.658 & 0.784 \\
\hline 0.08 & 0.899 & 0.325 & 0.891 & 0.637 & 0.767 \\
\hline 0.08 & 0.892 & 0.308 & 0.864 & 0.618 & 0.752 \\
\hline 0.11 & 0.870 & 0.267 & 0.778 & 0.565 & 0.707 \\
\hline 0.12 & 0.854 & 0.246 & 0.721 & 0.534 & 0.680 \\
\hline 0.14 & 0.838 & 0.229 & 0.667 & 0.506 & 0.654 \\
\hline 0.16 & 0.813 & 0.208 & 0.594 & 0.468 & 0.617 \\
\hline 0.18 & 0.786 & 0.191 & 0.528 & 0.433 & 0.582 \\
\hline 0.19 & 0.779 & 0.186 & 0.512 & 0.424 & 0.573 \\
\hline 0.22 & 0.743 & 0.170 & 0.445 & 0.387 & 0.532 \\
\hline 0.25 & 0.705 & 0.156 & 0.391 & 0.354 & 0.495 \\
\hline 0.28 & 0.666 & 0.145 & 0.346 & 0.325 & 0.460 \\
\hline 0.31 & 0.626 & 0.135 & 0.310 & 0.299 & 0.428 \\
\hline 0.34 & 0.586 & 0.127 & 0.279 & 0.275 & 0.398 \\
\hline 0.37 & 0.545 & 0.120 & 0.253 & 0.253 & 0.370 \\
\hline 0.46 & 0.432 & 0.104 & 0.199 & 0.201 & 0.298 \\
\hline 0.49 & 0.397 & 0.099 & 0.185 & 0.187 & 0.276 \\
\hline 0.59 & 0.280 & 0.087 & 0.149 & 0.140 & 0.208 \\
\hline 0.64 & 0.228 & 0.082 & 0.135 & 0.120 & 0.177 \\
\hline 0.75 & 0.138 & 0.074 & 0.114 & 0.080 & 0.119 \\
\hline 0.79 & 0.104 & 0.071 & 0.107 & 0.063 & 0.095 \\
\hline 0.85 & 0.064 & 0.067 & 0.099 & 0.040 & 0.063 \\
\hline 0.93 & 0.021 & 0.063 & 0.090 & 0.009 & 0.023 \\
\hline 1.00 & 0.000 & 0.060 & 0.083 & 0.000 & 0.000 \\
\hline
\end{tabular}

